Prepared in cooperation with the Missouri River Recovery-Integrated Science Program, U.S. Army Corps of Engineers, Yankton, South Dakota

\title{
Ecological Requirements for Pallid Sturgeon Reproduction and Recruitment in the Missouri River-A Synthesis of Science, 2005 to 2012
}
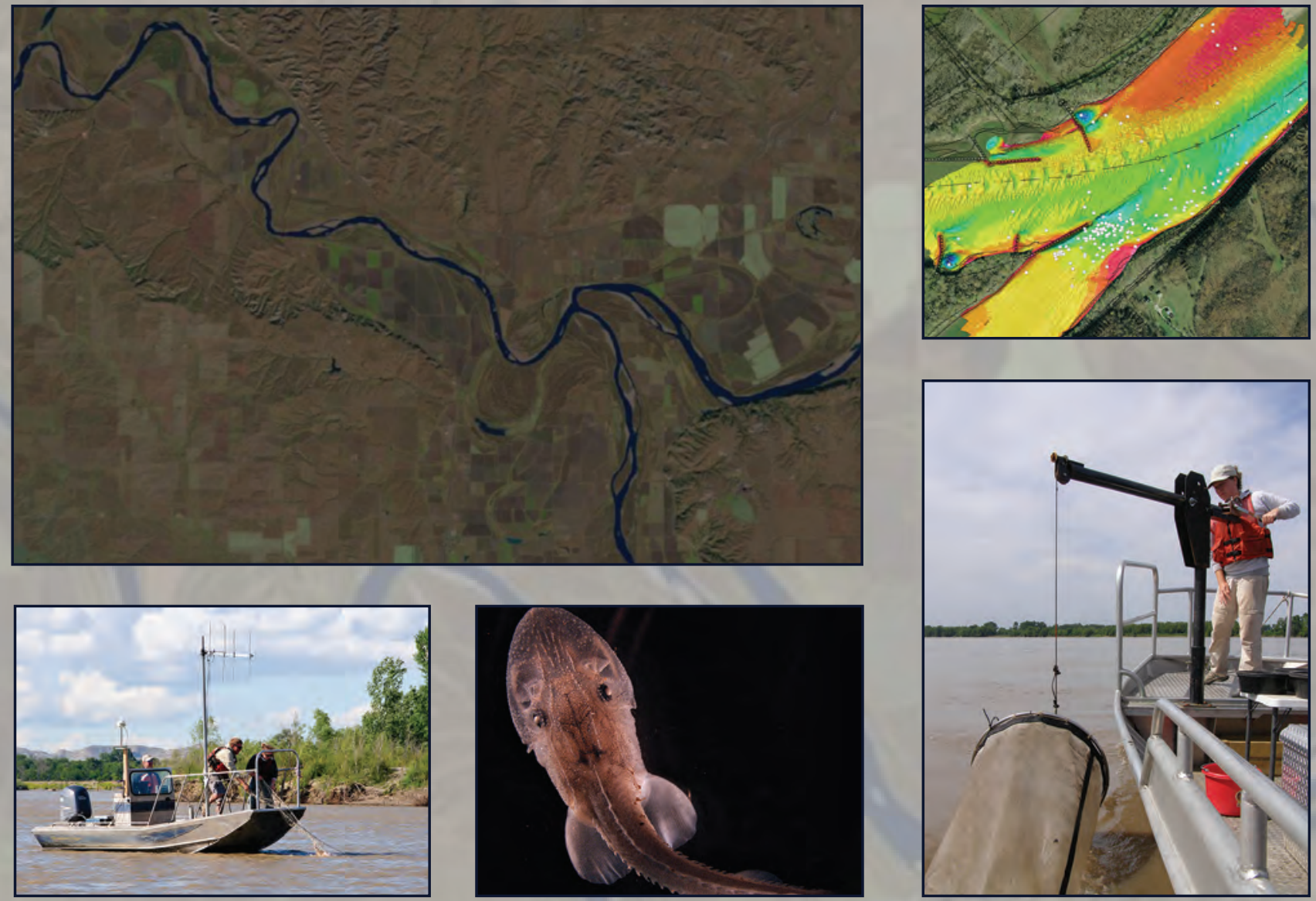

Scientific Investigations Report 2015-5145 

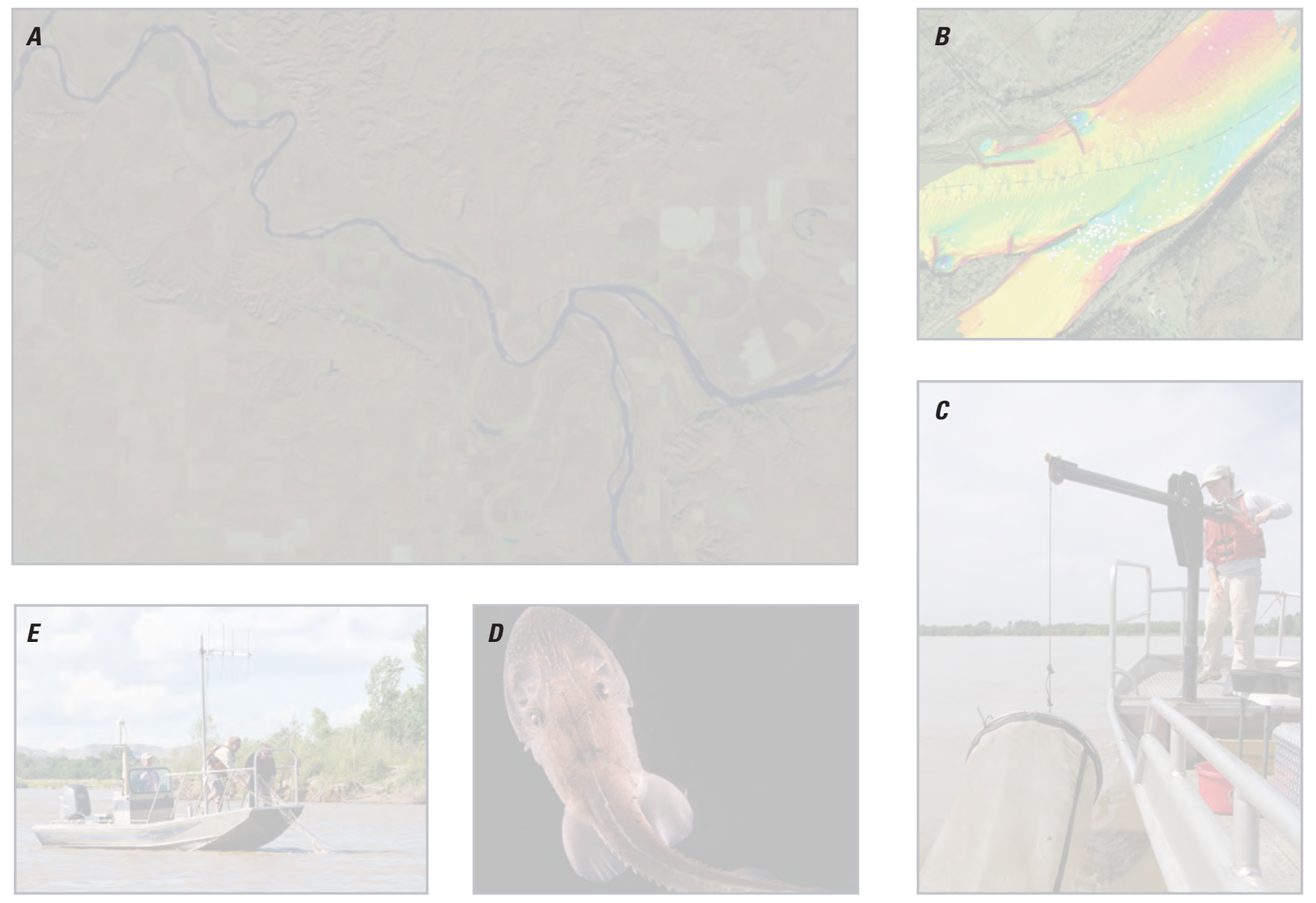

Cover photographs. A, LANDSAT TM image of the area around the confluence of the Missouri and Yellowstone Rivers on November 11, 2013. B, High resolution multibeam depth data and pallid sturgeon telemetry locations near the confluence of the Missouri and Osage Rivers. C, A researcher lowers an ichthyoplankton sampling net into the Missouri River near St. Charles, Missouri (photograph by David Combs, U.S. Geological Survey, May 2012). D, Microscopic image of sturgeon larva collected near the confluence of the Missouri and Mississippi Rivers during 2012 (photograph by Amy George, U.S. Geological Survey, July 2012). E, USGS biologists drift trammel nets on the Yellowstone River near Fairview, Montana to capture pallid sturgeon (photograph by Aaron DeLonay, U.S. Geological Survey, June 2012). 


\section{Ecological Requirements for Pallid Sturgeon Reproduction and Recruitment in the Missouri River-A Synthesis of Science, 2005 to 2012}

By Aaron J. DeLonay, Kimberly A. Chojnacki, Robert B. Jacobson, Janice L. Albers, Patrick J. Braaten, Edward A. Bulliner, Caroline M. Elliott, Susannah 0. Erwin, David B. Fuller, Justin D. Haas, Hallie L. A. Ladd, Gerald E. Mestl, Diana M. Papoulias, Mark. L. Wildhaber

Prepared in cooperation with the Missouri River Recovery-Integrated Science Program, U.S. Army Corps of Engineers, Yankton, South Dakota

Scientific Investigations Report 2015-5145 


\title{
U.S. Department of the Interior SALLY JEWELL, Secretary
}

\section{U.S. Geological Survey Suzette M. Kimball, Director}

\author{
U.S. Geological Survey, Reston, Virginia: 2016
}

For more information on the USGS - the Federal source for science about the Earth, its natural and living resources, natural hazards, and the environment—visit http://www.usgs.gov or call 1-888-ASK-USGS.

For an overview of USGS information products, including maps, imagery, and publications, visit http://www.usgs.gov/pubprod/.

Any use of trade, firm, or product names is for descriptive purposes only and does not imply endorsement by the U.S. Government.

Although this information product, for the most part, is in the public domain, it also may contain copyrighted materials as noted in the text. Permission to reproduce copyrighted items must be secured from the copyright owner.

Suggested citation:

DeLonay, A.J., Chojnacki, K.A., Jacobson, R.B., Albers, J.L., Braaten, P.J., Bulliner, E.A., Elliott, C.M., Erwin, S.O., Fuller, D.B., Haas, J.D., Ladd, H.L.A., Mestl, G.E., Papoulias, D.M., and Wildhaber, M.L., 2016, Ecological requirements for pallid sturgeon reproduction and recruitment in the Missouri River-A synthesis of science, 2005 to 2012: U.S. Geological Survey Scientific Investigations Report 2015-5145, 224 p. with appendixes, http://dx.doi.org/10.3133/sir20155145.

ISSN 2328-0328 (online) 


\section{Contents}

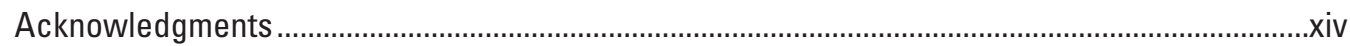

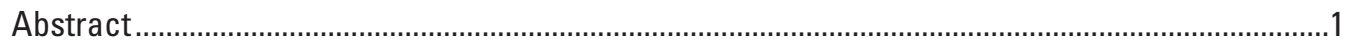

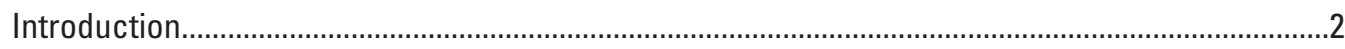

Scope and Objectives for This Report..................................................................................

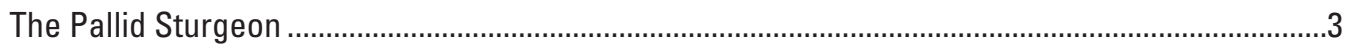

Geographic Range and Historic Abundance ...........................................................................

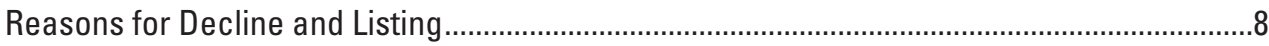

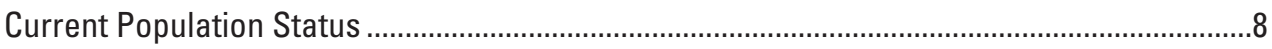

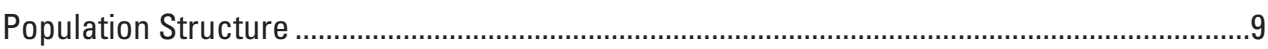

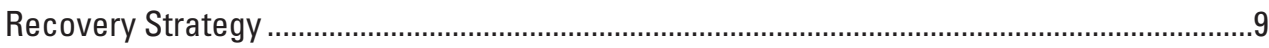

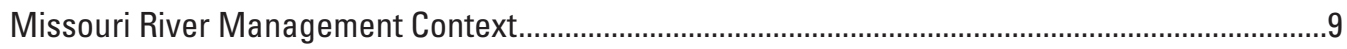

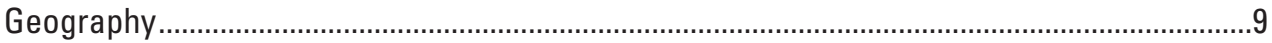

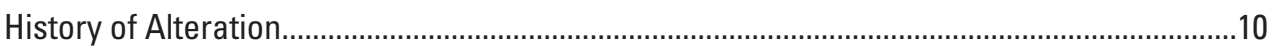

Missouri River Restoration Programs ......................................................................................13

The Comprehensive Sturgeon Research Project.............................................................................14

Comprehensive Sturgeon Research Project Approach ........................................................15

Pallid Sturgeon Conceptual Life-Stage Model ..........................................................................15

Sturgeon Habitat Variability within the Missouri River ....................................................................17

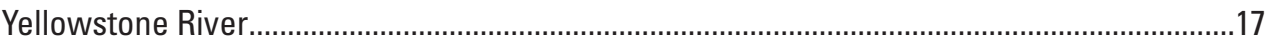

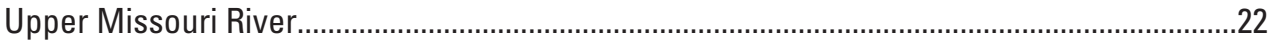

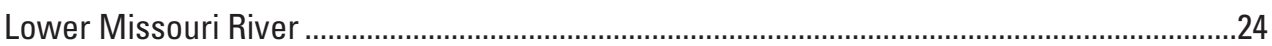

Comparative Physical Differences among Study Sections ......................................................34

Comparative Differences among Study Years .........................................................................35

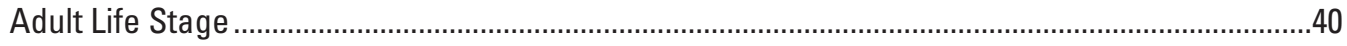

Habitat Requirements for Adult Reproductive Fish...................................................................40

Movement and Spawning Migration ................................................................................. 40

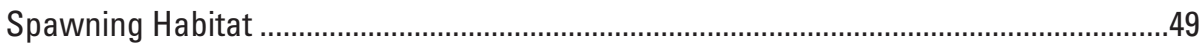

Long-Term Patterns of Habitat Use.................................................................................63

Connectivity and the Importance of Tributaries ...........................................................64

Spawning Periodicity and Readiness to Spawn .............................................................67

Contaminants in Reproductive Ecology of Pallid Sturgeon ............................................72

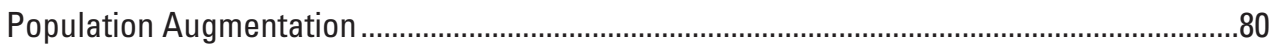

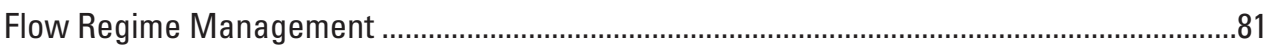

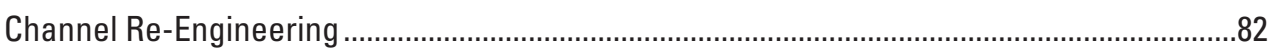

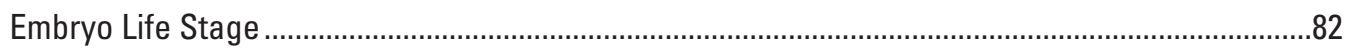

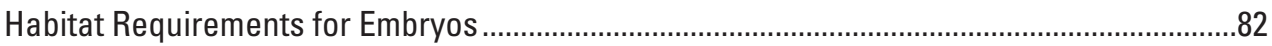

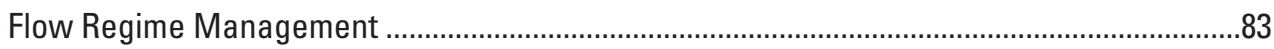

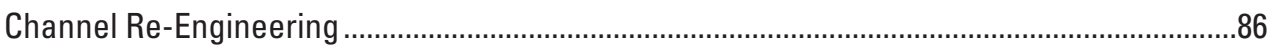

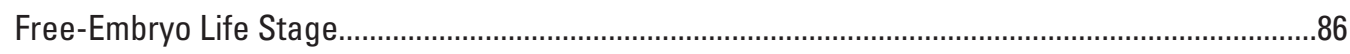

Habitat Requirements for Hatch to Free Embryo ....................................................................86

Immediate Drift and Interstitial Hiding Hypotheses ......................................................86

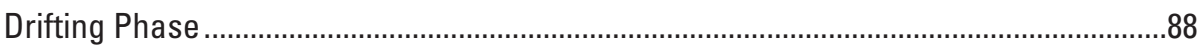

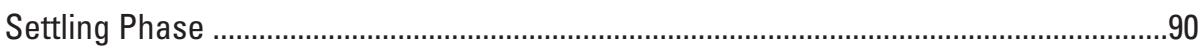




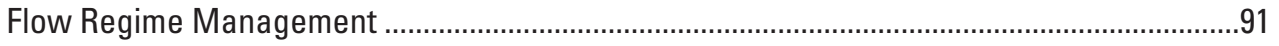

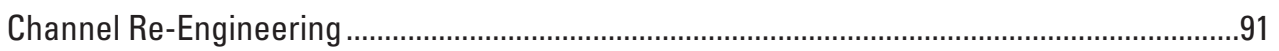

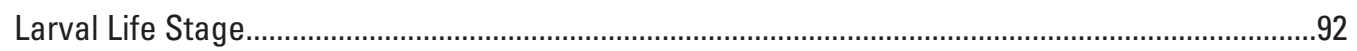

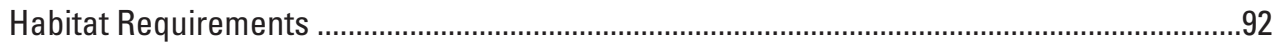

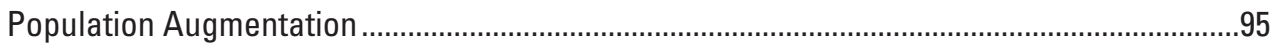

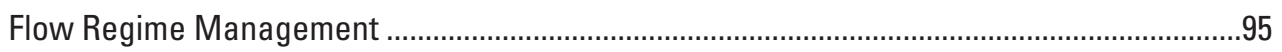

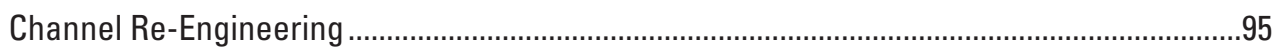

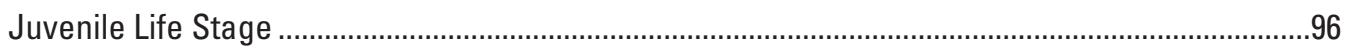

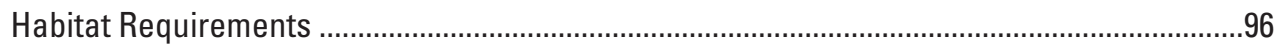

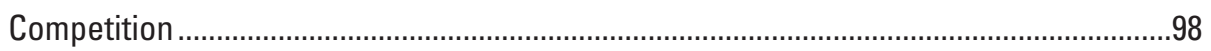

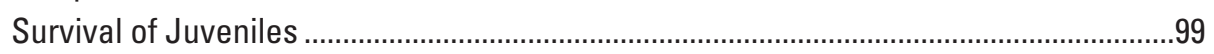

Population Augmentation Management ........................................................................99

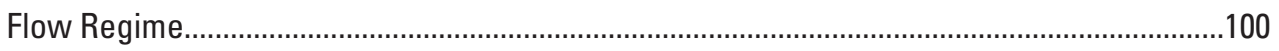

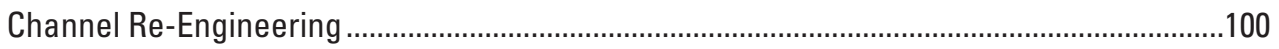

State of Scientific Understanding of Pallid Sturgeon Ecological Requirements and

Implications for River and Species Management ……....................................................100

Landscape Scale Genetics ........................................................................................100

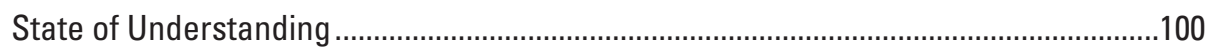

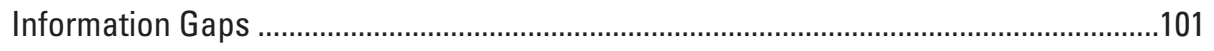

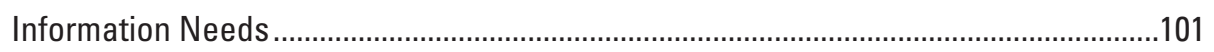

Reproductive Adults and the Spawning Population .......................................................101

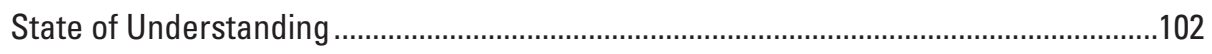

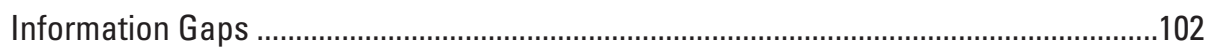

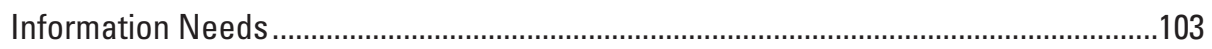

Early Life-Stage Limitations_Spawn, Fertilization, Hatch, Drift ............................................103

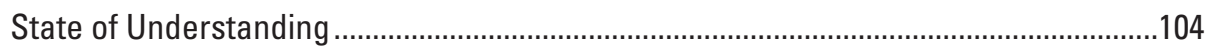

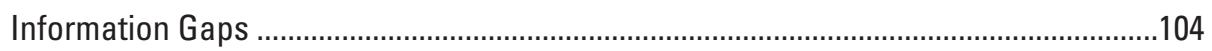

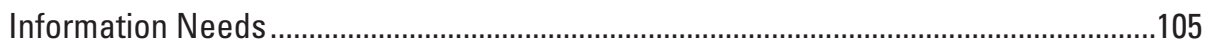

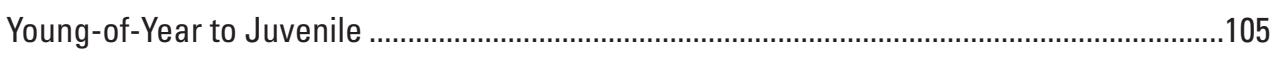

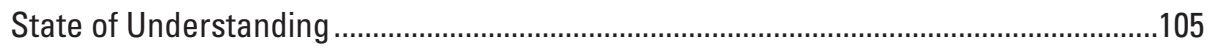

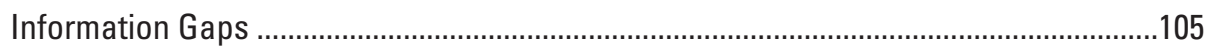

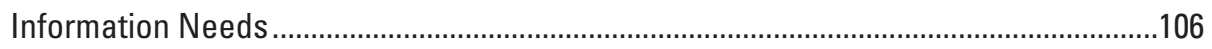

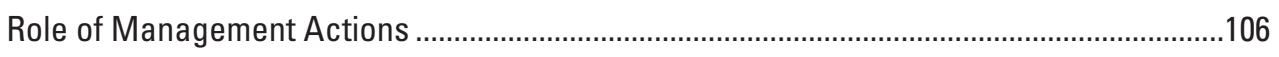

Population Augmentation ........................................................................................106

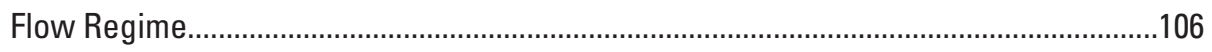

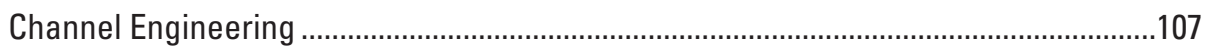

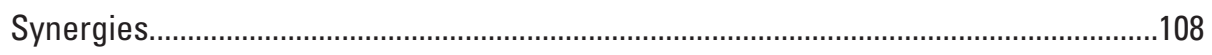

Strategies for Addressing Key Information Gaps..............................................................108

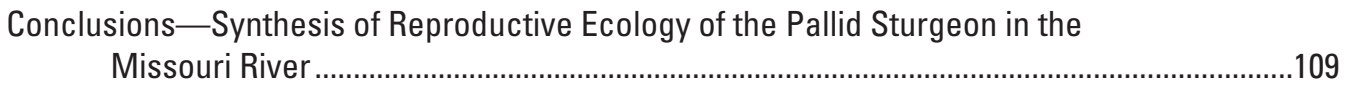

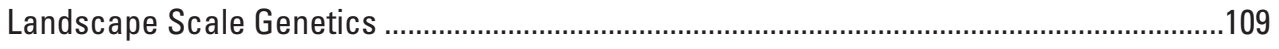

River Management and Population Dynamics ..................................................................109

Spawning Habitat and Cues..................................................................................110

Free-Embryo and Larval Dispersal, Retention, and Channel Morphology ....................111

Food Availability and Channel Morphology ..................................................................111

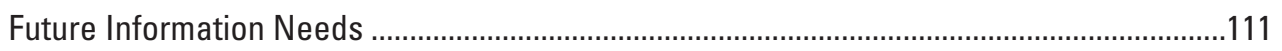


References Cited 111

Appendix 1. Reproductive Movements and Spawning, Lower Missouri River, 2012 .................126

Appendix 2. Examination of Pallid Sturgeon Use, Migrations, and Spawning in the Milk River and Missouri River downstream from Fort Peck Dam during 2012..................136

Appendix 3. Mapping and Quantifying Spawning and Larval Habitats, Lower Missouri and Yellowstone Rivers, 2012

Appendix 4. Migration Pathways, Habitat Use, and Reproduction of Pallid Sturgeon in the Yellowstone River, 2012

Appendix 5. Adult Pallid Sturgeon Blood Chemistry .

Appendix 6. Free-Embryo Drift Experiments in an Experimental Stream. 191

Appendix 7. Field Studies of Scaphirhynchus Sturgeon Embryo, Larvae, and Young-of-Year Dispersal, Distribution, and Habitat Use in the Lower Missouri River......198

Appendix 8. Influence of Channel Morphology and Flow Regime on Free-Embryo Drift of Pallid Sturgeon in the Lower Missouri River....

\section{Figures}

1. Maps showing historical and contemporary range of the pallid sturgeon

2. Map showing Pallid Sturgeon Recovery Management Units, Mississippi River drainage

3. Map showing Missouri River Basin and major tributary rivers with the Comprehensive Sturgeon Research Project study areas.

4. Maps showing geographical and geological context of pallid sturgeon recovery implementation.

5. Graphs showing variation in hydrologic alteration along the Missouri River.

6. Map showing modern channel overlain on historical channel map, Lower Missouri River at Hermann, Missouri

7. Graph showing cumulative number of peer-reviewed scientific articles and reports related to pallid sturgeon biology, ecology, and habitat, 1970-2012.

8. Diagram showing simplified conceptual life-stage model for pallid sturgeon ................16

9. Map showing location of Upper Missouri River and Yellowstone River study sections.

10. Map showing representative channel morphology in the Yellowstone study section

11. Box plots showing suspended sediment concentrations, Yellowstone River at Sidney, Montana, and Missouri River at Culbertson, Montana

12. Graphs showing channel and island width, number of channels, valley width, pallid sturgeon relocations and habitat data collection locations on the Lower Yellowstone River from the Powder River to the Missouri River, Montana and North Dakota .

13. Box plots showing turbidity distributions, Yellowstone River near mile 0.5 and Missouri River near Nohly, Montana, near mile 1,590

14. Box plots showing temperatures from 2001 to 2012, Upper Missouri River and Yellowstone River.....

15. Graph showing interquartile ranges of water temperatures by day of year on the Yellowstone and Upper Missouri River from daily means, 2001-2012.

16. Map showing representative channel morphology in the Upper Missouri River study section 
17. Graphs showing relation between air and water temperature near Fort Peck, Montana and Wolf Point, Montana, 63 river miles downstream

18. Map showing Lower Missouri River main stem and major tributary rivers within the Comprehensive Sturgeon Research Project study areas.

19. Maps showing examples of channel morphological variability in the Lower Missouri River ...

20. Graphs showing distributions of habitat variables by Lower Missouri River sections ..27

21. Maps showing natural potential spawning substrate in the Lower Missouri River .......28

22. Graphs showing channel width, flow constrictions, side channel locations, valley width and pallid sturgeon relocations and habitat data collection locations on the channelized Lower Missouri River from Sioux City, lowa, to St. Louis, Missouri .............30

23. Graphs showing relation between air and water temperature in the Missouri River near Yankton, South Dakota ...

24. Graphs showing plots of discharge from Gavins Point Dam and air and water temperature measured at Yankton, South Dakota, by year, 2006-12

25. Box plots showing seasonal water-temperature distributions at sites on the Lower Missouri River from 2005 to 2012

26. Graph showing example of water-quality variation at Hermann, Missouri, showing reciprocal relation of dissolved oxygen to discharge and turbidity .....

27. Graph showing annual runoff at four Missouri River system streamgages, 2005 to 2012

28. Hydrographs and thermographs for the Upper Missouri River and Yellowstone River, 2005-2012, water-temperature data were collected seasonally.............................36

29. Hydrographs and thermographs for the Lower Missouri River

30. Graph showing characteristic, single-apex migration pattern of female pallid sturgeon in the lower study section of the Lower Missouri River as illustrated by PLS08-009.

31. Graph showing characteristic complex or disrupted migration pattern in the upper study section of the Lower Missouri River as illustrated by PLS09-011

32. Graph showing fall migration followed by characteristic, single-apex spring migration pattern of female pallid sturgeon in the lower study section of the Lower Missouri River as illustrated by PLS11-007

33. Graphs showing migration distance of adult pallid sturgeon tracked during the spawn year from 2005 to 2012.

34. Box plots showing mean depth of pallid sturgeon collected from retrieved data storage tags.

35. Graphs showing pallid sturgeon migration habitat availability and use on the Lower Yellowstone and Lower Missouri River, 2010-12

36. Map showing spawning locations of pallid sturgeon in the Lower Missouri River, 2007-12

37. Examples of high-resolution bathymetry.

38. Bathymetric and acoustic Doppler current profiler velocity maps of reproductive female pallid sturgeon spawning sites mapped, 2008-12.

39. Graphs showing probable pallid sturgeon spawning habitat availability and use at the eight spawning locations mapped on the Lower Missouri River, 2008-12 ...........61

40. Three-dimensional reconstruction created from high-resolution multibeam sonar data of habitat used for spawning by female pallid sturgeon PLS09-007

41. Map showing density of pallid sturgeon telemetry locations in the Lower Missouri River in 2007-12, normalized for search effort 
42. Graph showing telemetry locations of male pallid sturgeon PLS08-006 in the Lower Missouri River illustrating annual seasonal migrations and a pattern of affinity for specific locations

43. Graph showing telemetry locations of male pallid sturgeon PLS07-020 in the Lower Missouri River illustrating annual seasonal migrations and a pattern of affinity for specific locations

44. Map showing telemetry locations of pallid sturgeon PLS08-012 at the confluence of the Platte and Missouri Rivers, Nebraska .68

45. Map showing telemetry locations of pallid sturgeon in the Osage River and at the confluence of the Osage and Missouri Rivers, Missouri

46. Graphs showing concentrations of reproductive hormones in a single female and male pallid sturgeon from the Lower Missouri River held at Neosho National Fish Hatchery.

47. Box plots showing annual changes in estradiol, testosterone, and 11-ketotestosterone measured as $\mathrm{pg} / \mathrm{mL}$ in reproductive female pallid sturgeon captured in the Lower Missouri River from 2005 to 2012

48. Box plots showing annual changes in estradiol, testosterone, and 11-ketotestosterone measured as $\mathrm{pg} / \mathrm{mL}$ in reproductive male pallid sturgeon captured in the Lower Missouri River from 2005 to 2012

49. Graphs showing mean reproductive hormone concentrations in noncycling adult female and male pallid sturgeon held at Neosho National Fish Hatchery...

50. Box plots showing annual changes in estradiol, testosterone, and 11-ketotestosterone measured as $\mathrm{pg} / \mathrm{mL}$ in nonreproductive female pallid sturgeon captured in the Lower Missouri River from 2005 to 2012

51. Box plots showing annual changes in estradiol, testosterone, and 11-ketotestosterone measured as $\mathrm{pg} / \mathrm{mL}$ in nonreproductive male pallid sturgeon captured in the Lower Missouri River from 2005 to 2012

52. Graphs showing concentrations of reproductive hormones in a non-ovulating and an atretic female pallid sturgeon from the Missouri River, held at the Neosho National Fish Hatchery

53. Graphs showing relation between reproductive readiness in female pallid sturgeon from the Missouri River, hydrograph, and temperature for 3 years 2010, 2011, 2013

54. Graph showing readiness to spawn in female Missouri River pallid sturgeon, as the ratio of 11-ketotestosterone:17-beta estradiol, to discharge and temperature in 2011

55. Graph showing readiness to spawn in female Missouri River pallid sturgeon, as the ratio of 11-ketotestosterone:17-beta estradiol, to discharge and temperature in 2012 .......

56. Box plots showing plasma vitellogenin concentrations in male pallid sturgeon from below river mile 300 and above river mile 500 in the Missouri River compared to plasma vitellogenin in female pallid sturgeon.

57. Graphs showing total number of fish counted per day passing a fixed point in the stream tank in trial 1 and trial 2.

58. Graphs showing probability density functions of velocity data collected using acoustic Doppler current profiler at spawning location documented on April 28, 2010, near river mile 202

59. Graphs showing one-dimensional advection-dispersion models of free-embryo drift 
60. Box plots showing longitudinal dispersion coefficients calculated for the Lower Missouri River from acoustic Doppler current profiler data

61. Map showing multibeam bathymetry near river mile 162 and U.S. Fish and Wildlife Service age-0 sturgeon sampling trawl endpoints

62. Graphs showing mean and standard deviation of riverine habitat characteristics when pallid sturgeon were captured in the Pallid Sturgeon Population Assessment Program from 2003 to 2010

63. Graphs showing proportion of time fish were active in clay and sand treatments with food.

\section{Appendix Figures}

1-1. Map showing Comprehensive Sturgeon Research Project study sections and pallid sturgeon hatchery locations within the Lower Missouri River Basin.

1-2. Telemetry and archival tag data of female pallid sturgeon PLS11-007

1-3. Telemetry and archival tag data of female pallid sturgeon PLS11-019

1-4. Telemetry and archival tag data of female pallid sturgeon PLS09-011

1-5. Telemetry and archival tag data of female pallid sturgeon PLS10-023.

1-6. Telemetry and archival tag data of female pallid sturgeon PLS10-029

2-1. Map showing location of Upper Missouri River and Yellowstone River study sections

2-2. Graph showing percent of telemetered adult pallid sturgeon located in the Missouri River above the confluence with the Yellowstone River, 2005-12

3-1. Map showing depth and depth-averaged velocity for probable spawning site, and location of reproductive female pallid sturgeon PLS11-007 near Missouri River mile 322.

3-2. Map showing depth and depth-averaged velocity for probable spawning site, and location of reproductive female pallid sturgeon PLS09-011 near Missouri River mile 580.

3-3. Map showing depth-averaged velocity and pallid sturgeon telemetry locations for code 52 near Yellowstone River mile 73.

3-4. Map showing flow characteristics of free-embryo pallid sturgeon sampling locations near Missouri River mile 33.3

$3-5$. Telemetry locations and multibeam bathymetry showing depth at locations used by male pallid sturgeon PLS08-006 from 2008-12 near river miles 638.5 and 582.5

4-1. Graph showing percent of telemetered pallid sturgeon detected, discharge, and mean daily water temperature of the Yellowstone River, April-August 2012

4-2. Graphs showing data for five telemetered pallid sturgeon migrating to Intake Dam on the Yellowstone River, April-August 2012

4-3. Graphs showing locations of telemetered male pallid sturgeon exhibiting migrations in the Yellowstone River, April-August 2012

4-4. Graphs showing mean daily locations of telemetered female pallid sturgeon exhibiting migrations in the Yellowstone River and Missouri River upstream from the confluence with the Yellowstone River, April-August, 2012.

4-5. Map showing migration pathway of male pallid sturgeon code 52 in the Yellowstone River approaching Intake Dam, June 9, 2012 
4-6. Map showing migration pathways of male pallid sturgeon codes 52 and 76 in the Yellowstone River approaching Intake Dam, June 9 and 22, 2012.

4-7. Map showing pallid sturgeon code 42 telemetry locations in the Yellowstone River, April 30, 2012 .160

4-8. Map showing pallid sturgeon code 16 telemetry locations in the Yellowstone River, May 17, 2012 161

4-9. Map showing pallid sturgeon code 51 telemetry locations in the Yellowstone River, May 21, 2012

4-10. Map showing pallid sturgeon code 92 telemetry locations in the Yellowstone River, May 21, 2012

4-11. Map showing pallid sturgeon codes 36 and 37 telemetry locations in the Yellowstone River, May 22, 2012

4-12. Map showing pallid sturgeon code 36 telemetry locations in the Yellowstone River, May 23, 2012

4-13. Map showing pallid sturgeon code 72 telemetry locations in the Yellowstone River, May 23, 2012 .166

4-14. Map showing pallid sturgeon code 69 telemetry locations in the Yellowstone River, June 5-6, 2012

4-15. Map showing pallid sturgeon code 30 telemetry locations in the Yellowstone River, June 6, 2012

4-16. Map showing pallid sturgeon code 69 telemetry locations in the Yellowstone River, June 7, 2012

4-17. Map showing pallid sturgeon code 69 telemetry locations in the Yellowstone River, June 8, 2012

4-18. Map showing pallid sturgeon code 30 telemetry locations in the Yellowstone River, June 13, 2012

4-19. Map showing pallid sturgeon code 83 telemetry locations in the Yellowstone River, April 10-June 21, 2012. 172

4-20. Graphs showing depths and depth-averaged velocities used by and available to migrating pallid sturgeon, Yellowstone River, 2012

4-21. Migration pathway, depth, and velocity of male pallid sturgeon codes 51 and 72 in the Yellowstone River, river mile 29.5, May 21 and 23, 2012

4-22. Graphs showing discharge, water temperature, and locations of gravid female pallid sturgeon in the Yellowstone River, May-August 2012

4-23. Map showing spawn location of female pallid sturgeon code 30 in the lower Yellowstone River, June 19-20, 2012.

5-1. Graph showing mean plasma cholesterol concentrations in pallid sturgeon ...............186

5-2. Graph showing mean plasma glucose concentrations in pallid sturgeon .....................186

5-3. Graph showing mean plasma lactate concentrations in pallid sturgeon .......................187

5-4. Graph showing mean plasma lipase concentrations in pallid sturgeon .......................188

5-5. Graph showing mean plasma total protein concentrations in pallid sturgeon ..............188

5-6. Graph showing mean plasma total triglyceride concentrations in pallid sturgeon ......189

6-1. Diagram of the oval stream tank used in the free-embryo drift experiments ...............191

6-2. Graph showing relation between days post-hatch and cumulative thermal units calculated for trials 1-4

6-3. Graph showing percent mortality of pallid sturgeon free embryos per days post-hatch 
6-4. Graph showing daily observations of free embryos drifting past a fixed point normalized to the number of free embryos in the stream, $0-12$ days post-hatch..........196

$6-5$. Graph showing frequency of free embryos near the pool ledge and dike eddy as percent of the total number of observations during each trial.

6-6. Graph showing mean number of drifting free embryos and water column positions recorded at a fixed point per days post-hatch

7-1. Maps showing free-embryo sampling locations in the Lower Missouri River, near river mile 33.3

7-2. Graph showing length of sturgeon free embryos and larvae, and mean hourly temperature and discharge from the U.S. Geological Survey streamgage near St. Charles, Missouri, 2012

7-3. Graph showing length of paddlefish free embryos and larvae, and mean hourly temperature and discharge from the U.S. Geological Survey streamgage near St. Charles, Missouri, 2012

8-1. Map showing Missouri River segments, U.S. Geological Survey streamgages, and velocity measurement sites used for calculation of longitudinal dispersion coefficients

8-2. Boxplots showing dispersion coefficients calculated for velocity measurement sites along the Lower Missouri River

8-3. Graphs showing downstream transport and dispersion of passively drifting free embryos using the one-dimensional advection-dispersion equation.

8-4. Graph showing relation between free embryo downstream drift distance and concentration of free embryos released at an arbitrary upstream point.

8-5. Graphs showing change in the longitudinal dispersion coefficient with discharge.....222

\section{Tables}

1. Pallid sturgeon life stage definitions used in this report

2. Probable spawning locations of telemetry tracked reproductive female pallid sturgeon, 2007-12

3. Habitat mapping data collected for reproductive pallid sturgeon in migration study from 2010-12.

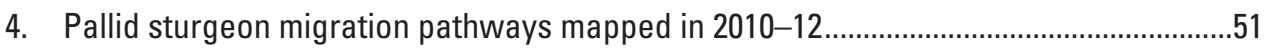

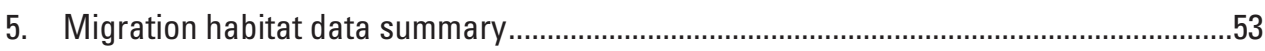

6. Spawning dates and discharges, 2008-12 ….....................................................55

7. Summary of water temperature, discharge, substrate, depth, depth-averaged velocity, and turbidity at pallid sturgeon spawning sites in the Lower Missouri River, 2008-12

8. Substrate at spawning sites interpreted from sidescan sonar and multibeam bathymetry data, 2010-12

9. Measures of sperm quality for milt collected from captive and wild pallid sturgeon during 2011

10. Minimum and maximum hourly thermal units for Scaphirhynchus sturgeon egg development and minimum and maximum hours to completion of each stage for 18-22 degrees Celsius

11. Daily mortalities of pallid sturgeon free embryos in an artificial stream tank with an average velocity of 14 centimeters per second from four separate experimental trials. 
12. Effect of day post-hatch cumulative thermal units of first feeding on survival of free-embryo pallid sturgeon reared at constant water temperature and water temperature fluctuating in accordance with modeled lower Missouri River temperatures during drift

\section{Appendix Tables}

2-1. Sampling dates and paddlefish, shovelnose sturgeon, and pallid sturgeon free embryos and larvae collected in the Missouri River near Wolf Point, Montana, in 2012

2-2. Total catch of fish by the benthic trawl in the Missouri River above the confluence of the Yellowstone River, Missouri River below the confluence of the Yellowstone River, and total catch from July 24 to September 11, 2012.

2-3. Catch of shovelnose sturgeon in standard trawls and targeted trawls in the Missouri River during 2012 by date.

3-1. Sturgeon habitat mapping 2012 data collection effort on the Missouri and Yellowstone Rivers

5-1. Plasma chemistry for pallid sturgeon according to sex, reproductive state, and whether they were captured from the wild and held in captivity for less than 1 month or held captive in the hatchery environment.

5-2. Blood chemistry of Missouri River pallid sturgeon...

6-1. Mean, standard deviation, and range of velocity in centimeters per second at seven locations in three trials of the artificial stream channel

7-1. Summary of sturgeon and paddlefish free embryo and larvae collection efforts in the Missouri River near St. Charles, Missouri, during 2012.

7-2. Summary of free embryo and larval sturgeon and paddlefish collected in the Missouri River at station 1

7-3. Summary of free embryo and larval sturgeon and paddlefish collected in the Missouri River at station 2.

7-4. Summary of free embryo and larval sturgeon and paddlefish collected in the Missouri River at station 3.

7-5. Summary of free embryo and larval sturgeon and paddlefish collected in the Missouri River at station 4.

7-6. Summary of free embryo and larval sturgeon and paddlefish collected in the Missouri River at station 5 .

7-7. Summary of free embryo and larval sturgeon and paddlefish collected in the Missouri River at station 6.

7-8. Summary of free embryo and larval sturgeon and paddlefish collected in the Missouri River at station 7.

7-9. Mean density, number per 100 cubic meters, of sturgeon free embryos and larvae collected in the Missouri River per sampling day.

7-10. Mean density, number per 100 cubic meters, of paddlefish free embryos and larvae collected in the Missouri River per sampling day.

8-1. Characteristics of Missouri River sites used to obtain data for estimating dispersion coefficients. .218

8-2. Descriptive statistics for longitudinal dispersion coefficient calculated for each measurement site in the Missouri River. 


\section{Conversion Factors}

Inch/Pound to SI

\begin{tabular}{lcc}
\hline & Multiply & To obtain \\
\hline & Length & \\
\hline mile $(\mathrm{mi})$ & 1.609 & kilometer $(\mathrm{km})$ \\
\hline \multicolumn{2}{c}{ Flow rate } \\
\hline cubic foot per second $\left(\mathrm{ft}^{3} / \mathrm{s}\right)$ & 0.02832 & cubic meter per second $\left(\mathrm{m}^{3} / \mathrm{s}\right)$ \\
\hline
\end{tabular}

SI to Inch/Pound

\begin{tabular}{|c|c|c|}
\hline Multiply & By & To obtain \\
\hline \multicolumn{3}{|c|}{ Length } \\
\hline micrometer $(\mu \mathrm{m})$ & 0.0000397 & inch (in.) \\
\hline millimeter (mm) & 0.03937 & inch (in.) \\
\hline centimeter $(\mathrm{cm})$ & 0.3937 & inch (in.) \\
\hline meter (m) & 3.281 & foot $(\mathrm{ft})$ \\
\hline kilometer (km) & 0.6214 & mile (mi) \\
\hline meter (m) & 1.094 & yard (yd) \\
\hline \multicolumn{3}{|c|}{ Area } \\
\hline square meter $\left(\mathrm{m}^{2}\right)$ & 10.76 & square foot $\left(\mathrm{ft}^{2}\right)$ \\
\hline hectare (ha) & 0.003861 & square mile $\left(\mathrm{mi}^{2}\right)$ \\
\hline square kilometer $\left(\mathrm{km}^{2}\right)$ & 0.3861 & square mile $\left(\mathrm{mi}^{2}\right)$ \\
\hline \multicolumn{3}{|c|}{ Volume } \\
\hline cubic meter $\left(\mathrm{m}^{3}\right)$ & 264.2 & gallon (gal) \\
\hline cubic meter $\left(\mathrm{m}^{3}\right)$ & 35.31 & cubic foot $\left(\mathrm{ft}^{3}\right)$ \\
\hline cubic meter $\left(\mathrm{m}^{3}\right)$ & 1.308 & cubic yard $\left(\mathrm{yd}^{3}\right)$ \\
\hline \multicolumn{3}{|c|}{ Flow rate } \\
\hline meter per second $(\mathrm{m} / \mathrm{s})$ & 3.281 & foot per second (ft/s) \\
\hline cubic meter per second $\left(\mathrm{m}^{3} / \mathrm{s}\right)$ & 35.31 & cubic foot per second $\left(\mathrm{ft}^{3} / \mathrm{s}\right)$ \\
\hline \multicolumn{3}{|c|}{ Mass } \\
\hline $\operatorname{gram}(\mathrm{g})$ & 0.03527 & ounce, avoirdupois (oz) \\
\hline kilogram (kg) & 2.205 & pound avoirdupois (lb) \\
\hline
\end{tabular}

To communicate effectively with stakeholders, managers, and other scientists working on the Lower Missouri River, this report uses a mix of U.S. customary units and International System of Units (SI) units of measure. Distances along the Missouri River are given in river miles upstream from the confluence with the Mississippi River at St. Louis, Missouri, as measured by the U.S. Army Corps of Engineers in 1960. Discharges are provided in the customary units of cubic feet per second. Reach-scale hydraulic variables—depth and velocity-are given in SI units of meters and meters per second.

Temperature in degrees Celsius $\left({ }^{\circ} \mathrm{C}\right)$ may be converted to degrees Fahrenheit $\left({ }^{\circ} \mathrm{F}\right)$ as follows: ${ }^{\circ} \mathrm{F}=\left(1.8 x^{\circ} \mathrm{C}\right)+32$ 


\section{Datums}

Vertical coordinate information is referenced to the North American Vertical Datum of 1988 (NAVD 88).

Horizontal coordinate information is referenced to the World Geodetic System of 1984 (WGS 84). 


\section{Acknowledgments}

This report benefitted from technical reviews by Michael Parsley, Dr. Brenda Pracheil, and Dr. Hal Schramm. Funding for this research was provided by the U.S. Army Corps of Engineers, Missouri River Recovery - Integrated Science Program and the U.S. Geological Survey. The authors gratefully acknowledge the collaboration and cooperation of the U.S. Fish and Wildlife Service, Columbia Fish and Wildlife Conservation Office; U.S. Fish and Wildlife Service, Gavins Point and Neosho National Fish Hatcheries; Nebraska Game and Parks Commission; South Dakota Game, Fish, and Parks; and the Missouri Department of Conservation. 


\title{
Ecological Requirements for Pallid Sturgeon Reproduction and Recruitment in the Missouri River-A Synthesis of Science, 2005 to 2012
}

\author{
By Aaron J. DeLonay, ${ }^{1}$ Kimberly A. Chojnacki, ${ }^{1}$ Robert B. Jacobson, ${ }^{1}$ Janice L. Albers, ${ }^{1}$ Patrick J. Braaten, ${ }^{1}$ \\ Edward A. Bulliner, ${ }^{1}$ Caroline M. Elliott, ${ }^{1}$ Susannah O. Erwin, ${ }^{1}$ David B. Fuller, ${ }^{2}$ Justin D. Haas, ${ }^{3}$ \\ Hallie L. A. Ladd, ${ }^{4}$ Gerald E. Mestl, ${ }^{3}$ Diana M. Papoulias, ${ }^{1}$ and Mark. L. Wildhaber ${ }^{1}$
}

\section{Abstract}

This report is intended to synthesize the state of the scientific understanding of pallid sturgeon ecological requirements to provide recommendations for future science directions and context for Missouri River restoration and management decisions. Recruitment of pallid sturgeon has been low to non-existent throughout its range. Emerging understanding of the genetic structure of pallid sturgeon populations sets a broad framework for species and river management decisions, including decisions about managing the future genetic diversity of the species, but also decisions about where and what type of river restoration actions will be effective for subpopulations of this highly migratory species. Adult pallid sturgeon may migrate hundreds of kilometers $(\mathrm{km})$ to spawn and their progeny may disperse even greater distances downstream as drifting free embryos. As a result of their complex life history pallid sturgeon naturally exploit a wide range of habitats during their life cycles. The construction of dams and reservoirs has fragmented habitats and may have shifted Missouri River subpopulations downstream. Research has not identified one primary biological or ecological constraint that appears to limit populations of the pallid sturgeon. With the present (2013) state of knowledge many life stages and life-stage transitions cannot be ruled out as contributing to recruitment failure.

Biological opinions in 2000 (and amended in 2003) presented the dominant hypotheses for recruitment failure that existed at that time. Emphasis was on the role of the flow regime, specifically spring flow pulses ("spring rises"), to condition spawning substrate and cue reproductive aggregations and migrations, and on low flows and additional slow, shallow-water area to serve as rearing habitat for age- 0 to juvenile pallid sturgeon. Studies on spawning habitat dynamics have

\footnotetext{
${ }^{1}$ U.S. Geological Survey.

${ }^{2}$ Montana Fish, Wildlife and Parks.

${ }^{3}$ Nebraska Game and Parks Commission.

${ }^{4}$ Five Rivers Services, LLC.
}

documented that habitat patches selected for spawning by fish in the Lower Missouri River (Missouri River downstream from Gavins Point Dam to the confluence with the Mississippi River) are dominantly on outside, revetted bends in the deepest, fastest, and most turbulent water. Studies in more natural habitat on the Yellowstone River have documented spawning in convergent flow in the middle of the channel on discrete patches of gravel within a sand-dominated channel, an arrangement that may be more effective in attracting aggregations of reproductive fish compared to the nearly continuous revetment on the Lower Missouri River. Pallid sturgeon spawn in the spring and early summer during periods of increasing day length. Water temperature consistently exerts a threshold effect for spawning at $16-18{ }^{\circ} \mathrm{C}$. In addition, the role of water temperature is indicated by pauses and reversals in upstream migrations that have been associated with cold weather fronts that create a transient decrease in water temperature. From 2005 to 2012 on the Lower Missouri River, no obvious relations between flow pulses and fish movements and spawning behaviors have been apparent. However, pallid sturgeon tracking at the Upper Missouri-Yellowstone confluence indicates that in most years, most telemetered pallid sturgeon migrate out of the Missouri River and into the Yellowstone River in the June-July timeframe in association with the spring pulse. This pattern was disrupted in 2011 when a high flow pulse with warm temperatures and high turbidity emanated from the Milk River, followed by record releases from Fort Peck Dam, and 36-39 percent of the telemetered population migrated up the Upper Missouri. This result supports the hypothesis that sufficiently large flow pulses may trigger migration and aggregation but it is not clear that functional pulses are within reservoir management authorities. Notably, a pallid sturgeon free embryo was captured on the Upper Missouri River in 2011 and another single, genetically confirmed embryo was captured on the Yellowstone River in 2012.

Research on free-embryo drift has indicated the potential for hundreds of miles of downstream dispersal. Lack of distance to accommodate the extended downstream dispersal period of free embryos on the Upper Missouri and 
Yellowstone Rivers is the predominant hypothesis for recruitment failure in the upper basin. Long drift distances in the Lower Missouri River may be responsible for shifting Lower Missouri River sub-populations further into the Middle Mississippi River. Physical understanding of drift processes indicates that mean velocities could be slowed through decreased discharges or increased channel hydraulic radius (width and topographic diversity) to reduce free-embryo dispersal distances. In addition, the probability that free embryos are transported into and retained in channel-margin habitats is theoretically amenable to channel re-engineering that would increase cross-channel secondary currents in bends or channel expansions. Considerable uncertainty persists, however, about whether extended drift of Lower Missouri River larvae is responsible for recruitment failure. If drift distance is limiting, it is important to discern whether it would be advisable to retain larvae within the Missouri River, and where along the river restoration projects should be placed to optimize survival and growth of age- 0 and juvenile sturgeon.

Longitudinal differences in female pallid sturgeon fecundity lend support to the hypothesis that recruitment failure may be due, in part, to fish having insufficient nutrition to produce the numbers of gametes needed for the population to grow, perhaps because of simultaneous declines in prey-fish populations and their habitats. Establishing a chain of causality from habitat decline, to prey-fish populations, to sturgeon diets, to sturgeon fecundity, and to pallid sturgeon population growth presents a considerable scientific challenge.

In addition to the dominant hypotheses relating pallid sturgeon populations to changes in flow regime and channel morphology, other factors have been identified that might be sources of stress and contribute to recruitment failure. Among these are water quality and contaminants. Ambient waterquality monitoring on the Missouri River has demonstrated summer episodes when dissolved oxygen dips below 5 milligrams per liter, a threshold that may be stressful especially to age- 0 and juvenile sturgeon. Documented cases of intersex in shovelnose and pallid sturgeon indicate that agricultural and municipal sources of endocrine disrupting chemicals also may have a role in pallid sturgeon recruitment failure.

Scientific understanding of the ecological requirements of pallid sturgeon has increased almost exponentially in the last two decades, and efforts are now turning from understanding fundamental biology of the species to quantifying how population dynamics relate to potential management actions. Progress in developing the science needed to inform management actions on the Missouri River may benefit from continuation of monitoring of reproductive cycles, reproductive movements, growth, and survival of telemetry tagged adults, increased emphasis on focused, complementary field and laboratory studies of factors influencing early life history, implementation of studies to resolve the role of food limitations in growth, survival, and reproductive condition, and implementation of studies designed specifically to parameterize models linking management to populations.

\section{Introduction}

The Comprehensive Sturgeon Research Project (CSRP) is designed to improve fundamental understanding of the reproductive ecology and population dynamics of the pallid sturgeon (Scaphirhynchus albus) and to facilitate application of scientific understanding to restoration and management of the species in the Missouri River system. This project is an interagency collaboration of the U.S. Geological Survey, Nebraska Game and Parks Commission (NGPC), U.S. Fish and Wildlife Service (USFWS), and Montana Fish, Wildlife and Parks (MTFWP), and is funded through the U.S. Army Corps of Engineers' (USACE) Missouri River RecoveryIntegrated Science Program. Specific objectives include the following:

- Determine movement, habitat use, and reproductive behavior of pallid sturgeon;

- Understand reproductive physiology of pallid sturgeon and relations to environmental conditions;

- Determine origin, transport, and fate of drifting pallid sturgeon larvae and evaluate bottlenecks for recruitment of early life stages;

- Quantify availability and dynamics of aquatic habitats needed by pallid sturgeon for all life stages;

- Integrate what is known about fish distributions into models of survival, bioenergetics, and population viability;

- Manage databases, integrate understanding, and publish information in the public domain relevant to management decisions; and

- Engage with stakeholders and managers to deliver actionable scientific information to the adaptive management process.

Management actions to increase reproductive success and survival of pallid sturgeon in the Lower Missouri River (Missouri River downstream from Gavins Point Dam to the confluence with the Mississippi River) have been focused on naturalizing the flow regime, re-engineering channel morphology, and propagation (U.S. Fish and Wildlife Service, 2003).

Recently (2015), management questions also have emphasized the possibility of constructing enhanced fish passage on the Yellowstone River. These management questions provide the context for prioritizing CSRP science efforts.

\section{Scope and Objectives for This Report}

The objective of this report is to synthesize research findings of the CSRP within the context of what is known about the ecological requirements of pallid sturgeon and their reproductive biology. The underlying goal is to clarify knowns 
and unknowns and to illustrate how the science may inform management decisions. In keeping with USGS policies, we do not make species- or river-management recommendations; rather, our intent is to synthesize available information in the context of specific management questions so managers and stakeholders have a better understanding of available options. The intended audience includes research scientists, resource managers, planners, and decision makers.

The science that underpins our understanding of pallid sturgeon biology and ecology is carried out in the broader setting of a highly altered, intensively managed large river ecosystem. The pallid sturgeon is a rare and complex species that relies on a single, continuous, longitudinal thread of river to complete its life history; it exists, and can be recovered, nowhere else. For this reason, we have synthesized information on the decline and recovery of the pallid sturgeon, the alterations and management constraints that structure the contemporary Missouri River, and the existing physical habitat template upon which pallid sturgeon restoration and recovery actions are implemented. Because the CSRP study design includes development of information from geographic comparisons among the Upper Missouri, Yellowstone, and Lower Missouri Rivers, this discussion provides critical context for the application of the scientific findings presented, and aids in clarifying future science directions and management opportunities.

In this synthesis we present discussion of pallid sturgeon research completed by CSRP, agency collaborators, and other scientists from 2005 through 2012. Results from specific studies completed in 2012 are discussed within the main text or presented in appendixes 1-8. We organize the analysis of the information by breaking scientific knowledge down by life stages (table 1), presenting what is known and unknown about those life stages, and then discussing reproduction, growth, and survival in terms of the three main management actions that have been under consideration on the Missouri River: population augmentation, flow-regime management, and channel re-engineering.

\section{The Pallid Sturgeon}

The pallid sturgeon was first brought to the attention of biologists by commercial fishermen near the confluence of the Missouri and Mississippi Rivers in the first decade of the twentieth century (Forbes and Richardson, 1905). Known locally as the "white sturgeon," the pallid sturgeon was uncommon in catches from the Mississippi River; perhaps as few as 1 in 500 sturgeon caught. Forbes and Richardson (1905) speculated that the species had yet to be described because so few specimens of Scaphirhynchus sturgeon had been examined by Ichthyologists within the species range (fig. 1). The new species of sturgeon (Parascaphirhynchus albus) was differentiated by Forbes and Richardson (1905) from the more common shovelnose sturgeon (Scaphirhynchus platorynchus) based on the examination of nine specimens, all male, collected on the Mississippi River near the mouth of the Illinois River at Grafton, Illinois (not shown). The distinctiveness of the pallid sturgeon led Forbes and Richardson (1905) to assign it to a separate genus. Once described, the species received little attention from biologists for the next half century beyond minor disagreements and refinements concerning the most appropriate taxonomic assignment and nomenclature for the new species. Bailey and Cross (1954) reviewed and reaffirmed the distinctiveness of the pallid sturgeon and assigned the shovelnose sturgeon and pallid sturgeon as species within the genus, Scaphirhynchus. Bailey and Allum (1962) revised the specific name, Scaphirhynchus album, to the currently (2015) accepted designation, Scaphirhynchus albus.

Bailey (1954) differentiated the two sympatric species using meristics and morphometric ratios from a small number of specimens collected across the range of the species. Until the recent development of more effective mitochondrial DNA analyses (Schrey and others, 2007), identification of juvenile and adult pallid sturgeon had been largely dependent on metrics developed by Bailey and Cross (1954), or indices and analyses combining these metrics with others (Carlson and others, 1985; Keenlyne and others, 1994; Sheehan and others, 1999; Wills and others, 2002; Kuhajda and others, 2005). While morphometric and genetic analyses have proven to be reasonably effective in discriminating pallid and shovelnose sturgeon in the Missouri River and the Middle Mississippi River (Mississippi River from the confluence with the Missouri River downstream to the confluence with the Ohio River; fig. 2) (Schrey and others, 2007), concordance between morphological and genetic discrimination of the two species on the Lower Mississippi River (Mississippi River downstream of the Ohio River confluence; fig. 2) has proven to be elusive due to complications arising from allometric growth, intraspecific geographic variation in size and age at maturity, potentially pervasive hybridization, and the absence of adequate genetic baseline data (Murphy and others, 2007; Schrey and Heist, 2007; Schrey and others, 2011).

In contrast to the dark brown to grey shovelnose sturgeon, pallid sturgeon are more commonly pale or white to light grey, with coloration darkening in less turbid waters. Pallid sturgeon have proportionally larger mouth widths and smaller eyes than shovelnose sturgeon and lack the scutes or bony plates that fully armor the ventral surface of shovelnose's abdomen (Bailey and Cross, 1954; Pflieger, 1997). Pallid sturgeon are further distinguished from shovelnose sturgeon based on the relative length and placement of the four fleshy barbels on the ventral surface of the elongated spade-shaped rostrum, anterior to their protrusible mouth. The inner barbels are reduced in pallid sturgeon. The outside barbels are 1.6 times the length of the inner barbels, or longer. The outside barbels are generally more posteriorly placed than the inner barbels resulting in a concave arrangement along a line parallel to the mouth. Barbels of the shovelnose sturgeon are more or less arranged in a row, with inner and outer barbels more similar 
Table 1. Pallid sturgeon life-stage definitions used in this report. Stages have been established following accepted sources. Transitions from embryo, free embryo, larval, juvenile life history stages are one way, whereas adult life history stages (pre-spawning adult, spawning adult, post-spawning adult, recrudescent adult) occur multiple times. Gonadal stages described from Wildhaber and others (2007b).

$\left[{ }^{\circ} \mathrm{C}\right.$, degrees Celsius; mm, millimeters; TL, total length; FL, fork length]

\begin{tabular}{|c|c|c|}
\hline Life stage & Definition & Description \\
\hline Embryo & A developing fish still within the chorion (egg membrane). & $\begin{array}{l}\text { Period from fertilization to hatch. The duration of the period is temperature-dependent. Gener- } \\
\text { ally, 5-8 days. }\end{array}$ \\
\hline Free embryo & A developing fish no longer within a protective chorion. & $\begin{array}{l}\text { Period from hatch to the initiation of feeding. The duration of the period is temperature- } \\
\text { dependent. Generally, } 8 \text { days at } 22^{\circ} \mathrm{C} \text { to } 12 \text { days at } 18^{\circ} \mathrm{C} \text {. Size will also be temperature- } \\
\text { dependent generally } 18-19 \mathrm{~mm} \text { TL at hatch. The free embryo is dependent on endogenous } \\
\text { yolk for nutrition and at the end of this stage transitions to exogenous feeding. During the } \\
\text { transition it expels its yolk plug and finishes absorbing the yolk. }\end{array}$ \\
\hline Larval & A developing fish without yolk, feeding exogenously. & $\begin{array}{l}\text { Period extends from the time the fish begins to feed until it has a full complement of rays in all } \\
\text { fins. It has the appearance of an adult fish in miniature. Duration of period and size of fish is } \\
\text { temperature- and food-dependent. May be } 186 \text { days and } 205 \mathrm{~mm} \text { TL (Snyder, 2002a). }\end{array}$ \\
\hline Juvenile & A sexually immature, sexually developing fish. & $\begin{array}{l}\text { Period extends until the fish begins gametogenesis and enters its first reproductive cycle. Dur- } \\
\text { ing this period, the juvenile pallid will begin to feed on fish. It may extend until the pallid is } \\
750 \mathrm{~mm} \text { FL. Within this stage, a Sub-Adult stage may be defined that extends approximate- } \\
\text { ly from the time fish is a major prey item in the pallid diet and gonads progress to stage } 2 \text {. }\end{array}$ \\
\hline Adult & $\begin{array}{l}\text { A fish capable of spawning during the spawning season } \\
\text { (when gametes are mature and environmental conditions } \\
\text { are correct). }\end{array}$ & This stage extends from the time the fish enters its first reproductive cycle until death. \\
\hline Pre-spawning adult & A fish in the final stages of preparing for spawning. & $\begin{array}{l}\text { Oocytes are grey to black; testis is sinuous containing distinct lobes. Gonads are at stage } 4 \text { and } \\
\text { germinal vesicle in oocytes is advancing to animal pole but oocytes are not capable of being } \\
\text { fertilized, and will not resume meiosis when progesterone assay is performed. }\end{array}$ \\
\hline Spawning adult & $\begin{array}{l}\text { A female fish with oocytes that can be fertilized and male } \\
\text { fish with flowing milt. }\end{array}$ & $\begin{array}{l}\text { Gonads are at stage } 5 \text {. Oocytes are black. Germinal vesicle is at the animal pole, oocytes will } \\
\text { resume meiosis in the progesterone assay, and oocytes are capable of being fertilized. }\end{array}$ \\
\hline Post-spawning adult & A fish that has finished releasing its gametes. & $\begin{array}{l}\text { Gonads are flaccid, may be slightly bloody, clear, and barely visible. Reproductive hormones } \\
\text { will be at their lowest levels. }\end{array}$ \\
\hline Recrudescent adult & $\begin{array}{l}\text { A fish with gonads/gametes in a regrowth phase, preparing } \\
\text { for the next spawning. }\end{array}$ & $\begin{array}{l}\text { Gonads are at stage } 2 \text { to } 4 \text {. The reproductive cycle periodicity for hatchery female } S \text {. albus is } \\
\text { two to four years and river-dwelling males one to four years (Albers and others, 2013). The } \\
\text { duration of this period is likely food-dependent. }\end{array}$ \\
\hline
\end{tabular}

duration of this period is likely food-dependent. 


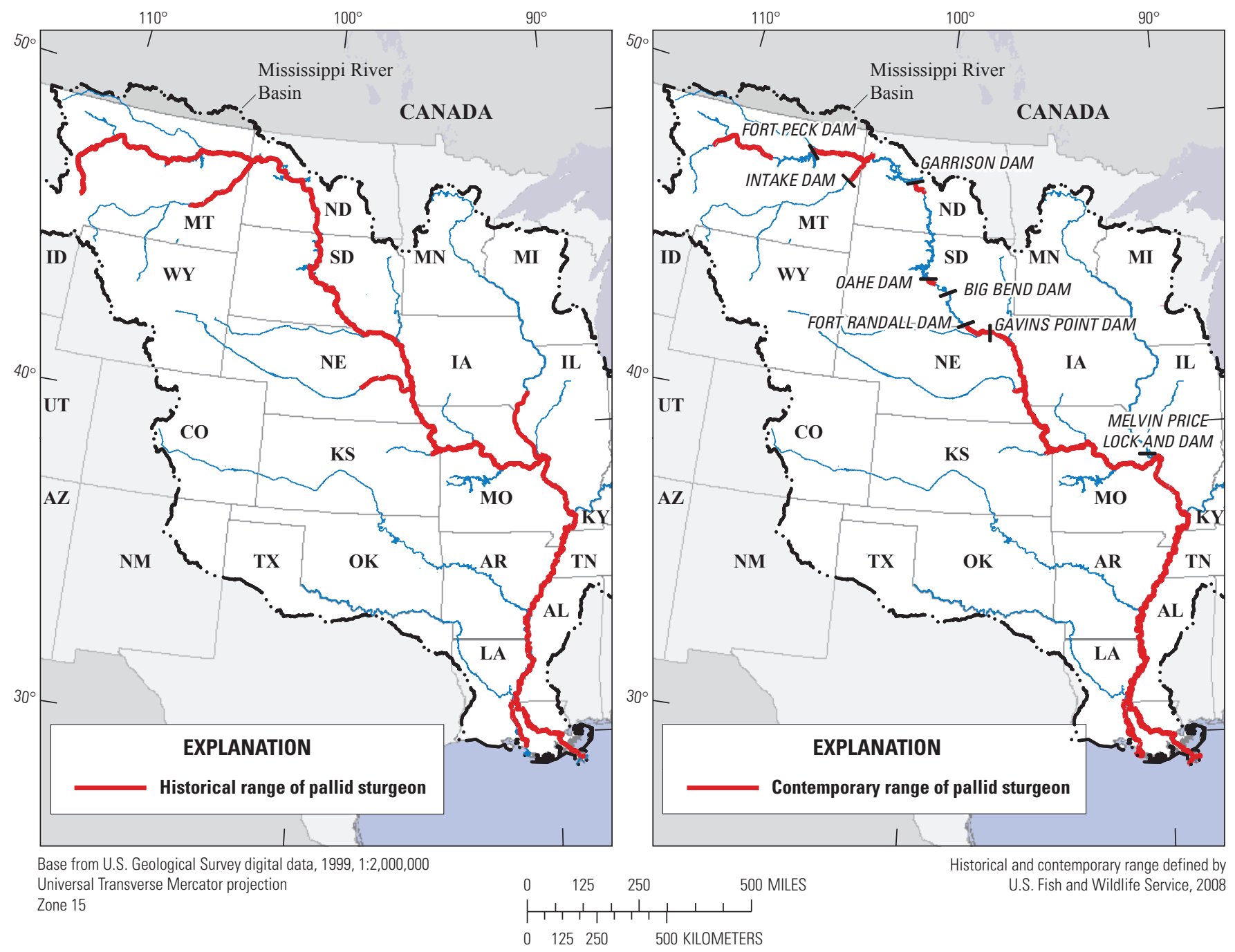

Figure 1. Historical and contemporary range of the pallid sturgeon.

in length. Hybrids between species may be phenotypically intermediate or may more closely resemble one parent species (Kuhajda and others, 2007).

Both species share common morphological adaptations to a benthic life in flowing water (for example, broad flattened rostrums, wide pectoral fins, more dorso-ventrally compressed body forms, and a long, slender heavily armored caudal peduncle). These shared adaptations result in strikingly similar appearance between the closely related species. Despite their substantial commonalities, pallid sturgeon and shovelnose sturgeon each possess dissimilar biological and ecological traits that determine differences in distribution and habitat use, predict population response in the presence of exploitation and environmental alteration, and ultimately explain disparities among the conservation status of the co-occurring species (Wildhaber and others, 2007a, 2011a).

The pallid sturgeon lives longer, matures later, and attains a larger maximum size than the shovelnose sturgeon throughout its range (Mayden and Kuhajda, 1997; U.S. Fish and Wildlife Service, 2007; Wildhaber and others, 2007a). Where it occurs, the pallid sturgeon is restricted predominately to the swifter waters of large, turbid sand-bedded rivers and the lower portions of their tributaries where a substantial portion of its diet is native cyprinids and other fish. In contrast, the shovelnose sturgeon matures earlier and at a smaller size, and feeds nearly exclusively on invertebrates. The shovelnose sturgeon commonly uses a wider range of substrates, in large main-stem rivers and in smaller, clearer tributaries throughout a broader geographic range. Not only does the combination of these interspecific differences make the pallid sturgeon more vulnerable to exploitation, habitat fragmentation alteration, and changes in community composition, these characteristics slow population responses to management actions and result in a tendency for the species to be resistant to recovery at very low densities (Bajer and Wildhaber, 2007; Wildhaber and others, 2007a, 2011a). 


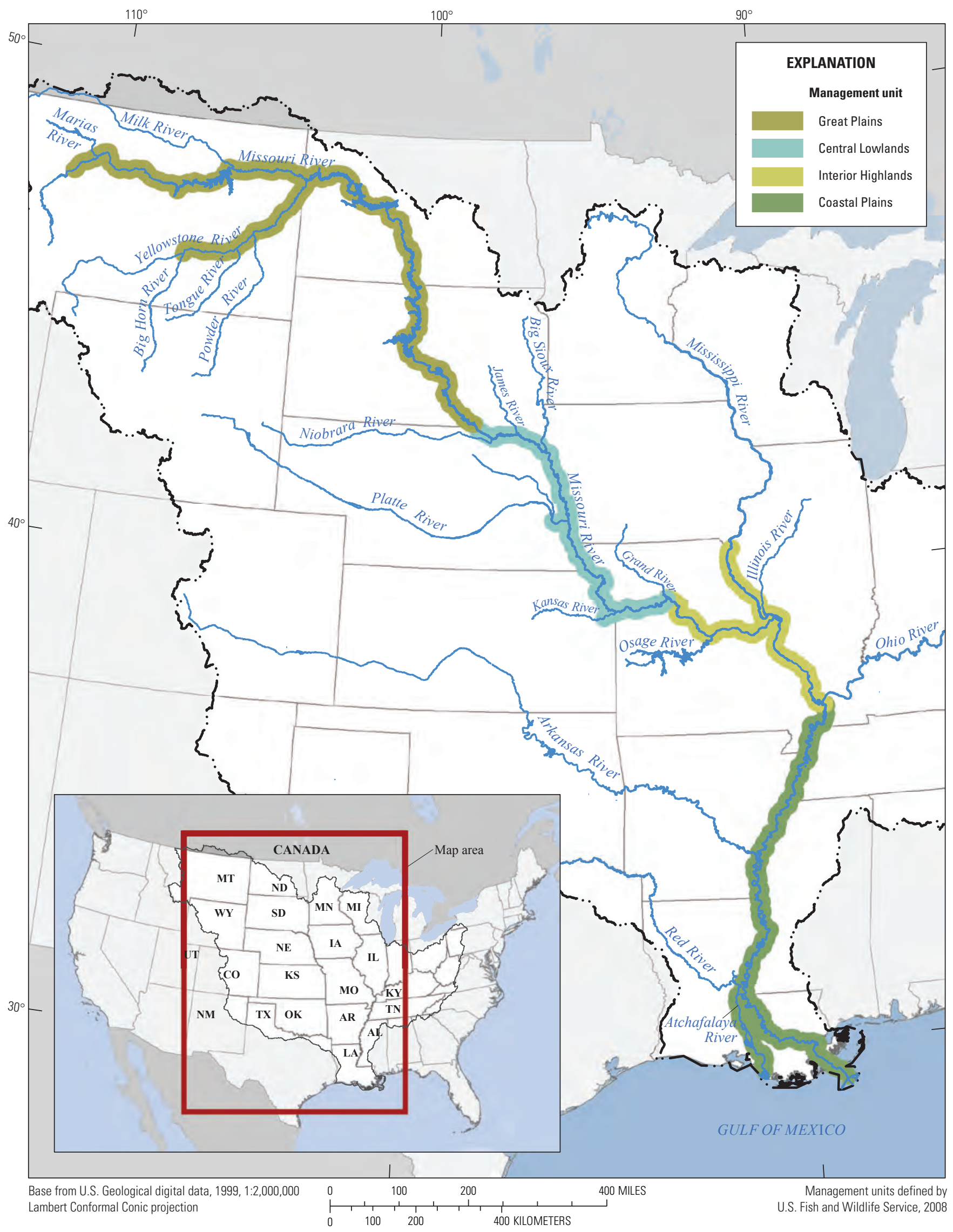

Figure 2. Pallid Sturgeon Recovery Management Units, Mississippi River drainage. 


\section{Geographic Range and Historic Abundance}

The pallid sturgeon is endemic to the turbid Missouri and Mississippi Rivers and the lower parts of larger tributaries (fig. 1). The described species range includes the Lower Yellowstone and Missouri Rivers downstream to the confluence with the Mississippi River, and the Mississippi River from Keokuk, Iowa (not shown) downstream to the Gulf of Mexico, including the Atchafalaya River. Pallid sturgeon have been documented in the lower parts of Missouri River tributaries, including the Milk River in Montana, Niobrara and Platte Rivers in Nebraska, Big Sioux River in Iowa, Kansas River in Kansas, and the Grand and Osage Rivers in Missouri (fig. 3). Species occurrence is coincident with turbid, flowing water and predominately sand substrate. Patterns of decline indicate that, like other Scaphirhynchus species, the pallid sturgeon cannot complete its life cycle within reservoirs or without significant reaches of free-flowing river (Braaten and others, 2012a). Despite a described range exceeding 3,500 miles of river, no part is without substantial alteration from dams or barriers to passage, impoundment, altered flows, or channelization and bank stabilization (U.S. Fish and Wildlife Service, 1993).
Anecdotal references to commercial catches early in the twentieth century suggest that pallid sturgeon were more common in highly turbid waters of the Missouri and Mississippi Rivers. Ratios of shovelnose to pallid sturgeon in the commercial catch in the Lower Missouri River near West Alton, Missouri (not shown) at times may have approached 5 to 1 , whereas shovelnose are reported to have outnumbered pallid sturgeon by 500 to 1 (Forbes and Richardson, 1905) or 300 to 1 (Forbes and Richardson, 1909) in the less turbid Middle Mississippi River upstream from the confluence with the Missouri River. Observations by Bailey and Cross (1954) from various locations along the Missouri and Lower Mississippi Rivers support a generalized historic pattern of distribution for the pallid sturgeon restricted to sandy-bottomed, turbid, flowing water.

Early descriptions of the species suggest that it was not common within its range (Forbes and Richardson, 1905; Bailey and Cross, 1954). However, the veracity of this assertion is difficult to assess. Early commercial records from the period did not discriminate among species of sturgeon and captures of pallid sturgeon likely were rare except when fishermen specifically targeted sturgeon for flesh or roe. Because pallid

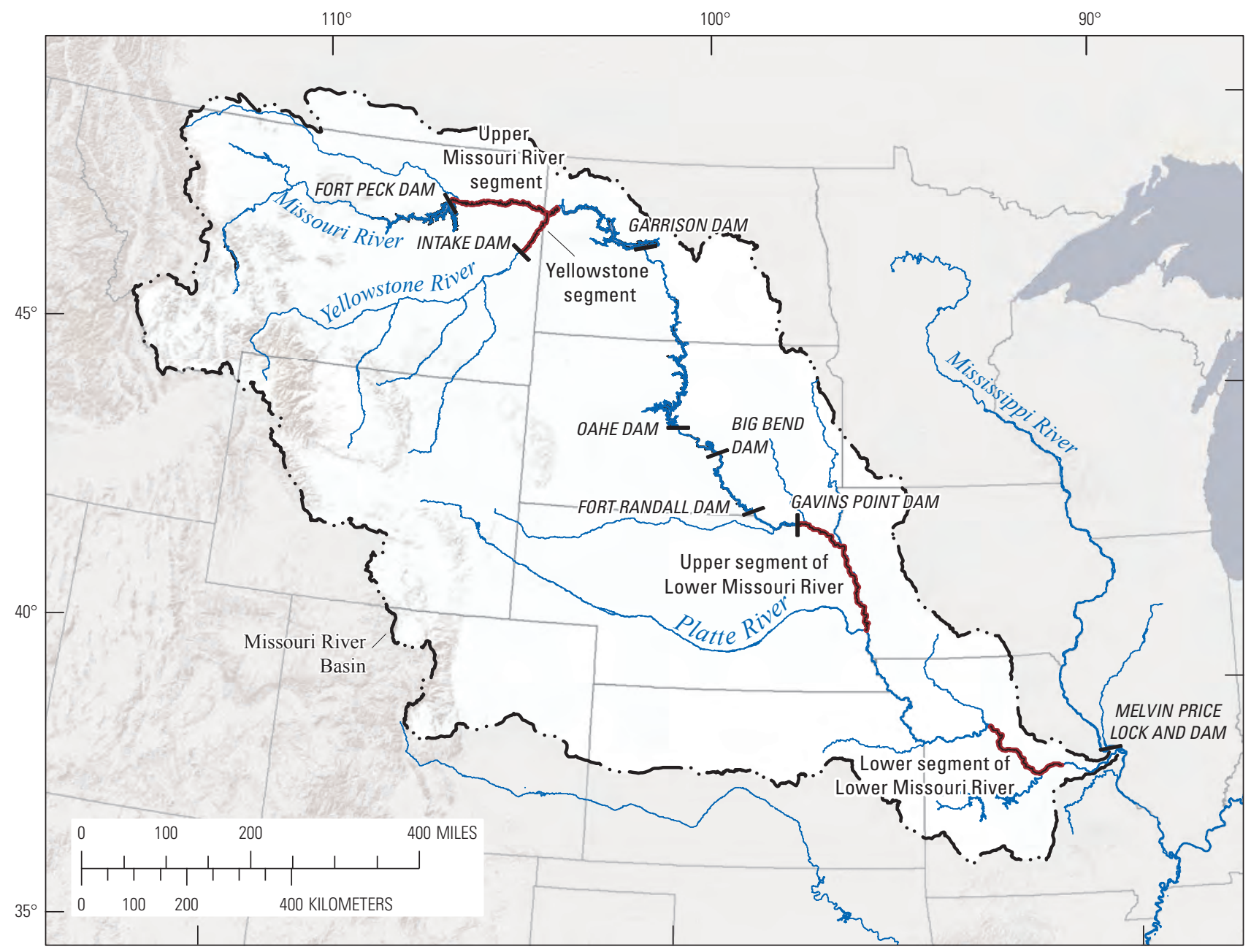

Base from U.S. Geological Survey digital data, 2002, 1:2,000,000 Albers Equal-Area Conic projection

Figure 3. Missouri River Basin and major tributary rivers with the Comprehensive Sturgeon Research Project study areas. 
sturgeon frequent deep, swift turbid waters they are more difficult to sample compared to shovelnose sturgeon and other native species, and it would not be unusual for early biological surveys to overlook the species (Funk and Robinson, 1974; Kallemeyn, 1983). By the early twentieth century the more common, sympatric shovelnose sturgeon had undergone widespread decline and reduction in range (Bailey and Cross, 1954; Becker, 1983). Overexploitation and habitat alteration likely impacted pallid sturgeon populations as well, far in advance of any systematic investigations of species distribution or abundance that could occur. The general paucity of information on historic densities or patterns of distribution throughout the species' range has limited the ability to understand the species' needs, document species' declines, and articulate recovery objectives and goals (Kallemeyn, 1983).

\section{Reasons for Decline and Listing}

Commercial harvest of sturgeon had diminished most North American sturgeon species before the turn of the twentieth century. Overexploitation was predominately responsible for the near extirpation of the lake sturgeon (Acipenser fulvescens) from the Missouri and Lower Mississippi Rivers in the first decades of the twentieth century; a scant few years after the pallid sturgeon was described (Carlson and Pflieger, 1981). Early dam construction, water withdrawals, and channelization had already resulted in population fragmentation (fig. 1), disrupted spawning migrations, and diminished habitat availability, and were associated with population declines and extirpation of native sturgeon from the Mississippi, Ohio, Illinois, Tennessee, and Rio Grande Rivers (not shown) (Bailey, 1954; Becker, 1983), and on many of their tributaries well before the initiation of main-stem dam construction and bank stabilization on the Missouri River.

As the sturgeon fishery began to decline in the Mississippi River Basin, intensive engineering and management of the Missouri River for the purposes of navigation, flood control and hydroelectric power substantially altered the riverine habitat of the pallid sturgeon. Increasing urban, agricultural, and industrial pollution throughout the last century likely exacerbated the continuing decline of sturgeon populations (U.S. Fish and Wildlife Service, 1993). Surveys by management agencies following the closure of the six main-stem dams in the Missouri River collected few sturgeon individuals (Schmulbach and others, 1975; Carlson and others, 1985). Low numbers of mature pallid sturgeon in surveys and the documented occurrence of hybridization with the closely related shovelnose sturgeon (Carlson and others, 1985) indicated that populations were below levels considered to be self-sustaining. The USFWS formally listed the species as Endangered in 1990 in accordance with the provisions of the Endangered Species Act of 1973, as amended (U.S. Fish and Wildlife Service, 1993). A species recovery plan was developed and released in 1993 (U.S. Fish and Wildlife Service, 1993), and a 5-year review of the species status was published in 2007 (U.S. Fish and Wildlife Service, 2007). A revised recovery plan was released in 2014 (U.S. Fish and Wildlife Service, 2014). In 2010 the shovelnose sturgeon was listed as a threatened species under the Endangered Species Act by the U.S. Fish and Wildlife Service because of its similarity of appearance to the endangered pallid sturgeon. Threatened status mostly eliminated commercial harvest for shovelnose sturgeon in the Missouri River and Middle and Lower Mississippi River to prevent incidental or intentional harvest of pallid sturgeon in areas where both species co-occur.

\section{Current Population Status}

The first estimates of pallid sturgeon abundance were summarized by Duffy and others (1996). Estimates from various sources and unpublished studies suggested that as few as 6,000 or as many as 21,000 wild pallid sturgeon may have existed throughout the range of the species at that time. Currently, the most precise estimates are from intensively studied small, isolated populations of large adults above Gavins Point Dam where evidence of natural recruitment has been absent for decades. Recent estimates based on markrecapture data for the largest of these populations between Fort Peck and Garrison Dams were reported by Braaten and others (2009). As few as 158 adults remain (95 percent confidence interval [CI] equals 129-193) in the longest free-flowing stretch of river between Missouri River mainstem reservoirs. Other reaches above main-stem Missouri River reservoirs likely hold a scattered few wild specimens. Populations upstream from Fort Peck Dam and between Fort Peck Dam and Garrison Dam are currently (2015) being augmented by progeny from the Pallid Sturgeon Conservation Augmentation Program (PSCAP) to forestall extirpation and conserve species diversity (U.S. Fish and Wildlife Service, 2008; Heist and others, 2013). Representative progeny from nearly all wild adults produced in the hatchery are held as potential broodstock at Gavins Point National Fish Hatchery, South Dakota (not shown) to serve as potential future broodstock and guard against unexpected catastrophic population events.

No reliable pallid sturgeon population size estimates yet exist for the entire Lower Missouri River (Wildhaber and others, 2015), but evidence indicates that populations are reproducing and recruiting, albeit at low levels (DeLonay and others, 2009). Using mark-recapture data for a pallid sturgeon population within an $80.5-\mathrm{km}$ reach of the Lower Missouri River, an estimated 5.4 to 8.9 wild fish $/ \mathrm{km}$ were present annually during 2008-2010, along with 28.6 to 32.3 hatchery fish $/ \mathrm{km}$ (Steffensen and others, 2012). The wide range of early estimates in the Lower Missouri River may, in part, be explained by differences in capture probability, low numbers of recaptures, poor tag retention, uneven stocking practices, and the vagaries of sturgeon migration and emigration. Given the variation and limited spatial extent of early estimates, it is not possible to extrapolate existing local population size 
estimates across the entire Lower Missouri River. Wildhaber and others (2014) did analyze available catch-per-unit-effort monitoring data for the entire Missouri River to examine population trends and found no evidence of an increase in relative abundance of pallid sturgeon in the Lower Missouri despite intermittent stocking efforts from the PSCAP (U.S. Fish and Wildlife Service, 2008).

Uncertainty surrounding population size and density estimates increases downstream in the Mississippi River. The scale of the Middle and Lower Mississippi River poses substantial challenges to sampling sturgeon and sustaining sufficient effort to conduct effective mark-recapture studies. The absence of barriers or boundaries to migration or immigration between the Missouri and Mississippi Rivers, or from the confluence of both rivers to the Gulf of Mexico challenges population estimate assumptions for a large, mobile riverine species. Several studies have examined pallid sturgeon populations in the Middle and Lower Missouri River using catchper-unit-effort statistics or comparative catch ratios with the more abundant shovelnose sturgeon (Killgore and others, 2007a; Killgore and others, 2007b; Garvey and others, 2009). These studies suggest that multiple year classes of pallid sturgeon are present and that recruitment is likely occurring. The prevalence of hybridization (Tranah and others, 2004) and the absence of verifiable field identification metrics to distinguish among pallid sturgeon, shovelnose sturgeon, and pallid $\mathrm{x}$ shovelnose sturgeon hybrids (Kuhajda and others, 2007) constrains the interpretation of abundance estimates.

\section{Population Structure}

Genetic studies have indicated rangewide genetic structuring of the pallid sturgeon population (Campton and others, 2000; Tranah and others, 2001; Schrey, 2007; Schrey and Heist, 2007). Genetic differentiation of pallid sturgeon initially was observed at the extremes of the species' geographic range (Campton and others, 2000; Tranah and others, 2001). Schrey and Heist subsequently detected significant genetic differentiation within the range of the pallid sturgeon; and, further, identified three genetic groups (Schrey and Heist, 2007). One group is characteristic in the Upper Missouri River Basin in Montana and North Dakota, another group is prominent in the Middle Mississippi and Atchafalaya Rivers and a third genetically intermediate group is prominent in the Lower Missouri River, downstream from the Gavins Point Dam (Schrey and Heist, 2007). The Upper Missouri River group was most distinct, and less genetic differentiation was observed between the Lower Missouri River and the Middle Mississippi and Atchafalaya Rivers (Schrey and Heist, 2007). These data indicate that genetic structuring of pallid sturgeon populations is natural and predates anthropogenic migratory barriers (Schrey, 2007; Schrey and Heist, 2007), suggesting that reproductive isolation mechanisms were established before construction of the dams on the Missouri River.

\section{Recovery Strategy}

Substantial progress has been made in understanding the biology and ecological requirements of pallid sturgeon since it was initially listed and provided protection under the Endangered Species Act in 1990 (U.S. Fish and Wildlife Service, 2007). Advances in knowledge of pallid sturgeon were summarized in the 5-year status review (U.S. Fish and Wildlife Service, 2007) and incorporated into the revised pallid sturgeon recovery plan (U.S. Fish and Wildlife Service, 2014). In the revised plan, the USFWS modified the organization and implementation of recovery strategies to better align with observed genetic population structure and the changing array of threats to the species across the breadth of its geographical range. The six Recovery Priority Management Areas (RPMA) once emphasized by the Recovery Program were revised to Recovery Management Units that loosely corresponded to physiographic regions (fig. 2), incorporating the potential for genetically structured populations on the landscape and varying management potential for implementation of recovery actions along the length of the species range (U.S. Fish and Wildlife Service, 2007).

The species range is divided into the Great Plains (GPMU), Central Lowlands (CLMU), Interior Highlands (IHMU), and Coastal Plains Management Units (CPMU). Though many gaps in species understanding and science needs are common among management units, recovery implementation strategies are tailored within geographic units to address the specific threats limiting populations (U.S. Fish and Wildlife Service, 2007).

\section{Missouri River Management Context}

The pallid sturgeon has declined in a large river system that has been substantially altered to support social and economic goods and services. The geography of the Missouri River system, its tributaries, and the Mississippi River system downstream present important context because the natural biophysical capacity of the river system is highly variable, the river is naturally very different in different places, and engineering alterations vary markedly along the river. Although this species has the potential to migrate hundreds of $\mathrm{km}$ during a reproductive cycle, there is evidence that indicates that genetically defined subpopulations occupied lengths of the river with distinctly different combinations of hydrology, physiography, water quality, and channel morphology.

\section{Geography}

Studies in the CSRP focus on the Missouri River main stem and larger tributaries (fig. 3). The Missouri River Basin is nearly 1.4 million square kilometers $\left(\mathrm{km}^{2}\right)$ in area and occupies parts of 10 states and a small part of Canada (fig. 1). It extends 24 degrees of longitude east to west and 13 degrees 
of latitude north to south. The highest elevations are in the continental divide in the Rocky Mountains of Montana (4,282 meters [m]) and the lowest elevation (124 m) is at the confluence with the Mississippi River near St. Louis, Missouri (not shown).

The geology of the Missouri River Basin is dominated by folded and faulted metamorphic and sedimentary rocks of the Rocky Mountains on the western divide, late Mesozoic and Tertiary sedimentary rocks created from sediments shed from the Rocky Mountains in the Great Plains, and Paleozoic marine sedimentary rocks in the Central Lowlands and Ozark Plateaus (fig. 4A). Bedrock geology and associated physiographic properties define the broad physiographic provinces of the Missouri River Basin (Fenneman and Hohnson, 1946). Combined with emerging genetics data, these physiographic provinces are presently used to define pallid sturgeon management units for recovery (U.S. Fish and Wildlife Service, 2007, 2014), and range wide population augmentation (U.S. Fish and Wildlife Service, 2008) (fig. 4A), based on the premise that the physiographic provinces are reflective of the natural factors that contributed to genetic structuring of the pallid sturgeon population.

As a species whose evolutionary ancestors can be traced back to the late Mesozoic Era (Bemis and Kynard, 1997), the lineage of the pallid sturgeon predates the contemporary (Quaternary) Missouri River by as much as 150 million years. Pliocene and Pleistocene reconstructions of the major river drainages of North America indicate that during the last 5 million years the contemporary Missouri River has been assembled from parts of three major river systems (fig. 4B) (Metcalf, 1966). Disruption and re-assembly of the drainage network has been attributed to 7-9 major advances of the continental Laurentide ice sheet during the last 2.4 million years (Roy and others, 2004; Balco and Rovey, 2010). Although the details of timing and locations of the early Pleistocene advances are obscure, the overall effect was to deflect formerly north- and east-draining rivers to the south (fig. $4 B$ ). These dynamics of the drainage network during the Pleistocene had the potential to mix and isolate populations of Scaphirhynchus sturgeon for various time intervals.

Well-preserved late-Pleistocene glacial drift shows that the southern glacial boundary interacted with the river in multiple locations from Montana to South Dakota resulting in direct effects on local habitat that persist today. Interaction of the Wisconsinan glaciers with the Missouri River in Montana resulted in formation of multiple proglacial lakes. A prominent example is glacial Lake Great Falls in Montana (not shown); overflow of the lake resulted in occupation of a new channel and cutting of Great Falls, which presents a formidable barrier to fish passage. Impingement of the ice sheets on the river valley also resulted in local influxes of coarse sediment, for example coarse gravel-cobble deposits that persist near the location of Gavins Point Dam at Yankton, South Dakota (Laustrup and others, 2007; fig. 3). Downstream from the late-Pleistocene glacial boundary, large quantities of glacial outwash underlie the broad alluvial valley of the Lower Missouri River.
Hydrologically, the Missouri River Basin mixes snow accumulation and melt processes in the Rocky Mountains and Great Plains with less predictable runoff from frontal storms and tropical air masses from the Gulf of Mexico (fig. 3). This mix of hydroclimatic processes produces a characteristic double-peaked annual hydrograph, with March and MayJune flood pulses (Galat and Lipkin, 2000; Pegg and others, 2003). As the Missouri River flows through the Great Plains, it drains a large area with annual precipitation ranging from 200 to 500 millimeters ( $\mathrm{mm})$, a precipitation range generally associated with the greatest sediment delivery rates per unit watershed area (Langbein and Schumm, 1958). This supply of sediment supported dynamic river habitats before channelization and provided the largest fraction of sediment contribution to the Mississippi River (Meade, 1995; Jacobson and others, 2009a).

\section{History of Alteration}

The Missouri River has been highly altered from its earliest documented condition in the 18th century. Alteration has produced great socioeconomic benefits (U.S. Army Corps of Engineers, 2006) but is also considered to be associated with substantial stressors on pallid sturgeon populations (Dryer and Sandvol, 1993). Agricultural and urban development throughout the basin have substantially altered the landscape, resulting in increases in the fluxes of sediment, nutrients, pesticides, and other contaminants to streams (Petty and others, 1995; Echols and others, 2008; Blevins, 2011; Brown and others, 2011; Heimann and others, 2011). The main stem is impounded with six large reservoirs that together comprise the largest reservoir storage project in North America, with nearly 73 million acre feet (MAF) of total capacity (U.S. Army Corps of Engineers, 2006) (fig. 3). The reservoir system is operated for power generation, flood control, public water supply, recreation, and to support threatened and endangered species. Operations have altered the flow regime variably along the river, and have generally decreased peak flows and increased base flows (Galat and Lipkin, 2000) (fig. 5). Reservoir operations at all mainstem dams except Gavins Point involve hydropower loadfollowing discharges resulting in large daily variations. The dams also have been effective in retaining sediment, thereby substantially decreasing transport of sediment downstream (Jacobson and others, 2009a), imposing barriers to upstream migration, and, for dams with hypolimnetic releases, decreasing downstream water temperatures (U.S. Fish and Wildlife Service, 2000). In addition to the main-stem dams, as many as 1,300 additional reservoirs in the basin contribute another 33 MAF of storage (Galat and others, 2005b).

Downstream from Sioux City, Iowa, the Missouri River main stem has been channelized and the banks stabilized to support navigation. Channel alterations have resulted in reduced channel complexity, a decline in habitat diversity, and loss of channel habitat dynamics (Funk and Robinson, 1974; Hesse and Sheets, 1993; Jacobson and Galat, 2006) (fig. 6). 


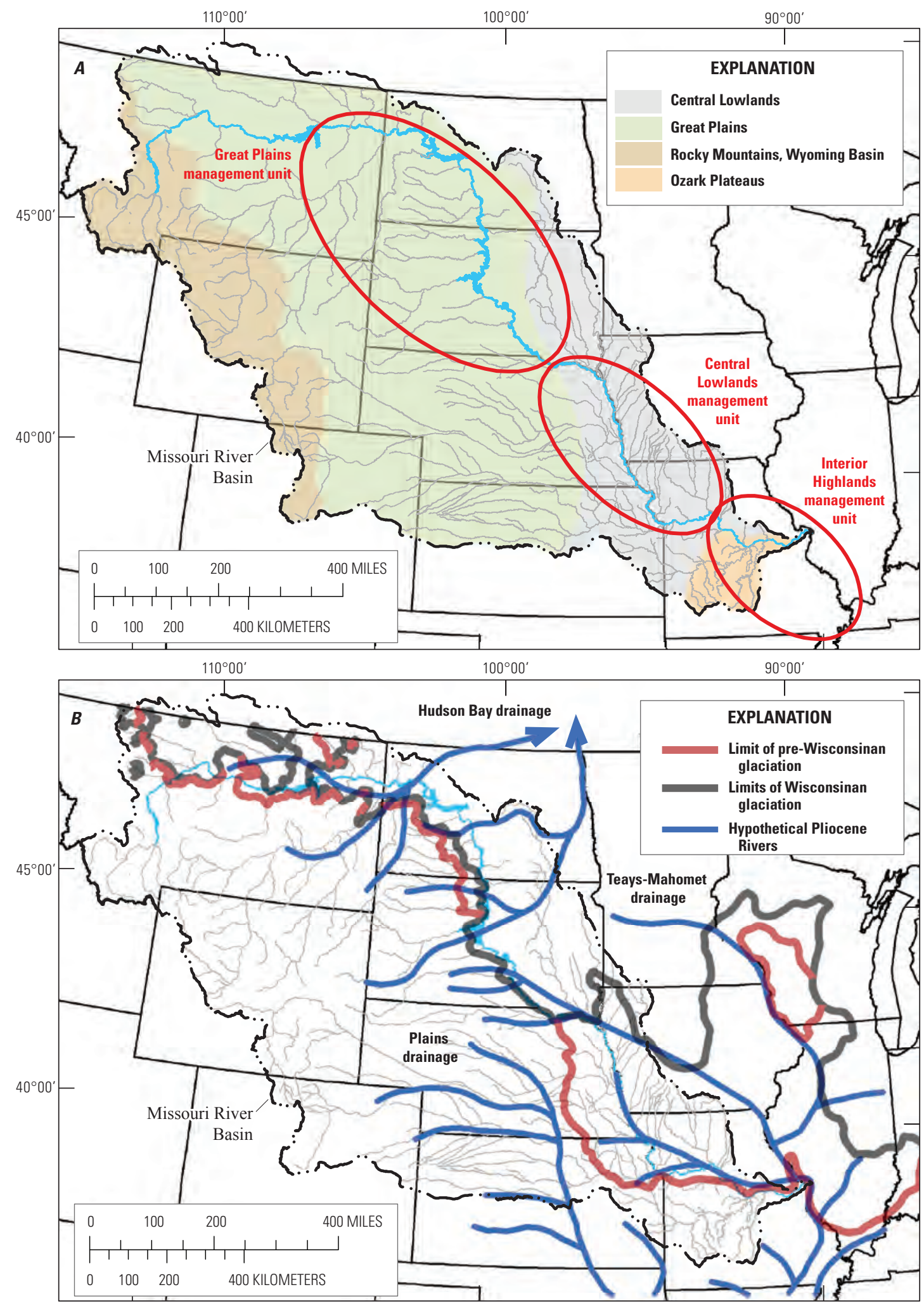

Base from U.S. Geological Survey digital data, 2012 Albers Equal-Area Conic projection

Figure 4. Geographical and geological context of pallid sturgeon recovery implementation. $A$, Physiographic provinces (Fenneman and others, 1946) and Pallid Sturgeon recovery management units, Missouri River Basin. B, Hypothetical Pliocene drainage network (Metcalf, 1966), pre-Wisconsinan and Wisconsinan glacial limits (Garrity and Soller, 2009), compared to the present-day drainage network. 

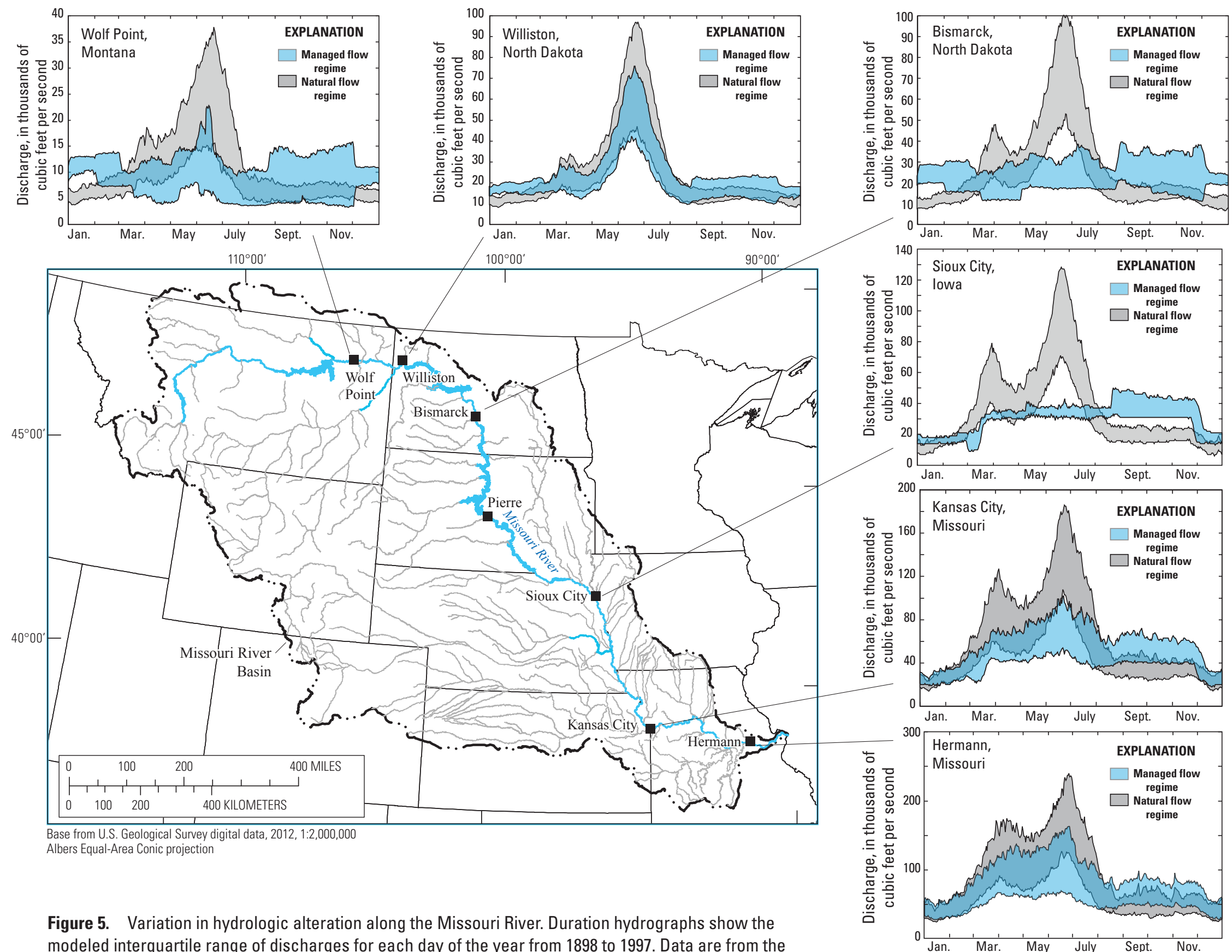

Figure 5. Variation in hydrologic alteration along the Missouri River. Duration hydrographs show the modeled interquartile range of discharges for each day of the year from 1898 to 1997. Data are from the USACE daily routing model (U.S. Army Corps of Engineers, 1998; unpub. data). 


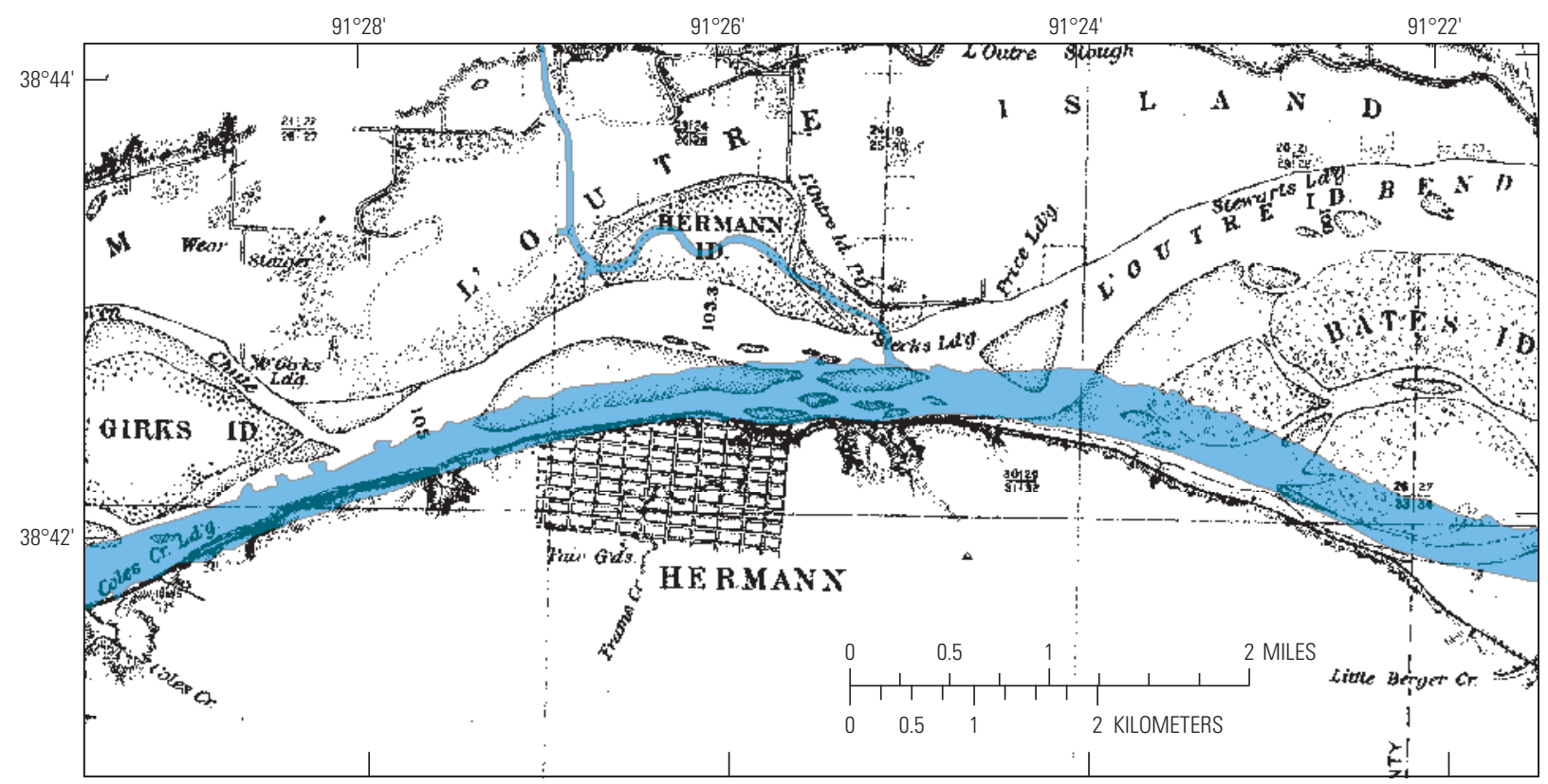

Figure 6. Modern (2000) channel overlain on historical (1894) channel map, Lower Missouri River at Hermann, Missouri (from Jacobson and Galat, 2006).

Channelization and snagging (removal of woody debris) projects started as early as steamboat navigation on the Missouri River (circa 1819) and continued through completion of the Bank Stabilization and Navigation Project (BSNP) in 1981 (Ferrell, 1996). Channelization, associated land accretion, and levees have been estimated to account for loss of $404 \mathrm{~km}^{2}$ of aquatic habitat, $274 \mathrm{~km}^{2}$ of sandbars and low-lying lands, and $1,432 \mathrm{~km}^{2}$ of terrestrial habitat within the riverine meander belt (U.S. Army Corps of Engineers, 2002).

The Missouri River main stem also serves as receiving waters for industrial and municipal waste and as cooling water for thermal power plants. With cumulative inputs from municipalities and agriculture throughout the basin there is potential for exposure of pallid sturgeon and other native fauna to elevated contaminant loads, including metals, pesticides, herbicides, pharmaceuticals, bacteria, and nutrients (Petty and others, 1995; Poulton and others, 2003; Echols and others, 2008; Blevins, 2011).

\section{Missouri River Restoration Programs}

Concerns about restoring some aspects of the Missouri River ecosystem began as early as the late 1950s with the Fish and Wildlife Coordination Act of 1958, which provided the USACE with authority to study how to "restore, preserve, or otherwise develop (Ferrell, 1996)" land and waters in the Missouri River BSNP area. The selected wording of "restore, preserve, or develop" is indicative of various definitions and perceptions of the restoration concept. Ecological "restoration" is usually defined similar to the following: "Reestablishment of the structure and function of an ecosystem, resulting in a dynamic and self-sustaining condition that is as close as possible to pre-disturbance conditions (National Research Council, 1992)." This definition can be problematic because of difficulties in defining and quantifying dynamic pre-disturbance conditions (Marris, 2011). Some restoration ecologists have used broader definitions or different terms, such as "rehabilitation": "Pragmatic recovery of ecosystem structure and function, but not necessarily to a pre-disturbance condition (Ormerod, 2003)" or, "putting back into good condition or working order (National Research Council, 1992)." A complicating factor on the Missouri River is the mixture of objectives, which are summarized in the authorizing legislation for the Missouri River Ecosystem Restoration, the Water Resources Development Act (WRDA) of 2007 (U.S. Congress, 2007) as the following: "(A) to mitigate losses of aquatic and terrestrial habitat; (B) to recover federally listed species under the Endangered Species Act of 1973 (16 USC 1531 et seq.); and (C) to restore the ecosystem to prevent further declines among other native species." Importantly, the term "recovery" is used specifically in the Endangered Species Act to mean: "The process by which the decline of an endangered or threatened species is stopped or reversed, or threats to its survival neutralized so that its long-term survival in the wild can be ensured, and it can be removed from the list of threatened and endangered species." Thus, recovery is specific to a species like the pallid sturgeon, and recovery of a species may happen with or without restoration or rehabilitation of its environment or associated native species. In this report we use the word "recovery" under this narrow definition. We use the definition of "restoration" adopted by the Society for Ecological Restoration: "Ecological restoration is the process of assisting the recovery of an ecosystem that has been degraded, damaged, or destroyed". "Mitigation" is used to 
denote an action to change the biophysical condition of a site to compensate for natural functions lost elsewhere (Society for Ecological Restoration International Science and Policy Working Group, 2004).

The Missouri River Bank Stabilization and Navigation Project Fish and Wildlife Mitigation Program (Mitigation Program) was authorized in the Water Resources Development Act (WRDA) of 1986, 5 years after completion of the BSNP, and amended in the WRDA of 1999 (National Research Council, 2002). The Mitigation Program was intended originally to mitigate for habitat losses due to the BSNP, with a goal of restoration of 166,750 acres (of channel, sandbar, and meander belt habitat, about 32 percent of estimated habitat lost (U.S. Army Corps of Engineers, 1981). In 2000, the USFWS published a biological opinion finding that USACE operations of the Missouri River were likely to jeopardize the existence of the pallid sturgeon and two shorebirds, the piping plover (Charadrius melodus) and interior least tern (Sternula antillarum); the biological opinion defined reasonable and prudent actions (RPAs) to avoid jeopardy to these species (U.S. Fish and Wildlife Service, 2000). The biological opinion was amended by a supplemental biological opinion in 2003 (U.S. Fish and Wildlife Service, 2003) and RPAs were modified. The RPAs for the pallid sturgeon include implementation of adaptive management, monitoring, and research; restoration of 20-30 acres per mile of shallow-water habitat; increased propagation and augmentation of pallid sturgeon; and flow pulses from Fort Peck and Gavins Point Dams. Both the 2003 biological opinion and the USACE biological assessment (U.S. Army Corps of Engineers, 2003) emphasized the importance of robust research, monitoring, and evaluation to support adaptive management.

In the WRDA of 2007, the goals for compliance with the amended biological opinion and for the Mitigation Program were collected into the Missouri River Recovery Program. In addition, the WRDA of 2007 formalized the creation of a stakeholders group, the Missouri River Recovery Implementation Committee (MRRIC), which is charged with providing recommendations and guidance on recovery and mitigation activities. The WRDA of 2007 also authorized mitigation projects along the Missouri River main stem in the upper basin, including Montana, North Dakota, Nebraska, and South Dakota, and authorized use of USACE funding to assist the Bureau of Reclamation with planning and construction of fish passage around the Lower Yellowstone Intake Diversion Dam (Intake Dam). The USACE developed the Missouri River Recovery Program Integrated Science Program (ISP) to understand and enhance knowledge of the Missouri River system to ensure that management decisions are based on the best available science.

\section{The Comprehensive Sturgeon Research Project}

The Comprehensive Sturgeon Research Project evolved from a request from the USACE to the USGS in 2003 to develop a research program that would address the basic question "What critical ecological factors contribute to successful pallid sturgeon and shovelnose sturgeon reproduction and survival in the Missouri River?" The fact that such a basic question was asked in 2003 is evidence of the lack of scientific understanding available then about the reproductive ecology of the pallid sturgeon in the Missouri River. Beginning with the first decade of the 21 st century the accumulated knowledge about pallid sturgeon ecology has grown substantially (fig. 7), coincident with the elevation of interest in the Missouri River Basin. At the same time, numerous engineering, hydrology, geomorphology, sediment transport, and ecology studies indirectly related to pallid sturgeon have been pursued on the Missouri River. As a result, the knowledge base that exists in 2012 is much improved from what existed at the turn of the 21 st century.

The science direction of CSRP has been guided by results of sturgeon research workshops convened in 2004 (Quist and others, 2004) and 2007 (Bergman and others, 2008), by hypotheses that emerged about the role of a naturalized flow regime in pallid sturgeon reproduction during a series of workshops in 2005 (Jacobson and Galat, 2008), by feedback from an independent science review (Sustainable Ecosystems Institute, 2008), and most recently by perspectives of the MRRIC Independent Science Advisory Panel (ISAP) (Doyle and others, 2011). As a result, CSRP research objectives have emphasized science information gaps related

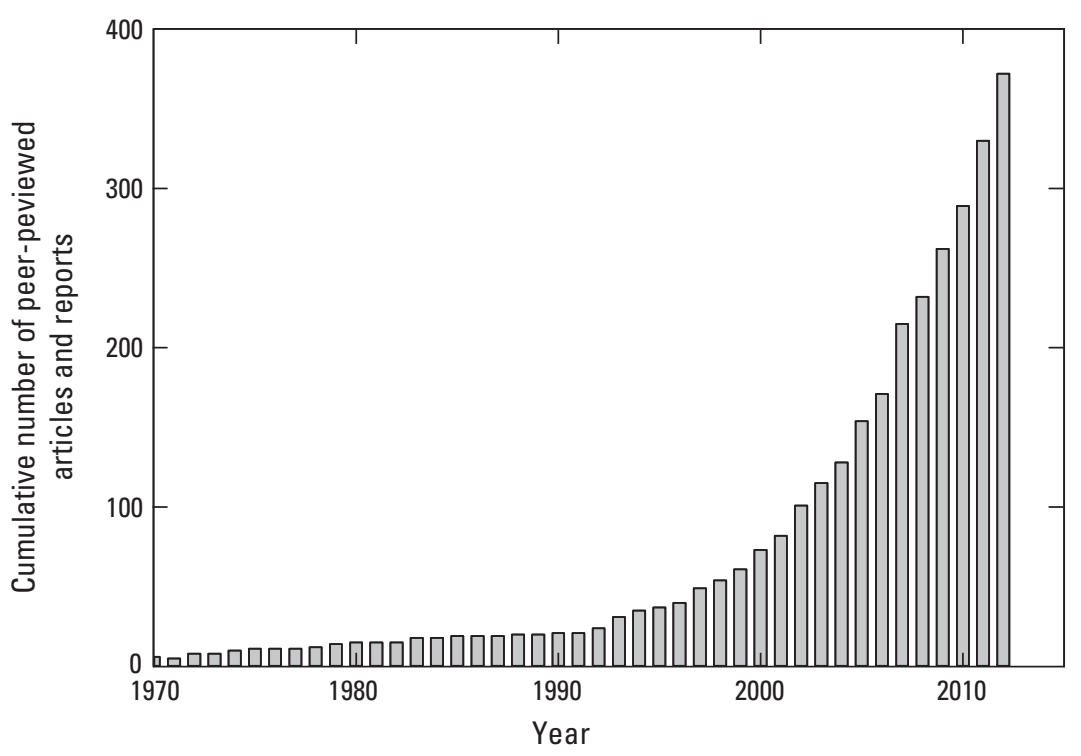

Figure 7. Cumulative number of peer-reviewed scientific articles and reports related to pallid sturgeon biology, ecology, and habitat, 1970-2012 
to priority management issues, including understanding of the role of pulsed flow releases from Gavins Point Dam and Fort Peck Dam (fig. 1), and understanding of the functions of constructed shallow-water habitat in the sturgeon life cycle. The goal of CSRP is to produce credible and salient scientific information and to interact with decision makers and stakeholders in a way that establishes the legitimacy and usefulness of the information (Cash and others, 2003).

\section{Comprehensive Sturgeon Research Project Approach}

The Comprehensive Sturgeon Research Project has applied an integrated, comprehensive research strategy. Field studies in three distinct river sections (Lower Missouri River, Yellowstone River, and Upper Missouri River) (fig. 3) provide a geographic comparative basis for discriminating physical and population controls on reproduction and recruitment. The natural and managed biophysical capacities of these river sections are distinctly different and varying fish responses within them provide fundamental insights into constraints on population growth. Within each of the three river sections our approach integrates reproductive behaviors and physiology of adult fish, understanding of where and when spawning occurs, validation of spawning through larval sampling, detailed assessments of migration, spawning, and drift/retention habitats, and integrative larval and young-of-year (YOY) sampling. These field studies are essential to place laboratory and theoretical information into the real-world context, and especially to establish how management actions may be linked to fish responses. Laboratory studies provide control and precise observations, whereas the field studies, with less control and precision, quantify the behaviors within the actual river environment. Information developed through laboratory and field studies also provides insights into cause and effect that provide essential context to mathematical models of pallid sturgeon populations (Bajer and Wildhaber, 2007) and complement population monitoring data being collected by the Pallid Sturgeon Population Assessment Project (Drobish, 2008) and the Habitat Assessment Monitoring Project (Schapaugh and others, 2010).

Some of the present (2015) understanding of pallid sturgeon biology relies on inference from other, comparative sturgeon species. Use of comparative species is typical when developing understanding of a very rare fish. When pallid sturgeon research on the Missouri River was beginning in the 2000s, we began with accepted models for the reproductive strategies of other, well-characterized sturgeon, including white sturgeon (Galbreath, 1985; Paragamian, 2012), shortnose sturgeon (Bain, 1997; Kynard, 1997; Kynard and others, 2009), and shovelnose sturgeon (Moos, 1978). The shovelnose sturgeon in particular has provided useful information, especially because documented hybridization between the pallid and shovelnose indicates some sharing of reproductive strategies (Carlson and others, 1985). Although these species provided a starting point for understanding, their informational value is now perceived as limited because of differences in known behaviors from other species; in the case of the shovelnose sturgeon, it has been documented that the juvenile shovelnose diet is dominated by insects whereas pallid sturgeon transition to a piscivorous diet around age 5-7 years (Gerrity and others, 2006; Grohs and others, 2009). In this report we differentiate between documented pallid sturgeon information and information that might be inferred from other sturgeon species.

\section{Pallid Sturgeon Conceptual Life-Stage Model}

Organization of information in this report is based on a conceptual model of pallid sturgeon life stages (Wildhaber and others, 2007a; Wildhaber and others, 2011a; table 1, fig. 8.) The life-stage model serves to organize understanding by focusing on populations during life stages, the transition probabilities between life stages, and the conditions and processes that affect the transition probabilities. Transitions between life stages are conceptual and are not instantaneous. Some transitions, such as hatching from embryo to free embryo, are rapid, and others, such as the transition from juvenile to adult are gradual. Moreover, although life stages can be defined conceptually based on a stage of development or function, the operational delineation of life stages is more difficult. For example, the transition from exogenously feeding larva to juvenile is conceptually based on when the fish has developed all its rays and fins, but capturing fish in the field is a function of size relative to the sampling gear and does not necessarily differentiate between fish on either side of this transition. Field assessment of annual reproduction may use gear types designed to sample YOY or age-0 individuals. Depending on the time of sampling and location within the species range, sampling efforts for age-0 sturgeon may include exogenously feeding larva and juveniles produced in the same season. Hence, we have operational definitions that are intended to align as much as possible with the concepts, but are acknowledged to be imperfect (table 1).

The terminology for the life stages used in this report is defined in table 1 . The life stages coincide with those in the conceptual model of the pallid sturgeon life cycle proposed by Wildhaber and others (2007a, 2011a; fig. 8). The five principle periods in the lifecycle of the pallid sturgeon consist of embryo, free embryo, larval, juvenile, and adult stages. These designations are intended to establish a common conceptual framework to facilitate communication and for biological study of the various phases in the pallid sturgeon life cycle. The terms embryo, free embryo, and larva are adopted from Balon's terms for the early intervals in fish development (Balon, 1984). Embryos are developing fish within a protective membrane; free embryos have hatched but rely on yolk for nutrition, whereas larvae have begun to feed exogenously. A pallid sturgeon larva (and Scaphirhynchus sturgeons in general) becomes a juvenile with absorption of the last of its pre-anal finfold (Snyder, 2002). Juveniles appear as adults morphologically but are sexually immature. An adult fish is classically considered a fish capable 


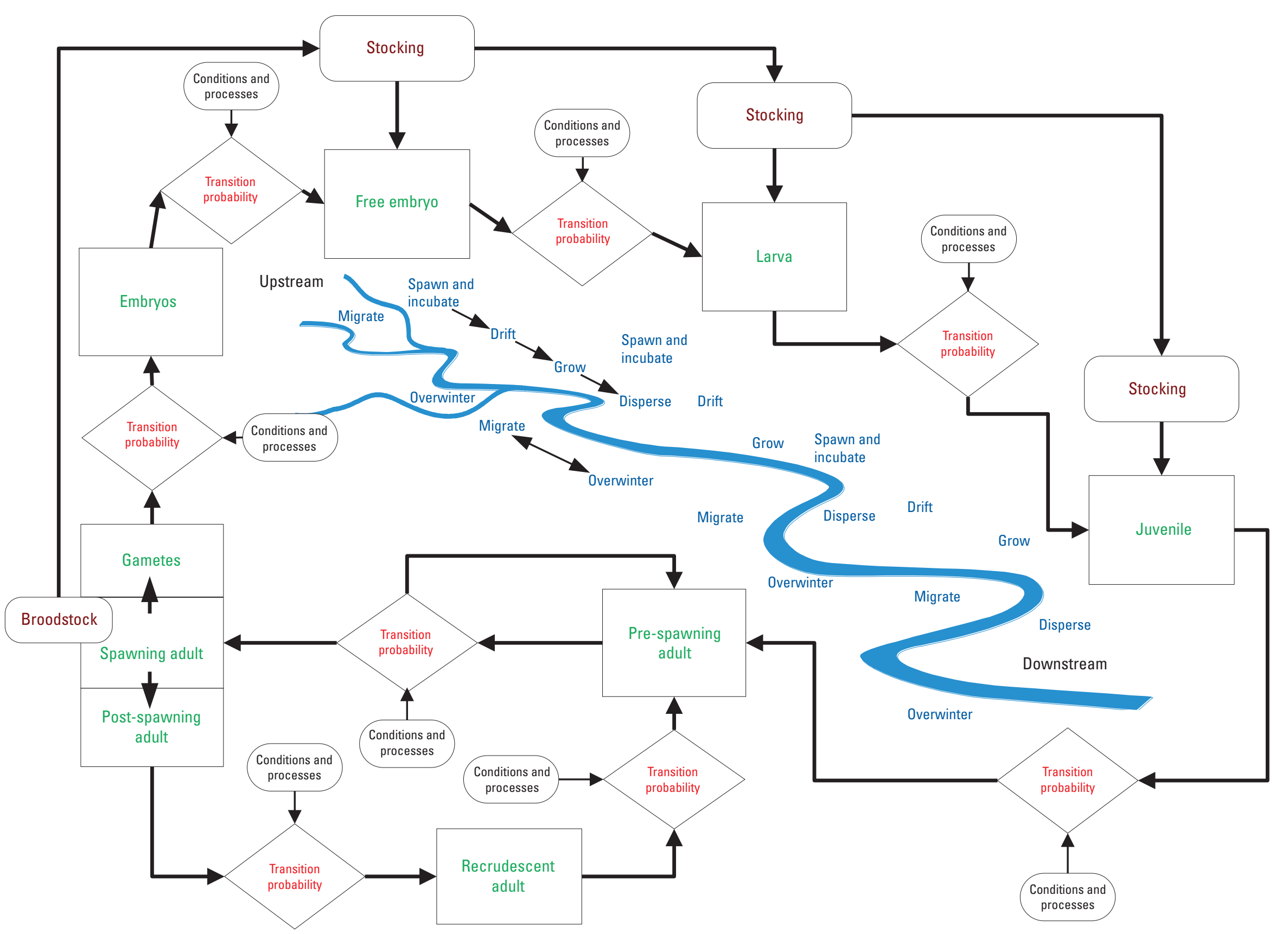

Figure 8. Simplified conceptual life-stage model for pallid sturgeon, modified from Wildhaber and others (2007a, 2011a). 
of spawning and therefore having developed the necessary organs and sensory structures to develop gametes and shed them if properly cued. We have expanded this definition to include pallid sturgeon that are in the process of gametogenesis for the first time and therefore entering their first reproductive cycle. Although much has been learned in the past decade, the normal biology of pallid sturgeon at many of these stages remains incompletely described and, as such, the descriptions we have provided are based on the best available science at this time. Within this set of discrete life stages, substages may be operationally defined for a particular study to facilitate analyses. This is particularly relevant to understanding and identifying limitations to survival and threats preventing transition from one life stage to the next. For example, within the free-embryo life stage, the period during which the free embryo is transitioning from passive drifting to active drifting may be operationally identified and defined as free embryos that have reached a specific developmental or behavioral milestone (as Cumulative Thermal Units or CTUs). The further splitting of the primary life stages in table 1 into substages is described in the text of this report where applicable.

Organization of the science by life stage is essential to focus on specific linkages between stressors, management actions, or restoration actions that can affect specific transitions. In addition, because the pallid sturgeon can migrate for 10 s or 100 s of miles in a season, different life stages play out in different parts of the river, generally with spawning habitat at the apex of reproductive migrations and "settling" habitat for the transition from free embryo to exogenously feeding larva substantially farther downstream.

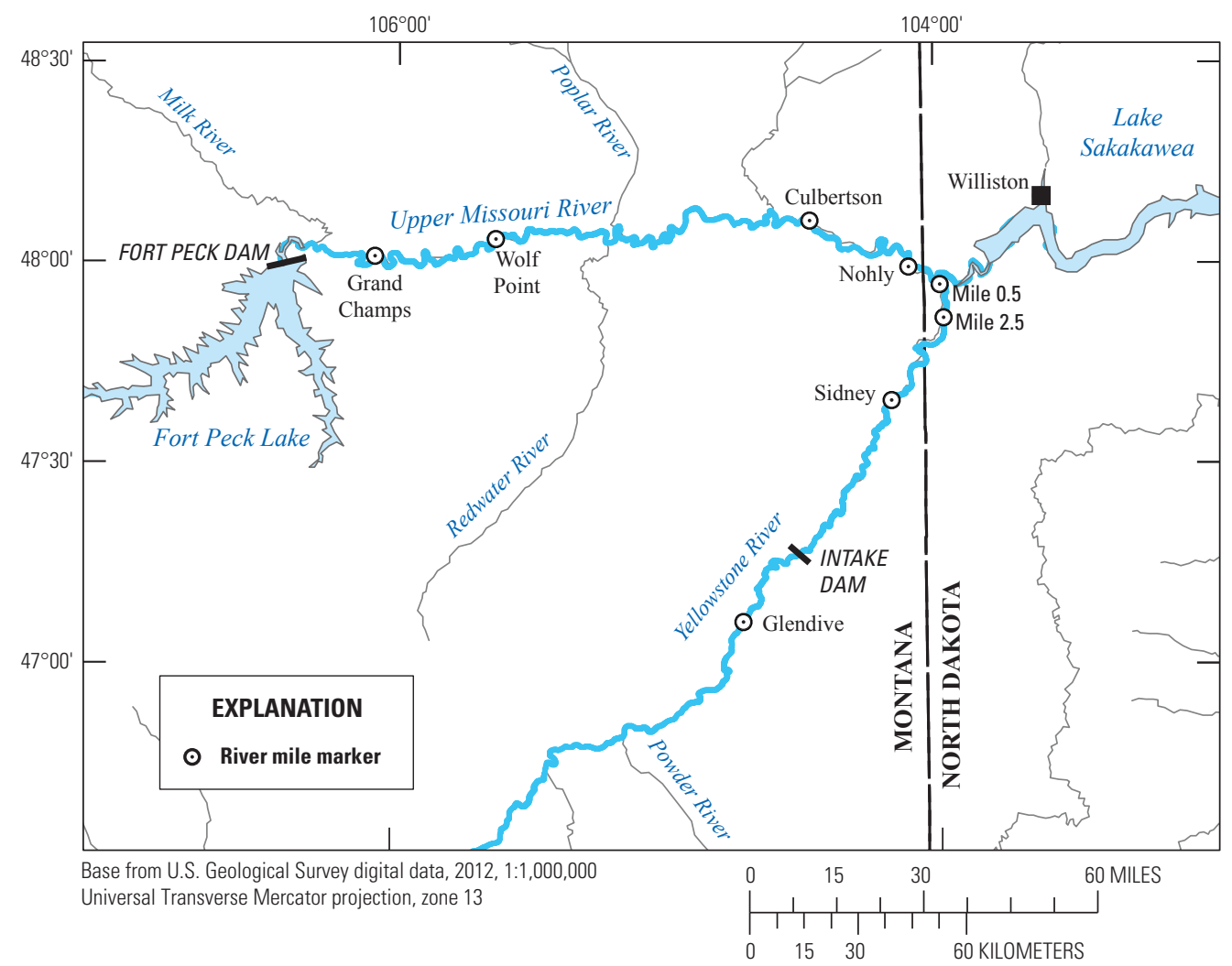

\section{Sturgeon Habitat Variability within the Missouri River}

Variability in hydrology, geomorphology, and water quality within the Missouri River Basin defines the template for CSRP field-based studies. The design compares sturgeon reproductive behavior, recruitment, and growth in distinctly different parts of the Missouri River system (fig. 3). The following sections describe the variation in hydrology, sediment regime, channel morphology, and water quality along the river and how the variability is used to constrain understanding of the pallid sturgeon ecology.

\section{Yellowstone River}

The Yellowstone River provides a nearly unaltered flow regime. The flow of the Upper Missouri River downstream from the confluence with the Yellowstone River retains the unregulated characteristics of the natural Yellowstone River hydrograph to the headwaters of Lake Sakakawea (fig. 9, as measured just downstream from its confluence with the Missouri River at Williston, North Dakota) (fig. 5) and channel morphology (fig. 10) that is relatively natural and complex. The Yellowstone River is the third greatest contributor of suspended sediment to the Missouri River main stem system. During 1975-1991 the median annual suspended sediment load at Sidney, Montana (fig. 9) was 9.2 metric tons (MT) (Heimann and others, 2011). Trends in suspended sediment concentration were negative indicating diminished yield over time; suspended sediment concentrations in the period after 1967 were 47 percent of historic values before 1953. Suspended sediment concentrations from 1971 to 2012 at Sidney, Montana had a median of 211 milligrams per liter $(\mathrm{mg} / \mathrm{L})$ and an interquartile range of $15,490 \mathrm{mg} / \mathrm{L}$ (fig. 11).

The Yellowstone River has a steep gradient and coarse bed throughout most of its course. The Lower Yellowstone River, defined as the downstream-most 150 miles, flows through the Great Plains from where the sediment-rich

Figure 9. Location of Upper Missouri River and Yellowstone River study sections. 


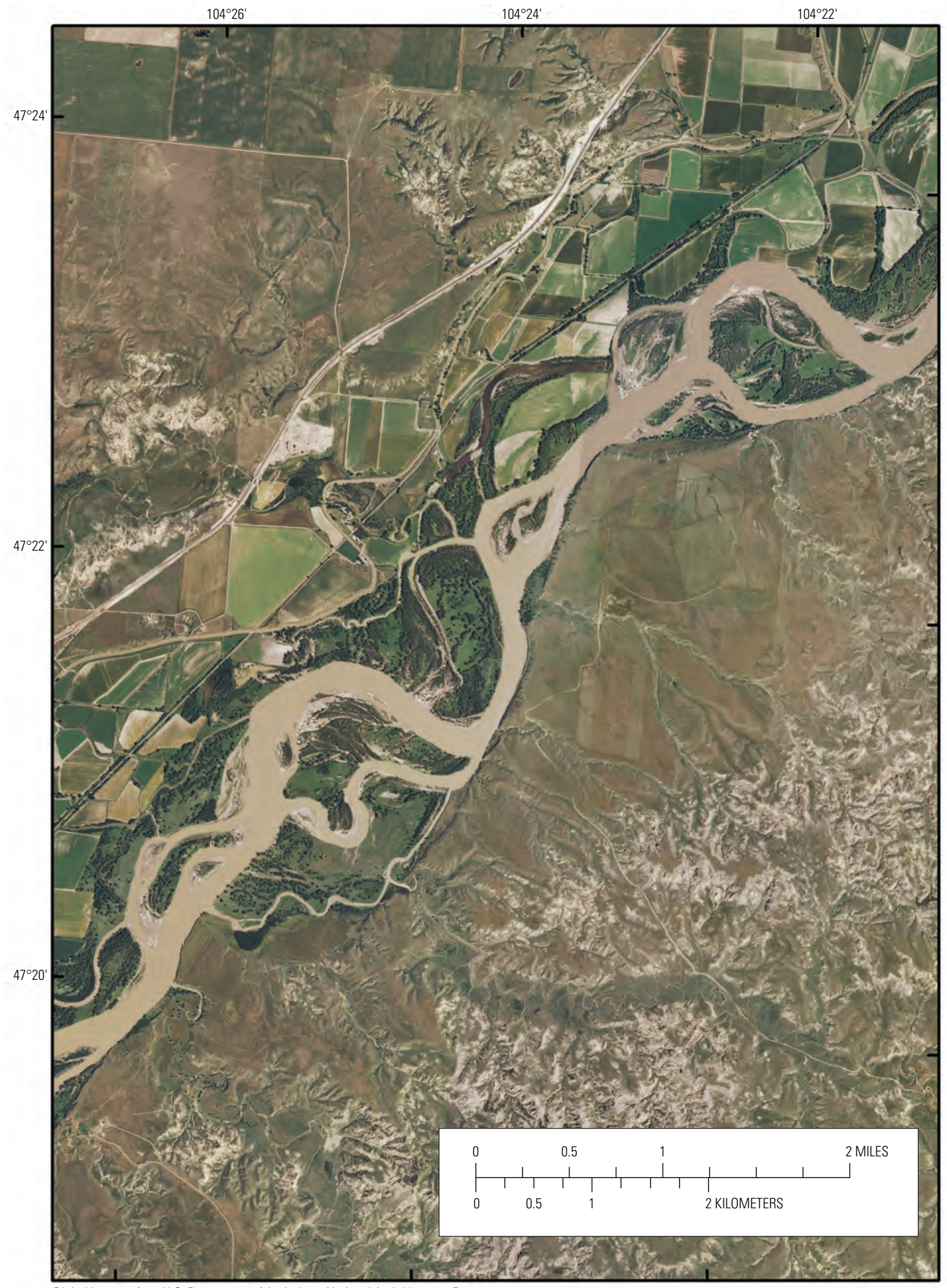

Digital imagery from U.S. Department of Agriculture National Aerial Imagery Program

Albers Equal-Area Conic projection

Figure 10. Representative channel morphology in the Yellowstone study section. 


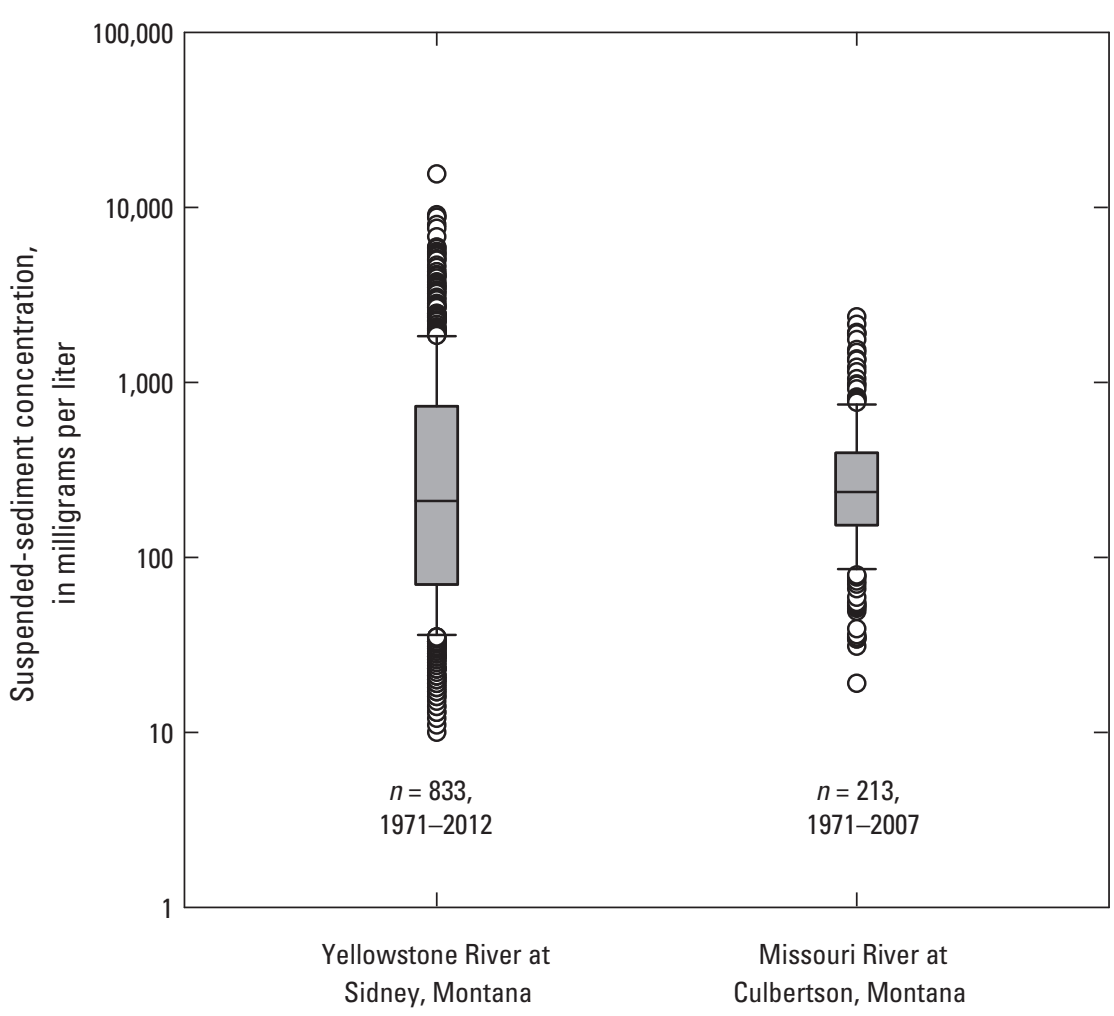

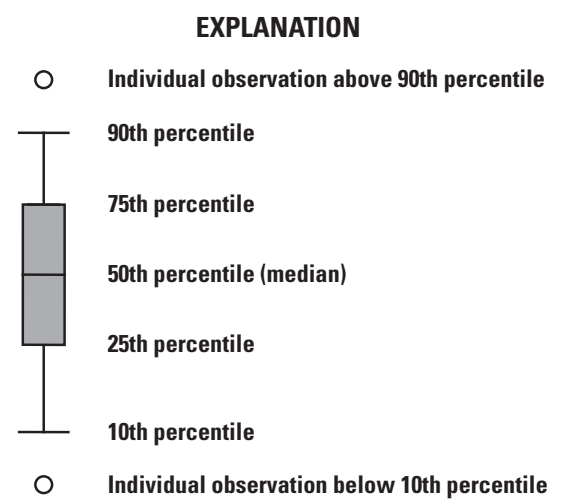

Figure 11. Suspended sediment concentrations, Yellowstone River at Sidney, Montana, and Missouri River at Culbertson, Montana.
Powder River enters the Yellowstone River at river mile (RM) 148 to its confluence with the Missouri River (Applied Geomorphology Inc., 2004). The Lower Yellowstone River's channel form ranges from reaches with a single-threaded channel to anabranching and braided reaches with frequent islands, chutes, backwater areas, and mid-channel bars (Koch and others, 1977). Total width of the river channel corridor (including islands) varies from 130 to 3,000 meters (m), and channel width (including side channels but not vegetated islands) varies from 130 to $1,090 \mathrm{~m}$. A highly braided section of the Lower Yellowstone River with frequent side channels extends from RM 104 to 38 and is roughly centered on Intake, Montana, at RM 73 (fig. 12). Downstream from this braided section, the Yellowstone River is primarily a single-threaded channel with numerous gravel bars until its confluence with the Missouri River. The Lower Yellowstone River is in frequent contact with bedrock bluffs of highly erodible shale rock and glacial outwash terraces, which are the source of much of the gravel in the river (Zelt and others, 1999; Applied Geomorphology Inc, 2004) (fig. 12). The river has a mixed bed of fine and gravel-to-cobble substrates with occasional bedrock outcrops in the channel.

The natural capacity of the Yellowstone River to support pallid sturgeon populations has been altered by two factors. Intake Dam at Intake, Montana (fig. 9), is 70 RM upstream from the Yellowstone and Missouri Rivers confluence and likely presents a limit to upstream passage of sturgeon as only one pallid sturgeon has been captured upstream from the dam (Watson and Stewart, 1991), and multiple pallid sturgeon migrations have been documented as far as Intake Dam with no evidence of passage (Fuller and others, 2008; DeLonay and others, 2014). Survival of drifting free embryos of fish that spawn in the Yellowstone River downstream from Intake Dam is likely limited downstream by the upper reaches of Lake Sakakawea, about 19 miles downstream from the confluence of the Yellowstone and Upper Missouri Rivers. It has been hypothesized that conditions in reservoirs are not suitable for survival of free embryos (Kynard and others, 2007; Braaten and others, 2012a). The resultant limited length of free-flowing river for free-embryo dispersal and development is the predominant hypothesis for the lack of recruitment in the Yellowstone and Upper Missouri Rivers (U.S. Fish and Wildlife Service, 2000).

Water quality in the Yellowstone River is generally good and not considered to be a limiting factor for most river biota. In the Yellowstone Basin National Water Quality Assessment Program report (Miller and others, 2005), concentrations of coliform bacteria were generally low and fecal coliform bacteria samples exceeded the U.S. Environmental Protection Agency (EPA) recommended limits in only 2.6 percent of samples. Nutrient concentrations were generally low although median total phosphorous concentrations exceeded the EPA goals for preventing nuisance plant growth in some samples. Concentrations of pesticides were also low and all below aquatic-life or human-health criteria. Measured turbidity recorded from 2002 to 2009 in the Yellowstone River near mile 0.8 had a median of 152 nephelometric turbidity units (NTU) and an interquartile range of 336 NTU (fig. 13). 


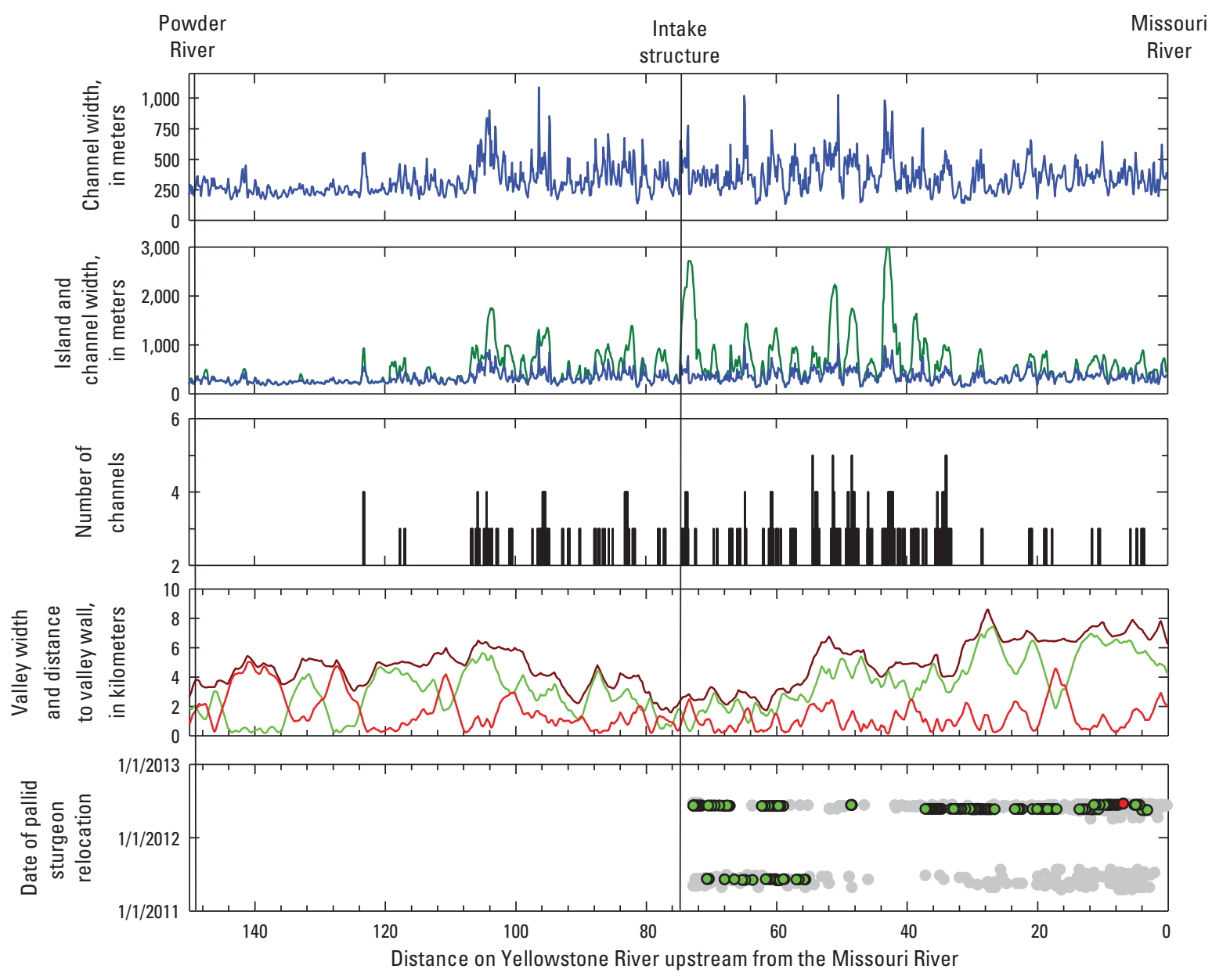

EXPLANATION
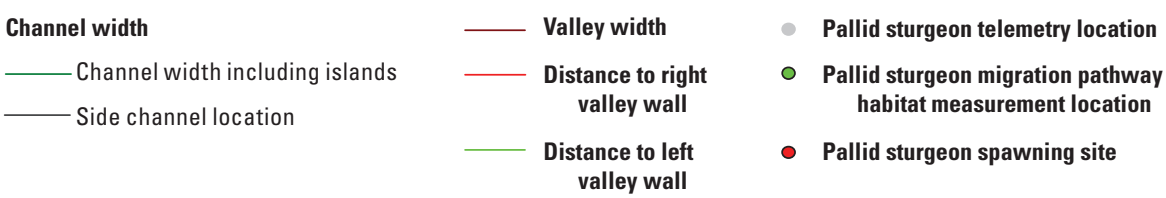

Figure 12. Channel and island width, number of channels, valley width, pallid sturgeon relocations and habitat data collection locations on the Lower Yellowstone River from the Powder River to the Missouri River, Montana and North Dakota.

Minimal published information exists on contaminant levels as related to pallid sturgeon ecology in the Yellowstone River. In one study from the late 1980s, a pallid sturgeon captured near the Yellowstone-Missouri River confluence was reported to have elevated levels of DDT and its metabolites, polychlorinated biphenyls (PCBs), chlordane, mercury, selenium, and cadmium (Ruelle and Keenlyne, 1993). In particular, this fish had PCB concentrations in its liver and flesh that were about 10 times the Federal Food and Drug Administration action level of 2.0 milligrams per kilogram $(\mathrm{mg} / \mathrm{kg})$ (Blevins, 2011). For long-lived fish like the pallid sturgeon, it would not be unusual to document the accumulation of persistent contaminants in older individuals. Information is lacking to determine whether contaminants are an important issue for sturgeon populations.

Annual water temperature regimes are considered to be stable in the Yellowstone River because of the lack of development in the basin (Miller and others, 2005). Historical datasets are generally lacking. Recent median temperature measured near RM 2.5 during late-May to October each year from 2002 to 2012 was $20.0^{\circ} \mathrm{C}$, with an interquartile range of $6.1^{\circ} \mathrm{C}$ (fig. 14). Temperatures are highly seasonal (fig. 15). 


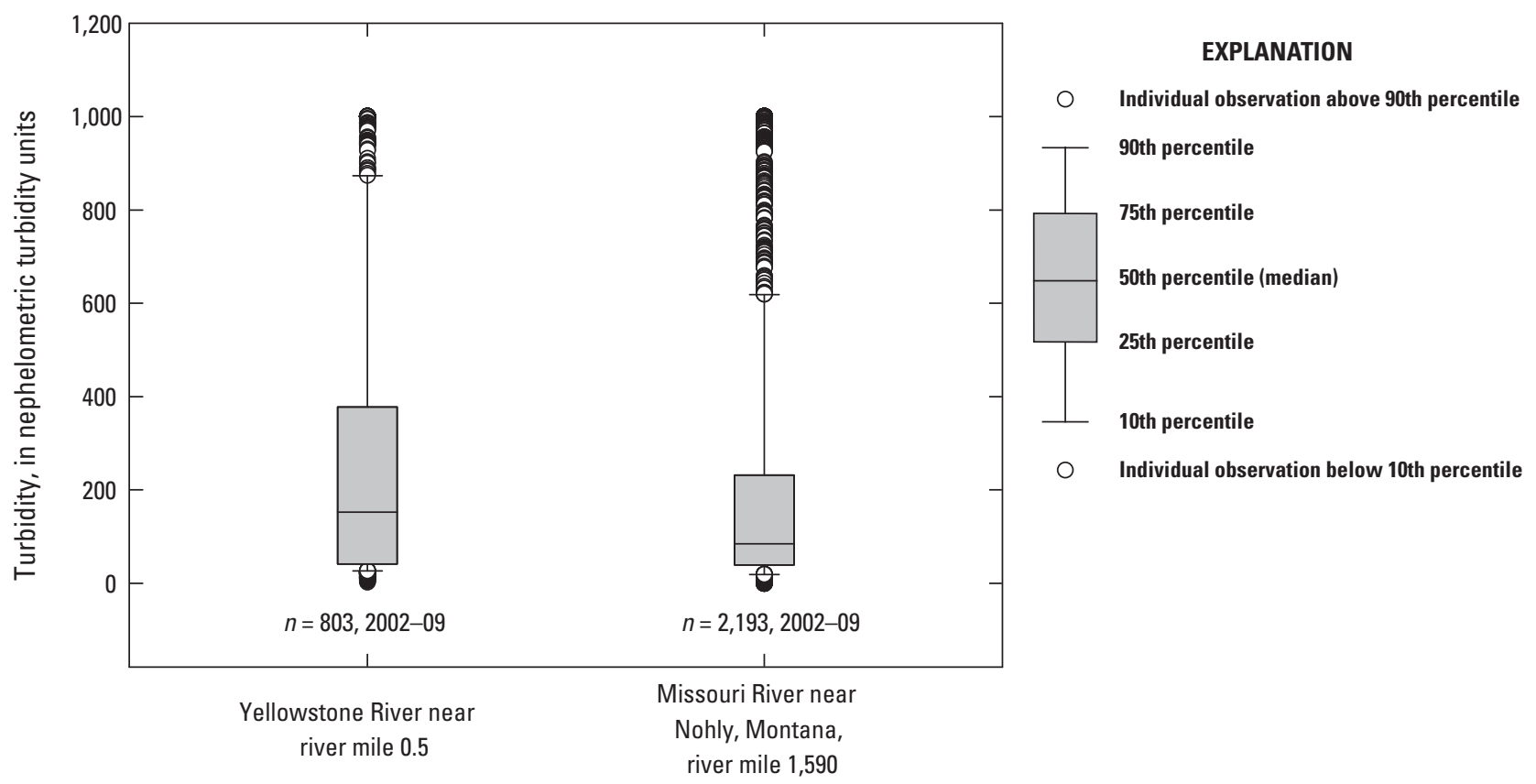

Figure 13. Turbidity distributions, Yellowstone River near mile 0.5 and Missouri River near Nohly, Montana, near mile 1,590. Note that the instruments were only capable of reading to 1,000 NTU, so the distributions are truncated above that value. Data from Fuller and Braaten (2012).

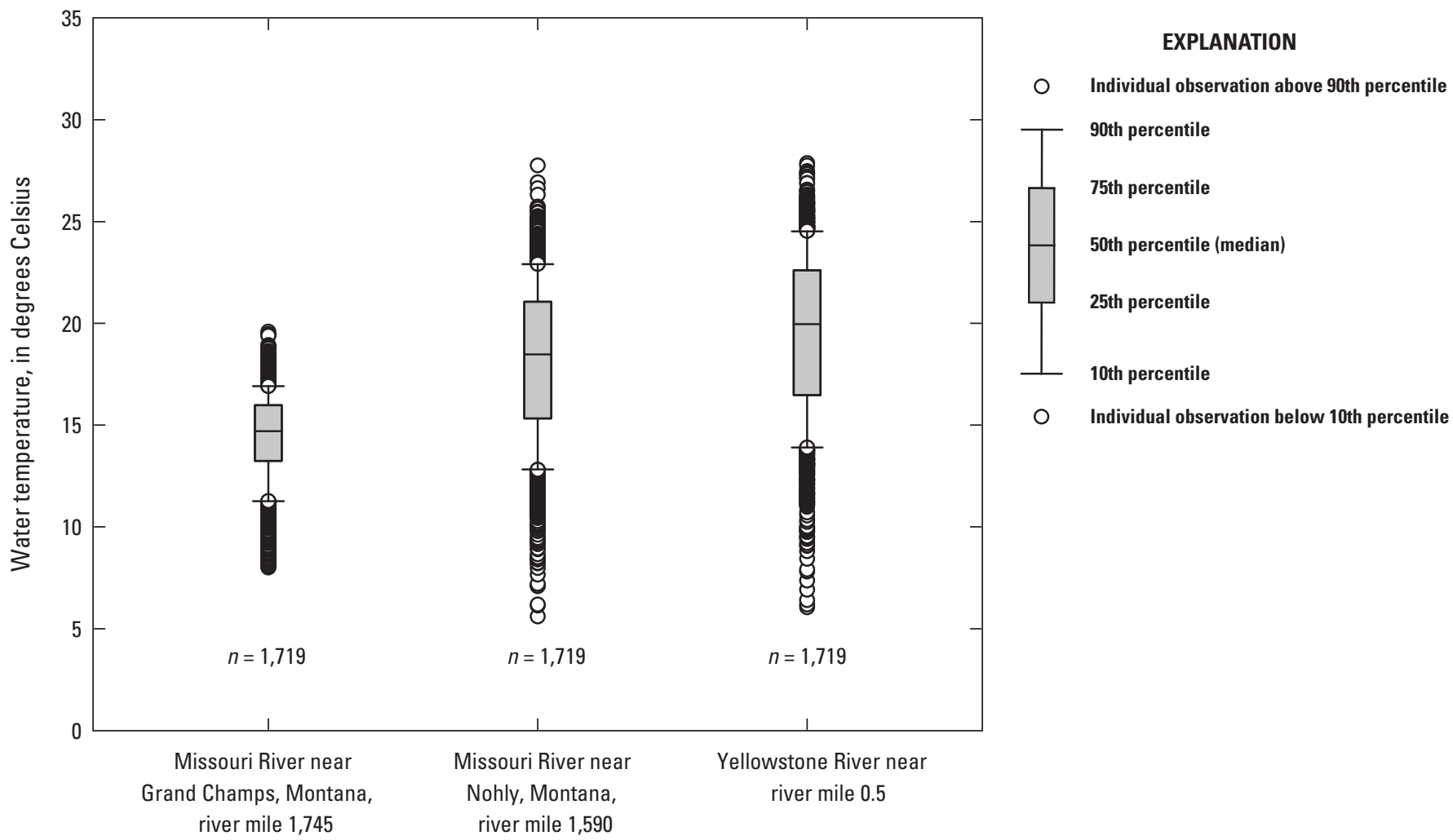

Figure 14. Temperatures from 2001 to 2012, Upper Missouri River and Yellowstone River. Records run from May 21 through October 11 of each year. 


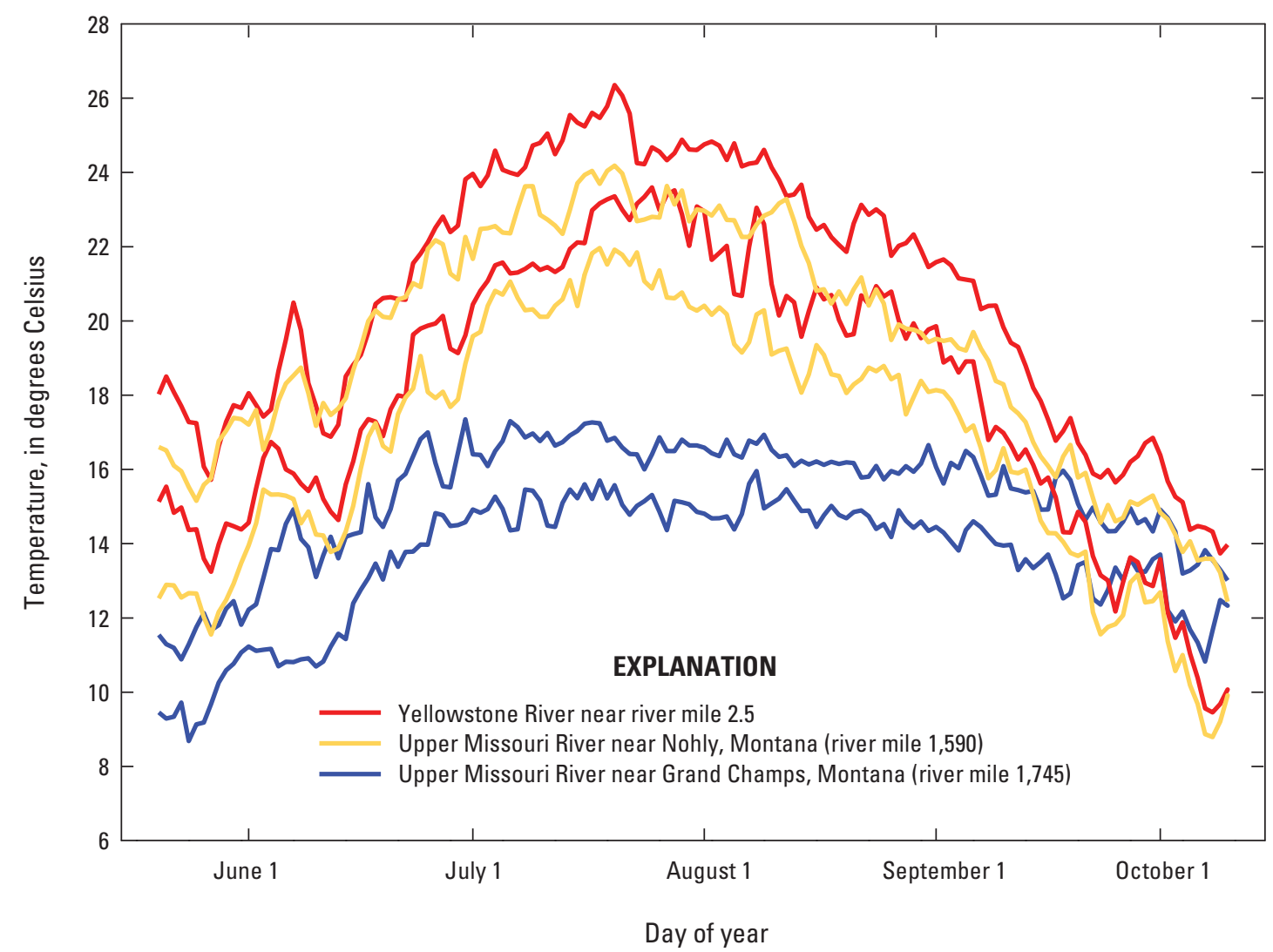

Figure 15. Interquartile ranges of water temperatures by day of year on the Yellowstone and Upper Missouri River from daily means, 2001-2012.

\section{Upper Missouri River}

The Upper Missouri River (used in this report to refer to the river from upper reaches of Lake Sakakawea to Fort Peck Dam) has a near-natural channel morphology with few instances of bank stabilization or other river training structures (fig. 16). However, because it is downstream from a large reservoir this segment of river has a highly altered flow regime (fig. 5). Recent calculations of sediment load are not available for the Upper Missouri River, but suspended sediment concentrations at Culbertson, Montana 1971-2007 report a median of $237 \mathrm{mg} / \mathrm{L}$ and an interquartile range of 2,351 mg/L. The median is very similar to that on the Yellowstone River although the interquartile range of concentrations on the Yellowstone is much greater (fig. 11). High suspended sediment concentrations at Culbertson indicate the additions of suspended sediment from the Milk, Poplar, and Redwater Rivers (fig. 9).

Channel morphology data are less available on the Upper Missouri River compared to the Yellowstone and Lower Missouri Rivers. The planform of the river is relatively complex and natural (fig. 16), and lack of sediment has resulted in channel incision since Fort Peck Lake (fig. 9) was completed. However, incision near the dam seems to have equilibrated since the 1960s (Williams and Wolman, 1984; U.S. Army Corps of Engineers, 2012). The Upper Missouri River also offers the opportunity to evaluate sturgeon selection of tributaries, notably the Poplar, Redwater, and Milk Rivers. Among these, the Milk River watershed is substantially the largest at 17,670 square miles and is a potential contributor of warmer water and increased turbidity relative to that available in the Upper Missouri River main stem.

Modeled and measured nutrient loads in the Upper Missouri River downstream from Fort Peck Dam are low, indicative of low inputs of nitrogen and phosphorous and the attenuating effects of Fort Peck Lake (Brown and others, 2011). Dams and reservoirs in the Upper Missouri River have been associated with as much as 60 percent attenuation of nitrogen and 72 percent of the phosphorous loads, with most of the attenuation being explained by Fort Peck Lake (Brown and others, 2011). Similar to suspended sediment concentrations, median turbidity in the Upper Missouri River is similar to the Yellowstone River but is less variable (fig. 13).

Water temperatures in this river segment are affected by the hypolimnetic releases from Fort Peck Dam, and generally increase in the downstream direction with atmospheric warming and tributary inputs. The effect of reservoir releases on water temperature can be seen by examining the relation between air temperature, water temperature, and discharge at the Wolf Point, Montana (fig. 9) streamgage. Residuals from a regression between air and water temperature, plotted against discharge, show a negative trend, indicating decreasing water 


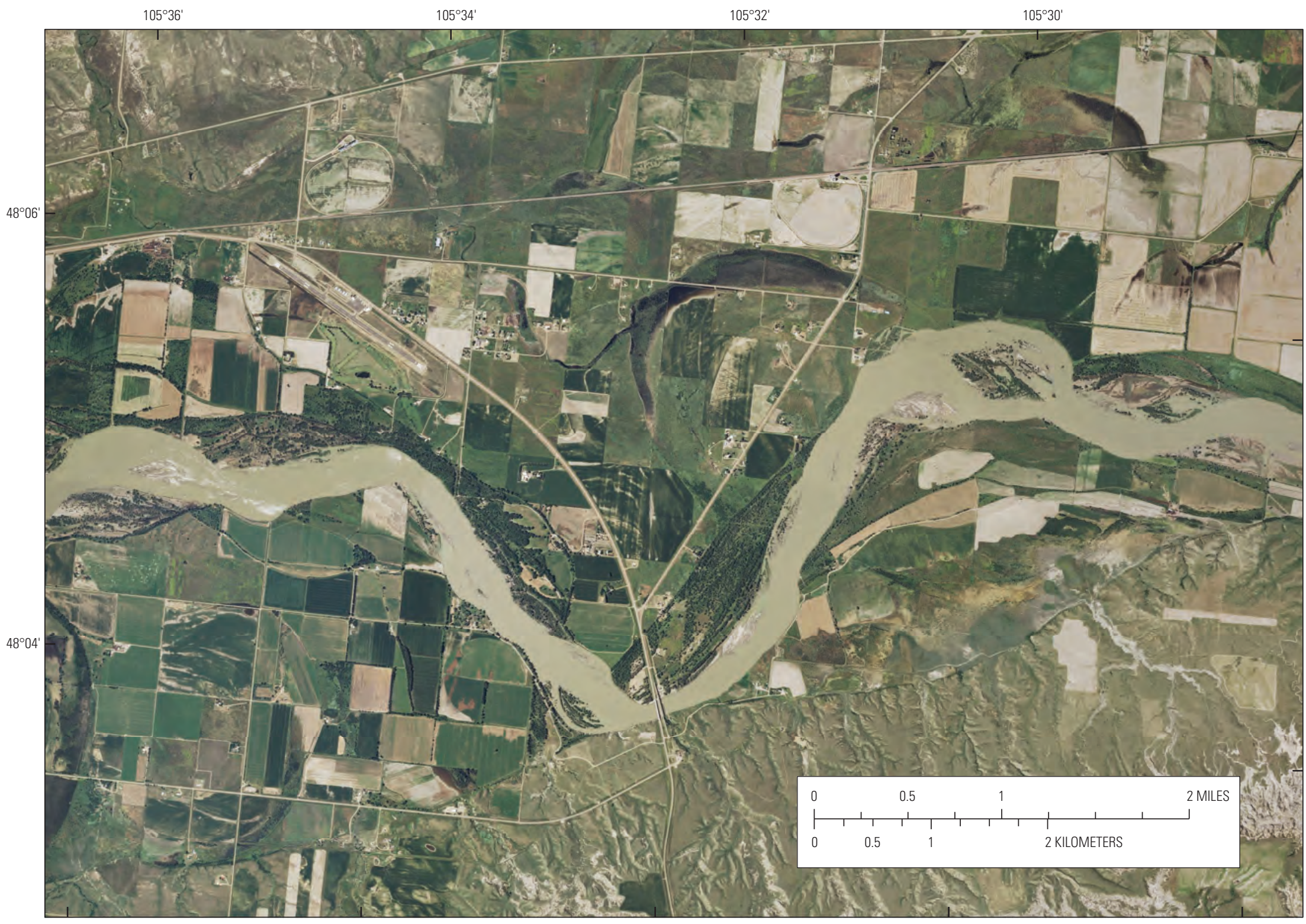

Digital imagery from U.S. Department of Agriculture National Aerial Imagery Program, 2011

Albers Equal-Area Conic projection

Figure 16. Representative channel morphology in the Upper Missouri River study section. 
temperature with increasing discharge from the dam (fig. 17). The warming trend downstream is evident comparing two sites on the Upper Missouri River. At Grand Champs, Montana (fig. 9), the temperature monitoring station closest to the dam, the median seasonal (May 20-October 1) water temperature from 2001 to 2012 was $14.7^{\circ} \mathrm{C}$ (interquartile range, 13.2-16.0) whereas downstream at Nohly, Montana, median water temperature was $18.5^{\circ} \mathrm{C}$ (interquartile range 15.3-21.0) (fig. 14). Temperature depression downstream from the dam persists during spring-fall season. At Nohly the seasonal temperature distribution of the Upper Missouri River more closely matches the Yellowstone River, although Upper Missouri River water temperatures are noticeably colder mid-July-midSeptember (fig. 15).

\section{Lower Missouri River}

The upstream study section of the Lower Missouri River has a highly altered flow regime (fig. 5) because of its position directly downstream from the main-stem reservoir system (fig. 18). Being close to the dam, this section presents options for experimental flow releases, which have been used to evaluate effects of pulsed flows on pallid sturgeon reproduction (Jacobson and Galat, 2008; Doyle and others, 2011). The flow regime regains seasonal variability in the downstream direction, although at Hermann, Missouri, RM 100, lowered spring peaks and increased late-summer/fall flows are still distinguishable (fig. 5).

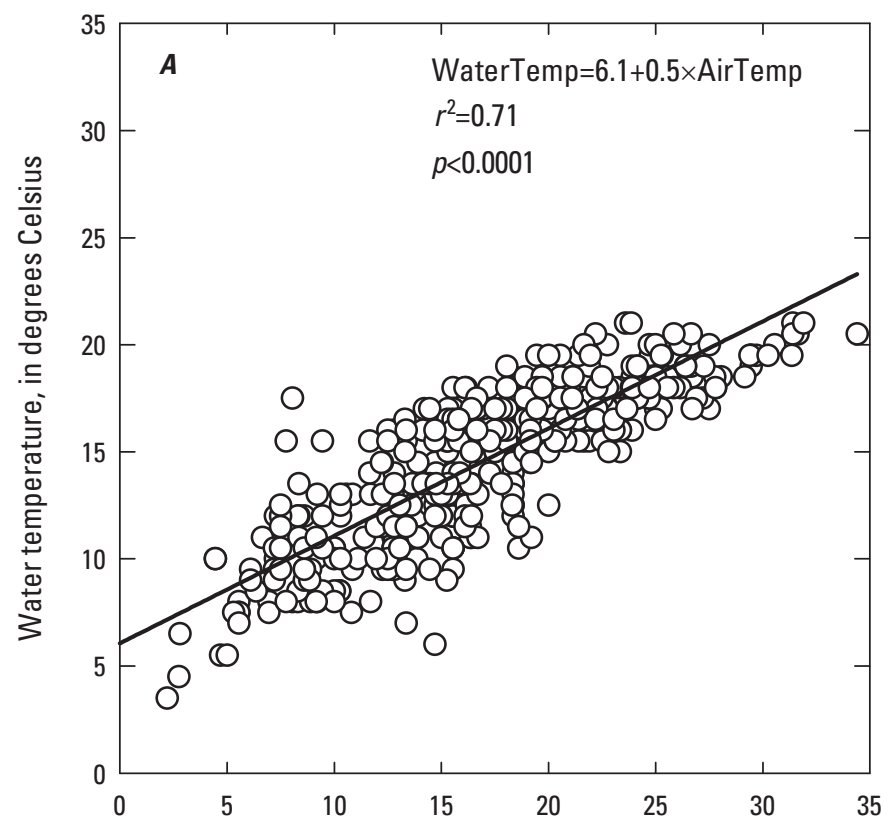

Air temperature, in degrees Celsius
The suspended sediment load is near zero at the dam and increases downstream to 6-10 MT/year (y) at Sioux City, Iowa; annual loads vary among published sources based on the years for which loads are calculated and averaged (Jacobson and others, 2009a; Heimann and others, 2011). Notably, modern suspended sediment loads are about a tenth of the earliest measured, pre-dam loads at Sioux City (64 MT/y; Jacobson and others, 2009). Post-dam sediment loads increase downstream throughout the upstream section to $16.4-18.9 \mathrm{MT} / \mathrm{y}$ at Omaha, 27.6-77.6 MT/y at St. Joseph, and 55.2-77.0 MT/y at Hermann (Jacobson and others, 2009a).

As a result of the lack of sediment from the dam, the channel has incised and water-surface elevations have decreased as much as $3.8 \mathrm{~m}$ since the dams were closed (U.S. Army Corps of Engineers, 2012). Decreases in stage and mean streambed elevation have been documented downstream to Omaha (Jacobson and others, 2009a). Stages at low flows have been stable for the last 10 years at Sioux City, Iowa, and Omaha, Nebraska, with the exception of steep decreases measured after the 2011 flood (U.S. Army Corps of Engineers, 2012). From Omaha to St. Joseph, Missouri, stage trends for low flows have been stable to slightly declining, whereas stage trends for flows 70,000-100,000 cubic feet per second $\left(\mathrm{ft}^{3} / \mathrm{s}\right)$ (5-10 percent flow exceedance) have been increasing, presumably because of loss of channel capacity due to sedimentation in overbank areas adjacent to the channel. From St. Joseph to Kansas City, Missouri, low-flow stages decrease markedly, a result considered to be associated with

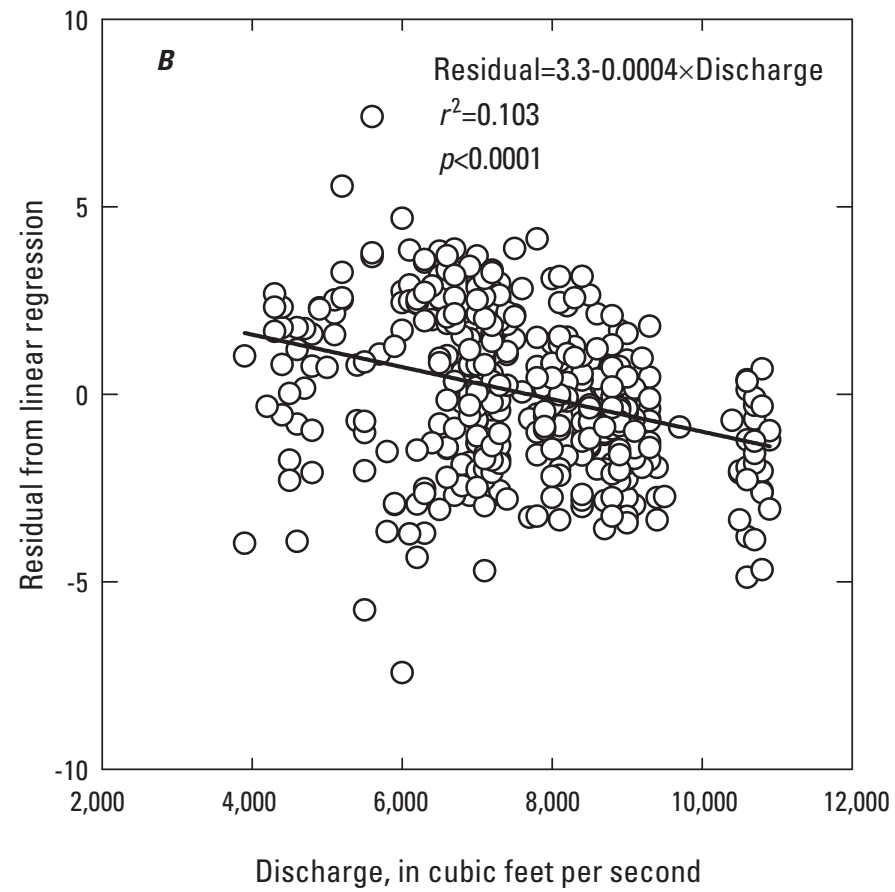

Figure 17. Relation between air and water temperature near Fort Peck, Montana and Wolf Point, Montana, 63 river miles downstream. $A$, Least-squares linear regression between air temperature and water temperature $(p<0.0001)$. $B$, Least-squares linear regression between residuals (actual minus predicted) of the air temperature and water temperature regression and discharge. The residual plot shows that water temperature is significantly correlated with discharge, accounting for air temperature $(p<0.0001)$. 


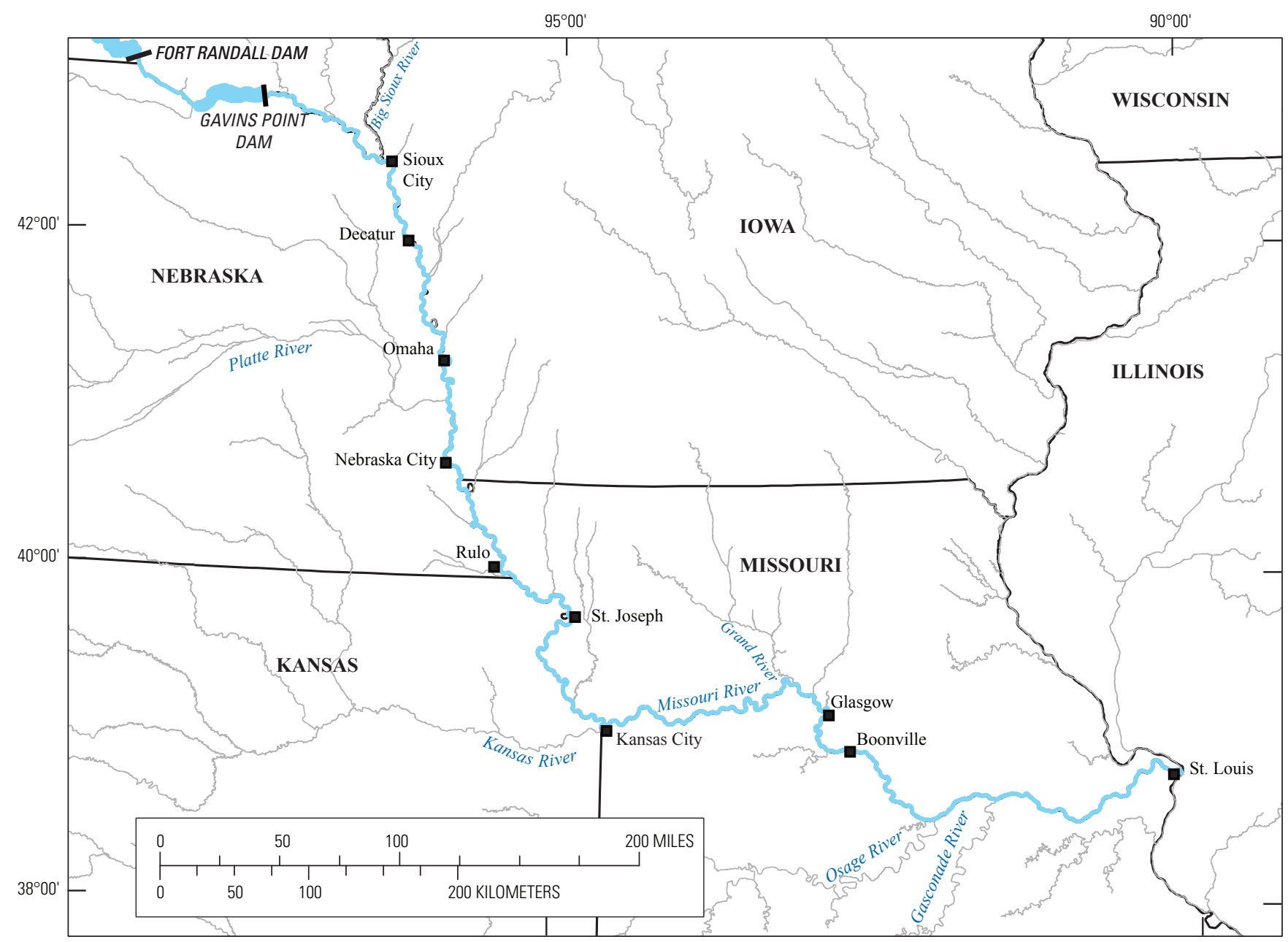

Base from U.S. Geological Survey digital data, 2012, 1:100,000

Albers Equal-Area Conic projection

Figure 18. Lower Missouri River main stem and major tributary rivers within the Comprehensive Sturgeon Research Project study areas.

a combination of commercial sand and gravel mining from the river and channelization. Downstream from Kansas City, low-flow stage trends recover and then are stable to slightly decreasing, whereas high-flow stages increase presumably due to the effects of levees constricting overbank flows (Pinter and Heine, 2005; Pinter and others, 2010).

Channel morphology in the Lower Missouri River varies geographically with the degree of channel engineering, geologic setting, and with downstream increases in discharge and sediment inputs from tributaries (Reuter and others, 2008; DeLonay and others, 2009; Elliott and others, 2009; Jacobson and others, 2009b; Reuter and others, 2009; DeLonay and others, 2010; Bonnot and others, 2011a; DeLonay and others, 2012; DeLonay and others, 2014). Although various habitat classification schemes have been proposed and applied to the Lower Missouri River, for the purposes of this report we will summarize data and break the Lower Missouri River into a minimally engineered section, an upstream channelized section, and a downstream channelized section (Reuter and others, 2009).
The section from Gavins Point Dam to the Big Sioux River (fig. 18) is the least engineered section of the Lower Missouri River including 59 miles of the Missouri National Recreational River (not shown), which retains much of the anabranching nature of the pre-dam river and has bare sandbars, variously vegetated islands, and multiple side channels (fig. 19) (Elliott and Jacobson, 2006). The minimally engineered segment has a range of depths, wide channel widths, and low mean velocities (fig. 20) (Reuter and others, 2009). A reach below Gavins Point Dam in the minimally engineered part of the Lower Missouri River has a substantial amount of coarse-bed substrate due to the presence of glacial materials and scouring downstream from the dam (fig. 21) (Laustrup and others, 2007; Elliott and others, 2009).

Downstream from Sioux City, Iowa, the Lower Missouri River has been channelized by the construction of wing dikes and bank revetment to create a single-threaded, self-scouring navigation channel managed by the U.S. Army Corps of Engineers (fig. 19). Nearly every outside bend on the channelized Lower Missouri River has been 


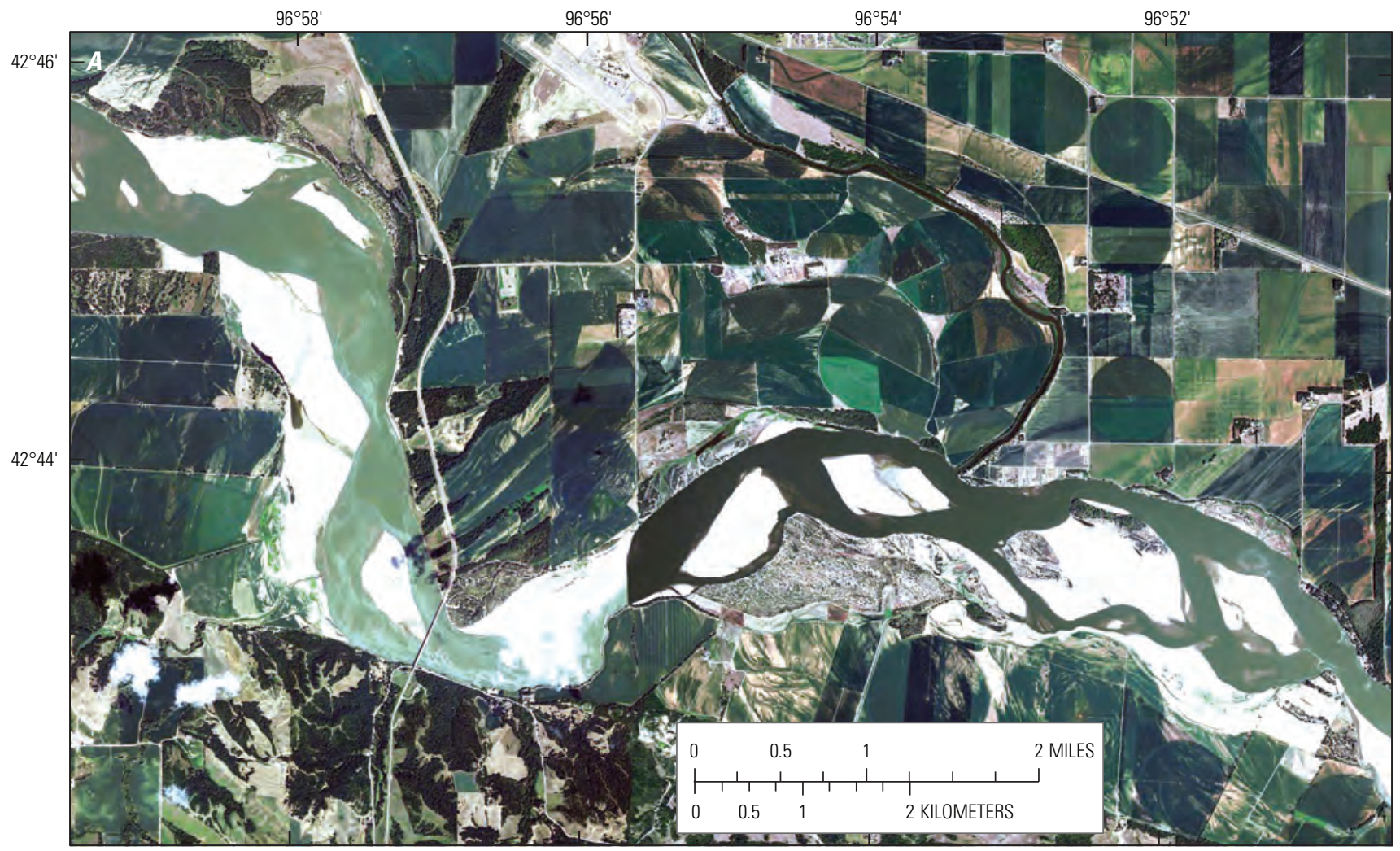

Digital Imagery from the U.S. Department of Agriculture National Aerial Imagery Program, 2012

Albers Equal-Area Conic projection

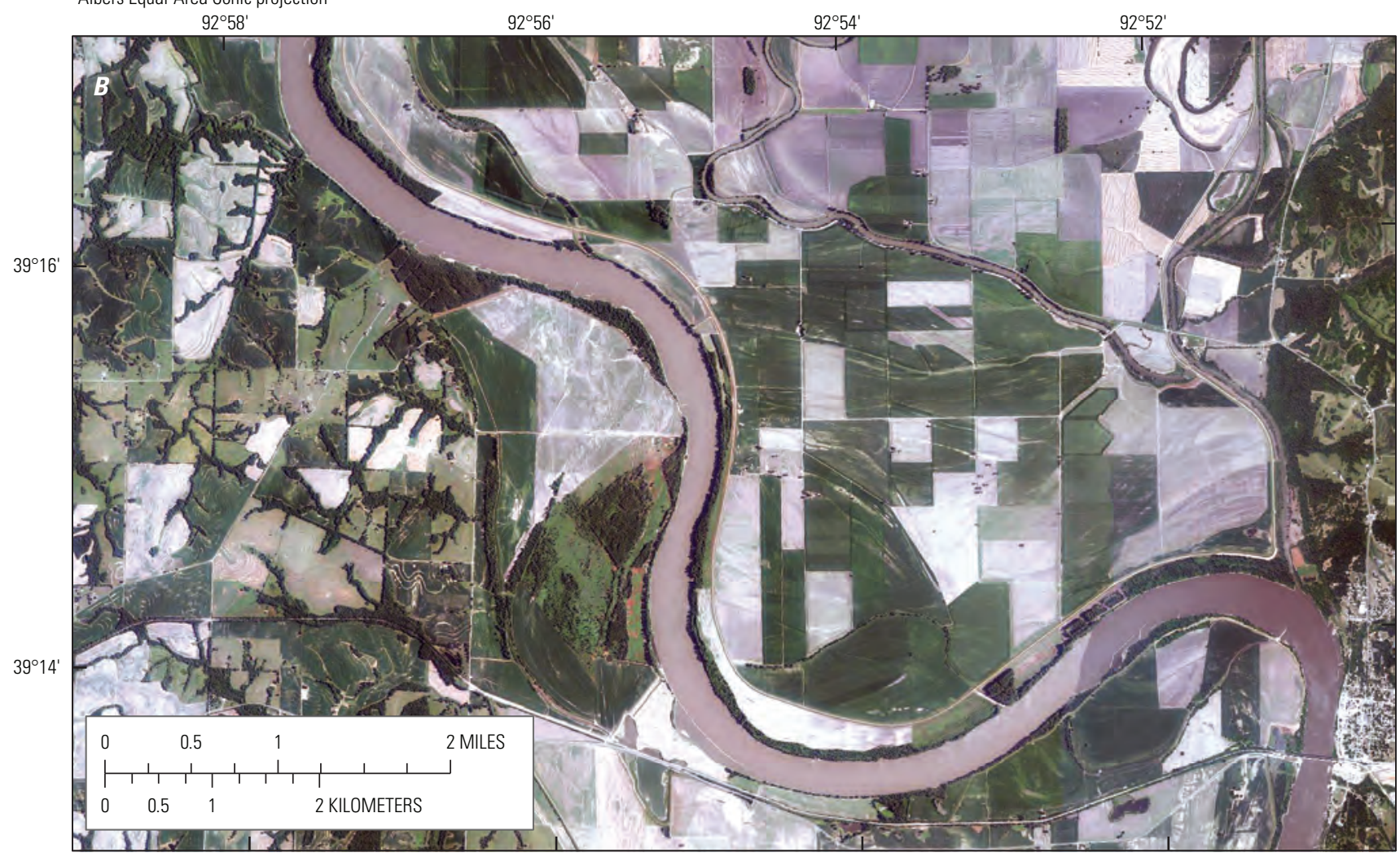

Digital Imagery from the U.S. Department of Agriculture National Aerial Imagery Program, 2012

Albers Equal-Area Conic projection

Figure 19. Examples of channel morphological variability in the Lower Missouri River. $A$, The minimally-engineered Gavins Point Dam to Big Sioux River segment. $B$, The channelized Grand River segment. 

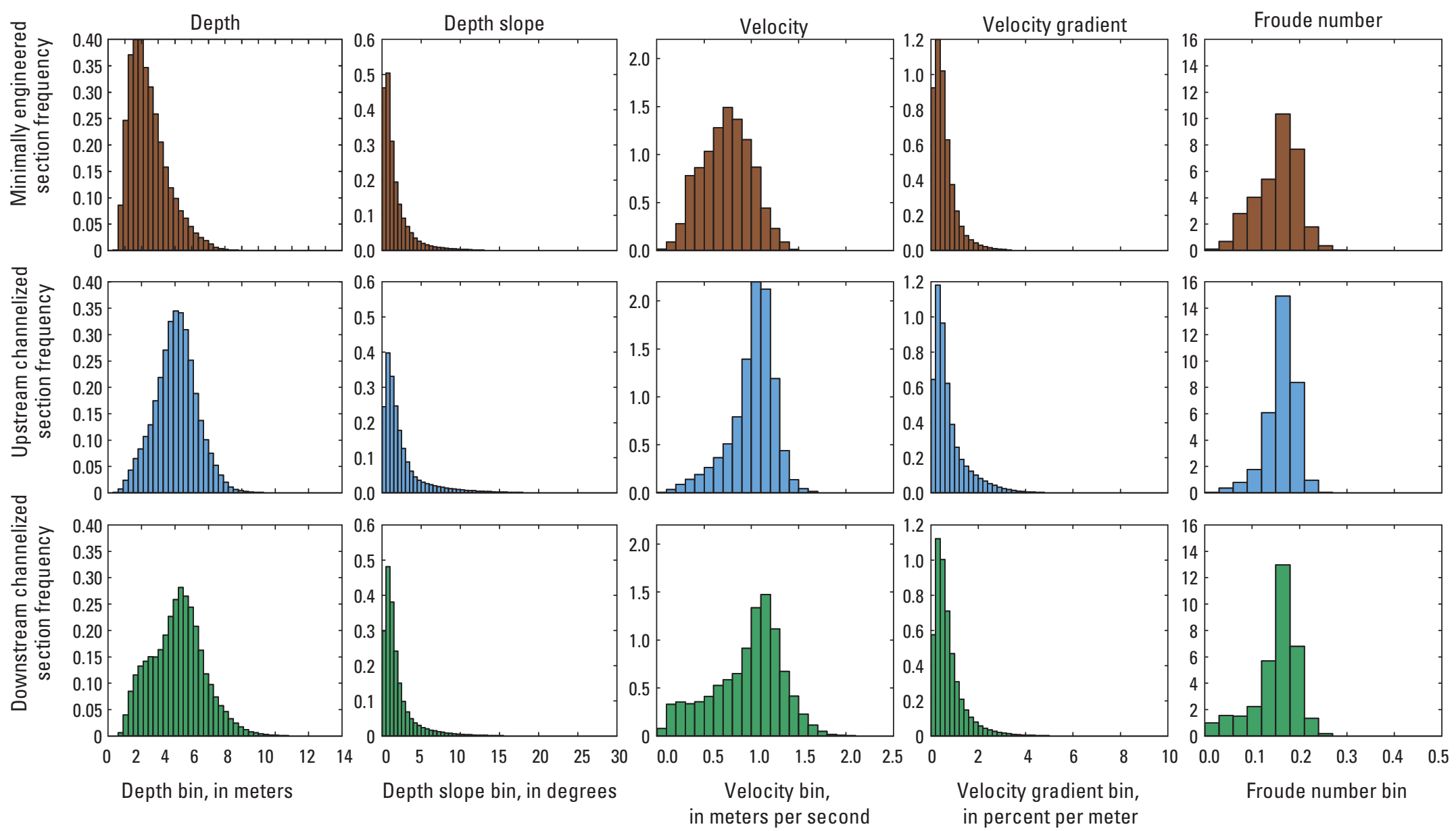

Figure 20. Distributions of habitat variables by Lower Missouri River sections, from Reuter and others (2009). The minimally engineered section extends from the Gavins Point Dam to the Big Sioux River. The upstream channelized section extends from Sioux City, lowa to the Kansas River. The downstream channelized section extends from the Kansas River to the Mississippi River. 

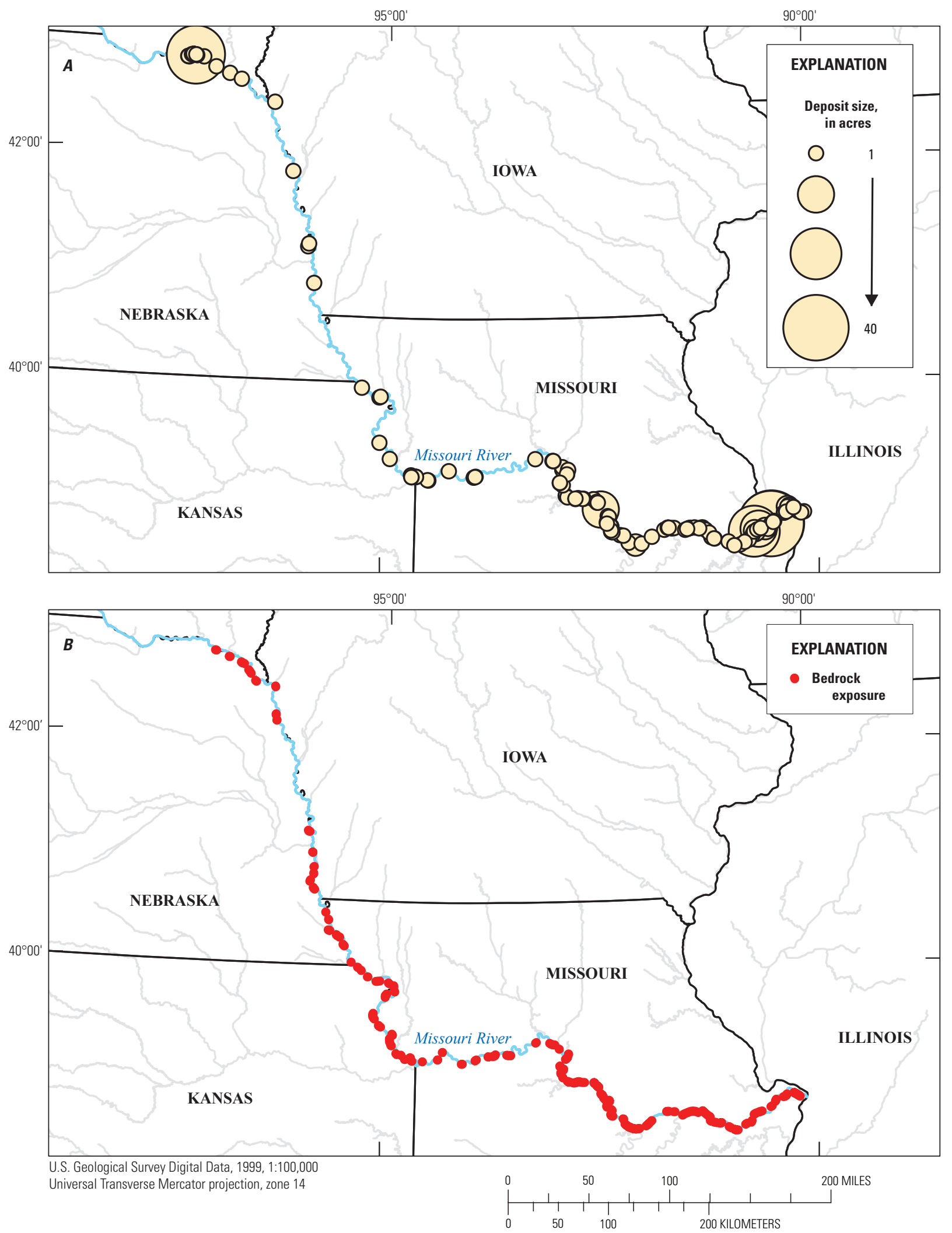

Figure 21. Natural potential spawning substrate in the Lower Missouri River. Data from Laustrup and others (2007). $A$, Gravel-cobble deposits. $B$, Bedrock adjacent to channel. 
armored with bank revetment consisting of coarse, angular, and variably sorted dolomite, limestone, or quartzite boulders. Wing, or spur dikes, also constructed of coarse hard rock, function to contract the natural channel and usually are constructed perpendicular to the thalweg or angling slightly downstream. Wing dike length controls the amount of channel constriction on a channelized river (Parchure, 2005). Constricted channel width-measured as the distance between wing dike tips and the opposite bank-and the ratio of constricted to total width vary substantially along the river (fig. 22). Because the wing dikes control velocity contractions and expansions, these metrics are fundamental descriptors of habitat complexity.

The upstream channelized section of the Lower Missouri River extends downstream from Sioux City, Iowa (RM 735) to the Kansas River (RM 367). The number of dikes per mile along the entire Lower Missouri River is relatively uniform, at about 4.5-5 dikes per mile. Channel width for this segment of river is relatively low ranging from 143 to $343 \mathrm{~m}$, with a mean width of $223 \mathrm{~m}$ (fig. 22). Superimposed on gradual downstream trends in channel morphology are several rather abrupt changes. Substantial changes in channel width, constricted width, and constriction ratio occur at tributary confluences (notably at the Platte, Kansas, Grand, and Osage River confluences) and near RM 500. Upstream from Rulo, Nebraska, dikes are shorter, with a mean length of $40 \mathrm{~m}$, and thereby constrict the channel to a lesser degree than downstream from Rulo (fig. 22). Constricted width ranges in the upstream channelized section from $135-286 \mathrm{~m}$, with a mean of $178 \mathrm{~m}$. The constriction ratio between channel width and the width between the dike tip and the opposite bank ranges from $0-0.5$ and has a mean value of 0.2 (fig. 22).

Compared to the minimally engineered and downstream channelized section of the Lower Missouri River the upstream channelized section has fewer regions of shallow depths and low velocity (fig. 20). This section is also more dynamic. Surveys repeated during a 2-year period in a 6-km reach near the Little Sioux River documented substantial amounts of deposition and erosion occurring as large sandbars migrated down the channel. In places, the channel eroded or deposited 3-4 m during the 2-year period yet maintained a low net rate of erosion and deposition for the reach as a whole (Elliott and others, 2009). A dynamic, shifting thalweg also has been documented through repeat surveys in other locations in the upstream channelized section of the Missouri River (Reuter and others, 2009).

Side channel and chute construction has been active in the upper channelized segment for habitat restoration, primarily upstream from Rulo, Nebraska (fig. 22). Dike notches, bank notches, and revetment notches also have been used to create habitat complexity in this part of the river. Valley widths are fairly wide although the river is occasionally in contact with the valley wall resulting in discontinuous reaches with natural bedrock exposures (Laustrup and others, 2007) (fig. 22).
In the downstream channelized section of the Lower Missouri River (Kansas River to the Mississippi River) the channel width ranges from 200 to $800 \mathrm{~m}$ with a mean width of $400 \mathrm{~m}$ (fig. 22). Mean wing dike length is $100 \mathrm{~m}$ and constricted width ranges from 155 to $760 \mathrm{~m}$ (mean $275 \mathrm{~m}$ ). Long wing dikes constrict the channel considerably, with constriction ratios as much as 0.6 (mean value is 0.3 ). Wing dikes create large recirculating eddies that tend to be associated with fine sediment deposition, areas of shallow water and low velocities, and emergent sandbars at lower discharges (Reuter and others, 2009; Tracy-Smith and others, 2012). There are also many small dikes and L-head dikes (L-head dikes are spur dikes with downstream extensions parallel to flow) on the lower channelized portion as illustrated by the wide range of constriction ratios (fig. 22).

Channel monitoring data for 2 years in a representative 6-km reach near RM 262 documented that the channel was stable at the crossover-bend scale. In contrast to the upstream channelized section where sandbars migrated along the thalweg, channel-morphology dynamics in this part of the river system were limited to scour and fill during high-flow events in patches downstream from wing dikes or on point bars (Elliott and others, 2009). Natural and constructed chutes occur on the downstream channelized Missouri River, and many spur and L-head dikes and areas of bank revetment have been notched to create more habitat complexity (fig. 22) (Jacobson and others, 2004a; Jacobson and others, 2004b). The Missouri River flows through a narrower valley as it enters the margin of the Ozark Plateaus Physiographic Province near RM 225. From RM 225 to the mouth, the Missouri River has the highest concentration of natural bedrock in and adjacent to the river channel (Laustrup and others, 2007) (fig. 22).

Water quality downstream from Gavins Point Dam reflects the effects of the upstream reservoir system and progressive changes from downstream tributary inputs. The reservoir created by Gavins Point Dam, is relatively shallow and less likely to stratify compared to larger upstream reservoirs. The effect of the reservoir release on water temperature can be seen by examining the relation between air temperature, water temperature, and discharge at the Yankton, South Dakota streamgage. There is a near-linear 1:1 relation between air and water temperature, with departures for negative air temperatures that are not associated with negative water temperatures (not shown), and with maximum water temperatures that do not increase much above $25^{\circ} \mathrm{C}$ due to evaporative cooling (fig. 23). The one-to-one model explains 80 percent of the variation. The slope on the residuals is negative and very small, suggesting a slight tendency for colder water temperatures to be associated with high discharges; however, the relation is affected by discharges in excess of $50,000 \mathrm{ft}^{3} / \mathrm{s}$, and especially the very high discharges greater than $100,000 \mathrm{ft}^{3} / \mathrm{s}$ in 2011. Operational releases for spring pulsed flows, for comparison, would rarely result in a release from Gavins Point Dam in excess of 47,000 $\mathrm{ft}^{3} / \mathrm{s}$ for 2 days (U.S. Army Corps of Engineers, 2006) and so would not be expected to alter ambient water temperatures. 


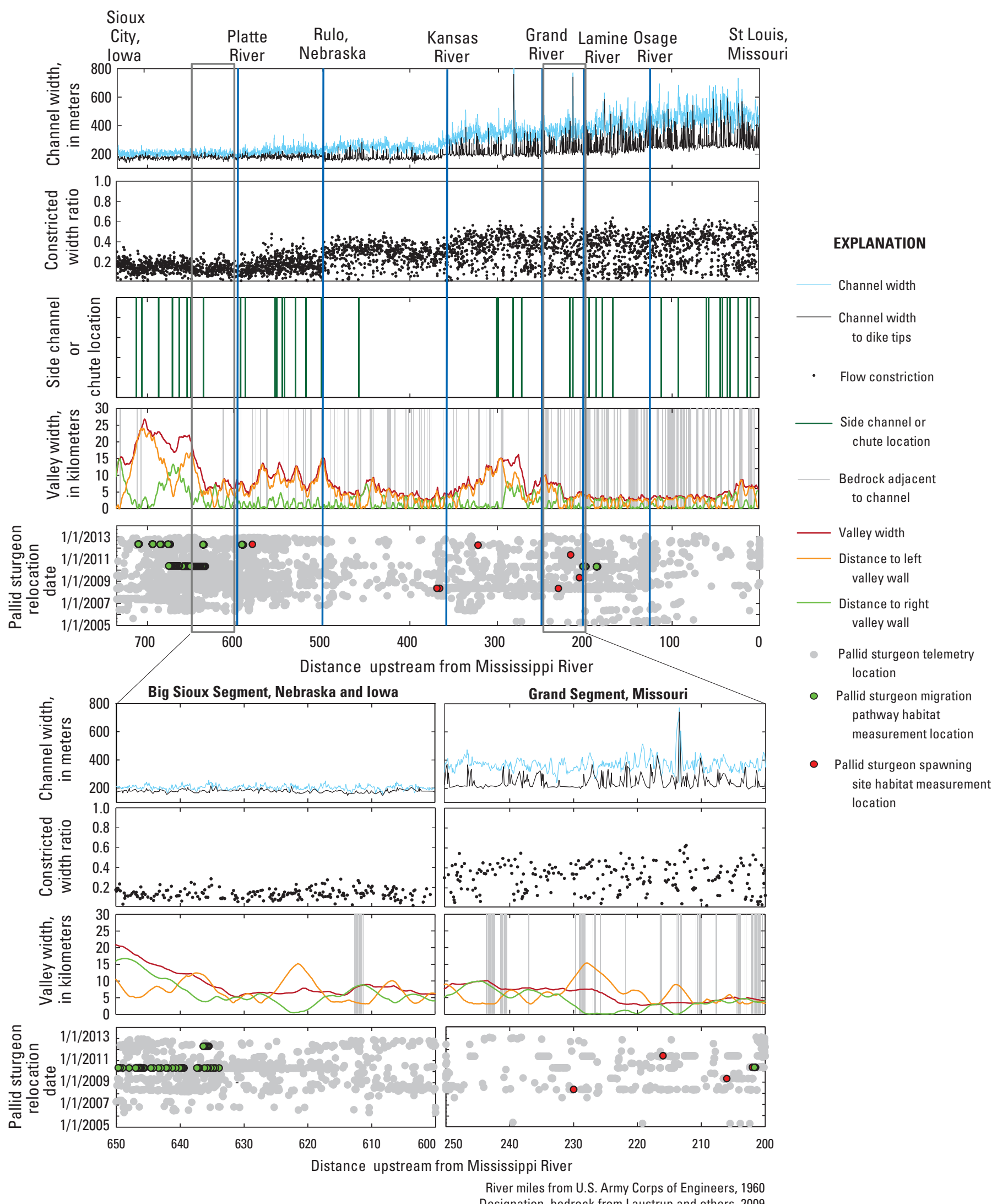

Figure 22. Channel width, flow constrictions (ratio between channel width and width between dike tip and opposite bank), side channel locations, valley width (bedrock wall to bedrock wall), and pallid sturgeon relocations and habitat data collection locations on the channelized Lower Missouri River from Sioux City, lowa, to St. Louis, Missouri. 

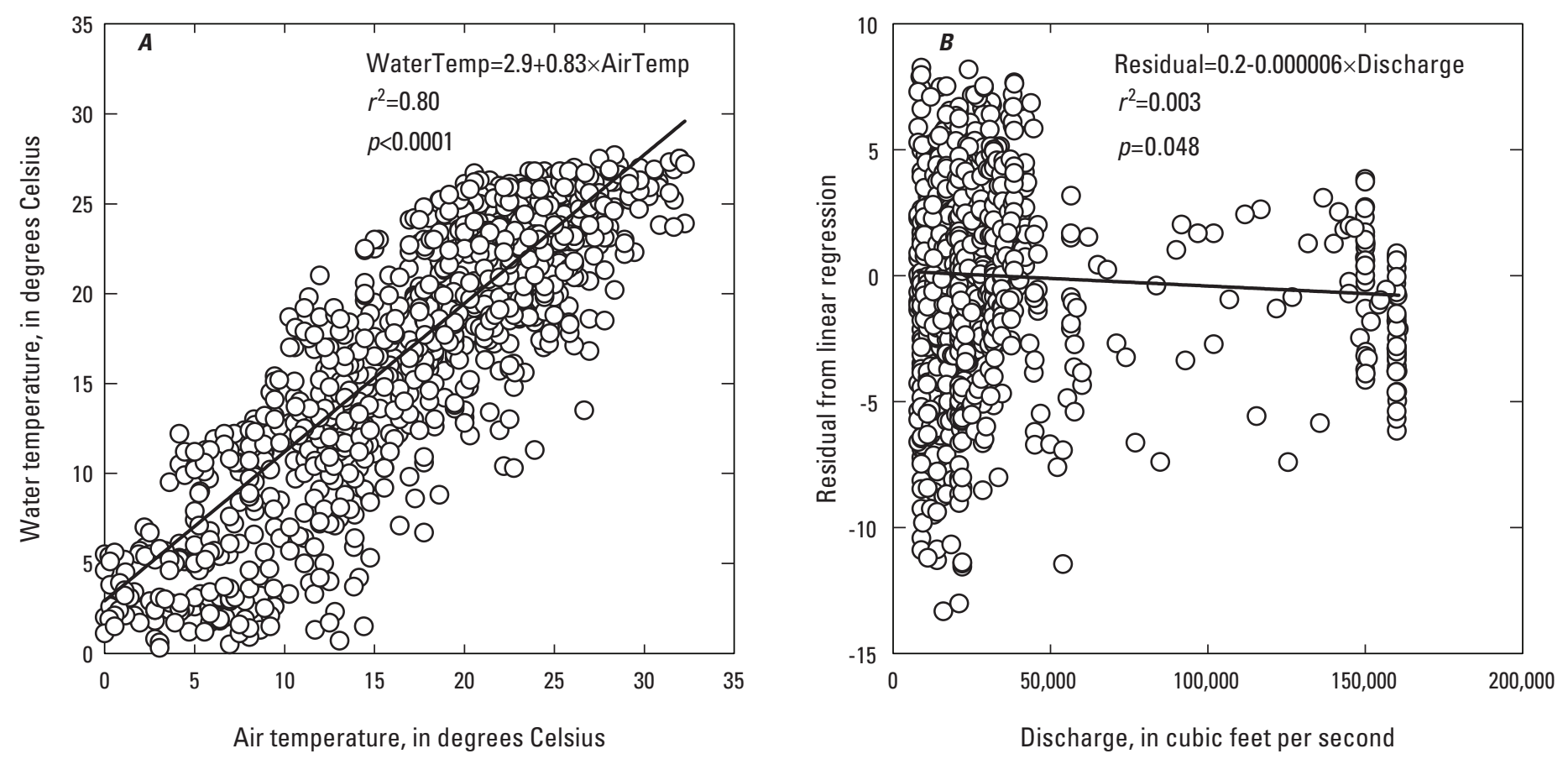

Figure 23. Relation between air and water temperature in the Missouri River near Yankton, South Dakota. $A$, Least-squares linear regression between air temperature and water temperature. $B$, Least-squares linear regression between residuals (actual minus predicted) of the air temperature and water-temperature regression and discharge. The residual plot shows that water temperature is poorly correlated with discharge, accounting for air temperature.

Whereas water temperatures downstream from Gavins Point Dam are relatively insensitive to flow releases, relations to air temperature indicate that they are sensitive to cold weather events. Detailed comparisons by year of discharge, for water temperature, and air temperature document how water and air temperature covary most of the time (fig. 24). Flow pulses as much as $50,000 \mathrm{ft}^{3} / \mathrm{s}$ are not obviously associated with multiday declines in water temperature. However, many water-temperature declines are strongly related in time to air-temperature declines, indicating that weather is a dominant control on multiday water-temperature variability in this segment. Flood releases in 2011 are an exception. Sustained high releases through the summer months were associated with a persistent lowering of water temperature below air temperature by as much as $10^{\circ} \mathrm{C}$.

Downstream from Gavins Point Dam water temperatures are affected by local tributary inflows. In general, seasonal water temperatures increase steadily from a median of $20.5^{\circ} \mathrm{C}$ at Yankton, South Dakota to $24.2^{\circ} \mathrm{C}$ at Hermann, Missouri (fig. 25). For reference, it has been estimated that optimal juvenile pallid sturgeon feeding temperature is $28^{\circ} \mathrm{C}$, and water temperatures are lethal to juvenile pallid sturgeon above $35^{\circ} \mathrm{C}$ (Chipps and others, 2008).

Other measures of water quality vary in expected ways downstream from Gavins Point Dam. The main-stem reservoir system is effective in attenuating major nutrients. Nitrogen and phosphorous increase downstream from the dam as nutrients are added from tributaries (Blevins and Fairchild, 2001; Brown and others, 2011). Because of the high turbidity of the
Missouri River, light penetration is low and little of this nutrient load is assimilated in the river channel. Lack of opportunities for connection between the channel and overbank areas also limits opportunities for nutrient processing on floodplains. Average annual load of total nitrogen at Hermann, Missouri has been calculated as 210,000 MT/y and total phosphorous as $32,000 \mathrm{MT} / \mathrm{y}$ (Aulenbach and others, 2007). There is no evidence that these nutrient loads would directly affect pallid sturgeon, but they could increase primary productivity at lower levels of the foodweb in parts of the river or floodplain where water clarity is not limiting (Blevins, 2011).

Low dissolved oxygen concentration has been identified as a potential concern for pallid sturgeon and other fish species on the Lower Missouri River (Blevins, 2011). Dissolved oxygen concentrations less than $5 \mathrm{mg} / \mathrm{L}$ (a standard for warmwater fishes) occur with spring-summer floods and associated increased levels of turbidity; turbidity is indicative of influxes of nutrients and organic material from tributary basins. The dissolved oxygen responses (or sags) can be highly transient and only captured through continuous water-quality monitoring such as occurs at streamgaging stations (fig. 26). Although instances of dissolved oxygen sags have been documented $(<2.0 \mathrm{mg} / \mathrm{L})$, it is not clear if they are of sufficient magnitude and duration to affect pallid sturgeon populations. In particular, it is not known how dissolved oxygen varies among habitat units on the river and whether fish can avoid areas with low levels. If low dissolved oxygen is deleterious to pallid sturgeon, it may be more likely at the free embryo or larval stages (Blevins, 2011). 

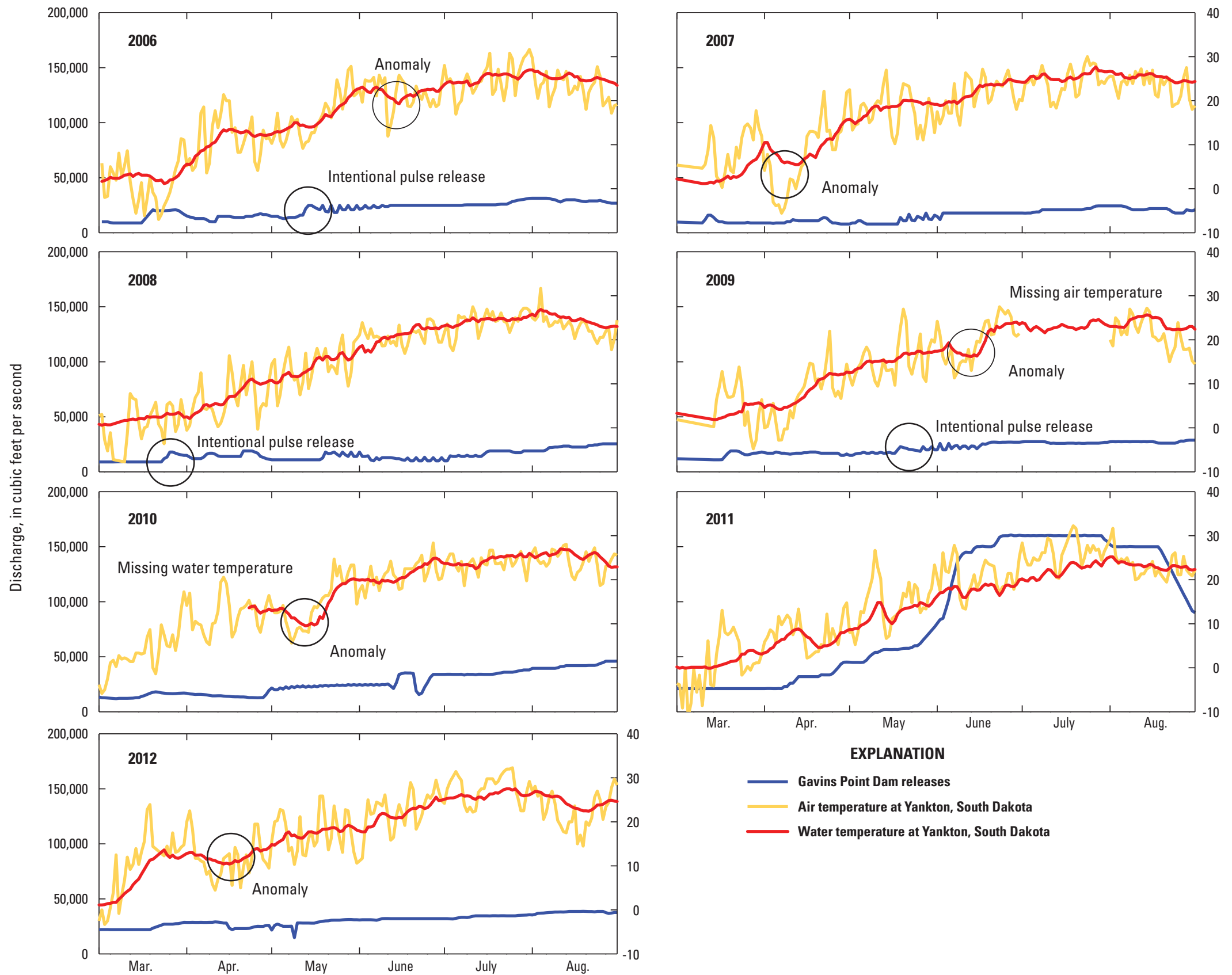

Figure 24. Plots of discharge from Gavins Point Dam and air and water temperature measured at Yankton, South Dakota, by year, 2006-12. Intentional releases from Gavins Point Dam are identified as well as selected water-temperature anomalies where water temperature increases or decreases are associated with air temperature and not with discharge pulses. 


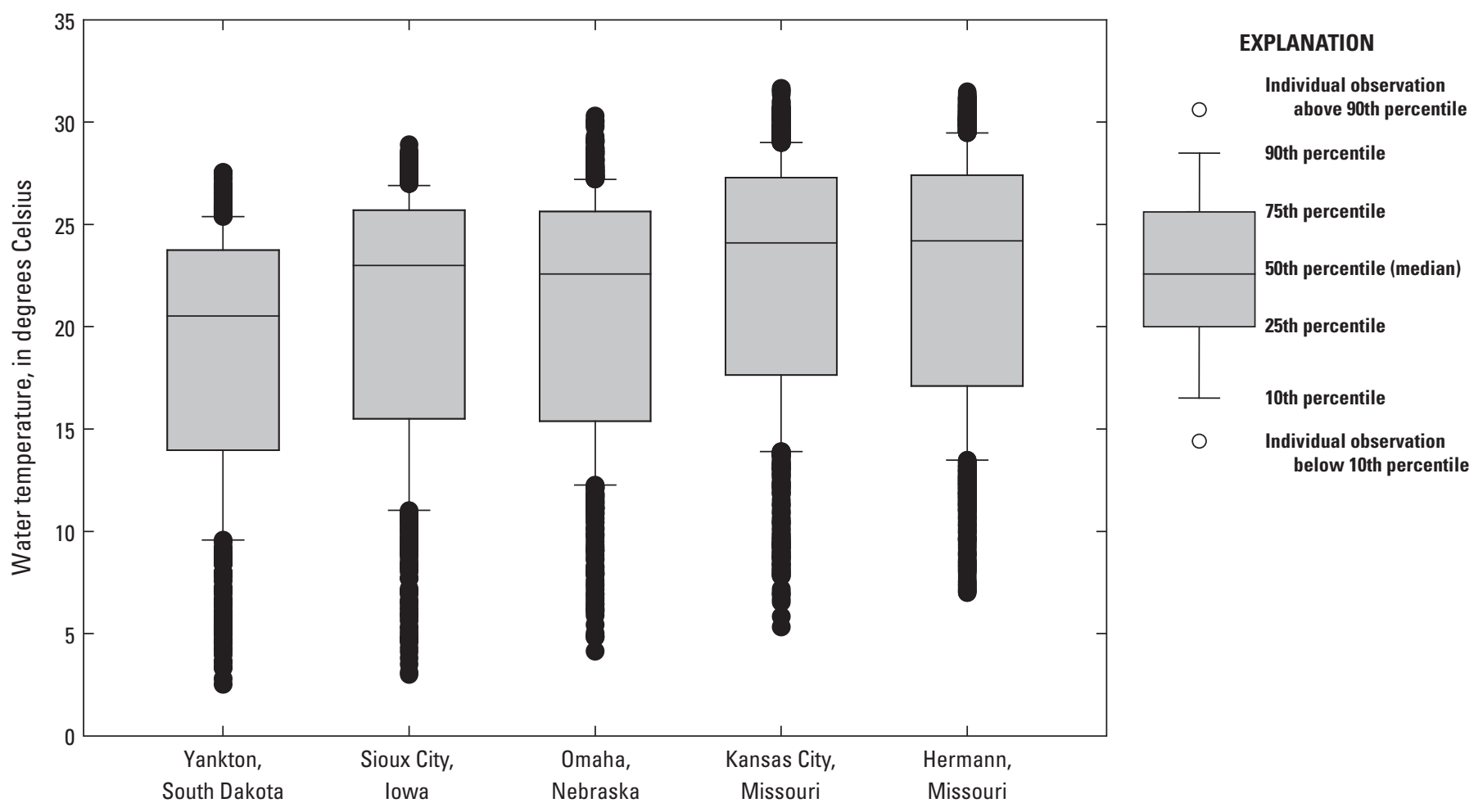

Figure 25. Seasonal (March through August) water-temperature distributions at sites on the Lower Missouri River from 2005 to 2012.

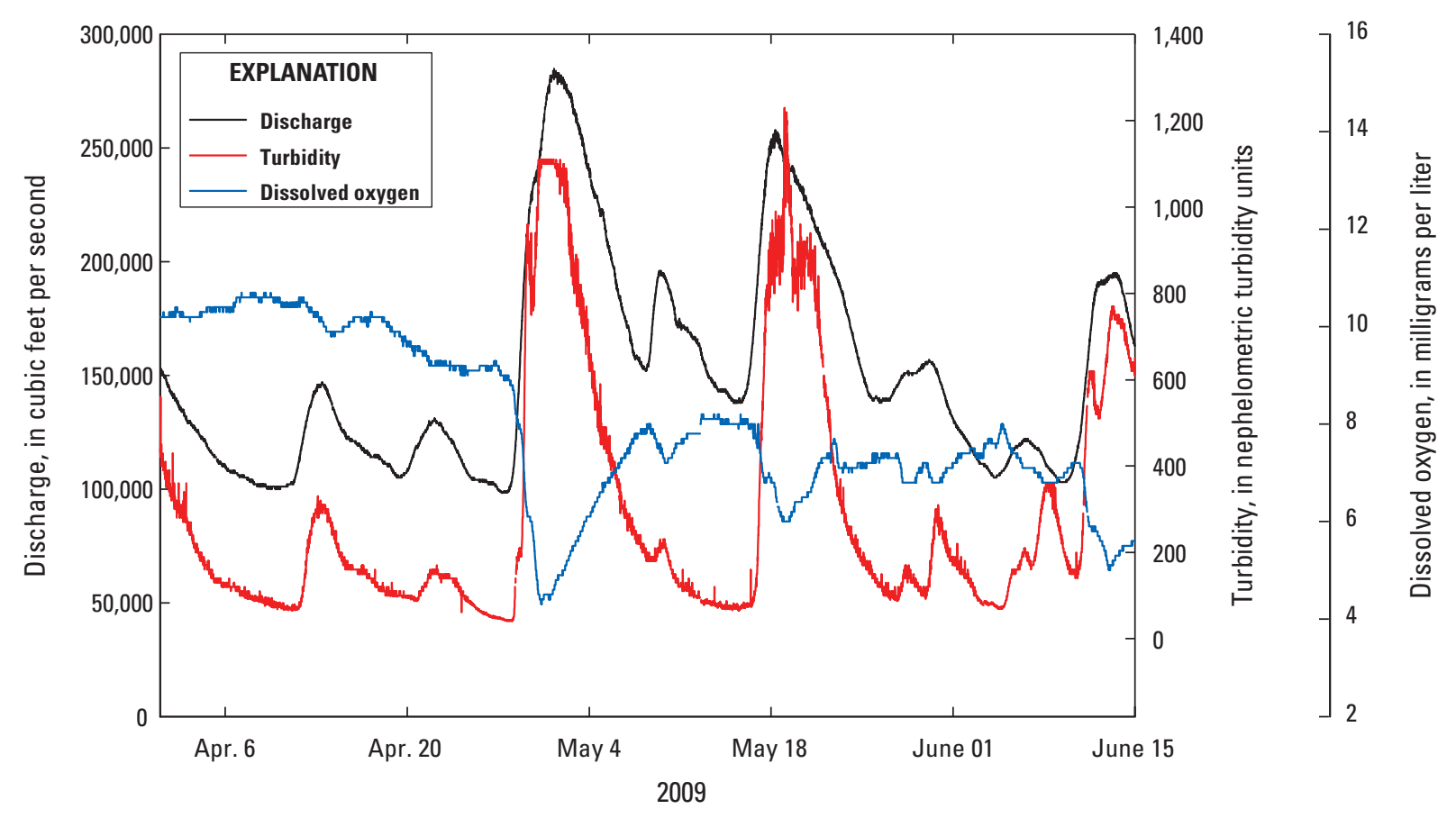

Figure 26. Example of water-quality variation at Hermann, Missouri, showing reciprocal relation of dissolved oxygen to discharge and turbidity. 


\section{Ecological Requirements for Pallid Sturgeon Reproduction and Recruitment in the Missouri River-2005 to 2012}

Contaminants are listed as a potential threat to pallid sturgeon populations (Dryer and Sandvol, 1993), and there is some evidence for contaminant exposure along the Lower Missouri River. A study of contaminants in a female pallid sturgeon captured near RM 535 in 1988 indicated the presence of elevated levels of DDT and its metabolites, polychlorinated biphenyls (PCBs), chlordane, mercury, selenium, and cadmium (Ruelle and Keenlyne, 1993). Concentrations of PCB measured in the ovaries of the sturgeon were $28.5 \mathrm{mg} / \mathrm{kg}$, far in excess of the Federal Food and Drug Administration's action level for PCBs in edible fish of $2.0 \mathrm{mg} / \mathrm{kg}$. Recent laboratory studies have indicated that persistent organic chemicals have potential to increase mortality of shovelnose sturgeon eggs and larvae (Buckler, 2011). Additionally, because of high PCB and chlordane content in shovelnose eggs, the State of Missouri has issued a no egg consumption advisory (Missouri Department of Health and Senior Services, 2011). A pilot study using longitudinal sampling of the Lower Missouri River with passive sampling devices demonstrated variable amounts of waterborne organochlorine (OC) pesticide residues from Sioux City, Iowa, to Hermann, Missouri, 1992 (Petty and others, 1995). Elevated concentrations of dieldrin, chlordane, DDT, and DDT metabolites were reported, generally increasing in the downstream direction with a peak at Glasgow, Missouri, followed by somewhat lower concentrations at Hermann. A follow-up study in 1994 included sampling for OC pesticides, $\mathrm{PCBs}$, and polyaromatic hydrocarbons (PAHs) (Petty and others, 1998). This study confirmed that the concentration of these chemical contaminants may be variable among locations, again with a general pattern of increases in the downstream direction to a peak near Glasgow, Missouri, followed by diminished concentrations toward Hermann, Missouri. The study also documented substantial increases in OCs compared to those measured in 1992 and attributed the increase to the mobilization of contaminants during the 1993 flood. Extracts from passively sampled water from an area of increased concentration were capable of triggering vitellogenin induction in rainbow trout, indicating that the mixture had potential to have an estrogenic effect on fishes in the Missouri River (Petty and others, 1998).

A subsequent study in 2002 sampled fine sediments in channel-margin environments from DeSoto, Iowa, to Jefferson City, Missouri, and confirmed a spatially variable distribution of sediment-hosted OC pesticides, PCBs, PAHs, and metals (Echols and others, 2008). The highest values of these substances were reported in the Kansas City, Missouri area, just downstream from the Kansas River; several sites exhibited concentrations of various substances, including some metals, exceeding expected ambient levels. This study concluded that the longitudinal distribution of contaminants was affected by point sources along the river, with major metropolitan areas like Kansas City being potentially important. The presence of OC pesticides (DDT, dieldrin, chlordane) and PCBs that have been banned for several decades indicates the potential for persistence and release of these substances from sediments. The authors noted that only a few sites had levels of metals or organic compounds that approached probable effects levels (Echols and others, 2008).

There are no definitive studies linking contaminants to reproductive failures or disease in pallid sturgeon. However, documented intersex, gonadal abnormalities, and teratomas in Missouri River sturgeon indicate the potential for endocrine disruption (DeLonay and others, 2009).

\section{Comparative Physical Differences among Study Sections}

Differences in physical characteristics among the study sections provide an experimental template that allows for learning through comparisons. The Yellowstone River provides a near-natural flow regime, sediment regime, channel morphology, thermal regime, and water quality. The Yellowstone River cannot qualify as an unimpacted reference condition because of impeded passage at Intake Dam and a shortened drift distance downstream to Lake Sakakawea. Nevertheless, the 73-mile segment downstream from Intake Dam provides near-natural habitats that can be used to assess migration and spawning for least-altered conditions. The Upper Missouri River also provides near-natural channel morphology and complexity but with highly altered flow, sediment, and thermal regimes. These two sections hold promise for isolating the role of flow regulation and thermal effects on the reproductive ecology of the species through comparison of pallid sturgeon migration, spawning, and drift behaviors. Unfortunately the comparison is imperfect because of uncontrollable factors such as flows entering the Upper Missouri River from the Milk, Redwater, and Poplar Rivers.

The Lower Missouri River allows for comparison with the upstream sections as well as a variety of conditions along the river. The degree of flow-regime alteration is highest immediately downstream from Gavins Point Dam, regaining much of the natural annual variability with increasing distance (fig. 5). Turbidity and temperature also increase gradually, providing a gradient against which some fish behaviors can be compared. In contrast to Fort Peck Dam releases, Gavins Point Dam releases do not depress water temperatures appreciably through a wide range of releases. This comparison helps isolate the effect of water temperature on reproductive ecology.

The 59 miles of river downstream from Gavins Point Dam has a complex channel morphology but highly altered flow, sediment, and water-quality regimes. Moving downstream, the Lower Missouri River is engineered to different degrees in different places, which is reflected in the channel characteristics of each segment (fig. 22). The gradient of variation in channel morphology provides opportunities to evaluate how morphological and hydraulic complexity contributes to habitat functions. In particular, variation in pallid sturgeon migration, spawning, drift, and settling behavior in different parts of the Lower Missouri River provides insights into how re-engineering the channel could promote reproduction and recruitment. 


\section{Comparative Differences among Study Years}

The CSRP field experiments include temporal variation superimposed on the physical variation of river segments. Year to year variability in flow regime and weather broadens comparative assessments but at the expense of replication. During the 2005 to 2012 period, annual runoff in the Missouri River Basin was highly variable, encompassing record high runoff in 2011 and an extreme drought year in 2006 (fig. 27). In most of the basin, 2005-08 was relatively dry and runoff increased into 2009-11.

In the Upper Missouri River, 2005 to 2012 was characterized by relatively steady releases from Fort Peck Dam and relatively steady flows downstream (fig. 28). Extreme discharges in 2011 were an exception. An April pulse from the Milk River pushed discharge at Culbertson, Montana, to nearly $30,000 \mathrm{ft}^{3} / \mathrm{s}$. The peak release of $66,000 \mathrm{ft}^{3} / \mathrm{s}$ occurred in mid-June and combined with high flows from tributaries to achieve $97,000 \mathrm{ft}^{3} / \mathrm{s}$ at Culbertson. High releases extended into October. The flood pulse of 2011 was much higher and longer than other flood pulses on the Upper Missouri River for 2005 to 2012 , which were limited to no more than $15,000 \mathrm{ft}^{3} / \mathrm{s}$ and occurred in 2005, 2007, 2008, 2010, and 2012 as a result of tributary floods.

In contrast, the Yellowstone River reported substantial spring-summer flood pulses in all years (fig. 28). Six of the eight years had dual-peaked flood pulses indicative of snowmelt from the plains and the Rocky Mountains. All years had peak flows in excess of $30,000 \mathrm{ft}^{3} / \mathrm{s}$ and remained above $10,000 \mathrm{ft}^{3} / \mathrm{s}$ for at least 30 days. Discharge in 2011 was an extreme, peaking at $121,000 \mathrm{ft}^{3} / \mathrm{s}$ on May 25 and staying above $10,000 \mathrm{ft}^{3} / \mathrm{s}$ for 145 days from April 18 to September 10. Comparisons of water temperature at downstream sites (Nohly, Montana, on the Missouri River and mile 2.5 on the Yellowstone River) indicate seasonal distributions with the Missouri River usually colder by a few degrees to as much as $10{ }^{\circ} \mathrm{C}$ (fig. 28). The seasonal variation is marked by numerous short-term declines and peaks lasting from several days to a week. These excursions do not appear related on a one to one basis to flow pulses and are frequently synchronized in both rivers, indicating that they are related to weather events rather than flow or dam releases. The exceptions may be the prolonged cold anomalies on the Upper Missouri River in 2011 and 2012 (fig. 28).

On the Lower Missouri River, the 2005 to 2012 hydrologic record is highly variable among years and from upstream to downstream (fig. 29). Discharges from Gavins Point Dam are small in all years except for 2011 when releases peaked at $160,700 \mathrm{ft}^{3} / \mathrm{s}$ on June 27 and stayed above 100,000 $\mathrm{ft}^{3} / \mathrm{s}$ for 84 days, June 5 to August 28. Intentional spring pulse releases to enhance reproduction of pallid sturgeon occurred in May 2006, March 2008, and May 2009 (fig. 29). The May 2006 pulse release peaked at 25,000 $\mathrm{ft}^{3} / \mathrm{s}$, the March 2008 release peaked at $18,000 \mathrm{ft}^{3} / \mathrm{s}$, and the May 2009 release peaked at $23,000 \mathrm{ft}^{3} / \mathrm{s}$.

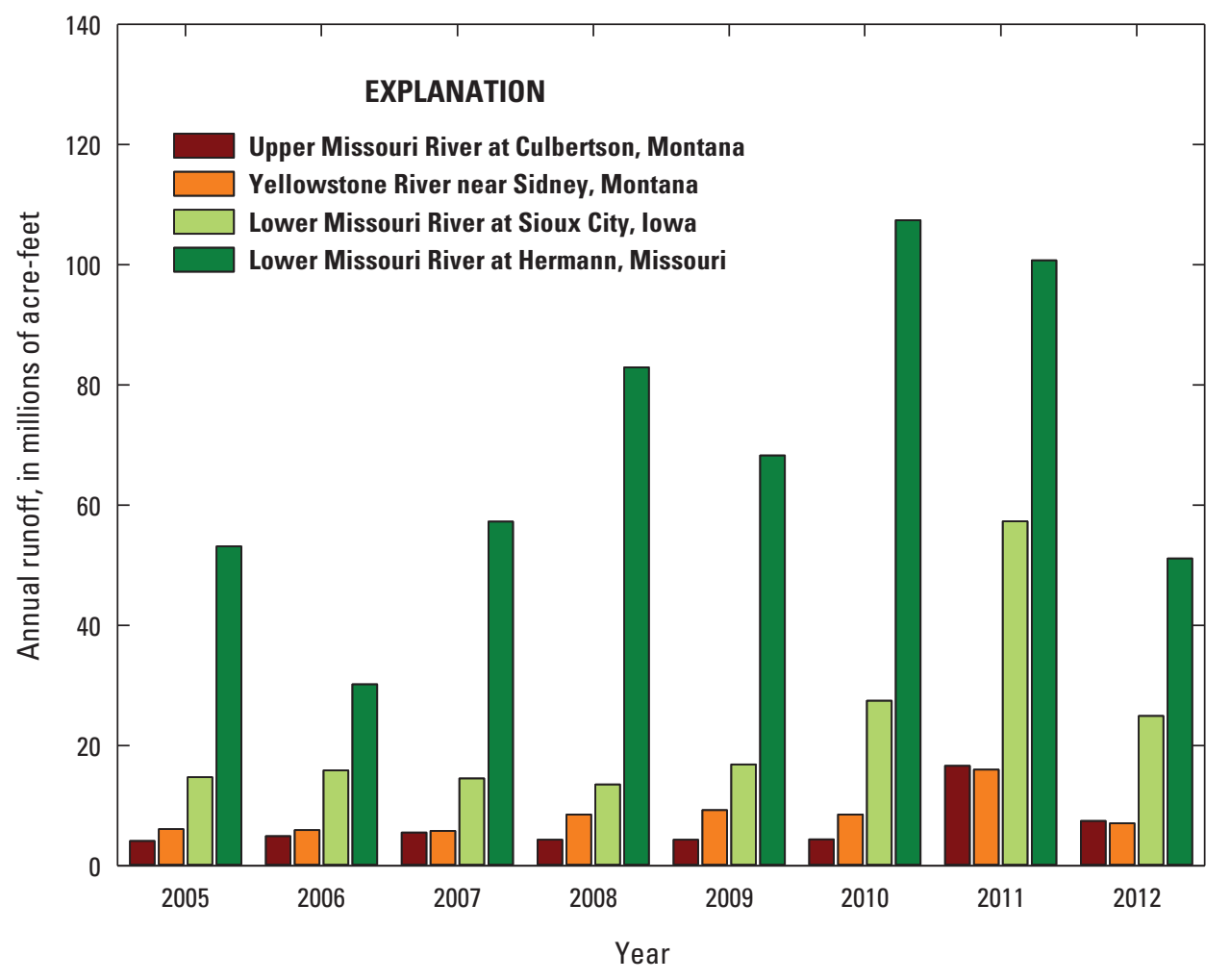

Figure 27. Annual runoff at four Missouri River system streamgages, 2005 to 2012. 

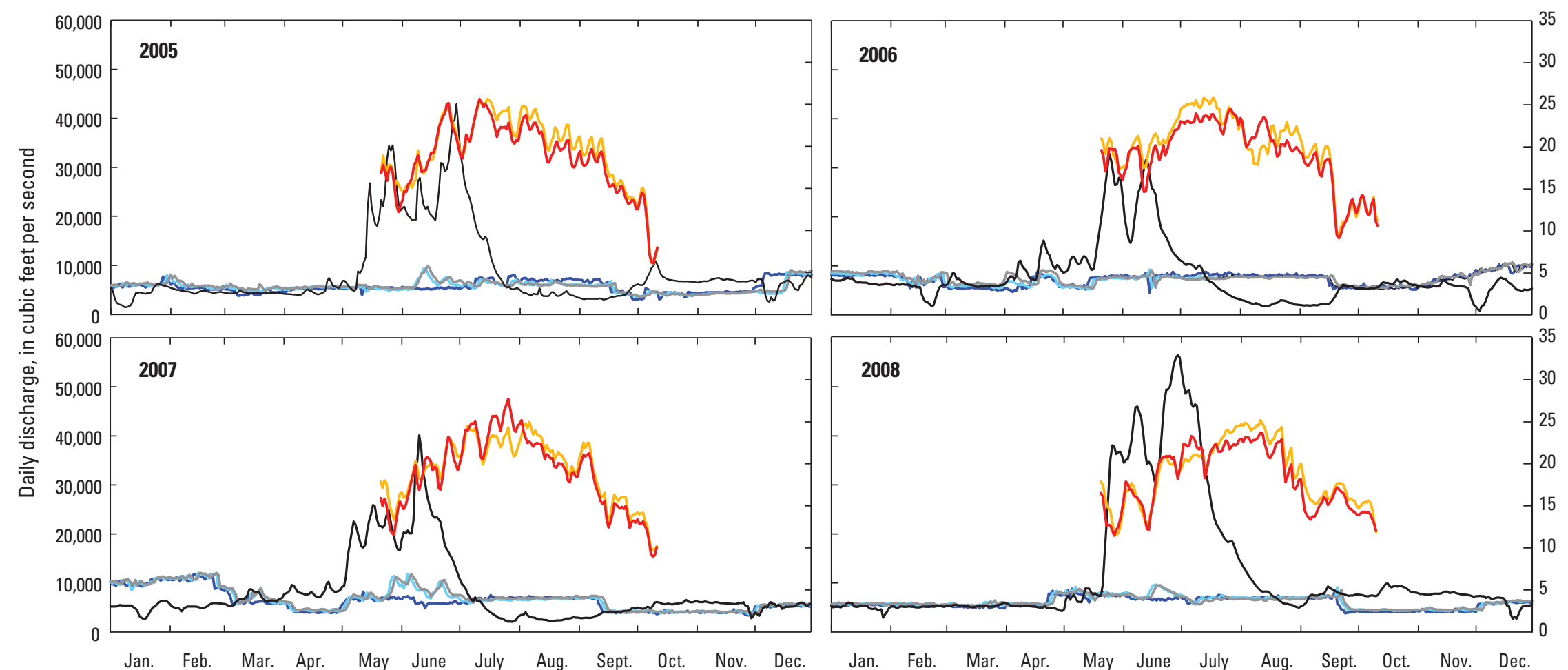

\section{EXPLANATION}

Upper Missouri River water temperature at Nohly, Montan

Yellowstone River water temperature at river mile 2.5

Upper Missouri River discharge from Fort Peck Dam

Upper Missouri River discharge at Wolf Point, Montana

Upper Missouri River discharge at Culbertson, Montana

Yellowstone River discharge at Sidney, Montana

Figure 28. Hydrographs and thermographs for the Upper Missouri River and Yellowstone River, 2005-2012, water-temperature data were collected seasonally. Note that the discharge axis in 2011 is double the length of other years to accommodate flood conditions. 

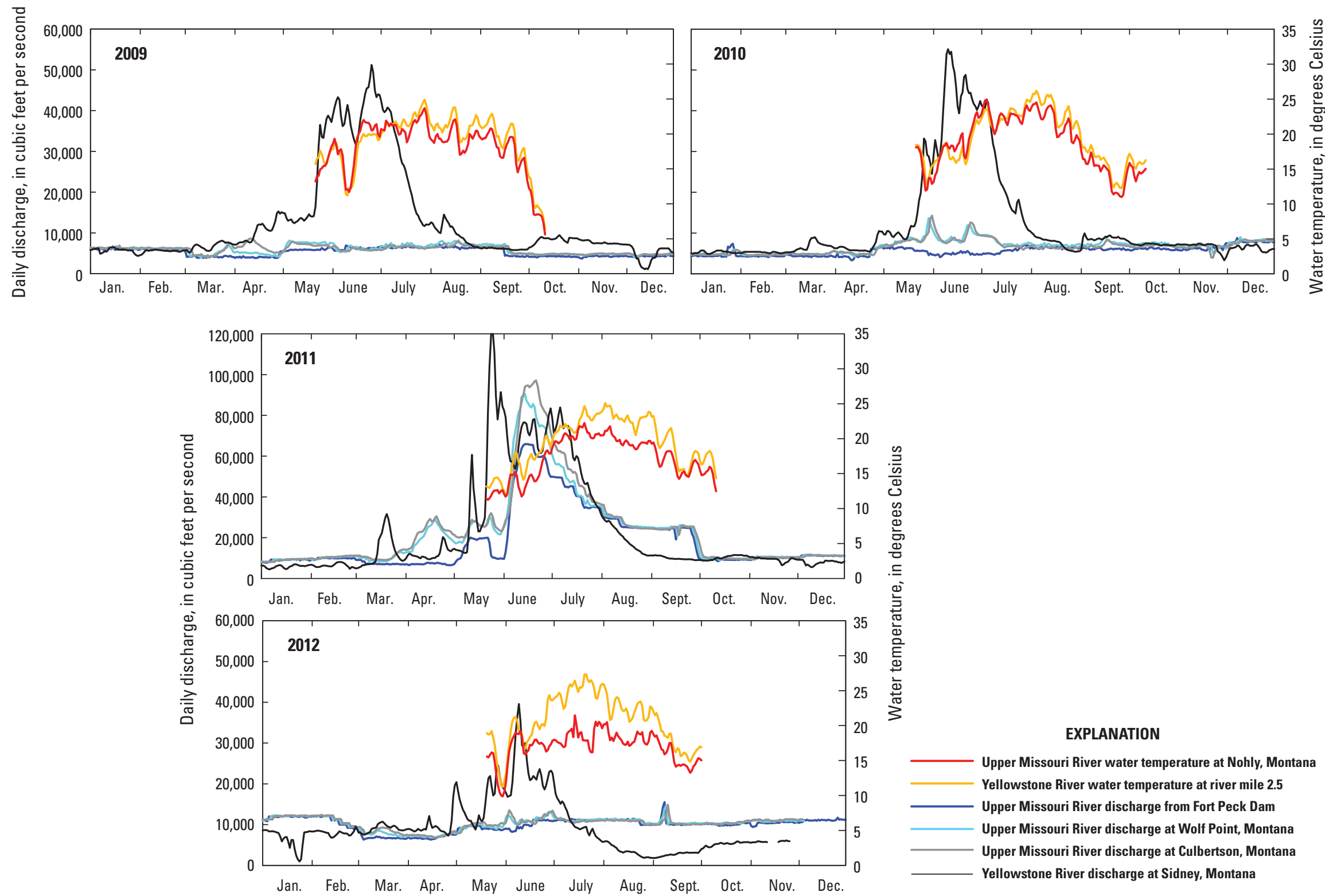

\section{EXPLANATION}

Upper Missouri River water temperature at Nohly, Montana Yellowstone River water temperature at river mile 2.5

Upper Missouri River discharge from Fort Peck Dam Upper Missouri River discharge at Wolf Point, Montana Upper Missouri River discharge at Culbertson, Montana Yellowstone River discharge at Sidney, Montana

Figure 28. Hydrographs and thermographs for the Upper Missouri River and Yellowstone River, 2005-2012, water-temperature data were collected seasonally. Note that the discharge axis in 2011 is double the length of other years to accommodate flood conditions.-Continued 

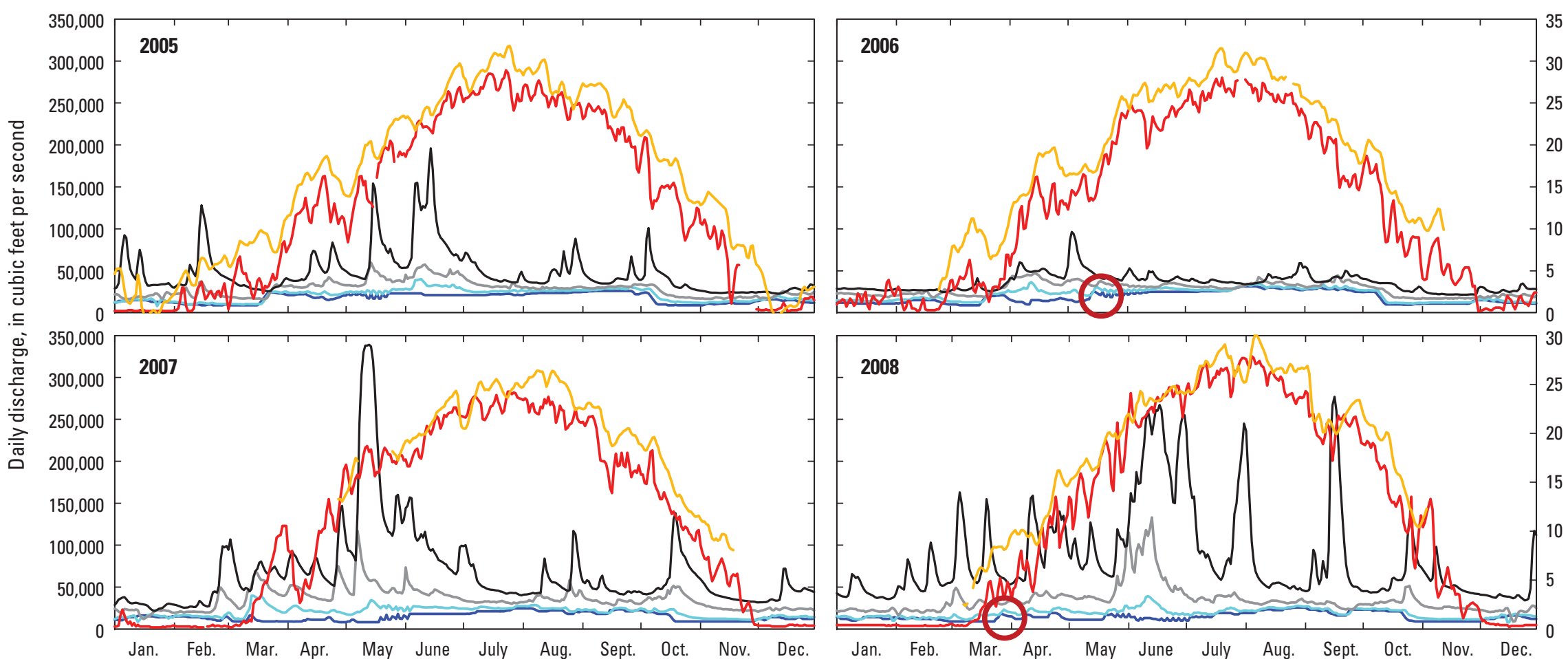

EXPLANATION

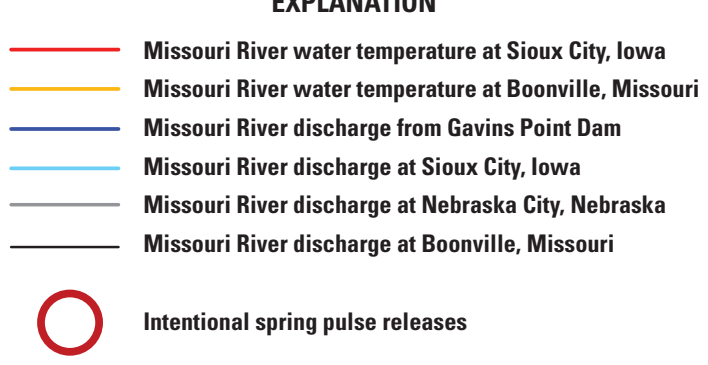

Figure 29. Hydrographs and thermographs for the Lower Missouri River. Gaps in water temperature record result from ice conditions or malfunctioning instrumentation. 

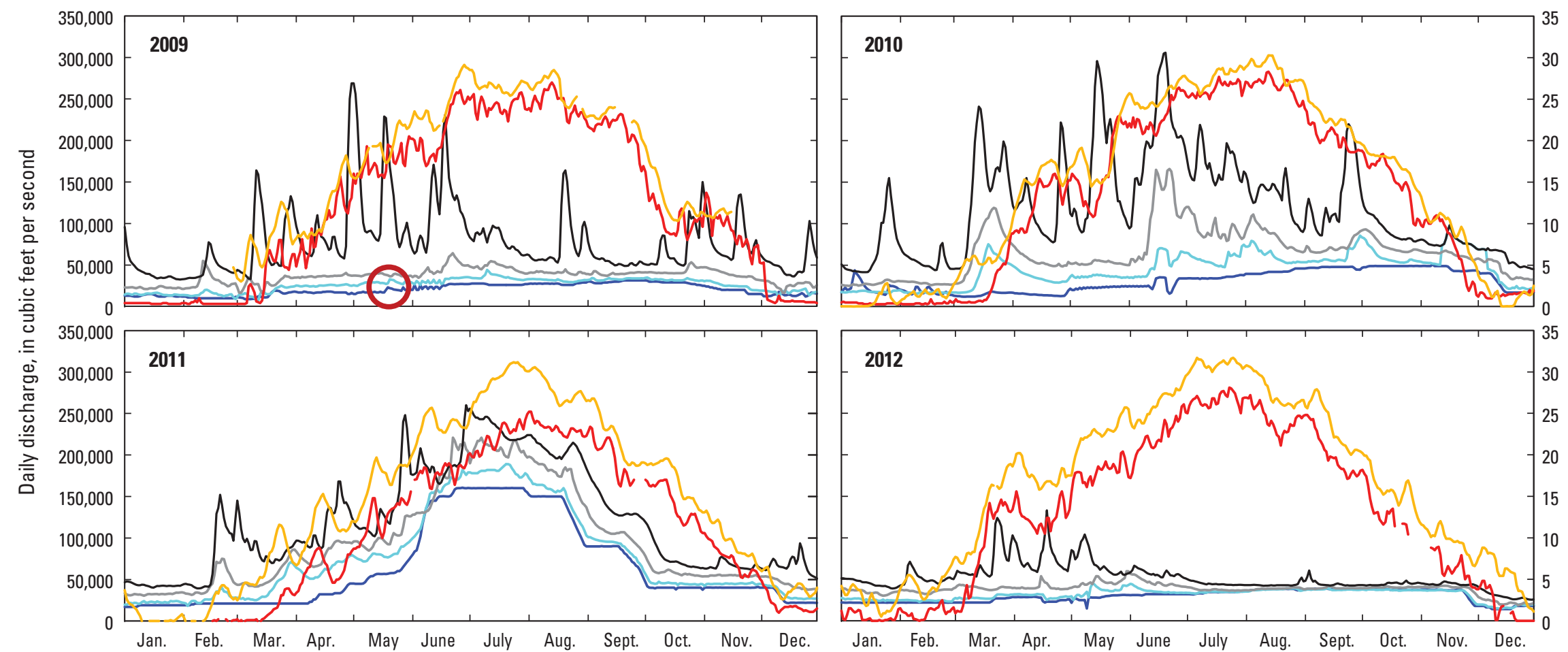

Figure 29. Hydrographs and thermographs for the Lower Missouri River. Gaps in water temperature record result from ice conditions or malfunctioning instrumentation.-

Continued

\section{Missouri River water temperature at Sioux City, lowa}

Missouri River water temperature at Boonville, Missouri

Missouri River discharge from Gavins Point Dam

Missouri River discharge at Sioux City, lowa

Missouri River discharge at Nebraska City, Nebraska

Missouri River discharge at Boonville, Missouri

Intentional spring pulse releases 
The intentional spring pulses in the upstream section were small relative to uncontrolled flow pulses in the downstream section. In all years, the downstream section (Boonville, Missouri streamgage) had substantial spring pulses at least four times the discharge of the intentional releases. Pulses of $200,000 \mathrm{ft}^{3} / \mathrm{s}$ or greater occurred in all years except 2006 and 2012, which were the two driest years of the time period on the Lower Missouri River. The peak spring pulse discharge in 2006 was $96,000 \mathrm{ft}^{3} / \mathrm{s}$ on May 3 and the peak in 2012 was 133,000 $\mathrm{ft}^{3} / \mathrm{s}$ on April 18.

With the possible exception of 2006, all years at the downstream section had multiple spring pulses. The presence of multiple pulses complicates inferences that fish behavior can be associated with specific properties of one pulse, such as magnitude, timing, duration, and rate of change.

Water temperatures in each year indicate a seasonal pattern centered on a peak in late July - early August. Water temperatures in the upstream section (Sioux City, Iowa) are typically colder than those in the downstream section (Boonville, Missouri) by $1-3{ }^{\circ} \mathrm{C}$. In 2011, Sioux City water temperatures were as much as $6{ }^{\circ} \mathrm{C}$ colder compared to Boonville. The seasonal arc of temperatures is disrupted by peaks and dips. Many of these anomalies are synchronous, but unrelated in time to flow pulses, implicating regional weather events (for example, declines in late April 2005, 2006, mid-September 2008, midJune 2009, and mid-August 2012). Among all years, one of the biggest temperature anomalies is the warm peak occurring throughout the region in mid-March to mid-April 2012.

\section{Adult Life Stage}

The adult life stage extends from the time the fish enters its first reproductive cycle until death. It consists of fish that are capable of spawning during the spawning season when gametes are mature and environmental conditions are correct (table 1).

\section{Habitat Requirements for Adult Reproductive Fish}

Before the initiation of CSRP studies, knowledge of the reproductive behavior and spawning habitats of pallid sturgeon was lacking and generally inferred from observations of the closely related shovelnose sturgeon (Moos, 1978; Keenlyne, 1997) or from broad generalizations of other sturgeon species (Kynard, 1997; Paragamian and Kruse, 2001; Bruch and Binkowski, 2002; Parsley and others, 2002). Studies by the CSRP have used minimally invasive assessment of reproductive readiness, telemetry, surgically implantable sensors, intensive tracking, acoustic sonar technologies, and a program of repeated recaptures of telemetered individuals to document habitat use, migration and spawning by pallid sturgeon (Wildhaber and others, 2005; Bryan and others, 2007; DeLonay and others, 2007; Wildhaber and others, 2007b; DeLonay and others, 2009; Wildhaber and others, 2011b; Albers and others, 2013). Pallid sturgeon have been tagged with radio or acoustic telemetry transmitters in the Lower Missouri River and tracked extensively (monthly) throughout the year, and intensively (weekly to hourly) along their migration pathways to their spawning locations in the Lower Missouri River, Upper Missouri River below Fort Peck Dam, and in the Lower Yellowstone River (Fuller and others, 2008; DeLonay and others, 2009; DeLonay and others, 2012).

The Comprehensive Sturgeon Research Project has used telemetry as part of a multidisciplinary approach in which telemetry is coordinated with physiological assessments of reproductive behavior and hydroacoustic habitat assessments (Bryan and others, 2007; DeLonay and others, 2007; Wildhaber and others, 2007b; DeLonay and others, 2009; Reuter and others, 2009; DeLonay and others, 2010; DeLonay and others, 2012; Albers and others, 2013; DeLonay and others, 2014). The physiologic context provides an understanding of the reproductive state of a tagged fish, and thereby provides interpretation of why the fish behaves as it does (Wildhaber and others, 2007a, 2011a). Similarly, detailed habitat mapping around tagged fish locations places the behavior of individuals within a spatial context that allows researchers to characterize habitat availability and selection and thereby understand how channel morphology and flow regime can be managed to maximize reproduction and survival (Reuter and others, 2008; DeLonay and others, 2009; Jacobson and others, 2009b; Reuter and others, 2009; Bonnot and others, 2011b).

This project has emphasized tagging male and female sturgeon in reproductive condition to focus on spawning cues, behaviors, and habitat (DeLonay and others, 2009; 2014). The tagging strategy of CSRP has emphasized retention of tagged individuals for study, and increasing the proportion of reproductive individuals in the study population to add power and statistical validity to the observations of rare individuals. Concerted efforts have been made to recapture, re-evaluate, and reimplant pallid sturgeon tagged and tracked in previous years.

\section{Movement and Spawning Migration}

Habitat use and movement data for adult, reproductively ready pallid sturgeon indicate consistent patterns of upstream migration before spawning (Fuller and others, 2008; DeLonay and others, 2009; DeLonay and others, 2010; DeLonay and others, 2012). Egg deposition at spawning sites is generally initiated after temperatures reach $16-18^{\circ} \mathrm{C}$ (DeLonay and others, 2009). Pallid sturgeon generally spawned from late April through May in the Lower Missouri River (DeLonay and others, 2012), except during the unusually warm spring of 2012 when spawning was documented as early as March 31 (table 2) (DeLonay and others, 2014). Spawning in the Upper Missouri River generally occurs in mid-June through early July (Bramblett and White, 2001; Fuller and others, 2008; DeLonay and others, 2014). 
Female pallid sturgeon in the Lower Missouri River tend to exhibit one of two migration patterns: a single-apex pattern or a complex, disrupted up-and-downstream pattern (DeLonay and others, 2010). All female pallid sturgeon $(n=5)$ tracked during 2005 to 2012 to their spawning locations in the Lower Missouri River study section downstream from the Kansas River exhibited the characteristic single-apex migration pattern, tending to spawn successfully at the apex of their migration from late April through the first two weeks of May (DeLonay and others, 2009; 2010b; 2012a) (table 2, fig. 30). Only one of five tracked female pallid sturgeon in the Lower Missouri River segment, upstream from the Kansas River, exhibited the singleapex migration pattern, spawning in late April (DeLonay and others, 2012). The remaining four females exhibited complex or disrupted patterns (fig. 31). Females with a disrupted or complex migratory pattern tended to spawn later or did not successfully spawn and their ovaries showed evidence of atresia (DeLonay and others, 2012). More observations are needed to substantiate observed patterns and to relate subsequent spawning success to environmental conditions.
Pallid sturgeon migration patterns in the Yellowstone and Upper Missouri Rivers are also complex, and do not show the characteristic single-apex patterns observed in Lower Missouri River pallid sturgeon and shovelnose sturgeon (Bramblett and White, 2001; Fuller and others, 2008; DeLonay and others, 2009; Wildhaber and others, 2011b) (see appendix 4). Upper Missouri River pallid sturgeon typically begin migration with rising temperatures and increasing flows from the Yellowstone River. The lack of sufficient miles of free-flowing river and a partial barrier at Intake Dam, Montana, likely disrupt the migration behavior and prevent fish from using upstream spawning sites. Fish unable to pass the dam eventually retreat downstream and successively repeat upstream movements until environmental conditions are conducive to spawning at a downstream location (DeLonay and others, 2014). Modified flows, altered temperatures, and reduced turbidity resulting from hypolimnetic releases from Fort Peck Dam may affect migration patterns and rates in the Upper Missouri River, similar to pallid sturgeon in the study section of the Lower Missouri River nearest to Gavins Point Dam. Although the

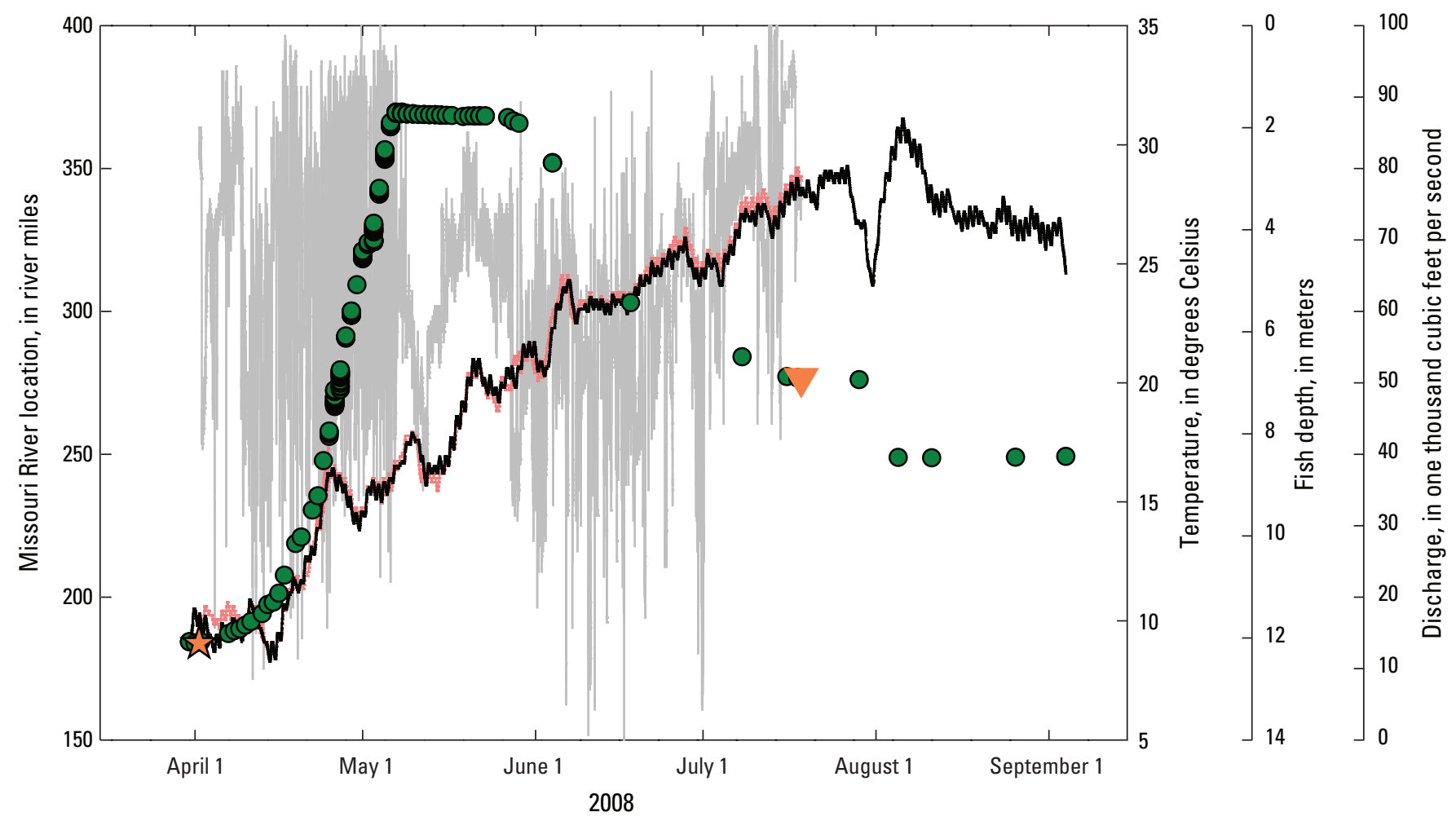

EXPLANATION

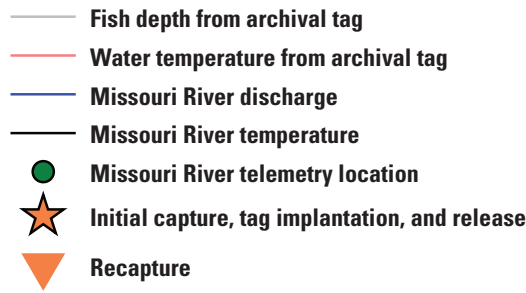

Figure 30. Characteristic, single-apex migration pattern of female pallid sturgeon in the lower study section of the Lower Missouri River as illustrated by PLS08-009. Depth and temperature recorded from data storage tag, discharge from the nearest streamgage at Boonville, Missouri, and telemetry locations for implanted gravid pallid sturgeon PLS008-009. Fish was implanted in reproductive condition, later recaptured, and determined to have spawned. 
Table 2. Probable spawning locations of telemetry tracked reproductive female pallid sturgeon, 2007-12.

[FishID, Fish identification code; >, greater than; <, less than; NA, not available; Nebr., Nebraska]

\begin{tabular}{|c|c|c|c|c|c|c|c|}
\hline \multirow{2}{*}{$\begin{array}{c}\text { Spawning site } \\
\text { confidence } \\
\text { score }^{1}\end{array}$} & \multirow[b]{2}{*}{ FishID } & \multicolumn{3}{|c|}{ Spawning period ${ }^{2}$} & \multicolumn{3}{|c|}{ Boundary of probable spawning extent ${ }^{3}$} \\
\hline & & $\begin{array}{c}\text { Spawning } \\
\text { year }\end{array}$ & $\begin{array}{l}\text { Spawning } \\
\text { begin date }\end{array}$ & $\begin{array}{l}\text { Spawning } \\
\text { end date }\end{array}$ & $\begin{array}{l}\text { Upstream extent, } \\
\text { in river miles }\end{array}$ & $\begin{array}{c}\text { Downstream extent, } \\
\text { in river miles }\end{array}$ & $\begin{array}{c}\text { Center of } \\
\text { spawning site }\end{array}$ \\
\hline 3 & PLS07-004 & 2007 & $5 / 17 / 2007$ & $5 / 23 / 2007$ & $>768.7$ & 756.3 & NA \\
\hline 3 & PLS07-007 & 2007 & $4 / 29 / 2007$ & $5 / 8 / 2007$ & $>694.9$ & 681.1 & NA \\
\hline 1 & PLS08-004 & 2008 & $5 / 4 / 2008$ & $5 / 5 / 2008$ & 230.7 & 230.0 & 230.4 \\
\hline 1 & PLS08-009 & 2008 & $5 / 7 / 2008$ & $5 / 8 / 2008$ & 369.7 & 369.3 & 369.5 \\
\hline 3 & PLS08-014 & 2008 & $5 / 22 / 2008$ & $5 / 31 / 2008$ & 688.4 & 670.7 & NA \\
\hline 3 & PLS07-001 & 2008 & NA & $6 / 3 / 2008$ & 811.0 & 790.7 & NA \\
\hline 1 & PLS10-006 & 2010 & $4 / 30 / 2010$ & $5 / 1 / 2010$ & 202.4 & 202.0 & 202.2 \\
\hline 1 & PLS10-013 & 2010 & $4 / 28 / 2010$ & $4 / 29 / 2010$ & 634.2 & 633.7 & 633.9 \\
\hline 5 & PLS10-023 & 2010 & $5 / 13 / 2010$ & $5 / 26 / 2010$ & 642.7 & 494.9 & NA \\
\hline
\end{tabular}

\begin{tabular}{|c|c|c|c|c|c|c|c|}
\hline 3 & PLS07-001 & 2011 & $5 / 8 / 2011$ & $5 / 23 / 2011$ & $799.6(3.3)$ & 787.1 & NA \\
\hline 1 & PLS11-008 & 2011 & $5 / 17 / 2011$ & $5 / 19 / 2011$ & 216.8 & 215.9 & 216.4 \\
\hline 4 & PLS11-014 & 2011 & NA & NA & $\begin{array}{l}\text { Missouri River, } \\
\text { Nebr. }\end{array}$ & NA & NA \\
\hline 4 & PLS11-016 & 2011 & NA & NA & $\begin{array}{c}\text { Platte River, } \\
\text { Nebr. }\end{array}$ & NA & NA \\
\hline 4 & PLS11-017 & 2011 & NA & NA & $\begin{array}{l}\text { Missouri River, } \\
\text { Nebr. }\end{array}$ & NA & NA \\
\hline 4 & PLS11-020 & 2011 & NA & NA & $\begin{array}{l}\text { Platte River, } \\
\text { Nebr. }\end{array}$ & NA & NA \\
\hline 1 & PLS09-011 & 2012 & $4 / 26 / 2012$ & $4 / 26 / 2012$ & 580.6 & 579.8 & 580.2 \\
\hline 4 & PLS10-029 & 2012 & NA & NA & $\begin{array}{c}\text { Platte River, } \\
\text { Nebr. }\end{array}$ & NA & NA \\
\hline
\end{tabular}

${ }^{1} 1=$ probable spawning site located within $>1$ river mile; $2=$ probable spawning site located within $1-10$ miles; $3=$ probable spawning site located within 10-25 miles; 4=probable spawning site located within $25-100$ miles; $5=$ probable spawning site located within $>100$ miles.

${ }^{2}$ The act of spawning by a female sturgeon may take from 8 to 24 hours. The spawning begin and end dates indicate the time during which spawning may have occurred for an individual fish. The time period reported reflects the uncertainty surrounding the actual timing of the spawning event, not the actual time spent spawning by an individual. 


\begin{tabular}{|c|c|c|c|}
\hline \multicolumn{3}{|c|}{ Tracking details ${ }^{4}$} & \multirow[b]{2}{*}{ Notes } \\
\hline $\begin{array}{l}\text { Pre-spawn } \\
\text { evaluation }\end{array}$ & Tracking & $\begin{array}{l}\text { Spawning } \\
\text { confirmed }\end{array}$ & \\
\hline Yes & Intensive & Yes & $\begin{array}{l}\text { Spawning occurred in unchannelized river. Tracking boats could not follow fish at night and lost con- } \\
\text { tact. Complete migration and spawning not observed. }\end{array}$ \\
\hline Yes & Intensive & Yes & Intensive tracking interupted by lethal tornado. Complete migration and spawning not documented. \\
\hline Yes & Intensive & Yes & Intensive tracking to spawning location. Complete migration and spawning behavior documented. \\
\hline Yes & Intensive & Yes & Intensive tracking to spawning location. Complete migration and spawning behavior documented. \\
\hline Yes & Intensive & Yes & $\begin{array}{l}\text { Intensively tracked female showed complex disrupted pattern. Complete migration pattern document- } \\
\text { ed, but spawning behavior difficult to discern. }\end{array}$ \\
\hline No & Extensive & Yes & $\begin{array}{l}\text { Female not intensively tracked. Recovered in July after spawning season with spent ovaries indicating } \\
\text { she had spawned that spring, most likely prior to downstream movement. Minimal observations sug- } \\
\text { gest that this fish most likley spawned in the unchannelized reach above } 790 \text {. }\end{array}$ \\
\hline Yes & Intensive & Yes & Intensive tracking to spawning location. Complete migration and spawning behavior documented. \\
\hline Yes & Intensive & Yes & Intensive tracking to spawning location. Complete migration and spawning behavior documented. \\
\hline Yes & Intensive & Yes & $\begin{array}{l}\text { Translocated fish from propagation program. Intially intensively tracked as it moved upstream to } \\
\text { spawn. It reached its upstream apex and began moving downstream. It was recovered on May } 13 \text { af- } \\
\text { ter its intial downstream movement and it had not yet spawned. It was recovered again June } 9 \text { more } \\
\text { than nearly } 150 \text { miles downstream and it had spawned. }\end{array}$ \\
\hline Yes & Intensive & Yes & $\begin{array}{l}\text { Intensively tracked. Complete migration documented. Complex, disrupted migrations. May have } \\
\text { spawned in the James River. Most likely spawning location is in the Missouri River. Spawning } \\
\text { behavior not documented. }\end{array}$ \\
\hline Yes & Intensive & Yes & $\begin{array}{l}\text { Intensive tracking to spawning location. Complete migration documented. Spawning behavior not } \\
\text { documented. }\end{array}$ \\
\hline Yes & NA & Yes & $\begin{array}{l}\text { The fish was not located during the spawning period. Spawning location is inferred from data storage } \\
\text { tag records of temperature matching the temperature profile of the mainstem Missouri River, Nebr. }\end{array}$ \\
\hline Yes & NA & Yes & $\begin{array}{l}\text { The fish was not located during the spawning period. Spawning location is inferred from data storage } \\
\text { tag records of temperature matching the temperature profile of the Platte River, Nebr. }\end{array}$ \\
\hline Yes & Intensive & Yes & Intensive tracking to spawning location. Complete migration and spawning behavior documented. \\
\hline Yes & Intensive & Yes & $\begin{array}{l}\text { Intensively tracked female showed complex distrupted pattern. Complete migration pattern and spawn- } \\
\text { ing behavior not documented. Spawning confirmed but spawning behavior difficult to discern. }\end{array}$ \\
\hline Yes & Intensive & Yes & $\begin{array}{l}\text { Intensive tracking to spawning location. Female showed complex, disrupted migration. Spawning } \\
\text { behavior documented. }\end{array}$ \\
\hline No & NA & Yes & $\begin{array}{l}\text { The fish was not evalauted prior to spawning, but was recaptured in post-spawn condtion with few re- } \\
\text { maining oocytes in } 2012 \text {. The fish was not located during the spawning period. Spawning location is } \\
\text { inferred from data storage tag records of temperature matching the temperature profile of the Platte } \\
\text { River, Nebr. }\end{array}$ \\
\hline
\end{tabular}

${ }^{3}$ The spawning of an individual sturgeon occurs over a fairly limited area. As we understand it, spawning by pallid sturgeon may occur over a patch of spawning habitat ranging from 0.3 to 0.7 river miles in length. The upstream and downstream extents reported reflect the uncertainty surrounding where the patch of spawning habitat is located, not the extent over which the individual actually deposited eggs. Values in parentheses are river miles in a Missouri River tributary. In some instances the female sturgeon was tracked to the probable spawning site and spawning behavior was documented. In this case a river mile for the center of the spawning habitat patch is reported.

${ }^{4}$ The tracking details indicate whether the female sturgeon was evaluated for reproductive condition in the months just prior to spawning, if the sturgeon was targeted for intensive tracking (daily) or extensively tracked as resources allowed, and if the female sturgeon was recaptured following spawning to confirm that eggs had been released successfully. 


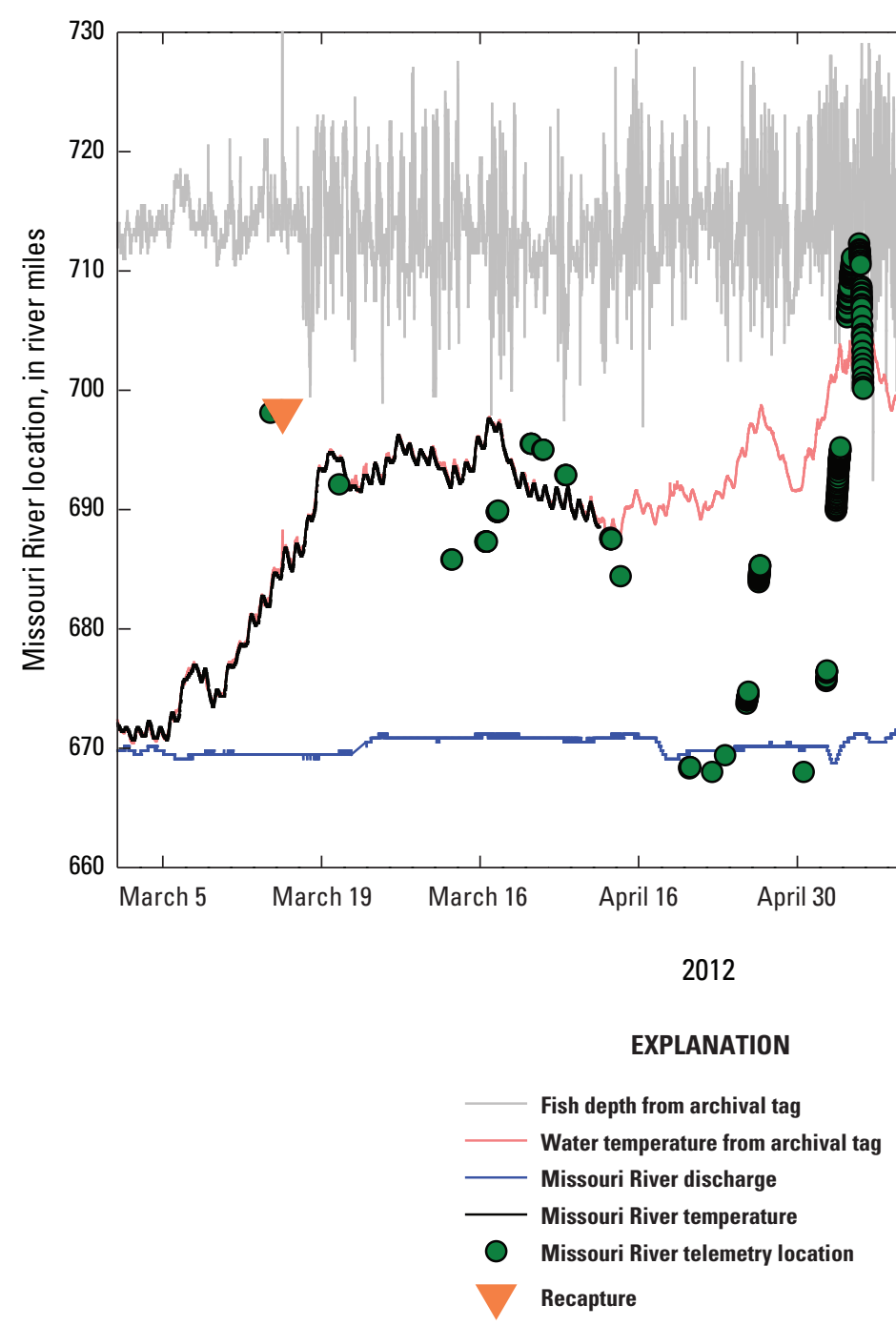

Figure 31. Characteristic complex or disrupted migration pattern in the upper study section of the Lower Missouri River as illustrated by PLS09-011. Depth and temperature recorded from data storage tag, discharge from the nearest streamgage at Nebraska City, Nebraska, and telemetry locations for implanted gravid pallid sturgeon PLS09-011. Fish was implanted in reproductive condition, later recaptured, and determined to have spawned.

tagged individuals in the Upper Missouri River are substantially larger than those in the Lower Missouri River, and their migration constrained by barriers, the documented migration distances of reproductive adults are similar among populations (Fuller and others, 2008; DeLonay and others, 2009).

Migration patterns of reproductively ready male pallid sturgeon in the Lower Missouri River are less regular than those of females and may include upstream and downstream movements at or near the apex of migration, giving the impression that they are actively searching for mates or occupying multiple spawning sites during the spawning season (DeLonay and others, 2012). Similar patterns were observed among male shovelnose sturgeon in the Lower Missouri River (DeLonay and others, 2009). Insufficient numbers of male pallid sturgeon have been tagged in the Lower Missouri River to document spawning aggregations and to resolve whether males migrate and select spawning locations in advance of the arrival of females, as exhibited by other sturgeon species (Bruch and Binkowski, 2002). Low population densities of reproductive sturgeon may contribute to complex migration patterns, as individuals may need to actively search for conspecifics. Aggregations of males have been documented in the Lower Yellowstone River, and areas of frequent aggregations are coincident with sites where spawning by females has been documented (Bramblett and White, 2001; Fuller and others, 2008; DeLonay and others, 2014).

Observations of tagged fish have increased with successive years, and as a result a greater understanding of the complex seasonal spawning migrations in the Lower Missouri River has emerged. In 2010 and 2011 several female pallid sturgeon anticipated to spawn in the coming spring exhibited a fall pre-spawning migration, followed by a shorter subsequent spring migration to the final spawning location (fig. 32). PLS11-007, for example, is a female pallid sturgeon captured 


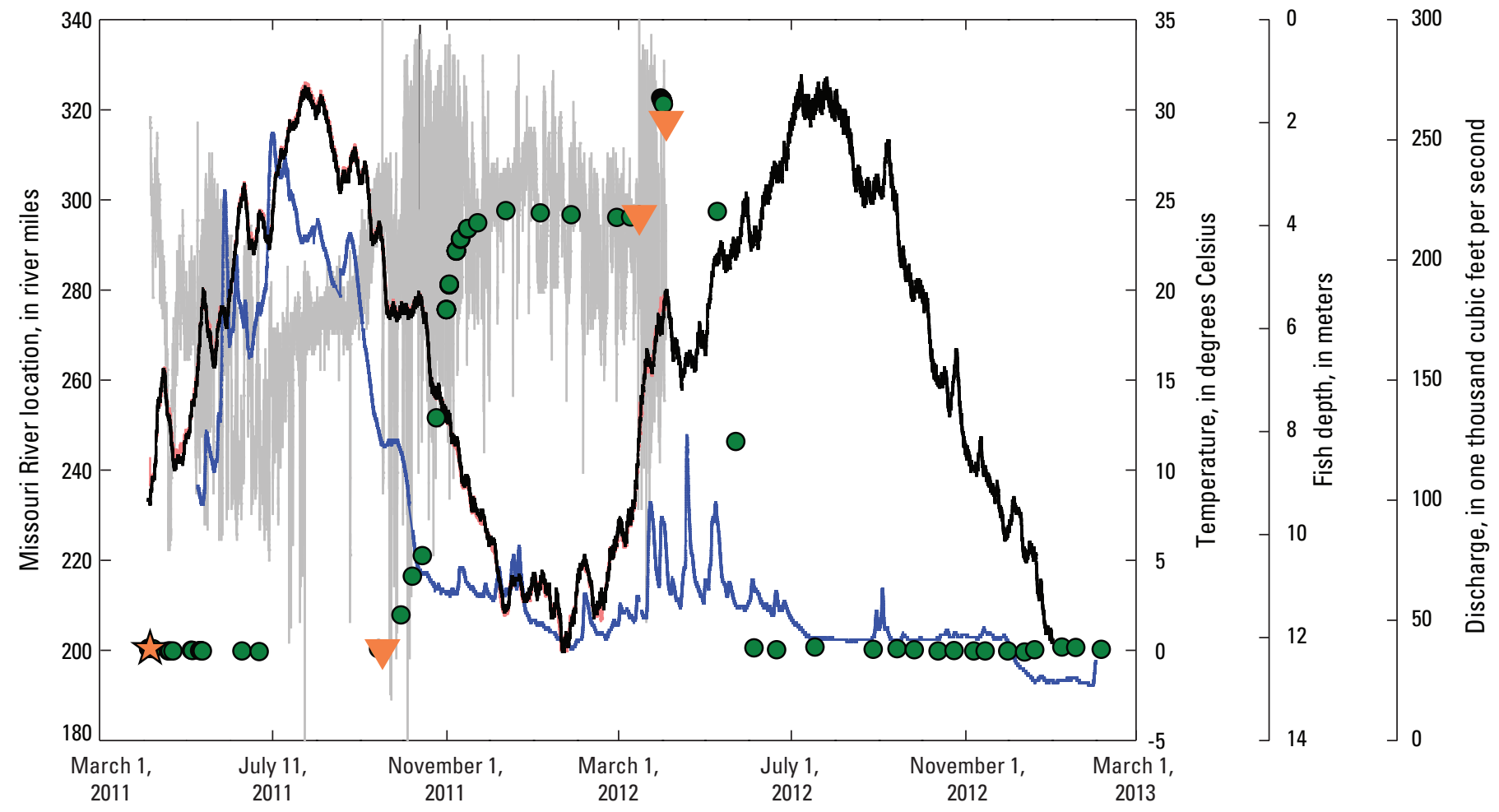

EXPLANATION

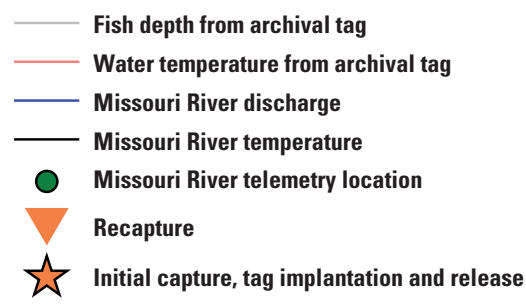

Figure 32. Fall migration followed by characteristic, single-apex spring migration pattern of female pallid sturgeon in the lower study section of the Lower Missouri River as illustrated by PLS11-007. Depth and temperature recorded from data storage tag, discharge from the nearest streamgage at Boonville, Missouri, and telemetry locations for implanted gravid pallid sturgeon PLS11-007. Fish was assessed before fall migration in 2011 and determined to be ready to spawn in spring 2012. It was recaptured and determined to have spawned.

in nonreproductive condition during April 2011 near RM 200. This female remained relatively stationary through the summer of 2011. A reproductive evaluation performed on September 16, 2011, indicated this female would be ready to spawn during spring 2012. From late September through December she moved upstream about 100 RM, to a location near RM 296 where she spent the winter. During March 2012, PLS11-007 moved upstream about 20 miles to near RM 322 and initiated spawning behavior on March 31, 2012. Female PLS11-007 was recaptured on April 3, 2012, and found to have spawned completely. It is unknown what prompts some fish to migrate a distance upstream in the fall, stop, then finish the migration during the next year's spawning season, and others to complete their spawning migration in a single-step journey during spring. Fall upstream migration of pallid sturgeon from the Upper Missouri River into the Yellowstone River does not occur, perhaps because flows in the Yellowstone River decline in late summer and fall, whereas flows in the Lower Missouri River do not typically exhibit historical patterns of low summer or winter flows.

Movement patterns of nonreproductive adult pallid sturgeon indicate patterns of behavior and migration differ between sexes. Nonreproductive females tend to remain relatively stationary, using a single bend or small habitat patch, whereas nonreproductive males may remain relatively stationary or they may migrate substantial distances ( $>50$ miles) upstream (fig. 33). Depth-use data from implanted data-storage tags also indicate a difference between sexes. Pallid sturgeon females consistently use a wider range and greater depths than males. The differences in depth use between the sexes is less pronounced in years when they are in reproductive condition compared to years when they are nonreproductive (fig. 34). 


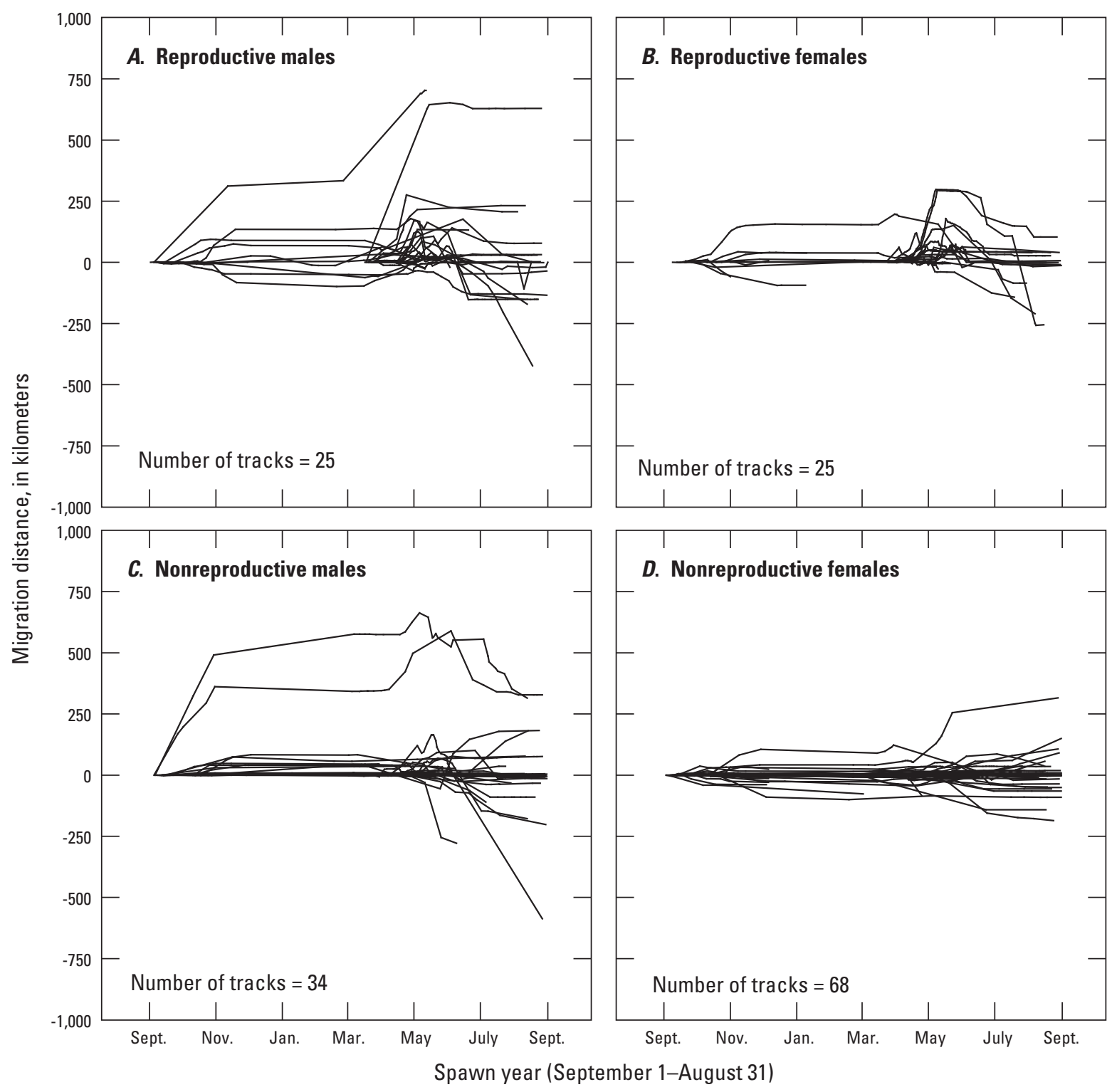

Figure 33. Migration distance of adult pallid sturgeon tracked during the spawn year (September 1st to August 31st) from 2005 to 2012. Migration distance represents upstream (+) and downstream movements. Fish had to be located at least three times to be included in these plots. Fish are grouped using their sex and reproductive status during the spawn year: reproductive or nonreproductive separately for males and females. Multiple lines can be from the same fish if the fish was followed for more than one spawn year. 


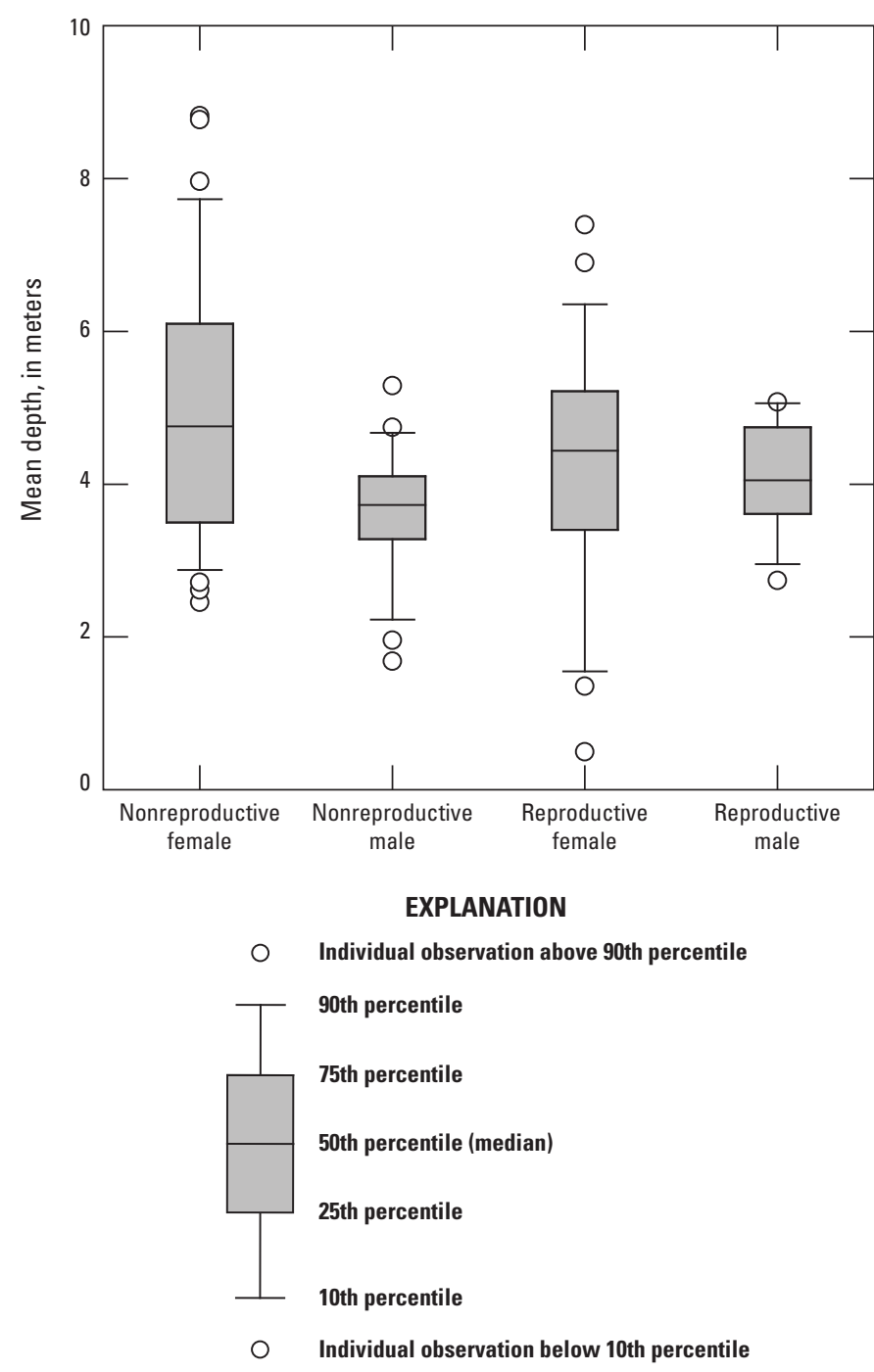

Figure 34. Mean depth of pallid sturgeon collected from retrieved data storage tags. Reproductive status during the spawn year (September 1st to August 31st).

We cannot yet explain the observed differences in depth use between pallid sturgeon males and females, although real differences in depth use would suggest that the sexes are using different habitats or similar habitats differently.

Past investigations of habitat use during migration and upstream migration pathways of pallid sturgeon culminated in intensive, multidisciplinary studies in 2010-12. These studies were designed to explore whether upstream migration may be impeded, especially in the channelized Lower Missouri River, and to quantify velocities of pathways selected by fish during upstream migration. Telemetry-tagged pallid sturgeon from the upstream and downstream channelized sections of the Lower Missouri River and Yellowstone River were selected for intensive mapping of habitat use during migration. Pre-spawning evaluations of the fish selected for mapping on the channelized Lower Missouri River in March and April of all years ranged from 874-1,102 $\mathrm{mm}$ fork length (FL) and weighed from $2,710-6,800$ grams (table 3 ). Five out of the nine reproductive females were recaptured and determined to have spawned after migration. Two additional females on the Lower Missouri River went atretic, or re-absorbed their eggs, and the spawning status of the additional two females on the Yellowstone River is unknown.

Sturgeon migration pathways were mapped using precise locations from acoustic telemetry on the Lower Missouri River and radio telemetry on the Yellowstone River. Four reciprocal transects (pairs of transects surveyed traveling in both directions perpendicular to the flow) were driven across the channel perpendicular to fish locations using Hypack navigation software, a differential Global Positioning System, and an acoustic Doppler current profiler (ADCP) (DeLonay and others, 2012; McElroy and others, 2012; DeLonay and others, 2014). With a few exceptions habitat measurements were made at discharges that were within 10 percent of the discharge at the time of fish movement (table 4). Output ADCP files were summarized using automated scripts to map transects in a Geographic Information System (GIS) and to extract the minimum, maximum, and mean velocity per vertical ensemble (profile of velocities at increasing depths from the surface to near the bottom) and the depth at that ensemble. Selectivity of habitat characteristics was calculated using Ivlev's selectivity coefficient (Manly and others, 2002; Reuter and others, 2009).

The complete dataset included a total of 445 reproductive pallid sturgeon migration locations making up 40 distinct pathways from 22 individual fish (table 4). Pathways were recorded by following individual sturgeon continuously through a river bend or side channel and recording telemetry locations at frequencies ranging from once every 15 minutes to hourly, depending on the rate of travel. Pathways from the same individual on different dates were considered distinct. All locations represented pathways of 3-23 locations of upwardly migrating telemetered pallid sturgeon with a mean number of 11 fish locations making up a pathway. Twenty-two individual fish were represented with 9 females and 13 males (table 4). The dataset included migration pathways for April through June from 2010 to 2012 in three Missouri River and Yellowstone River sections. Most of the migrating males (12) were from the Yellowstone River, and 6 females were from the Lower Missouri River.

Fish migration pathways examined ranged from 0.3 to $11.2 \mathrm{~km}$ long (mean $3.7 \mathrm{~km}$ ) representing intensive telemetry tracking periods from 41 minutes to nearly 24 hours. The average tracking pathway time period was 7 hours and 38 minutes. Total migration distance is unknown, as fish were not tracked during their entire migration period. Minimum migration distances were calculated using known telemetry locations for the fish from initial assessment in the spring to spawn date on the Lower Missouri River, and by using telemetry locations from May and June on the Yellowstone River. Minimum migration distances ranged from 20 to 190 miles. Several fish on the 
Table 3. Habitat mapping data collected for reproductive pallid sturgeon in migration study from 2010-12.

[FishID, Fish identification code; --, no data]

\begin{tabular}{|c|c|c|c|c|c|c|c|c|c|}
\hline $\begin{array}{c}\text { Year } \\
\text { mapped }\end{array}$ & River section & $\begin{array}{l}\text { Acoustic or } \\
\text { radio code } \\
\text { number }\end{array}$ & FishID & Sex & $\begin{array}{c}\text { Date of } \\
\text { evaluation }\end{array}$ & $\begin{array}{l}\text { Weight, in } \\
\text { kilograms }\end{array}$ & $\begin{array}{l}\text { Fork length, } \\
\text { in millimeters }\end{array}$ & Spawn information & $\begin{array}{c}\text { Minimum } \\
\text { migration } \\
\text { distance }\end{array}$ \\
\hline 2010 & Lower Missouri River, Missouri & 1053 & PLS10-006 & Female & $4 / 15 / 2010$ & 3.55 & 932 & Complete spawn May 2010 & 30.3 \\
\hline 2010 & Lower Missouri River, Nebraska and Iowa & 1066 & PLS10-023 & Female & $4 / 28 / 2010$ & 4.496 & 1,000 & Complete spawn May 2010 & 32.6 \\
\hline 2010 & Lower Missouri River, Nebraska and Iowa & 1057 & PLS08-014 & Female & $3 / 9 / 2010$ & 2.855 & 923 & Atretic May 2010 & 42.4 \\
\hline 2011 & Lower Missouri River, Missouri & 1139 & PLS11-003 & Male & $3 / 23 / 2011$ & 2.71 & 874 & Unknown & 83.6 \\
\hline 2011 & Yellowstone River, Montana & ${ }^{1} 56$ and ${ }^{2} 30$ & & Female & $6 / 15 / 2011$ & 17 & 1,362 & Unknown & 27.8 \\
\hline 2011 & Yellowstone River, Montana & 70 & & Male & $5 / 21 / 2009$ & 13 & 1,346 & Unknown & 103.6 \\
\hline 2011 & Yellowstone River, Montana & 142 & & Male & $5 / 25 / 2010$ & 19 & 1,435 & Unknown & 27.7 \\
\hline 2011 & Yellowstone River, Montana & ${ }^{1} 19$ and ${ }^{2} 72$ & & Male & $5 / 19 / 2009$ & 14.5 & 1,412 & Unknown & 152.2 \\
\hline 2012 & Lower Missouri River, Nebraska and Iowa & 1155 & PLS09-011 & Female & $3 / 23 / 2012$ & 4.655 & 980 & Complete spawn April 2012 & 166.5 \\
\hline 2012 & Lower Missouri River, Nebraska and Iowa & 1125 & PLS11-019 & Female & $3 / 15 / 2012$ & 6.8 & 1,102 & Complete spawn May 2012 & 130 \\
\hline 2012 & Lower Missouri River, Nebraska and Iowa & 1143 & PLS10-023 & Female & $4 / 13 / 2012$ & 5.46 & 1,019 & Atretic May 2012 & 87.3 \\
\hline 2012 & Yellowstone River, Montana & 51 & & Male & $5 / 8 / 2012$ & 14.5 & 1,385 & Unknown & 35.8 \\
\hline 2012 & Yellowstone River, Montana & 36 & & Female & $4 / 26 / 2012$ & 17.5 & 1,333 & Probable spawn June 2012 & 79 \\
\hline 2012 & Yellowstone River, Montana & 37 & & Female & $4 / 23 / 2012$ & 15 & 1,350 & Unknown & 85.4 \\
\hline 2012 & Yellowstone River, Montana & 272 and ${ }^{1} 19$ & & Male & $5 / 9 / 2012$ & -- & -- & Unknown & 158.9 \\
\hline 2012 & Yellowstone River, Montana & 55 & & Male & $4 / 25 / 2012$ & 17.5 & 1,451 & Unknown & 19.8 \\
\hline 2012 & Yellowstone River, Montana & 16 & & Male & $5 / 12 / 2009$ & 20 & 1,400 & Unknown & 46.7 \\
\hline 2012 & Yellowstone River, Montana & 92 & & Male & $10 / 15 / 2008$ & 22 & 1,468 & Unknown & 45.1 \\
\hline 2012 & Yellowstone River, Montana & 52 & & Male & $4 / 24 / 2012$ & 18.75 & 1,483 & Unknown & 189.8 \\
\hline 2012 & Yellowstone River, Montana & 69 & & Male & $5 / 9 / 2012$ & 6 & 1,120 & Unknown & 102.8 \\
\hline 2012 & Yellowstone River, Montana & 76 & & Male & $5 / 8 / 2012$ & 11.25 & 1,220 & Unknown & 65.9 \\
\hline 2012 & Yellowstone River, Montana & ${ }^{2} 30$ and ${ }^{156}$ & & Female & $4 / 25 / 2012$ & 17 & 1405 & Successful spawn June 2012 & 142.1 \\
\hline
\end{tabular}

${ }^{1}$ Radio code in 2011

${ }^{2}$ Radio code in 2012 . 
Yellowstone River traveled distances greater than 150 miles, which included multiple movements up and downstream in the 73 miles downstream from Intake Dam.

Habitat measurements are representative of discharges on the Yellowstone and Lower Missouri Rivers during spring pallid sturgeon migrations and were made at flow percentiles ranging from 50 to 100 percent of the historical record from 1970 to 2012 (table 4). Lower Missouri River discharges in the upstream channelized section fell within the 50-80th percentile range. Discharges in the downstream channelized Missouri River fell within the 60-90th percentile and Yellowstone River discharges fell within the 90-100th percentile range.

Migrating sturgeon used depths on the Yellowstone River in similar proportion to the range of available depths (fig. 35, table 5). Velocities also were used in similar proportion to available velocities on the Yellowstone River, with Ivlev's selectivity coefficient suggesting avoidance of velocities at the high and low ends of the distribution. In the Yellowstone River there were several examples of migrating sturgeon using chutes and secondary channels as well as the main channel. Two pallid sturgeon were tracked on their approach to Intake Dam (see appendix 4).

In the upstream channelized Lower Missouri River in Nebraska and Iowa, pallid sturgeon used depths representing the ranges of depths and velocities available to them with the exception of avoidance of very shallow areas. Velocity use data indicated sturgeon using most of the range of velocities available to them with a similar pattern of avoiding velocities on the low and high ends of the distribution (greater than 1.5 meters $/$ second $[\mathrm{m} / \mathrm{s}])$. In contrast, sturgeon in the downstream channelized Lower Missouri River in Missouri selected for very shallow and very deep places in the channel, and velocities on the low end of the distribution. Sturgeon avoided velocities greater than $2.0 \mathrm{~m} / \mathrm{s}$ in the downstream channelized Lower Missouri River.

Migration results in the downstream channelized Lower Missouri River support the model presented by McElroy and others (2012) that suggests that pallid sturgeon select the least-cost pathway during their migration, optimizing energy expenditure by moving along inside bends and moving laterally across channels at crossovers. Pallid sturgeon throughout the upstream channelized Lower Missouri River and on the Yellowstone River selected less distinct, less repeatable pathways, possibly because they do not need to avoid high velocities in the navigation channel; ranges of velocities available for sturgeon migration during the period of measurements were much lower than those on the downstream channelized Lower Missouri River in Missouri. Mean depth-averaged velocities used by migrating pallid sturgeon was similar on the Yellowstone River $(1.20 \mathrm{~m} / \mathrm{s}$ available, $1.18 \mathrm{~m} / \mathrm{s}$ used) and the upstream channelized Lower Missouri River in Nebraska and Iowa $(1.16 \mathrm{~m} / \mathrm{s}$ available, $1.14 \mathrm{~m} / \mathrm{s}$ used) (table 5). Mean depth-averaged velocities used for migration were lower than available $(1.72 \mathrm{~m} / \mathrm{s}$ available, $1.27 \mathrm{~m} / \mathrm{s}$ used $)$ on the downstream channelized Lower Missouri River. The characteristic use of inside bends and crossovers for upstream migration in the Lower Missouri River may be enhanced, in part, by avoidance of the engineered navigation channel. Adverse conditions in the navigation channel and reduced slow velocity marginal area may narrow the width of suitable upstream migration pathways selected by sturgeon, and also may explain the use of side channels during migration.

\section{Spawning Habitat}

Comprehensive Sturgeon Research Project studies in the Lower Missouri River from 2007 through 2012 have documented 19 spawning events, 12 in the upper study section and 7 in the lower study section of the Lower Missouri River (table 2). Pallid sturgeon also are suspected of spawning in the Platte River based on extensive tracking data and comparative examination of archival temperature data from surgically implanted data storage tags with temperature loggers or USGS streamgage stations (DeLonay and others, 2012). Spawning in each case was verified through recapture and reassessment of female reproductive status using minimally invasive ultrasonography with surgical verification. No viable pallid sturgeon eggs or free embryos have been collected immediately downstream from spawning sites on the Lower Missouri River; therefore, fertilization and thus survival through hatch have not been demonstrated in these study sections.

Studies on the Upper Missouri River have demonstrated that spawning has resulted in fertilization and survival through the free-embryo stage. CSRP studies documented one spawning location in 2011 on the Upper Missouri River downstream from the confluence with the Milk River inferred from an aggregation of males and the collection of a genetically confirmed pallid sturgeon free embryo (DeLonay and others, 2014). A second spawning location was identified in 2012 on the Lower Yellowstone River based on aggregations of tagged male and female pallid sturgeon, recovery of ripe males accompanied by a tagged female releasing eggs, and the subsequent collection of a genetically confirmed pallid sturgeon free embryo. Genetic parentage analyses indicated that neither of the free embryos collected in 2011 or 2012 were progeny of tracked pallid sturgeon located at the probable spawning sites suggesting that multiple females spawned in each area (DeLonay and others, 2014).

The precision with which the timing of spawning and spawning locations were determined on the Lower Missouri River varied among individuals tracked depending on the tracking strategy used and recapture success, which varied from year to year based on the number of available gravid females, logistics associated with geographic distributions of tagged fish, and river conditions. Females tracked with high frequency near their spawning locations indicated that spawning occurred within a few hundred meters along an outside river bend within a 36-hour period. Estimates of the timing and location of spawning of other telemetered females were less precise, especially when the migration pattern was complex, disrupted, lacked clear observation of spawning behavior, or if the females were only tracked extensively or at low 
Table 4. Pallid sturgeon migration pathways mapped in 2010-12.

[FishID, Fish identification code]

\begin{tabular}{|c|c|c|c|c|c|c|}
\hline 2 & $4 / 28 / 2010$ & Missouri River, Missouri & 1053 & PLS10-006 & 16 & Boonville, Missouri \\
\hline 3 & $4 / 29 / 2010$ & Missouri River, Missouri & 1053 & PLS10-006 & 4 & Boonville, Missouri \\
\hline 5 & $5 / 1 / 2010$ & Missouri River, Nebraska and Iowa & 1066 & PLS10-023 & 14 & Decatur, Nebraska \\
\hline 6 & $5 / 2 / 2010$ & Missouri River, Nebraska and Iowa & 1066 & PLS10-023 & 12 & Decatur, Nebraska \\
\hline 7 & $5 / 3 / 2010$ & Missouri River, Nebraska and Iowa & 1066 & PLS10-023 & 14 & Decatur, Nebraska \\
\hline 8 & $5 / 4 / 2010$ & Missouri River, Nebraska and Iowa & 1066 & PLS10-023 & 23 & Decatur, Nebraska \\
\hline 9 & $5 / 5 / 2010$ & Missouri River, Nebraska and Iowa & 1066 & PLS10-023 & 12 & Decatur, Nebraska \\
\hline 13 & $4 / 30 / 2011$ & Missouri River, Missouri & 1139 & PLS-11-003 & 9 & Boonville, Missouri \\
\hline 14 & $6 / 3 / 2011$ & Yellowstone River, Montana & ${ }^{1} 56$ and ${ }^{2} 30$ & & 3 & Sidney, Montana \\
\hline 15 & $6 / 4 / 2011$ & Yellowstone River, Montana & ${ }^{1} 56$ and ${ }^{2} 30$ & & 3 & Sidney, Montana \\
\hline 16 & $6 / 6 / 2011$ & Yellowstone River, Montana & 70 & & 4 & Sidney, Montana \\
\hline 17 & 6/7/2011 & Yellowstone River, Montana & 142 & & 3 & Sidney, Montana \\
\hline 18 & $6 / 8 / 2011$ & Yellowstone River, Montana & ${ }^{1} 19$ and ${ }^{2} 72$ & & 9 & Sidney, Montana \\
\hline 19 & 6/9/2011 & Yellowstone River, Montana & ${ }^{1} 19$ and ${ }^{2} 72$ & & 3 & Sidney, Montana \\
\hline 20 & $4 / 19 / 2012$ & Missouri River, Nebraska and Iowa & 1155 & PLS09-011 & 15 & Decatur, Nebraska \\
\hline 21 & $4 / 25 / 2012$ & Missouri River, Nebraska and Iowa & 1125 & PLS11-019 & 13 & Decatur, Nebraska \\
\hline 29 & $5 / 22 / 2012$ & Yellowstone River, Montana & 36 & & 12 & Sidney, Montana \\
\hline 30 & $5 / 22 / 2012$ & Yellowstone River, Montana & 37 & & 9 & Sidney, Montana \\
\hline 31 & $5 / 23 / 2012$ & Yellowstone River, Montana & 272 and ${ }^{1} 18$ & & 17 & Sidney, Montana \\
\hline 32 & $5 / 23 / 2012$ & Yellowstone River, Montana & 36 & & 12 & Sidney, Montana \\
\hline 33 & $5 / 21 / 2012$ & Yellowstone River, Montana & 55 & & 5 & Sidney, Montana \\
\hline 34 & $5 / 17 / 2012$ & Yellowstone River, Montana & 16 & & 6 & Sidney, Montana \\
\hline 35 & $5 / 18 / 2012$ & Yellowstone River, Montana & 92 & & 6 & Sidney, Montana \\
\hline 36 & 6/9/2012 & Yellowstone River, Montana & 52 & & 16 & Sidney, Montana \\
\hline 37 & $6 / 7 / 2012$ & Yellowstone River, Montana & 69 & & 12 & Sidney, Montana \\
\hline 38 & $6 / 8 / 2012$ & Yellowstone River, Montana & 69 & & 6 & Sidney, Montana \\
\hline 39 & $6 / 12 / 2012$ & Yellowstone River, Montana & 76 & & 6 & Sidney, Montana \\
\hline 40 & $6 / 12,6 / 13$ & Yellowstone River, Montana & ${ }^{2} 30$ and ${ }^{156}$ & & 20 & Sidney, Montana \\
\hline
\end{tabular}

${ }^{1}$ Radio code in 2011.

${ }^{2}$ Radio code in 2012. 


\begin{tabular}{|c|c|c|c|c|c|c|}
\hline $\begin{array}{l}\text { Telemetry date } \\
\text { discharge, in cubic } \\
\text { feet per second }\end{array}$ & $\begin{array}{c}\text { Discharge } \\
\text { percentile } \\
1970-2012 \\
\text { (upper limit) }\end{array}$ & Map date & $\begin{array}{l}\text { Map date discharge, } \\
\text { in cubic feet per } \\
\text { second }\end{array}$ & $\begin{array}{l}\text { Discharge } \\
\text { percentile } \\
1970-2012 \\
\text { (upper limit) }\end{array}$ & $\begin{array}{l}\text { Discharge } \\
\text { difference between } \\
\text { telemetry and } \\
\text { mapping }\end{array}$ & $\begin{array}{c}\text { Percent } \\
\text { discharge } \\
\text { diffference }\end{array}$ \\
\hline 78,800 & 80 & $4 / 22 / 2010$ & 77,300 & 70 & 1,500 & 2 \\
\hline 191,000 & 100 & $4 / 28 / 2010$ & 191,000 & 90 & -- & 0 \\
\hline 168,000 & 100 & $4 / 29 / 2010$ & 168,000 & 90 & -- & 0 \\
\hline 32,700 & 70 & $5 / 20 / 2010$ & 36,700 & 80 & 4,000 & 12 \\
\hline 35,900 & 80 & $5 / 20 / 2010$ & 36,700 & 80 & 800 & 2 \\
\hline 38,100 & 80 & $5 / 20 / 2010$ & 36,700 & 80 & 1,400 & 4 \\
\hline 35,800 & 80 & $5 / 19 / 2010$ & 37,500 & 80 & 1,700 & 5 \\
\hline 34,800 & 70 & $5 / 19 / 2010$ & 37,500 & 80 & 2,700 & 8 \\
\hline 36,000 & 80 & $5 / 19 / 2010$ & 37,500 & 80 & 1,500 & 4 \\
\hline 34,800 & 70 & $5 / 19 / 2010$ & 37,500 & 80 & 2,700 & 8 \\
\hline 37,500 & 80 & $5 / 26 / 2010$ & 33,200 & 70 & 4,300 & 11 \\
\hline 36,700 & 80 & $5 / 27 / 2010$ & 32,500 & 70 & 4,200 & 11 \\
\hline 125,000 & 90 & $5 / 2 / 2011$ & 115,000 & 90 & 10,000 & 8 \\
\hline 69,300 & 100 & 6/4/2011 & 61,500 & 100 & 7,800 & 11 \\
\hline 61,500 & 100 & 6/4/2011 & 61,500 & 100 & -- & 0 \\
\hline 57,300 & 100 & 6/6/2011 & 57,300 & 100 & -- & 0 \\
\hline 55,300 & 100 & 6/9/2011 & 57,200 & 100 & 1,900 & 3 \\
\hline 53,800 & 100 & $6 / 8 / 2011$ & 53,800 & 100 & -- & 0 \\
\hline 57,200 & 100 & 6/9/2011 & 57,200 & 100 & -- & 0 \\
\hline 26,300 & 40 & $4 / 26 / 2012$ & 28,700 & 50 & 2,400 & 9 \\
\hline 28,300 & 50 & $4 / 26 / 2012$ & 28,700 & 50 & 400 & 1 \\
\hline 39,000 & 50 & $4 / 27 / 2012$ & 38,200 & 50 & 800 & 2 \\
\hline 45,500 & 70 & $4 / 27 / 2012$ & 38,200 & 50 & 7,300 & 16 \\
\hline 25,200 & 40 & $5 / 3 / 2012$ & 28,800 & 50 & 3,600 & 14 \\
\hline 28,700 & 50 & $5 / 3 / 2012$ & 28,800 & 50 & 100 & 0 \\
\hline 28,800 & 50 & $5 / 4 / 2012$ & 31,300 & 60 & 2,500 & 9 \\
\hline 31,300 & 60 & $6 / 1 / 2012$ & 44,500 & 90 & 13,200 & 42 \\
\hline 21,400 & 90 & $5 / 22 / 2012$ & 21,900 & 90 & 500 & 2 \\
\hline 21,900 & 90 & $5 / 24 / 2012$ & 17,100 & 90 & 4,800 & 22 \\
\hline 21,900 & 90 & $5 / 24 / 2012$ & 17,100 & 90 & 4,800 & 22 \\
\hline 19,300 & 90 & $5 / 25 / 2012$ & 17,600 & 90 & 1,700 & 9 \\
\hline 19,300 & 90 & $5 / 29 / 2012$ & 19,900 & 90 & 600 & 3 \\
\hline 21,400 & 90 & $5 / 30 / 2012$ & 19,100 & 90 & 2,300 & 11 \\
\hline 10,800 & 70 & $5 / 31 / 2012$ & 18,600 & 90 & 7,800 & 72 \\
\hline 21,400 & 90 & $6 / 1 / 2012$ & 17,700 & 90 & 3,700 & 17 \\
\hline 39,600 & 90 & $6 / 11 / 2012$ & 29,400 & 100 & 10,200 & 26 \\
\hline 32,300 & 90 & $6 / 12 / 2012$ & 29,200 & 100 & 3,100 & 10 \\
\hline 36,500 & 90 & $6 / 12 / 2012$ & 29,200 & 100 & 7,300 & 20 \\
\hline 29,200 & 90 & $6 / 13 / 2012$ & 30,000 & 100 & 800 & 3 \\
\hline 29,200 & 90 & $6 / 14 / 2012$ & 25,700 & 100 & 3,500 & 12 \\
\hline
\end{tabular}


A. Yellowstone River, Montana, 2011 and 2012

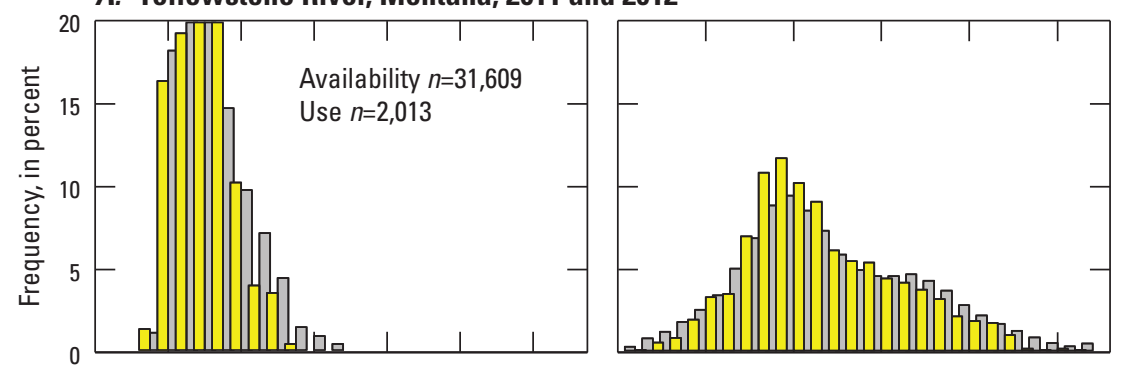

EXPLANATION

Available habita

Migratory habitat use

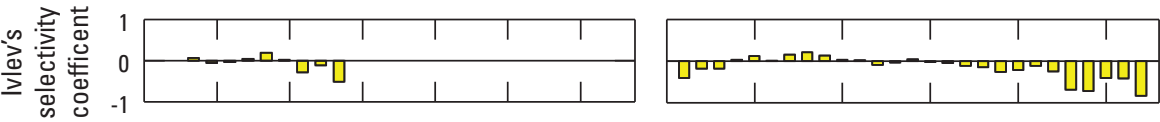

B. Missouri River, Nebraska and lowa, 2010 and 2012

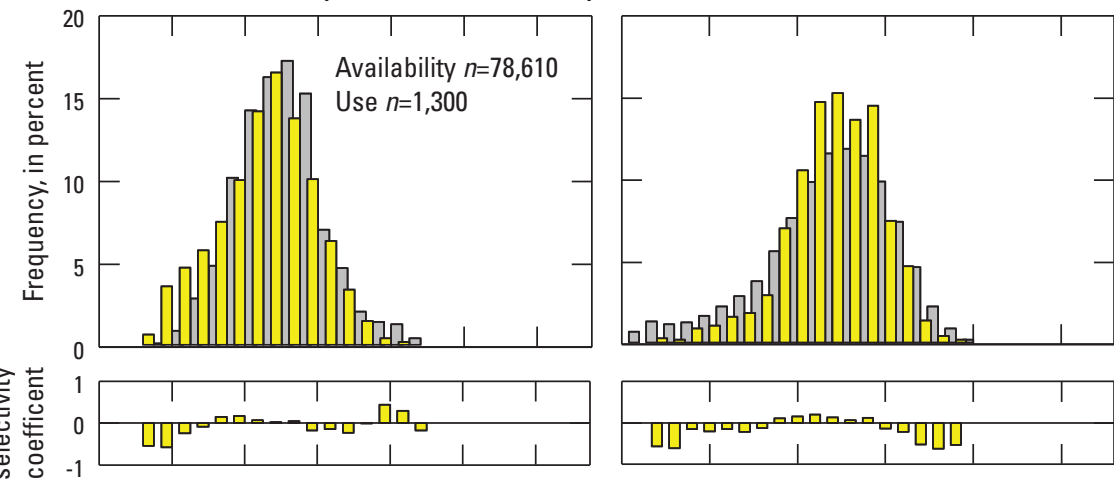

C. Missouri River, Missouri, 2010 and 2011
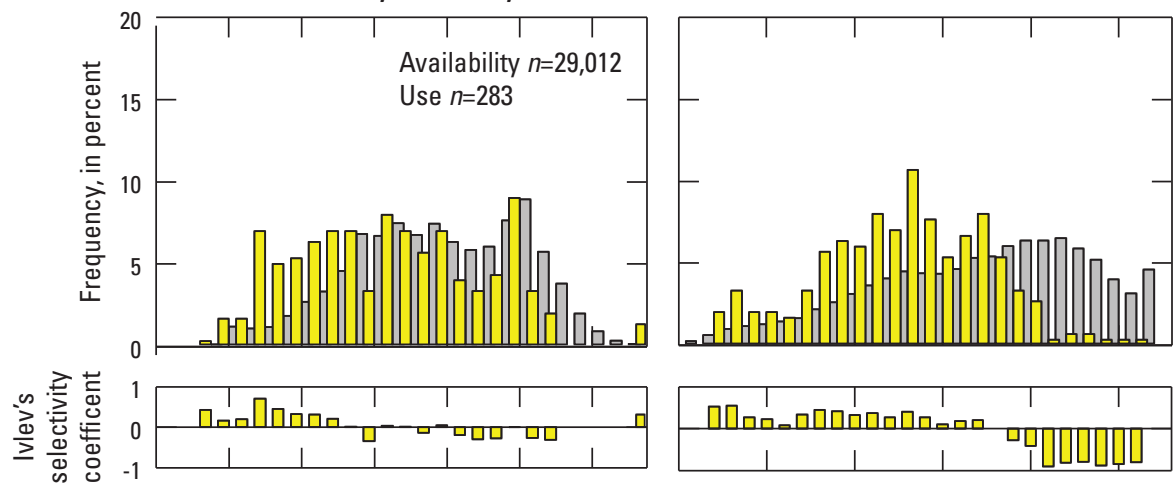

D. All river segments, 2010-12

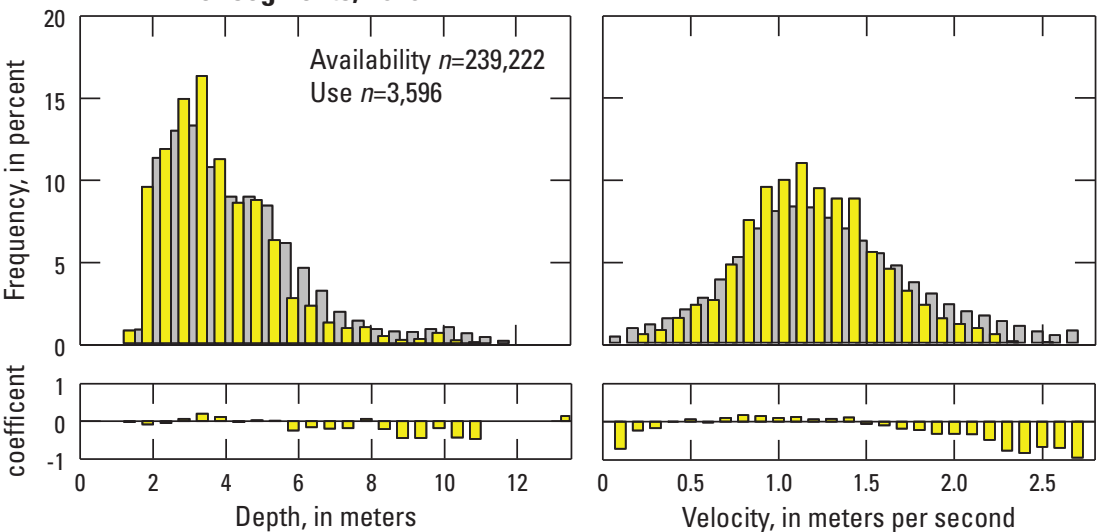

Figure 35. Pallid sturgeon migration habitat availability and use on the Lower Yellowstone and Lower Missouri River, 2010-12. 


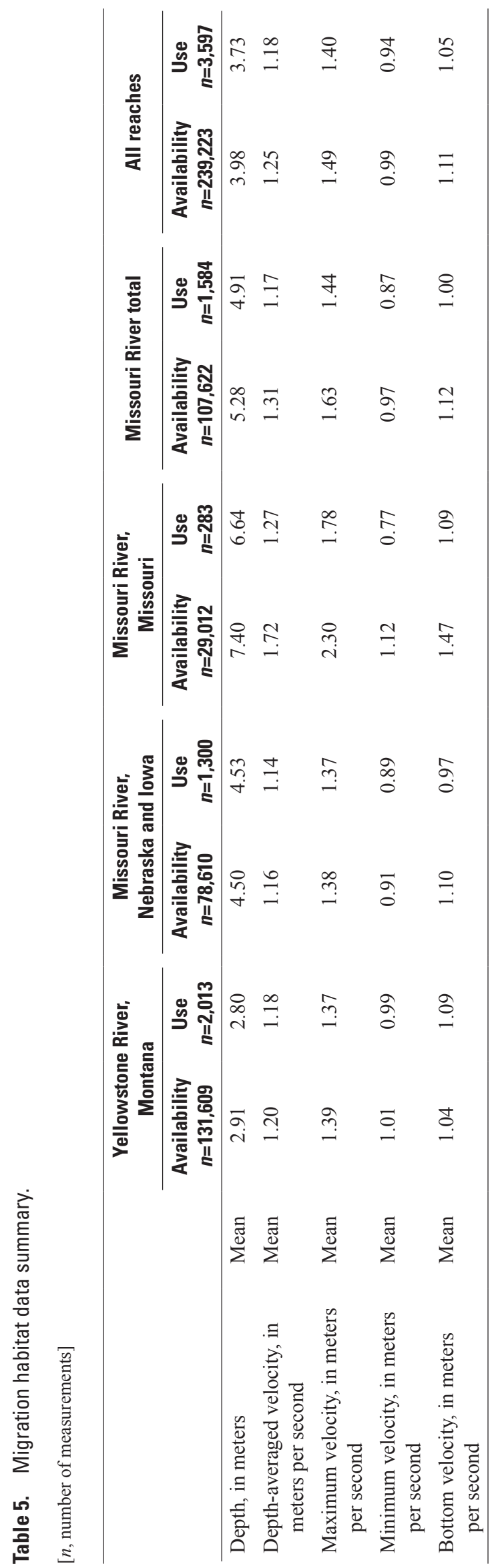

frequency with few observations between the initial reproductive evaluation and the post-spawn evaluation (DeLonay and others, 2009; DeLonay and others, 2010; DeLonay and others, 2012; DeLonay and others, 2014).

Pallid sturgeon spawning has been documented in most segments of the Lower Missouri River (fig. 36), including the channelized reaches upstream and downstream from the Kansas and Platte Rivers, and in the unchannelized reach downstream from Gavins Point Dam. The large apparent differences in channel morphology resulting from natural physiographic gradients and channel engineering across reaches where spawning has occurred in the Lower Missouri River suggest that pallid sturgeon can spawn in a wide range of environmental conditions. However, these differences do not indicate whether spawning is more or less successful within any particular reach. Limited reach-scale observations of spawning in a highly altered system are not necessarily indicative of broadscale patterns of species habitat preference. The distribution of sturgeon spawning locations on the landscape is likely shaped by habitat characteristics at multiple spatial scales, and may be structured by genetics, the distribution or behavior of conspecifics, and an individual's past experience. Resolving these complex relations in the highly altered contemporary river is challenging and many more observations may be necessary to understand pallid sturgeon spawning dynamics.

The expectation, based on other sturgeon species, is that pallid sturgeon aggregation and spawning should occur at a few readily identifiable locations, and that spawning would occur at the same locations annually with some measure of predictability. Although the observations of pallid sturgeon spawning are limited, spawning locations appear to be distributed widely along the Lower Missouri River. Synchronization of spawning in sturgeons may affect reproductive success of uncommon or geographically dispersed species by ensuring that males and females are present at spawning sites at the same time, and that aggregations are sufficient to result in egg deposition and fertilization. Synchronization of spawning can be mediated temporally through environmental variables (cues) or spatially through the discrete distribution of suitable spawning habitats. Highly altered environments may result in changes in physiological readiness to spawn or alterations of spawning habitat so that it becomes either too abundant, too rare, or of poor suitability. Consequences of altered spawning synchronicity or insufficient aggregations of sturgeon at spawning sites may produce an Allee effect resulting in poor reproductive success, altered population genetic structure, and hybridization with co-occurring congeneric species, notably shovelnose sturgeon.

Eight of the nine probable pallid sturgeon spawning locations where the spatial extent of spawning was known with high confidence (within one RM) based on locations from reproductive females (table 2) were mapped on the channelized Lower Missouri River from 2008 to 2012 (DeLonay and others, 2009; DeLonay and others, 2012). Spawning locations were mapped using boat-based high-resolution hydroacoustic tools, including a multibeam echosounder (MBES), an 


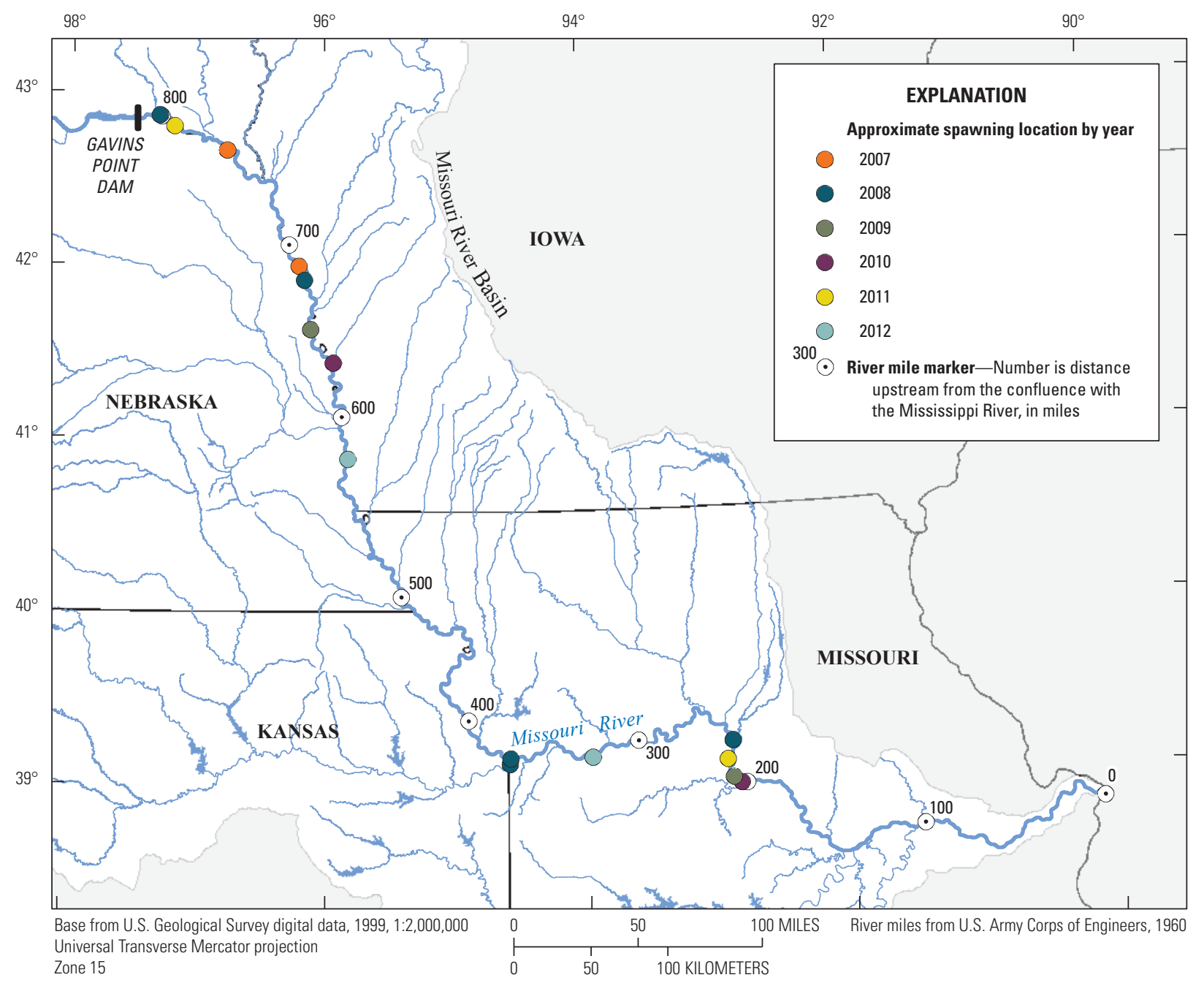

Figure 36. Spawning locations of pallid sturgeon in the Lower Missouri River, 2007-12.

ADCP, and high-resolution global positioning systems (GPS) (table 6). One site was downstream from the confluence with the Platte River (2012, RM 580.2) on the Nebraska-Iowa border in the upstream channelized region of the Lower Missouri River. The remaining seven sites were in the downstream channelized section of the Lower Missouri River; two were near Kansas City, Missouri (2008, RM 366.4 and 369.5), one was near RM 322.2 (2012), and four were near Boonville, Missouri (2008-12, RM 230-202) (table 6).

Spawning locations were determined from precise acoustic telemetry locations and represent pallid sturgeon behavior during the entire course of the spawning activity, usually $24-48$ hours. Telemetry locations are representative of spawning activity that includes repeated bursts of activity, documented in most sites as episodic movements along revetted outside bends (DeLonay and others, 2009; DeLonay and others, 2010). All telemetry points recorded during the time period in which this pattern of behavior was observed were used in the analysis of spawning habitat. Maps of depth and velocity were created from hydroacoustic data collected at spawning locations using previously established methods (Reuter and others, 2008; DeLonay and others, 2009; Reuter and others, 2009; DeLonay and others, 2012) A bathymetric terrain classification was performed using depth and slope information (Weiss, 2001; Lundblad and others, 2006; Jacobson and others, 2009b; Reuter and others, 2009). Substrate at spawning sites was inferred from sidescan sonar and multibeam data. Sand dunes, revetment, and bedrock are clearly visible on sidescan sonar imagery and can be visualized with multibeam point cloud data or multibeam data gridded at a high resolution $(0.10 \mathrm{~m})$ (fig. 37). Revetment slope was measured from multibeam data gridded to $0.10 \mathrm{~m}$ at a spawning site. Selectivity was calculated using Ivlev's selectivity coefficient (Manly and others, 2002; Reuter and others, 2009).

Spawning occurred in patches of deep and fast water when compared to the ranges of depths and velocities available within the entire channel in a reach (fig. 38, fig. 39, table 7). Depths at spawning telemetry locations were greater 
Table 6. Spawning dates and discharges, 2008-12.

[FishID, Fish identification code; ADCP, acoustic Doppler current profiler]

\begin{tabular}{|c|c|c|c|c|c|c|c|c|}
\hline $\begin{array}{c}\text { Pallid sturgeon FishID } \\
\text { and probable } \\
\text { spawning dates }\end{array}$ & Date & $\begin{array}{l}\text { Missouri River } \\
\text { mile } \\
\text { (reach center) }\end{array}$ & Type of data & Nearest streamgage & $\begin{array}{l}\text { Discharge, } \\
\text { in cubic feet } \\
\text { per second }\end{array}$ & $\begin{array}{l}\text { Streamgage with longer } \\
\text { flow record }\end{array}$ & $\begin{array}{l}\text { Discharge, } \\
\text { in cubic feet } \\
\text { per second }\end{array}$ & $\begin{array}{l}\text { Flow percentile } \\
\text { from 1970-2012 } \\
\text { (upper limit) }\end{array}$ \\
\hline PLS08-004 & $5 / 4 / 2008$ & 230 & Telemetry & Glasgow, Missouri & 98,600 & Boonville, Missouri & 108,000 & 90 \\
\hline \multirow[t]{3}{*}{$5 / 4 / 2008-5 / 5 / 2008$} & $5 / 5 / 2008$ & & Telemetry & Glasgow, Missouri & 84,400 & Boonville, Missouri & 91,000 & 80 \\
\hline & $5 / 7 / 2008$ & & Multibeam & Glasgow, Missouri & 69,700 & Boonville, Missouri & 73,100 & 70 \\
\hline & $7 / 10 / 2008$ & & $\mathrm{ADCP}$ & Glasgow, Missouri & 81,700 & Boonville, Missouri & 89,700 & 80 \\
\hline PLS08-009 & $5 / 7 / 2008$ & 369 & Telemetry & Kansas City, Missouri & 54,800 & Kansas City, Missouri & 54,800 & 60 \\
\hline \multirow[t]{2}{*}{ 5/7/2008-5/8/2008 } & $5 / 8 / 2008$ & & Telemetry & Kansas City, Missouri & 56,900 & Kansas City, Missouri & 56,900 & 60 \\
\hline & $5 / 14 / 2008$ & & Multibeam, ADCP & Kansas City, Missouri & 63,600 & Kansas City, Missouri & 63,600 & 70 \\
\hline PLS08-008 & $5 / 8 / 2008$ & 366 & Telemetry & Kansas City, Missouri & 56,900 & Kansas City, Missouri & 56,900 & 70 \\
\hline \multirow[t]{2}{*}{$5 / 8 / 2008-5 / 9 / 2008$} & $5 / 9 / 2008$ & & Telemetry & Kansas City, Missouri & 61,800 & Kansas City, Missouri & 61,800 & 70 \\
\hline & $5 / 13 / 2008$ & & Multibeam, ADCP & Kansas City, Missouri & 68,600 & Kansas City, Missouri & 68,600 & 80 \\
\hline PLS09-007 & $4 / 25 / 2009$ & 206 & Spawn event & Boonville, Missouri & 59,400 & Boonville, Missouri & 59,400 & 70 \\
\hline $4 / 25 / 2009-4 / 26 / 2009$ & $4 / 26 / 2009$ & & Multibeam, ADCP & Boonville, Missouri & 57,800 & Boonville, Missouri & 57,800 & 50 \\
\hline PLS10-006 & $4 / 30 / 2010$ & 202 & Spawn event & Boonville, Missouri & 135,000 & Boonville, Missouri & 135,000 & 100 \\
\hline $4 / 31 / 2010-5 / 1 / 2010$ & $5 / 1 / 2010$ & & Multibeam, ADCP & Boonville, Missouri & 112,000 & Boonville, Missouri & 112,000 & 90 \\
\hline PLS11-008 & $5 / 16 / 2011$ & 216 & Telemetry & Glasgow, Missouri & 123,000 & Boonville, Missouri & 131,000 & 90 \\
\hline \multirow[t]{4}{*}{ 5/17/2011-5/19/2011 } & $5 / 17 / 2011$ & & Telemetry & Glasgow, Missouri & 120,000 & Boonville, Missouri & 127,000 & 90 \\
\hline & $5 / 18 / 2011$ & & Telemetry & Glasgow, Missouri & 118,000 & Boonville, Missouri & 123,000 & 90 \\
\hline & $5 / 21 / 2011$ & & Multibeam & Glasgow, Missouri & 115,000 & Boonville, Missouri & 130,000 & 90 \\
\hline & $5 / 19 / 2011$ & & $\mathrm{ADCP}$ & Glasgow, Missouri & 115,000 & Boonville, Missouri & 119,000 & 90 \\
\hline PLS11-007 & $3 / 31 / 2012$ & 322 & Telemetry & Waverly, Missouri & 62,500 & Kansas City, Missouri & 66,100 & 80 \\
\hline \multirow[t]{2}{*}{$3 / 31 / 2012$} & $4 / 12 / 2012$ & & Multibeam & Waverly, Missouri & 52,700 & Kansas City, Missouri & 51,200 & 70 \\
\hline & $4 / 13 / 2012$ & & $\mathrm{ADCP}$ & Waverly, Missouri & 51,600 & Kansas City, Missouri & 50,700 & 50 \\
\hline PLS09-011 & $4 / 26 / 2012$ & 580 & Telemetry & Nebraska City, Nebraska & 38,000 & Nebraska City, Nebraska & 38,000 & 50 \\
\hline \multirow[t]{2}{*}{$4 / 26 / 2012$} & $5 / 2 / 12012$ & & Multibeam & Nebraska City, Nebraska & 40,800 & Nebraska City, Nebraska & 40,800 & 60 \\
\hline & $5 / 1 / 2012$ & & $\mathrm{ADCP}$ & Nebraska City, Nebraska & 39,700 & Nebraska City, Nebraska & 39,700 & 60 \\
\hline
\end{tabular}




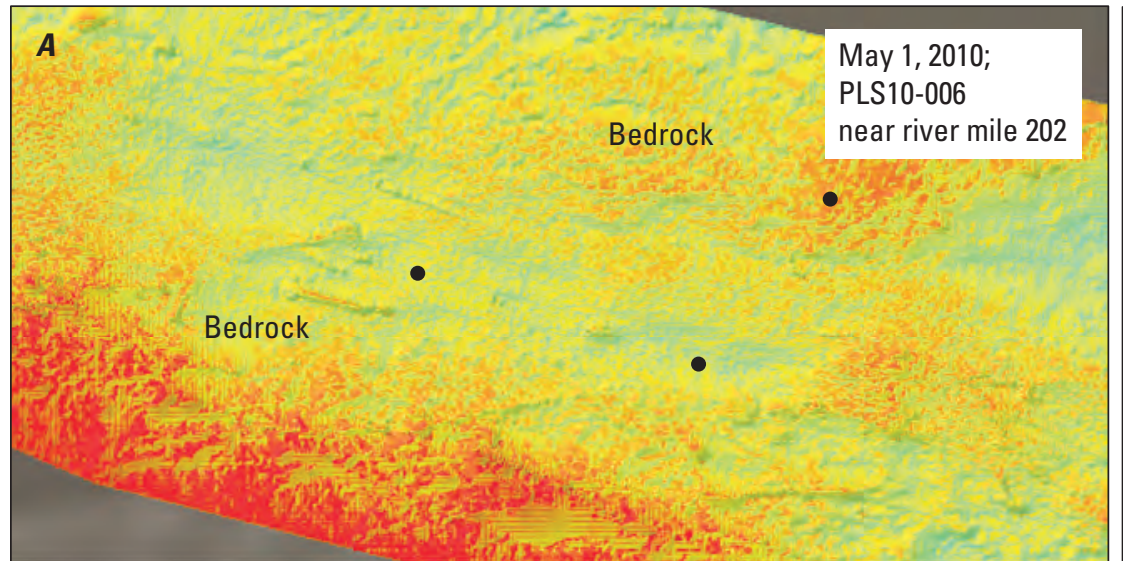

Discharge at the U.S. Geological Survey streamgage at Boonville, Missouri, was 112,000 cubic feet per second

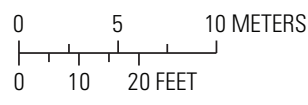

EXPLANATION

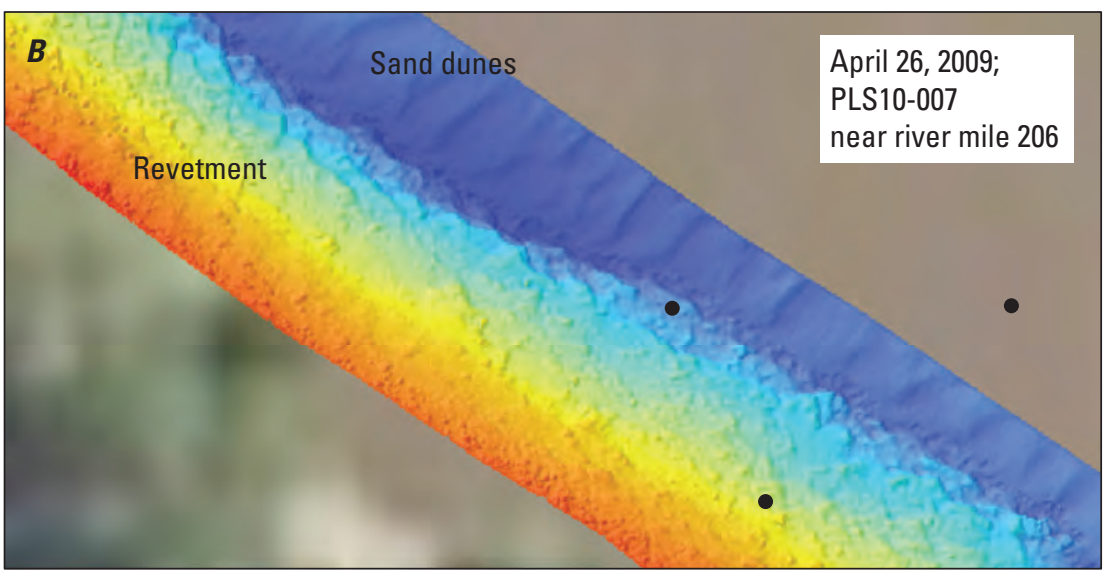

Discharge at the U.S. Geological Survey streamgage at Boonville, Missouri, was 57,800 cubic feet per second

- Pallid sturgeon spawning location

Depth, in meters

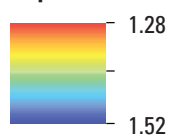

1.52

Figure 37. Examples of high-resolution bathymetry showing $A$, bedrock and $B$, revetment and sand dune substrates at probable spawning locations in the Lower

Missouri River. 


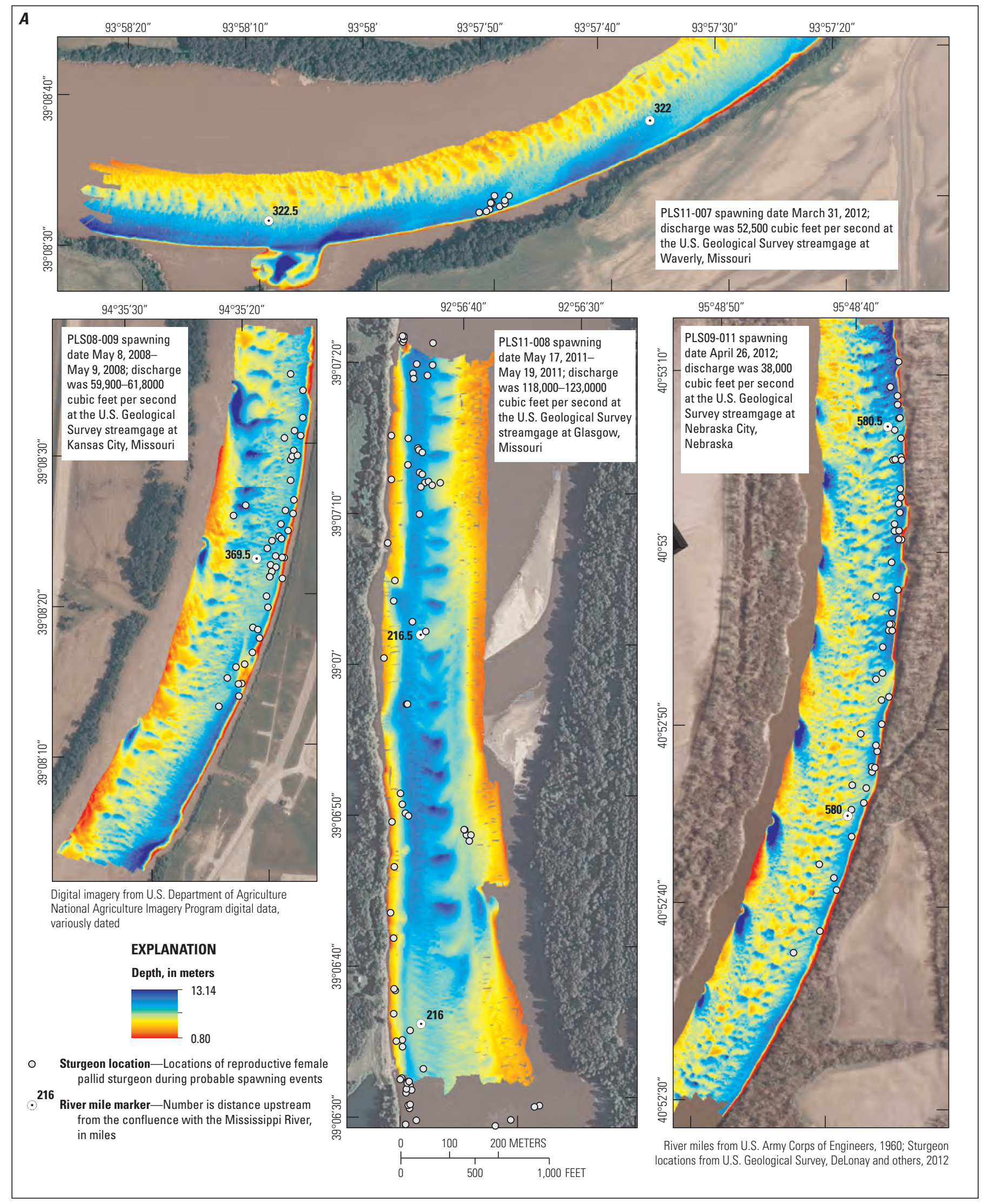

Figure 38. Bathymetric and acoustic Doppler current profiler velocity maps of reproductive female pallid sturgeon spawning sites mapped, 2008-12. A, B, Multibeam depth maps. $C, D$, Acoustic Doppler current profiler velocity maps. 


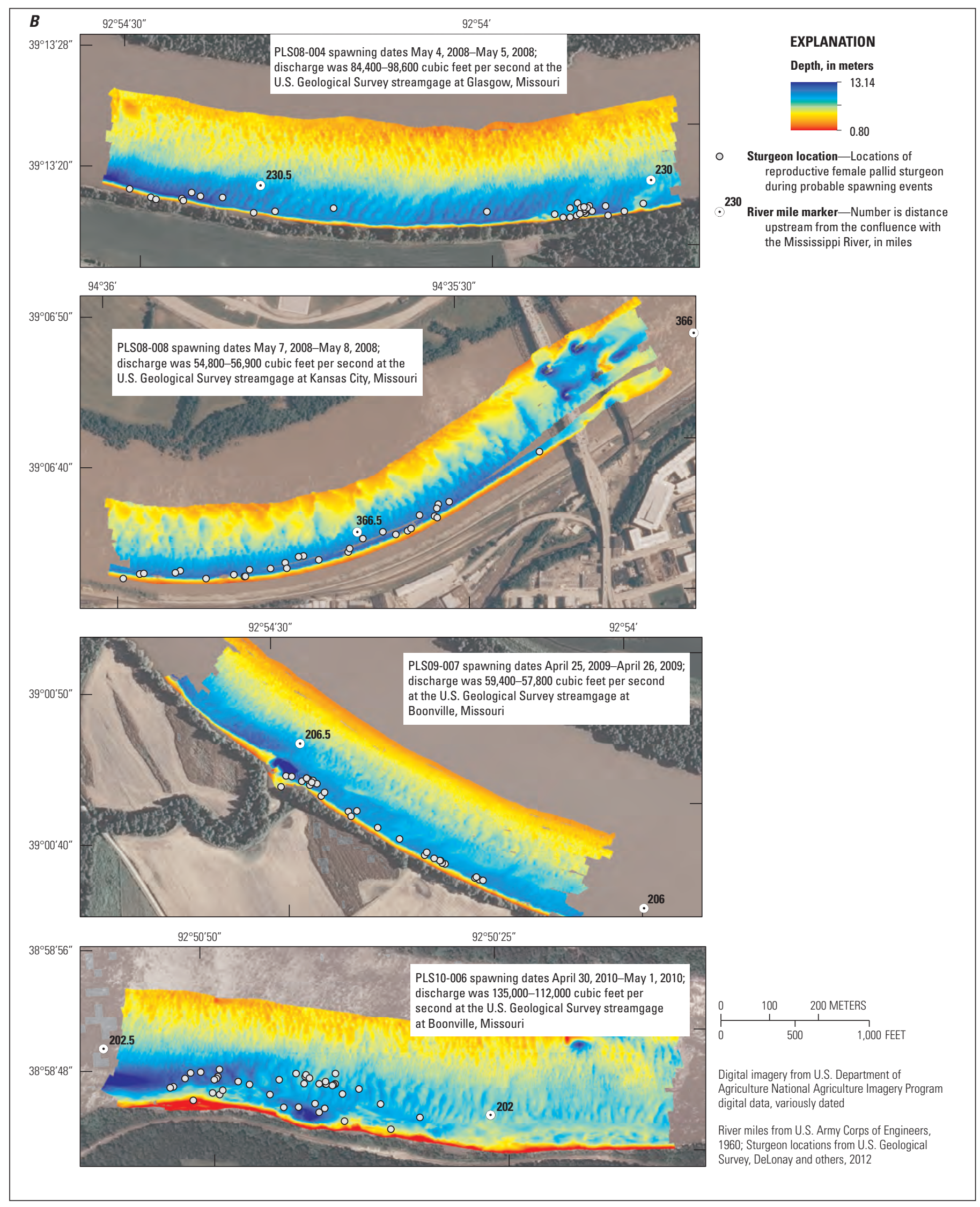

Figure 38. Bathymetric and acoustic Doppler current profiler velocity maps of reproductive female pallid sturgeon spawning sites mapped, 2008-12. A, B, Multibeam depth maps. C, D, Acoustic Doppler current profiler velocity maps. - Continued 


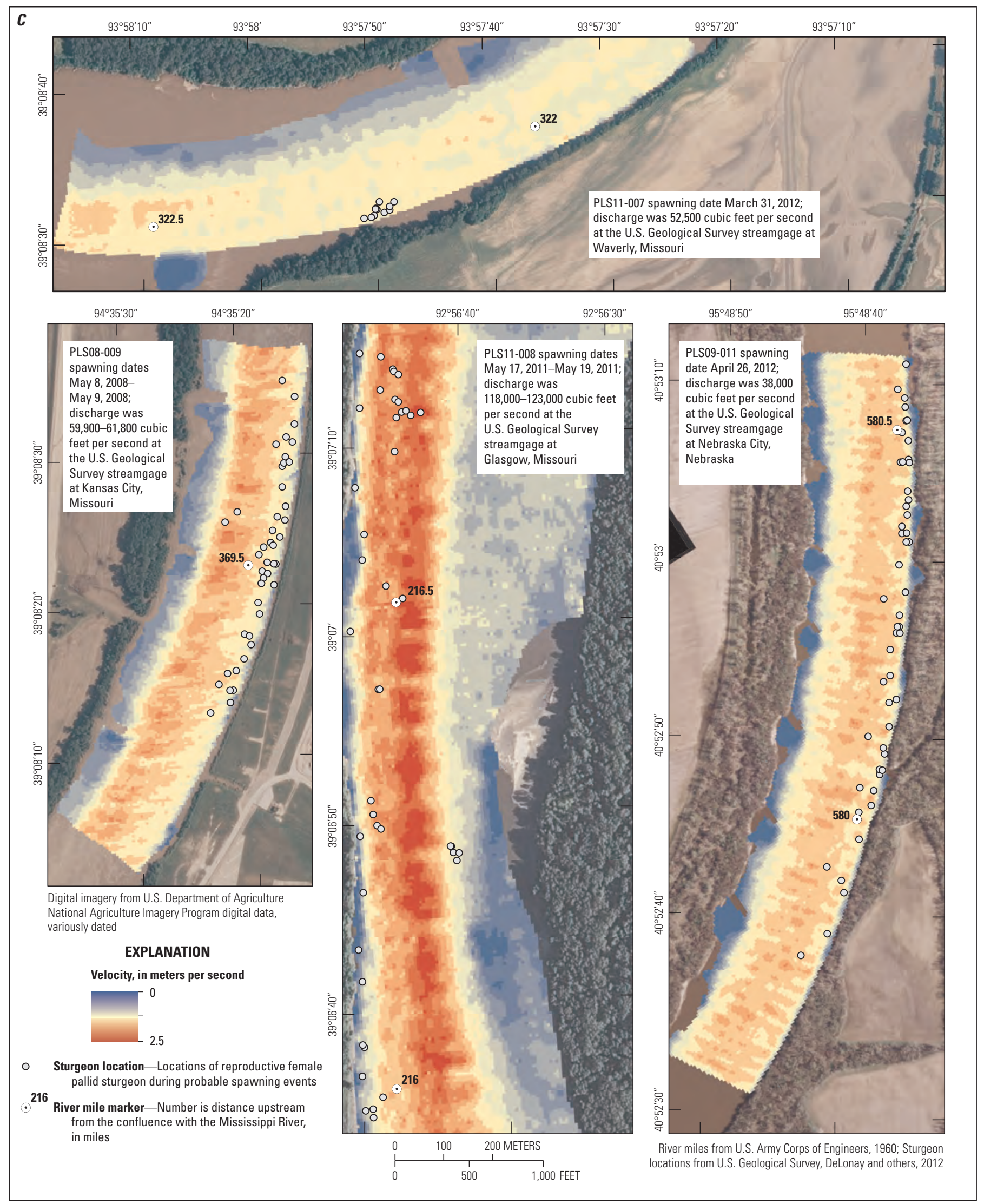

Figure 38. Bathymetric and acoustic Doppler current profiler velocity maps of reproductive female pallid sturgeon spawning sites mapped, 2008-12. A, B, Multibeam depth maps. C, D, Acoustic Doppler current profiler velocity maps. - Continued 


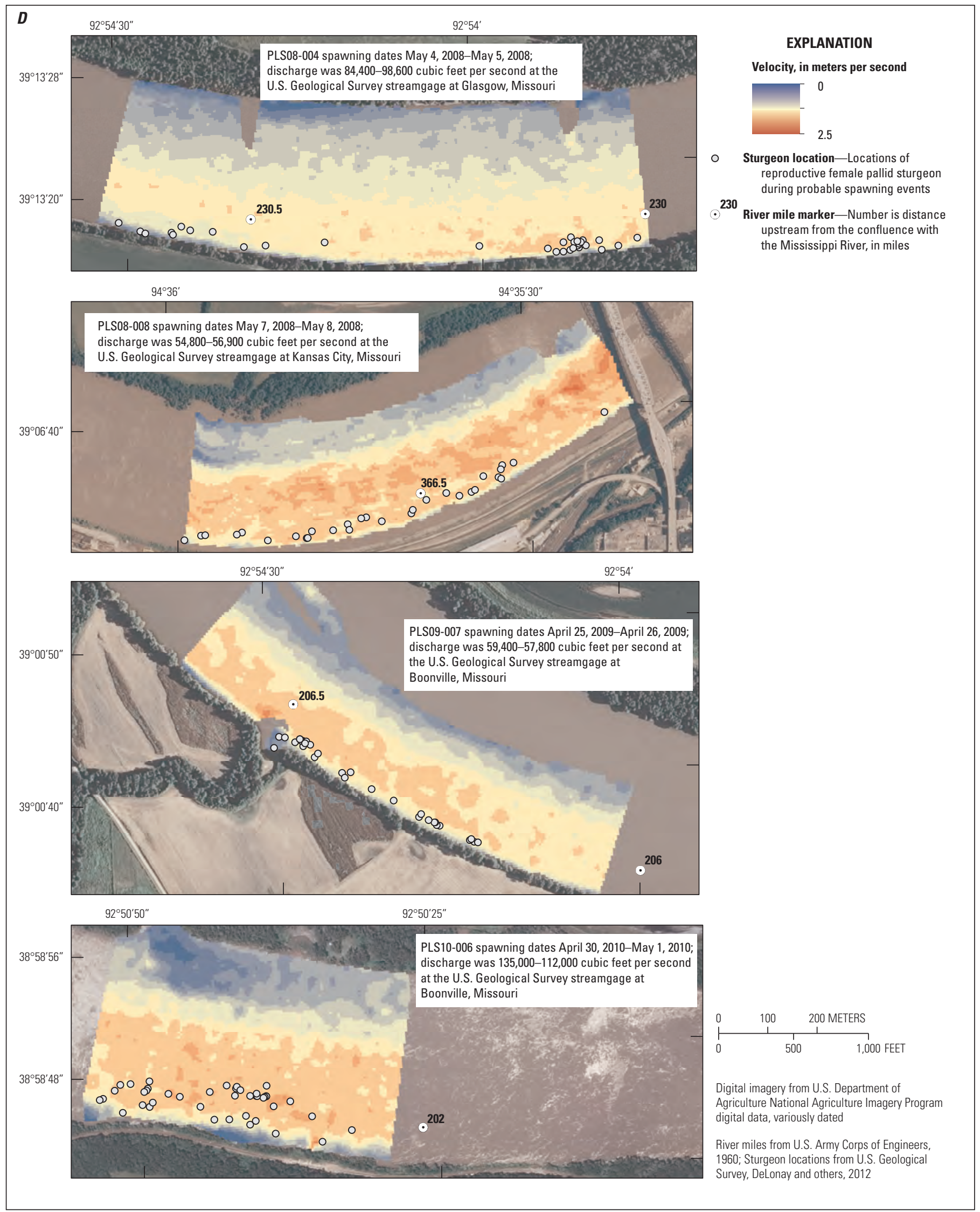

Figure 38. Bathymetric and acoustic Doppler current profiler velocity maps of reproductive female pallid sturgeon spawning sites mapped, 2008-12. A, B, Multibeam depth maps. C, D, Acoustic Doppler current profiler velocity maps. - Continued 

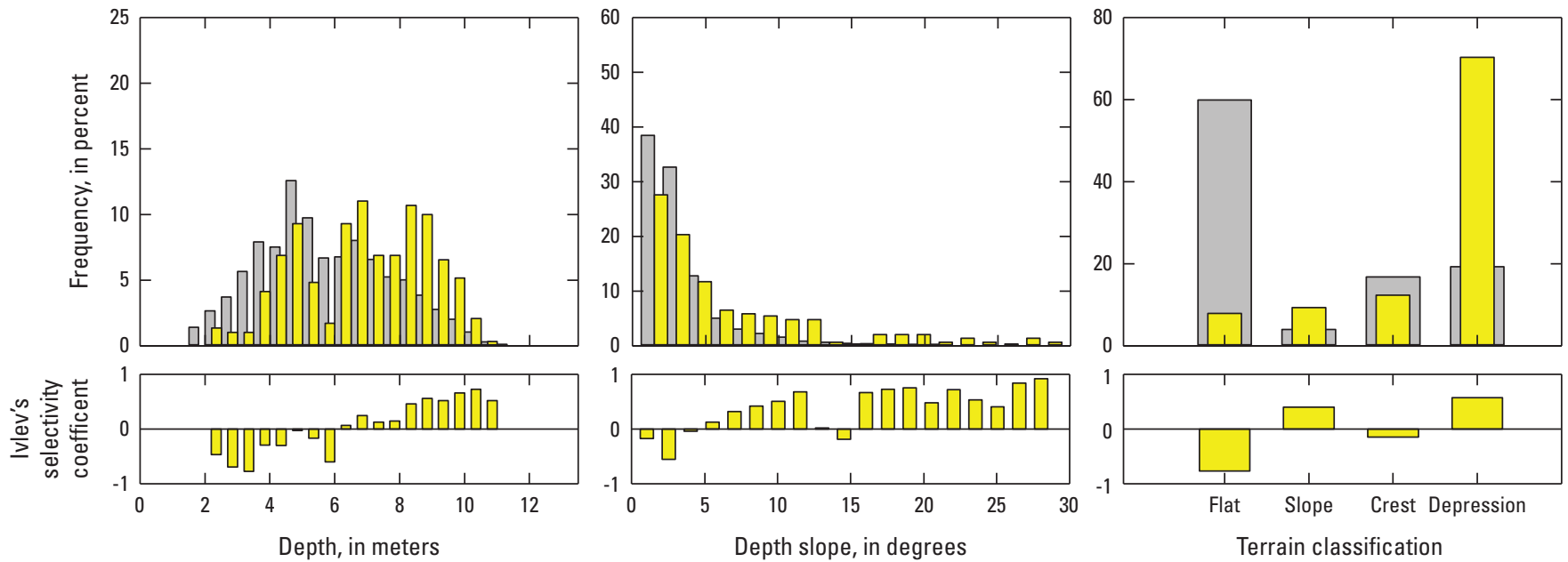

EXPLANATION

All habitat measurements

Probable pallid sturgeon spawning telemetry locations
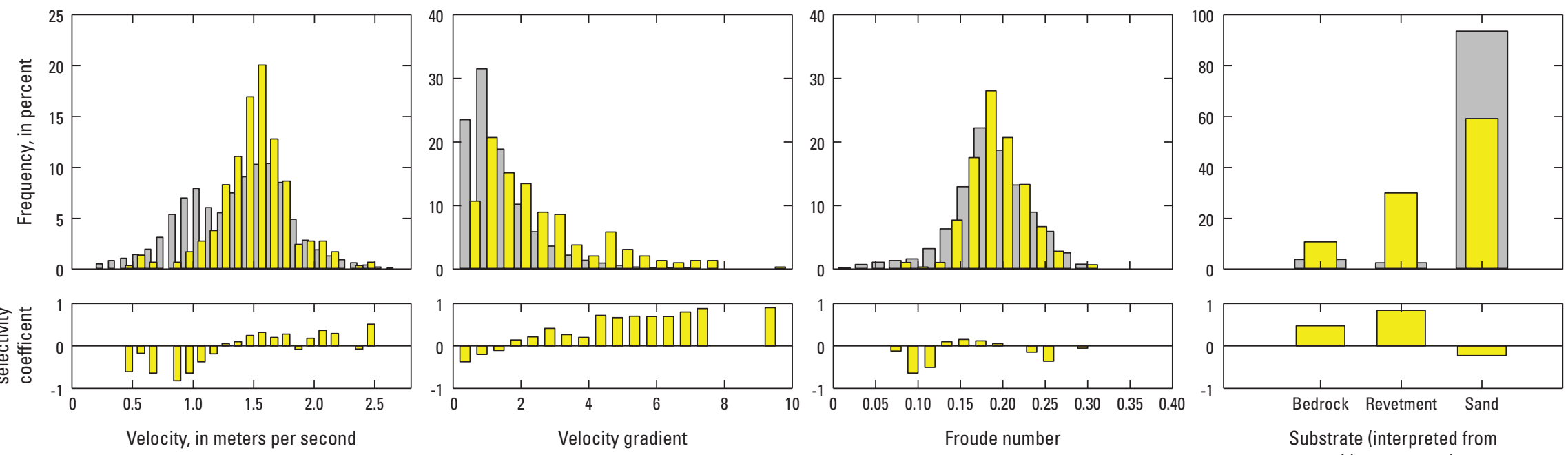

sidescan sonar)

Figure 39. Probable pallid sturgeon spawning habitat availability and use at the eight spawning locations mapped on the Lower Missouri River, 2008-12. 
Table 7. Summary of water temperature, discharge, substrate, depth, depth-averaged velocity, and turbidity at pallid sturgeon spawning sites in the Lower Missouri River,

2008-12.

[FishID, Fish identification code; NTU; nephelometric turbidity units; --, no data]

\begin{tabular}{|c|c|c|c|c|c|c|c|c|}
\hline $\begin{array}{c}\text { Pallid sturgeon } \\
\text { FishID }\end{array}$ & Spawning dates & $\begin{array}{l}\text { Missouri River } \\
\text { mile } \\
\text { (reach center) }\end{array}$ & $\begin{array}{l}\text { Mean temperature, } \\
\text { field measurements, } \\
\text { in degrees Celsius }\end{array}$ & Substrate & & $\begin{array}{l}\text { Depth, } \\
\text { in meters }\end{array}$ & $\begin{array}{l}\text { Depth-averaged } \\
\text { velocity, } \\
\text { in meters per second }\end{array}$ & $\begin{array}{l}\text { Turbidity } \\
\text { range } \\
\text { in NTU1 }\end{array}$ \\
\hline \multirow[t]{2}{*}{ PLS08-004 } & $5 / 4 / 2008-5 / 5 / 2008$ & 230 & 15.9 & sand, revetment & mean & 6.65 & 1.31 & \\
\hline & & & & & range & $2.18-10.59$ & $0.57-1.62$ & $210-390$ \\
\hline \multirow[t]{2}{*}{ PLS08-008 } & $5 / 8 / 2008-5 / 9 / 2008$ & 366 & 17.8 & sand, revetment & mean & 8.09 & 1.49 & \\
\hline & & & & & range & $2.20-9.53$ & $0.58-1.77$ & -- \\
\hline \multirow[t]{2}{*}{ PLS08-009 } & $5 / 7 / 2008-5 / 8 / 2008$ & 369 & 17.0 & sand, revetment & mean & 6.42 & 1.39 & \\
\hline & & & & & range & $5.00-8.11$ & $0.97-1.88$ & \\
\hline \multirow[t]{2}{*}{ PLS09-007 } & $4 / 25 / 2009-4 / 26 / 2009$ & 206 & 17.4 & sand, revetment & mean & 7.66 & 1.33 & \\
\hline & & & & & range & $5.21-8.94$ & $0.49-1.58$ & $50-68$ \\
\hline \multirow[t]{2}{*}{ PLS10-006 } & $4 / 31 / 2010-5 / 1 / 2010$ & 202 & 16.6 & sand, bedrock, potential gravel & mean & 8.55 & 1.58 & \\
\hline & & & & & range & $3.65-10.27$ & $1.25-1.80$ & \\
\hline \multirow[t]{2}{*}{ PLS11-008 } & $5 / 16 / 2011-5 / 19 / 2011$ & 216 & 17.1 & sand, bedrock, potential gravel & mean & 7.21 & 1.59 & \\
\hline & & & & & range & $2.45-10.01$ & $0.46-2.36$ & -- \\
\hline \multirow[t]{2}{*}{ PLS11-007 } & $3 / 31 / 2012$ & 322 & 19.4 & sand, revetment & mean & 6.50 & 1.33 & \\
\hline & & & & & range & $6.17-6.93$ & $1.27-1.38$ & \\
\hline \multirow[t]{2}{*}{ PLS09-011 } & $4 / 26 / 2012$ & 580 & 16.8 & sand, revetment & mean & 4.55 & 1.4 & \\
\hline & & & & & range & $3.53-5.32$ & $0.52-1.72$ & -- \\
\hline
\end{tabular}

${ }^{1}$ Turbidity measurements for PLS08-004 and PLS09-007 are from the U.S. Geological Survey streamgage at Boonville, Missouri, near river mile 197. 
than those for the entire reach, with a range of 2.2-10.6 m between all eight sites and mean depths ranging from 4.5-8.1 m. Depths for the entire spawning reach at all sites ranged from 0.6 to $13.1 \mathrm{~m}$ with means between 4.1 and $6.4 \mathrm{~m}$. Ivlev's selectivity coefficients suggest selection of depths greater than $6 \mathrm{~m}$ and avoidance of depths less than $6 \mathrm{~m}$ (fig. 39). Depth-averaged velocities of fish locations ranged between 1.3 and $1.6 \mathrm{~m} / \mathrm{s}$ with an overall vertically averaged mean of $1.44 \mathrm{~m} / \mathrm{s}$, somewhat higher than mean velocities for the entire reach of $1.3 \mathrm{~m} / \mathrm{s}$. (Notably, habitat availability in spawning reaches typically is assessed based on habitat that can be surveyed with a shallow-draft hydroacoustic vessel in relatively uniform outside bends; shallow, slow water on the inside bends is not assessed and is not reflected in availability and selection calculations). Velocity selection is positive for velocities generally greater than $1.5 \mathrm{~m} / \mathrm{s}$ and avoidance was strongest for depths less than $1 \mathrm{~m}$. Fish selected regions with slopes greater than 5 degrees and selection was strong in slopes approaching 30 degrees (fig. 39). Regions with high velocity gradients, a measure of the spatial change in velocity, were positively selected. Nearly all spawning points were located in parts of the channel classified as depressions, areas of converging flow in or adjacent to the channel thalweg (fig. 39) (Reuter and others, 2009). Spawning sites were located near hard substrate in all 8 sites, probable spawning activity occurred near or adjacent to revetment in 6 sites ( 75 percent) and bedrock in 2 sites ( 25 percent) (table 8 , fig. 37).

Cross-channel slopes at these spawning sites can be quite steep with high surface roughness, which may affect where eggs are deposited and may affect relative fertilization and hatch success. At a typical site, the mean slope of the revetment from $1 \mathrm{~m}$ below the water surface to the toe of the revetment was 50 percent (fig. 40), and ranged from 38-63 percent. Bedrock on the bed of the channel (mean depth $7 \mathrm{~m}$ ) at both spawning sites that had natural outcrops was generally rough, with $0.3-1 \mathrm{~m}$ topographic mounds that could potentially be coarse gravels or bedrock knobs (fig. 37).

Although detailed habitat measurements were not made in 2012, a probable spawning site was identified on the Yellowstone River based on documented spawning and a prolonged period of fish aggregation. The probable spawning site was in the center of a single-threaded reach of the Yellowstone River about 6.9 RM upstream of the confluence with the Missouri River. It was a roughly elliptical area no more than $450 \mathrm{~m}$ long and less than $100 \mathrm{~m}$ wide (see appendix 4). This location was also the site of a fish aggregation during the 2011 spawning season.

\section{Long-Term Patterns of Habitat Use}

From 2005 to 2012 CSRP has recorded more than 8,600 locations from 158 pallid sturgeon along the entire 811 mile length of the Lower Missouri River, from Gavins Point Dam, South Dakota, downstream to the mouth at Saint Louis, Missouri, with a few scattered locations in the

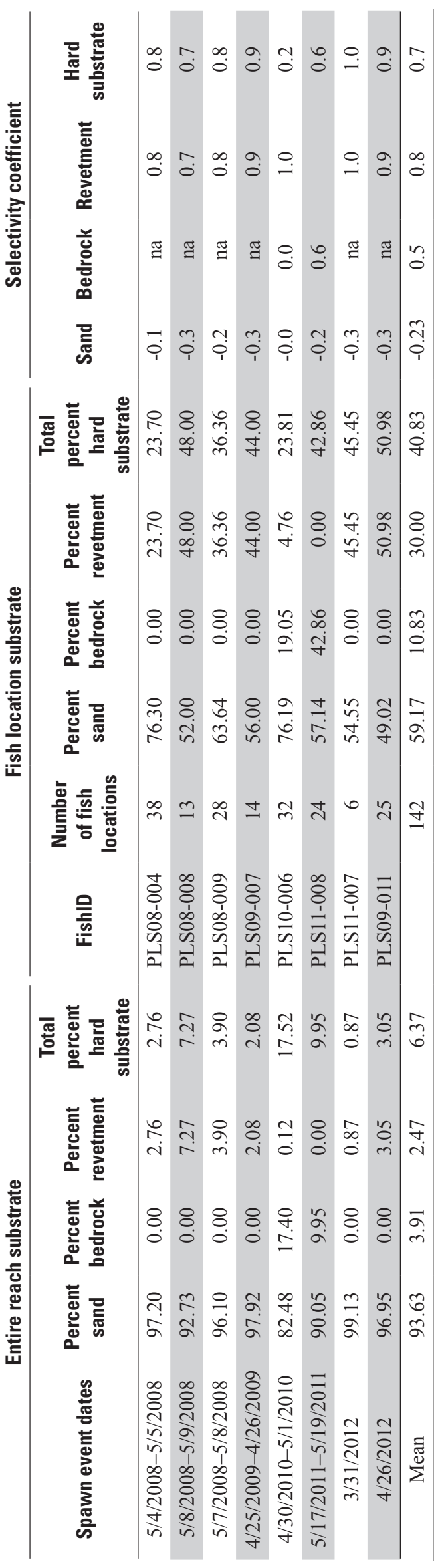




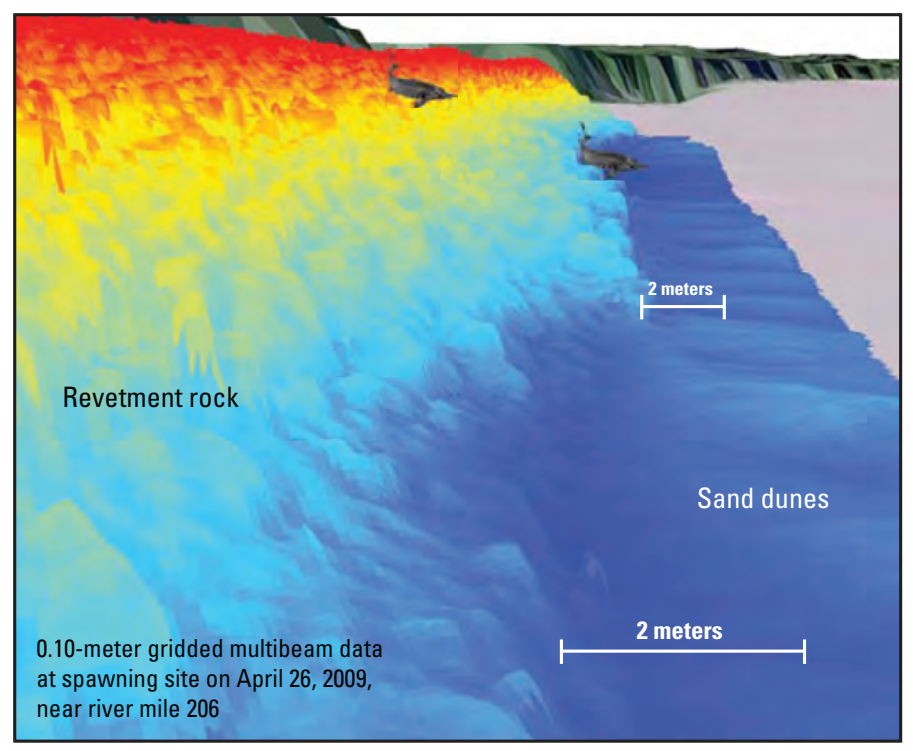

EXPLANATION

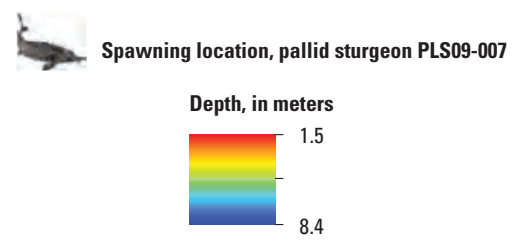

Discharge at the U.S. Geological Survey streamgage at Boonville, Missouri, was 57,800 cubic feet per second

Figure 40. Three-dimensional reconstruction created from highresolution multibeam sonar data of habitat used for spawning by female pallid sturgeon PLS09-007. Pallid sturgeon in the Lower Missouri River spawn on or at the base of steep, rock-covered or revetted banks. Nearly all outside bends on the Lower Missouri River are revetted and characterized by a narrow transition between transporting sand and artificial rock substrate placed for bank stabilization.

Mississippi River downstream from the confluence with the Missouri River to the mouth of the Ohio River. Analyses of pallid sturgeon telemetry locations on the Lower Missouri River resulting from this study are greatly affected by the nature of the original, upstream-downstream comparative design and where the fish in the study were captured (DeLonay and others, 2009). Early CSRP efforts have focused on obtaining adult sturgeon in reproductive condition from two, more or less discrete study areas (fig. 3): an upper and lower study section within the Lower Missouri River. As a result sampling efforts were uneven or intentionally geographically biased in the context of the entire Lower Missouri River. Capture efforts also were strongly affected by successful broodstock collection efforts near the Platte River, Nebraska. Because pallid sturgeon adults are rare on the Lower Missouri River, the opportunity to increase implanted individuals in the upper study section was favored over an even geographic distribution of implanted sturgeon.

Examination of the geographic distribution of location data indicates a general pattern of increased location density in the areas near tributary confluences. Pallid sturgeon locations from 2007 to 2012 were examined along the length of the Lower Missouri River. Locations were normalized and standardized using search efforts in 10 RM segments (fig. 41). Multiple daily fish locations for individual fish tracked on their spawning migrations were not used in the analyses because the locations would have biased the sample. The Osage River in Missouri and the Platte River in Nebraska appear to strongly and positively affect the distribution of tagged pallid sturgeon. Smaller tributaries, including the Lamine, Grand, Chariton, Nemaha, Kansas, Boyer, and Little Sioux Rivers (fig. 41) also may exert some effect on distributions. The value of most tributaries to pallid sturgeon and other large river specialists has received far less attention than the main stem of the Lower Missouri River. Pracheil and others (2013) have suggested that larger tributaries may provide many of the same values to large river fishes as the main stem, and may be appropriate avenues for the conservation and restoration of diversity.

Pallid sturgeon in the Lower Missouri River are capable of moving hundreds of miles in a season (DeLonay and others, 2007); however, multiyear tracking of individuals has demonstrated a propensity for at least some pallid sturgeon to use single bends or small habitat patches for many months at a time (DeLonay and others, 2012). Patch size in some instances was as small as a few tens of meters, and several tagged fish were incorrectly designated at times as potentially expired fish or expelled tags. Subsequent recapture attempts or sonar observation determined that the tagged individuals were in good condition (DeLonay and others, 2010).

Telemetered pallid sturgeon of both sexes have been documented migrating to the same section of river in the Lower Missouri River to spawn with high fidelity and tend to return to a previously occupied bend or habitat patch following migration (fig. 42, fig. 43). For example, PLS08-006 is a male pallid sturgeon that was captured in nonreproductive condition in the spring of 2008. For more than 4 years, from 2008 to 2011 regardless of his reproductive readiness, PLS08006 made repeated upstream migrations in the fall, spending winter and spring near RM 640. After the spring spawning season, PLS08-006 returned downstream to a location near RM 583 (fig. 42). Similar behavior was documented for male pallid sturgeon PLS07-020, which has been making annual upstream migrations during the fall and spring. PLS07-020 returns downstream to nearly the same location occupied the previous summer near RM 566 after spawning season (fig. 43; DeLonay and others, 2012). Telemetry tracking of pallid sturgeon for longer periods will be necessary to assess the level of spawning site fidelity and the role of geographic specificity in creating and maintaining genetic population structure.

\section{Connectivity and the Importance of Tributaries}

Telemetry data have indicated that nonreproductive pallid sturgeon use the tributary confluence area and lower segments of large tributaries, such as the Platte and Osage Rivers, for extended periods of time. A total of 8 telemetered adult 


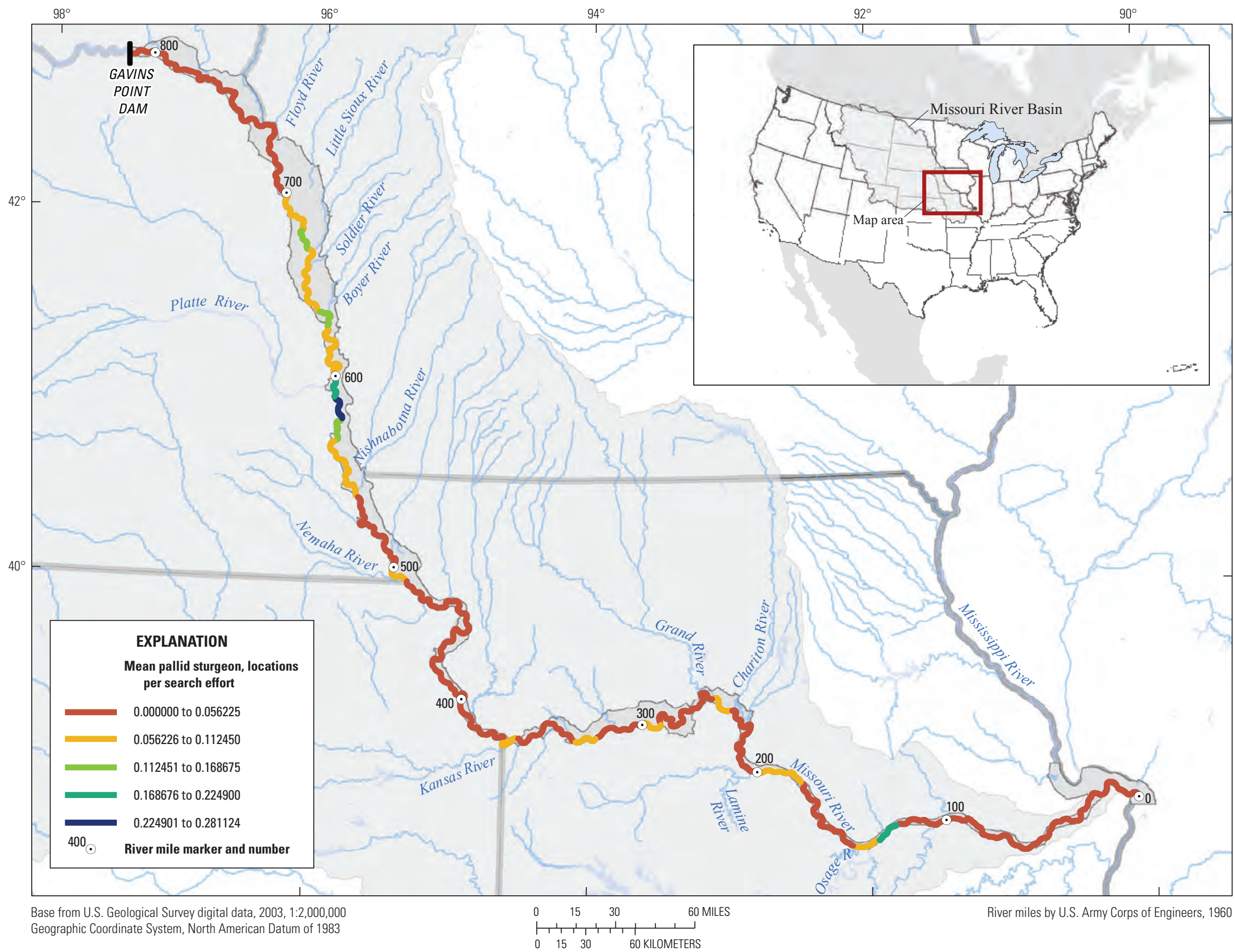

Figure 41. Density of pallid sturgeon telemetry locations in the Lower Missouri River in 2007-12, normalized for search effort. 


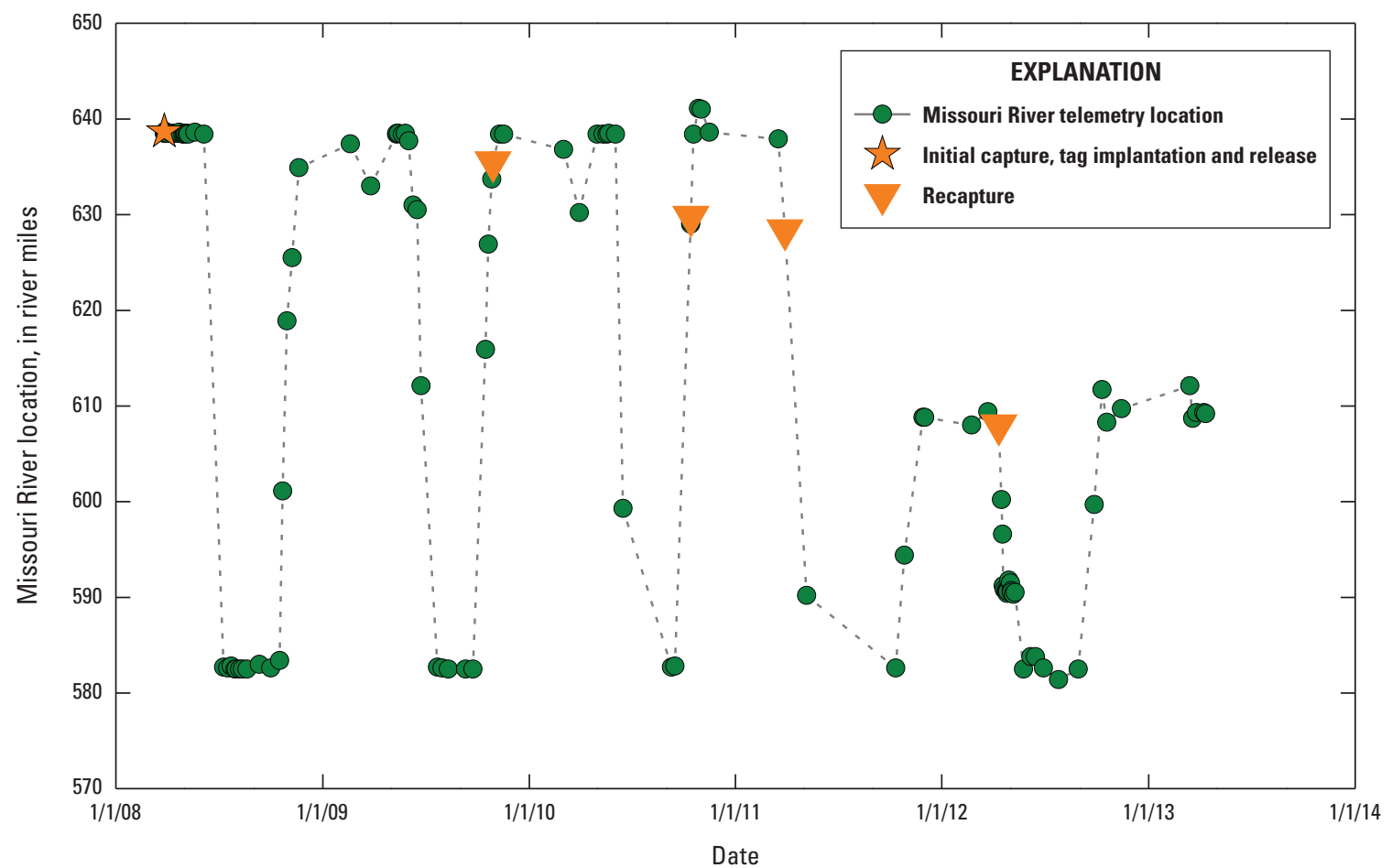

Figure 42. Telemetry locations of male pallid sturgeon PLS08-006 in the Lower Missouri River illustrating annual seasonal migrations and a pattern of affinity for specific locations.

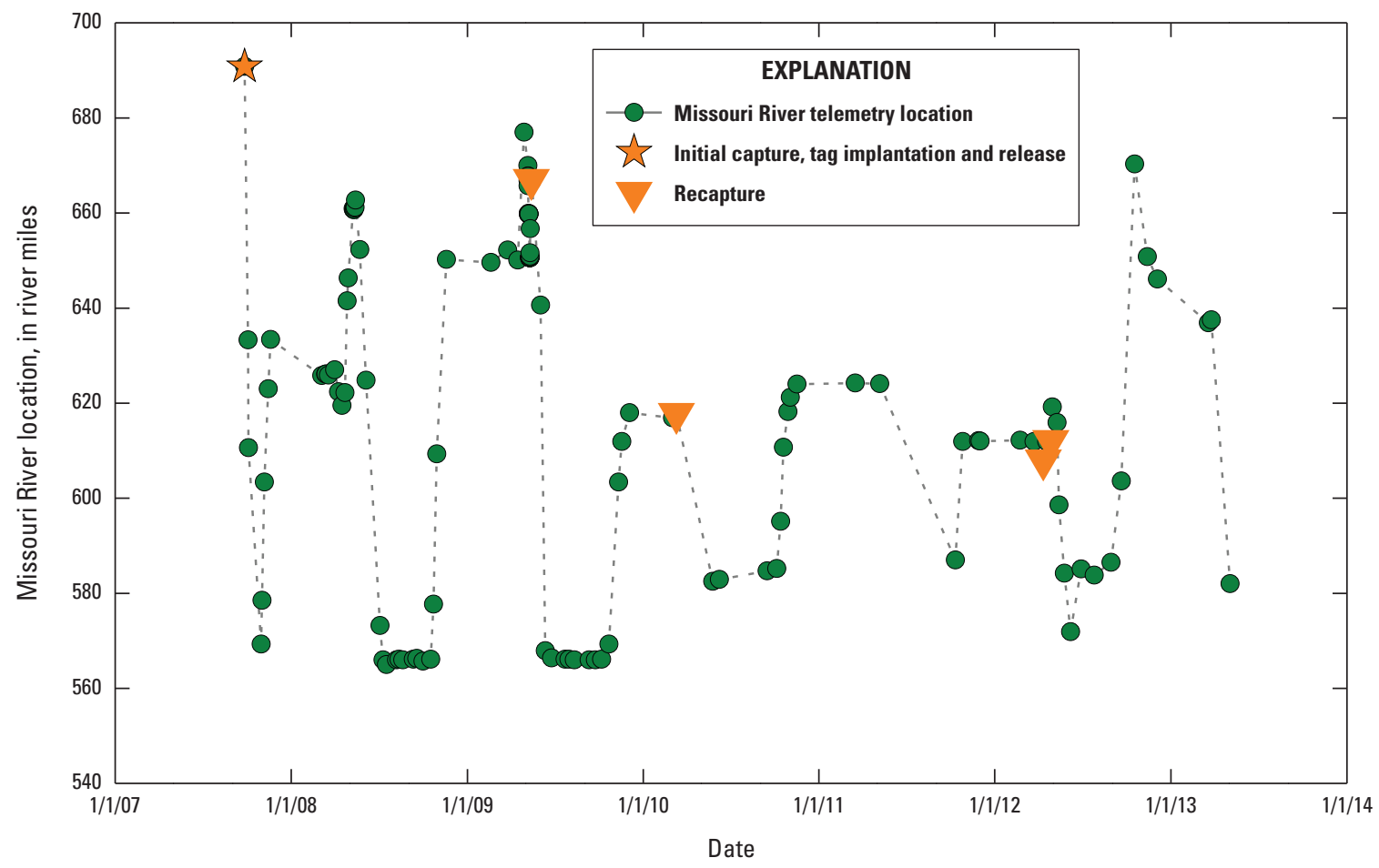

Figure 43. Telemetry locations of male pallid sturgeon PLS07-020 in the Lower Missouri River illustrating annual seasonal migrations and a pattern of affinity for specific locations. 
pallid sturgeon, 3 females and 5 males, was located during 16 search attempts in the Platte River from 2011 through 2012. These sturgeon were generally found less than 7 miles up the Platte River. For example, female pallid sturgeon PLS08-012 was initially captured in nonreproductive condition near the mouth of the Platte River at Missouri River RM 594.7 on March 30, 2008. PLS08-012 was located within 3.5 miles upstream or downstream from the mouth of the Platte River on 65 occasions from April 2008 through April 2011 (fig. 44). Female pallid sturgeon PLS10-029 was found about 33 miles up the Platte River, near the confluence of the Platte and Elkhorn Rivers, during May 2011. This female was likely not in spawning condition during the spring of 2011. Female PLS10029 did, however, return to the Platte River to spawn during spring 2012 (see appendix 1).

A total of 8 telemetered pallid sturgeon, 4 females and 4 males, was located during 28 search attempts in the Osage River from 2010 through 2012 (fig. 45). All eight fish were in nonreproductive condition at the time. Telemetered pallid sturgeon have been located in the Osage River more than 10 miles upstream, near Lock and Dam 1 (fig. 45; about 12 miles upstream from the confluence with the Missouri River) and have remained in the tributary from spring through early fall. Additionally, five pallid sturgeon in nonreproductive condition have continuously occupied the Missouri and Osage River confluence area for more than 1 year.

Pallid sturgeon recorded in the confluence areas of large tributaries have included potentially wild and hatchery-origin individuals, reproductive and nonreproductive adults, and migratory and nonmigratory sturgeon. The relative value of tributaries to pallid sturgeon recovery is as yet unknown. Tributary confluences and the lower segments of large tributaries may provide important habitat for overwintering, aggregation, refuge from floods or ice, feeding or reproduction in the highly modified Missouri River Basin.

Pallid sturgeon tagged with transmitters by the CSRP have been documented to move between the Missouri and Mississippi Rivers. The extent of the interconnectedness of Missouri River and Mississippi River pallid sturgeon populations is unknown, but the confluence of the Missouri River is not a barrier to movement. Telemetry crews located two pallid sturgeon tagged in the Lower Missouri River (PLS08-008 and PLS08-047) in the Middle Mississippi River (DeLonay and others, 2010) during 1 week of search effort in July 2009, from Mississippi River mile 200 downstream to RM 0 near the confluence with the Ohio River. Female pallid sturgeon PLS08-008 was initially captured by USGS biologists in the Missouri River near RM 183 on March 31, 2008. This female continued her upstream migration and spawned in the Missouri River during spring of 2008 near RM 366 (DeLonay and others, 2009). PLS08-008 was located by telemetry crews at RM 94.5 in the Middle Mississippi River on July 14, 2009 , about 465 RM downstream from the 2008 spawning location. Female pallid sturgeon PLS08-047 also was captured in the Missouri River near RM 773 on March 20, 2008, by South Dakota Game, Fish and Parks Department and transported to
Gavins Point National Fish Hatchery for use in the population augmentation program. This female was not successfully spawned and was released near her initial capture site on July 9, 2008, after being implanted with a telemetry device. Shortly after release, PLS08-047 began moving downstream and ultimately was recorded near RM 187 in the Middle Mississippi River on July 13, 2009, about 780 RM downstream from her initial capture location.

\section{Spawning Periodicity and Readiness to Spawn}

It is well known that pallid sturgeon do not spawn on a 12-month cycle (Dettlaff and others, 1993). Estimates made on the length of the pallid sturgeon spawning cycle have ranged from 12 to 60 months (Kallemeyn, 1983; Keenlyne and Jenkins, 1993; Wildhaber and others, 2007a). The CSRP's multiyear tracking study has provided an opportunity to better define spawning periodicity in male and female pallid sturgeon. Spawning periodicity and fecundity are critical parameters in determining potential for pallid sturgeon population growth (Wildhaber and others, 2007a; 2011a). Seven male fish captured and reproductively assessed multiple times (2-4) during CSRP studies were evaluated for spawning cycle length based on when they were in and out of reproductive condition. All males were captured from the upper study section of the Lower Missouri River. One male had a 2-year spawning cycle. The remaining fish were determined to have spawning cycles longer than 1 year however; insufficient data were available to determine whether spawning cycles were completed in 2 years or longer. Twenty female pallid sturgeon were captured multiple times (2-5) and could be evaluated for spawning cycle length. Most of the fish $(n=8)$ had spawning cycles longer than 2 years, 6 fish had spawning cycles longer than 1 year and 2 fish had spawning cycles longer than 3 years. Four female pallid sturgeon were determined to have cycles of exactly 2 years.

The general pattern of hormonal changes that occurs in a reproductive female pallid sturgeon from October to May was obtained by repeatedly collecting plasma from the same female and male pallid sturgeon held for several months at Neosho National Fish Hatchery. Hormonal patterns in reproductively cycling sturgeon are predictable and are diagnostic for readiness to spawn. Anomalous patterns may be suggestive of environmental factors that disrupt the progression of maturation and spawning in hatcheries or natural populations (DeLonay and others, 2009). In the female, estradiol and testosterone declined from October to February at which time testosterone began to increase whereas estradiol continued to decline until spawning (fig. 46). In March, 11-ketotestosterone began to increase sharply and continued increasing until the female was ready to spawn at which time testosterone and 11-ketotestosterone levels dropped (fig. 46). A similar hormonal pattern was observed for female pallid sturgeon collected from the Lower Missouri River with month-tomonth differences likely attributable to differences in river and hatchery water temperatures (fig. 47). A partial hormonal 


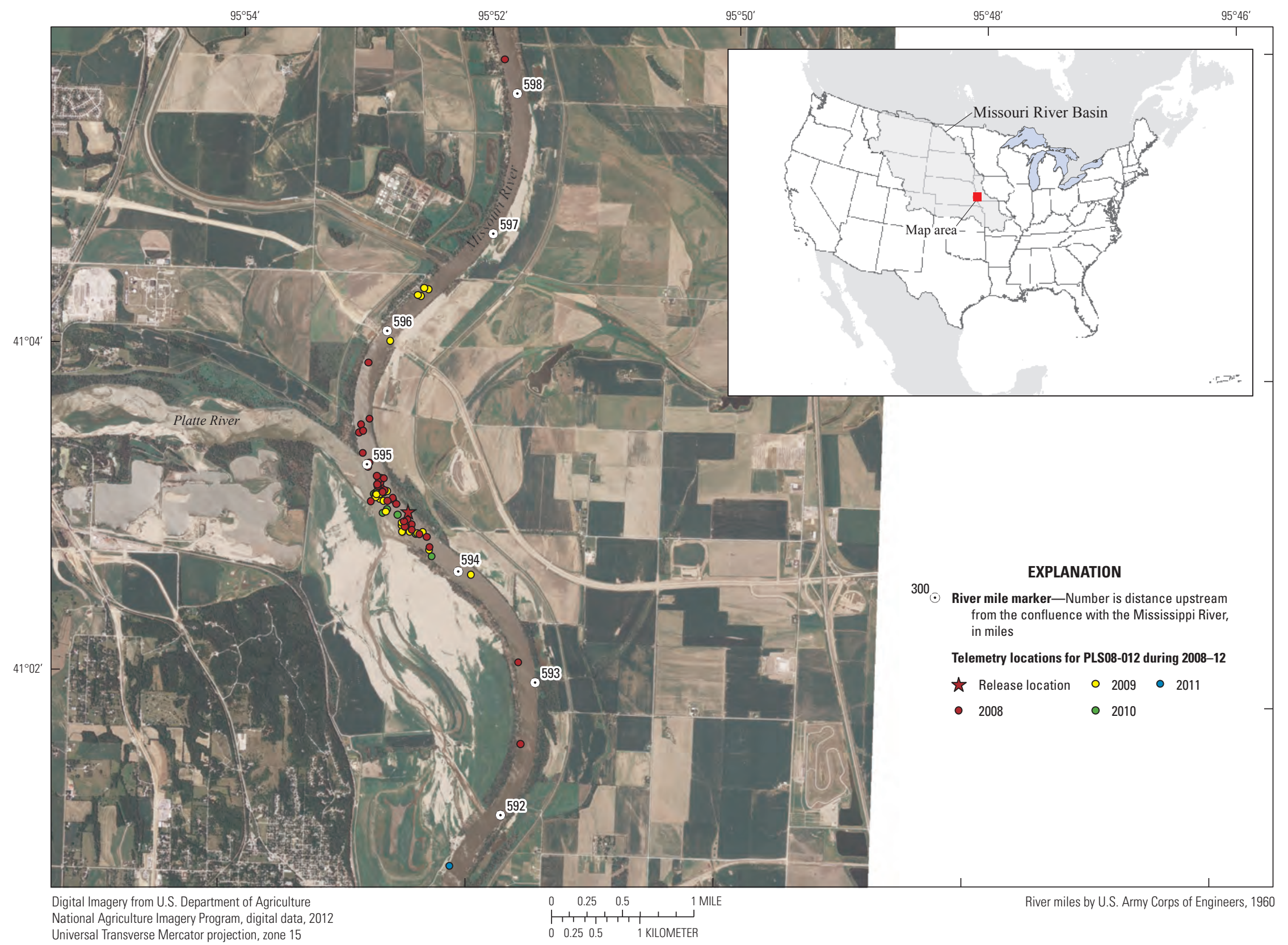

Figure 44. Telemetry locations of pallid sturgeon PLS08-012 at the confluence of the Platte and Missouri Rivers, Nebraska. Female pallid sturgeon PLS08-012 was at the Platte River confluence area 65 times between 2008 and 2011 and was not in reproductive condition at any time during the observation period. 

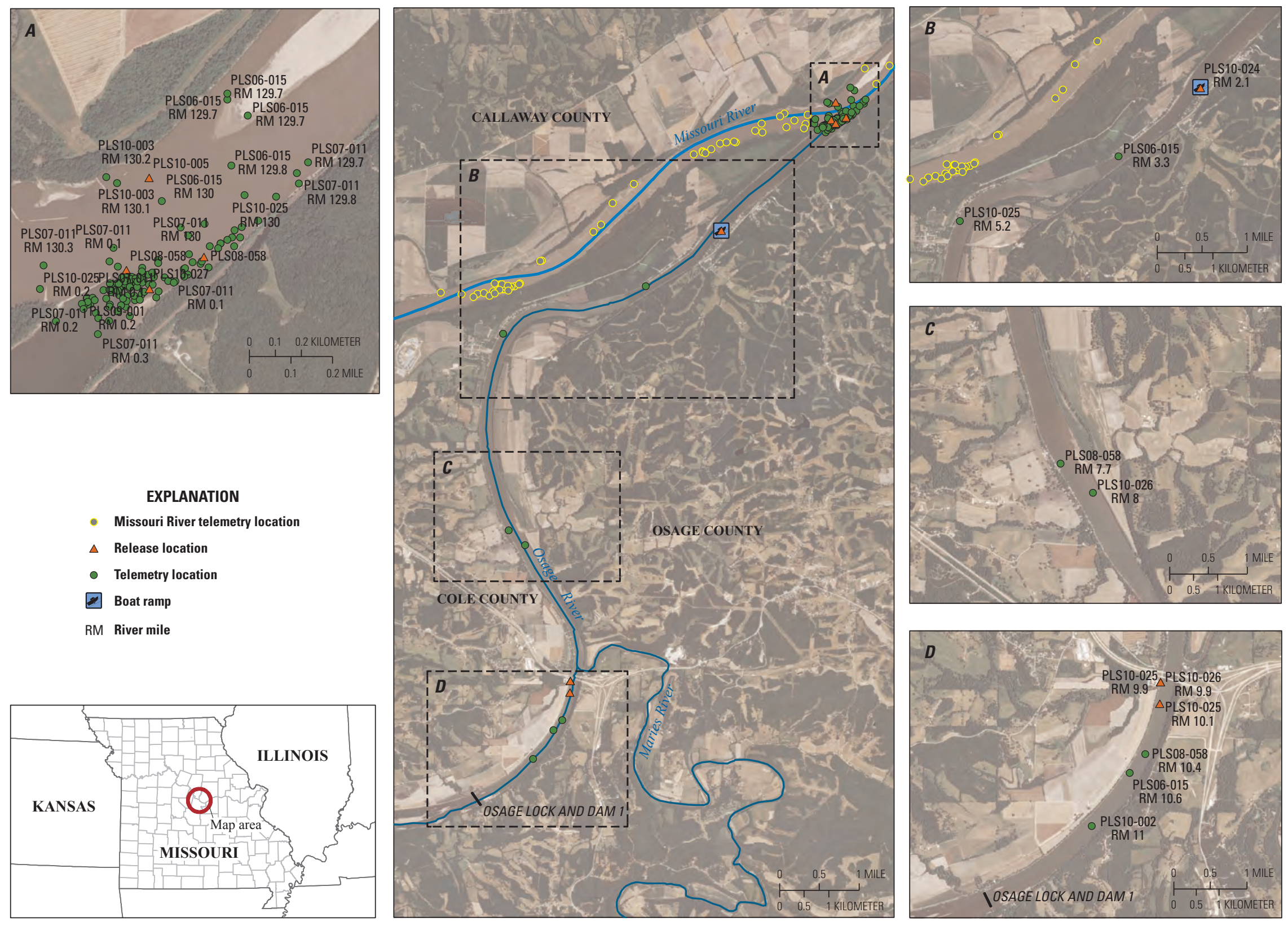

- Missouri River telemetry location

$\Delta$ Release location

- Telemetry location

Boat ramp

RM River mile

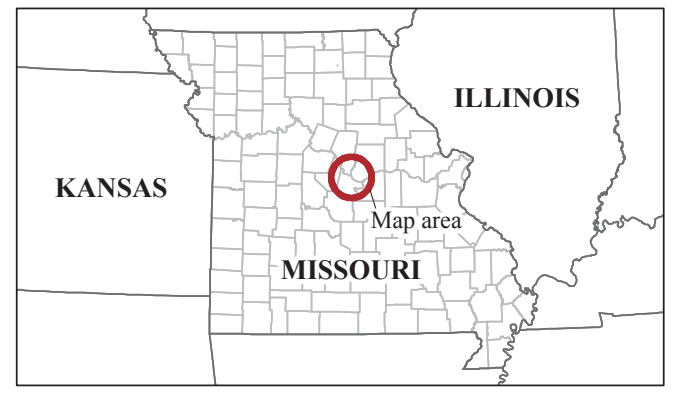

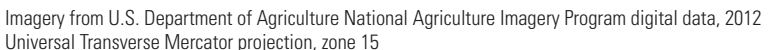

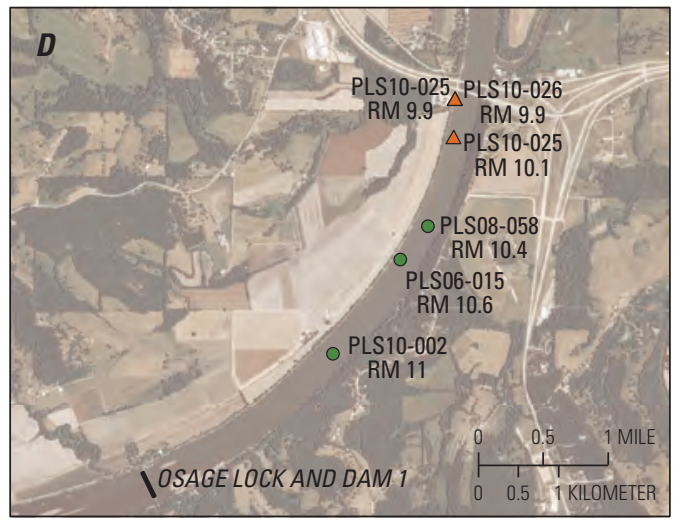

Figure 45. Telemetry locations of pallid sturgeon in the 0sage River and at the confluence of the Osage and Missouri Rivers, Missouri. Locations of 13 individuals 6 males and 7 females) were recorded during 28 search attempts in 2010-12. 

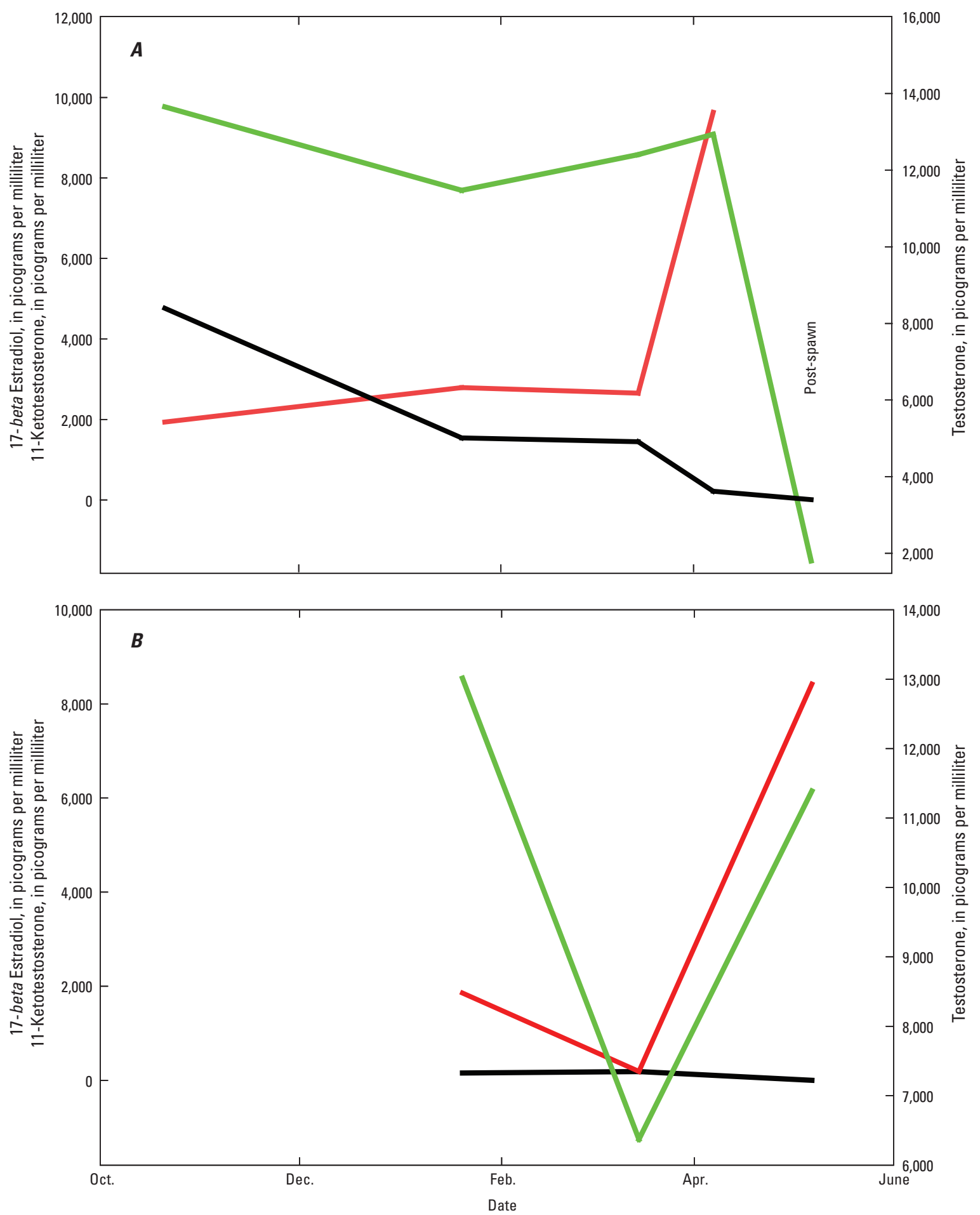

EXPLANATION

17-beta Estradiol

11-Ketotestosterone

Testosterone

Figure 46. Concentrations of reproductive hormones in $A$, a single female and $B$, male pallid sturgeon from the Lower Missouri River held at Neosho National Fish Hatchery. Female ovulated normally and male produced milt normally. Data are from samples collected in 2009 and 2010. 

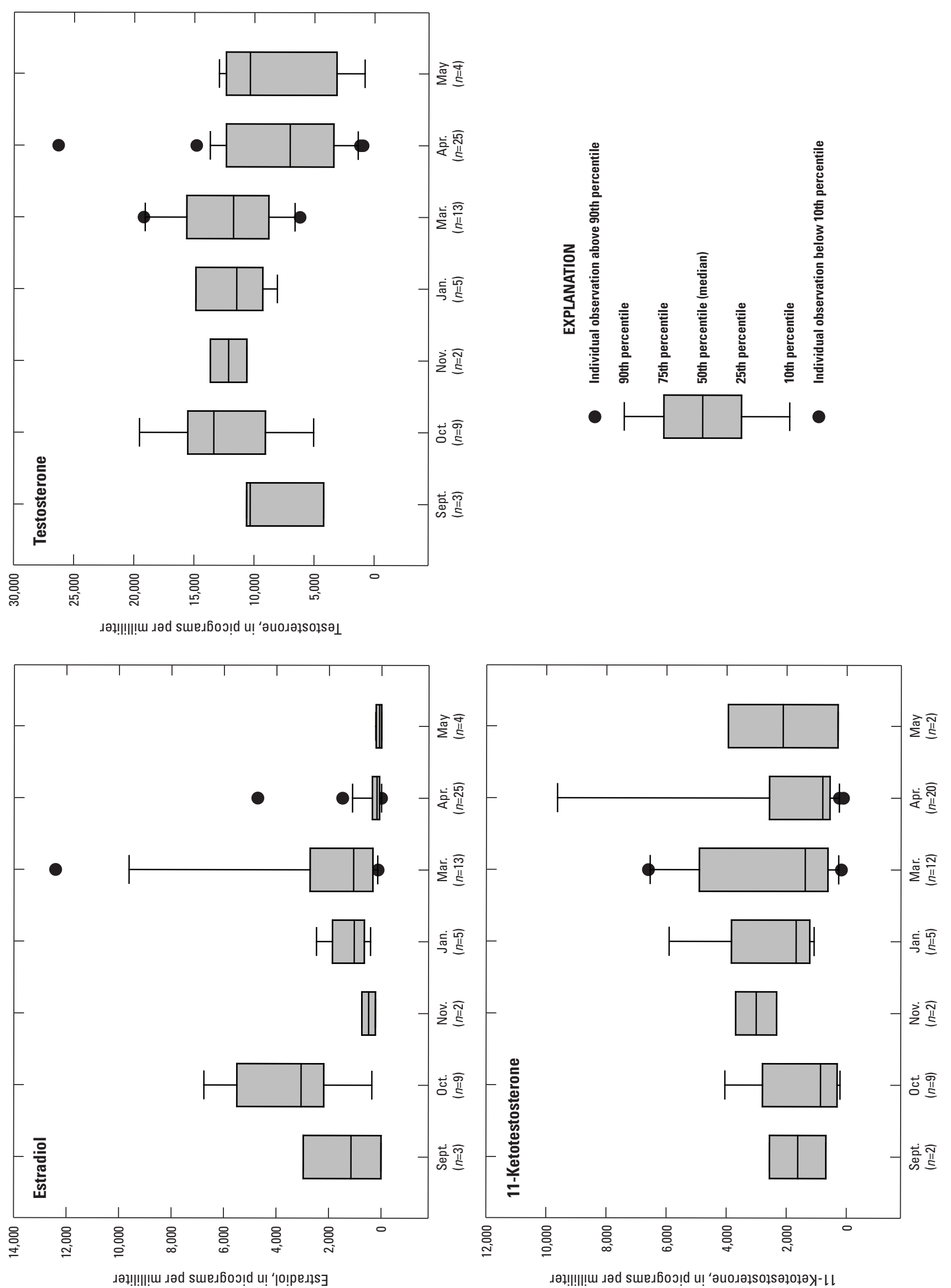

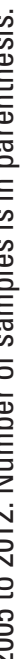




\section{Ecological Requirements for Pallid Sturgeon Reproduction and Recruitment in the Missouri River-2005 to 2012}

pattern could be obtained from one captive male (fig. 46), and a slightly more complete annual pattern obtained from a male pallid sturgeon from the Lower Missouri River (albeit missing data from the fall before spawning) revealed similar patterns (fig. 48). Both patterns are consistent with low and decreasing concentrations of estradiol and low levels of the androgens that increase as the fish approaches spawning.

The general pattern of hormonal changes that occurs in nonreproductive pallid sturgeon from October to April was obtained by repeatedly collecting plasma from many individuals held for several months at Neosho National Fish Hatchery. Immediately after spawning, all hormones are either declining or at their lowest concentrations in both sexes. During the several months before the next spawning, estradiol and testosterone in females, and testosterone and 11-ketotestosterone in males increase (fig. 49). Monthly hormonal concentrations measured in pallid sturgeon sampled upon capture from the Lower Missouri River follow similar trends. However, field data indicate seasonal fluctuations and the higher monthly variability reflects the differences in degree of gonadal development (recrudescence) among nonreproductive fish (fig. 50, fig. 51).

Twenty female pallid sturgeon, tracked during all or a portion of their reproductive cycle, were subsequently recaptured and assessed for evidence of spawning at some date after expected spawning. Of these, only two individuals were classified as not having spawned; the ovaries of these two females were at varying stages of oocyte follicle resorption. Hormonal patterns of hatchery-held pallid sturgeon that did not ovulate after induction or that had identifiable oocyte atresia differed from similar fish that successfully ovulated (fig. 52). Females that did not ovulate displayed a steep drop in testosterone months before the projected spawning date followed by an increase in testosterone closer to the expected spawning date (fig. 52). Females with atretic oocytes appeared to experience an earlier decline in testosterone and a delay in the increase of 11-ketotestosterone (fig. 52).

Reproductive readiness in our tracking studies has been determined using the polarization index (PI) and results of the progesterone assay (DeLonay and others, 2009). Polarization data have been collected for 95 pallid sturgeon since 2005; however, data were sufficient to evaluate annual temporal trends only for 2010, 2011, and 2013 (fig. 53). Previously, using shovelnose sturgeon, we have determined that water temperature more closely associates with reproductive readiness than discharge parameters, for example total discharge, timing of peaks, and rate of change (DeLonay and others, 2009; Papoulias and others, 2011). This relation continues to be supported by the pallid sturgeon data (fig. 54, fig. 55).

\section{Contaminants in Reproductive Ecology of Pallid Sturgeon}

Chemical contamination of the Missouri River has been identified as a potential threat to the reproductive success of adult pallid sturgeon and the survival of early life stages. Longevity, high lipid content, use of benthic habitat, piscivorous feeding behavior, and multiyear reproductive cycles are characteristics that make the pallid sturgeon particularly vulnerable to some contaminants. Health departments of the states bordering the Missouri River regularly analyze fishes from the Missouri River and its tributaries for chemicals that bioaccumulate in fish tissues in order to protect people from consuming contaminated flesh and eggs. Concentrations of chlordane, DDT, and mercury have decreased for the last two decades, as expected for these legacy chemicals, following similar trends for these compounds nationally (U.S. Environmental Protection Agency, 2013). Few additional studies have measured contaminants in Missouri River water, sediments, and biota; even fewer studies have been done to determine whether legacy chemicals or modern, less persistent chemicals, are affecting the health of Missouri River fish populations.

Ruelle and Keenlyne (1993) first presented data indicating that pallid sturgeon had elevated levels of heavy metals, PCBs, and some banned pesticides, yet few pallid sturgeon tissues have been examined recently (2015) because of the rarity of the fish. However, analysis of shovelnose sturgeon tissues in the intervening years provides an important record from which pallid sturgeon exposure can be inferred. The trends for the Lower Missouri River and generally throughout the range of the pallid sturgeon indicate that older industrial chemicals and pesticides such as polychlorinated biphenyls (PCBs), dioxins, chlordane, DDT, and metabolites have decreased. However, some contaminants remain at elevated concentrations at specific locations (Mike Mckee, Missouri Department of Conservation, oral commun., 2014; Blevins, 2011) reflecting the decline in water and sediment concentrations (Coffey and others, 2000; Petty and others, 2004; Echols and others, 2008; Blevins, 2011). Nevertheless, the biological and ecological characteristics of pallid sturgeon (benthic, piscivorous, long-lived, multiyear reproductive cycles) increase their chances of exposure even to low concentrations of these legacy compounds that easily bioaccumulate in lipid-rich tissues of the sturgeon. Effects on eggs and early life stages of offspring by way of maternal exposure are likely more a cause for concern for the legacy chemicals than direct effects on adult pallid sturgeon as Buckler (2011b) demonstrated.

Contemporary contaminants of greatest concern for affecting health of pallid sturgeon include the flame retardants (for example, PBDEs, polybrominated diphenyl ethers), hormonally active compounds reported in wastewaters, and the high-volume use pesticides such as glyphosate and atrazine. These chemicals and others, collectively referred to as endocrine disrupting chemicals (EDCs), have known effects on the vertebrate endocrine system that lead to effects on reproduction, growth, and behavior (Mills and Chichester, 2005). Except for the PBDEs, endocrine disruptors do not readily bioaccumulate in tissue and have shorter environmental half-lives making them more difficult to measure in water, sediment, and tissue. Exposure to EDCs, therefore, is commonly evaluated based on bioindicators. Bioindicators for fish, including the 

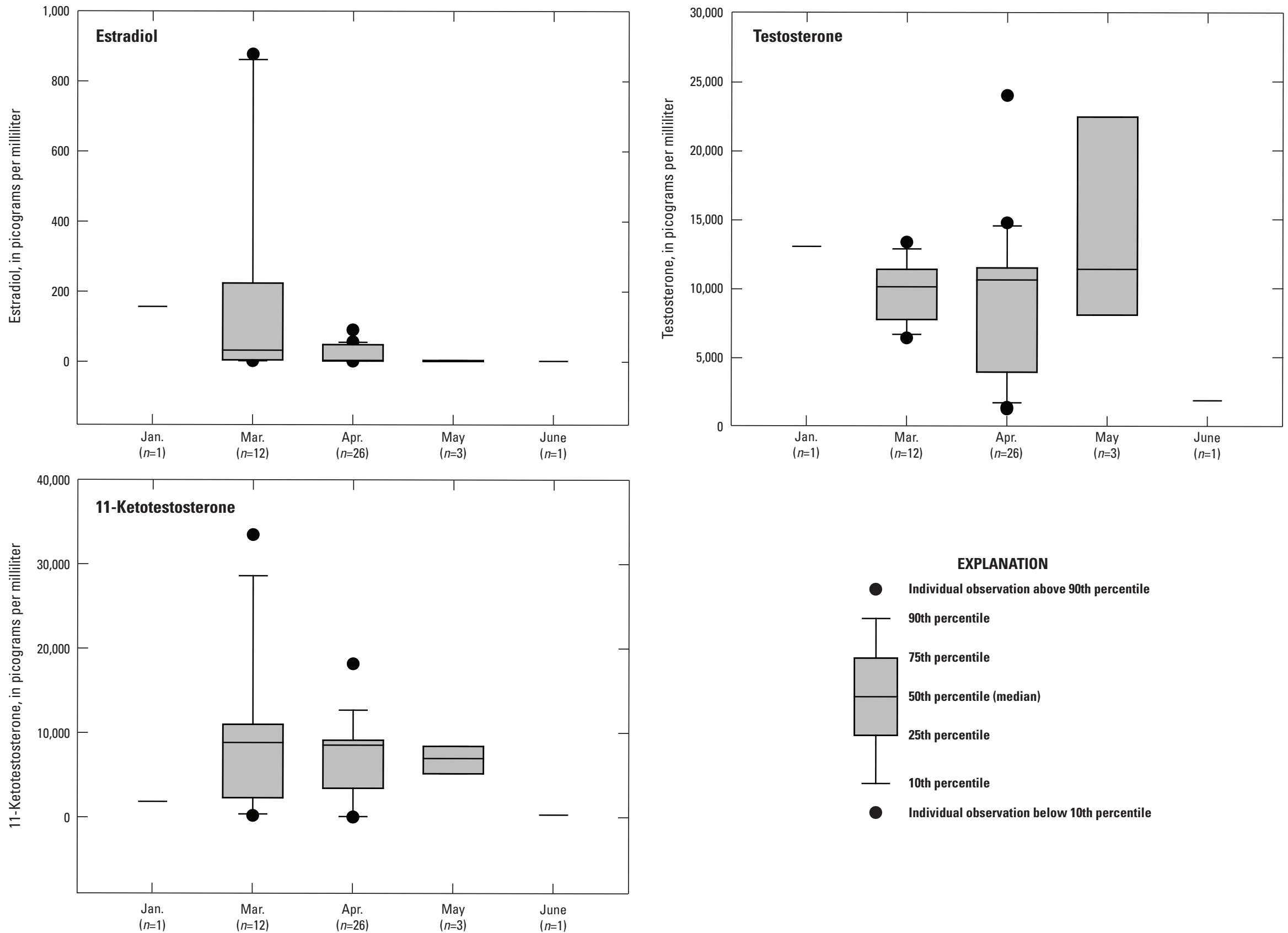

\section{EXPLANATION}

- Individual observation above 90th percentile

T 90th percentile

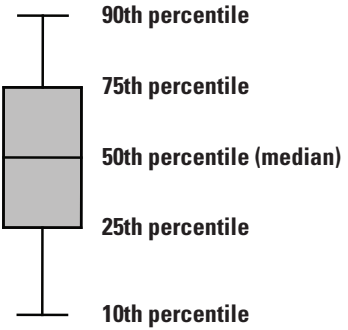

- Individual observation below 10th percentile

Figure 48. Annual changes in estradiol, testosterone, and 11-ketotestosterone measured in reproductive male pallid sturgeon captured in the Lower Missouri River from 2005 to 2012. Number of samples is in parenthesis. 

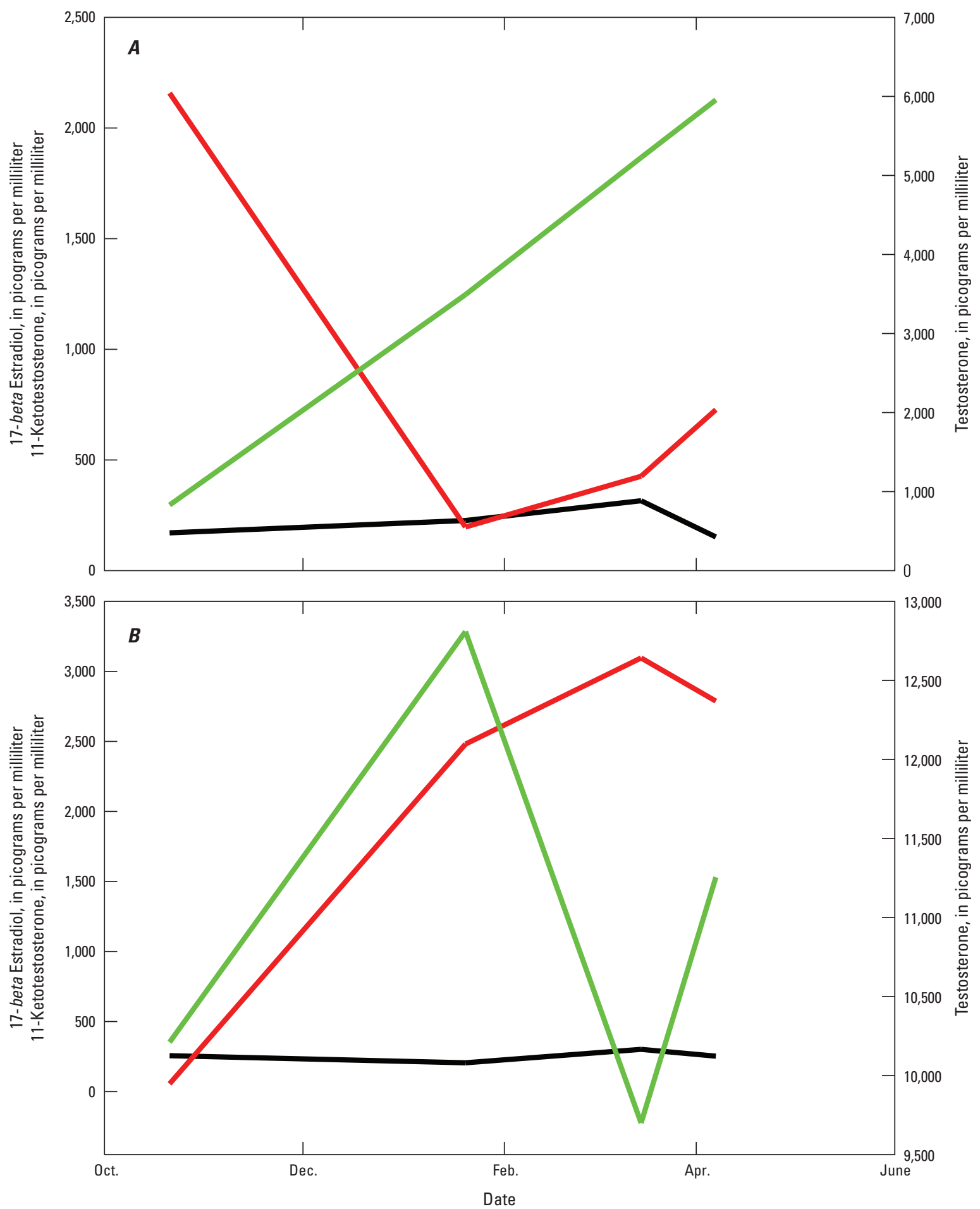

EXPLANATION

17-beta Estradiol

11-Ketotestosterone

Testosterone

Figure 49. Mean reproductive hormone concentrations in $A$, noncycling adult female and $B$, male pallid sturgeon held at Neosho National Fish Hatchery. Data are from samples collected in 2009 and 2010. 

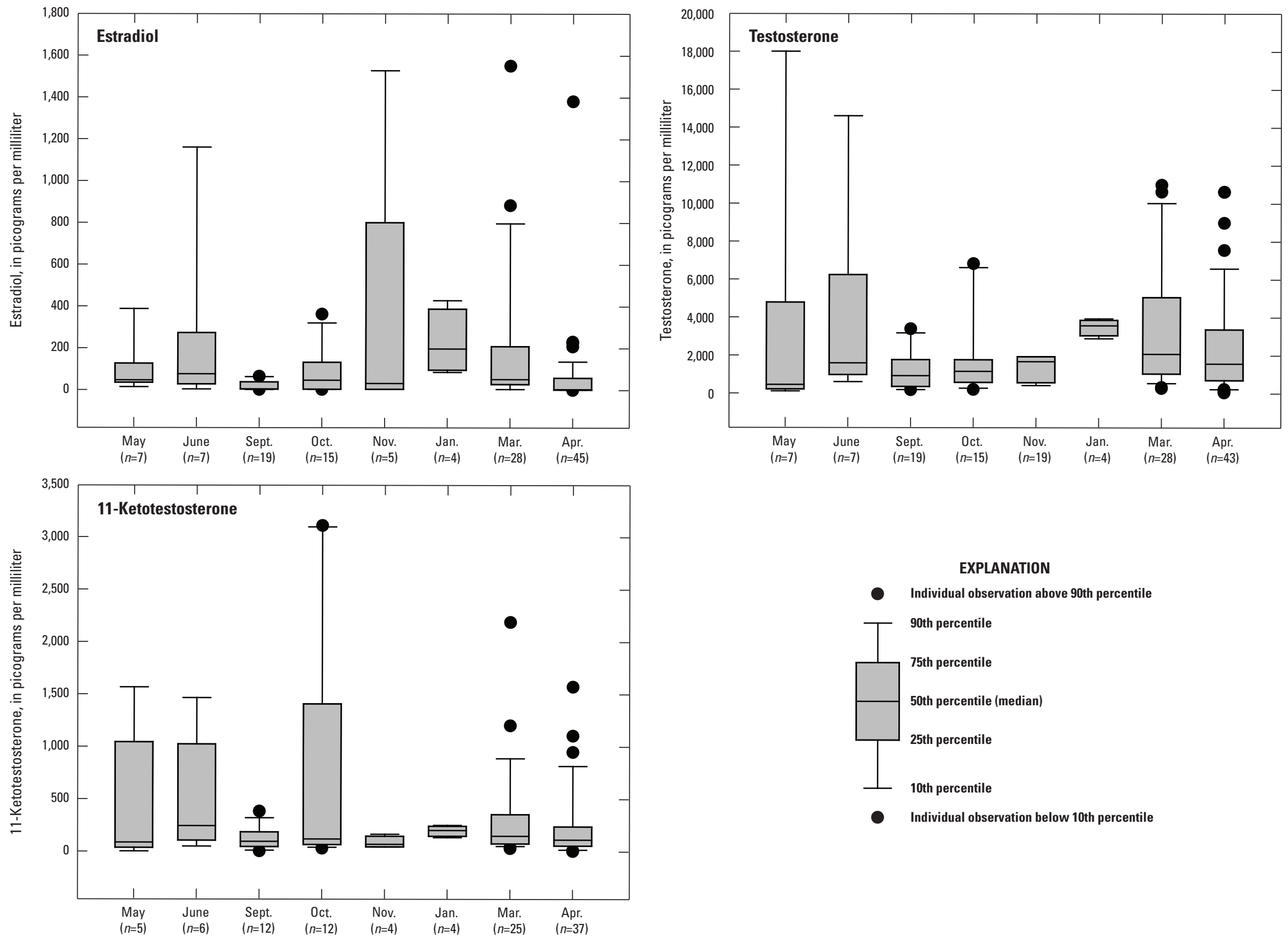

Figure 50. Annual changes in estradiol, testosterone, and 11-ketotestosterone measured in nonreproductive female pallid sturgeon captured in the Lower Missouri River from 2005 to 2012. Number of samples is in parenthesis. 

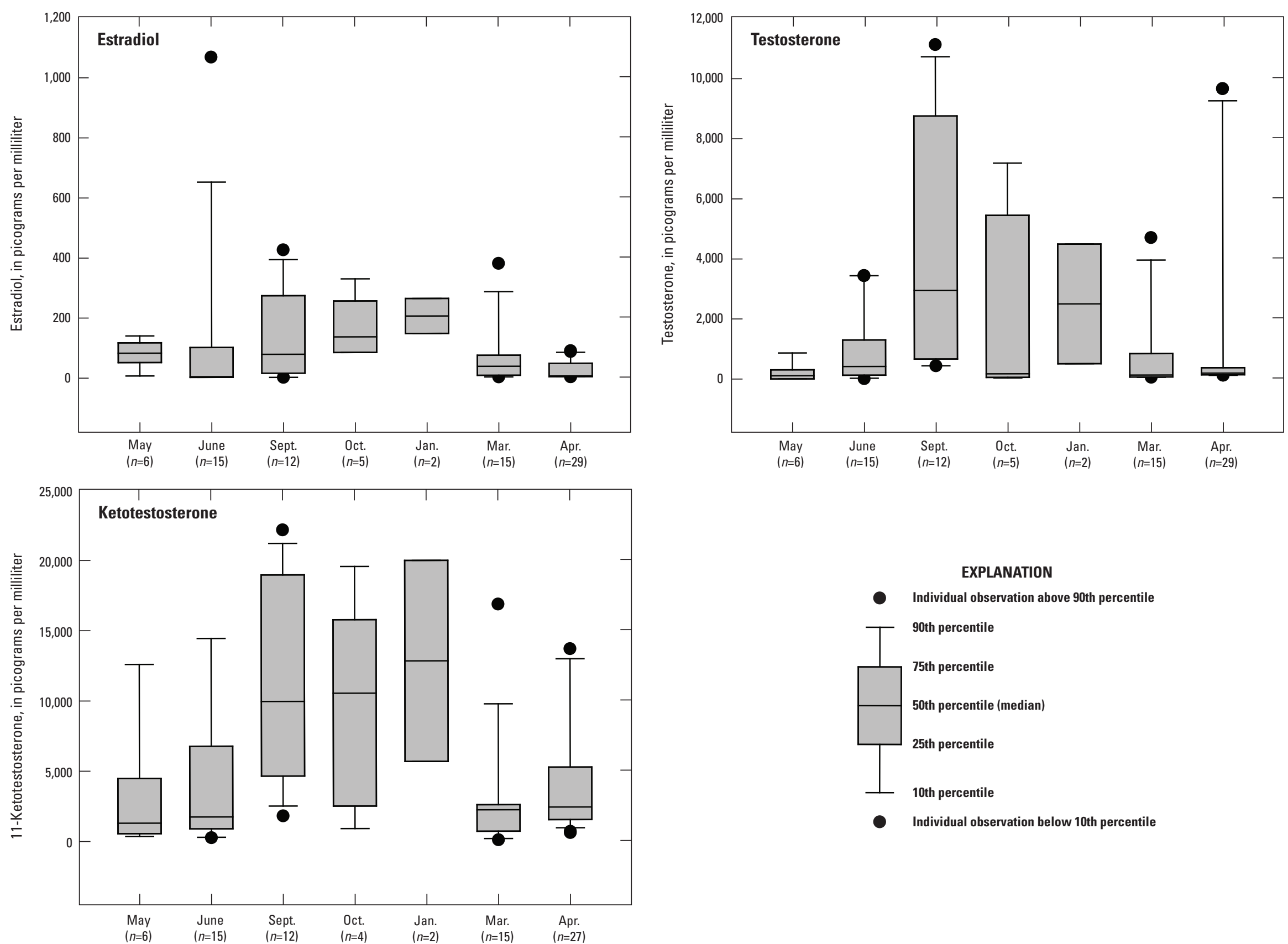

\section{EXPLANATION}

- Individual observation above 90th percentile

T 90th percentile

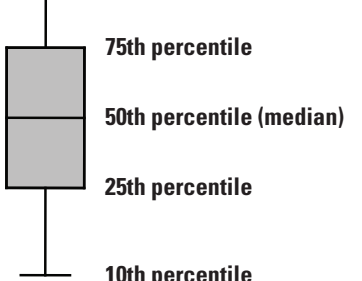

- Individual observation below 10th percentile

Figure 51. Annual changes in estradiol, testosterone, and 11-ketotestosterone measured in nonreproductive male pallid sturgeon captured in the Lower Missouri River from 2005 to 2012. Number of samples is in parenthesis. 

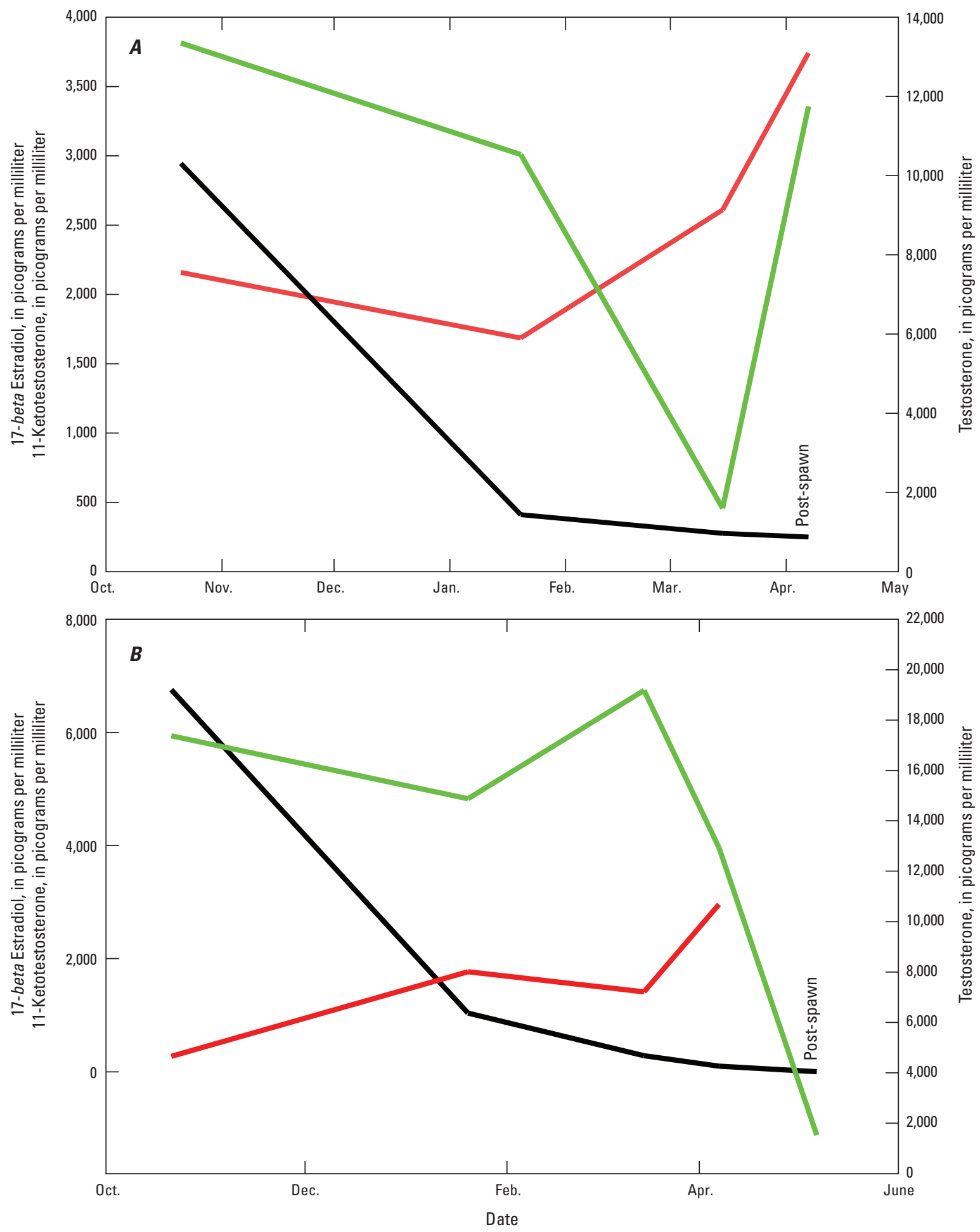

EXPLANATION

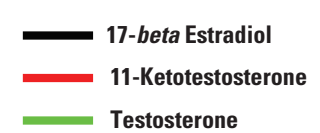

Figure 52. Concentrations of reproductive hormones in $A$, a non-ovulating and $B$, an atretic female pallid sturgeon from the Missouri River, held at the Neosho National Fish Hatchery. Data are from samples collected in 2009 and 2010. 

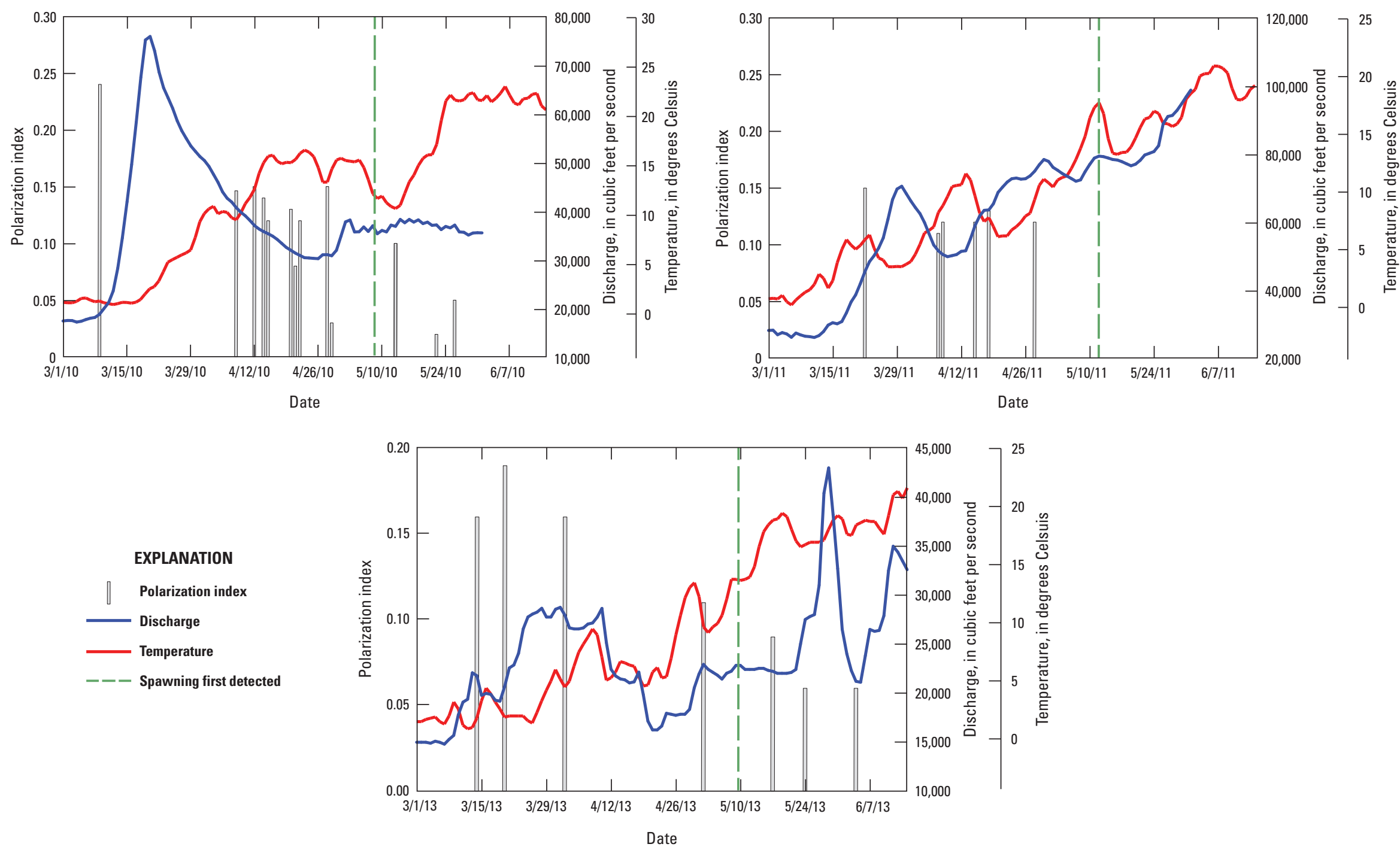

Figure 53. Relation between reproductive readiness in female pallid sturgeon from the Missouri River, hydrograph, and temperature for 3 years 2010, $2011,2013$.

Reproductive readiness is indicated by the polarization index (PI). A lower PI value indicates the fish is closer to spawning. Discharge and temperature from data collected at the U.S. Geological Survey streamgage at Decatur, Nebraska. 


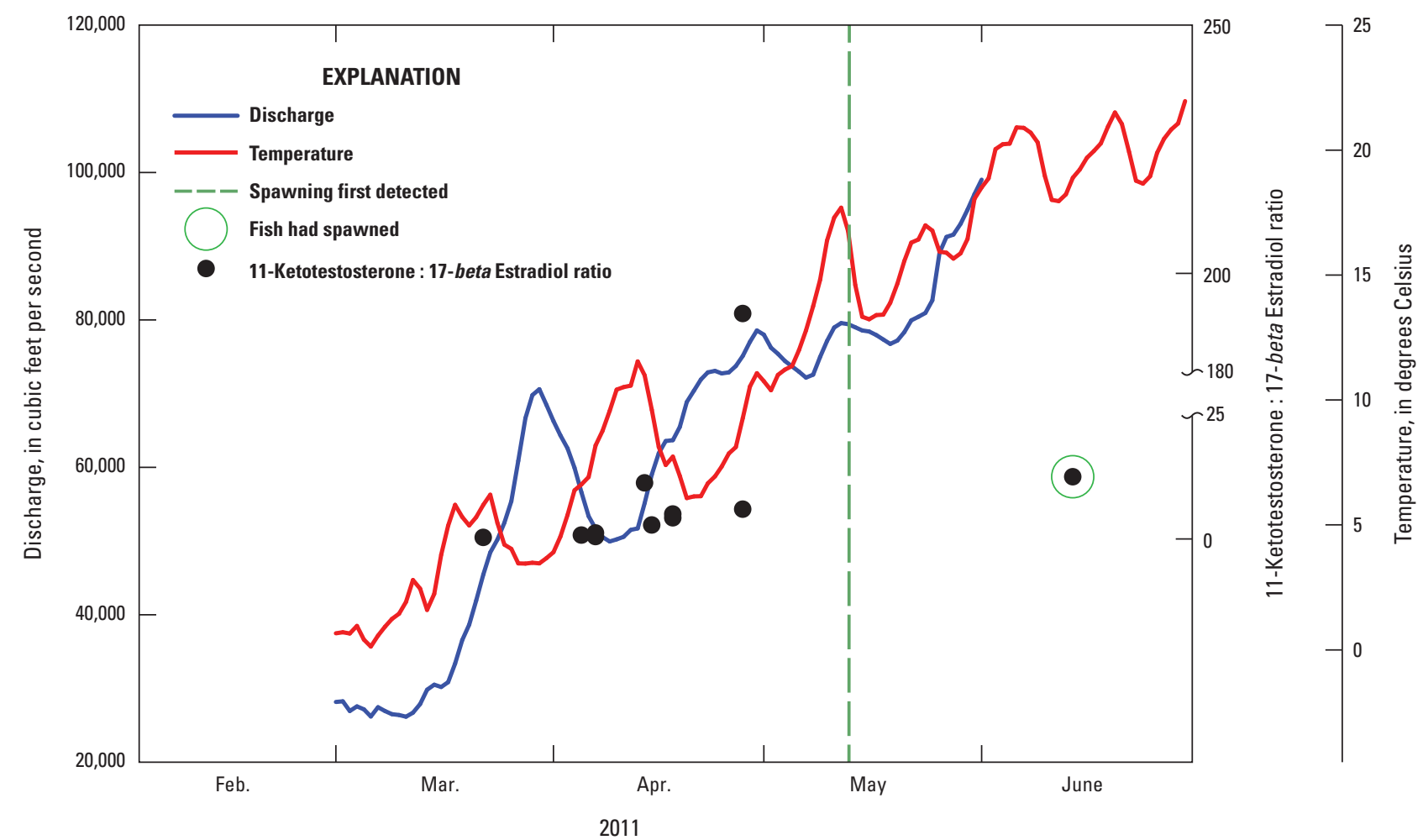

Figure 54. Readiness to spawn in female Missouri River pallid sturgeon, as the ratio of 11-ketotestosterone:17-beta estradiol (11KT:E2), to discharge and temperature in 2011. Discharge and temperature from data collected at the USGS Decatur, Nebraska streamgage.

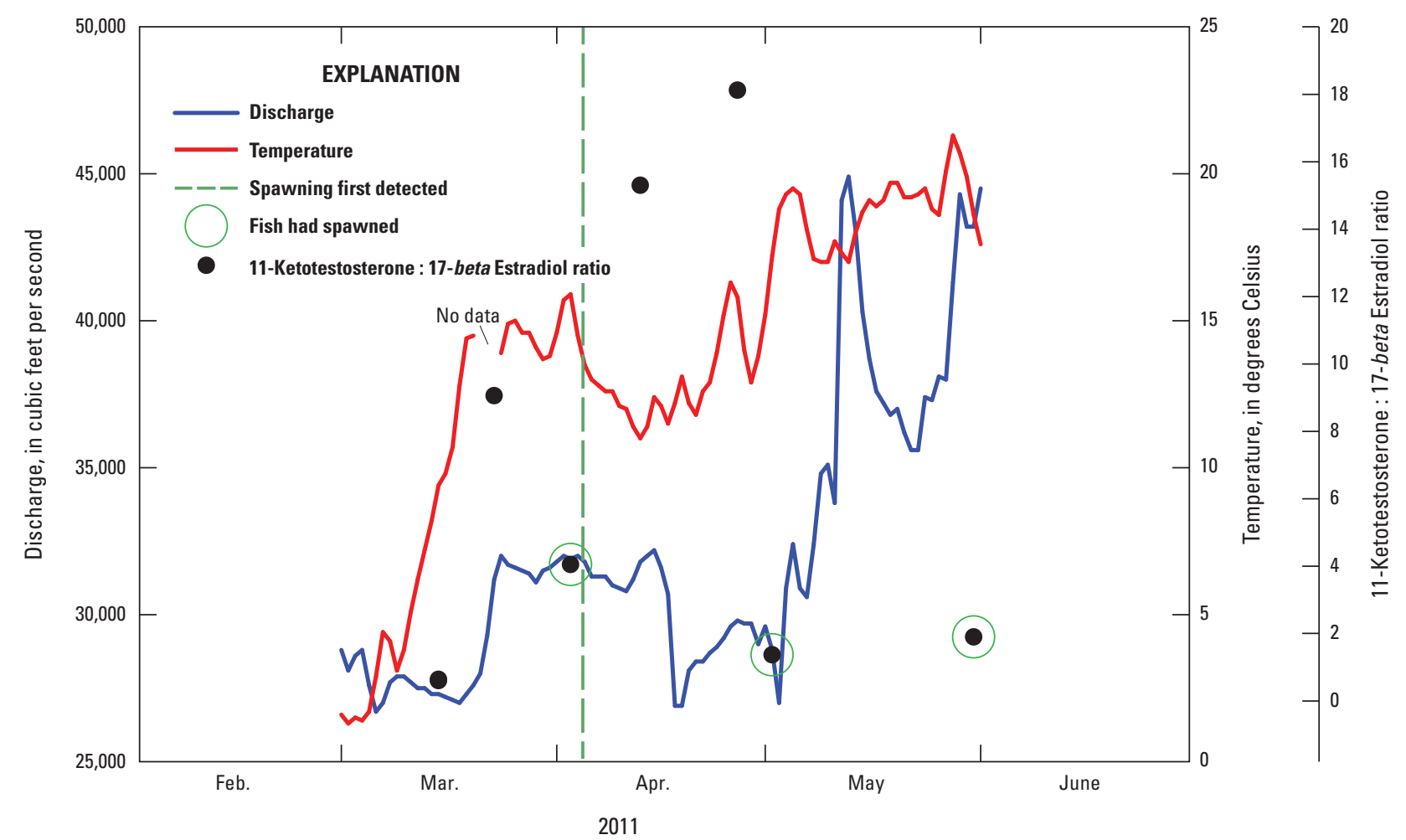

Figure 55. Readiness to spawn in female Missouri River pallid sturgeon, as the ratio of 11-ketotestosterone:17-beta estradiol (11KT:E2), to discharge and temperature in 2012. Discharge and temperature from data collected at the USGS Decatur, Nebraska streamgage. 
pallid and shovelnose sturgeon, in the Lower Missouri River and the Mississippi River and their tributaries consist of measuring vitellogenin in immature and male fish and identifying animals with intersex gonads and males with abnormal plasma estrogen:androgen levels (Harshbarger and others, 2000; Papoulias and others, 2003; Koch and others, 2006; Papoulias and others, 2006; Schwarz and others, 2006; Colombo and others, 2007; Papoulias and others, 2009b). The study of pallid sturgeon reproductive behavior and response to the contemporary Missouri River flow regime also has provided an opportunity to evaluate plasma hormone concentrations and to examine gonad development (Wildhaber and others, 2005; Papoulias and others, 2009b). However, no controlled laboratory studies that investigate the links between exposure to endocrine disruptors and effects, in particular population-level effects, on pallid and shovelnose sturgeon exist.

Biomarkers measured to evaluate exposure to estrogenic chemicals typically include vitellogenin protein, plasma estrogen:testosterone ratio, and the presence of intersex gonads. Current evidence for endocrine disruption affecting pallid sturgeon rests on the incidence and severity of intersex gonads found in this species and closely related shovelnose sturgeon. Vitellogenin, a yolk protein precursor, is typically elevated in male and juvenile fish exposed to estrogens (Miller and others, 2007). Vitellogenin levels in male pallid sturgeon from the Missouri River are in the normal range and are three to four orders of magnitude lower than females (fig. 56). Estrogen:androgen ratios also measure within the normal range for males (data not shown) and there is only slight evidence of lowered sperm quality in fish captured from the river compared with hatchery-captive fish (table 9). Nevertheless, intersex gonads have been identified in two pallid sturgeon and occurs at a rate as high as 24 percent in male shovelnose sturgeon in some locations in the Lower Missouri River (Papoulias and others, 2007; Papoulias and others, 2009a). The detected incidence of intersex in pallid sturgeon is necessarily low because few animals are opened and examined. Additional gonadal abnormalities have been observed for pallid and shovelnose sturgeon including testicular dysgenesis and teratomas ( 2 in shovelnose sturgeon and 1 in pallid sturgeon), but only the former is a known estrogenic effect.

\section{Population Augmentation}

Evidence indicates that hatchery-origin pallid sturgeon are surviving, growing, reaching sexual maturity, and spawning in the Lower Missouri River (DeLonay and others, 2009). In all study sections of the Missouri River, hatchery-origin pallid sturgeon will soon out-number wild adults in the population. To date the CSRP has recorded the spawning locations of six female hatchery-origin pallid sturgeon in the lower study section of the Lower Missouri River. No known hatcheryorigin pallid sturgeon have been documented spawning in the upper study section to date (2015). Although documentation of spawning of hatchery-origin individuals is an important

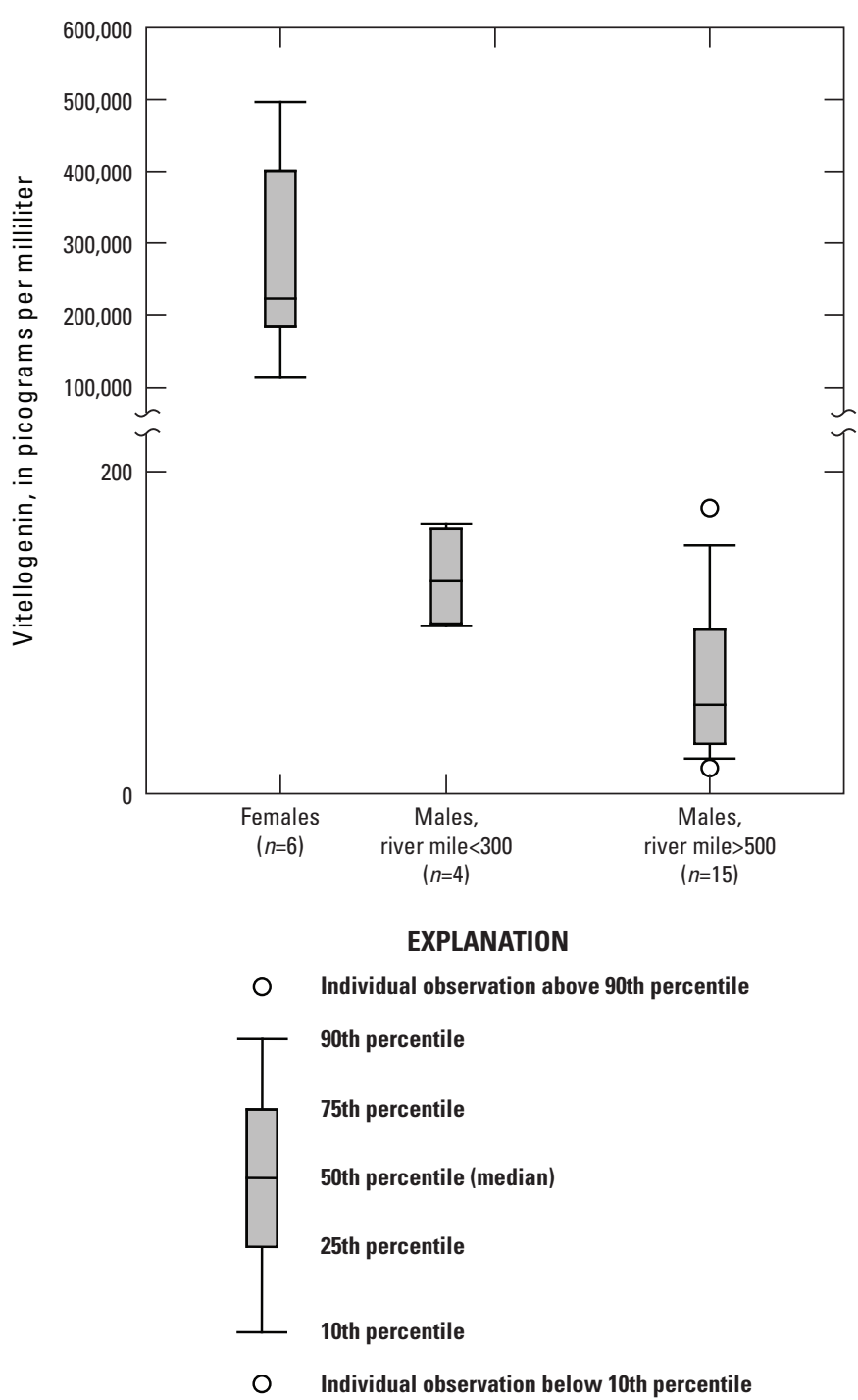

Figure 56. Plasma vitellogenin concentrations in male pallid sturgeon from below river mile 300 and above river mile 500 in the Missouri River compared to plasma vitellogenin in female pallid sturgeon. Samples were collected during 2012. Number of samples is in parenthesis.

measure of success for the pallid sturgeon recovery program, uncertainties remain about the viability of hatchery-origin individuals. It is unknown whether or not hatchery fish respond to the same environmental cues as wild fish and whether hatchery fish have similar spawning success, in terms of viable fertilized eggs and larvae. Studies of reproductive success of steelhead trout (Araki and others, 2007) and coho salmon (Theriault and others, 2011), for example, have concluded that hatcheryorigin progeny have lower reproductive success than their wild counterparts. Studies by Sloss and others (2009) documented evidence of hatchery-selection and a reduction of genetic diversity in paddlefish. More information is needed to evaluate the relative contribution of hatchery-origin pallid sturgeon to reproduction, recruitment, and population recovery in the Lower Missouri River. Additional movement and spawning 


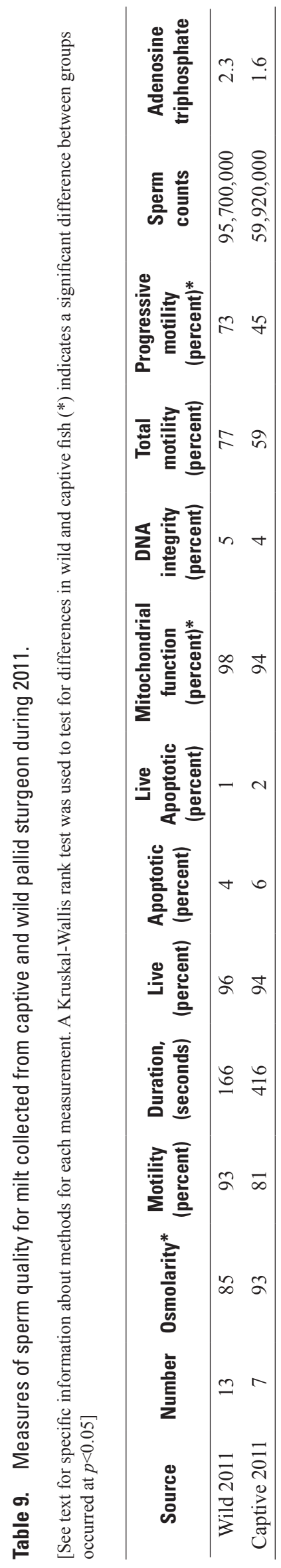

data for wild adult fish are needed to refine the understanding of the genetic population structure of pallid sturgeon (Schrey and Heist, 2007). Movement and spawning data for adult hatchery-origin pallid sturgeon may provide managers with information needed to balance the risk of population augmentation in the Missouri River to locally adapted populations in the Middle and Lower Mississippi River.

\section{Flow Regime Management}

Spawning migration data have not indicated consistent linkages to discharge conditions or flow pulses in the Lower Missouri River. Lack of clear linkages does not indicate that discharge is not an important variable for sturgeon reproduction, but it does indicate that discharge in the regulated Lower Missouri River does not exert an overwhelming control or may interact with other variables in complex ways (DeLonay and others, 2012). Migration patterns indicate linkages to watertemperature fluctuations that seem to fall into two categories (DeLonay and others, 2009; 2010b). The first is a temperature threshold for spawning at $16-18^{\circ} \mathrm{C}$. Water temperatures above this threshold seem to be necessary for spawning of pallid sturgeon, but temperature alone is insufficient to insure spawning because other requirements (for example, presence of mates, substrate, local flow conditions) may not be satisfied.

The other effect is a notable linkage between changes in water temperature and migration rate or direction (DeLonay and others, 2010). Sudden decline in water temperature during the generally increasing temperatures of the spring spawning season may delay or disrupt spawning migrations (DeLonay and others, 2009; 2010b; 2012a). The disrupted migration patterns of reproductively ready female pallid sturgeon may translate into reduced spawning success if eggs are not ovulated or are deposited in sub-optimal habitats under inappropriate environmental temperatures or flows.

On the Upper Missouri River, the Yellowstone River is significant in that it has an intact natural hydrograph with a natural turbidity regime. In most years, pallid sturgeon move up the Yellowstone River from the Missouri River in response to increasing temperatures and flows (Fuller and others, 2008; DeLonay and others, 2014). Annually the disproportionate percentage of adults using the Yellowstone River compared to the Missouri River above the confluence suggests that the pallid sturgeon either prefer the warmer, more turbid Yellowstone River or are avoiding the cooler, clearer Missouri River. During extreme flow events in 2011, pallid sturgeon use changed substantially, and a larger percentage of adults moved up the Missouri River below Fort Peck Dam (DeLonay and others, 2014). It is unclear what the relative role of discharge, temperature, or tributary flows from the Milk River may have played in 2011 that ultimately changed sturgeon distribution and resulted in the first documented successful spawning in the Missouri River. It is clear from study results that pallid sturgeon are capable of responding to environmental variables on the landscape and retain the flexibility to use spawning areas in both rivers when conditions are suitable. 


\section{Channel Re-Engineering}

There is potential for reproductive adult life stage processes to be affected by channel re-engineering that would improve spawning habitats or migration pathways. All spawning locations documented in Lower Missouri River study sections were on outside revetted bends, over or adjacent to coarse substrate and bedrock. Water depths were generally the deepest available in the reach with relatively fast and turbulent flow (DeLonay and others, 2009; 2010b; 2012a). These areas are relatively insensitive to changes in discharge (Jacobson and others, 2009b) and may be less sensitive to temperature variations than other areas with suitable coarse substrate but with shallow depth or away from the main flow of the river (DeLonay and others, 2010).

Most sturgeon species, including lake sturgeon, gulf sturgeon (Acipenser oxyrinchus desotoi), white sturgeon (Acipenser transmontanus), Chinese sturgeon (Acipenser sinensis), and Amur sturgeon (Acipenser schrenckii) spawn in rivers on a variety of generally hard substrates ranging from gravel mantled bedrock (Sulak and Clugston, 1998; Fox and others, 2000) to gravels, cobbles, and boulders (Parsley and others, 1993; Krykhtin and Svirskii, 1997; Perrin and others, 2003; Du and others, 2011), sand (Paragamian, 2012), and including artificial substrates such as cinders (Manny and Kennedy, 2002), wooden pilings, and artificial gravels (Bruch and Binkowski, 2002; Johnson and others, 2006b). On the channelized Lower Missouri River the bank slope on the outside of every bend has been covered in bank revetment made up primarily of angular limestone and dolomite boulders similar to those found at six pallid sturgeon spawning locations. Additional sources of hard substrate on the channelized Lower Missouri River occur in discontinuous patches including natural bedrock outcrops, natural gravel and cobble outcrops of glacial origin, deposits of re-worked engineered material, and in tributaries draining higher-relief terrain, such as the Ozark Plateau in Missouri (Laustrup and others, 2007). Bedrock exposures are densest in places along the Missouri River adjacent to bluffs, and particularly in regions with narrower valleys such as the lower 250 miles of the Missouri River in Missouri (Laustrup and others, 2007) (fig. 3).

The historic unchannelized Missouri River was a dynamic, braided, sand-bedded and shifting river system. Locations of persistent pre-channelization bedrock outcrops are unknown. However, there is a greater probability that coarse substrates occurred on the pre-channelization Missouri River in regions with narrow valleys, glacial deposits, and with coarse-bedded tributary inputs. Outside revetted bends are now a common habitat type in the channelized Missouri River (Laustrup and others, 2007) and may not be a limiting factor for spawning. Revetment is a relatively new addition to the Missouri River landscape. Consequently, revetted bends may be the best available spawning habitat, rather than optimal habitat. As such, research needs to address how well embryos deposited on revetted bends survive and hatch (DeLonay and others, 2012).
Comparative observations in the Yellowstone River indicate that more natural spawning habitat may consist of patches of gravel on relatively flat slopes in the center of the channel and surrounded by actively transporting sand dunes. If subsequent research confirms that the Yellowstone River sites provide greater spawning success than Lower Missouri River spawning sites, measurements of Yellowstone River spawning sites may provide useful design parameters for restoring spawning habitat in the Lower Missouri River. Possibly, fewer high-quality habitat sites would serve to attract pallid sturgeon away from abundant, less productive revetment sites and result in a net increase in spawning success. However, much needs to be known about the relation between arrangement of spawning habitat and free-embryo dispersal and recruitment success.

Migration pathways could be managed to decrease energy expenditures in upstream migrations by re-engineering the channel to increase areas of slower velocity. Present (2015) information, however, does not indicate that upstream migration by adult pallid sturgeon is substantially impeded. In the more natural channel segments in the Yellowstone River and the upper segment of the Lower Missouri River, migrating adults use available depths and velocities in nearly the same proportion that they are available, showing little selection. In the lower segment of the Lower Missouri River, migrating adults clearly avoid the fastest and deepest parts of the navigation channel, yet they select pathways with velocities similar to those used on the Yellowstone River and that minimize total energy expenditure (McElroy and others, 2012). Therefore, although these observations indicate that the channelization has diminished some pathways, reproductive sturgeon can still find functional pathways within the channel as presently (2015) engineered.

\section{Embryo Life Stage}

An embryo is a developing fish still within the chorion (egg membrane). The embryo life stage lasts from fertilization to hatch, usually about 5-8 days, depending on temperature. Because of the embryo's small size and the location of their habitat at substantial depth in the Missouri River, most of what is known about habitat requirements is extrapolated from laboratory measurements.

\section{Habitat Requirements for Embryos}

Water hardened pallid sturgeon embryos are approximately $3.0 \mathrm{~mm}$ in diameter and weigh $16 \mathrm{mg}$. Naturally spawned pallid sturgeon eggs become sticky or adhesive 1 to 3 minutes after fertilization (Dettlaff and others, 1993) and presumably fall through the water column to affix to a solid substrate such as rock. Experiments in 2010 (DeLonay and others, 2012) indicated that adhesive embryos falling at an average rate of $1.98 \mathrm{~m} / \mathrm{sec}$ through $2.4 \mathrm{~m}$ of water under turbid conditions (97-689 Nephelometric Turbidity Units, 
NTUs) did not adhere to substrate at the bottom of the water column because fine silt particles had coated the embryos during their descent. In contrast, embryos that fell through clear water did adhere. Qualitative observations indicated that eggs lost their ability to adhere within 0.3 to $0.6 \mathrm{~m}$ below the surface after release into the turbid water suggesting that pallid sturgeon females must ovulate in close proximity to the substrate if embryos are to attach and develop while adhered to a solid substrate. Turbidity on the Lower Missouri River has decreased considerably from pre-dam levels (Blevins, 2006) and has been reported to vary within 2 to 3 orders of magnitude with increasing discharge (Blevins, 2011). Turbidity measurements near two spawning sites during spawning activity on the lower Missouri River were high, but not excessively high (210-390 and 50-68 NTUs) given the magnitude of historic measurements and the variability in turbidity seen in the contemporary river (2015) (Blevins, 2006) (fig. 26, table 7). The relative importance of turbidity for the deposition, fertilization and hatch of pallid sturgeon embryos is unknown.

Observations of hatching pallid embryos in an artificial stream at the Columbia Environmental Research Center (CERC) in 2012 indicated that the embryo is very active as hatching nears. The chorion became thinner over several hours as enzymes released from the embryo's hatching gland softened the chorion membrane (Dettlaff and others, 1993). In the CERC 2012 experiments, adherent embryos were manually placed on a rock cobble substrate arranged in a simple monolayer formation. When the embryo broke out of the chorion, the moving water forced it to the bottom of the tank where it was swept away and into the current.

Fertilization rate, time to hatch, and percent of embryos that hatch are known only from laboratory studies and hatchery propagation efforts. Four pallid sturgeon have been spawned at the CERC using hormone induction followed by hand stripping of ovulated eggs. Fertilization rates for these fish ranged from 91 percent to 98 percent, with a mean and median of 94 percent. In comparison, 29 shovelnose sturgeon have been spawned with fertilization rates ranging from 44 percent to 98 percent, mean $=83$ percent, median $=85$ percent, and mode $=92$ percent. Development times did not differ substantially between species. A general guide compiled from embryo development and hatch times from both sturgeon species reared at five temperatures in studies at the CERC are reported in table 10. As temperature increases, development accelerates and time to hatch is reduced. Webb and others (2007) documented a similar trend with increasing temperatures; however, time to various developmental milestones in their studies was slightly shorter, albeit time to hatching was slightly longer, than in trials done at similar temperatures in CERC studies. Hatching generally occurs over 2 days. Percent hatch of pallid sturgeon embryos at the CERC ranged from 80-90 percent at approximately $18{ }^{\circ} \mathrm{C}$ (Buckler, 2011). Webb and others (2007) reported similar rates of hatch success between 16 and $20^{\circ} \mathrm{C}$, whereas at $24^{\circ} \mathrm{C}$ hatch was significantly less but still greater than 75 percent.
Six probable spawning locations mapped with high-resolution multibeam and sidescan sonar on the Lower Missouri River were on or near bank revetment on the outside bend of the channel near the thalweg with depths ranging from 2.2 to $10.6 \mathrm{~m}$ and mean water-column velocities ranging from 0.49 to $2.36 \mathrm{~m} / \mathrm{s}$ (fig. 40 , table 7 ). The availability of clean spawning substrate (suitable for egg adhesion) and the amount of interstitial spaces between rocks in bank revetment are unknown. Probable pallid sturgeon spawning also has been documented in two locations on or adjacent to natural dolomite bedrock outcrops on the Missouri River (fig. 7, table 7). Bedrock at these sites is exposed on the channel banks, as well as at depth, and has a rough topography with 0.3 to $1 \mathrm{~m}$ of relief that may indicate gravel deposits or bedrock knobs on the bed of the river. Due to the logistical and safety challenges of working in deep, fast, and muddy water, direct observations of spawning substrate and embryo release during a spawning event have not been made, and embryos have not been collected from the field. A probable spawning site on the Yellowstone River near RM 4 to 7 (Fuller and others, 2008) presents an opportunity to evaluate spawning habitat in a less-altered system; however, spawning substrates at this site have not yet been directly measured. Preliminary analysis of sidescan sonar imagery indicates that this site is likely composed of mixed gravel, cobble, and sand.

Predation has been demonstrated to occur on white sturgeon embryos on the Columbia River (Miller and Beckman, 1996), Chinese sturgeon embryos on the Yangtze River in China (Yu and others, 2002; Zhang and others, 2011) and is a common fate for lake sturgeon embryos (Caroffino and others, 2010b). Although many species of fish native to the Missouri and Yellowstone Rivers eat embryos, it is unknown whether predation is a threat to pallid sturgeon embryos and the pallid sturgeon populations on the Missouri and Yellowstone Rivers. Interstitial spaces and high turbidity may provide cover for embryos from opportunistic feeders, and the high velocities and deep water near assumed embryo deposition sites on bank revetment and bedrock on the Lower Missouri River may present a difficult environment for some predator fish to feed.

\section{Flow Regime Management}

It has been hypothesized that one of the functions of spring pulses on the Missouri River was to "condition" spawning substrate by cleaning it of fine sediment to allow embryos to adhere (U.S. Fish and Wildlife Service, 2003; Jacobson and Galat, 2008). Sediment transport and substantial channel change occur on the Lower Missouri River for a wide range of discharges including managed and natural flow events (Elliott and others, 2009). Flow pulses on the scale of the spring rises that occurred on the Missouri River in 2006 are capable of transporting sediment and flushing fine sediment from spawning substrate where hard substrates occur on the bed of the river (Elliott and others, 2009). Documented 
Table 10. Minimum and maximum hourly thermal units for Scaphirhynchus sturgeon egg development and minimum and maximum hours to completion of each stage for 18-22 degrees Celsius.

[Hourly thermal units is a measure designed to approximate the relation between temperature and developmental time. Red numbers are extrapolated, no data were collected for these stages. HTU, hourly thermal units; ${ }^{\circ} \mathrm{C}$, degrees Celsius; Min, minimum; Max, maximum; >, greater than]

\begin{tabular}{|c|c|c|c|c|c|c|c|c|c|c|c|c|c|c|}
\hline \multirow{3}{*}{ Stage $^{1}$} & \multirow{3}{*}{ Description } & & & & \multicolumn{10}{|c|}{ Hours to completion } \\
\hline & & \multicolumn{3}{|c|}{ HTU } & \multicolumn{2}{|c|}{$18^{\circ} \mathrm{C}$} & \multicolumn{2}{|c|}{$19^{\circ} \mathrm{C}$} & \multicolumn{2}{|c|}{$20^{\circ} \mathrm{C}$} & \multicolumn{2}{|c|}{$21^{\circ} \mathrm{C}$} & \multicolumn{2}{|c|}{$22^{\circ} \mathrm{C}$} \\
\hline & & Mean & Min & Max & Min & Max & Min & Max & Min & Max & Min & Max & Min & Max \\
\hline 0 & Start of fertilization & 0.0 & 0.0 & 0.0 & 0.0 & 0.0 & 0.0 & 0.0 & 0.0 & 0.0 & 0.0 & 0.0 & 0.0 & 0.0 \\
\hline 1 & Unfertilized egg & 0.0 & 0.0 & 0.0 & 0.0 & 0.0 & 0.0 & 0.0 & 0.0 & 0.0 & 0.0 & 0.0 & 0.0 & 0.0 \\
\hline 2 & Egg after turning & 0.0 & 0.0 & 0.0 & 0.0 & 0.0 & 0.0 & 0.0 & 0.0 & 0.0 & 0.0 & 0.0 & 0.0 & 0.0 \\
\hline 3 & Light crescent stage & 0.0 & 0.0 & 0.0 & 0.0 & 0.0 & 0.0 & 0.0 & 0.0 & 0.0 & 0.0 & 0.0 & 0.0 & 0.0 \\
\hline \multirow[t]{2}{*}{4} & 1st cleavage division & 62.5 & 57 & 71 & 3.2 & 3.9 & 3 & 3.7 & 2.9 & 3.6 & 2.7 & 3.4 & 2.6 & 3.2 \\
\hline & Start 2 nd cleavage division & 71.9 & 72 & 72 & 4 & 4 & 3.8 & 3.8 & 3.6 & 3.6 & 3.4 & 3.4 & 3.3 & 3.3 \\
\hline \multirow[t]{2}{*}{5} & 2nd cleavage (fertility rates) & 77.8 & 72 & 84 & 4 & 4.7 & 3.8 & 4.4 & 3.6 & 4.2 & 3.4 & 4 & 3.3 & 3.8 \\
\hline & End of 2 nd cleavage & 84.4 & 81.5 & 87.5 & 4.5 & 4.9 & 4.3 & 4.6 & 4.1 & 4.4 & 3.9 & 4.2 & 3.7 & 4 \\
\hline 6 & 3rd cleavage division & 91 & 91 & 91 & 5.1 & 5.1 & 4.8 & 4.8 & 4.6 & 4.6 & 4.3 & 4.3 & 4.1 & 4.1 \\
\hline 7 & 4th cleavage division & 123.9 & 122.7 & 130.9 & 6.8 & 7.3 & 6.5 & 6.9 & 6.1 & 6.5 & 5.8 & 6.2 & 5.6 & 5.9 \\
\hline 8 & 5th cleavage division & 156.7 & 154.4 & 170.7 & 8.6 & 9.5 & 8.1 & 9 & 7.7 & 8.5 & 7.4 & 8.1 & 7 & 7.8 \\
\hline 9 & 7th cleavage division & 189.6 & 186.1 & 210.6 & 10.3 & 11.7 & 9.8 & 11.1 & 9.3 & 10.5 & 8.9 & 10 & 8.5 & 9.6 \\
\hline 10 & Late cleavage & 222.4 & 217.9 & 250.4 & 12.1 & 13.9 & 11.5 & 13.2 & 10.9 & 12.5 & 10.4 & 11.9 & 9.9 & 11.4 \\
\hline 11 & Early blastula & 255.3 & 249.6 & 290.3 & 13.9 & 16.1 & 13.1 & 15.3 & 12.5 & 14.5 & 11.9 & 13.8 & 11.3 & 13.2 \\
\hline 12 & Late blastula & 321 & 313 & 370 & 17.4 & 20.6 & 16.5 & 19.5 & 15.7 & 18.5 & 14.9 & 17.6 & 14.2 & 16.8 \\
\hline 13 & Onset of gastrulation & 380.6 & 360 & 399 & 20 & 22 & 19 & 21 & 18 & 20 & 17 & 19 & 16 & 18 \\
\hline 14 & Early gastrula & 444.1 & 404 & 565 & 22 & 31 & 21 & 30 & 20 & 28 & 19 & 27 & 18 & 26 \\
\hline 15 & Middle gastrula & 540.8 & 486 & 652 & 27 & 36 & 26 & 34 & 24 & 33 & 23 & 31 & 22 & 30 \\
\hline 16 & Large yolk plug & 583.9 & 573 & 595 & 32 & 33 & 30 & 31 & 29 & 30 & 27 & 28 & 26 & 27 \\
\hline 17 & Small yolk plug & 680.6 & 665 & 706 & 37 & 39 & 35 & 37 & 33 & 35 & 32 & 34 & 30 & 32 \\
\hline 18 & Slit-like blastopore & 771.4 & 706 & 828 & 39 & 46 & 37 & 44 & 35 & 41 & 34 & 39 & 32 & 38 \\
\hline 19 & Early neural & 895.8 & 875 & 914 & 49 & 51 & 46 & 48 & 44 & 46 & 42 & 44 & 40 & 42 \\
\hline 20 & Broad neural plate & 932.3 & 915.6 & 946.8 & 51 & 53 & 48 & 50 & 46 & 47 & 44 & 45 & 42 & 43 \\
\hline 21 & Neural folds draw together & 968.7 & 956.2 & 979.6 & 53 & 54 & 50 & 52 & 48 & 49 & 46 & 47 & 43 & 45 \\
\hline 22 & Late neuralation & $1,005.1$ & 996.8 & $1,012.4$ & 55 & 56 & 52 & 53 & 50 & 51 & 47 & 48 & 45 & 46 \\
\hline 23 & Closed neural tube & $1,041.6$ & $1,037.4$ & $1,045.2$ & 58 & 58 & 55 & 55 & 52 & 52 & 49 & 50 & 47 & 48 \\
\hline 24 & Appearance of eye protrusion & 1,078 & 1,078 & 1,078 & 60 & 60 & 57 & 57 & 54 & 54 & 51 & 51 & 49 & 49 \\
\hline 25 & Drawing of the lateral plates & $1,187.4$ & 1,119 & 1,256 & 62 & 70 & 59 & 66 & 56 & 63 & 53 & 60 & 51 & 57 \\
\hline
\end{tabular}


Table 10. Minimum and maximum hourly thermal units for Scaphirhynchus sturgeon egg development and minimum and maximum hours to completion of each stage for 18-22 degrees Celsius.-Continued

[Hourly thermal units is a measure designed to approximate the relation between temperature and developmental time. Red numbers are extrapolated, no data were collected for these stages. HTU, hourly thermal units; ${ }^{\circ}$ C, degrees Celsius; Min, minimum; Max, maximum; >, greater than]

\begin{tabular}{|c|c|c|c|c|c|c|c|c|c|c|c|c|c|c|}
\hline \multirow{3}{*}{ Stage $^{1}$} & \multirow{3}{*}{ Description } & & & & \multicolumn{10}{|c|}{ Hours to completion } \\
\hline & & \multicolumn{3}{|c|}{ HTU } & \multicolumn{2}{|c|}{$18^{\circ} \mathrm{C}$} & \multicolumn{2}{|c|}{$19^{\circ} \mathrm{C}$} & \multicolumn{2}{|c|}{$20^{\circ} \mathrm{C}$} & \multicolumn{2}{|c|}{$21^{\circ} \mathrm{C}$} & \multicolumn{2}{|c|}{$22^{\circ} \mathrm{C}$} \\
\hline & & Mean & Min & Max & Min & Max & Min & Max & Min & Max & Min & Max & Min & Max \\
\hline 26 & Fusion of lateral plates & 1,240 & 1,176 & 1,304 & 65 & 72 & 62 & 69 & 59 & 65 & 56 & 62 & 53 & 59 \\
\hline 27 & Short elongated cardiac tube & $1,300.2$ & 1,237 & $1,363.5$ & 69 & 76 & 65 & 72 & 62 & 68 & 59 & 65 & 56 & 62 \\
\hline 28 & Straight cardiac tube & $1,360.4$ & 1,298 & 1,423 & 72 & 79 & 68 & 75 & 65 & 71 & 62 & 68 & 59 & 65 \\
\hline 29 & Formation of cardiac tube & $1,421.4$ & 1,039 & 1,605 & 58 & 89 & 55 & 84 & 52 & 80 & 49 & 76 & 47 & 73 \\
\hline 30 & Tail tip approaches heart & $1,729.9$ & 1,704 & 1,755 & 95 & 98 & 90 & 92 & 85 & 88 & 81 & 84 & 77 & 80 \\
\hline 31 & Tail tip reaches heart & $1,859.1$ & 1,846 & $1,871.5$ & 103 & 104 & 97 & 99 & 92 & 94 & 88 & 89 & 84 & 85 \\
\hline 32 & Tail tip reaches head & $1,988.3$ & 1,988 & 1,988 & 110 & 110 & 105 & 105 & 99 & 99 & 95 & 95 & 90 & 90 \\
\hline 33 & Tail tip reaches beyond head & $2,060.1$ & 2,030 & 2,090 & 113 & 116 & 107 & 110 & 102 & 105 & 97 & 100 & 92 & 95 \\
\hline 34 & Tail tip reaches myelencephalon & $2,083.8$ & $2,189.7$ & $2,160.5$ & 122 & 120 & 115 & 114 & 109 & 108 & 104 & 103 & 100 & 98 \\
\hline \multirow[t]{4}{*}{35} & Hatching begins & $2,107.5$ & $2,352.6$ & 2,231 & 131 & 124 & 124 & 117 & 118 & 112 & 112 & 106 & 107 & 101 \\
\hline & $>50$ percent hatch & $2,509.3$ & 2,509 & 2,509 & 139 & 139 & 132 & 132 & 125 & 125 & 119 & 119 & 114 & 114 \\
\hline & 90 percent hatch & $2,678.7$ & $2,678.5$ & $2,678.5$ & 149 & 149 & 141 & 141 & 134 & 134 & 128 & 128 & 122 & 122 \\
\hline & End of hatch & $2,848.2$ & 2,848 & 2,848 & 158 & 158 & 150 & 150 & 142 & 142 & 136 & 136 & 129 & 129 \\
\hline
\end{tabular}

${ }^{1}$ Stages based on Detlaff and others (1993). 
spawning locations on bedrock and revetment on outside bends are locations where sand and finer sediment are always in transport, and patches of clean substrate in these areas can be expected to change size and change shape depending on flow strength. What is not known is whether, at the scale of spawning and embryo deposition, these patches of substrate are susceptible to episodic sediment deposition or abrasion from transporting sediment. More detailed understanding of where embryos are deposited is necessary to fully evaluate whether conditions at spawning sites can be manipulated with flow management.

\section{Channel Re-Engineering}

Whereas the distribution of natural hard substrate is patchy and discontinuous on the Lower Missouri River (fig. 21) (Laustrup and others, 2007), channelization of the Missouri River has resulted in the emplacement of large, angular cobble- to boulder-sized rock revetment material over most of the bank surface on the outside banks of nearly every bend on the lower 735 miles of the Missouri River. Although spawning on and adjacent to revetment has been documented, the suitability of this artificial substrate for spawning success and embryo survival is unknown. In particular, it is not known whether quarried rock surfaces, size distribution, and interstitial space are adequate to retain and nurture sturgeon embryos. Moreover, the geometry and hydraulics of outside-bend revetment differ substantially from conditions on natural gravel-cobble bar deposits and may not be conducive to embryo survival. Documented spawning patches on revetted outside bends are also adjacent to actively transporting sand dunes, and the transition zone between steep bank revetment and sand dunes is narrow (fig. 40, table 8). The typical 3 to $5 \mathrm{~m}$ accuracy of telemetry tracking and inherently variable fish behavior during spawning do not allow for precise placement of where eggs are released in this narrow zone. Sand dunes are transported on the bottom of the Missouri River for a wide range of flow conditions (Elliott and others, 2009); if spawning substrate is covered with sand, embryos may not adhere firmly and be buried by sand. Increased understanding of fine-scale conditions experienced by sturgeon embryos during deposition and incubation may lead to insights into how channel engineering could promote survival through this life stage.

\section{Free-Embryo Life Stage}

A free embryo is a developing fish no longer within a protective chorion, from hatch to the initiation of feeding. The small size of this life stage also challenges field assessments. Concerted field sampling is complemented with laboratory studies and deductive reasoning from physical transport models.

\section{Habitat Requirements for Hatch to Free Embryo}

Little is known about the biology of pallid sturgeon during their free-embryo life stage. This life stage, defined in this report as occurring from hatch to yolk absorption and first feeding, has rarely been caught in the wild. Only one genetically confirmed pallid sturgeon free embryo was collected during 2011 in the Missouri River downstream from Fort Peck Dam and one from the Yellowstone River in 2012. What information is available primarily comes from laboratory studies, hatchery propagation observations, and the stocking of propagated free embryos for field-based studies in the Missouri River.

Newly hatched pallid sturgeon embryos (7-9 mm; Snyder, 2002) are not well-developed and have a large yolk sac. Eyes are not pigmented for the first 2 days, pelvic fin buds do not appear until the fifth day post-hatch (dph), and fin development in pallid sturgeon is not complete until the fish is greater than $80 \mathrm{~mm}$ (Snyder, 2002). As a result, the newly hatched pallid sturgeon free embryo has limited ability to control its movement in the river current for several days after hatch.

\section{Immediate Drift and Interstitial Hiding Hypotheses}

The scientific literature on pallid sturgeon free-embryo habitat use is dominated by the hypothesis that drift generally commences immediately after hatch. Recently, a competing hypothesis has emerged from laboratory investigations and studies of other sturgeon species that free embryos may spend one to several days immediate post-hatch hiding in interstitial spaces in substrate (Hastings and others, 2013; Kynard and others, 2013; Crossman and Hildebrand, 2012). The two hypotheses may not be mutually exclusive; instead, there may be a continuum from immediate drift to interstitial hiding with varying probability of survival depending on drift distance and habitat availability when the free embryos transition to exogenous feeding. In the following section we review the evidence for both of these hypotheses. The issue is critical to understanding pallid sturgeon reproductive ecology in relation to river management because the time a newly hatched free embryo may spend growing in interstitial space reduces downstream drift distance and may increase chances of survival.

Continuing laboratory studies examining drift and dispersal of pallid sturgeon free embryos (Kynard and others, 2002; Kynard and others, 2007) and field studies done in a Missouri River side channel during 2004 (Braaten and others, 2008) and the main stem Missouri River in 2007 (Braaten and others, 2012a) provided inferences on free-embryo drift and dispersal dynamics under relatively natural river conditions. These studies indicated that (1) pallid sturgeon free embryos drift and disperse downstream at a rate slightly less than mean water column velocity; (2) downstream drift and dispersal occur during day and night; (3) duration of the free-embryo drift period is dependent on water temperature and rate of development 
and; (4) free embryos will drift and disperse several hundred $\mathrm{km}$ during ontogenetic development into exogenously feeding larvae, with total drift distance a function of water temperature, developmental rate, and velocity conditions in the river channel.

Drift distances calculated in these studies assumed drift commenced immediately after hatch. Although this assumption is exceedingly difficult to verify with direct observation in the field, it is supported by two lines of reasoning. First, is the lack of recruitment from known spawning populations in the Yellowstone-Upper Missouri River confluence area populations (Fuller and others, 2008; Braaten and others, 2009). Calculated drift distances from the upstream-most potential spawning locations at Intake Dam and Fort Peck Dam, assuming immediate drift and drift behaviors documented in field experiments (Braaten and others, 2008; Braaten and others, 2012a), indicate that the free embryos would not have time to develop to the larval (exogenously feeding) stage before entering Lake Sakakawea. Lake Sakakawea is considered be an inhospitable environment for free embryo and larval sturgeon, although the precise mechanism has not been established. Dispersing sturgeon may settle in anoxic sediments upon reaching the reservoir, they may be vulnerable to sight feeding predators in the clear water, or they may be unable to find food or feed efficiently. If the reservoir environment is the primary source of mortality then the lack of drift distance may explain recruitment failure; however, other substantial sources of mortality cannot yet be ruled out.

The immediate drift hypothesis also is supported by recent captures of naturally spawned pallid sturgeon free embryos. Two genetically confirmed pallid sturgeon free embryos (estimated 0-1 dph) sampled in the Missouri River Basin (below Fort Peck Dam in 2011 and in the Yellowstone River in 2012) were collected from the drift downstream from natural spawning sites and substrates. Based on their stage of development these individuals did not spend a period of residency in the substrate immediately after hatching. With so few individuals collected, it remains uncertain what portion of free embryos actively enter the drift immediately after hatch or entrain into the drift immediately after hatch by river currents. It is unknown whether the substrate in the spawning area would provide interstitial hiding space adequate to retain hatched free embryos. Directly sampling the spawning substrate for later stages of free-embryo development would provide direct evidence needed to determine the timing of the initiation of dispersal.

The interstitial hiding hypothesis is supported by inference from other species and laboratory experiments. Recently, white sturgeon free embryos, a species that was previously hypothesized to drift immediately upon hatch, have been observed to spend the first few days post-hatch under rock cover when suitable cover was available (Kynard and Parker, 2005, 2006; Kynard and others, 2012). Early studies collecting white sturgeon free embryos indicated that drift was dominated by individuals that were less than four dph (Perrin and others, 2003), suggesting immediate drift. Recent field and experimental studies, however, have related retention of white sturgeon free embryos to the quality and size distribution of substrate and whether the substrate provides adequate interstitial space (McAdam, 2011; Crossman and Hildebrand, 2012). In these studies, white sturgeon free embryos selected interstitial space, delaying drift by as many as 15 days. Variability of drift behaviors within one species suggests that a continuum of behaviors may exist controlled, in part, by abiotic factors such as substrate characteristics, current velocity, and turbulence (McAdam, 2012).

Experimental studies on pallid sturgeon hatch and freeembryo drift at the CERC provide some evidence consistent with the interstitial hiding hypothesis or facultative use of coarse substrate during downstream dispersal. In 2012 experiments (appendix 6), pallid sturgeon embryos attached to rocks and placed in an oval stream tank initially began drifting passively immediately after hatch in $0.14 \mathrm{~m} / \mathrm{s}$ current velocity. During the period 0-7 dph, the drifting free embryos would, at various times, get caught in small eddies and slack water where they would sink to the bottom of the tank. Their saltatory swimming behavior off the bottom into the water column only infrequently allowed them to be caught by the flowing water and carried around the stream tank. As a result, much of the time during the first few days post-hatch, the free embryos remained in eddies and slack water. Daily mortalities of free embryos were high for all experimental trials until seven or eight dph (table 11; appendix 6).

Movement and position of the free embryos around the stream tank for trials 3 and 4 indicated free-embryo time in drift increasing until about the seventh dph then decreasing (fig. 57). The numbers of fish in eddies or pools were high during the period of mortalities and decreased when

Table 11. Daily mortalities (percent) of pallid sturgeon free embryos in an artificial stream tank with an average velocity of 14 centimeters per second from four separate experimental trials.

$[--$, no data $]$

\begin{tabular}{|c|c|c|c|c|c|c|c|c|c|c|c|c|c|}
\hline \multirow{2}{*}{ Trial } & \multirow{2}{*}{$\begin{array}{c}\text { Number } \\
\text { fish }\end{array}$} & \multicolumn{12}{|c|}{ Days post-hatch } \\
\hline & & 1 & 2 & 3 & 4 & 5 & 6 & 7 & 8 & 9 & 10 & 11 & 12 \\
\hline 1 & 23 & -- & 78 & 96 & -- & -- & -- & -- & -- & -- & -- & -- & -- \\
\hline 3 & 47 & 100 & 40 & 50 & 33 & 17 & 30 & 0 & 0 & 0 & 0 & 0 & -- \\
\hline 4 & 20 & -- & -- & 80 & -- & 100 & 20 & 75 & 17 & 0 & 0 & 0 & 0 \\
\hline
\end{tabular}



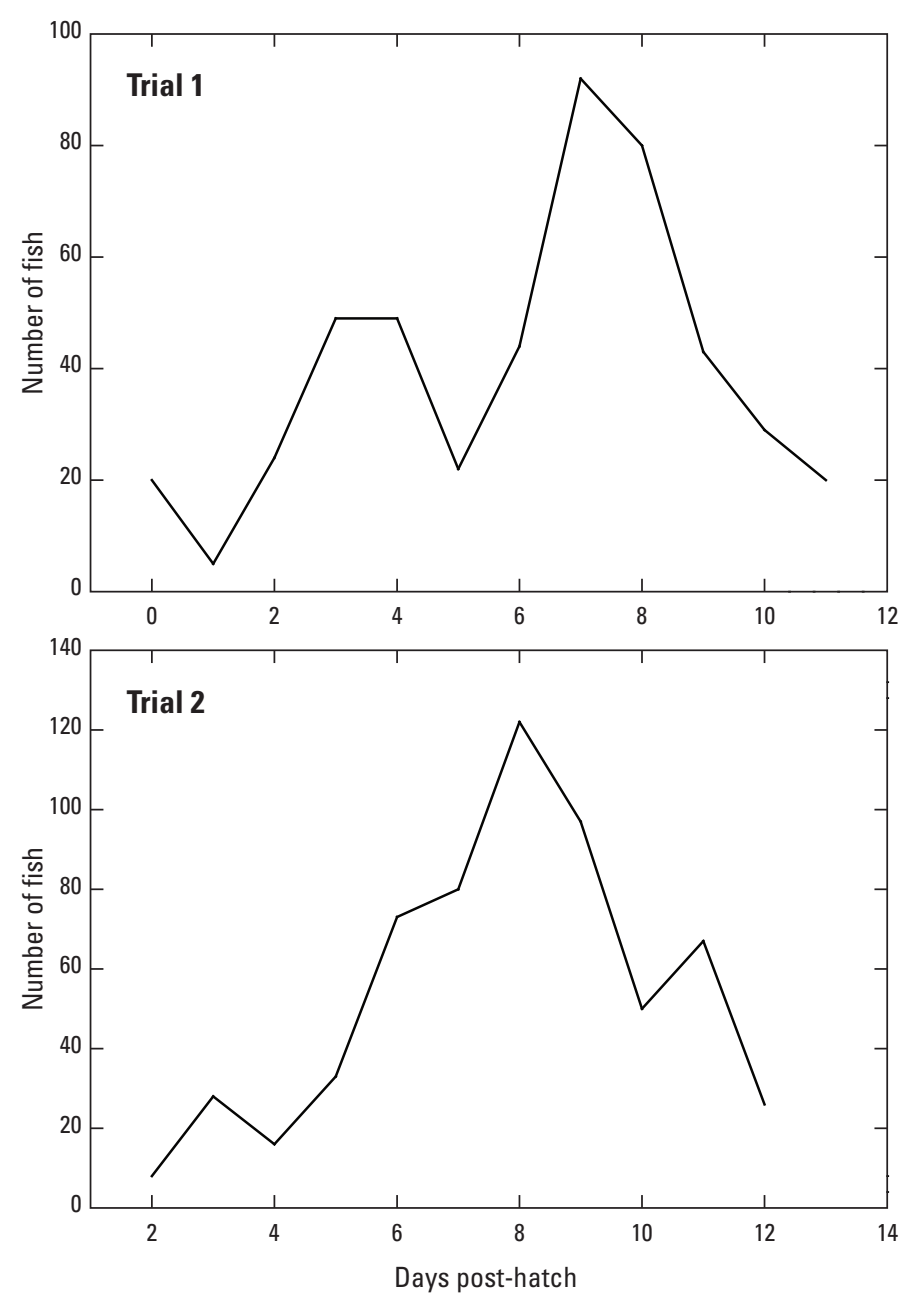

Figure 57. Total number of fish counted per day passing a fixed point in the stream tank in trial 1 and trial 2.

free-embryo survival began to increase. Sturgeon free embryos from 6 dph were increasingly able to hold their position in the stream system and by 12 and $13 \mathrm{dph}$ were no longer drifting (fig. 57).

These results suggest that the hydraulic conditions in the stream tank were lethal to pallid sturgeon free embryos through the first 4-5 dph. Kynard and others (2004) also tested drift behavior of pallid sturgeon free embryos in a flowing tank system with eddies. Velocities in their experiments averaged approximately $0.15,0.20$, and $0.28 \mathrm{~m} / \mathrm{s}$ in three separate treatments. As in our experiments, Kynard and others (2004) reported that free embryos from 0-3 dph were unable to control their movements up or downstream in the flow and behaved as passive particles. At $0.28 \mathrm{~m} / \mathrm{s}$ velocity, flow controlled the movement of the pallid sturgeon free embryos such that they never stopped drifting. Our results, however, and those of Kynard and others (2004) were consistent in indicating that at slower velocities $4 \mathrm{dph}$ pallid sturgeon began to hold their position longer in the current and eddies and by $13 \mathrm{dph}$ they were no longer drifting (Kynard and others, 2007).
One explanation for these observations is that pallid sturgeon free embryos have a biological necessity to drift immediately after hatch and their seeming inability to do so (because they were trapped in slack water and eddies for the first several dph) caused the high mortalities observed in the first few days after hatch. An alternative hypothesis to explain these observations is that pallid sturgeon free embryos require as many as $5 \mathrm{dph}$ in a protected environment to continue developing before beginning the drift phase. Following this hypothesis, those embryos that begin to drift immediately after hatch are subject to higher rates of mortality.

The CERC 2012 experiments were designed based on the assumption that pallid sturgeon would initiate downstream drift immediately after hatch. However, in trial 2, gravel was placed on the bottom of the pool and pallid sturgeon 0-5 dph in that trial burrowed into and hid in the gravel interstices rather than drifting immediately. Mortalities in trial two were as high as the other trials and it may be that the single layer of gravel was not adequate to provide interstitial spaces for free embryos to be protected. Although Kynard and others (2002; 2004) indicated that the free-embryo pallid sturgeon swam in the open water and almost never sought cover under rocks. In hatchery and laboratory settings in the absence of current, free embryos are predominately on the bottom of raceway tanks or clustered head down into a corner of a tank (James Candrl, U.S. Geological Survey, oral commun., 2013).

Developing the understanding necessary to select between the competing hypotheses is complicated by the lack of direct observations in the field, potential errors in inference based on other species, and limits of laboratory investigations. In particular, laboratory investigations of free-embryo drift are limited because of the constrained range of velocities that it is possible to simulate in flume settings. The experiments of Kynard and others (2007) documented larval drift during low, medium, and high velocity treatments corresponding to mean flow velocities of $0.17,0.21$, and $0.32 \mathrm{~m} / \mathrm{s}$, respectively. In the experiments completed at CERC in 2012, mean velocity was approximately $0.14 \mathrm{~m} / \mathrm{s}$. Velocities in both sets of flume experiments are substantially less than typical velocities observed on the main stem Missouri River (fig. 58). Progress in understanding the very early life history of pallid sturgeon free embryos may require increased realism in laboratory experimental conditions as well as increased resolution of sampling and observations in the field.

\section{Drifting Phase}

Whether free embryos drift immediately or hide for several days in interstitial spaces, eventually they disperse downstream. Free embryos progressively gain the ability to move on their own as they drift and undergo development from free embryos to larvae. Conceptually, free embryos continue to drift, using up their yolk sacs and developing swimming ability until they "settle" in an environment conducive to feeding and growth. It is important to note, however, that during the transition of newly hatched free embryos to swimming larvae, 


\section{A. All velocity data}

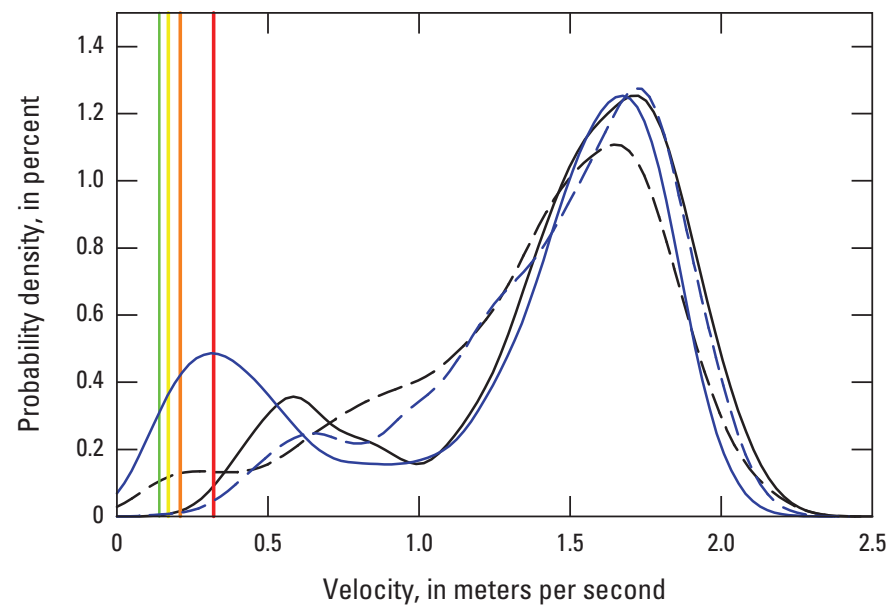

B. Minimum (near-bed) velocity

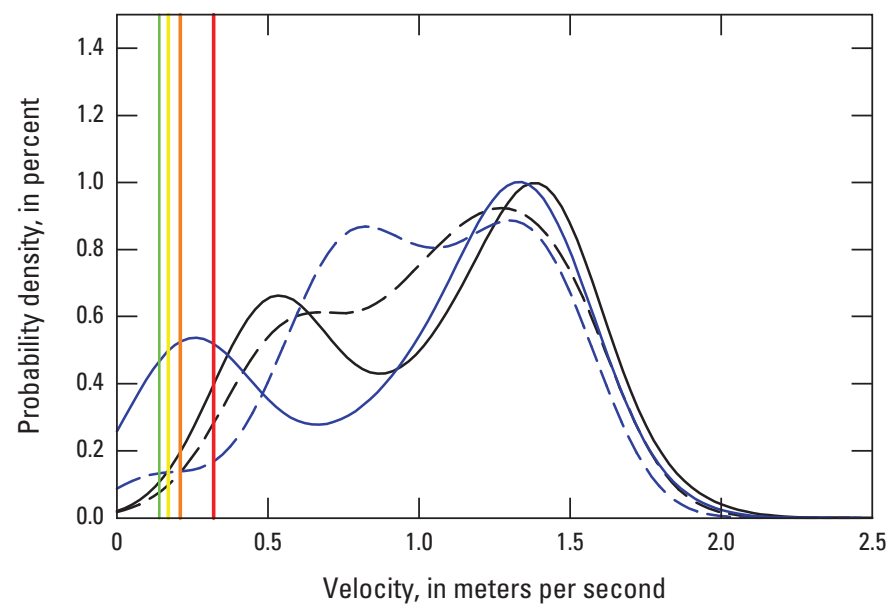

EXPLANATION

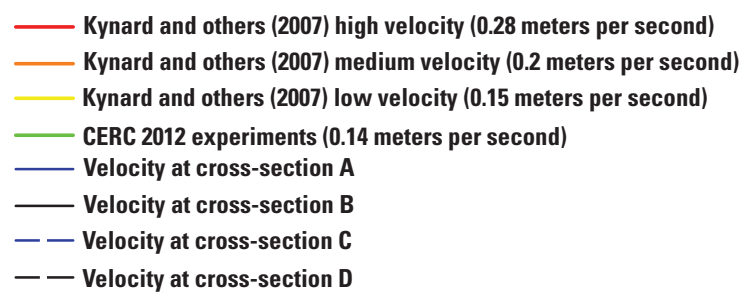

Figure 58. Probability density functions of velocity data collected using acoustic Doppler current profiler at spawning location documented on April 28, 2010, near river mile 202.

the behavior, and therefore the dispersal characteristics of pallid sturgeon may change substantially. The total drift distance will be a function of free-embryo behavior, development, channel hydraulics, and water temperature, a key control on development rate.

The potential for long duration of drift (9-15 plus days) coupled with channelized flow and high velocities likely results in high cumulative drift distances (DeLonay and others, 2009). It is currently (2015) hypothesized that downstream transport of larvae into lotic environments may lead to mortality of larvae transitioning to exogenous feeding. Simple calculations in the Upper Missouri River indicate that most free embryos would drift into Lake Sakakawea (Braaten and others, 2012a). Similarly, calculations based on mean velocities in the Lower Missouri River indicate that passively drifting larvae spawned in all but the most upstream locations, are likely to be transported out of the Missouri River and into the Middle Mississippi River (DeLonay and others, 2009). Recent (2015) field data provide confirming evidence that pallid sturgeon free embryos originating in the upper segments of the Lower Missouri River may be exported into the Mississippi River. In this study fin-ray strontium:calcium ratios from four age- 0 sturgeon captured in the Middle Mississippi River were interpreted to argue that the larvae originated more than 589 $\mathrm{km}$ upstream in the upper part of the Lower Missouri River (Phelps and others, 2012b).

Calculations based on mean velocities do not address the potential for complex channels and flow patterns to create hydraulics amenable to slowing or retention of drifting free embryos. An approach to incorporating flow complexity into drift calculations is based on incorporation of retention capacity by using an advection-dispersion model (Fischer, 1973). In advection-dispersion models, downstream movement of particles or solutes is a function of mean channel velocity (advection) and hydraulic factors that tend to slow and spread out solutes or particles longitudinally (dispersion). The strength of dispersion in the longitudinal direction is quantified by the longitudinal dispersion coefficient (henceforth referred to as the dispersion coefficient, or DL; see appendix 8). Simulations of drift distance using a one-dimensional advection-dispersion model for the Lower Missouri River indicate that drift originating at documented spawning locations would transport free embryos into the Mississippi River (fig. 59), similar to results of the simple mean-velocity model, but with a range of downstream movement as result of dispersion. Our estimates of dispersion coefficients for each segment of the Lower Missouri River are based on a method that uses cross-stream velocity components from acoustic Doppler current profiler data (Kim, 2012) (fig. 60). This method allows us to explicitly consider how spatial variability in channel complexity may contribute to retention, although the spatial resolution is limited and may not, for example, resolve retention at the scale of exchange with substrate. Another important assumption is that drift is entirely passive, an assumption challenged by empirical data that suggest that free embryos drift downstream at a rate slightly slower than the mean channel velocity (Braaten and others, 2012a). Nevertheless, using mean velocities and dispersion coefficients, these models support the assertion that advection dominates more than dispersion, and drift of passive free embryos on the Lower Missouri River can be calculated largely as a function of mean velocities.

Free-embryo sampling at a predefined transect in the Lower Missouri River near St. Charles, Missouri, during 2012 collected 336 sturgeon free embryos and larvae (appendix 7). Genetic analyses revealed that of 334 specimens submitted for analysis ( 2 of the 336 specimens were inadequately 

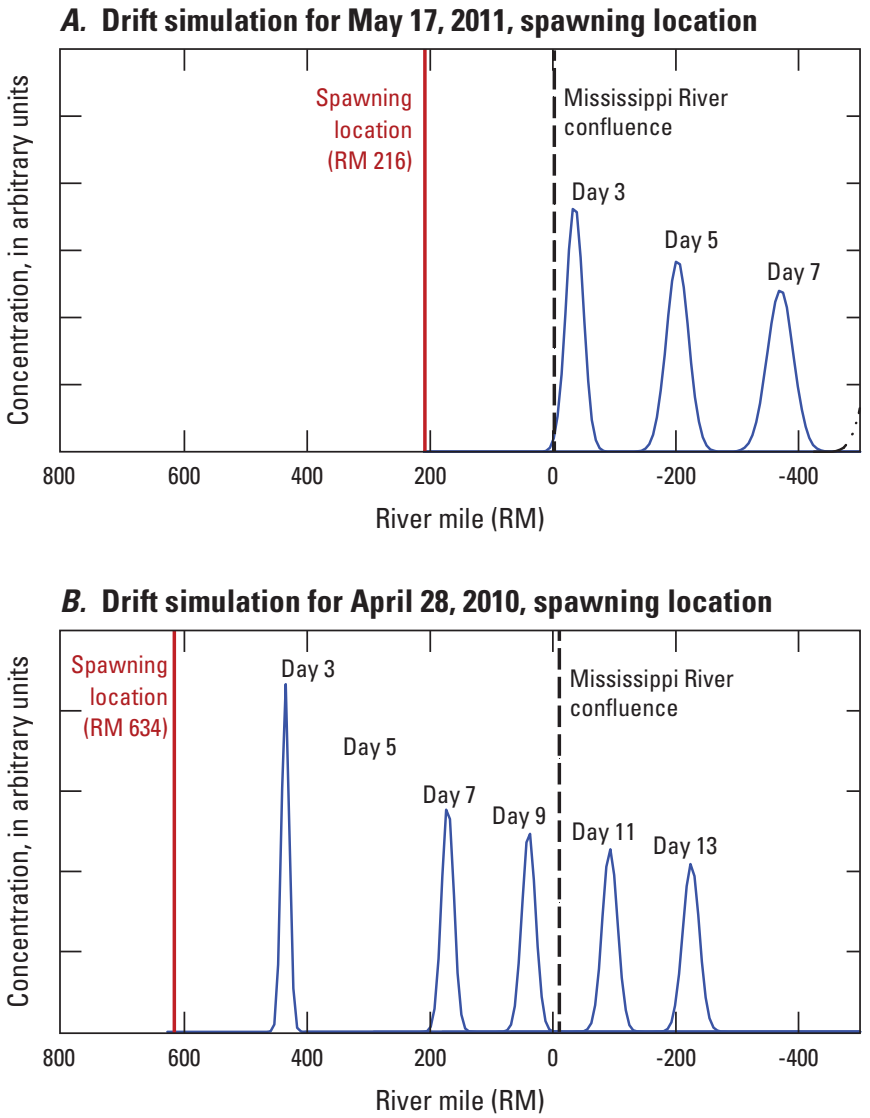

Figure 59. One-dimensional advection-dispersion models of free-embryo drift. Longitudinal dispersion coefficients for each simulation were calculated using acoustic Doppler current profiler data collected at each spawning site. Discharge data was taken from USGS streamgage Missouri River at $A$, Boonville and $B$, Missouri River at Omaha.

preserved), 329 were identified as shovelnose sturgeon and 5 were consistent with shovelnose sturgeon-pallid sturgeon hybrids. Most free embryos were captured May 1 to July 1 , although a secondary pulse of free embryos also was detected in early September, indicating a possible fall spawning event. The bulk of the free embryos were collected near the bottom in the thalweg, consistent with drift studies in the Upper Missouri River (Braaten and others, 2008; Braaten and others, 2012a).

\section{Settling Phase}

The drift period ends conceptually in "settling" of free embryo into environments that are conducive to feeding, growth, and survival. The end of the drifting period seems to coincide with the onset of feeding, which occurs at about 11 dph (Snyder, 2002; Kynard and others, 2007), and notably, the filling of the swim bladder (Diana Papoulias, U.S. Geological Survey, written commun., 2014). At 15 dph at $19{ }^{\circ} \mathrm{C}$, free embryos must begin to feed or they will die of starvation within a week (Candrl and others, 2009). Settling areas also are thought to be areas of relatively low velocity because of the inability of larvae to hold position in fast water. Kynard and others (2007) observed that at $0.32 \mathrm{~m} / \mathrm{s}$ pallid sturgeon free embryos could not hold position in the tank or swim into slow water until eight dph. In stamina experiments at the CERC in 2012 (appendix 6), 14-dph pallid sturgeon were still unable to hold position in flows greater than or equal to $0.39 \mathrm{~m} / \mathrm{s}$. This is substantially slower than the mean water column velocities in the contemporary Missouri River. Pallid sturgeon larvae are benthic and the current velocities reported near the river bottom are likely a fraction of the mean column velocity. Understanding the relation between mean column velocity and near bottom velocities experienced by larval sturgeon is critical to determining habitat suitability for this life stage. If near bottom velocities exceed the capacity of larval sturgeon to control their movements in fast flowing water they are unlikely to avoid predation or forage effectively.

Little direct evidence exists for what constitutes settling habitat on the Missouri River, in large part due to the challenges of statistically sampling for tiny fish across the diverse habitats in the Missouri River. It has been hypothesized that the channelization of the Missouri River has reduced channel complexity and constrained successional habitat forming processes that provided the habitats needed for larval and juvenile fish, including sturgeon (U.S. Fish and Wildlife Service, 2000, 2003b). Habitat restoration in the Lower Missouri River has coupled the goals of increased habitat diversity and complexity to the creation of shallow, slow water, bordering the main channel. For the purpose of setting restoration goals, the concept of shallow-water habitat (SWH) has been defined operationally as $0-5 \mathrm{ft}(0-1.5 \mathrm{~m})$ depth and $0-2 \mathrm{ft} / \mathrm{s}(0-0.6 \mathrm{~m} / \mathrm{s})$ current velocity (U.S. Fish and Wildlife Service, 2000); a recent clarification emphasized dynamics and variability of SWH and elaborated on its hypothesized functions: "Shallow water habitat provides locations for increased primary productivity, invertebrate production, and larval/young-of-year nursery habitat" (Olson, 2009). The low velocities incorporated in SWH definitions are consistent with the $0.39 \mathrm{~m} / \mathrm{s}$ velocity threshold for larval pallid sturgeon to hold position and forage cited in the previous paragraph.

Several hydrodynamic modeling studies have evaluated the extent of SWH, patch characteristics, and relations to flow regime (Jacobson and Galat, 2006; Johnson and others, 2006a; Jacobson and others, 2009b; Papanicolaou and others, 2010). These studies documented the historical extent of SWH and its relation to discharge in the contemporary channel. Importantly, SWH in the engineered Lower Missouri River channel is maximized at the lowest discharges (which are incompatible with navigation) or in overbank floods; restored reaches showed substantially more SWH and less sensitivity to discharge (Jacobson and Galat, 2006). In general, SWH and conditions that we hypothesize are likely to retain free embryos are associated with hydraulic complexity and constriction/expansions associated with river bends and wing dikes; conditions that are likely to promote advection of free embryos from the main 


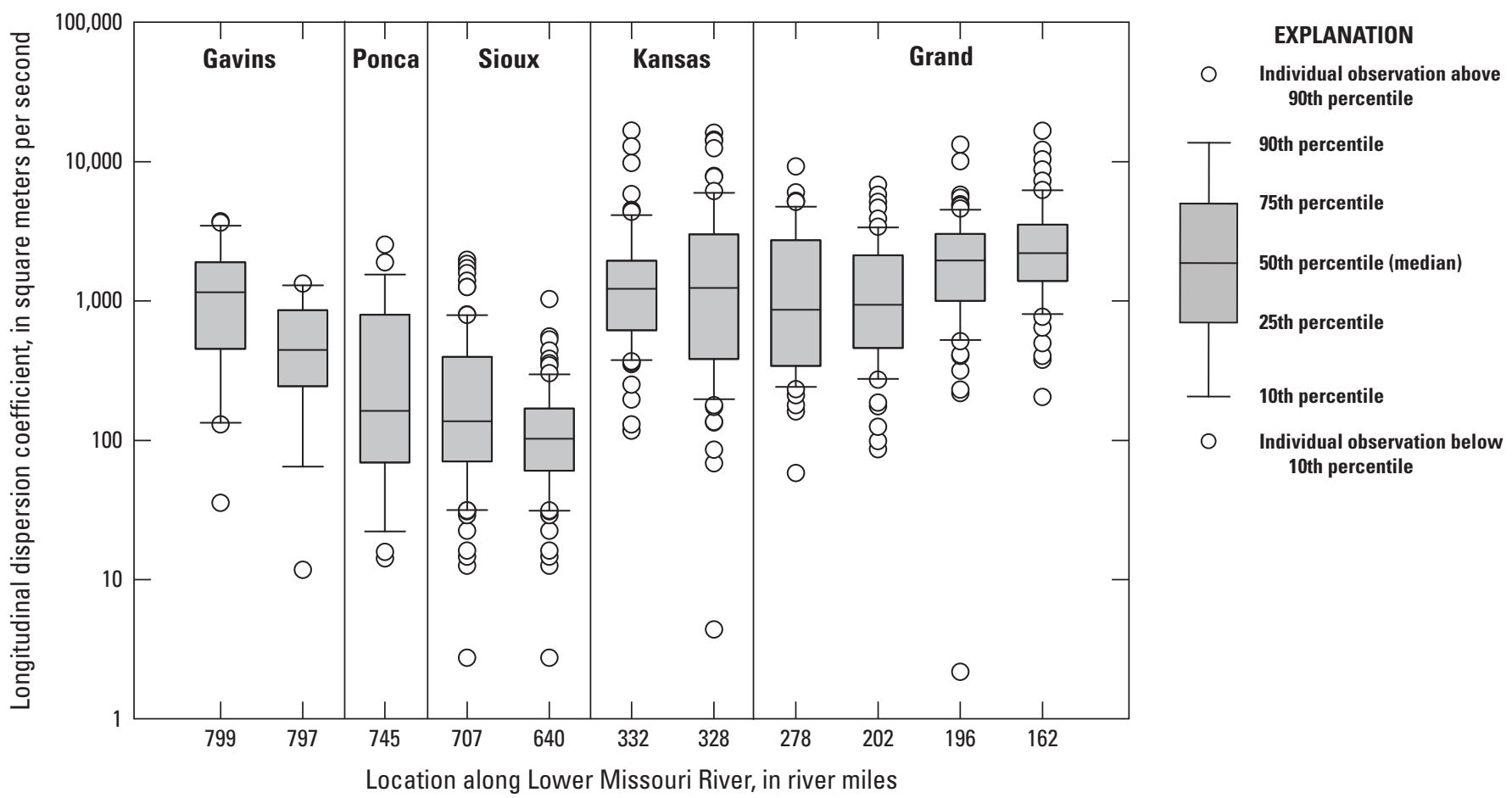

Figure 60. Longitudinal dispersion coefficients calculated for the Lower Missouri River from acoustic Doppler current profiler data. The wide range in values of longitudinal dispersion at each measurement site arises from the within-reach heterogeneity in channel morphology and hydraulic patterns. Differences in longitudinal dispersion among sections reflect the distinct geomorphic characteristics and styles of channel engineering used in different segments and sections of the Lower Missouri River.

channel into channel-margin SWH areas. These areas of complexity, evident in measures of increased channel width and constriction width ratios, increase substantially from upstream to downstream in the contemporary river (fig. 22), but their role in retaining free embryos has not been documented.

\section{Flow Regime Management}

Complex interactions of discharge, hydraulics, and channel morphology determine drift and dispersion of free embryos. Changes in flow regime affect drift in two distinct ways: (1) discharge and mean velocity control the advection, or downstream transport, of free embryos, and (2) changes in flow regime alter channel hydraulics, which affect the dispersion and retention of free embryos. Thus, although higher flows would increase downstream advection of drifting pallid sturgeon larvae, flow pulses also have the potential to increase dispersion of drifting free embryos along a longitudinal gradient.

Models suggest that the retention of pallid sturgeon free embryos is affected by the availability of shallow-water habitat, which has been substantially reduced throughout the Missouri River Basin by flow regulation and channel alterations (Bowen and others, 2003; Jacobson and Galat, 2006). However, although total area of shallow-water habitat is substantially less than would have occurred in the absence of channel alterations, high flows have the potential to increase retention of free embryos by inundating low-lying alluvial surfaces within the active channel, secondary channels, and vegetated riparian habitats in the channel margins that may exist in natural or restored reaches of the river. The reduced flow velocities and high roughness values characteristic of these environments increase hydraulic gradients, thus promoting retention of drifting free embryos.

\section{Channel Re-Engineering}

The effects of flow regime on dispersion of free embryos are tightly coupled to channel morphology and free-embryo behavior. A spring flow pulse may affect dispersal of free embryos in very different ways at different stages of development, and in different parts of the river, reflecting the unique interaction of discharge, channel engineering, and hydraulics. For example, Jacobson and Galat (2006) demonstrated that in channelized reaches of the river that display reduced morphologic and hydraulic complexity, increases in discharge result in no increase in total area of shallow-water habitat until the channel overtops its banks. In contrast, hydrodynamic models of flow through reconstructed topography for the unchannelized river demonstrate that total shallow-water habitat would have steadily increased with discharge as low elevation alluvial surfaces were gradually inundated. The implications of this analysis for drift of free embryos is that in segments of the Lower Missouri River with minimal channel engineering, 
such as downstream from Gavins Point Dam, changes in flow regime have greater potential to increase retention of larval sturgeon than in reaches where hydraulic variability is less sensitive to discharge, such as the Big Sioux segment of the river (fig. 22). The coincidence of the spatial arrangement of the existing potential in the system to improve retention coincides with the development of dispersing free embryos is critical for growth and survival.

The distinct geomorphic characteristics and styles of channel engineering used in different segments of the Lower Missouri River are manifested in longitudinal dispersion coefficients calculated from ADCP data (see appendix 8). The lowest values of dispersion coefficients are found in the Ponca and Big Sioux segments where the flow field is relatively homogeneous (fig. 60). Increased topographic and hydraulic complexity within the Gavins segment translates into higher dispersion coefficients, reflecting the greater potential for retention of drifting free embryos within this reach. Notably, although the channel within the Kansas and Grand segments is highly engineered, these sections of river have the highest dispersion coefficients, because the large dikes generate pronounced zones of recirculation and strong cross-stream velocity gradients.

Present (2015) understanding of the potential for channel engineering to retain and grow free embryos to the larval stages is based on the concept of SWH, which defines a volume of habitat but fails to address the processes that lead to exchange between the main channel and channel-margin habitats. Improved understanding of the details of hydraulics and free-embryo survival at scales ranging from individual wing dikes to bends of rivers, combined with intensive sampling of free embryos and larvae, will be needed to establish how channel engineering and flow regime may be optimized to retain and nurture early life stages.

\section{Larval Life Stage}

Larval life stage describes a developing fish without yolk, feeding exogenously (table 1). This stage extends from the time the fish begins to feed until it has a full complement of rays in all fins, and so has the appearance of an adult fish in miniature. The duration of period and size of fish is temperature- and food-dependent. Beginning of the larval stage is typically equated with "settling" from the drift and the beginning of the ability to move independently in the current. Limited knowledge is available on the biology, ecology, and habitat requirements of pallid sturgeon larvae. This information gap stems from limited reproduction and the extreme rarity of collections of progeny from wild spawning events. Preliminary information, however, on the fundamental biological characteristics and ecological processes that occur during this critical life stage is emerging from laboratory and field investigations.

\section{Habitat Requirements}

Pallid sturgeon transition from endogenous-feeding free embryos to exogenous-feeding larvae after exposure to about 200 cumulative thermal units (CTU; sum of daily mean water temperatures, in degrees Celsius, for each day of life after hatch) during the free-embryo life stage (Kynard and others, 2007; Webb and others, 2007; Braaten and others, 2008). Based on the 200 CTU requirements, age at transition from endogenous to exogenous feeding can be estimated for thermal regimes. For example, for exposures to daily mean water temperatures of $18{ }^{\circ} \mathrm{C}$ during the free-embryo life stage, yolk absorption and the transition to exogenous feeding occurs in about $11 \mathrm{dph}\left(200 \mathrm{CTU}\right.$ divided by $18^{\circ} \mathrm{C}=11.1$ days $)$. Pallid sturgeon are typically $18-20 \mathrm{~mm}$ when the yolk is absorbed and they transition to exogenous feeding (Snyder, 2002; Braaten and others, 2008; Braaten and others, 2012b).

The transition period from endogenous to exogenous feeding is generally termed the "critical period" because it is critical that the larva finds sufficient foods of the correct size and type to avoid starvation (Gisbert and Williot, 1997, 2002; Deng and others, 2003; Gisbert and Doroshov, 2003). The point-of-no-return (PNR) defines the maximum amount of time larvae have to either passively or actively find food (May, 1974). Defining the PNR may be beneficial for predicting larval survival in the contemporary Missouri River. Spawning location, temperature, flow, and to a great degree, velocity determine where larvae will settle and begin to search for food. Where larvae settle and first find food likely differs from the pre-dam period. Experiments at CERC in 2009 and 2012 have identified the PNR as occurring between 276 and 314 CTU post-hatch. Larvae receiving food at 314 and 353 CTU had greatly reduced size and survival ( $\leq 20$ percent). Those not receiving food were dead from starvation by $28 \mathrm{dph}$ at $19{ }^{\circ} \mathrm{C}$ with death occurring earlier at warmer temperatures (table 12).

Currently (2015), data do not indicate that food (mainly Dipterans from the family Chironomidae) is limiting survival of first-feeding pallid sturgeon in the Missouri River. In the Upper Missouri River, the release of nearly 600,000 freeembryo pallid sturgeon in 2004 (Braaten and others, 2008) and 2007 (Braaten and others, 2012a), and subsequent capture of survivors, provide the only source of information on feeding and growth dynamics of pallid sturgeon early life stages in natural settings. Larval pallid sturgeon have been reported to consume the larvae and pupae of Diptera and Ephemeroptera nymphs, exhibit growth rates of $1.9 \mathrm{~mm} /$ day during the initial 13-48 dph at water temperatures averaging $23.5^{\circ} \mathrm{C}$, and attain lengths of $120-140 \mathrm{~mm}$ by the end of September, before the onset of winter (Braaten and others, 2012b). Thus, at least for the Upper Missouri River, conditions can support feeding and growth of pallid sturgeon during the early life stages. Evidence that pallid sturgeon can survive or grow, however, does not suggest that conditions are optimum, or that the species is realizing its full potential for survival or growth. Specific 
information on pallid sturgeon feeding and growth is lacking for other regions of the Missouri River and Mississippi River.

Few studies have assessed habitat use characteristics of age- 0 pallid sturgeon, and limited information is available to discern habitat requirements. In the Upper Missouri River, Braaten and others (2012) collected 10 age- 0 pallid sturgeon $(19-87 \mathrm{~mm}$ ) surviving from the free-embryo release studies. The age-0 pallid sturgeon were collected at sites where minimum depth varied from $1.0 \mathrm{~m}$ to $4.3 \mathrm{~m}($ mean $=2.9 \mathrm{~m})$ and maximum sample depth varied from $1.5 \mathrm{~m}$ to $5.6 \mathrm{~m}$ (mean $=4.3 \mathrm{~m})($ David Fuller, Montana Fish Wildlife and Parks, written commun., 2012). Four presumed age-0 pallid sturgeon (identification based on morphometrics and meristics rather than genetics) were sampled in the Mississippi River from habitats where mean bottom velocity was $0.25-0.65 \mathrm{~m} / \mathrm{s}$ and depth varied from 2.7 to $3.6 \mathrm{~m}$ (Hrabik and others, 2007). In laboratory settings, young pallid sturgeon $(27-200 \mathrm{~mm})$ tend to select sand substrates and deep water habitats (Allen and others, 2007).

Given the rarity of age- 0 pallid sturgeon, some research in the Missouri and Mississippi Rivers has focused on the biology, ecology, and habitat selection of age-0 shovelnose sturgeon and undifferentiated Scaphirhynchus spp. to make inferences about pallid sturgeon (Braaten and Fuller, 2007; Braaten and others, 2007; Kappenman and others, 2009; Tripp and others, 2009; Ridenour and others, 2011; Phelps and others, 2012a; Phelps and others, 2012b; Sechler and others, 2012, 2013). Results from shovelnose sturgeon and undifferentiated Scaphirhynchus spp. suggest some commonalities to known information from pallid sturgeon (for example, feeding and growth), but the extent to which inferences comprehensively depict the early life ecology and habitat requirements of pallid sturgeon is unknown.

Most studies linking catches of age- 0 pallid and shovelnose sturgeon to habitats have been based on measures of depth, velocity, or substrate in the vicinity of nets or trawls, stratified by meso- or macro-habitat units (Ridenour and others, 2011; Sechler and others, 2012). These habitat characterizations help define conditions at sampling locations where fish are found, but fail to address aspects of habitat complexity, dynamics, and interactions and exchanges among habitats. Preliminary studies of the habitat context associated with age-0 Scaphirhynchus larval trawl catches on the Lower Missouri River have focused on detailed and continuous maps of bathymetry and velocity fields (DeLonay and others, 2014). These studies provide an understanding of the hydraulic processes responsible for transport and retention of small fish, plankton, and organic matter as well as providing a more general understanding of habitat use compared to availability (fig. 61). Suitability and interactions of channel-margin habitats vary considerably with discharge, indicating a need for well-informed hydraulic models to quantify availability through time and to relate to flow regime. Availability of conventionally delineated SWH units (serving as an operational metric for age-0 sturgeon habitat) in channelized river segments can be sensitive to discharge at very low flow but 


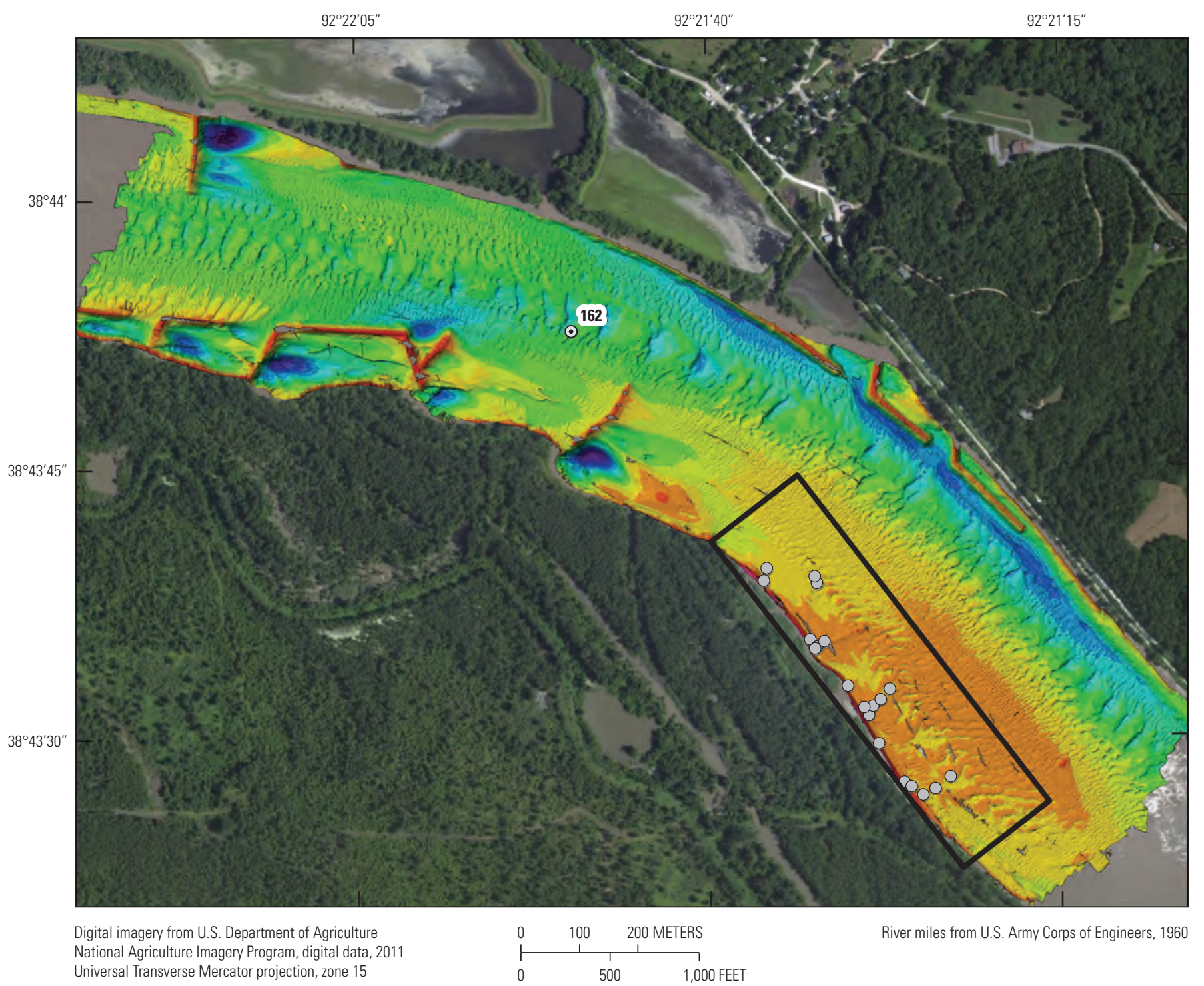

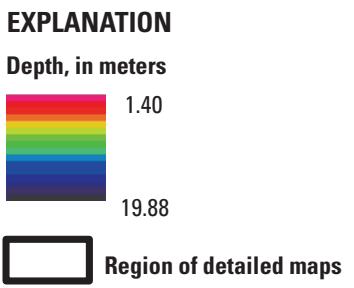

Trawl locations-Trawls conducted by the U.S. Fish and Wildlife the stop and start points of trawl samples

${ }^{162} \odot$ River-mile marker-Number is distance upstream from the
confluence with the Mississipp River, in miles

Discharge on the dates of survey,

August 18, 2011, at the U.S. Geological Survey streamgage 06909000 at Boonville, Missouri, was 195,000 cubic feet per second

Figure 61. Multibeam bathymetry near river mile 162 and U.S. Fish and Wildlife Service age-0 sturgeon sampling trawl endpoints. Mapped on August 18, 2011. The bedform orientations indicate that the area is a zone of transport of sediment and other constituents from the main channel to the channel-margin habitat. From DeLonay and others, 2014. 
insensitive to higher flows until they go overbank (Jacobson and others, 2009). In a nonchannelized reach of the Lower Missouri River and in restored reaches, SWH is more abundant for a wide range of discharge (Jacobson and Galat, 2006; Jacobson and others, 2009b). These results indicate that SWH is amenable to quantification and restoration, but the existing linkages between SWH and conditions that affect pallid sturgeon survival and recruitment are poorly described. Existing occupancy and growth/survival data for age-0 sturgeon are not sufficient to conclude that SWH captures the full complement of habitat conditions that are supportive of age- 0 sturgeon.

Field and laboratory studies have been done to elucidate potential factors limiting survival of pallid sturgeon during the early life stages. In the Upper Missouri River Basin, fragmentation induced by dam and reservoir construction has emerged as a leading hypothesis eliminating survival of pallid sturgeon. Specifically, as pallid sturgeon free embryos require an extended length of free-flowing river downstream from hatch locations to complete development (Kynard and others, 2007; Braaten and others, 2008; Braaten and others, 2012a), reservoirs prematurely terminate the drift period, disrupting the natural drift and dispersal processes of pallid sturgeon. The specific mechanism(s) of mortality in reservoir environments is unknown, but likely includes factors acting on the free embryo or larval life stage or both. As applied to the Lower Missouri River where dams are not present, extended drift requirements of free-embryo pallid sturgeon coupled with increased velocities of the river could transport Missouri River-spawned free embryos to the Mississippi River where the transition to exogenous feeding would occur (fig. 59) (DeLonay and others, 2009; Phelps and others, 2012b). In this situation, the lack of exogenous-feeding and age-0 pallid sturgeon in the Missouri River would not necessarily reflect mortality in the Missouri River, rather physical transport out of the system. Age-0 pallid sturgeon (as confirmed with genetic testing) are exceptionally rare in the Mississippi River (Boley and Heist, 2011), possibly indicating that spawning is limited or that survival during the early life stages is low.

Predation is well-recognized as a source of mortality acting on fishes during the early life stages (Houde, 2008); however, the role of predation on the exogenous-feeding and age- 0 life stages of pallid sturgeon has received limited inquiry. In the Upper Missouri River, gut contents of several potential predators (burbot, Lota lota; channel catfish, Ictalurus punctatus; freshwater drum, Aplodinotus grunniens; goldeye, Hiodon alosoides; northern pike, Esox lucius; sauger, Sander canadense; shovelnose sturgeon; and walleye, Sander vitreus), did not reveal remains or any evidence that age-0 Scaphirhynchus spp. were consumed (Braaten and Fuller, 2002). French and others (2010) completed laboratory trials with age-0 pallid sturgeon and fathead minnows (Pimephales promelas) as prey, and flathead catfish (Pylodictis olivaris), smallmouth bass (Micropterus dolomieu), and walleye as potential predators. The authors concluded that predation risk from smallmouth bass and walleye was low on pallid sturgeon when an alternative prey type was available; however flathead catfish consumed larval pallid sturgeon $40-50 \mathrm{~mm}$ in length in proportion to their availability. Flathead catfish introduced into the Satilla River, Georgia have been reported to consume Atlantic sturgeon (Acipenser oxyrinchus) to as much as $160 \mathrm{~mm}$ (Flowers and others, 2011) raising concerns that predation by catfish may be responsible for the decline of native sturgeons. Flathead catfish are a prominent native predator in the Lower Missouri River, and have been documented to consume sturgeon (Hogberg, 2014).

\section{Population Augmentation}

Recapture data of hatchery progeny released as larvae in the Yellowstone and Upper Missouri Rivers suggest that survival rates from the larval stage through winter to age 1 range from 32 to 79 percent (Jay Rotella, Montana State University, written comm., 2012). This suggests that pallid sturgeon population augmentation at the larval stage is a possible strategy if suitable habitats are available. What constitutes suitable habitat for larval sturgeon remains a challenging obstacle for designing augmentation strategies. At regional scales augmentation of populations with larval (or older) fish may be more effective if release locations are based on an understanding of where free embryos and larval fish would tend to settle out from the drift under natural conditions or, in the engineered and fragmented river, where the larvae would settle out downstream from contemporary spawning locations.

\section{Flow Regime Management}

Provided that the present understanding of what constitutes suitable habitat for larval pallid sturgeon is accurate, analyses indicate those habitats are relatively insensitive to flow regime in the Lower Missouri River, except at extremely low discharge or flood discharges that are generally outside of flow-management options (Jacobson and Galat, 2006; Jacobson and others, 2009b). Understanding of sensitivity to flow regime may change as refinements are made in understanding habitat suitability for this life stage. In the Upper Missouri River, flow regime management would not be relevant to the larval life stage for most conditions because survival of the embryo and free-embryo stages appears to be limited by drift distance. An exception would be if Lake Sakakawea were managed to reduce water levels and extend the available drift distance, provided that extended fluvial conditions in the upper end of the reservoir resulted in suitable flow and substrate conditions for larval sturgeon. The amount of additional drift distance needed and the extent of the drawdown necessary to attain that length of additional river has not been determined.

\section{Channel Re-Engineering}

Channel re-engineering can change hydraulic complexity and the ranges of depth, velocity, and substrates available to larval pallid sturgeon. Providing more larval and juvenile 
habitat has been one of the reasonable and prudent alternatives of the Missouri River Biological Opinion (U.S. Fish and Wildlife Service, 2000, 2003) and one of the main objectives of the SWH component of the Missouri River Recovery Program. Although progress is being made toward the eventual goal of 20-30 acres per mile of SWH, the biological results have been equivocal (Schapaugh and others, 2010), and concerns have been raised that the operational definition of $0-5 \mathrm{ft}(0-1.75 \mathrm{~m})$ and $0-2 \mathrm{ft} / \mathrm{s}(0-0.6 \mathrm{~m} / \mathrm{s})$ ignores ecological complexity and may result in nonfunctional acreage (National Research Council, 2011). A process-based understanding of how abiotic and biotic processes are linked in channel-margin habitats would provide improved guidance to channel re-engineering so it will contribute to growth and survival of larval (and older) pallid sturgeon.

\section{Juvenile Life Stage}

The juvenile life stage consists of sexually immature fish (table 1). The juvenile life stage extends until the fish begins gametogenesis and enters its first reproductive cycle. During this period, the juvenile pallid shifts its diet from insects to fish (Gerrity and others, 2006; Grohs and others, 2009). Substantially greater amounts of information are available for juveniles compared to free embryo and larval life stages because of information collected in the field from hatchery-raised fish and because juveniles are amenable to laboratory experiments.

\section{Habitat Requirements}

Observed conditions where pallid sturgeon have been collected as part of the Pallid Sturgeon Population Assessment Program (PSPAP) between 2003 and 2010 (Welker and Drobish, 2009) provide notable differences between juveniles and adults that suggest differences in habitat use (fig. 62). During late spring through fall, juveniles found in the Missouri River above Gavins Point Dam tended to be collected in cooler temperatures than adults, with the reverse pattern observed below Gavins Point Dam. However, during this same season, juveniles tended to be collected in shallower, slower water than adults throughout the river. During late fall through early spring, throughout the river, juveniles tended to be collected in warmer water than adults with depth differences still present but not as dramatic as observed during late spring through fall, and with no obvious differences in velocity.

Concentration of juveniles in habitats that are shallower and slower than the main channel may expose them to elevated risks associated with water quality. In particular, episodes of decreased dissolved oxygen ("sags") and seasonal warm temperatures in the Lower Missouri River in recent years at USGS streamgaging stations have approached the limits of physiological tolerance for juvenile pallid sturgeon (Blevins, 2011). DeLonay and others (2009) also observed these oxygen sags during their telemetry studies of adult pallid sturgeon. If such extreme conditions were to become more widespread and persistent, it is unknown to what extent juvenile sturgeon would be able to find water-quality refugia within the well-mixed contemporary Missouri River channel.

For early juvenile stages, restricted availability and intake of food may reduce growth rates, alter distributions, and limit densities of individuals across habitat types (Deng and others, 2003). Therefore, viability through this life stage is primarily affected by predation, competition with other insectivorous species for available, appropriate food and habitat (Wildhaber and others, 2011a).

Growth of juvenile pallid sturgeon to adults is highly affected by diet composition (Grohs and others, 2009) with chironomids (Order: Diptera) and mayflies (Order: Ephemeroptera) serving as important components of early juvenile diets (Sechler, 2010; Sechler and others, 2013). Pallid sturgeon diets shift from macroinvertebrates to fish as they grow. Juvenile pallid sturgeon between 350 and $500 \mathrm{~mm}$ fork length (FL) have been documented to have diets that consist of 57 percent fish, whereas juvenile pallid sturgeon greater than $500 \mathrm{~mm}$ FL consumed 90 percent fish (Gerrity and others, 2006; Grohs and others, 2009). Isotope analyses of pectoral spines support gut analyses and indicate that the diet shift of juvenile pallid sturgeon from invertebrates to principally fish likely occurs at or before $500 \mathrm{~mm}$ FL, well before pallid sturgeon reach reproductive maturity (French, 2010).

Mortality of early juvenile stages (that is, late stage age- 0 larvae) appears to be primarily driven by prey availability; most research focuses on juvenile health as it relates to nutrient sources rather than physical habitat (Wildhaber and others, 2011a). However, alterations to physical habitat including longitudinal fragmentation by reservoirs, temperature reductions below dams, channelization, and bank stabilizations likely reduce the production and retention of food (Wildhaber and others, 2011a). This was particularly evident in the Mississippi River in 2006, a year that represented high water temperatures and low stage heights. During this period about 30 percent of age-0, wild-caught Scaphirhynchus spp. were determined to have empty stomachs. Similar sampling efforts in years with greater discharge and lower temperatures (considered to be more hydrologically favorable) typically yielded 1-8 percent of age-0 fish with empty stomachs (Sechler, 2010).

Limited prey sources increase mortality and may suppress growth in surviving juveniles (Deng and others, 2003; DeLonay and others, 2009). No clear relations have been documented between abiotic factors (for example, water temperature) and pallid sturgeon recruitment, but early diet and growth are considered to affect recruitment into adult, spawning populations (DeLonay and others, 2009; Sechler, 2010). Studies of other fish diets, including the similar shovelnose sturgeon, have reported that higher river stages are associated with increased levels of food intake (Held, 1969; Modde and Schmulbach, 1977). Higher river stage may increase and improve foraging habitat, and reduce competition among individuals (Sechler and others, 2013) or improve physical conditions for prey production or foraging, such as water temperature and turbidity (Blevins, 2011). The decrease of turbidity 
July 1-0ctober 31 Sampling Season
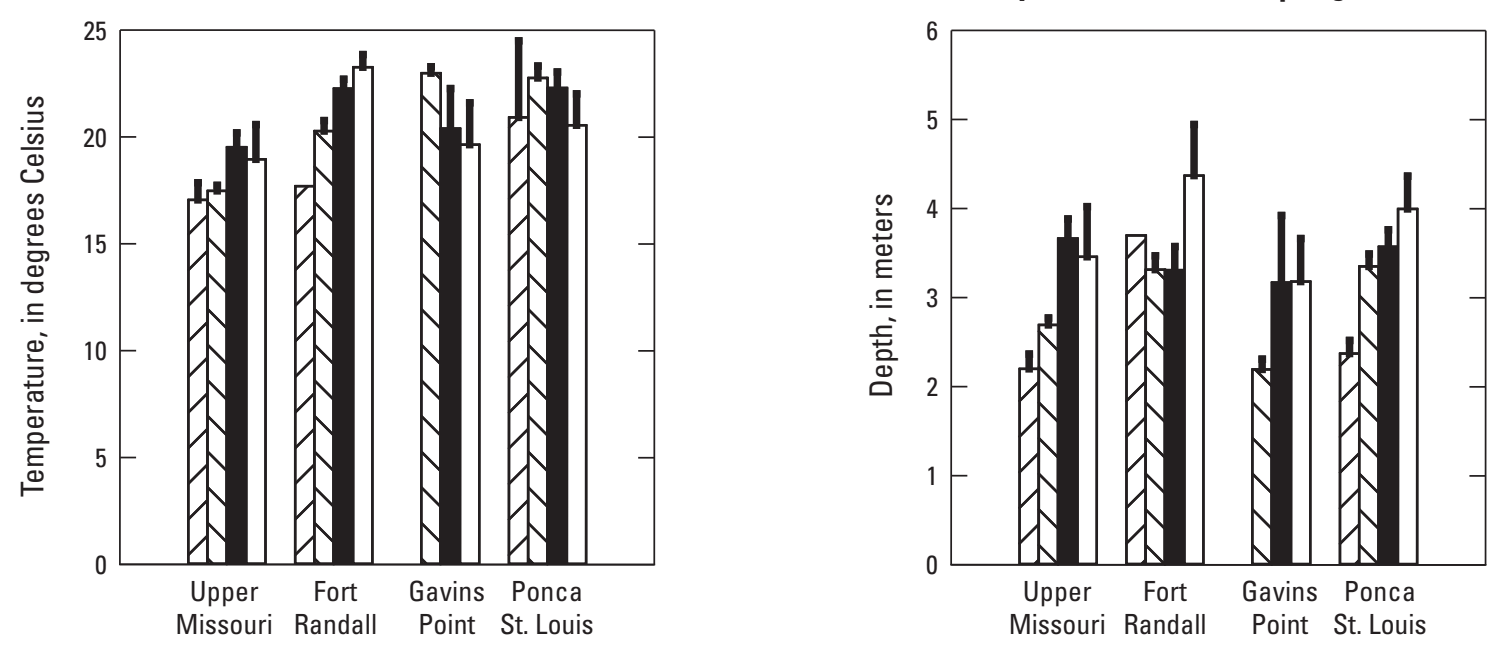

November-End of June Sampling Season

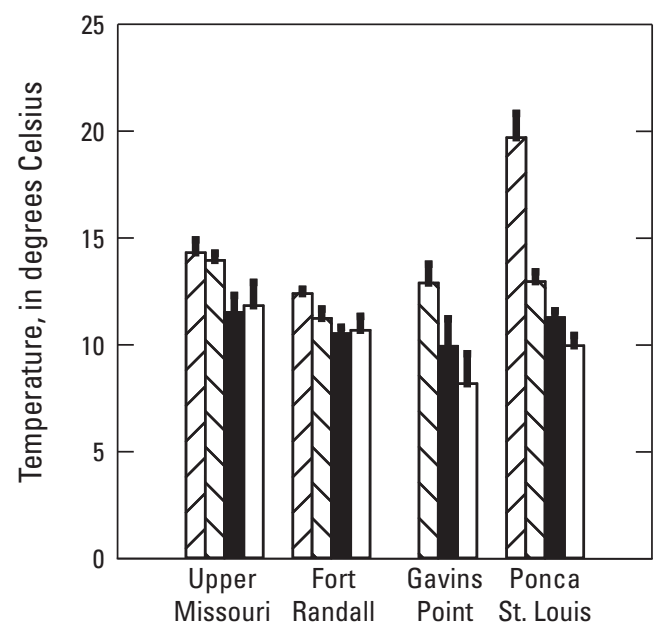

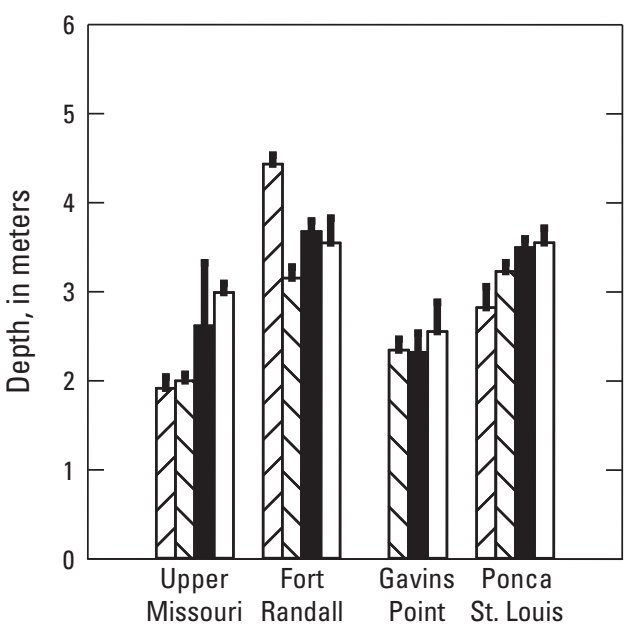

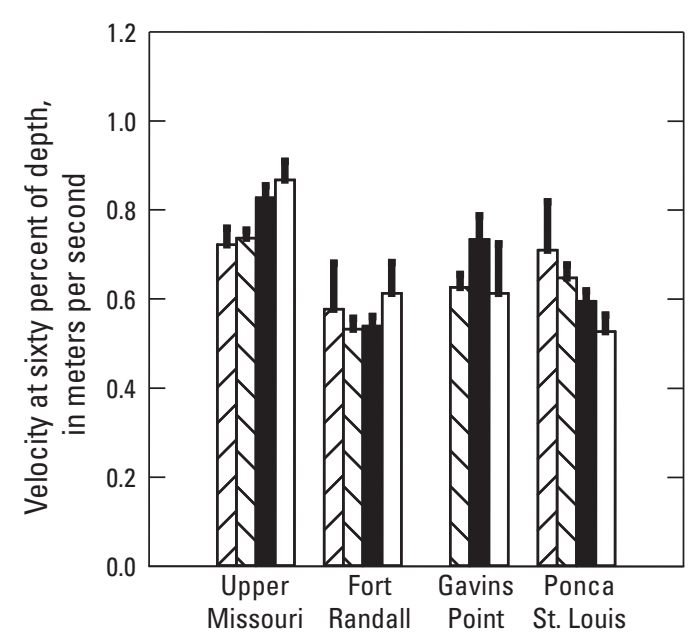

EXPLANATION

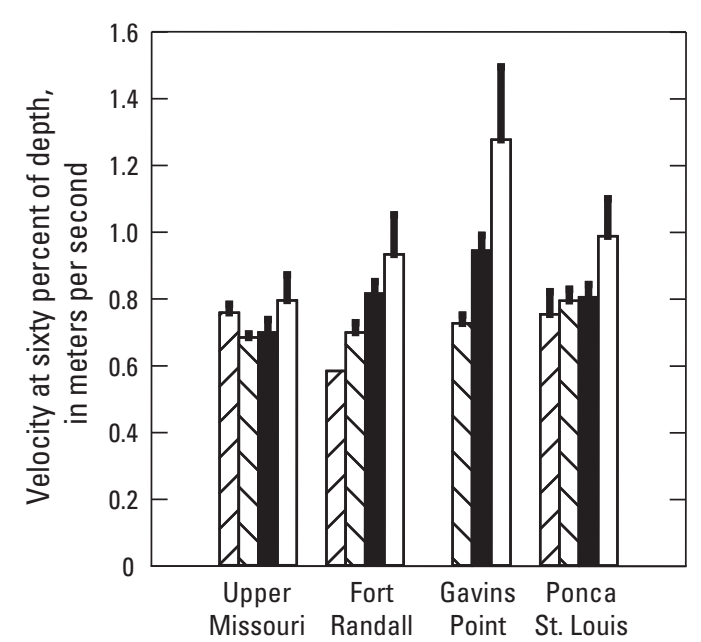

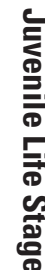

Figure 62. Mean and standard deviation of riverine habitat characteristics when pallid sturgeon were captured in the Pallid Sturgeon Population Assessment Program from 2003 to 2010. Fish are grouped by sample segments, season, and length categories where data used are from the randomized sampling protocol. 


\section{Ecological Requirements for Pallid Sturgeon Reproduction and Recruitment in the Missouri River-2005 to 2012}

in the Missouri River due to anthropogenic alterations has improved conditions for species that may be in competition with juvenile pallid sturgeon for similar food sources and potential pallid sturgeon predators (Blevins, 2011; Wildhaber and others, 2011a). Juvenile pallid sturgeon are easily captured by potential predators but, in laboratory settings, do not seem to represent a preferred prey source if other options exist (French and others, 2010).

\section{Competition}

To ensure adequate growth and survival of young sturgeon, food availability must be high, whereas competition and predation risk must be low for these life stages to recruit successfully to the adult population within any given river reach. Sturgeon are subject to intra- and interspecific competition at each life stage because of the number of benthic species found in the Missouri River (Berry and others, 2004; Wildhaber and others, 2012), all of which may be competing directly for space and food resources. Each of these benthic species may use slightly different habitat, food resources, or feeding strategies to reduce competition and improve foraging success; however, in highly modified habitats the availability and distribution of food resources may reduce foraging success of some species and thereby increase competition. Recent field studies have demonstrated that juvenile pallid and shovelnose sturgeon use the same habitat during nonwinter periods when rates of food consumption and growth are expected to be greatest (Gerrity and others, 2008). Studies of white sturgeon in the Kootenai River (not shown) report evidence of density-dependence mortality among hatchery-stocked juvenile sturgeon during the first year of life, possibly as a result of competition for food or habitat resources, or increased predation (Justice and others, 2009).

Diet studies of juvenile shovelnose and pallid sturgeon indicate that both feed primarily on invertebrates including chironomids, trichopterans, and ephemeropterans (Hoopes, 1960; Held, 1969; Modde and Schmulbach, 1977; Gerrity and others, 2006; Braaten and Fuller, 2007; Hoover and others, 2007; Wanner and others, 2007). The specific mode of feeding, the ability of young sturgeon to feed on drifting organisms, and the effects of temperature, turbidity, and substrate on feeding have not been thoroughly examined. This information is critical to understanding the relation between habitat and survival of early life history pallid sturgeon.

Evidence (Gerrity and others, 2006; Hoover and others, 2007) exists for several Macrhybopsis chubs as important prey items for pallid sturgeon adults. Since adult chubs likely use the same habitats and food resources they also may be predators and competitors of pallid sturgeon during early life stages. Recently, populations of several of these chub species have declined (Hesse and others, 1989; Galat and others, 2005a), which may hinder growth and development in adult pallid sturgeon while simultaneously decreasing competition for early juveniles.
Food availability is a potentially limiting factor that is confounded with questions of habitat availability and competition. Even if juvenile pallid and shovelnose sturgeon are able to find preferred habitat with minimal competition, poor growth and survival will result if the necessary food resources are not present in those habitats. The complexity of the Missouri River makes it nearly impossible to document factors affecting food availability and habitat selection of juvenile shovelnose and pallid sturgeon in the wild (DeLonay and others, 2009; Reuter and others, 2009; Bonnot and others, 2011a). Therefore, these factors are commonly investigated in the laboratory under controlled conditions.

A laboratory study was done to understand habitat and food selection of juvenile sturgeon and the shoal chub (Macrhybopsis hyostoma). The objective of this study was to assess habitat choice as it relates to food availability, examining the strength of substrate selection in the presence of food and whether that selection changed with varying levels of turbidity. The purpose of studying both sturgeon species along with shoal chubs was to gain a better understanding of the potential competition for resources between species and whether or not management actions affect the species differently.

The CERC laboratory study consisted of a series of 24 isolated aquaria each equipped with their own computercontrolled lighting (visual and infrared) and heating system. Each tank was assigned a random combination of clay and sand substrate relative to tank side, resulting in a half clay/ half sand, tank bottom. One fish was placed in each tank and tanks were continuously monitored using a closed-circuit camera and digital video recorder. To test light intensity as a surrogate for turbidity the tanks were randomly assigned to two treatments. One set of tanks was kept in continuous darkness (monitored with infrared), whereas the second set of tanks were on a 12 hour light: 12 hour dark cycle. To test food consumption (that is, growth rates), one-half of each of the two lighting groups were fed a maximum ration daily, whereas the other one-half was fed one-half of that maximum ration. To test the effect of food on substrate choice, delivery of food to a given substrate type (that is, clay or sand) was randomized among tanks and compared to habitat choice without food. Pallid and shovelnose sturgeon tended to forage on clay compared to sand, at least under zero velocity conditions. Shoal chubs reported less substrate-related selection, but similarity in habitat choice among all three species indicated that there is potential for competition and, thus, possible limitations of habitat and food resources (fig. 63). These results provide initial data needed to model the potential population impacts of these behaviors in the context of available food and habitat present in the Lower Missouri River. This information is useful for developing the submodel for this life stage in the overall sturgeon population model (Bajer and Wildhaber, 2007; Wildhaber and others, 2007a, 2011a) as part of a larger adaptive management approach directed at increasing pallid sturgeon populations through habitat alteration within the Missouri River. Additional data are needed to determine if sturgeon at this life stage forage in groups and use social cues 

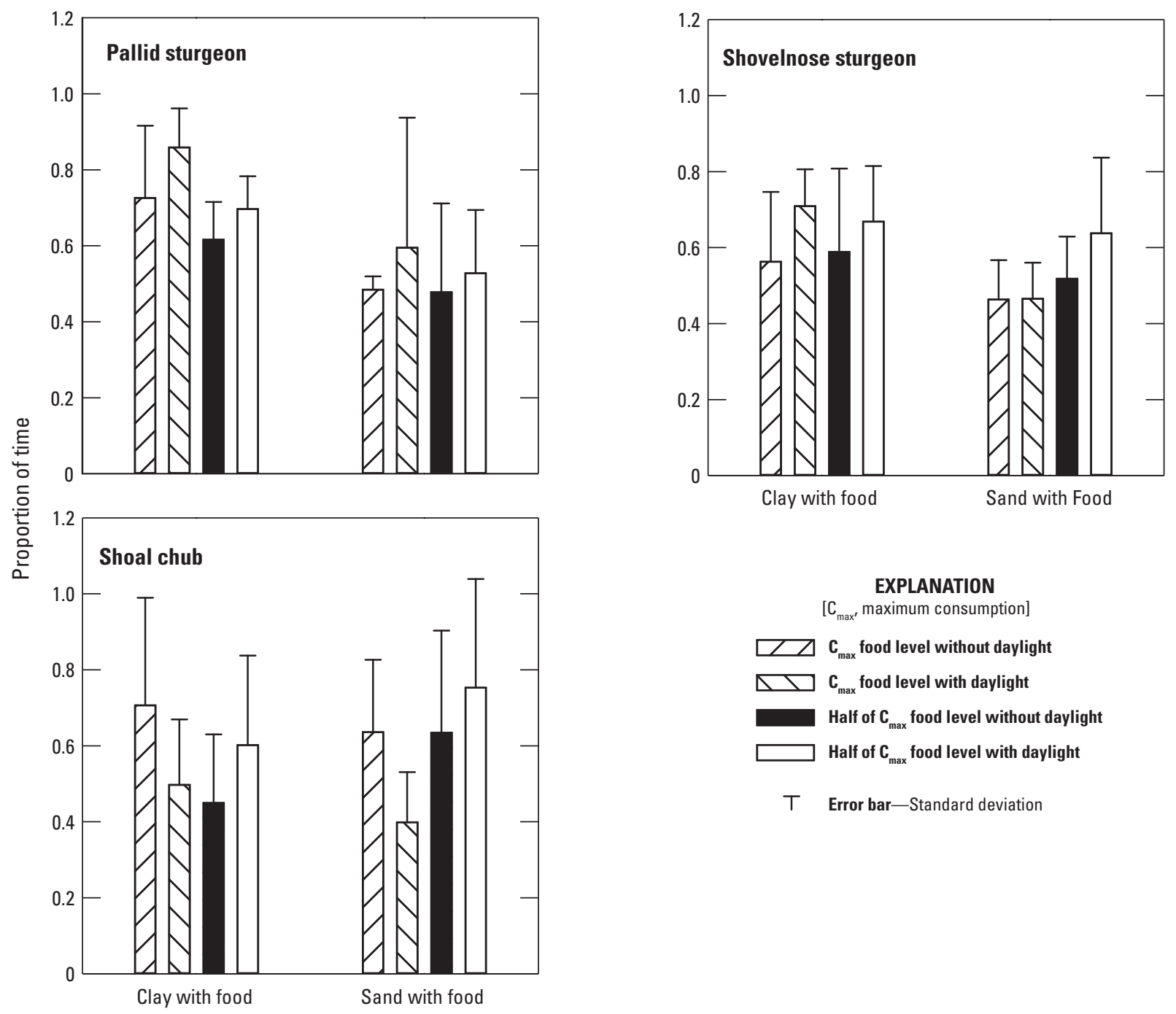

Figure 63. Proportion of time fish were active in clay and sand treatments with food. Treatments consisted of food fed at maximum consumption $\left(\mathrm{C}_{\max }\right.$ ) or one-half of maximum consumption with or without daylight.

to find and exploit resources more effectively. An additional submodel would be required if social interactions are shown to have significant benefits.

\section{Survival of Juveniles}

Survival rates of stocked pallid sturgeon in the highly altered Lower Missouri River have been estimated to be $0.051(\mathrm{SE}=0.008)$ for age- 0 fish and $0.686(\mathrm{SE}=0.117)$ for age-1 fish (Steffensen and others, 2010). Pallid sturgeon in the Lower Missouri River typically are stocked as age-1, juvenile fish at 9 inches $(23-\mathrm{cm})$ or larger. Some stocking has occurred using older, larger fish. The survival rate of age-1+ fish increased to $0.922(\mathrm{SE}=0.015)$ (Steffensen and others, 2010).

Population augmentation practices have resulted in concentrations of surviving stocked fish in the upper part of the Lower Missouri River where they had been stocked, whereas no such concentration of stocked fish occurs in the part of the Lower Missouri River near its mouth where stocking also occurred (Scott Holan, University of Missouri, written commun., 2014). The latter observation may suggest higher mortality or dispersal or both to the Mississippi River for age- 0 and age- 1 hatchery-reared pallid sturgeon stocked in the lower part of the Lower Missouri River. In contrast, a 2-year study with radio-tagged juveniles in the Upper Missouri River determined that stocked sturgeon did not disperse immediately (Oldenburg and others, 2011). These observations suggest that the locations chosen for stocking may be critical to improving survival.

\section{Population Augmentation Management}

Under the Propagation and Stocking Plan for the pallid sturgeon the U.S. Fish and Wildlife Service recommends stocking age-1 fish at a rate of 24.5 fish per river kilometer 
per year in the Lower Missouri River and limiting offspring stocked from a single female to 10,000 individuals (U.S. Fish and Wildlife Service, 2008). The success of these stocking efforts is dependent on the consistent augmentation efforts that preserve the genetic diversity of populations, while stocking progeny that will survive to contribute to subsequent generations to increase the effective population size. Whereas environmental factors and stocking locations have the potential to affect the survivorship of juvenile pallid sturgeon, survival rates may be high and there is no documented evidence that habitat, food availability, or competition limits this life stage. Thus, recruitment failure may be occurring before pallid sturgeon transition to the juvenile stage.

\section{Flow Regime}

To the extent that flow regime affects spawning locations of reproductive adults and, therefore, the starting point for downstream drift, flow regime may indirectly affect where larval fish settle and the river location where juvenile life stage begins. Within that location, flow regime may affect availability of habitat types. The areas where age- 0 pallid sturgeon (early juveniles mostly less than $100 \mathrm{~mm}$ fork length) have been documented on the Lower Missouri River $(0.5-0.7 \mathrm{~m} / \mathrm{s}$ velocity near the bottom and 2-3 m depth; Ridenour and others, 2011) are sensitive to discharge variation at low flows and overbank flows. In the highly engineered Kansas segment of the Lower Missouri River, these habitats decrease substantially with increasing discharge, especially at discharges greater than 75 percent of the median. Whereas, in the more natural channel morphology of the Gavins segment, these habitats increase substantially with increasing discharge, peaking at about the median discharge (Jacobson and others, 2009b). Importantly, data on habitat occupation of juveniles are limited on the Missouri River and have not been related directly to availability to determine selection. Moreover, habitat occupations in the highly altered Lower Missouri River cannot be assumed to represent ideal locations (Wildhaber and others, 2011a). Although present (2015) information does not indicate that physical habitat is a limiting factor for juvenile growth and survival at current low densities, it is possible that food transport into habitat areas or habitat-mediated competition is affected in part by flow regime.

\section{Channel Re-Engineering}

Re-engineering of channel morphology of the Lower Missouri River has focused on establishing SWH with the goal of increasing rearing habitat for larval and juvenile pallid sturgeon (U.S. Fish and Wildlife Service, 2007). Age-0 sturgeon, pallid and shovelnose, have been most frequently recorded around dikes and island areas and rarely are observed in the main channel, however depths and velocities in these areas tend to be greater than those defined for SWH in the Lower Missouri River (Phelps and others, 2010a; Ridenour and others, 2011). Age-1 and older juvenile-specific habitat use is rarely recorded but is probably no shallower or slower than that used by early-stage juveniles. Channel re-engineering has been reported to be effective in creating SWH and increasing habitat complexity (Jacobson and Galat, 2006) but, as noted above, the linkages to growth and survival of pallid sturgeon juveniles have not been established. Evidence suggests that channel re-engineering activities themselves, such as use of cutter-head dredges, may in specific cases lead directly to increased juvenile mortality (Hoover and others, 2011), although the long-term benefits of habitat creation may outweigh short-term losses of individuals.

\section{State of Scientific Understanding of Pallid Sturgeon Ecological Requirements and Implications for River and Species Management}

In this section we discuss the present (2012) state of scientific understanding of pallid sturgeon ecological requirements, information gaps, and the application of ecological understanding to restoration and management decisions. We begin with the broad subject of pallid sturgeon genetics across the landscape, followed by focused discussion about what we know and what we do not know about ecological requirements and survival of reproductive adults, hatch to larval life stages, and YOY to juvenile life stages. We complete this section with discussion of applications of ecological information to the types of river restoration and management actions under consideration on the Missouri River to retain genetic diversity.

\section{Landscape Scale Genetics}

Development of genetics methods, decreased analysis costs, and concerted genetic sampling efforts have resulted in broadened understanding of genetic structuring of the pallid sturgeon throughout the past 5 years (Schrey and Heist, 2007; Eichelberger and others, 2014). Documentation of genetic structure is central to population augmentation strategies. Moreover, understanding how genetically defined subpopulations formerly and presently (2015) relate to the template of physical habitat is critical to understanding where and what types of habitats need to be restored on the Missouri River.

\section{State of Understanding}

Genetic studies have suggested rangewide genetic structuring of pallid sturgeon populations (Campton and others, 2000; Tranah and others, 2001; Schrey, 2007; Schrey and Heist, 2007). These data indicate that genetic 
structuring of pallid sturgeon populations is natural and predates anthropogenic migratory barriers (Schrey, 2007; Schrey and Heist, 2007), suggesting that reproductive isolation was established before construction of the dams on the Missouri River. The historic genetic structure likely has been altered by past stocking of juvenile pallid sturgeon that transferred genetic stocks from the Middle Mississippi and Upper Missouri Rivers into the Lower Missouri River (Schrey and Heist, 2007).

Genetic introgression (hybridization) between pallid and shovelnose sturgeon has been occurring for several generations (Carlson and others, 1985; Tranah and others, 2004; Schrey and others, 2011). Evidence of genetic introgression has been reported in all management units, but appears to be highest in the southern extreme of the range (Schrey and others, 2011). Reproductive studies using telemetry by the CSRP have included genetically determined hybrid sturgeon and have confirmed that they spawn in the Lower Missouri River. Studies for the CSRP have been unsuccessful in collecting pallid sturgeon free embryos below known spawning sites and from continually sampled stations near the mouth of the Missouri River, but hybrid pallid/shovelnose sturgeon have been found in both types of collections (appendix 7).

\section{Information Gaps}

Studies are underway to better characterize the rangewide genetic structure of wild pallid sturgeon (wild is used here to denote fish that have been spawned in the river naturally, without human intervention). It is not known, however, what mechanisms were responsible for creating or sustaining the pre-dam structure on the landscape, or whether measured genetic differences translate into important locally adapted traits that affect growth and survival (Meyer, 2011). Various spatial, temporal, and biological factors may have acted alone or in concert to create the observed population structure, and it is unclear whether those factors and their effect remain intact in the altered Missouri River system.

Additionally, the degree to which the historic genetic structure has been affected by the substantial intra-basin transfer of genetic stocks in past population augmentation efforts is not clearly understood at this time (Krentz and others, 2005; U.S. Fish and Wildlife Service, 2008). The effect of population augmentation on genetic structure may become apparent soon as numbers of hatchery-origin fish exceed wild pallid sturgeon and begin spawning (DeLonay and others, 2009).

Reproductive interactions between pallid sturgeon and the more common and sympatric shovelnose sturgeon are poorly understood at this time. The geographic extent, distribution, and rates of hybridization between the two species and the threat of hybridization to the recovery of pallid sturgeon across the range of the species are poorly understood (Schrey, 2007).

\section{Information Needs}

A more robust understanding of the pre-dam, rangewide genetic structure of the pallid sturgeon population is needed to evaluate the necessity for the delineation of distinct population segments (DPS), as described in the revised Pallid Sturgeon Recovery Plan (U.S. Fish and Wildlife Service, 2014). The Pallid Sturgeon Conservation Augmentation Program (PSCAP) requires population genetics structure information to guide the selection of individuals for use as broodstock within the management units where propagation is advisable (U.S. Fish and Wildlife Service, 2008). Genetic structure information, combined with knowledge of spawning locations and the early life history and dispersal of young sturgeon from spawning sites (defining the population's functioning geographic range), would provide the data necessary to devise the best possible strategies for population augmentation. Improved movement and distribution data for hatchery progeny would provide managers with information necessary to balance the risks and benefits of population augmentation in genetically structured populations to best retain local geographic adaptations.

Although spawning of hatchery-origin pallid sturgeon has been documented (DeLonay and others, 2009; DeLonay and others, 2010; DeLonay and others, 2012; DeLonay and others, 2014), it is unknown whether they respond to environmental spawning cues and available habitat in a similar manner as wild fish. More information is needed to evaluate the relative contribution of hatchery-origin fish to reproduction, recruitment, and recovery.

Information necessary to determine the consequences of hybridization is lacking. Mechanisms that contribute to hybridization may include low population densities, barriers to migration, altered spawning habitat, and disrupted environmental cues that would ordinarily serve to synchronize reproductive readiness and behavior in unaltered systems. Given the longitudinal life history of the pallid sturgeon documented by CSRP studies, the presence of substantial numbers of hybrid sturgeon in the Middle Mississippi River would suggest that hybridization by spawning adults is a concern on the Lower Missouri River (appendix 7). No comprehensive studies examining the extent and cause of hybridization currently (2015) exist on the Missouri River and proposed management actions rarely consider preventing hybridization or curtailing the potential threat as an explicit objective.

\section{Reproductive Adults and the Spawning Population}

The Missouri River biological opinions (U.S. Fish and Wildlife Service, 2000, 2003), sturgeon science workshops (Quist and others, 2004; Bergman and others, 2008), and the 2005 Spring Rise Plenary Group process (Jacobson and Galat, 2008) all put substantial emphasis on the need to understand adult sturgeon reproductive requirements. As a result, CSRP research prioritized understanding of basic reproductive biology, starting with adults. 


\section{State of Understanding}

Little was known about pallid sturgeon reproduction before 2005. No spawning had been documented outside of hatcheries, nor had migratory strategies been described or spawning habitats identified. Telemetry tracking and repeated recapture of telemetered individuals over several years have been instrumental in providing insight into the reproductive behavior and ecology of pallid sturgeon (DeLonay and others, 2009). Presently (2015) we know that wild and hatchery-origin pallid sturgeon are surviving, growing, attaining reproductive maturity and spawning in the Missouri River. Gamete development requires several seasons in pallid sturgeon, and spawning likely occurs every 1 to 3 years for males and 2 to 5 years for females. Atresia resulting from disrupted reproductive development and the failure of gravid females to release eggs is more common in the upper study section of the Lower Missouri River, near Gavins Point Dam than in other study sections. Fecundity of telemetry females in this study section is lower as well, commonly 50 percent lower than telemetered females in the lower study section (DeLonay and others, 2012; DeLonay and others, 2014).

Pallid sturgeon have the capacity to migrate long distances upstream to spawn and females spawn at the apex of their migration (DeLonay and others, 2009; DeLonay and others, 2010; DeLonay and others, 2012; DeLonay and others, 2014). Female pallid sturgeon exhibiting complex or disrupted upstream migration patterns tend to spawn later than females exhibiting the more typical migration pattern or may fail to spawn altogether. This behavior is especially notable in the upper study section of the Lower Missouri River, downstream from Gavins Point Dam and in the Upper Missouri and Yellowstone Rivers. Male pallid sturgeon exhibit more complex migratory patterns, perhaps because they are actively seeking suitable mates or attempting to spawn at multiple locations during the spawning period. Migrating pallid sturgeon in the lower study section of the Lower Missouri River migrate along inside bends, possibly to reduce energy expenditure during spawning by avoiding high velocities in the main channel. Pallid sturgeon in the upper study section of the Lower Missouri River, and Upper Missouri and Yellowstone Rivers do not have to contend with the high velocities similar to those in the lower study section of the Missouri River, and their migration pathways are less constrained. Reproductive pallid sturgeon in the Lower and Upper Missouri Rivers use constructed (Lower) and natural (Upper) side channel habitats in their upstream migrations.

Pallid sturgeon spawn in late-April through May on the Lower Missouri River, and in mid-June through early July on the Upper Missouri and Yellowstone Rivers when temperatures exceed $16-18{ }^{\circ} \mathrm{C}$ (Fuller and others, 2008; DeLonay and others, 2009; DeLonay and others, 2010; DeLonay and others, 2012; DeLonay and others, 2014). The distribution of spawning locations derived through intensive telemetry tracking indicates that pallid sturgeon are capable of spawning in most reaches of the main-stem Missouri River under a wide variety of conditions. Spawning also occurs in select tributaries, including the Platte and Yellowstone Rivers (DeLonay and others, 2014). Spawning habitat in the Lower Missouri River is characterized by deep, relatively fast and turbulent flow, on the outside revetted bends. Under the current (2015) management of the Lower Missouri River, this habitat is common and widespread. Pallid sturgeon on the Upper Missouri and Yellowstone Rivers spawn on gravel patches interspersed with compacted sand in deep, relatively fast flow. This habitat is presumed to be relatively rare on the Lower Missouri River. Sampling resulted in the collection of dispersing free-embryo pallid sturgeon on the Upper Missouri River in 2011, and the Yellowstone River in 2012. These collections document that conditions in those segments are suitable for the fertilization, survival, and hatch of pallid sturgeon eggs and embryos.

Data collected over several years on telemetered pallid sturgeon with known reproductive histories have revealed patterns of behavior. Repeated patterns of habitat use have been documented for male and female pallid sturgeon. Individual pallid sturgeon have been documented migrating to the same section of river to spawn with surprising affinity in the Lower Missouri River. These individuals tend to return downstream to a previously occupied bend or habitat patch following migration indicating a well-developed sense of spatial awareness in a highly altered open river system. Additionally, telemetered pallid sturgeon of both sexes have been documented migrating upstream in the Lower Missouri River during the fall before the initiation of a spring spawning migration, a behavior that has not been described in the Upper Missouri or Yellowstone Rivers.

Several reproductive abnormalities have been observed in shovelnose and pallid sturgeon collected in the Lower Missouri River (DeLonay and others, 2009). Intersex individuals with hermaphroditic gonads (either testis with developing eggs or ovary with small patches of testicular tissue) have been documented. Other abnormalities also have been observed, including individuals with one testicular lobe and one ovarian lobe, or individuals missing a lobe altogether, as well as teratomas (DeLonay and others, 2009). These observations led to the hypothesis that contaminants and water quality may have a role in diminished reproduction of pallid sturgeon.

\section{Information Gaps}

Although knowledge of pallid sturgeon spawning ecology and behavior has increased, many basic aspects remain unknown. Despite documentation of spawning across a broad geographic extent, it remains unclear whether it is occurring at appropriate locations, times, and under conditions that result in viable progeny. Diminished spatial and temporal spawning synchronicity would provide flexibility for pallid sturgeon to select suitable spawning habitat; conversely, spawning at many locations, distributed across a large geographic extent and for an extended time period, could serve to decrease the probability of finding suitable mates, and potentially encourage hybridization. Because no information is available on 
spawning habitat associations or habitat choice in a pristine, unaltered river, it is unknown whether or not the adequate spawning habitat of the pallid sturgeon is available under current (2015) management of the Missouri River.

Extremely high discharges during 2011 provided insights to pallid sturgeon responses to rare flood events, but also raised many questions. The fact that sturgeon uncharacteristically migrated up the Upper Missouri River, formed aggregations, and spawned (DeLonay and others, 2014) supports the hypothesis that sturgeon will respond to flow pulses when provided. But it is not known what specific combination of environmental factors (discharge, water temperature, turbidity) were responsible and whether functional flow pulses are within operational constraints of the Missouri River reservoir system.

Record high releases from Gavin Point Dam also occurred in 2011 and affected pallid sturgeon populations on the Lower Missouri River. Although flows came too late to alter migration and spawning, pallid sturgeon were found on and adjacent to inundated floodplains (DeLonay and others, 2014). Recaptured pallid sturgeon also demonstrated rapid increases in weight during 2011, but reexamination of the same individuals a year later indicated that much of the gains accumulated during the 2011 flood were lost after the drought of 2012. The loss in weight was not attributable to changes in gonad associated with spawning. The extent to which pallid sturgeon would exploit naturally inundated habitats during flood events or whether increased growth potential would be realized from greater access to the floodplain is not well established.

Pallid sturgeon on the Lower Missouri River are growing and do not appear to be starving, but the relation between forage availability and growth potential, condition, age at first reproduction, fecundity, and spawning periodicity is not known. Pallid sturgeon forage fish populations, consisting dominantly of native, turbid-adapted cyprinids, have declined substantially since the closure of the main-stem dams, and it is possible that there is a link between decline of forage species and pallid sturgeon reproductive condition. Additionally, the cause of intersex, how intersex develops, and the severity of intersex on reproductive behavior and viability are unknown.

Tracking of pallid sturgeon has demonstrated some spawning site fidelity, suggesting a role of geographic specificity in creating and maintaining genetic population structure. In the presence of strong site fidelity or natal affinities, management actions to benefit spawning and early life stages of pallid sturgeon should be aligned with where on the landscape spawning is occurring or can be successful. A high degree of affinity by a large river predator outside of the spawning period suggests the possibility of limitations on population density and carrying capacity in highly altered habitats with few patches of suitable habitat and limited prey availability. The carrying capacity for adult pallid sturgeon in contemporary altered river segments or under historic unaltered conditions is unknown.

\section{Information Needs}

Recent studies have documented what is possible in range of movement, habitat use, and behavior of pallid sturgeon. However, there is much to be learned and quantified about what conditions are necessary for pallid sturgeon to thrive and to sustain viable populations. A more robust understanding of basic demographic parameters, including optimal growth and condition, age of first reproduction, sex ratios, size of reproductive population, fecundity, and spawning success are essential to assess current (2015) population status and forecast population trends. Developing functional relations between these parameters and management actions is critical for monitoring species response and progress toward recovery. Defining where on the landscape and the spatial range within which critical species functions occur is fundamental to devising strategies for implementation of recovery actions, including connectivity with tributaries and the Mississippi River. Such efforts will help define the functions of habitat used by these fish and may provide insight into the maintenance of the rangewide genetic structure of the population.

More information is needed to quantify what characteristics comprise quality adult habitat. Restoring or engineering quality habitat requires an understanding of how sturgeon use habitat, forage, and spawn at a very fine scale. For example, habitat assessments on the Mississippi River have demonstrated the spatial association of pallid sturgeon with wing dikes (Koch and others, 2012). However, because of the strong hydraulic effects that wing dikes have on velocity gradients and local sediment transport, habitats around wing dikes are extremely diverse (Jamieson and others, 2009; Reuter and others, 2009; Jamieson and others, 2011), and without detailed tracking and habitat assessment at the scale of an individual fish it is difficult to identify specific habitat characteristics being exploited by sturgeon. Moreover, the predominant use of dikes by sturgeon cannot be assumed to indicate that dikes represent optimal habitat (as opposed to best available), nor can it be ruled out that use of dike fields result from avoidance of other habitats, such as the navigation channel. Our experience and that of others indicate that pallid sturgeon use habitat in complex ways, commonly orienting to bedforms or other hydraulic features. Understanding how pallid sturgeon perceive, and benefit from complexity is key to evaluating pallid sturgeon habitat quality.

\section{Early Life-Stage Limitations-Spawn, Fertilization, Hatch, Drift}

Although considerable uncertainties persist about the role of reproductive adults in recruitment failure, it has been recognized that pallid sturgeon research needs to shift emphasis to also consider recruitment failure in early life stages (Quist and others, 2004; Bergman and others, 2008). Early life stages as embryos, free embryos, and exogenously feeding larvae typically are highly susceptible to mortality. 


\section{State of Understanding}

The period of spawning through the first year of life is known to be critical in determining year-class strength, recruitment, and population growth in sturgeon (Nilo and others, 1997; D'Amours and others, 2001; Parsley and others, 2002). As is typical for most sturgeon, little information is available on survival and mortality rates of pallid sturgeon during the early life stages; however, mortality is likely high for young pallid sturgeon based upon inferences from other species. Field studies of lake sturgeon (Acipenser fulvescens) resulted in estimates of mortality rates of 90-98 percent during the exogenous-feeding and larval age-0 life stage (Caroffino and others, 2010a). Moreover, the authors determined that mortality from the egg through age-0 life stage was 99.925-99.984 percent. Stellate sturgeon (Acipenser stellatus) in the Volga River (not shown) have an estimated mean survival rate of 2.5 percent between the pre-larva $(5 \mathrm{dph})$ and fingerling (50-60 dph) stages, but survival from the egg to fingerling stages averaged 0.75 percent (Usova, 2009). A study in the Mississippi River determined that undifferentiated Scaphirhynchus spp. during the age-0 life stage exhibited instantaneous mortality rates of $0.25-0.64$ (Phelps and others, 2010b). Whereas pallid sturgeon-specific survival information is lacking for the age-0 life stage, inferences on survival through the first winter of life are becoming available from the pallid sturgeon population augmentation and monitoring programs. Rotella (2012) reported that hatchery-produced age-0 pallid sturgeon in the Upper Missouri and Yellowstone Rivers exhibited survival rates of 78-79 percent between the September release period and capture period the following April.

Survival estimates from Caroffino and others (2010a) and Rotella (2012) can be used to gain insight into potential dynamics of pallid sturgeon populations through the first year of life. For example, based on a mortality rate of 99.92599.984 percent from the egg through age-0 life stages, about 6-30 age-0 pallid sturgeon would survive through the first growing season from a spawning event involving 40,000 eggs. Of these age- 0 survivors, an estimated 5 to 23 individuals would survive through winter and be present as age-1 individuals based on an over-winter survival rate of 78 percent. The known presence of multiple gravid females and documented spawning in the Upper and Lower Missouri River (Fuller and others, 2008; DeLonay and others, 2009; DeLonay and others, 2010; DeLonay and others, 2012) in combination with survival projections to age-1, suggest that young pallid sturgeon should be present. However, evidence of wild-produced pallid sturgeon progeny surviving through the first year of life is lacking throughout the species' range. These results imply that spawning success and mortality during the first year of life are among the primary drivers for lack of recruitment throughout the species' range.

Available information detailing the early life stages of pallid sturgeon, including fertilization rates, time to hatch, percent of embryos that hatch, drifting behavior, yolk absorption, and first feeding, is known mostly from laboratory studies and hatchery propagation efforts. The end of the drifting period coincides with the onset of feeding and filling of the swim bladder, which occurs at about $11 \mathrm{dph}$. Information on drift velocities from the release of artificially propagated free embryos for field-based studies in the Upper Missouri River suggests that, in general, free embryos drift in the thalweg, and slightly slower than mean water velocities. Calculations based on these estimated drift velocities indicate that sturgeon larvae have the potential to drift long distances and require similarly long segments of free-flowing river to complete the ontogenetic development to benthically oriented, exogenously feeding larvae.

The protracted free-embryo dispersal period for pallid sturgeon suggests that larvae spawned throughout much of the Lower Missouri River may drift into the Middle Mississippi River (DeLonay and others, 2009), and larvae spawned in the Yellowstone and Upper Missouri Rivers will likely drift into the upper reaches of Lake Sakakawea (Braaten and others, 2008; Braaten and others, 2012a). Studies of genetics, microchemistry, and stable isotopes may provide insight into longitudinal and latitudinal distribution. In the Lower Missouri River, the present-day mean river velocities are higher and distributions of velocities substantially different than the historical condition, and early analyses indicate that the spatial and temporal scale of free-embryo dispersal, and the sequence and arrangement of early life-stage drift and settling habitat may be altered. Laboratory studies examining first feeding and time to starvation in pallid sturgeon free embryos suggest that early food availability during the transition to exogenous feeding is critical to survival. The existence of imprinting in young pallid sturgeon is unknown, but altered early dispersal patterns could be manifest in altered adult spawning migrations and consequent changes in population dynamics.

\section{Information Gaps}

Little is known about egg deposition, fertilization, and retention in spawning substrate outside the controlled setting of laboratories and little direct evidence exists concerning adaptive nature of drift strategies (immediate compared to delayed drift), ontogenetic development during the free drift phase, and the "settling" processes in the Missouri River or its tributaries. Due in large part to low densities of reproductive adults and the challenges of statistically sampling for larvae across the diverse habitats of the Missouri River, little is understood about the distribution of larval sturgeon between the main channel and adjacent channel border habitats or the value of these habitats to free embryos. Moreover, little is known about the behavior of drifting free embryos as they transition to benthic habitats. In addition, little is known about other threats that may affect dispersing free embryos, including the potential for mortality associated with the numerous water withdrawals and intakes along the Missouri River, increased predation with reduced turbidity in the contemporary channel, and reduced growth and development from altered thermal regimes below main-stem dams. 
Early life stages are generally considered the most sensitive to contaminants. Exposure may occur during maternal egg development or during incubation while in contact with water or sediments (Wildhaber and others, 2007a; Buckler, 2011). Although pallid sturgeon have been successfully hatched and reared in captivity, few data exist on the tolerance of these early life stages to specific environmental stressors and contaminants (Wildhaber and others, 2007a). The relative susceptibility of early life-stage pallid sturgeon to predation in the presence of native and introduced predation likely plays a role in early survival, but the relative importance of predation, especially in the altered contemporary river in comparison to other sources of mortality is not known.

\section{Information Needs}

Understanding of egg deposition, and adhesion would provide insight on whether substantial, suitable, and adequately conditioned spawning substrates exist in the current (2015) Missouri River or whether these conditions are sensitive to flow or channel engineering. Improved understanding of typical egg drift distances, egg settling processes, and settling habitats of larval pallid sturgeon would provide useful guidance for placement and design of channel-restoration projects that are intended to provide spawning and corresponding downstream rearing habitat. Improved understanding of drift dynamics would document whether flow or channel re-engineering designed to decrease mean velocity and increase drift retention would be effective for increasing recruitment. Understanding transport, dispersion, and fate of pallid sturgeon eggs and larvae would help to determine if they successfully drift into habitats conducive to hatch, survival, feeding, and growth. Examining differences in early dispersal and development among populations of pallid sturgeon also would be important in the design of effective monitoring programs to evaluate annual reproductive success.

\section{Young-of-Year to Juvenile}

Compared to earlier life stages, more information exists on YOY to juvenile stages because of studies on propagated, hatchery-origin fish. These life stages also are considerably less difficult to sample with conventional gears compared to eggs, free embryos, and exogenously feeding larvae.

\section{State of Understanding}

The factors most likely to affect juvenile sturgeon are human exploitation, availability of food resources, habitat quality, predation, and competition (Wildhaber and others, 2007a, 2011a). The well-documented dietary shift during juvenile life stage, from consuming mainly invertebrates to consuming mainly fish, is thought be important in pallid sturgeon growth and lends support to the hypothesis that declines in forage fish (for example, Macrhybopsis chubs) may be associated with pallid sturgeon declines (Gerrity and others, 2006). Emerging information on habitat use of age-0 Scaphirhynchus (undifferentiated shovelnose and pallid sturgeon) indicates that they are found associated with wing dikes and rootless dikes with bottom velocities of $0.5-0.7$ $\mathrm{m} / \mathrm{s}$ and depth generally greater than $1.0 \mathrm{~m}$ (Ridenour and others, 2011). The effects of predation on juveniles are unknown. Flathead catfish have consumed small juveniles (40-50 $\mathrm{mm}$ fork length) in proportion to their availability in laboratory studies while avoiding larger sturgeon (French and others, 2014). Shovelnose sturgeon and pallid sturgeon have been documented in the stomachs of flathead catfish in the Lower Missouri River (Kirk Steffensen, Nebraska Game and Parks Commission, oral commun., 2015). The extent to which predation by native or nonnative predators is enhanced in the contemporary altered Missouri River is unknown and requires further study.

\section{Information Gaps}

There is little information on habitat selection - habitat use compared to availability - by age- 0 and juvenile pallid sturgeon. Further, it is unknown whether preferred habitat of YOY and juvenile pallid sturgeon is available under current (2015) management of the Missouri River. If juvenile pallid sturgeon need to select habitat conditions, including temperature and water quality that vary from those present in the main channel, the options in the altered river are limited. Differences between juvenile pallid sturgeon and shovelnose sturgeon habitat use have not been described, and the nature and extent of competition among the species is not known. Information on growth rates of pallid sturgeon in the wild is limited due to the limitations in aging methodologies (Wildhaber and others, 2007a). Data on juvenile pallid sturgeon growth are available for hatchery progeny stocked in the Missouri River, and observed rates have been described as acceptable (Shuman and others, 2011). However, interpretation of the data is limited by a lack of knowledge of the potential for growth of pallid sturgeon in unaltered, quality habitat, and the lack of information for older pallid sturgeon, which must transition to piscivory before reaching reproductive maturity.

Hypotheses about prolonged drift of pallid sturgeon free embryos suggest that successful larvae will disperse downstream far from spawning sites. The strategy for upstream migrations by pallid sturgeon is only partially described, however, and only for the reproductive adults. Reproductive adult migrations described by CSRP to date have been far shorter than the estimated drift distances for free embryos. This inconsistency may be due to several life history traits, acting alone or in combination, including shorter downstream dispersal by free embryos than currently (2015) hypothesized, multistep migrations for a return to the spawning location beginning as early as the juvenile stage, and shorter downstream postspawn migrations by adults relative to free-embryos dispersal distances, which result in shorter subsequent spawning migrations. The geographic extent of the river used through the peak 
of migration to the downstream limit of juvenile dispersal is unknown, and the strategy used by pallid sturgeon to migrate and disperse also is poorly understood.

\section{Information Needs}

Understanding the distribution and dispersal of juvenile pallid sturgeon would provide insight on habitat preference that would provide useful guidance for placement of channelrestoration projects that are intended to provide rearing habitat. Understanding of optimal food items, and habitat requirements and flow conditions required by these species, may provide guidance to increase or improve these conditions in the context of the current (2015) Missouri River. Additionally, understanding the age, growth and survival of juvenile pallid sturgeon in the wild is essential for assessing current (2015) population status and forecasting population trends (Wildhaber and others, 2007a).

\section{Role of Management Actions}

Management actions for recovery of pallid sturgeon on the Missouri River have emphasized hatchery population augmentation, flow regime changes, and re-engineering of the previously channelized Missouri River. The challenge to recovery strategies has been how to use the available scientific information to determine the most effective investments in these three actions. Understanding is complicated by spatial variation among river segments and interactions of management actions.

\section{Population Augmentation}

Whereas population augmentation practices are helping to avoid extirpation and maintain the species, successful spawning and natural recruitment are required for long-term pallid sturgeon recovery. Hatchery-origin pallid sturgeon are surviving, growing and reaching sexual maturity; however, more information is needed to evaluate their contribution to reproduction, recruitment and recovery, especially in light of the emerging genetic evidence of the rangewide population structure of the species. Into the foreseeable future, the conservation augmentation program will have the greatest effect on pallid sturgeon population growth, genetic diversity and viability. Population augmentation or the recovery of endangered species carries risks that may be minimized by methods that do the following:

- Select appropriate broodstock,

- Develop breeding protocols that assure even, consistent contribution of diverse matings,

- Implement hatchery practices that reduce the incidence and transmission of disease to wild populations,
- Implement population augmentation strategies that preserve contributions of wild fish and natural genetics structure on the landscape,

- Implement stocking strategies that emphasize adaptation to local environments and preservation of imprinting opportunities for natal areas (such as, streamside rearing or egg and free-embryo repatriation) to increase fitness, reduce hatchery selection, and enhance the return of spawning adults to appropriate spawning sites,

- Implement robust marking protocols and genetic analyses to monitor performance and assess risks, and,

- Administer complete, accurate record keeping systems to prevent errors and document success.

In addition, there is a recognized symbiosis between the conservation augmentation program and sturgeon research. Hatcheries that consistently can produce high quality reproductive products and progeny are invaluable partners to support focused, controlled laboratory studies of pallid sturgeon critical spawning requirements and early life history stages. Although the long-term use of captive broodstock is strongly cautioned, the anticipated limited use of captive adults to produce progeny for population augmentation in the Yellowstone and Upper Missouri Rivers requires fundamental research to understand long-term effects of hatchery culture on broodstock viability and to develop methods to improve the reliability of induction, fertilization, and hatch success, tools for the identification and prevention of sturgeon diseases, and measures to improve and evaluate the quality and survivability of hatchery progeny.

\section{Flow Regime}

The hypothesis that spawning behavior relates to environmental cues - thresholds or episodes of variation in discharge, temperature, turbidity, conductivity, or factors such as day length or moon phase - has been pervasive in sturgeon literature (Paragamian and Kruse, 2001; Forsythe and others, 2012; Goodman and others, 2012). Sturgeon scientists have been challenged to isolate which interacting external environmental conditions might be instrumental in triggering suspected fish behaviors, including pre-migration aggregations, migration, and spawning. The ability of field-based research to infer causal relations has been limited by extreme year-to-year hydrologic and climatic variability, the relatively small size of intentional spring pulsed releases (fig. 29), and small numbers of subject fish. Pallid sturgeon spawn in the spring and early summer during periods of increasing day length. Water temperature consistently exerts a threshold affect for spawning at $16-18{ }^{\circ} \mathrm{C}$. Moreover, pauses and reversals in upstream migrations have been associated with cold weather fronts that create a transient decrease in water temperature (DeLonay and others, 2009). From 2005 to 2012 on the Lower Missouri 
River no obvious relations between flow pulses and fish movements and spawning behaviors have been apparent.

Although pallid sturgeon migration and spawning on the Lower Missouri River do not appear to be linked consistently to discharge conditions in the Lower Missouri River, it does not follow that discharge is not important to overall spawning success. Linkages have been noted between changes in water temperature and migration rate or direction (DeLonay and others, 2010); to the extent that water temperature varies with discharge, flow events could cause disruptions in migration, and disrupted migration patterns of female pallid sturgeon in reproductively ready condition have the potential to reduce spawning success or trigger deposition in suboptimal habitats or in inappropriate conditions. Evidence of linkages between flow regime and sturgeon migration and spawning are clearer in the Upper Missouri River where typical movement patterns were disrupted during high flows in 2011. In a typical year, pallid sturgeon predictably move from the Missouri River into the Yellowstone River in the spring with increasing flow and temperature, leaving once spawning is complete and discharge declines. Similarly, shovelnose sturgeon move from the Yellowstone River into the Tongue and Powder Rivers (fig. 2) to spawn with increasing temperature and discharge, leaving after spawning is complete. In 2011, extreme discharge in the Upper Missouri River was associated with pallid sturgeon electing to move up the Missouri River in atypical numbers, resulting in aggregations and successful spawning. The contrast in responsiveness to flow regime by adults in the two study sections is a valuable comparison that warrants further study.

Presently available information on reproductive responses to intentional pulsed-flow releases documents the lack of response to small releases on the Lower Missouri River up to 2011 (Doyle and others, 2011) and substantive, but unreplicated responses to extreme forced releases in 2011. Little information exists to evaluate responses to intermediate flow releases except for investigations of reproductive responses in the lower study section of the Lower Missouri River where uncontrolled flow pulses are confounded with varying water temperature and interacting pulses. The possibility exists that pallid sturgeon would respond to intentional flow pulses of a magnitude that have not yet been implemented.

The extent to which flow regime affects spawning of pallid sturgeon, and therefore the initiation of the start of the drifting phase of larval development, remains unclear at this time. A more detailed understanding of egg deposition is necessary to fully evaluate whether substrate conditions at spawning sites may be improved with flow management. Flow regime likely affects where larvae settle, and thus the location where the juvenile life stage begins. Flow regime also may affect habitat availability to juvenile and adult pallid sturgeon, as well as affect complex processes such as food transport and availability and competition in those habitats. The efficacy of flow regime in influencing habitat availability and food-web processes is interdependent with channel morphology and how it is being re-engineered as a restoration action.

\section{Channel Engineering}

Spawning habitat.-Studies on spawning habitat dynamics have reported that habitat patches selected for spawning by fish in the Lower Missouri River are dominantly on outside, revetted bends in the deepest, fastest, and most turbulent water. Hydroacoustic maps and images document that these sites have steep slopes underlain by revetment adjacent to actively migrating sand dunes. Although these sites are abundant in the Lower Missouri River and would appear not to be limiting to reproduction, questions remain about the fate of released eggs because of the steep slopes, angular revetment rock, unknown interstitial space in the revetment, high velocities and turbulence, and potential for burial if eggs end up at the base of the revetment slope. Hydraulic modeling of these patches has indicated that depths and velocities are not sensitive to discharge because of the simple channel morphology. Geomorphic monitoring, however, has indicated that because the sand bed material is always in transport, there is potential for bedload transport to modify these patches, either before spawning to scour sand from spawning substrate, or during and after spawning when sand substrate could bury eggs.

Increased intensity of spawning assessment in the Yellowstone River in 2011 and 2012 has presented an alternative view of spawning habitat and its relation to fish reproductive behaviors. Spawning habitats on the Yellowstone River downstream from Intake Dam appear to be more discrete and controlled by the presence of patches of gravel within a sanddominated channel. Because they are discrete, we hypothesize that the Yellowstone River patches may be more effective in attracting aggregations of reproductive fish compared to the nearly continuous revetment on the Lower Missouri River, which may operate to spread spawning aggregations out along the river. This hypothesis needs additional exploration.

The sedimentological and hydraulic conditions of habitat patches also have a bearing on how hatched larvae are introduced into their environment. A key question is whether larvae drift immediately after hatch or instead spend some time in substrate interstices before drifting. Field and laboratory data presented in this report support either hypothesis, and it is not known whether either behavior would lead to greater survival from hatch to age- 0 . The two hypotheses may not be mutually exclusive; instead, there may be a continuum from immediate drift to interstitial hiding with varying probability of survival depending on drift distance and habitat availability when the free embryos transition to exogenous feeding.

An increased understanding of the importance of finescale conditions at spawning habitats to successful fertilization, incubation, hatch, and initial drift of pallid sturgeon embryos has prompted the development of new hypotheses. Laboratory experiments can provide critical insights into these processes, albeit the range of conditions in laboratories cannot replicate field conditions. Experiments based on testing how well embryos deposited on artificial substrates survive and hatch will be useful to understand the effect of this aspect of channel engineering on spawning success. If additional 
research confirms the importance of fine-scale processes in spawning habitats, quantitative hydraulic and sedimentological data from reference sites in the Yellowstone River may provide guidance for restoration designs on the Lower Missouri River.

Rearing and feeding habitat.-It has been reported that channel re-engineering can increase the amount of shallowwater habitat, as well as habitat complexity (Jacobson and Galat, 2006); however, the linkages to larval retention, survival, and growth of the early life stages of pallid sturgeon have not yet been established. Design decisions for re-engineering actions intended to slow drift or provide greater rearing habitat would necessarily depend on correct diagnosis that these factors are, in whole or in part, responsible for recruitment failure. Drift models indicate the role of mean velocity in downstream transport of free embryos; mean velocities could be slowed through decreased discharges or by channel re-engineering that increases hydraulic radius (width and topographic diversity). In addition, the probability that free embryos are transported into and retained in channel-margin habitats is theoretically amenable to channel re-engineering that would increase cross-channel secondary currents in bends or channel expansions. Considerable uncertainty persists, however, about what channel-margin habitats should look like to optimize survival and growth of age- 0 and juvenile sturgeon, and where along the river such habitats would most contribute to population growth.

In addition to a hypothesized function as rearing habitat, increased habitat diversity in channel-margin habitats has been hypothesized to increase productivity and food production, with eventual effects on pallid sturgeon growth and survival. Channel engineering and bank stabilization have reduced the interaction of the river with the floodplain, simplified channel form (including limiting large woody debris retention, a key invertebrate habitat), and limited functional processes related to primary and secondary productivity. Direct functional relations between productivity, food availability, and community composition that can predict changes in parameters that affect population growth, although intuitive, have not yet been documented or quantified for pallid sturgeon at any life stage.

Nevertheless, correlations suggest a linkage may exist. Longitudinal differences in female pallid sturgeon fecundity have been documented in this report and others (Albers and others, 2013), leading to the hypothesis that recruitment failure may be due, at least in part, to adult fish having insufficient nutrition to produce the numbers of gametes needed for the population to grow. Documented declines in populations of known pallid sturgeon prey fish (Galat and others, 2005a) also are broadly correlative with recruitment failure, lending support to the hypothesis that food may be limiting. These associations point to a need to continue to develop diet energetics models for juvenile and adult fish (Gerrity and others, 2006), and to consider population dynamics of prey fish like Macrhybopsis chubs. If food availability is determined to be an important factor in growth and reproductive potential of pallid sturgeon, restoration of habitats used by prey fish may a useful strategy. However, establishing a chain of causality from physical habitat, to prey-fish populations, to use of prey-fish in sturgeon diets, to increased sturgeon fecundity, and eventually to pallid sturgeon population growth presents a considerable scientific challenge. Effective restoration of channel-margin habitats specifically to increase food availability also would require understanding where in the geographic range and life cycle of the pallid sturgeon food might be most limiting. This would require improved understanding of movement and habitat affinities of juveniles and reproductive adults.

\section{Synergies}

Modifications of flow regime and channel engineering are not independent or isolated. Reducing flows from main-stem dams during high tributary flows could have beneficial results for sturgeon responsive to water quality and temperature. A renewed appreciation for the potential importance of select tributaries for feeding or spawning may suggest increased opportunities or added flexibility in management strategies to aid pallid sturgeon. Similarly the Mississippi River likely has a substantial effect on the survival of early life-stage pallid sturgeon spawned in the Lower Missouri River. Eventual recruitment of pallid sturgeon to the Missouri River adult spawning population may be limited by habitat conditions in the Middle Mississippi River.

Other factors outside of the direct effect of Missouri River management also may affect pallid sturgeon growth and survival. Among these, contaminant effects may be the most important to understand in context of other threats. Although the threat of legacy chemical loads (DDT, PCB) is diminishing and likely localized, the potential for persistent and widespread exposure to endocrine disrupting chemicals from agricultural and waste-water treatment sources is present throughout the Midwest and the Missouri River Basin (Kolpin and others, 2010; Wiener and Sandheinrich, 2010; Blevins, 2011; Larsen and others, 2013).

\section{Strategies for Addressing Key Information Gaps}

Early studies with pallid sturgeon struggled with the overall rarity of a poorly known, endangered species against the backdrop of their existence in large, turbid rivers. The development of technologies for better sampling and monitoring of pallid sturgeon populations rapidly advanced scientific knowledge. Informed by results of previous studies, and with opportunities afforded by increased number of pallid sturgeon available through population augmentation, future hypotheses for study can be more focused and directed towards management and recovery objectives. A measured approach to science investment would be to develop a diverse portfolio with complementary long-term monitoring and hypothesis-driven, focused studies that integrate field and laboratory perspectives. We believe the following are high science priorities: 
- Continuation of long-term monitoring of reproductive cycles, reproductive movements, growth, and survival of telemetry tagged adults. These studies are essential to further define the life-ranges of pallid sturgeon subpopulations and how those sub populations interact with spatially variable habitats along the river. The studies provide the basis for determining where to invest in different channel-re-engineering actions to best support species' needs. Assessment of reproductive movements will continue to provide insights into the role of environmental variables in life-stage transitions.

- Increased emphasis on focused, complementary field and laboratory studies of factors influencing early life history. These studies are essential to understand how substrate conditions and local hydraulics may affect survival through egg deposition, fertilization, hatch, and initial drift; the studies would provide design parameters for re-engineering channels to restore spawning habitat. Field studies of physical processes affecting larval drift and retention would provide a template for sampling of larvae and the physical understanding needed to design channels to enhance retention. Early life history studies can use comparative studies among least and highly altered river systems to advantage.

- Implement studies to resolve role of food limitations in growth, survival, and reproductive condition. These studies are necessary to establish whether linkages exist between pallid sturgeon populations and food production, especially to determine how restoration of channel-margin habitats may affect pallid food supply. These studies would use assessments of fitness and fecundity derived from the Pallid Sturgeon Population Assessment Program and continued monitoring of the telemetry population, combined with diet studies and increased energetics modeling to determine if the forage base is sufficient to maintain reproduction in the population.

- Conduct monitoring, field, and laboratory studies to produce information needed to parameterize quantitative models relating management actions to pallid sturgeon population responses. Effective use of quantitative modeling can aid in identifying uncertainty and prioritizing information needs. The development of population viability models can help to place information in the context of population growth and allow simulations or sensitivity analyses to direct resources towards critical life stages and factors limiting survival. Physical models that incorporate biological requirements or functions in the context of the engineered river environment provide powerful tools for communication and integrated management. Ideally, monitoring and research results should feed into a population dynamics modeling framework.

\section{Conclusions-Synthesis of Reproductive Ecology of the Pallid Sturgeon in the Missouri River}

Although substantial progress has been made by the Comprehensive Sturgeon Research Project (CSRP) and other researchers from 2005 to 2012 in understanding the reproductive ecology of the pallid sturgeon, in many ways the pallid sturgeon remains an enigmatic, poorly understood species. This is expected given the rarity of the species and its characteristic use of benthic habitats in deep, turbid rivers. Although there has been rapid progression in understanding of fundamental biology and habitat affinities (fig. 7), critical uncertainties in the existing science base confound many management decisions. There exists an acute need to move from observation to prediction, especially to provide predictive understanding of future prospects for the population given changing river management, land use, and climate. The objective of this report was to synthesize the state of the science as a precursor to moving to predictive modeling.

\section{Landscape Scale Genetics}

Present-day (2015) population dynamics and recovery actions play out within the fragmented Missouri and Mississippi River systems. Dams have created barriers to upstream migration and reservoirs may have created unsuitable habitats for dispersing larvae. As a consequence, the lengths of river and types of habitats available to pallid sturgeon have been severely altered. The Upper Missouri and Yellowstone Rivers subpopulations may have insufficient space to carry out its life cycle without substantial re-engineering to create additional drift distance. It is critical to establish the causal link between free-embryo dispersal and mortality to explore all possible restoration options. In the Lower Missouri River, closure of the main-stem dam system may have pushed the population downstream with unknown consequences for habitat availability and potential interactions with Mississippi River subpopulations. Recognition of genetic structure has clear implications for management of the Pallid Sturgeon Conservation and Augmentation Program, but also for how restoration activities are arranged along the river. If conservation of genetically structured pallid sturgeon populations with locally adapted traits is a high priority, restoration actions may be designed to minimize downstream dispersal by re-engineering the channel to decrease velocities and increase probability of retention in channel-margin habitats.

\section{River Management and Population Dynamics}

Landscape scale fragmentation and potential displacement of the naturally occurring genetic structure of the pallid sturgeon population set broadscale context for recovery of the 
species. Within that context, recovery requires understanding how river restoration and management decisions affect processes that, in turn, affect survival probabilities from one life stage to the next. Research has not identified a single biological or ecological constraint that appears to limit populations of the pallid sturgeon. With the present (2015) state of knowledge, many life stages and life-stage transitions cannot be ruled out as contributing to recruitment failure.

Pallid sturgeon have complex life histories, with discrete ontogenetic transitions, each with specific requirements that play out across a relatively large spatial and temporal scale. Addressing this complexity through management action on the landscape can be reduced to a series of simple guiding principles. Effective restoration of viable sturgeon populations requires unimpeded connectivity of substantial distances of freeflowing river, continuous alignment between habitat availability and life history requirements, sufficient availability of habitats, and adequate habitat quality to sustain survival and growth. Although the principles are simple, the information needed to incorporate these principles into management is substantial.

The 2000 and 2003 biological opinions presented the dominant hypotheses for recruitment failure that existed at that time. Emphasis was on the role of the flow regime, specifically spring flow pulses ("spring rises"), to condition spawning substrate and cue reproductive aggregations and migrations, and on the need for additional shallow-water habitat to serve as rearing habitat for age- 0 to juvenile pallid sturgeon. Understanding from CSRP and other studies has broadened restoration perspectives to emphasize increased opportunities for upstream passage of migrating adults to provide greater habitat availability and to improve the functionality of the downstream array of habitats throughout the geographic extent of populations to accommodate free-embryo dispersal.

\section{Spawning Habitat and Cues}

The Comprehensive Sturgeon Research Project addressed the hypotheses related to spawning and spawning habitat by implementing directed research based on following tagged reproductive pallid sturgeon to spawning sites, quantifying the potential for environmental cues before, during, and after their migration, and applying concerted mapping and modeling efforts to quantify spawning habitat availability and dynamics. Studies on spawning habitat dynamics have determined that habitat patches selected for spawning by fish in the Lower Missouri River are dominantly on outside, revetted bends in the deepest, fastest, and most turbulent water. Increased intensity of spawning assessment in the Yellowstone River in 2011 and 2012 has provided an alternative view of spawning habitat and its relation to fish reproductive behaviors in a more natural setting. Spawning habitat on the Yellowstone River downstream from Intake Dam is characterized by discrete patches of gravel within a sand-dominated channel, an arrangement that may be more effective in attracting aggregations of reproductive fish compared to the nearly continuous revetment on the Lower Missouri River.
The sedimentological and hydraulic conditions of habitat patches also have a bearing on how hatched free embryos are introduced into their environment. A key question is whether free embryos drift immediately after hatch or instead spend some time in substrate interstices before drifting. Field and laboratory data presented in this report support either hypothesis, and further study would aid in determining which would lead to greater survival from hatch to age 0 . Hypotheses relating fine-scale conditions in spawning habitat to successful fertilization, incubation, hatch, and initial drift are challenging to test in the Missouri River. However, comparative research on spawning habitats in the Yellowstone River can provide hydraulic and sedimentological data that may be useful for restoration designs on the Lower Missouri River. In addition, laboratory experiments can provide critical and complementary insights into processes, despite their limitations in replicating field conditions.

The hypothesis that spawning behavior relates to environmental cues - thresholds or episodes of variation in discharge, temperature, turbidity, conductivity, or factors such as day length or moon phase - has been pervasive in sturgeon literature. Pallid sturgeon spawn in the spring and early summer during periods of increasing day length. Water temperature consistently exerts a threshold effect for spawning at 16-18 ${ }^{\circ} \mathrm{C}$. Moreover, pauses and reversals in upstream migrations have been associated with cold weather fronts that create a transient decrease in water temperature (DeLonay and others, 2009). From 2005 to 2012 on the Lower Missouri River, no obvious relations between flow pulses and fish movements and spawning behaviors have been apparent.

These observations do not necessarily indicate that flow has no role in pallid sturgeon reproduction. Pallid sturgeon tracking at the Upper Missouri River-Yellowstone River confluence indicates that in most years, most telemetered pallid sturgeon migrate out of the Missouri River and into the Yellowstone River in the June-July timeframe in association with the spring pulse in the Yellowstone River. This pattern held consistently from 2004 to 2010, and in 2012. However, in 2011 when a high flow pulse with warm temperatures and high turbidity emanated from the Milk River, followed by record releases from Fort Peck Dam, 36-39 percent of the telemetered population migrated up the Upper Missouri River in a distinct anomaly (DeLonay and others, 2014). This supports the hypothesis that flow pulses can operate to cue pallid sturgeon reproductive behavior. It is important to note, however, that the hydrologic conditions in 2011 were extreme and the size of flow pulses in the Upper Missouri River resulted in record releases from Fort Peck Dam. Comparative and repeated studies would aid in resolving the cues or causative factors responsible for the observed response to altered flows (Carpenter, 1990).

Apparent reproductive failure in pallid sturgeon in the Missouri River may result from a lack of adequate numbers of spawning adults, poor survival of early life stages, or from emigration of dispersing free embryos out of the Missouri River, or through hybridization with shovelnose sturgeon. The 
importance of the Mississippi River in pallid sturgeon recruitment in the Missouri River should be addressed. Hybridization occurs, but the rate of hybridization is unknown and the threat is poorly characterized in the Lower Missouri River. The factors responsible for an increased incidence of hybridization and introgression include low numbers of adults, barriers that fragment habitat and limit access to spawning locations, and alterations of habitat and flow that erode spatial and temporal separation between the two species. Each of these factors is present in the contemporary Lower Missouri River and may contribute to the current (2015) level of introgression. Which factor is most important is currently unknown and a comprehensive strategy to remediate the threat has yet to be formulated.

\section{Free Embryo and Larval Dispersal, Retention, and Channel Morphology}

Dispersal distance and characteristics of rearing habitat are also amenable to restoration and management actions. Decisions in investing in actions to slow drift or provide greater rearing habitat would necessarily depend on correct diagnosis that these factors are, in whole or in part, responsible for recruitment failure. Current velocities could be slowed through decreased discharges or increased channel hydraulic radius (width and topographic diversity). In addition, the probability that free embryos are transported into and retained in channel-margin habitats is theoretically amenable to channel re-engineering that would increase cross-channel secondary currents in bends or channel expansions. Considerable uncertainty persists, however, about what channel-margin habitats should look like to optimize survival and growth of age- 0 and juvenile sturgeon, and where along the river such habitats would most contribute to population growth. A process-based understanding of how abiotic and biotic processes are linked in channel-margin habitats would provide improved guidance for channel re-engineering efforts to benefit pallid sturgeon.

\section{Food Availability and Channel Morphology}

Differences in female pallid sturgeon fecundity along the length of the Missouri River have been documented in this report and others. Although this phenomenon may be affected by natural latitudinal clines in species growth, it may also, at least in part, be affected by insufficient availability of forage to produce the greater numbers of gametes. Reduced gamete quality and fecundity would result in decreased individual lifetime reproductive output and poor survival of progeny. Declines in populations of known prey fish like Macrhybopsis chubs (Galat and others, 2005a) also are broadly correlative with the pallid sturgeon population decline. This leads to the hypothesis that restoration of channel-margin habitat complexity would result in an increase in chub populations, and subsequently an increase in growth and fecundity of adult pallid sturgeon (Gerrity and others, 2006). Establishing a chain of causality from physical habitat, to prey-fish populations, to use of prey-fish in sturgeon diets, to increased sturgeon fecundity, and eventually to pallid sturgeon population growth presents a considerable scientific challenge. The challenge is not insurmountable. A detailed food web model coupled with physical and biological models informed by field and laboratory studies is needed to establish these critical linkages. Effective restoration of channel-margin habitats specifically to increase food availability would also require understanding where in the home range of the pallid sturgeon food is most limiting.

\section{Future Information Needs}

Scientific understanding of the ecological requirements of pallid sturgeon has increased almost exponentially in the last two decades (fig. 7). The challenge for science now is to transition from understanding what is possible (for example, Can pallid sturgeon spawn in the Missouri River? Does spawning habitat exist?) to what is probable and quantifiable (for example, Are pallid sturgeon spawning in sufficient numbers for population growth? How much habitat restoration is needed to meaningfully increase the number of wild-produced fish?). Progress in developing the science needed to inform management actions on the Missouri River will benefit from continuation of long-term monitoring of reproductive cycles, reproductive movements, growth, and survival of telemetry tagged adults. With new understanding, studies will increase emphasis on focused, complementary field and laboratory studies of factors influencing early life history, implementation of studies to resolve the role of food limitations in growth, survival, and reproductive condition, and design of studies so results can be used to parameterize models to assess effects of management actions.

\section{References Cited}

Albers, J.L., Wildhaber, M.L., and DeLonay, A.J., 2013, Gonadosomatic index and fecundity of lower Missouri and middle Mississippi River endangered pallid sturgeon estimated using minimally invasive techniques: Journal of Applied Ichthyology, v. 29, p. 968-977. [Also available at http://dx.doi.org/10.1111/jai.12231.]

Allen, T.C., Phelps, Q.E., Davinroy, R.D., and Lamm, D.M., 2007, A laboratory examination of substrate, water depth, and light use at two water velocity levels by individual juvenile pallid (Scaphirhynchus albus) and shovelnose (Scaphirhynchus platorynchus) sturgeon: Journal of Applied Ichthyology, v. 23, p. 375-381.

Applied Geomorphology Inc, 2004, Geomorphic reconnaissance and GIS development, Yellowstone River, Montana: Applied Geomorphology, Inc., 108 p. 
Araki, H., Waples, R.S., Ardren, W.R., Cooper, B., and Blouin, M.S., 2007, Effective population size of steelhead trout: influence of variance in reproductive success, hatchery programs, and genetic compensation between life-history forms: Molecular Ecology, v. 16, no. 5, p. 953-966. [Also available at http://dx.doi.org/10.1111/j.1365294X.2006.03206.x.]

Aulenbach, B.T., Buxton, H.T., Battaglin, W.A., and Coupe, R.H., 2007, Streamflow and nutrient fluxes of the Mississippi-Atchafalaya River Basin and subbasins for the period of record through 2005: U.S. Geological Survey Open-File Report 2007-1080, accessed on April 24, 2013, at http:// toxics.usgs.gov/pubs/of-2007-1080/index.html.

Bailey, R.M., 1954, Distribution of the American cyprinid fish Hybognathus hankinsoni with comments on its original description: Copeia, v. 194, no. 4, p. 289-291.

Bailey, R.M., and Allum, M.O., 1962, Fishes of South Dakota: Ann Arbor, Michigan, Musuem of Zoology, University of Michigan, $131 \mathrm{p}$.

Bailey, R.M., and Cross, F.B., 1954, River sturgeons of the American genus Scaphirynchus: Characters, distribution and synonymy: Papers of the Michigan Academy of Science, Arts, and Letters, v. 39, p. 169-207.

Bain, M.B., 1997, Atlantic and shortnose sturgeons of the Hudson River: common and divergent life history attributes: Environmental Biology of Fishes, v. 48, no. 1-4, p. 347-358.

Bajer, P.G., and Wildhaber, M.L., 2007, Population viability analysis of Lower Missouri River shovelnose sturgeon with initial application to the pallid sturgeon: Journal of Applied Ichthyology, v. 23, no. 4, p. 457-464.

Balco, G., and Rovey, C.W., 2010, Absolute chronology for major Pleistocene advances of the Laurentide Ice Sheet: Geology, v. 38, no. 9, p. 795-798. [Also available at http:// dx.doi.org/10.1130/g30946.1.]

Balon, E.K., 1984, Reflections on some decisive events in the early life of fishes: Transactions of the American Fisheries Society, v. 113, no. 2, p. 178-185.

Becker, G.C., 1983, Sturgeon and paddlefish, Fishes of Wisconsin: Madison, Wisconsin, University of Wisconsin Press, p. 219-237.

Bemis, W.E., and Kynard, B., 1997, Sturgeon rivers: An introduction to acipsenseriform biogeography and life history: Environmental Biology of Fishes, v. 48, p. 167-183.
Bergman, H.L., Boelter, A.M., Parady, K., Fleming, C., Keevin, T., Latka, D.C., Korschgen, C., Galat, D.L., Hill, T., Jordan, G., Krentz, S., Nelson-Stastny, W., Olson, M., Mestl, G.E., Rouse, K., and Berkley, J., 2008, Research needs and management strategies for pallid sturgeon recovery: William D. Ruckelshaus Institute of Environment and Natural Resources, University of Wyoming, Laramie, 37 p.

Berry, C.R., Wildhaber, M.L., and Galat, D., 2004, Population structure and habitat use of benthic fishes along the Missouri and lower Yellowstone Rivers_-Volume 3: Fish distribution and abundance: U.S. Army Corps of Engineers and U.S. Bureau of Reclamation.

Blevins, D.W., 2006, The response of suspended sediment, turbidity, and velocity to historical alterations of the Missouri River: U.S. Geological Survey Circular 1301, 8 p.

Blevins, D.W., 2011, Water-quality requirements, tolerances, and preferences of pallid sturgeon (Scaphirhynchus albus) in the lower Missouri River: U.S. Geological Survey Scientific Investigations Report 2011-5186, 20 p.

Blevins, D., and Fairchild, J., 2001, Applicability of NASQAN data for ecosystem assessments on the Missouri River: Hydrological Processes, v. 15, no. 7, p. 1347-1362.

Boley, R.M., and Heist, E.J., 2011, Larval surveys indicate low levels of endangered pallid sturgeon reproduction in the middle Mississippi River: North American Journal of Fisheries Management, v. 140, no. 6, p. 1604-1612.

Bonnot, T.W., Wildhaber, M.L., Millspaugh, J.J., DeLonay, A.J., Jacobson, R.B., and Bryan, J.L., 2011, Discrete choice modeling of shovelnose sturgeon habitat selection in the Lower Missouri River: Journal of Applied Ichthyology, v. 27, no. 2, p. 291-300. [Also available at http://dx.doi.org/10.1111/j.1439-0426.2010.01637.x.]

Bowen, Z.H., Bovee, K.D., and Waddle, T.J., 2003, Effects of channel modification on fish habitat in the upper Yellowstone River: U.S. Geological Survey Open-File Report 03-476, 30 p.

Braaten, P.J., and Fuller, D.B., 2002, Fort Peck flow modification biological data collection plan: Report prepared for the U.S. Army Corps of Engineers: Montana Fish, Wildlife, and Parks, 57 p.

Braaten, P.J., and Fuller, D.B., 2007, Growth rates of youngof-year shovelnose sturgeon in the Upper Missouri River: Journal of Applied Ichthyology, v. 23, p. 506-515. [Also available at http://dx.doi.org/10.1111/j.14390426.2006.00822.x.] 
Braaten, P.J., Fuller, D.B., Holte, L.D., Lott, R.D., Viste, W., Brandt, T.F., and Legare, R.G., 2008, Drift dynamics of larval pallid sturgeon and shovelnose sturgeon in a natural side channel of the Upper Missouri River, Montana: North American Journal of Fisheries Management, v. 28, p. 808826.

Braaten, P.J., Fuller, D.B., Lott, R.D., Haddix, T.M., Holte, L.D., Wilson, R.H., Bartron, M.L., Kalie, J.A., DeHaan, P.W., Ardren, W.R., Holm, R.J., and Jaeger, M.E., 2012b, Natural growth and diet of known-age pallid sturgeon (Scaphirhynchus albus) early life stages in the upper Missouri River basin, Montana and North Dakota: Journal of Applied Ichthyology, v. 28, no. 4, p. 496-504. [Also available at http://dx.doi.org/10.1111/j.1439-0426.2012.01964.x.]

Braaten, P.J., Fuller, D.B., Lott, R.D., and Jordan, G.R., 2009, An estimate of the historic population size of adult pallid sturgeon in the upper Missouri River Basin, Montana and North Dakota: Journal of Applied Ichthyology, v. 25, no. Supplement 2, p. 2-7.

Braaten, P.J., Fuller, D.B., Lott, R.D., Ruggles, M.P., Brandt, T.F., Legare, R.G., and Holm, R.J., 2012a, An experimental test and models of drift and dispersal processes of pallid sturgeon (Scaphirhynchus albus) free embryos in the Missouri River: Environmental Biology of Fishes, v. 93, p. 377-392. [Also available at http://dx.doi. org/10.1007/s10641-011-9925-9.]

Braaten, P.J., Fuller, D.B., and McClenning, N.D., 2007, Diet composition of larval and young-of-year shovelnose sturgeon in the Upper Missouri River: Journal of Applied Ichthyology, v. 23, p. 516-520. [Also available at http:// dx.doi.org/10.1111/j.1439-0426.2006.00822.x.]

Bramblett, R.G., and White, R.G., 2001, Habitat use and movements of pallid and shovelnose sturgeon in the Yellowstone and Missouri Rivers in Montana and North Dakota: Transactions of the American Fisheries Society, v. 130, no. 6, p. 1006-1025.

Brown, J.B., Sprague, L.A., and Dupree, J.A., 2011, Nutrient sources and transport in the Missouri River Basin, with emphasis on the effects of irrigation and reservoirs: Journal of the American Water Resources Association, v. 47, no. 5, p. 1034-1060. [Also available at http://dx.doi.org/10.1111/ j.1752-1688.2011.00584.x.]

Bruch, R.M., and Binkowski, F.P., 2002, Spawning behavior of lake sturgeon (Acipenser fulvescens): Journal of Applied Ichthyology, v. 18, no. 4-6, p. 507-579.

Bryan, J.L., Wildhaber, M.L., Papoulias, D.M., DeLonay, A.J., Tillitt, D.E., and Annis, M.L., 2007, Estimation of gonad volume, fecundity, and reproductive stage of shovelnose sturgeon using sonography and endoscopy with application to the endangered pallid sturgeon: Journal of Applied Ichthyology, v. 23, p. 411-419.
Buckler, J., 2011, Persistent organic pollutant effects on middle Mississippi River Scaphirhynchus sturgeon reproduction and early life stages: Columbia, Missouri, University of Missouri, $154 \mathrm{p}$.

Campton, D.E., Bass, A.L., Chapman, F.A., and Bowen, B.W., 2000, Genetic distinction of pallid, shovelnose, and Alabama sturgeon: emerging species and the US Endangered Species Act: Conservation Genetics, v. 1, no. 1, p. 17-32.

Candrl, J.S., Papoulias, D.M., and Tillitt, D.E., 2009, The point of no return in first-feeding pallid sturgeon larvae [abs.], Missouri River Natural Resources Conference \& BiOp Forum, March 24-27, 2009: Billings, Montana.

Carlson, D.M., and Pflieger, W.L., 1981, Abundance and life history of the lake, pallid, and shovelnose sturgeons in Missouri: Missouri Department of Conservation.

Carlson, D.M., Pflieger, W.L., Trial, L., and Haverland, P.S., 1985, Distribution, biology, and hybridization of Scaphirhynchus albus and Scaphirhynchus platorhynchus in the Missouri and Mississippi Rivers: Environmental Biology of Fishes, v. 14, no. 1, p. 51-59.

Caroffino, D.C., Sutton, T.M., Elliott, R.F., and Donofrio, M.C., 2010a, Early life stage mortality rates of lake sturgeon in the Peshtigo River, Wisconsin: North American Journal of Fisheries Management, v. 30, p. 295-304.

Caroffino, D.C., Sutton, T.M., Elliott, R.F., and Donofrio, M.C., 2010b, Predation on early life stages of lake sturgeon in the Peshtigo River, Wisconsin: Transactions of the American Fisheries Society, v. 139, p. 1846-1856. [Also available at http://dx.doi.org/10.1577/T09-227.1.]

Carpenter, S.R., 1990, Large-scale perturbations: opportunities for innovation: Ecology, v. 71, no. 6, p. 2038-2043.

Cash, D.W., Clark, W.C., Alcock, F., Dickson, N.M., Eckley, N., Guston, D.H., Jager, J., and Mitchell, R.B., 2003, Knowledge systems for sustainable development: Proceedings of the National Academy of Sciences, v. 100, p. 1-7.

Chipps, S.R., Klumb, R.A., and Wright, E.B., 2008, Developement and application of juvenile pallid sturgeon bioenergetics model-Final report, Study T-24-R Study No. 2424: South Dakota State University, 40 p.

Coffey, M.J., Harshbarger, J.C., Phillips, K., Berg, C., and Gross, T., 2000, Middle Mississippi River Sturgeon Preliminary Contaminants Investigation-Final Report: U.S. Fish and Wildlife Service, Rock Island, Illinois., p. 26.

Colombo, R.E., Garvey, J.E., and Wills, P.S., 2007, Gonadal development and sex-specific demographics of the shovelnose sturgeon in the Middle Mississippi River: Journal of Applied Ichthyology, v. 23, p. 420-427. 
Crossman, J.A., and Hildebrand, L.R., 2012, Evaluation of spawning substrate enhancement for white sturgeon in a regulated river: effects on larval retention and dispersal: River Research and Applications, v. 30, p. 1-10. [Also available at http://dx.doi.org/10.1002/rra.2620.]

D'Amours, J., Thibodeau, S., and Fortin, R., 2001, Comparison of lake sturgeon (Acipenser fulvescens), Stizostedion spp., Catostomus spp., Moxostoma spp., quillback (Carpiodes cyprinus), and mooneye (Hiodon tergisus) larval drift in Des Prairies River, Quebec: Canadian Journal of Zoology, v. 79, no. 8, p. 1472-1489.

DeLonay, A.J., Jacobson, R.B., Annis, M.L., Braaten, P.J., Chojnacki, K.A., Elliott, C.M., Fuller, D.B., Haas, J.D., Haddix, T.M., McElroy, B.J., Mestl, G.E., Papoulias, D.M., Rhoten, J.C., and Wildhaber, M.L., 2014, Ecological requirements for pallid sturgeon reproduction and recruitment in the Missouri River: annual report 2011: U.S. Geological Survey, Open-File Report 2014-1106, 96 p.

DeLonay, A.J., Jacobson, R.B., Papoulias, D.M., Simpkins, D.G., Wildhaber, M.L., Reuter, J.M., Bonnot, T.W., Chojnacki, K.A., Korschgen, C.E., Mestl, G.E., and Mac, M.J., 2009, Ecological requirements of pallid sturgeon reproduction and recruitment in the Lower Missouri River-A research synthesis 2005-08: U.S. Geological Survey, U.S. Geological Survey Scientific Investigations Report 2009-5201, 59 p. [Also available at http://pubs.usgs. gov/sir/2009/5201/.]

DeLonay, A.J., Jacobson, R.B., Papoulias, D.M., Wildhaber, M.L., Chojnacki, K.A., Pherigo, E.K., Bergthold, C.L., and Mestl, G.E., 2010, Ecological requirements of pallid sturgeon reproduction and recruitment in the Lower Missouri River: Annual Report 2009: U.S. Geological Survey, U.S. Geological Survey Open-File Report 2010-1215, 64 p.

DeLonay, A.J., Jacobson, R.B., Papoulias, D.M., Wildhaber, M.L., Chojnacki, K.A., Pherigo, E.K., Haas, J.D., and Mestl, G.E., 2012, Ecological requirements for pallid sturgeon reproduction and recruitment in the Lower Missouri River-Annual report 2010: U.S. Geological Survey, U.S. Geological Survey Open-File Report 2012-1009, 51 p.

DeLonay, A.J., Papoulias, D.M., Wildhaber, M.L., Annis, M.L., Bryan, J.L., Griffith, S.A., Holan, S.H., and Tillitt, D.E., 2007, Use of behavioral and physiological indicators to evaluate Scaphirhynchus sturgeon spawning success: Journal of Applied Ichthyology, v. 23, no. 4, p. 428-435.

Deng, D.F., Koshio, S., Yokoyama, S., Bai, S.C., Shao, Q.J., Cui, Y.B., and Hung, S.S.O., 2003, Effects of feeding rate on growth performance of white sturgeon (Acipenser transmontanus) larvae: Aquaculture, v. 217, no. 1-4, p. 589-598.

Dettlaff, T.A., Ginsburg, A.S., and Schmalhausen, O.I., 1993, Sturgeon fishes-Developmental biology and aquaculture: Berlin, Springer-Verlag, 300 p.
Doyle, M., Murphy, D., Bartell, S., Farmer, A., Guy, C.S., and Palmer, M., 2011, Final report on spring pulses and adaptive management: Missouri River Recovery Program Independent Science Advisory Panel, U.S. Institute for Environmental Conflict Resolution, 64 p.

Drobish, M.R., 2008, Pallid sturgeon population assessment project, volume 1.3: U.S. Army Corps of Engineers, Omaha District, $56 \mathrm{p}$.

Dryer, M.P., and Sandvol, A.J., 1993, Recovery plan for the pallid sturgeon (Scaphirhynchus albus): U.S. Fish and Wildlife Service, $55 \mathrm{p}$.

Du, H., Wei, Q.W., Zhang, H., Liu, Z., Wang, C., and Li, Y., 2011, Bottom substrate attributes relative to bedform morphology of spawning site of Chinese sturgeon Acipenser sinensis below the Gezhouba Dam: Journal of Applied Ichthyology, v. 27, no. 2, p. 257-262. [Also available at http:// dx.doi.org/10.1111/j.1439-0426.2010.01660.x.]

Duffy, W.G., Berry, C.R., and Keenlyne, K.D., 1996, Biology of the pallid sturgeon with an annotated bibliography through 1994: Cooperative Fish and Wildlife Research Unit, South Dakota State University, 32 p.

Echols, K.R., Brumbaugh, W.G., Orazio, C.E., May, T.W., Poulton, B.C., and Peterman, P.H., 2008, Distribution of pesticides, PAHs, PCBs, and bioavailable metals in depositional sediments of the lower Missouri River, USA: Archives of Environmental Contamination and Toxicology, v. 55, p. 161-172. [Also available at http://dx.doi. org/10.1007/s00244-007-9123-0.]

Eichelberger, J.S., Braaten, P.J., Fuller, D.B., Krampe, M.S., and Heist, E.J., 2014, Novel single-nucleotide polymorphism markers confirm successful spawning of endangered Pallid Sturgeon in the Upper Missouri River Basin. Transactions of the American Fisheries Society, v. 143, p. 13731385 .

Elliott, C.M., and Jacobson, R.B., 2006, Geomorphic classification and assessment of channel dynamics in the Missouri National Recreational River, South Dakota and Nebraska: U.S. Geological Survey, 66 p.

Elliott, C.M., Reuter, J.M., and Jacobson, R.B., 2009, Channel morphodynamics in four reaches of the Lower Missouri River, 2006-07: U.S. Geological Survey Scientific Investigations Report 2009-5074, 258 p. [Also available at http:// pubs.usgs.gov/sir/2009/5074/.]

Fenneman, N.M., and Johnson, D.W., 1946, Map of physiographic divisions of the conterminous U.S.: U.S. Geological Survey special map.

Ferrell, J., 1996, Soundings_-100 years of the Missouri River navigation project: Omaha, Nebr., U.S. Army Corps of Engineers, $171 \mathrm{p}$. 
Fischer, H.B., 1973, Longitudinal dispersion and turbulent mixing in open-channel flow: Annual Review of Fluid Mechanics, v. 5, p. 59-78.

Flowers, H.J., Bonvechio, T.F., and Peterson, D.L., 2011, Observation of Atlantic sturgeon predation by a Flathead Catfish: Transactions of the American Fisheries Society, v. 140 , p. $250-252$.

Forbes, S.A., and Richardson, R.E., 1905, On a new shovelnose sturgeon from the Mississippi River: Bulletin of the Illinois State Laboratory of Natural History, v. 7, p. 37-44.

Forbes, S.A., and Richardson, R.E., 1909, The fishes of Illinois: Danville, Illinois, Illinois Printing Company, 357 p.

Forsythe, P.S., Scribner, K.T., Crossman, J.A., Ragavendran, A., Baker, E.A., Davis, C., and Smith, K.K., 2012, Environmental and lunar cues are predictive of the timing of river entry and spawning-site arrival in lake sturgeon Acipenser fulvescens: Journal of Fish Biology, v. 81, no. 1, p. 35-53. [Also available at http://dx.doi.org/10.1111/j.10958649.2012.03308.x.]

Fox, D.A., Hightower, J.E., and Paruka, F.M., 2000, Gulf sturgeon spawning migration and habitat in the Choctawhatchee River system, Alabama-Florida: Transactions of the American Fisheries Society, v. 129, no. 3, p. 811-826.

French, B.W.E., Graeb, B.D.S., Chipps, S.R., Bertrand, K.N., Selch, T.M., and Klumb, R.A., 2010, Vulnerability of age-0 pallid sturgeon Scaphirhynchus albus to fish predation: Journal of Applied Ichthyology, v. 26, no. 1, p. 6-10. [Also available at http://dx.doi.org/10.1111/j.14390426.2009.01356.x.]

French, W.E., 2010, Predation vulnerability and trophic interactions of pallid sturgeon Scaphirhynchus albus: Brookings, South Dakota, South Dakota State University, 59 p.

French, W.E., Graeb, B.D.S., Chipps, S.R., and Klumb, R.A., 2014, Vulnerability of age-0 pallid sturgeon Scaphirhynchus albus to predation; effects of predator type, turbidity, body size, and prey density: Environmental Biology of Fishes, v. 97, p. 635-646. [Also available at http://dx.doi. org/10.1007/s10641-013-0166-y.]

Fuller, D.B., and Braaten, P.J., 2012, Fort Peck flow modification biological collection plan compendium: summary of 2001-2009 activities: Report submitted to the U.S. Geological Survey and the U.S. Army Corps of Engineers, Omaha District: Montana Fish, Wildlife and Parks, 122 p.

Fuller, D.B., Jaeger, M., and Webb, M., 2008, Spawning and associated movement patterns of pallid sturgeon in the lower Yellowstone River: Report submitted to the Western Area Power Administration, Upper basin pallid sturgeon work group: Montana Fish, Wildlife and Parks, 22 p.
Funk, J.L., and Robinson, J.W., 1974, Changes in the channel of the Lower Missouri River and effects on fish and wildlife: Jefferson City, Missouri., Missouri Department of Conservation, $52 \mathrm{p}$.

Galat, D.L., Berry, C.R., Gardner, W.M., Hendrickson, J.C., Mestl, G.E., Power, G.J., Stone, C., and Winston, M.R., 2005a, Spatiotemporal patterns and changes in Missouri River fishes, in Rinne, J.N., Hughes, R.M., and Calamusso, R., eds., Historical changes in large river fish assemblages of the Americas: Bethesda, Maryland, American Fisheries Society, Symposium 45, p. 249-291.

Galat, D.L., Berry, C.R., Jr., Peters, E.J., and White, R.G., 2005b, Missouri River Basin, in Benke, A.C., and Cushing, C.E., eds., Rivers of North America: Oxford, Elsevier, p. $427-480$.

Galat, D.L., and Lipkin, R., 2000, Restoring ecological integrity of great rivers: historical hydrographs aid in defining reference conditions for the Missouri River: Hydrobiologia, v. 422 , p. $29-48$.

Galbreath, J.L., 1985, Status, life history, and management of Columbia river white sturgeon, Acipenser transmontanus: Environmental Biology of Fishes, v. 14, no. 1, p. 119-126.

Garrity, C.P., and Soller, D.R., 2009, Database of the Geologic Map of North America; adapted from the map by J.C. Reed, Jr. and others (2005): U.S. Geological Survey Data Series 424 [Also available at http://pubs.usgs.gov/ds/424/.]

Garvey, J.E., Heist, E.J., Brooks, R.C., Herzog, D.P., Hrabik, R.A., Killgore, K.J., Hoover, J., and Murphy, C., 2009, Current status of the pallid sturgeon in the Middle Mississippi River: habitat, movement, and demographics: Saint Louis District, US Army Corps of Engineers, 422 p. [Also available at http://fishdata.siu.edu/pallid.]

Gerrity, P.C., Guy, C.S., and Gardner, W.M., 2006, Juvenile pallid sturgeon are piscivorous - A call for conserving native cyprinids: Transactions of the American Fisheries Society, v. 135, no. 3, p. 604-609.

Gerrity, P.C., Guy, C.S., and Gardner, W.M., 2008, Habitat use of juvenile pallid sturgeon and shovelnose sturgeon with implication for water-level management in a downstream reservoir: North American Journal of Fisheries Management, v. 28, p. 832-843.

Gisbert, E., and Doroshov, S.I., 2003, Histology of the developing digestive system and the effect of food deprivation in larval green sturgeon (Acipenser medirostris): Aquatic Living Resources, v. 16, p. 77-89.

Gisbert, E., and Williot, P., 1997, Larval behavior and effect of the timing of initial feeding on growth and survival of Siberian sturgeon (Acipenser baeri) larvae under small scale hatchery production: Aquaculture, v. 156, p. 63-76. 
Gisbert, E., and Williot, P., 2002, Advances in larval rearing of Siberian sturgeon: Journal of Fish Biology, v. 60, p. 107.

Goodman, B.J., Guy, C.S., Camp, S.L., Gardner, W.M., Kappenman, K.M., and Webb, M.A.H., 2012, Shovelnose sturgeon spawning in relation to varying discharge treatments in a Missouri River tributary: River Research and Applications, p. 1004-1015. [Also available at http://dx.doi. org/10.1002/rra.2587.]

Grohs, K.L., Klumb, R.A., Chipps, S.R., and Wanner, G.A., 2009, Ontogenetic patterns in prey use by pallid sturgeon in the Missouri River, South Dakota and Nebraska: Journal of Applied Ichthyology, v. 25, no. Supplement 2, p. 48-53. [Also available at http://dx.doi.org/10.1111/j.14390426.2009.01279.x.]

Harshbarger, J.C., Coffey, M.J., and Young, M.Y., 2000, Intersexes in Mississippi River shovelnose sturgeon sampled below Saint Louis, Missouri, USA: Marine Environmental Research, v. 50, no. 1-5, p. 247-250.

Hastings, R.P., Bauman, J.M., Baker, E.A., and Scribner, K.T., 2013, Post-hatch dispersal of lake sturgeon (Acipenser fulvescens, Rafinesque, 1817) yolk-sac larvae in relation to substrate in an artificial stream: Journal of Applied Ichthyology, v. 29, p. 1208-1213. [Also available at http://dx.doi. org/10.1111/jai.12273.]

Heimann, D.C., Cline, T.L., and Glaspie, L.M., 2011, Suspended-sediment and suspended-sand concentrations and loads for selected streams in the Mississippi River Basin, 1940-2009: U.S. Geological Survey Data Series 593, 6 p.

Heist, E., Barton, M., Kalie, J., and Leary, R., 2013, Population genetics management plan for pallid sturgeon in the upper Missouri River Basin: Final Report to Western Area Power Authority, 40 p.

Held, J.W., 1969, Some early summer foods of the shovelnose sturgeon in the Missouri River: Transactions of the American Fisheries Society, v. 98, no. 3, p. 514-517.

Hesse, L.W., Schmulbach, J.C., Carr, J.M., Keenlyne, K.D., Unkenholz, D.G., Robinson, J.W., and Mestl, G.E., 1989, Missouri River fishery resources in relation to past, present, and future stresses, in Dodge, D.P., ed., Proceedings of the International Large River Symposium: Ottawa, Canadian Special Publication of Fisheries and Aquatic Sciences, p. 353-371.

Hesse, L.W., and Sheets, W., 1993, The Missouri River hydrosystem: Fisheries, v. 18, no. 5, p. 5-14.

Hogberg, N.P., 2014, Response of large river fishes to a prolonged high water event in the Missouri River, Nebraska: Lincoln, Nebraska, University of Nebraska, 107 p.
Hoopes, D.T., 1960, Utilization of mayflies and caddis flies by some Mississippi River fishes: Transactions of the American Fisheries Society, v. 89, no. 1, p. 32-34.

Hoover, J.J., Boysen, K.A., Beard, J.A., and Smith, H., 2011, Assessing the risk of entrainment by cutterhead dredges to juvenile lake sturgeon (Acipenser fulvescens) and juvenile pallid sturgeon (Scaphirhynchus albus): Journal of Applied Ichthyology, v. 27, no. 2, p. 369-375. [Also available at http://dx.doi.org/10.1111/j.1439-0426.2011.01746.x.]

Hoover, J.J., George, S.G., and Killgore, K.J., 2007, Diet of shovelnose sturgeon and pallid sturgeon in the free-flowing Mississippi River: Journal of Applied Ichthyology, v. 23, p. 494-499.

Houde, E.D., 2008, Emerging from Hjort's shadow: Journal of Northwestern Atlantic Fisheries Sciences, v. 41, p. 53-70.

Hrabik, R.A., Herzog, D.P., Ostendorf, D.E., and Petersen, M.D., 2007, Larvae provide first evidence of successful reproduction by pallid sturgeon Scaphirhynchus albus, in the Mississippi River: Journal of Applied Ichthyology, v. 23, p. 436.

Jacobson, R.B., Blevins, D.W., and Bitner, C.J., 2009a, Sediment regime constraints on river restoration-An example from the Lower Missouri River, in James, L.A., Rathburn, S.L., and Whittecar, G.R., eds., Management and restoration of fluvial systems with broad historical changes and human impacts: Denver, Colo., Geological Society of America Special Paper 451, p. 1-22.

Jacobson, R.B., Elliott, C.M., and Johnson, H.E.,III., 2004a, Assessment of shallow-water habitat availability in modified dike structures, Lower Missouri River, 2004: U.S. Geological Survey Open-File Report, 2004-1409, 20 p. [Also available at http://www.cerc.usgs.gov/pubs/center/pdfDocs/ OFR-2004-1409.pdf.]

Jacobson, R.B., and Galat, D.L., 2006, Flow and form in rehabilitation of large-river ecosystems: An example from the Lower Missouri River: Geomorphology, v. 77, no. 3-4, p. 249-269.

Jacobson, R.B., and Galat, D.L., 2008, Design of a naturalized flow regime on the Lower Missouri River: Ecohydrology, v. 1 , no. 2, p. 81-104.

Jacobson, R.B., Johnson, H.E., III, and Dietsch, B.J., 2009b, Hydrodynamic simulations of physical aquatic habitat availability for pallid sturgeon in the Lower Missouri River, at Yankton, South Dakota, Kenslers Bend, Nebraska, Little Sioux, Iowa, and Miami, Missouri, 2006-07: U.S. Geological Survey Scientific Investigations Report 2009-5058, 67 p. [Also available at http://pubs.usgs.gov/ $\operatorname{sir} / 2009 / 5058 /$. 
Jacobson, R.B., Johnson, H.E., Laustrup, M.S., D’Urso, G.J., and Reuter, J.M., 2004b, Physical habitat dynamics in four side-channel chutes, lower Missouri River: U.S. Geological Survey Open-File Report 2004-1071, 60 p.

Jamieson, E., Rennie, C.D., and Jacobson, R.B., 2009, Evaluation of flow structure and bed load velocity in the vicinity of a submerged wing dike in a large sand bed river, in Proceedings - Water engineering for a sustainable environment, 33rd IAHR 2009 Congress: Vancouver, BC, p. 1-8.

Jamieson, E.C., Rennie, C.D., Jacobson, R.B., and Townsend, R.D., 2011, 3-D flow and scour near a submerged wing dike-ADCP measurements on the Missouri River: Water Resources Research, v. 47, no. 7, p. [Also available at http://dx.doi.org/10.1029/2010wr010043.]

Johnson, H.E., Jacobson, R.B., and Delonay, A.J., 2006a, Hydroecological modeling of the Lower Missouri River, in Proceedings of the Third Federal Interagency Hydrologic Modeling Conference, Reno, Nevada, April 2-6, 2006: Subcommittee on Hydrology of the Interagency Advisory Committee on Water Information, p. 1-8.

Johnson, J.H., LaPan, S.R., Klindt, R.M., and Schiavone, A., 2006b, Lake sturgeon spawning on artificial habitat in the St. Lawrence River: Journal of Applied Ichthyology, v. 22, p. $465-470$.

Justice, C., Pyper, B.J., Beamesderfer, R.C.P., Paragamian, V.L., Rust, P.J., Neufeld, M.D., and Ireland, S.C., 2009, Evidence of density- and size-dependent mortality in hatchery-reared juvenile white sturgeon (Acipenser transmontanus) in the Kootenai River: Canadian Journal of Fisheries and Aquatic Sciences, v. 66, p. 802-815. [Also available at http://dx.doi.org/10.1139/F09-034.]

Kallemeyn, L.W., 1983, Status of the pallid sturgeon Scaphirhynchus albus: Fisheries, v. 8, no. 1, p. 3-9.

Kappenman, K.M., Fraser, W.C., Toner, M., Dean, J., and Webb, M.A.H., 2009, Effect of temperature on growth, condition, and survival of juvenile shovelnose sturgeon: Transactions of the American Fisheries Society, v. 138, p. 927-937.

Keenlyne, K.D., 1997, Life history and status of the shovelnose sturgeon, Scaphirhynchus platorynchus: Environmental Biology of Fishes, v. 48, no. 1-4, p. 291-298.

Keenlyne, K.D., Henry, C.J., Tews, A., and Clancey, P., 1994, Morphometric comparisons of upper Missouri River sturgeons: Transactions of the American Fisheries Society, v. 123 , no. 5 , p. $779-785$.

Keenlyne, K.D., and Jenkins, L.G., 1993, Age at sexual maturity of the pallid sturgeon: Transactions of the American Fisheries Society, v. 122, p. 393-396.
Killgore, K.J., Hoover, J.J., George, S., Lewis, B.R., Murphy, C.E., and Lancaster, W.E., 2007a, Distribution, relative abundance and movements of pallid sturgeon in the freeflowing Mississippi River: Journal of Applied Ichthyology, v. 23 , p. $476-483$.

Killgore, K.J., Hoover, J.J., Kirk, J., George, S., Lewis, B.R., and Murphy, C.E., 2007b, Age and growth of pallid sturgeon in the free-flowing Mississippi River: Journal of Applied Ichthyology, v. 23, p. 452-456.

Kim, D., 2012, Assessment of longitudinal dispersion coefficients using acoustic Doppler current profilers in large river: Journal of Hydro-environment Reserach, v. 6, p. 29-39.

Koch, B., Brooks, R.C., Oliver, A., Herzog, D., Garvey, J.E., Hrabik, R., Colombo, R., Phelps, Q., and Spier, T., 2012, Habitat selection and movement of naturally occurring pallid sturgeon in the Mississippi River: Transactions of the American Fisheries Society, v. 141, no. 1, p. 112-120. [Also available at http://dx.doi.org/10.1080/00028487.2011.6520 08.]

Koch, B.T., Garvey, J.E., You, J., and Lydy, M.J., 2006, Elevated organochlorines in the brain-hypothalamic-pituitary complex of intersexual shovelnose sturgeon: Environmental Toxicology and Chemistry, v. 25, no. 7, p. 1689-1697.

Koch, R., Curry, R., and Weber, M., 1977, The effect of altered streamflow on the hydrology and geomorphology of the Yellowstone River Basin, Montana: Water Resources Division, Montana Department of Natural Resources and Conservation, Technical Report 2, $163 \mathrm{p}$.

Kolpin, D.W., Hoerger, C.C., Meyer, M.T., Wettstein, F.E., Hubbard, L.E., and Bucheli, T.D., 2010, Phytoestrogens and mycotoxins in Iowa Streams - An examination of underinvestigated compounds in agricultural basins: Journal of Environmental Quality, v. 39, no. 6, p. 2089-2099. [Also available at http://dx.doi.org/10.2134/jeq2010.0121.]

Krentz, S., Holm, R., Bollig, H., Dean, J., Rhodes, M., Hendrix, D., Heidrich, G., and Krise, B., 2005, Pallid sturgeon spawning and stocking summary report 1992-2004: Bismark, N.D., U.S. Fish and Wildlfie Service, 40 p.

Krykhtin, M.L., and Svirskii, V.G., 1997, Endemic sturgeons of the Amur River-Kaluga, Huso dauricus, and Amur sturgeon, Acipenser schrenckii: Environmental Biology of Fishes, v. 48, no. 1-4, p. 231-240.

Kuhajda, B.R., Mayden, R.L., and Wood, R.M., 2005, Identification of Scaphirhynchus albus, S. platorhynchus, and S. albus $x$ S. platorhynchus hybrids using morphological characters, Scaphirhynchus Conference-Alabama, Pallid, and Shovelnose Sturgeon: St. Louis, Missouri. 
Kuhajda, B.R., Mayden, R.L., and Wood, R.M., 2007, Morphologic comparisons of hatchery-reared specimens of Scaphirhynchus albus, Scaphirhynchus platorynchus, and S. albus x S. platorynchus hybrids (Acipenseriformes: Acipenseridae): Journal of Applied Ichthyology, v. 23, p. 324-347.

Kynard, B., 1997, Life history, latitudinal patterns, and status of the shortnose sturgeon, Acipenser brevirostrum: Environmental Biology of Fishes, v. 48, no. 1-4, p. 319-334.

Kynard, B., Breece, M., Atcheson, M., Kieffer, M., and Mangold, M., 2009, Life history and status of shortnose sturgeon (Acipenser brevirostrum) in the Potomac River: Journal of Applied Ichthyology, v. 25, supplement 2, p. 34-38.

Kynard, B., Henyey, E., and Horgan, M., 2002, Ontogenetic behavior, migration, and social behavior of pallid sturgeon, Scaphirhynchus albus, and shovelnose sturgeon, S. platorynchus, with notes on the adaptive significance of body color: Environmental Biology of Fishes, v. 63, no. 4, p. 389-403.

Kynard, B., and Parker, E., 2005, Ontogenetic behavior and dispersal of Sacramento River white sturgeon, Acipenser transmontanus, with a note on body color: Environmental Biology of Fishes, v. 74, no. 1, p. 19-30.

Kynard, B., and Parker, E., 2006, Ontogenetic behavior and dispersal of Kootenai River white sturgeon early life intervals - A laboratory study: Environmental Biology of Fishes, v. 88, no. 1, p. 65-77. [Also available at http:// dx.doi.org/10.1007/s10641-010-9618-9.]

Kynard, B., Parker, E., and Kynard, B., 2012, Guidelines for rearing substrate size for sturgeon free embryos and larvae-Behavioral response of Kootenai White Sturgeon early life stages to gravel, pebble, and rubble substrates in Annual Meeting of the American Fisheries Society, August 19-23, 2012: St. Paul, Minnesota.

Kynard, B., Parker, E., Kynard, B., and Horgan, M., 2013, Behavioural response of Kootenai white sturgeon (Acipenser transmontanus, Richardson, 1836) early life stages to gravel, pebble, and rubble substrates - guidelines for rearing substrate size: Journal of Applied Ichthyology, v. 29, p. 951-957. [Also available at http://dx.doi.org/ 10.1111/jai.12279.]

Kynard, B., Parker, E., Pugh, D., and Parker, T., 2007, Use of laboratory studies to develop a dispersal model for Missouri River pallid sturgeon early life intervals: Journal of Applied Ichthyology, v. 23, p. 365-374.

Langbein, W.B., and Schumm, S.A., 1958, Yield of sediment in relation to mean annual precipitation: American Geophysical Union Transactions, v. 39, p. 1076-1084.
Larsen, M.C., Hamilton, P.A., and Werkheiser, W.H., 2013, 2 - Water Quality Status and Trends in the United States, in Satinder, A., ed., Monitoring Water Quality: Amsterdam, Elsevier, p. 19-57. [Also available at http://www.sciencedirect.com/science/article/pii/B9780444593955000029.]

Laustrup, M.S., Jacobson, R.B., and Simpkins, D.G., 2007, Distribution of potential spawning habitat for sturgeon in the lower Missouri River, 2003-06: U.S. Geological Survey Open-File Report 2007-1192, 26 p.

Lundblad, E., Wright, D.J., Miller, J., Larkin, E.M., Rinehart, R., Battista, T., Anderson, S.M., Naar, D.F., and Donahue, B.T., 2006, A benthic terrain classification scheme for American Samoa: Marine Geodesy, v. 29, no. 2, p. 89-111. [Also available at http://dx.doi. org/10.1080/01490410600738021.]

Manly, B.F.J., McDonald, L.L., Thomas, D.L., McDonald, T.L., and Erickson, W.P., 2002, Resource selection by animals - Statistical design and analysis for field studies (2d ed.): Dordrecht, the Netherlands, Kluwer Academic Publishers, $221 \mathrm{p}$.

Manny, B.A., and Kennedy, G.W., 2002, Known lake sturgeon (Acipenser fulvescens) spawning habitat in the channel between lakes Huron and Erie in the Laurentian Great Lakes: Journal of Applied Ichthyology, v. 18, no. 4-6, p. $486-490$.

Marris, E., 2011, Rambunctious Garden - Saving nature in a post-wild world: New York, Bloomsbury, $210 \mathrm{p}$.

May, R.C., 1974, Larval mortality in marine fishes and the critical period concept, in Blaxter, J.H.S., ed., The Early Life History of Fish-Proceedings of an international symposium held at the Dunstaffnage Marine Research Laboratory of the Scottish Marine Biological Association at Oban, Scotland May 17-23, 1973: New York, Springer-Verlag, p. 3-19.

Mayden, R.L., and Kuhajda, B.R., 1997, Threatened fishes of the world-Scaphirhynchus albus (Forbes \& Richardson, 1905) (Acipenseridae): Environmental Biology of Fishes, v. 48 , no. $1-4$, p. $420-421$.

McAdam, S.O., 2011, Effects of substrate condition on habitat use and survival by white sturgeon (Acipenser transmontanus) larvae and potential implications for recruitment: Canadian Journal of Fisheries and Aquatic Sciences, v. 68 , no. 5 , p. $812-822$. [Also available at http://dx.doi. org/10.1139/F2011-021.]

McAdam, S.O., 2012, Diagnosing causes of white sturgeon (Acipenser transmontanus) recruitment failure and the importance of substrate condition to yolksac larvae survival: Vancouver, British Columbia, University of British Columbia, $175 \mathrm{p}$. 
McElroy, B., DeLonay, A., and Jacobson, R., 2012, Optimum swimming pathways of fish spawning migrations in rivers: Ecology, v. 93, no. 1, p. 29-34. [Also available at http:// dx.doi.org/10.1890/11-1082.1.]

Meade, R.H., ed., 1995, Contaminants in the Mississippi River, 1987-92: U.S. Geological Survey Circular 1133. [Also available at http://pubs.usgs.gov/circ/circ1133/.]

Metcalf, A.L., 1966, Fishes of the Kansas River System in relation to zoogeography of the Great Plains: Lawrence, Kansas, University of Kansas, 165 p.

Meyer, H.A., 2011, Influence of diet and environmental variation on physiological responses of juvenile pallid sturgeon (Scaphirhynchus albus): Brookings, South Dakota, South Dakota State University, 78 p.

Miller, A.I., and Beckman, L.G., 1996, First record of predation on white sturgeon eggs by sympatric fishes: Transactions of the American Fisheries Society, v. 125, no. 2, p. 338-340.

Miller, D.H., Jensen, K.M., Villeneuve, D.L., Kahl, M.D., Makynen, E.A., Durhan, E.J., and Ankley, G.T., 2007, Linkage of biochemical responses to population-level effects - A case study with vitellogenin in the fathead minnow (Pimephales promelas): Environmental Toxicology and Chemistry, v. 26, no. 3, p. 521-527. [Also available at http://dx.doi.org/10.1897/06-318R.1.]

Miller, K.A., Clark, M.L., and Wright, P.R., 2005, Water-quality assessment of the Yellowstone River Basin, Montana and Wyoming - Water quality of fixed sites, 1999-2001, Scientific Investigations Report (- ed.): U.S. Geological Survey Scientific Investigations Report 2004-5113, p. 96 p.

Mills, L.J., and Chichester, C., 2005, Review of evidenceAre endocrine-disrupting chemicals in the aquatic environment impacting fish populations?: Science of The Total Environment, v. 343, no. 1-3, p. 1-34. [Also available at http://dx.doi.org/10.1016/j.scitotenv.2004.12.070.]

Missouri Department of Health and Senior Services, 2011, 2011 Fish Advisory: Jefferson City, Missouri, Missouri Department of Health and Senior Services, 22 .

Modde, T., and Schmulbach, J.C., 1977, Food and feeding behavior of the shovelnose sturgeon, Scaphirynchus platorhynchus, in the unchannelized Missouri River, South Dakota: Transactions of the American Fisheries Society, v. 106 , no. 6, p. 602-608.

Moos, R.E., 1978, Movement and reproduction of shovelnose sturgeon, Scaphirhynchus platorynchus (Rafinesque), in the Missouri River in South Dakota: Vermillion, University of South Dakota, dissertation, 213 p.
Murphy, C.E., Hoover, J.J., George, S.G., and Killgore, K.J., 2007, Morphometric variation among river sturgeons (Scaphirhynchus spp.) of the Middle and Lower Mississippi River: Journal of Applied Ichthyology, v. 23, p. 313-323.

National Research Council, 1992, Restoration of Aquatic Ecosystems: Washington, D.C., National Academy Press, 552 p.

National Research Council, 2002, The Missouri River ecosystem, exploring the prospects for recovery: Washington, D.C., National Academy Press, 176 p.

National Research Council, 2011, Missouri River PlanningRecognizing and Incorporating Sediment Management: Washington, D.C., National Academy Press, 152 p.

Nilo, P., Dumont, P., and Fortin, R., 1997, Climatic and hydrological determinants of year-class strength of St Lawrence River lake sturgeon (Acipenser fulvescens): Canadian Journal of Fisheries and Aquatic Sciences, v. 54, no. 4, p. 774-780.

Oldenburg, E.W., Guy, C.S., Cureton, E.S., Webb, M.A.H., and Gardner, W.M., 2011, Effects of acclimation on poststocking dispersal and physiological condition of age-1 pallid sturgeon: Journal of Applied Ichthyology, v. 27, no. 2, p. $436-443$.

Olson, M., 2009, Clarification of the definition of shallowwater habitat - Letter to the U.S. Army Corps of Engineers: U.S. Fish and Wildlife Service, 2 p.

Ormerod, S.J., 2003, Restoration in applied ecology-Editor's introduction: Journal of Applied Ecology, v. 40, no. 1, p. 44-50. [Also available at http://dx.doi.org/10.1046/ j.1365-2664.2003.00799.x.]

Papanicolaou, A.N., Elhakeem, M., Dermisis, D., and Young, N., 2010, Evaluation of the Missouri River shallow water habitat using a 2D-hydrodynamic model: River Research and Applications, v. 27, no. 2, p. 157-167. [Also available at http://dx.doi.org/10.1002/rra.1344.]

Papoulias, D.M., Chapman, D.C., and Tillitt, D.E., 2006, Reproductive condition and occurrence of intersex in bighead carp and silver carp in the Missouri River: Hydrobiologia, v. 571, p. 355-360.

Papoulias, D.M., DeLonay, A.J., Annis, M.L., Wildhaber, M.L., and Tillitt, D.E., 2009b, Contaminant concentrations in shovelnose sturgeon from the Missouri River with abnormal intersex gonads [abs.], Missouri River Natural Resource Conference and BiOp Forum, March 25-27, 2009: Billings, Montana. 
Papoulias, D.M., DeLonay, A.J., Annis, M.L., Wildhaber, M.L., and Tillitt, D.E., 2011, Characterization of environmental cues for initiation of reproductive cycling and spawning in shovelnose sturgeon Scaphirhynchus platorynchus in the lower Missouri River, USA: Journal of Applied Ichthyology, v. 27, no. 2, p. 335-342. [Also available at http://dx.doi.org/10.1111/j.1439-0426.2010.01657.x.]

Papoulias, D.M., DeLonay, A.J., Wildhaber, M.L., Annis, M.L., and Tillitt, D.E., 2007, Incidence and severity of intersex in sturgeons: are contaminants the cause [abs.]: Proceeding of the American Fisheries Society 137th Annual Meeting, San Francisco, California, September 2-6, 2007.

Papoulias, D.M., DeLonay, A.J., Wildhaber, M.L., Annis, M.L., and Tillitt, D.E., 2009a, Intersex and other gonadal abnormalities in sturgeons from the Missouri River, USA [abs.], Proceeding of the 4th International Workshop on Gonadal Histology: Cadiz, Spain.

Papoulias, D.M., Villalobos, S.A., Meadows, J.M., Noltie, D.B., Glesy, J.P., and Tillitt, D.E., 2003, In ovo exposure to o,p'-DDE affects sexual development but not sexual differentiation in Japanese medaka (Oryzias latipes): Environmental Health Perspectives, v. 111, no. 1, p. 29-32.

Paragamian, V.L., 2012, Kootenai River white sturgeon: synthesis of two decades of research: Endangered Species Research, v. 17, p. 157-167. [Also available at http://dx.doi. org/10.3354/esr00407.]

Paragamian, V.L., and Kruse, G., 2001, Kootenai River white sturgeon spawning migration behavior and a predictive model: North American Journal of Fisheries Management, v. 21 , no. 1 , p. 10-21.

Parchure, T.M., 2005, Structural Methods to Reduce Navigation Channel Shoaling: U.S. Army Corps of Engineers, Engineer Research and Development Center, ERDC/CHL TR-05-13, 77 p.

Parsley, M.J., Anders, P.J., Miller, A.I., Beckman, L.G., and McCabe, G.T., 2002, Recovery of white sturgeon populations through natural production: understanding the influence of abiotic and biotic factors on spawning and subsequent recruitment: American Fisheries Society Symposium, v. 28 , p. 55-66.

Parsley, M.J., Beckman, L.G., and McCabe, G.T., 1993, Spawning and rearing habitat use by white sturgeons in the Columbia River downstream from McNary Dam: Transactions of the American Fisheries Society, v. 122, p. 217-227.

Pegg, M.A., Pierce, C.L., and Roy, A., 2003, Hydrological alteration along the Missouri River basin: a time series approach: Aquatic Sciences, v. 65, p. 63-72.
Perrin, C.J., Rempel, L.L., and Rosenau, M.L., 2003, White sturgeon spawning habitat in an unregulated river: Fraser River, Canada: Transactions of the American Fisheries Society, v. 132, no. 1, p. 154-165.

Petty, J.D., Huckins, J.N., Alvarez, D.A., Brumbaugh, W.G., Cranor, W.L., Gale, R.W., Rastall, A.C., Jones-Lepp, T.L., Leiker, T.J., Rostad, C.E., and Furlong, E.T., 2004, A holistic passive integrative sampling approach for assessing the presence and potential impacts of waterborne environmental contaminants: Chemosphere, v. 54, p. 695-705.

Petty, J.D., Huckins, J.N., Orazio, C.E., Lebo, J.A., Poulton, B.C., Gale, R.W., Charbonneau, C.S., and Kaiser, E.M., 1995, Determination of waterborne bioavailable organochlorine pesticide residues in the Lower Missouri River: Environmental Science and Technology, v. 29, p. 25612566.

Petty, J.D., Poulton, B.C., Charbonneau, C.S., Huckins, J.N., Jones, S.B., Cameron, J.T., and Prest, H.F., 1998, Determination of bioavailable contaminants in the Lower Missouri River following the flood of 1993: Environmental Science and Technology, v. 32, no. 7, p. 837-842.

Pflieger, W.F., 1997, Fishes of Missouri: Jefferson City, Missouri Department of Conservation.

Phelps, Q.E., Herzog, D.P., Solomon, L.E., Crites, J.W., Ostendorf, D.E., Ridings, J.W., and Hrabik, R.A., 2012a, Measurement error in shovelnose sturgeon: evidence from field observation and controlled experiment data: Journal of Freshwater Ecology, v. 28, no. 1, p. 133-138.

Phelps, Q.E., Tripp, S.J., Garvey, J.E., Herzog, D.P., Ostendorf, D., Ridings, J.W., Crites, J.W., and Hrabik, R.A., 2010a, Habitat use during early life history infers recovery needs for shovelnose sturgeon and pallid sturgeon in the middle Mississippi River: Transactions of the American Fisheries Society, v. 139, p. 1060-1068. [Also available at http://dx.doi.org/10.1577/T09-199.1.]

Phelps, Q.E., Tripp, S.J., Hintz, W.D., Garvey, J.E., Herzog, D.P., Ostendorf, D.E., Ridings, J.W., Crites, J.W., and Hrabik, R.A., 2010b, Water temperature and river stage influence mortality and abundance of naturally occurring Mississippi River Scaphirhynchus sturgeon: North American Journal of Fisheries Management, v. 30, no. 3, p. 767-775. [Also available at http://dx.doi.org/10.1577/ M09-176.1.] 
Phelps, Quinton E., Whitledge, Gregory W., Tripp, Sara J., Smith, Kurt T., Garvey, James E., Herzog, David P., Ostendorf, David E., Ridings, Joseph W., Crites, Jason W., Hrabik, Robert A., Doyle, Wyatt J., and Hill, Tracy D., 2012 b, Identifying river of origin for age-0 Scaphirhynchus sturgeons in the Missouri and Mississippi Rivers using fin ray microchemistry: Canadian Journal of Fisheries and Aquatic Sciences, v. 69, no. 5, p. 930-941. [Also available at http://dx.doi.org/10.1139/f2012-038.]

Pinter, N., and Heine, R.A., 2005, Hydrodynamic and morphodynamic response to river engineering documented by fixed-discharge analysis, Lower Missouri River, U.S.A.: Journal of Hydrology, v. 302, p. 70-91.

Pinter, N., Jemberie, A.A., Remo, J.W.F., Heine, R.A., and Ickes, B.S., 2010, Cumulative impacts of river engineering, Mississippi and Lower Missouri Rivers: River Research and Applications, v. 26, no. 5, p. 546-571. [Also available at http://dx.doi.org/10.1002/rra.1269.]

Poulton, B.C., Wildhaber, M.L., Charbonneau, C.S., Fairchild, J.F., Mueller, B.G., and Schmitt, C.J., 2003, A longitudinal assessment of the aquatic macroinvertebrate community in the channelized Lower Missouri River: Environmental Monitoring and Assessment, v. 85, no. 1, p. 23-53. [Also available at http://dx.doi.org/10.1023/a:1023301016001.]

Pracheil, B.M., McIntyre, P.B., and Lyons, J.D., 2013, Enhancing conservation of large-river biodiversity by accounting for tributaries: Frontiers in Ecology and the Environment, v. 11, no. 3, p. 124-128. http://dx.doi.org/10.1890/120179.

Quist, M.C., Boelter, A.M., Lovato, J.M., Korfanta, N.M., Bergman, H.L., Latka, D.C., Korschgen, C., Galat, D.L., Krentz, S., Oetker, M., Olson, M., Scott, C.M., and Berkley, J., 2004, Research and assessment needs for pallid sturgeon recovery in the Missouri River-Final report to the U.S. Geological Survey, U.S. Army Corps of Engineers, U.S. Fish and Wildlife Service, and U.S. Environmental Protection Agency: Laramie, Wyo., William D. Ruckelshaus Institute of Environment and Natural Resources, University of Wyoming, $82 \mathrm{p}$.

Reuter, J.M., Jacobson, R.B., Elliott, C.M., and DeLonay, A.J., 2009, Assessment of Lower Missouri River physical aquatic habitat and its use by adult sturgeon (genus Scaphirhynchus) 2005-07: U.S. Geological Survey, U.S. Geological Survey Scientific Investigations Report 2009-5121, 81 p. [Also available at http://pubs.er.usgs.gov/usgspubs/sir/ sir20095121.]

Reuter, J.M., Jacobson, R.B., Elliott, C.M., Johnson, H.E., III, and DeLonay, A.J., 2008, Hydraulic and substrate maps of reaches used by sturgeon (Genus Scaphirhynchus) in the Lower Missouri River, 2005-07: U.S. Geological Survey Data Series Report 386, 442 p. [Also available at http:// pubs.usgs.gov/ds/386/.]
Ridenour, C.J., Doyle, W.J., and Hill, T.D., 2011, Habitats of age-0 sturgeon in the lower Missouri River: Transactions of the American Fisheries Society, v. 140, no. 5, p. 1351-1358. [Also available at http://dx.doi.org/10.1080/00028487.2011 .620493.]

Rotella, J., 2012, Upper basin pallid sturgeon survival estimation project-2010 update: Report submitted to the Upper Basin Pallid Sturgeon Work Group, 64 p.

Roy, M., Clark, P.U., Barendregt, R.W., Glasmann, J.R., and Enkin, R.J., 2004, Glacial stratigraphy and paleomagnetism of late Cenozoic deposits of the north-central United States: Geological Society of America Bulletin, v. 116, no. 1-2, p. 30-41. [Also available at http://dx.doi.org/10.1130/ b25325.1.]

Ruelle, R., and Keenlyne, K.D., 1993, Contaminants in Missouri River pallid sturgeon: Bulletin of Environmental Contamination and Toxicology, v. 50, no. 6, p. 898-906.

Schapaugh, A., Hiller, T.L., and Tyre, A.J., 2010, The pallid sturgeon habitat assessment and monitoring program 2007-2009: University of Nebraska, School of Natural Resources, 29 p.

Schmulbach, J.C., Gould, G., and Groen, C.L., 1975, Relative abundance and distribution of fishes in the Missouri River, Gavins Point Dam to Rulo, Nebraska: Proceedings of the South Dakota Academy of Science, v. 54, p. 194-222.

Schrey, A.W., 2007, Discriminating pallid sturgeon (Scaphirynchus albus) and shovelnose sturgeon (S. platorhynchus) and intraspecific geographic variation based on genetic and morphological characters: Carbondale, Illinois, Southern Illinios University, 239 p.

Schrey, A.W., Boley, R., and Heist, E.J., 2011, Hybridization between pallid sturgeon Scaphirhynchus albus and shovelnose sturgeon Scaphirhynchus platorynchus: Journal of Fish Biology, v. 79, no. 7, p. 1828-1850. [Also available at http://dx.doi.org/10.1111/j.1095-8649.2011.03123.x.]

Schrey, A.W., and Heist, E.J., 2007, Stock structure of pallid sturgeon analyzed with microsatellite loci: Journal of Applied Ichthyology, v. 23, p. 297-303.

Schrey, A.W., Sloss, B., Sheehan, R., Heidinger, R., and Heist, E., 2007, Genetic discrimination of middle Mississippi River Scaphirhynchus sturgeon into pallid, shovelnose, and putative hybrids with multiple microsatellite loci: Conservation Genetics, v. 8, p. 8683-8693.

Schwarz, M.S., Lydick, C.D., Tillitt, D.E., Papoulias, D.M., and Gross, T.S., 2006, A health risk evaluation for pallid sturgeon (Scaphirhynchus albus) in the lower Platte River using shovelnose sturgeon (Scaphirhynchus platorynchus) as a surrogate: U.S. Fish and Wildlife Service, Division of Environmental Quality, Region 6, 105 p. 
Sechler, D.R., 2010, Effects of abiotic and biotic factors on diet composition of age-0 sturgen (Scaphirhynchus spp.) in the middle Mississippi River: Carbondale, Illinois, Southern Illinois University, $79 \mathrm{p}$.

Sechler, D.R., Phelps, Q.E., Tripp, S.J., Garvey, J.E., Herzog, D.P., Ostendorf, D.E., Ridings, J.W., Crites, J.W., and Hrabik, R.A., 2012, Habitat for age-0 shovelnose sturgeon and pallid sturgeon in a large river: interactions among abiotic factors, food, and energy intake: North American Journal of Fisheries Management, v. 32, no. 1, p. 24-31. [Also available at http://dx.doi.org/10.1080/02755947.2012 .655848.]

Sechler, D.R., Phelps, Q.E., Tripp, S.J., Garvey, J.E., Herzog, D.P., Ostendorf, D.E., Ridings, J.W., Crites, J.W., and Hrabik, R.A., 2013, Effects of river stage height and water temperature on diet composition of year-0 sturgeon (Scaphirhynchus spp.): a multi-year study: Journal of Applied Ichthyology, v. 29, p. 44-50. [Also available at http://dx.doi. org/10.1111/jai.12047.]

Sheehan, R.J., Heidinger, R.C., Wills, P.S., Schmidt, M.A., Conover, G.A., and Hurley, K.L., 1999, Guide to the pallid sturgeon shovelnose sturgeon character index $(\mathrm{Cl})$ and morphometric character index $(\mathrm{mCl})$ : Fisheries Research Laboratory, Southern Illinois University, $19 \mathrm{p}$.

Shuman, D.A., Klumb, R.A., Wilson, R.H., Jaeger, M.E., Haddix, T., Gardner, W.M., Doyle, W.J., Horner, P.T., Ruggles, M., Steffensen, K.D., Stukel, S., and Wanner, G.A., 2011, Pallid sturgeon size structure, condition, and growth in the Missouri River Basin: Journal of Applied Ichthyology, v. 27, no. 2, p. 269-281. [Also available at http://dx.doi. org/10.1111/j.1439-0426.2010.01645.x.]

Sloss, B.L., Klumb, R.A., and Heist, E.J., 2009, Genetic conservation and paddlefish propagation, in Paukert, C.P., and Scholten, G.D., eds., Paddlefish management, propagation, and conservation in the 21st Century: Bethesda, Maryland, American Fisheries Society, p. 307-327.

Snyder, D.E., 2002, Pallid and shovelnose sturgeon larvaeMorphological description and identification: Journal of Applied Ichthyology, v. 18, no. 4-6, p. 240-265.

Society for Ecological Restoration International Science and Policy Working Group, 2004, The SER International Primer on Ecological Restoration: Tucson, Society for Ecological Restoration International, 15 p. [Also available at http:// ser.org/resources/resources-detail-view/ser-internationalprimer-on-ecological-restoration.]

Steffensen, K.D., Powell, L.A., and Koch, J.D., 2010, Assessment of hatchery-reared pallid sturgeon survival in the lower Missouri River: North American Journal of Fisheries Management, v. 30, p. 671-678. [Also available at http:// dx.doi.org/10.1577/M09-151.1.]
Steffensen, K.D., Powell, L.A., and Pegg, M.A., 2012, Population size of hatchery-reared and wild pallid sturgeon in the lower Missouri River: North American Journal of Fisheries Management, v. 32, no. 1, p. 159-166. [Also available at http://dx.doi.org/ 10.1080/02755947.2012.661388.]

Sulak, K.J., and Clugston, J.P., 1998, Early life history stages of Gulf sturgeon in the Suwannee River, Florida: Transactions of the American Fisheries Society, v. 127, no. 5, p. $758-771$.

Sustainable Ecosystems Institute, 2008, Review of comprehensive sturgeon research program: Sustainable Ecosystems Institute, 49 p. [Also available at http://www.resolv.org/sitecollaborativescience/files/2013/02/Sturgeon.pdf.]

Theriault, V., Moyer, G.R., Jackson, L.S., Blouin, M., and Banks, M.A., 2011, Reduced reproductive success of hatchery coho salmon in the wild-Insights into most likely mechanisms: Molecular Ecology, v. 20, no. 9, p. 18601869. [Also available at http://dx.doi.org/10.1111/j.1365294X.2011.05058.x.]

Tracy-Smith, E., Galat, D.L., and Jacobson, R.B., 2012, Effects of flow dynamics on the aquatic-terrestrial transition zone (ATTZ) of lower Missouri River sandbars with implications for selected biota: River Research and Applications, v. 28, no. 7, p. 793-813. [Also available at http://dx.doi. org/10.1002/rra.1492.]

Tranah, G., Campton, D.E., and May, B., 2004, Genetic evidence for hybridization of pallid and shovelnose sturgeon: Journal of Heredity, v. 95, no. 6, p. 474-480.

Tranah, G.J., Kincaid, H.L., Krueger, C.C., Campton, D.E., and May, B., 2001, Reproductive isolation in sympatric populations of pallid and shovelnose sturgeon: North American Journal of Fisheries Management, v. 21, no. 2, p. 367-373.

Tripp, S.J., Phelps, Q.E., Colombo, R.E., Garvey, J.E., Burr, B.M., Herzog, D.P., and Hrabik, R.A., 2009, Maturation and reproduction of shovelnose sturgeon in the Middle Mississippi River: North American Journal of Fisheries Management, v. 29, no. 3, p. 730-738.

U.S. Army Corps of Engineers, 1981, Missouri River bank stabilization and navigation project final feasibility report and final EIS for the fish and wildlife mitigation plan: U.S. Army Corps of Engineers, Northwest Division, 85 p.

U.S. Army Corps of Engineers, 2002, Draft supplemental environmental impact statement, Missouri River fish and wildlife mitigation project: U.S. Army Corps of Engineers, Northwest Division. 
U.S. Army Corps of Engineers, 2003, Final biological assessment on the operation of the Missouri River Mainstem Reservoir System, the operation and maintenance of the Bank Stabilization and Navigation Project, and the Operation of the Kansas River Reservoir System: U.S. Army Corps of Engineers, Northwestern Division, Missouri River Basin Water Management Division, 29 p.

U.S. Army Corps of Engineers, 2006, Missouri River Mainstem Reservoir System-Master Water Control Manual, Missouri River Basin: Omaha, Nebraska, Northwestern Division, Missouri River Basin, Water Management Division, $432 \mathrm{p}$.

U.S. Army Corps of Engineers, 2012, Missouri River Stage Trends: U.S. Army Corps of Engineers, Northwestern Division, Reservoir Control Center Technical Report A-10, 24 p. [Also available at http://www.nwd-mr.usace.army.mil/rce/ reports/pdfs/MRStageTrends2012.pdf.]

U.S. Congress, 2007, Water Resources Development Act of 2007: Public Law 110-114.

U.S. Environmental Protection Agency, 2013, National listing of Fish Consumption Advisories: accessed on April 24, 2013, at http://water.epa.gov/scitech/swguidance/fishshellfish/fishadvisories/index.cfm.

U.S. Fish and Wildlife Service, 1993, Pallid sturgeon recovery plan: U.S. Fish and Wildlife Service, 55 p.

U.S. Fish and Wildlife Service, 2000, Biological opinion on the operation of the Missouri River main stem reservoir system, operation and maintenance of the Missouri River bank stabilization and navigation project, and operation of the Kansas River reservoir system: U.S. Fish and Wildlife Service, accessed on April 15, 2013, at http://www.nwd-mr. usace.army.mil/mmanual/opinion.html.

U.S. Fish and Wildlife Service, 2003, Amendment to the 2000 biological opinion on the operation of the Missouri River main stem reservoir system, operation and maintenance of the Missouri River bank stabilization and navigation project, and operation of the Kansas River reservoir system: U.S. Fish and Wildlife Service, 308 p. [Also available at http://www.nwd-mr.usace.army.mil/mmanual/FinalBO2003. pdf.]

U.S. Fish and Wildlife Service, 2007, Pallid sturgeon (Scaphirhynchus albus) 5-year review summary and evaluation: U.S. Fish and Wildlife Service, $120 \mathrm{p}$.

U.S. Fish and Wildlife Service, 2008, Pallid sturgeon (Scaphirhynchus albus) range wide stocking and augmentation plan: U.S. Fish and Wildlife Service, 55 p.

U.S. Fish and Wildlife Service, 2014, Revised recovery plan for the pallid sturgeon (Scaphirhynchus albus): U.S. Fish and Wildlife Service, $115 \mathrm{p}$.
Usova, T.V., 2009, Survival of naturally spawned stellate sturgeon fry during downstream migration in the Volga river: Russian Journal of Ecology, v. 40, no. 5, p. 374-376. [Also available at http://dx.doi.org/ 10.1134/ S1067413609050117.]

Wanner, G.A., Shuman, D.A., and Willis, D.W., 2007, Food habits of juvenile pallid sturgeon and adult shovelnose sturgeon in the Missouri River downstream of Fort Randall Dam, South Dakota: Journal of Freshwater Ecology, v. 22, no. 1, p. 81-92.

Watson, J.H., and Stewart, P.A., 1991, Lower Yellowstone River pallid sturgeon study: Montana Department of Fish, Wildlife, and Parks, 48 p.

Webb, M.A., Kappenman, K., and Guy, C.S., 2007, Investigation to improve larval pallid sturgeon survival during the onset of exogeneous feeding: Report submitted to the Missouri River Upper Basin Pallid Sturgeon Workgroup.

Weiss, A.D., 2001, Topographic position and landforms analysis, ESRI International User Conference: San Diego, California.

Welker, T.L., and Drobish, M.R., 2009, Missouri River standard operating procedures for fish sampling and data collection: U.S. Army Corps of Engineers, Omaha District,v. 1.4, $208 \mathrm{p}$.

Wiener, J., and Sandheinrich, M., 2010, Contaminants in the Upper Mississippi River-Historic trends, responses to regulatory controls, and emerging concerns: Hydrobiologia, v. 640, no. 1, p. 49-70. [Also available at http://dx.doi. org/10.1007/s10750-009-0064-7.]

Wildhaber, M.L., Albers, J.L., Green, N.S., and Moran, E.H., 2015, A fully-stochasticized, age-structured population model for population viability analysis of fish: Lower Missouri River endangered pallid sturgeon example: Ecological Modelling, 15 p. [Also available at http://dx.doi. org/10.1016/j.ecolmodel.2015.07.019.]

Wildhaber, M.L., DeLonay, A.J., Papoulias, D.M., Galat, D.L., Jacobson, R.B., Simpkins, D.G., Braaten, P.J., Korschgen, C.E., and Mac, M.J., 2007a, A conceptual life-history model for pallid and shovelnose sturgeon: U.S. Geological Survey Circular 1315, 18 p. [Also available at http://pubs.usgs.gov/ circ/2007/1315/.]

Wildhaber, M.L., DeLonay, A.J., Papoulias, D.M., Galat, D.L., Jacobson, R.B., Simpkins, D.G., Braaten, P.J., Korschgen, C.E., and Mac, M.J., 2011a, Identifying structural elements needed for development of a predictive life-history model for pallid and shovelnose sturgeons: Journal of Applied Ichthyology, v. 27, no. 2, p. 462-469. [Also available at http:// dx.doi.org/10.1111/j.1439-0426.2011.01731.x.] 
Wildhaber, M.L., Gladish, D.W., and Arab, A., 2012, Distribution and habitat use of the Missouri River and lower Yellowstone River benthic fishes from 1996 to 1998: a baseline for fish community recovery: River Research and Applications, v. 28, p. 1780-1803. [Also available at http://dx.doi. org/10.1002/rra.1559.]

Wildhaber, M.L., Holan, S.H., Davis, G.M., Gladish, D.W., DeLonay, A.J., Papoulias, D.M., and Sommerhauser, D.K., 2011b, Evaluating spawning migration patterns and predicting spawning success of shovelnose sturgeon in the Lower

Missouri River: Journal of Applied Ichthyology, v. 27, no. 2, p. 301-308. [Also available at http://dx.doi.org/10.1111/ j.1439-0426.2010.01663.x.]

Wildhaber, M.L., Papoulias, D.M., DeLonay, A.J., Tillitt, D.E., Bryan, J.L., and Annis, M.L., 2007b, Physical and hormonal examination of Missouri River shovelnose sturgeon reproductive stage - A reference guide: Journal of Applied Ichthyology, v. 23, p. 382-401.

Wildhaber, M.L., Papoulias, D.M., DeLonay, A.J., Tillitt, D.E., Bryan, J.L., Annis, M.L., and Allert, J.A., 2005, Gender identification of shovelnose sturgeon using ultrasonic and endoscopic imagery and the application of the method to the pallid sturgeon: Journal of Fish Biology, v. 67, no. 1, p. 114-132.

Wildhaber, M.L., Yang, W.H., and Arab, A., 2014, Population trends, bend use relative to available habitat and withinriver-bend habitat use of eight indicator species of Missouri and lower Kansas River benthic fishes: 15 years after baseline assessment: River Research and Applications, $30 \mathrm{p}$. [Also available at http://dx.doi.org/10.1002/rra.2846.]

Williams, G.P., and Wolman, M.G., 1984, Downstream effects of dams on alluvial rivers: U.S. Geological Survey Professional Paper 1286, 83 p.

Wills, P.S., Sheehan, R.J., Heidinger, R.C., and Sloss, B.L., 2002, Differentiation of pallid sturgeon and shovelnose sturgeon using an index based on meristics and morphometrics: American Fisheries Society Symposium, v. 28, p. 249-258.

Winders, K.R., and Steffensen, K.D., 2014, Population size of pallid sturgeon, Scaphirhynchus albus (Forbes \& Richardson, 1905), in the Lower Missouri River near Kansas City, Missouri, U.S.A.: Journal of Applied Ichthyology, v. 30, no. 6, p. 1356-1361. [Also available at http://dx.doi. org/10.1111/jai.12558.]

Yu, G., Liu, J., Xu, Y., and Chang, J., 2002, Estimation on abundance of benthonic fishes preying on eggs of Chinese sturgeon in reach below the Gezhouba Dam in the Yangtze River: Acta Hydrobiologica Sinica, v. 26, no. 6, p. 591-599.
Zelt, R.B., Boughton, G., Miller, K.A., Mason, J.P., and Gianakos, L.M., 1999, Environmental setting of the Yellowstone River basin, Montana, North Dakota, and Wyoming: U.S. Geological Survey, Water-Resources Investigations Report 98-4269, 113 p.

Zhang, H., Wei, Q.W., Kynard, B.E., Du, H., Yang, D.G., and Chen, X.H., 2011, Spatial structure and bottom characteristics of the only remaining spawning area of Chinese sturgeon in the Yangtze River: Journal of Applied Ichthyology, v. 27, no. 2, p. 251-256. [Also available at http://dx.doi. org/10.1111/j.1439-0426.2011.01708.x.] 
Comprehensive Sturgeon Research Project, Annual Report 2012, Appendixes 1-8 


\section{Appendix 1. Reproductive Movements and Spawning, Lower Missouri River, 2012}

\section{Background}

During 2012, the Comprehensive Sturgeon Research Project (CSRP) had 67 tagged pallid sturgeon (Scaphirhynchus albus) under surveillance. Members of this population were located at various times during the year, and fish becoming reproductive or fish with expiring tag batteries were selected for recapture and retagging. Those fish that were determined to be reproductive were used for intensive tracking during migration and spawning to address the following questions:

- Where and under what conditions do pallid sturgeon spawn in the Lower Missouri River?

- Are there hydraulic impediments to migration to spawning sites?

- Are migrations or spawning behavior associated with specific environmental cues?

Information developed during 2012 also addressed emerging evidence of strong overwintering and spawning site fidelity for some fish and the potential for some fish to use tributaries for spawning, particularly the Platte River.

\section{Scope and Objectives}

This study addresses movements of reproductive, adult pallid sturgeon downstream of Gavins Point Dam on the Lower Missouri River. The objectives are to elucidate environmental conditions and cues associated with spawning, identify and characterize spawning sites, attempt to validate successful spawning with collection of free embryos, and continue to add information on geographic range of the pallid sturgeon.

\section{Methods}

Methods used in 2012 closely follow those developed and used by the CSRP during previous years (DeLonay and others, 2007; DeLonay and others, 2009; DeLonay and others, 2010; DeLonay and others, 2012). In 2012, the U.S. Geological Survey (USGS) and the Nebraska Game and Parks Commission (NGPC) implanted and tracked female and male pallid sturgeon larger than 2 kilograms $(\mathrm{kg})$ with 2-year acoustic transmitters and data storage tags (DSTs) recording depth and temperature at 30-minute intervals. At least one, but no more than four gravid females were targeted for device implantation within each of the two Lower Missouri River study sections (fig. 1-1). At least one, but no more than three, ripe males also were targeted for device implantation within each study section. Throughout the study, concerted efforts were made to recapture, reevaluate, and reimplant telemetered pallid sturgeon. Pallid sturgeon collected by other agencies for use as broodstock in the pallid sturgeon hatchery population augmentation program also were implanted with transmitters before release back into the Missouri River near the site of capture. The annual goal of this study is to retain more than 80 adult sturgeon with active transmitters and known reproductive histories for long-term (5-10 years) analyses of migration patterns, spawning site selection and fidelity, and reproductive frequency and success.

Telemetered pallid sturgeon were located and tracked by USGS and NGPC field crews to record habitat use and seasonal movements. During pre- and post-spawn periods, segments of the Lower Missouri River were searched in an attempt to locate tagged sturgeon approximately one to three times per month (extensive tracking). During the spawning period, tracking strategies focused on the frequent location of individual tagged sturgeon rather than searching segments of the Missouri River (intensive tracking). Pallid sturgeon in reproductive condition were located weekly to daily from March through June when water temperatures reached 14-16 degrees Celsius $\left({ }^{\circ} \mathrm{C}\right)$ until spawning behavior was observed or reproductive assessments indicated that spawning was unsuccessful. Spawning behavior of female pallid sturgeon is recognized as a repeated series of movements up and down along a $0.5-0.8$-kilometer $(\mathrm{km})$ length of a revetted outside bend or over other coarse substrate (DeLonay and others, 2009). Repeated series of movements cease after 12-36 hours, and the female remains stationary for some period of time before leaving the spawning area, typically moving downstream. Spawning in each case was verified through recapture and reassessment of female reproductive status using minimally invasive ultrasonography with surgical verification. Telemetry crews attempted to collect daily to hourly observations of fish locations and habitat use during upstream migration and spawning. Telemetry tracking of pallid sturgeon in reproductive condition was prioritized to better allocate resources and increase the probability of documenting spawning events. Selected individuals were located several times daily during intensive tracking to monitor direction and rate of movement. Migrating females that were stationary for more than 6 hours were targeted for continuous monitoring and habitat characterization. Measurements of water quality (temperature, conductivity, dissolved oxygen, and turbidity) and habitat characteristics (depth and substrate) were recorded at each telemetry location. Spawning sites of telemetered pallid sturgeon were assessed using a combination of sampling for eggs or free embryos, capturing adult pallid sturgeon in reproductive condition, and identifying and documenting spawning behavior using dual-frequency identification sonar $\left(\right.$ DIDSON $^{\circledR}$ ) or side-scan sonar. Not all assessment methods were employed at each spawning location. Methods used at each location were determined by resource availability, river conditions, and safety considerations. 


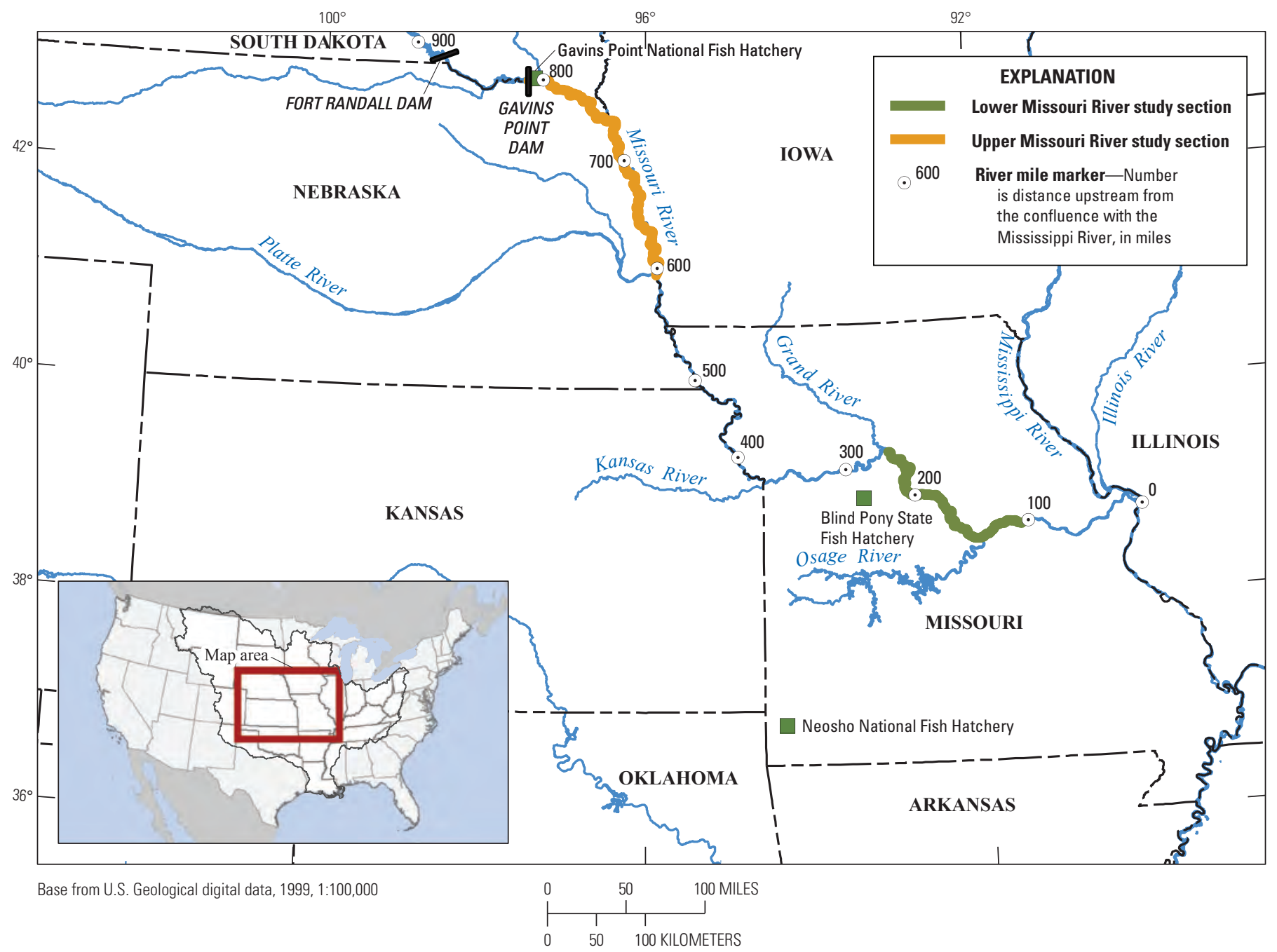

Figure 1-1. Comprehensive Sturgeon Research Project study sections and pallid sturgeon hatchery locations within the Lower Missouri River Basin.

\section{Results}

During the fall of 2011, the USGS and NGPC began recapturing and reimplanting telemetered pallid sturgeon in anticipation of 2012 studies. Using the Sturgeon Information Management System (SIMS), individual pallid sturgeon of both sexes were identified for recapture and reassessment based upon sex, reproductive history, movement within the past six months, and transmitter life expectancy. Sturgeon targeted by CSRP researchers were located and recaptured using drifted trammel nets as described in DeLonay and others (2009) from September through November 2011 and from February through November 2012. Trotline and gill net sampling for new, untagged reproductive adults began in February and continued through mid-March 2012. Temperatures in spring 2012 were exceptionally warm and few new adults were collected because field crews were shifted to intensively track reproductively ready female pallid sturgeon.
During 2012, 48 pallid sturgeon were captured, assessed, implanted with telemetry and DST devices, and released back into the Lower Missouri River. Of those, 46 were telemetry tagged pallid sturgeon that were recaptured and either reimplanted with a new acoustic tag or received a reproductive assessment. Spring 2012 sampling efforts yielded only one additional female pallid sturgeon in nonreproductive condition to the CSRP. An additional female in nonreproductive condition was transferred to the CSRP from the population augmentation program and tagged before return to the river. Four female pallid sturgeon (PLS11-007, PLS11-019, PLS09-011, and PLS10-023) captured during the fall of 2011 and spring of 2012 using targeted recapture methods were examined and determined to be likely to spawn in the spring of 2012. One of the reproductive females (PLS11-007) was recaptured in the lower Missouri River study section, whereas the other three females were recaptured in the upper Missouri River study section. The four females were intensively tracked during the 
spring of 2012 to document spawning location and success. Two of the four females were tracked to their likely spawning locations, subsequently recaptured, and determined to have spawned. Free-embryo sampling was executed at these two locations, one in the lower Missouri River study section and one in the upper Missouri River study section. One intensively tracked female (PLS11-019) in the upper Missouri River study section exhibited a complex movement pattern, which made determining the exact spawning location difficult. Another intensively tracked female (PLS10-023) failed to begin upstream migration and ultimately failed to spawn. Examination of her ovaries upon recapture showed that she had not released her eggs and was in an advanced stage of atresia. One additional female pallid sturgeon (PLS10-029) was not reproductively assessed before the spawning season but was extensively tracked during the spring of 2012. Late recapture of PLS10-029 indicated that it had been in reproductive condition in 2012 and likely spawned in the Platte River.

Female pallid sturgeon PLS11-007 was captured in nonreproductive condition on April 5, 2011, in the lower Missouri River study section. Female pallid sturgeon PLS11-007 was implanted with a telemetry transmitter and DST device and released back into the Missouri River near river mile (RM) 200. This female was located near (within 0.5 mile [mi]) her initial capture location on 13 occasions throughout the remainder of spring and summer 2011. Evaluations of reproductive readiness on September 16, 2011, and again on March 15, 2012, indicated that PLS11-007 would be ready to spawn during spring 2012. From September through December 2011, PLS11-007 moved upstream approximately $100 \mathrm{mi}$ and resumed her migration into the spring, travelling $20 \mathrm{mi}$ upstream in March of 2012. PLS11-007 was hypothesized to have spawned on an outside bend near RM 322 from March 30 through 31 (fig. 1-2). Water temperature during this time ranged from 19.3 to $20^{\circ} \mathrm{C}$. This spawning event was approximately 4-6 weeks earlier than previous spawning events documented from 2007 through 2011. DIDSON ${ }^{\circledR}$ imagery of PLS11-007 at the spawning site on March 31 was suggestive of spawning behavior. The female was present with other large sturgeon and moving short distances upstream and downstream along the base of the revetted outside bend. The repeated movement series ended abruptly, and the female moved into the navigation channel and began moving downstream. DIDSON ${ }^{\circledR}$ imagery showed that she was alone. Female PLS11-007 was recaptured on April 3, 2012, and found to have spawned completely. Field crews sampled for free embryos during the time that eggs were likely to hatch based on calculated developmental times at ambient river temperatures. The expectation was that free embryos would disperse immediately upon hatching. Free-embryo sampling from April 3 through 6, 2012, resulted in the collection of one early stage Scaphirhynchus spp. free embryo immediately downstream from the probable spawning site of PLS11-007. Subsequent genetic analyses confirmed that the collected free embryo was a shovelnose sturgeon (Scaphirhynchus platorynchus) (Heist and Eichelberger, 2013).
Female pallid sturgeon PLS11-019 was captured near RM 717 in the upper Missouri River study section and transported to the Neosho National Fish Hatchery (fig. 1-1) on March 30, 2010. This female was retained in the conservation augmentation program for more than 1 year before being released to the CSRP on May 4, 2011, in nonreproductive condition. She was implanted with a telemetry transmitter and DST device and released near the initial capture site. PLS11-019 moved approximately 50 RM downstream by October 13, 2011. During late October and November 2011 she moved back upstream approximately $25 \mathrm{mi}$ near RM 700. PLS11-019 was recaptured near this location on March 15, 2012 (fig. 1-3). A reproductive evaluation performed at that time indicated female PLS11-019 would be ready to spawn during spring 2012. Intensive tracking of this female pallid sturgeon began on April 2, 2012. The migration pattern of PLS11-019 was recorded as an irregular series of upstream and downstream movements, making the exact spawning behavior and location difficult to discern. PLS11019 was recaptured on May 31, 2012, and found to have spawned completely. PLS11-019 was hypothesized to have spawned between RM 700.1 and 713.7 between May 5 and May 31, 2012.

Female pallid sturgeon PLS09-011 was initially captured in nonreproductive condition near RM 563 on September 11, 2009. Evaluations of reproductive readiness on November 1, 2011, and again on March 23, 2012, indicated that this female would be ready to spawn during the spring of 2012 (fig. 1-4). Intensive tracking of PLS09-011 was initiated on March 31, 2012. PLS09-011 moved consistently upstream until April 2, when she began moving downstream suggesting that she may have spawned; however, this downstream movement may have been related instead to a sudden drop in river temperatures. PLS09-011 was recaptured on April 10, 2012, and at that time had not yet spawned. This female then resumed upstream movements, reaching an apex near RM 636 on April 18; however, PLS09-011 did not exhibit a movement pattern indicative of spawning behavior. By April 24, PLS09-011 had moved more than 50 mi downstream, initiating what appeared to be spawning behavior on April 26. Based on these movement patterns, PLS09-011 was hypothesized to have spawned between RM 579.8 and 580.6 from April 26 to 27, 2012. Water temperatures in the Missouri River during this time ranged from 16.1 to $17.4^{\circ} \mathrm{C}$. PLS09-011 was recaptured on April 27, 2012, and found to have spawned completely. The suspected spawning location was sampled for free embryos from May 1 through 4, 2012. Six early stage Scaphirhynchus spp. free embryos were collected immediately downstream from the probable spawning site of PLS09-011. The free embryos were estimated at less than 1 day post hatch. Subsequent genetic analyses confirmed that none of the free embryos were pallid sturgeon (Heist and Eichelberger, 2013).

Female pallid sturgeon PLS10-023 had been intensively tracked as a reproductive female in 2010. She was captured near RM 552.4 in the upper section of the Lower Missouri River and transported to the Blind Pony State Fish Hatchery 

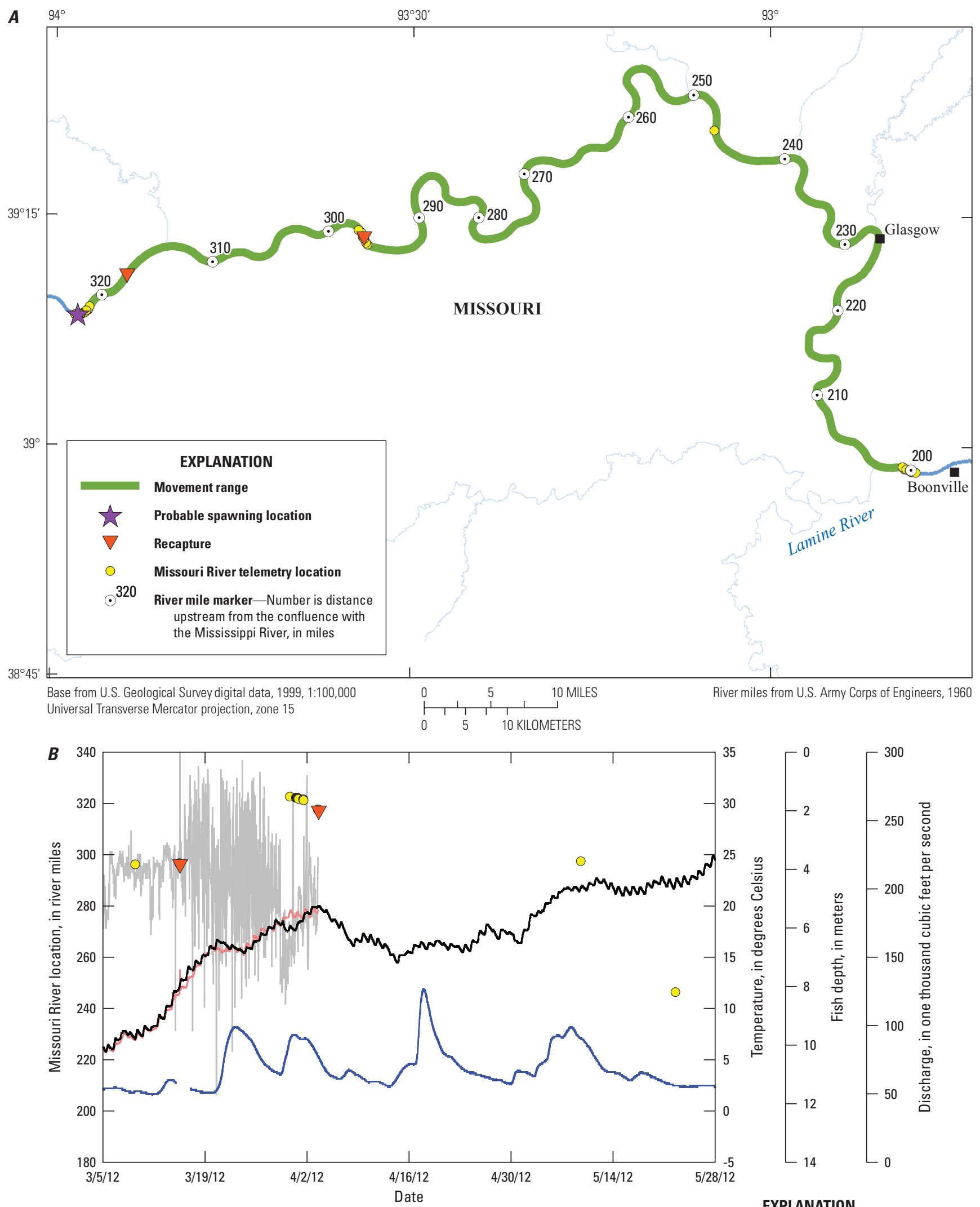

Figure 1-2. Telemetry and archival tag data of female pallid sturgeon PLS11007. $A$, Movement range, probable spawning location, recapture locations, and Missouri River telemetry locations; and, $B$, fish depth and water temperature from archival tag, and Missouri River temperature and discharge from the 

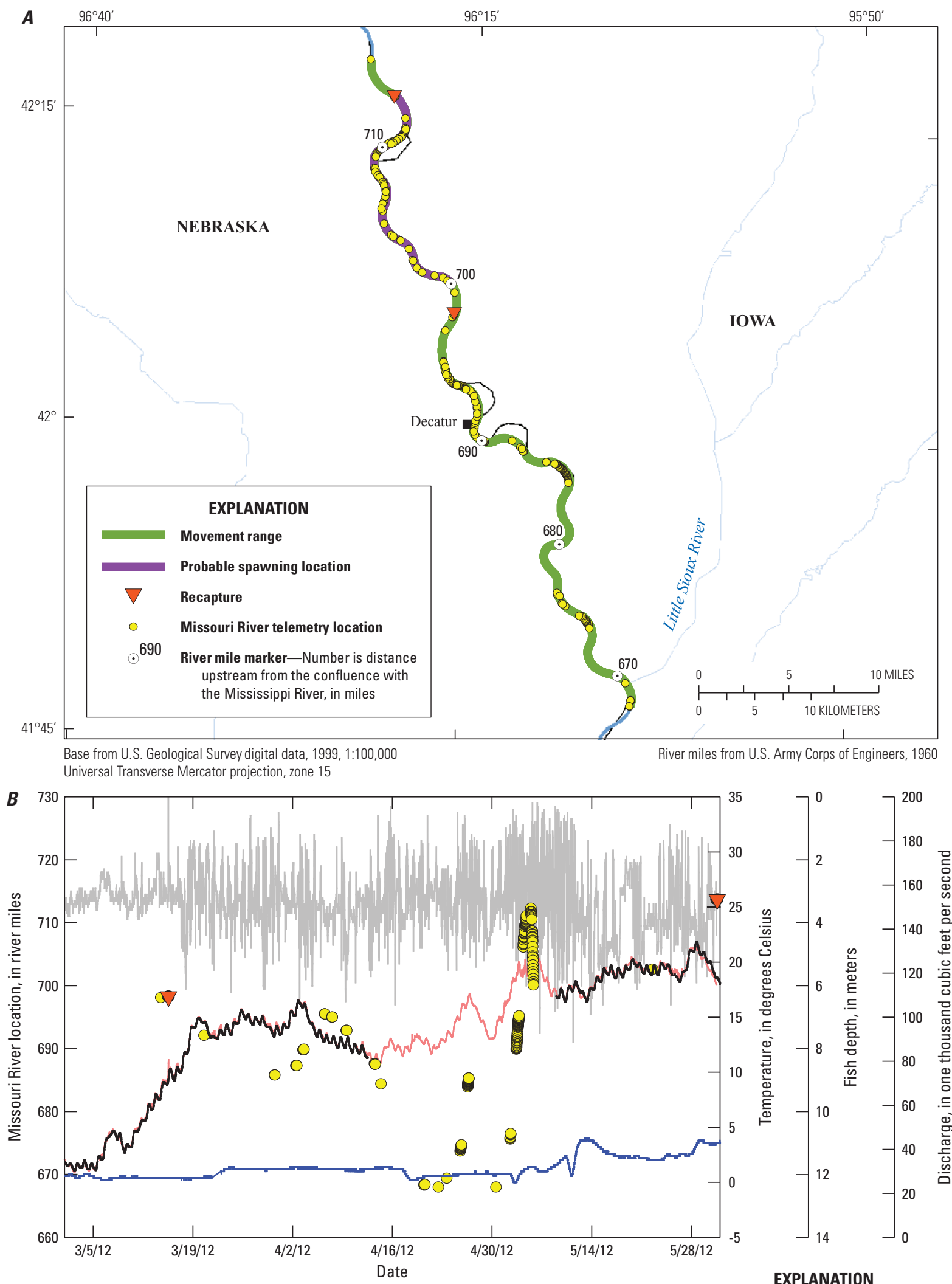

Figure 1-3. Telemetry and archival tag data of female pallid sturgeon PLS11-019. A, Movement range, probable spawning locations, recapture locations, and Missouri River telemetry locations; and, $B$, fish depth and water temperature from archival tag, and Missouri River temperature and EXPLANATION discharge from the streamgage at Decatur, Nebraska.

Fish depth from archival tag Water temperature from archival tag Missouri River temperature Missouri River discharge
Recapture

Missouri River telemetry location 

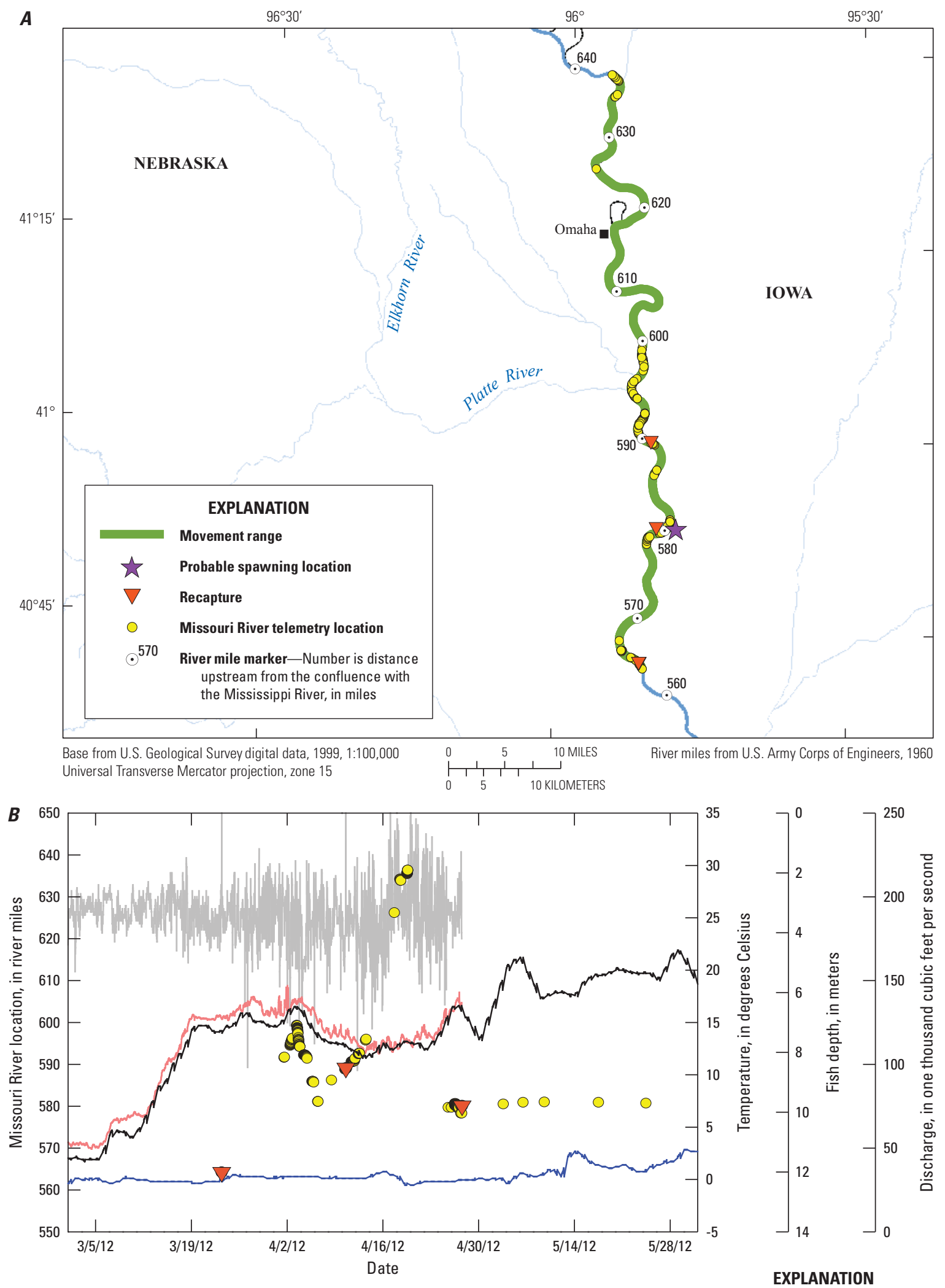

Figure 1-4. Telemetry and archival tag data of female pallid sturgeon PLS09-011. $A$, Movement range, probable spawning location, recapture locations, and Missouri River telemetry locations; and, $B$, fish depth and water temperature from archival tag, and Missouri River temperature and

— Fish depth from archival tag Water temperature from archival tag Missouri River temperature Missouri River discharge
Recapture

Missouri River telemetry location discharge from the streamgage at Omaha, Nebraska. 
(fig. 1-1) on April 14, 2010. The female did not meet genetic criteria for use as propagation broodstock and was released back into the river with an implanted transmitter. Conservative species probability assignment thresholds used in the conservation augmentation program could not sufficiently rule out the possibility of hybridization with shovelnose sturgeon one or more generations removed from this individual's parents (Heist and others, Southern Illinois University Carbondale, Carbondale, Illinois, written commun., 2010; DeLonay and others, 2012). This female subsequently spawned in 2010 , though the exact location was not documented (DeLonay and others, 2012). This female was targeted for recapture and transmitter reimplantation on April 13, 2012 (fig. 1-5). Field assessments of reproductive condition at the time indicated that this female was reproductively ready and would likely spawn during spring 2012. Female PLS10-023 did not initiate upstream migration, displaying minor upstream and downstream movements between RM 592 and 583 from April 15 to May 3, 2012. Between May 3 and May 6, PLS10-023 moved downstream approximately $18 \mathrm{RM}$, indicating that she may have spawned. PLS10-023 was recaptured on May 8, 2012, at RM 563.1. Reproductive assessments determined that PLS10$023 \mathrm{had}$ failed to spawn and was in advanced state of atresia.

Female pallid sturgeon PLS10-029 was captured near RM 563.2 in the Missouri River and transported to the Neosho National Fish Hatchery (fig. 1-1) on March 31, 2009. PLS10-029 spent more than 1 year in captivity before being used as broodstock for the population augmentation program in the spring of 2010. This female pallid sturgeon was then released to the CSRP on May 7, 2010, in post-spawn condition, implanted with a telemetry transmitter and DST device, and released near her initial capture site. The movements of PLS10-029 were recorded from approximately RM 700 to 590 in the Missouri River during 2010 and 2011. On May 11, 2011, PLS10-029 was located in the Platte River near the mouth of the Elkhorn River, approximately 33 RM upstream from the confluence of the Platte and Missouri Rivers. By October 2011, PLS10-029 was located near RM 590 in the Missouri River. The reproductive condition of PLS10-029 was not evaluated prior to the spring 2012, nor was this female intensively tracked during that time, but was recaptured in post-spawn condition with few remaining oocytes on May 2,2012 . Temperature data downloaded from the implanted DST device closely matched the temperature profile of the Platte River for much of March and April 2012 (fig. 1-6). Based on the comparison of temperature profiles, PLS10029 was hypothesized to have spawned in the Platte River. Although the exact spawning location was not observed, this data supports the hypothesis that pallid sturgeon are spawning somewhere in the Platte River or its tributaries (DeLonay and others, 2014).

\section{Summary}

Intensive and extensive tracking efforts since 2007 have resulted in the documentation of 18 spawning events of female pallid sturgeon in the Lower Missouri River and 4 spawning events in the Platte River. The precision of documentation varies for spawning events. Descriptions of spawning events for some intensively tracked and recaptured females have defined spawning as depositing eggs over a few hundred meters of an outside bend of the river in a 24-36-hour period (DeLonay and others, 2009) after a characteristic upstream migration. Estimates of the spawning location and timing of other telemetered females were broadly defined, especially if the migration pattern of intensively tracked females was complex and disrupted without clear observation of spawning behavior, or if the females were tracked only extensively and had only a few observations between the initial reproductive evaluation and the post-spawn recapture (DeLonay and others, 2009; DeLonay and others, 2012). Individual pallid sturgeon of both sexes have been documented returning to the same section of river to spawn (DeLonay and others, 2010; DeLonay and others, 2012). Long-term (5-10 years) tracking of individual pallid sturgeon will be required to assess the level of spawning site fidelity and the role this geographic specificity may play in preserving the population genetic structure. 

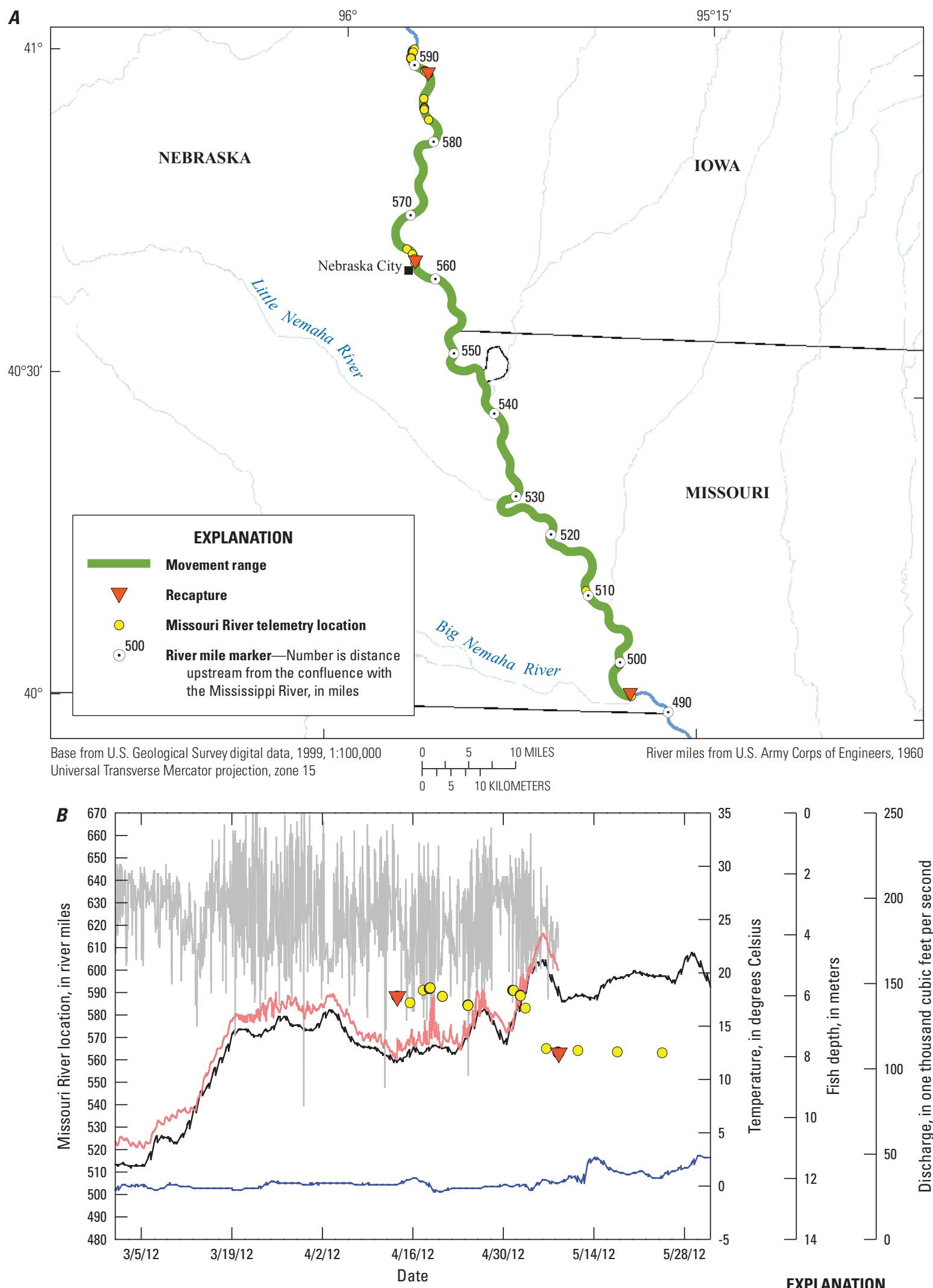

Figure 1-5. Telemetry and archival tag data of female pallid sturgeon PLS10-023. A, Movement range, recapture locations, and Missouri River telemetry locations; and, $B$, fish depth and water temperature from archival tag, and Missouri River temperature and discharge from the streamgage at Omaha, Nebraska.

EXPLANATION 

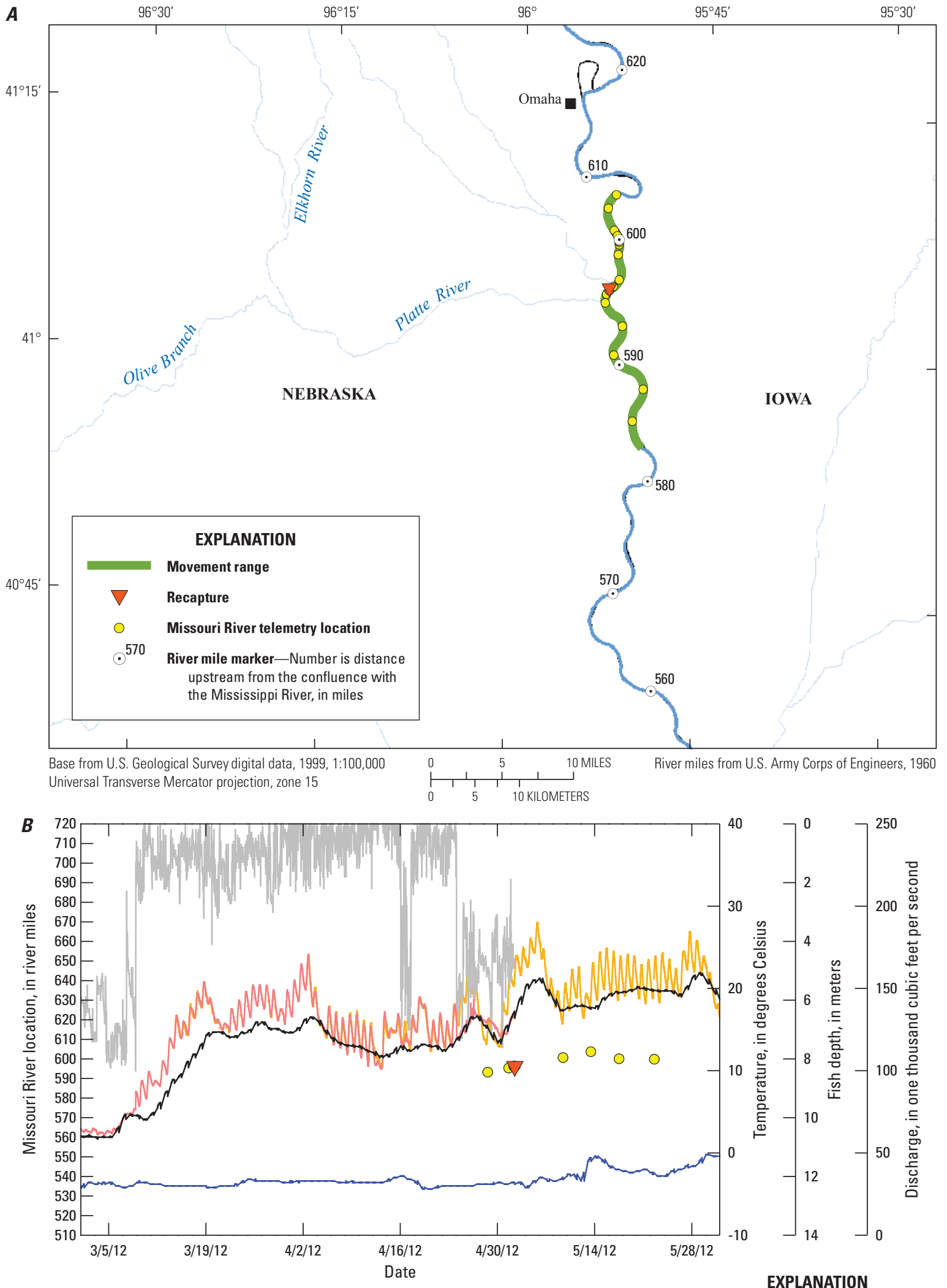

Figure 1-6. Telemetry and archival tag data of female pallid sturgeon PLS10-029. $A$, Movement range, recapture location, and Missouri River telemetry locations; and, $B$, fish depth and water temperature from archival tag, Platte River temperature from the streamgage at Louisville, Nebraska, and Missouri River temperature and discharge EXPLANATION from the streamgage at Omaha, Nebraska.

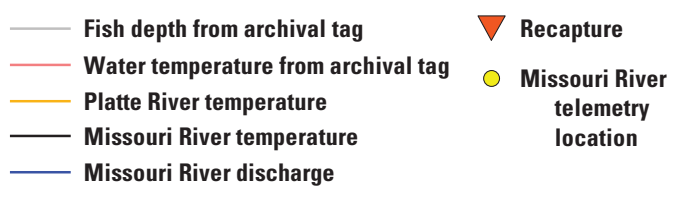




\section{References Cited}

DeLonay, A.J., Everitt, D.W., Papoulias, D.M., Wildhaber, M.L., Mestl, G.E., and Chojnacki, K.A., 2007, Movement, habitat use, and reproductive behavior of shovelnose sturgeon and pallid sturgeon in the lower Missouri River, in Korschgen, C.E., ed., Factors affecting the reproduction, recruitment, habitat, and population dynamics of pallid sturgeon and shovelnose sturgeon in the Missouri River: U.S. Geological Survey Open-File Report 20071262, p. 23-102. [Also available at http://pubs.usgs.gov/ of/2007/1262/pdf/OF2007-1262.pdf.]

DeLonay, A.J., Jacobson, R.B., Papoulias, D.M., Simpkins, D.G., Wildhaber, M.L., Reuter, J.M., Bonnot, T.W., Chojnacki, K.A., Korschgen, C.E., Mestl, G.E., and Mac, M.J., 2009, Ecological requirements of pallid sturgeon reproduction and recruitment in the lower Missouri River-A research synthesis 2005-08: U.S. Geological Survey OpenFile Report 2009-5201, 59 p. [Also available at http://pubs. usgs.gov/sir/2009/5201/.]

DeLonay, A.J., Jacobson, R.B., Papoulias, D.M., Wildhaber, M.L., Chojnacki, K.A., Pherigo, E.K., Bergthold, C.L., and Mestl, G.E., 2010, Ecological requirements of pallid sturgeon reproduction and recruitment in the lower Missouri River-Annual report 2009: U.S. Geological Survey OpenFile Report 2010-1215, 64 p. [Also available at http://pubs. usgs.gov/of/2010/1215/.]

DeLonay, A.J., Jacobson, R.B., Papoulias, D.M., Wildhaber, M.L., Chojnacki, K.A., Pherigo, E.K., Haas, J.D., and Mestl, G.E., 2012, Ecological requirements for pallid sturgeon reproduction and recruitment in the lower Missouri River-Annual report 2010: U.S. Geological Survey OpenFile Report 2012-1009, 51 p. [Also available at http://pubs. usgs.gov/of/2012/1009/.]

DeLonay, A.J., Jacobson, R.B., Annis, M.L., Braaten, P.J., Chojnacki, K.A., Elliott, C.M., Fuller, D.B., Haas, J.D., Haddix, T.M., McElroy, B.J., Mestl, G.E., Papoulias, D.M., Rhoten, J.C., and Wildhaber, M.L., 2014, Ecological requirements for pallid sturgeon reproduction and recruitment in the Missouri River-Annual report 2011: U.S. Geological Survey Open-File Report 2014-1106, 96 p. [Also available at http://dx.doi.org/10.3133/ofr20141106.]

Heist, E.J., and Eichelberger, J., 2013, 2012 genetic analysis of Missouri River sturgeon larvae: Center for Fisheries, Aquaculture, and Aquatic Sciences, Southern Illinois University Carbondale, $27 \mathrm{p}$. 


\section{Appendix 2. Examination of Pallid Sturgeon Use, Migrations, and Spawning in the Milk River and Missouri River downstream from Fort Peck Dam during 2012}

\section{Background}

The Lower Yellowstone River and Missouri River between Fort Peck Dam and Lake Sakakawea is inhabited by a wild adult population of federally endangered pallid sturgeon (Scaphirhynchus albus). During the last 2 decades, pallid sturgeon in this section of the Upper Missouri River Basin have been the focus of several studies examining movements, migrations, and habitat use (Bramblett and White, 2001; Fuller and others, 2008; Fuller and Braaten, 2012).

In 2011, record setting snowfall coupled with record spring rains resulted in rapid filling of Fort Peck Reservoir above full pool, and subsequently releasing water over the Fort Peck Spillway. The hydrologic regime in the Missouri River downstream of Fort Peck Dam during 2011 was unique among the last several years because of these spillway releases, increased discharge from the Fort Peck powerhouses, and elevated discharge conditions during spring and early summer from the Milk River. This resulted in an increased use by adult pallid sturgeon (DeLonay and others, 2014) and hatcheryreared juvenile pallid sturgeon (Hunziker and others, 2013) in the reach of the Missouri River from Fort Peck Dam to Wolf Point. Additionally, an aggregation of adult pallid sturgeon was located just downstream of the Milk River, and the first genetically confirmed, naturally spawned pallid sturgeon free embryo was collected in this reach (DeLonay and others, 2014).
Additional information is being collected to determine the flow regimes needed to trigger migrations and spawning of pallid sturgeon in the Missouri River below Fort Peck Dam. This study focused on evaluating use, migrations, and spawning of pallid sturgeon in the Milk River and Missouri River downstream from Fort Peck Dam.

\section{Scope and Objectives}

The objectives of this work were (1) to assess pallid sturgeon migrations and use of the Milk River and Missouri River between Fort Peck Dam and the Yellowstone River confluence; (2) to quantify reproductive products (eggs, free embryos, larvae) and potential spawning reaches in the Milk River and Missouri River below Fort Peck Dam; and (3) to assess and quantify settlement of pallid sturgeon larvae from the drift based on collections of young-of-year pallid sturgeon in lower reaches of the Missouri River.

\section{Study Area}

The Missouri River study area extended from Fort Peck Dam located at river mile (RM) 1,770 downstream to RM 1,553.5 (near Williston, North Dakota; fig. 2-1). The study area also included the lower 115 miles of the Milk River from Vandalia Dam to its confluence with the Missouri River.
Figure 2-1. Location of Upper Missouri River and Yellowstone River study sections.

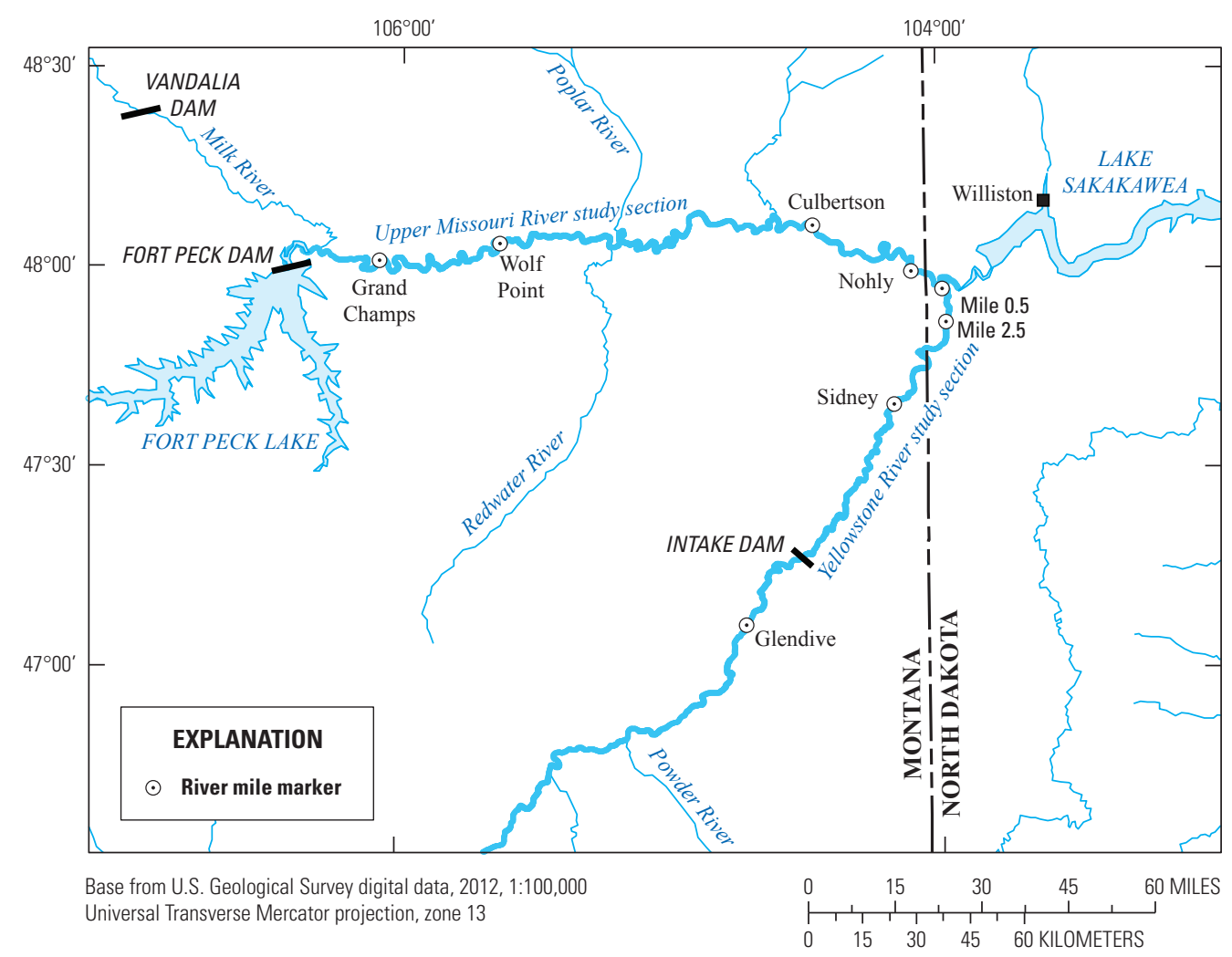




\section{Methods}

Pallid sturgeon were captured using drifted trammel nets and were implanted with radio tags (MCFT-3L tags, 16 millimeters $[\mathrm{mm}] \times 73 \mathrm{~mm}$, air weight $=26$ grams [g], 2,929-day longevity, 5-second pulse interval, 149.760 megahertz [MHz], Lotek Wireless Incorporated, New Market, Ontario). The coded signal emitted by each tag is unique to facilitate identification of individual fish. Most fish were collected and tagged during broodstock collections in previous years near the confluence of the Missouri and Yellowstone Rivers.

Manual tracking of fish during 2012 was initiated in April. The Missouri River between Fort Peck Dam and Wolf Point (70 kilometers [km]) was tracked from April through October. The Milk River was not manually tracked in 2012 (see, "Results"). One radio frequency $(149.760 \mathrm{MHz})$ was monitored during the boat-tracking run using a 4-element Yagi antenna. Fish code, latitude, longitude, and time of day were recorded at fish locations.

Stationary telemetry logging stations were deployed in April 2012 at four sites on the Missouri River (Nickels, RM 1,760; near Wolf Point, RM 1,720; near Culbertson, RM 1,620; at RM 1,584 just upstream from the Yellowstone River confluence), one site on the Milk River (RM 2.5), and several sites on the Yellowstone River, which are mentioned in a separate section of this report ("Appendix 4"). The logging stations were placed on shore with two 4-element Yagi antennae facing upstream and downstream. Each logging station was equipped with a battery powered receiver (Lotek SRX-400), solar panel, an environmental enclosure kit containing dual 12-volt batteries, and an antenna switchbox. Data recorded by the logging stations were downloaded to a laptop computer two times per month between April and October. Coupled with manual tracking efforts, the array of telemetry logging stations facilitated detection of dates and times of movement events between and within rivers and river reaches.

Free embryos and larvae were sampled in the lower Milk River and Missouri River near Wolf Point following methods outlined in Braaten and others (2010). Sampling was done two times per week at multiple replicate locations. After sampling was completed, net contents were transferred to black rubber trays where Acipenseriformes free embryos and larvae (sturgeon and paddlefish) were extracted from the detritus. Extracted Acipenseriformes were placed immediately in 95-percent nondenatured ethanol for genetic analysis. After extracting the specimens, the remaining sample was placed in a 10-percent formalin solution containing phloxine-B dye, and contents were separated and identified in the lab.

Targeted sampling for young-of-year pallid sturgeon followed trawling methods outlined in Braaten and Fuller (2007) and was conducted every week from mid-July through midSeptember. Sampling for young-of-year sturgeon (Scaphirhynchus spp.) was conducted with a benthic beam trawl in the Missouri River above the confluence (ATC) with the Yellowstone River and Missouri River below the confluence
(BTC) with the Yellowstone River. Four replicate-sampling locations were established at each site where each replicate consisted of an inside bend, outside bend, and channel crossover habitat complex associated with a river bend. Fin clips were obtained for all Scaphirhynchus spp. collected, stored in 95-percent ethanol, and genetically processed by Southern Illinois University to distinguish individuals as pallid sturgeon or shovelnose sturgeon (Scaphirhynchus platorynchus). If identified as a pallid sturgeon, further analysis was done to determine parentage.

\section{Results}

Telemetered wild adult pallid sturgeon $(n=41)$ were manually tracked in the Missouri River ATC to Fort Peck Dam. There was no use of the Milk River by telemetered pallid sturgeon in 2012. Similar to 2005-2010, use of the Missouri River ATC by adult pallid sturgeon in 2012 declined through the spring and reached a low during the spawning season (less than $[<] 10$ percent from late May to July; fig. 2-2). Only two fish were located upstream of Wolf Point in 2012 prior to the spawning season; however, both emigrated out of this reach and into the Yellowstone River by late May. Use of this reach increased in July as fish completed spawning in the Yellowstone River and migrated to post-spawn areas in the Missouri River ATC and BTC with the Yellowstone River where most would eventually winter.

Free embryos and larvae were sampled in the Milk River during 16 events spanning from May 22 through July 17, 2012. No sturgeon or paddlefish larvae were collected during this time. Free embryo and larval sampling was done on the Missouri River near Wolf Point during 20 events from May 23 through July 26, 2012. A total of 109 paddlefish and 31 Scaphirhynchus sturgeon was collected (table 2-1). Genetic analysis of the Scaphirhynchus sturgeon indicated that they were all shovelnose sturgeon.

Beam trawling for young-of-year sturgeon was done weekly from July 24 through September 11, 2012. Channel catfish (Ictalurus punctatus) and sturgeon chub (Macrhybopsis gelida) made up 65 percent and 19 percent of the catch, respectively (table 2-2). A total of 156 young-of-year sturgeon was collected in the Missouri River ATC, whereas one was collected in the Missouri River BTC. All were determined to be shovelnose sturgeon through genetic analysis (Heist and Eichelberger, 2013).

Based on the small size of these shovelnose sturgeon collected in September (34-152 $\mathrm{mm}$ ) spawning was prolonged in 2012 (table 2-3). This was most likely because of sustained high discharge (approximately 12,000 cubic feet per second $\left[\mathrm{ft}^{3} / \mathrm{s}\right]$ ) from Fort Peck Dam and cool water temperatures associated with hypolimnetic releases from the dam. Although sampling ceased on July 26 , it is likely shovelnose-sturgeon embryos were hatching into mid-August based on growth models developed by Braaten and Fuller (2007). 


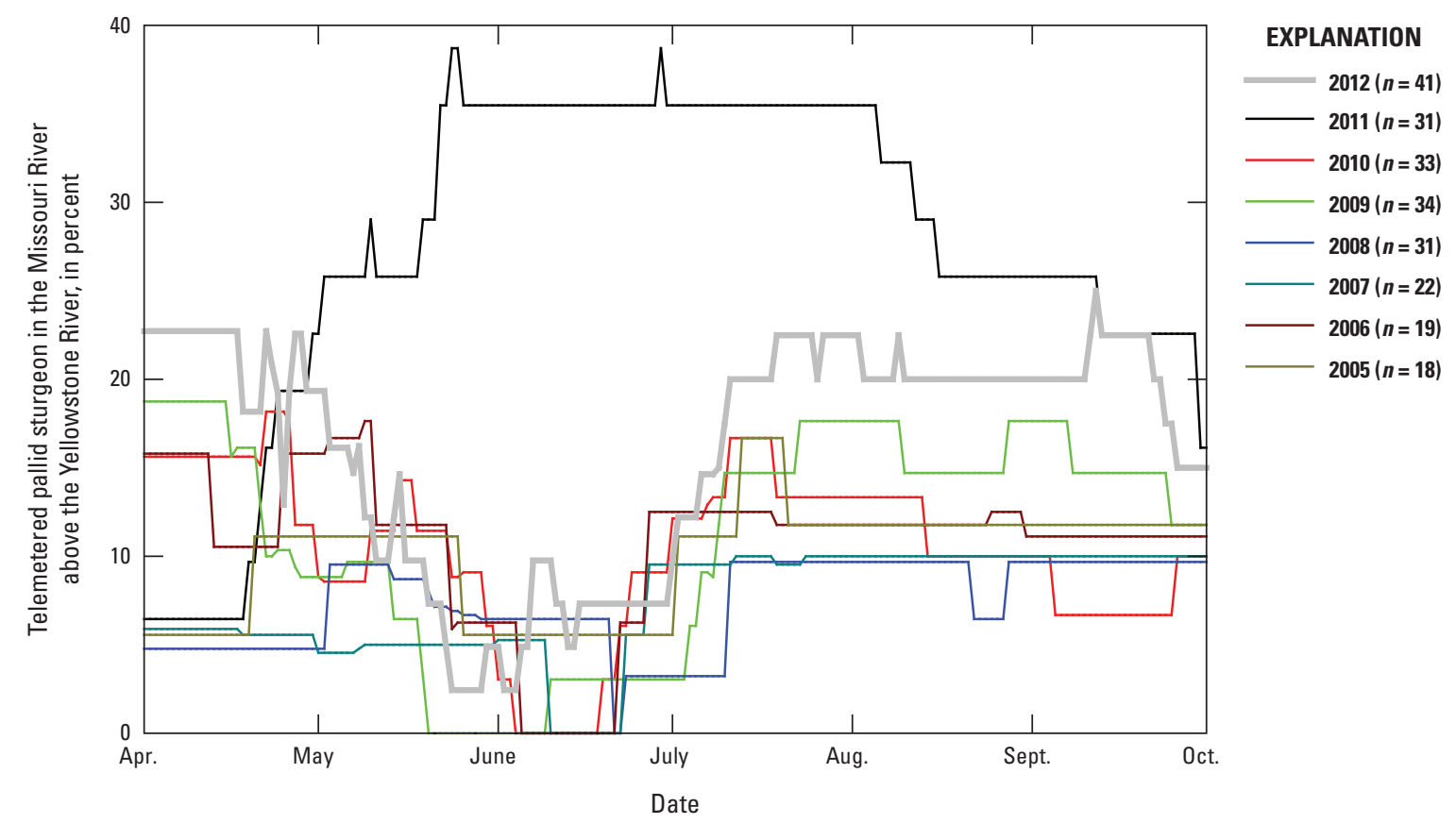

Figure 2-2. Percent of telemetered adult pallid sturgeon located in the Missouri River above the confluence with the Yellowstone River, 2005-12.

Table 2-1. Sampling dates and paddlefish, shovelnose sturgeon, and pallid sturgeon free embryos and larvae collected in the Missouri River near Wolf Point, Montana, in 2012.

\begin{tabular}{|c|c|c|c|c|c|c|c|c|c|c|c|c|c|c|c|c|c|c|c|c|c|}
\hline \multirow{2}{*}{ Date } & \multicolumn{3}{|c|}{ May } & \multicolumn{9}{|c|}{ June } & \multicolumn{8}{|c|}{ July } & \multirow{2}{*}{ Total } \\
\hline & 23 & 25 & 29 & 1 & 6 & 7 & 11 & 14 & 18 & 21 & 26 & 28 & 2 & 5 & 11 & 13 & 16 & 19 & 22 & 26 & \\
\hline Paddlefish & 0 & 0 & 0 & 0 & 0 & 0 & 0 & 13 & 13 & 1 & 7 & 2 & 7 & 29 & 21 & 12 & 3 & 0 & 1 & 0 & 109 \\
\hline Pallid sturgeon & 0 & 0 & 0 & 0 & 0 & 0 & 0 & 0 & 0 & 0 & 0 & 0 & 0 & 0 & 0 & 0 & 0 & 0 & 0 & 0 & 0 \\
\hline
\end{tabular}

\section{Summary}

During 2012, there was very little use by wild adult pallid sturgeon of the Missouri River above the confluence with the Yellowstone River, and no sturgeon were detected in the Milk River. These results are very similar to every other year in which no spillway releases were implemented or in which high flows did not originate from the Milk River.

Documentation of pallid sturgeon using, spawning, hatching, and dispersing free embryos in the Upper Missouri River downstream of Fort Peck Dam in 2011 indicates that the Missouri River can be used by pallid sturgeon when there are large flow pulses (DeLonay and others, 2014). Results of the 2011 study added substantial new information on pallid sturgeon movement, river use, and behavior. Verification of successful reproduction by wild pallid sturgeon has provided information that shows spawning, fertilization, egg survival, and hatching is possible in the Missouri River when flows deviate from baseline operations.
In comparison, successful spawning of shovelnose sturgeon has been documented in the Missouri River downstream from Fort Peck Dam every year since 2001 (DeLonay and others, 2014; Fuller and Braaten, 2013). These spawning events may be from a population of shovelnose sturgeon that resides year-round in areas of the Missouri River upstream of Wolf Point; therefore, unlike pallid sturgeon, which typically reside lower in the Missouri River outside of the spawning season, flow-pulse migration cues may not be required to draw shovelnose sturgeon to upstream spawning reaches in the Upper Missouri River.

Further studies on conditions required to cue pallid sturgeon to migrate into the Missouri River and spawn would have value. The 2011 hydrologic conditions were extreme and may have had much higher flows than were necessary to cue migration. Since very few sexually mature adult pallid sturgeon have been observed in the Missouri River with the exception of 2011, limited data exist that details the minimum flow parameters required to stimulate wild pallid sturgeon migrations and spawning. 
Table 2-2. Total catch of fish by the benthic trawl in the Missouri River above the confluence of the Yellowstone River (MRATC), Missouri River below the confluence of the Yellowstone River (MRBTC), and total catch from July 24 to September 11, 2012.

[YOY, young-of-year; --, none collected]

\begin{tabular}{|c|c|c|c|}
\hline Species & (MRATC) & (MRBTC) & Total \\
\hline Number of trawls without fish & 26 & 10 & 36 \\
\hline Blue sucker (Cycleptus elongatus) & -- & 2 & 2 \\
\hline Channel catfish (Ictalurus punctatus) & 26 & 1,635 & 1,661 \\
\hline Common carp (Cyprinus carpio) & -- & 3 & 3 \\
\hline Emerald shiner (Notropis atherinoides) & 4 & 12 & 16 \\
\hline Flathead chub (Platygobio gracilis) & 19 & 25 & 44 \\
\hline Freshwater drum (Aplodinotus grunniens) & 1 & 23 & 24 \\
\hline Goldeye (Hiodon alosoides) & -- & 1 & 1 \\
\hline Longnose dace (Rhinichthys cataractae) & -- & 4 & 4 \\
\hline Paddlefish (Polyodon spathula) & -- & 1 & 1 \\
\hline Pallid sturgeon (Scaphirhynchus albus) ${ }^{1}$ & 3 & 7 & 10 \\
\hline River carpsucker (Carpiodes carpio) & -- & 5 & 5 \\
\hline Sauger (Sander canadensis) & -- & 25 & 25 \\
\hline Sicklefin chub (Macrhybopsis meeki) & 19 & 18 & 37 \\
\hline Sturgeon chub (Macrhybopsis gelida) & 92 & 396 & 488 \\
\hline Shovelnose sturgeon (Scaphirhynchus platorynchus) & 4 & 17 & 21 \\
\hline Shovelnose sturgeon (YOY) & 1 & 156 & 157 \\
\hline Stonecat (Noturus flavus) & 1 & 55 & 56 \\
\hline Unidentified chub (Hybognathus spp.) & -- & 9 & 9 \\
\hline Unidentified Cyprinidae & -- & 1 & 1 \\
\hline Walleye (Sander vitreus) & -- & 3 & 3 \\
\hline White bass (Morone chrysops) & -- & 1 & 1 \\
\hline White crappie (Pomoxis annularis) & -- & 3 & 3 \\
\hline White sucker (Catostomus commersonii) & -- & 1 & 1 \\
\hline Total & 170 & 2,403 & 2,573 \\
\hline
\end{tabular}

${ }^{1}$ Nonwild, hatchery-origin.

Table 2-3. Catch of shovelnose sturgeon in standard trawls and targeted trawls in the Missouri River during 2012 by date.

$[n$, number $]$

\begin{tabular}{lcccccc}
\hline \multicolumn{1}{c}{ Date } & $\begin{array}{c}\text { Total } \\
(\boldsymbol{n})\end{array}$ & $\begin{array}{c}\text { Standard } \\
(\boldsymbol{n})\end{array}$ & $\begin{array}{c}\text { Targeted } \\
(\boldsymbol{n})\end{array}$ & $\begin{array}{c}\text { Minimum length, } \\
\text { in millimeters }\end{array}$ & $\begin{array}{c}\text { Maximum length, } \\
\text { in millimeters }\end{array}$ & $\begin{array}{c}\text { Mean length, } \\
\text { in millimeters }\end{array}$ \\
\hline $7 / 24 / 2012$ & 5 & 1 & 4 & 18 & 45 & 29 \\
$7 / 30 / 2012$ & 13 & 4 & 9 & 13 & 67 & 29.8 \\
$8 / 8 / 2012$ & 37 & 8 & 29 & 20 & 112 & 38 \\
$8 / 14 / 2012$ & 39 & 8 & 31 & 27 & 63 & 34.8 \\
$8 / 22 / 2012$ & 7 & 5 & 2 & 33 & 76 & 53.1 \\
$8 / 28 / 2012$ & 18 & 8 & 10 & 26 & 135 & 50.8 \\
$9 / 5 / 2012$ & 12 & 5 & 7 & 34 & 152 & 71.6 \\
$9 / 11 / 2012$ & 26 & 4 & 22 & 38 & 98 & 66.1 \\
\hline
\end{tabular}




\section{References Cited}

Bramblett, R.G., and White, R.G., 2001, Habitat use and movements of pallid and shovelnose sturgeon in the Yellowstone and Missouri Rivers in Montana and North Dakota: Transactions of the American Fisheries Society, v. 130, no. 6, p. 1006-1025. [Also available at http://dx.doi. org/10.1577/1548-8659(2001)130<1006:HUAMOP > 2.0 .CO;2.]

Braaten, P.J., and Fuller, D.B., 2007, Growth rates of youngof-year shovelnose sturgeon in the upper Missouri River: Journal of Applied Ichthyology, v. 23, no. 4, p. 506-515. [Also available at http://dx.doi.org/10.1111/j.14390426.2006.00821.x.]

Braaten, P.J., Fuller, D.B., Lott, R.D., Ruggles, M.P., and Holm, R.J., 2010, Spatial distribution of drifting pallid sturgeon larvae in the Missouri River inferred from two net designs and multiple sampling locations: North American Journal of Fisheries Management, v. 30, no. 4, p. 1062-1074. [Also available at http://dx.doi.org/10.1577/ M09-149.1.]

DeLonay, A.J., Jacobson, R.B., Papoulias, D.M., Wildhaber, M.L., Chojnacki, K.A., Pherigo, E.K., Hass, J.D., and Mestl, G.E., 2014, Ecological requirements of pallid sturgeon reproduction and recruitment in the lower Missouri River-Annual report 2011: U.S. Geological Survey, 63 p.

Fuller, D.B., and Braaten, P.J., 2012, Fort Peck flow modification biological collection plan compendium - A summary of 2001-2009 activities: Report prepared for the U.S. Geological Survey and the U.S. Army Corps of Engineers, Omaha District, Montana Fish, Wildlife and Parks.

Fuller, D.B., and Braaten, P.J., 2013, Fort Peck flow modification biological data collection plan-Summary of 20012009 activities: Report submitted to the U.S. Army Corps of Engineers, Montana Fish, Wildlife and Parks.

Fuller, D.B., Jaeger, M.E., and Webb, Molly, 2008, Spawning and associated movement patterns of pallid sturgeon in the lower Yellowstone River: Western Area Power Administration, Upper Basin Pallid Sturgeon Work Group, U.S. Army Corps of Engineers, Montana Fish, Wildlife and Parks, 22 p.

Heist, E.J., and Eichelberger, J., 2013, 2012 genetic analysis of Missouri River sturgeon larvae: Center for Fisheries, Aquaculture, and Aquatic Sciences, Southern Illinois University Carbondale, $27 \mathrm{p}$.

Hunziker, J.R., Haddix, T.M., Holte, L.D., and Lott, R.D., 2013, 2012 annual report-Pallid sturgeon population assessment and associated monitoring for the Missouri River-Segment 2: Fort Peck, Mont., Montana Fish, Wildlife and Parks, $30 \mathrm{p}$. 


\section{Appendix 3. Mapping and Quantifying Spawning and Larval Habitats, Lower Missouri and Yellowstone Rivers, 2012}

\section{Background}

Habitat is the three-dimensional space that animals inhabit; habitat commonly includes time as the fourth dimension to address dynamic changes through time. Habitat is also an intermediary between restoration and management actions that alter flow regime and channel morphology, and biotic responses to those management actions (Jacobson and Berkley, 2011). As such, understanding habitat quality, quantity, use, availability, and selection is critical to management of pallid sturgeon (Scaphirhynchus albus) populations in the Missouri River.

Detailed habitat mapping by the Comprehensive Sturgeon Research Project (CSRP) around tagged-fish locations places the behavior of individuals within a larger spatial context that allows researchers to characterize habitat availability and selection and, thereby, understand how channel morphology and flow regime can be managed to maximize reproduction and survival (Reuter and others, 2008; DeLonay and others, 2009; Jacobson and others, 2009; Reuter and others, 2009; Bonnot and others, 2011).

\section{Scope and Objectives}

Habitat assessments in 2012 were done in the Lower Missouri and Yellowstone Rivers to quantify habitats used by pallid sturgeon and habitats that were available but not used to understand habitat selection. Paired with studies of reproductive movements and physiology, patterns of habitat selection can indicate if specific habitats are limiting the reproduction and survival of pallid sturgeon. Definition and quantification of spawning habitat was complemented with assessments of habitats used by upstream migrating reproductive sturgeon and assessments of channel-marginal habitats hypothesized to be the settling habitat of drifting larval sturgeon.

The first objective was to survey spawning habitats to replicate assessments done in 2008-2011 and to increase understanding of how fine-scale habitat characteristics may affect spawning success and recruitment (Reuter and others, 2008; DeLonay and others, 2009; Elliott and others, 2009; Reuter and others, 2009). An enhanced, high-resolution habitat-mapping protocol was implemented as described below (and as used in previous years) around fish locations identified by telemetry crews. The second objective was to survey habitats associated with upstream-migrating reproductive pallid sturgeon. These surveys were designed to test the hypothesis that migrating fish take paths that minimize the energetic expenditure necessary to arrive at spawning sites. Understanding the migration paths, and the energetic costs involved in navigating them, may lead to channel re-engineering designs that increase fecundity and reproductive success of sturgeon.
The third objective was to quantify habitats associated with catches of free-embryo sturgeon in the Lower Missouri River. Within this objective we attempted to understand how reach-scale hydraulics may affect transport and retention of larvae, and to quantify velocity fields associated with coordinated larval sampling efforts.

\section{Methods}

Habitat survey methods employed in 2012 replicated those used in 2008-2011; detailed documentation of methods are on file at the Columbia Environmental Research Center (CERC). For the spawning habitat objective, fish locations were selected based on their likelihood as spawning sites as documented by telemetric data. Hydroacoustic boats were deployed to fish locations for high-resolution multibeam bathymetry and acoustic Doppler current profiler (ADCP) surveys when discharges were within 10 percent of the discharge that existed when the fish was located. For the second objective of mapping migration habitats, hydroacoustic boats surveyed over fish locations as they followed the upstream movements of tagged fish. Some of these surveys took place in near real-time with the survey vessel following as closely as 15 minutes behind the fish. As with the spawning habitat surveys, all surveys were completed when discharge was within 10 percent of discharge that existed when the fish were located.

The Research Vessel (R/V) Brush is equipped with a dual-receiver global positioning system (GPS) and inertial motion-sensing system, a multibeam echosounder for detailed mapping of the riverbed, and an ADCP for mapping current-velocity fields. Base stations were used to obtain real-time kinematic (RTK) positioning with nominal positioning errors of plus or minus (+/-) 0.02 meter (m) horizontal and $+/-0.1 \mathrm{~m}$ vertical. The multibeam system is a RESON SeaBat ${ }^{\circledR} 7125$ (RESON, Inc., Slangerup, Denmark) operating at 455 kilohertz $(\mathrm{kHz})$. The transducer and receiver arrays are mounted on the front of the survey vessel on a tilt-up mount. The multibeam system collects data from 512 beams at 0.25 -degree $\left({ }^{\circ}\right)$ spacing and is capable of mapping depths of approximately $1-200 \mathrm{~m}$. The geometry allows a $128^{\circ}$ swath covering a width of approximately four times the water depth. Positioning and motion sensing data were acquired using an Applanix POS-MV Wavemaster ${ }^{\circledR}$ system receiving broadcast RTK corrections from the base station. This unit also provides corrections for vessel heading, pitch, roll, and heave that are used to calculate sounding locations in conjunction with the multibeam sonar.

The multibeam system and boat mount were calibrated with a "patch" test that corrects for internal geometry of the boat, transducer/receiver, and GPS receiver. Patch test results were used to update geometry files used by the data-acquisition 
software. In addition, sound-velocity profiles were collected to assess stratification of sound velocity with depth. HYPACK/ HYSWEEP ${ }^{\circledR}$ software (Hypack, Inc., Middletown, Connecticut) was used to acquire, compile, correct, and edit GPS and multibeam data. Hypack and RESON provide real-time quality-control displays that are monitored to ensure quality data are collected. Total propagated vertical errors have been estimated at $0.06-0.15 \mathrm{~m}$ (Huizinga and others, 2010).

For high-resolution surveys, longitudinal survey lines were laid out in Hypack at intervals to ensure at least 50-percent overlap in multibeam coverage. The lines were parallel to the flow of the river and centered over the chosen fish location. A helm display showed the boat pilot the boat position, and the quality and extent of incoming data. Multibeam files were edited in the office to remove erroneous data. These data were subsequently exported from the Hypack environment and imported into Fledermaus (Quality Positioning Services [QPS], Portsmouth, New Hampshire) where the data were gridded at the 1-m scale using the Combined Uncertainty and Bathymetry Estimator (CUBE) algorithm (Calder and Mayer, 2003; Calder and Wells, 2007) for analysis and display. The final grids were imported into ArcMap (Esri, Redlands, California) for map production and analysis with sturgeon telemetry data and other data.

Current velocity fields were mapped using a $1200 \mathrm{kHz}$ ADCP (Teledyne RD Instruments, Poway, Calif.). Acoustic Doppler current profiler data were logged simultaneously with GPS data on a laptop computer running WinRiver ${ }^{\circledR}$ (version 10.06, Teledyne RD Instruments, Poway, Calif.). Magnetic variation was set for each reach mapped by using GeoMagix ${ }^{\circledR}$ software (Interpex, Ltd., Golden, Colorado). Mapping crews completed the "Method 3" compass-calibration procedure at each site by rotating the boat in a tight circle (RD Instruments, 2003). This procedure corrects for one-cycle compass errors and was repeated until the total error reading was less than $1^{\circ}$. Configuration settings for ADCP data have a vertical resolution of $0.25 \mathrm{~m}(1200 \mathrm{kHz})$ and a blanking distance of $0.50 \mathrm{~m}$ below the transducer head. Data from the ADCP were collected using water mode 1 with six water pings and bottom mode 5 with one bottom ping.

For spawning habitat surveys (objective one), channel cross-section lines for the ADCP survey were laid out in a grid with 20-m spacing in the direction of water flow over an area that equally covered the multibeam survey, which is approximately twice the width of the river. For migration habitat surveys (objective two), channel cross-section lines were laid out orthogonally to the local flow direction through the points where the fish was located. The spacing of these lines was determined by the rate of movement of the fish upstream and the rate at which a single cross-section could be surveyed or the fish could be relocated.

\section{Results}

Mapping efforts in 2012 were executed to document Missouri and Yellowstone River habitats used by pallid sturgeon over a range of life stages. Reproductive adult habitat use was assessed during migration and spawning life stages, age- 0 habitat use was documented over a range of discharges, and nonreproductive adult habitat was mapped in selected reaches where persistent occupancy has been established through multiyear, telemetry monitoring.

Probable pallid sturgeon spawning was assessed in two locations, one for reproductive female PLS11-007 near Lexington, Missouri, near river mile (RM) 322, and another for reproductive female PLS09-011 downstream from the Platte River near RM 580 ( fig. 3-1, fig. 3-2, table 3-1). Migration habitat measurements were done on the Lower Missouri River in Nebraska and on the Yellowstone River and included four repeat reciprocal transects at each fish location (table 3-1) (McElroy and others, 2012; DeLonay and others, 2014). Measurements on the Yellowstone River included documentation of pallid sturgeon migration habitat over a reach approaching Intake Dam near RM 73 (fig. 3-3). Larval and free-embryo sampling habitats were mapped over a range of discharges in a patch centered on a sampling transect in the Lower Missouri River near RM 33.3. Mapping efforts included four reciprocal transects over the fish sampling location and a patch of transects with a spacing of $20 \mathrm{~m}$ extending $200 \mathrm{~m}$ upstream and downstream from the sampling transect (fig. 3-4). The bend was mapped once to assess velocity and depth trends over a larger scale (table 3-1).

Mapping was also done to quantify habitat use of age- 0 sturgeon in reaches identified by U.S. Fish and Wildlife Service trawling crews (table 3-1). Additional mapping of pallid sturgeon habitat on the Lower Missouri River focused on persistent, multi-year telemetry patterns demonstrating site affinity of PLS08-006, a male pallid sturgeon who has migrated in a fairly predictable pattern from 2008 to 2012 (fig. 3-5). An additional site was mapped near RM 200; this site has been persistently occupied by several pallid sturgeon during the course of 2011-2012.

\section{Summary}

Habitat mapping in support of pallid sturgeon research in 2012 was done over a wide range of life stages. The results for habitat use and availability of probable pallid sturgeon spawning and migration life stages are analyzed in the main body of this report (see "Adult Life Stage - Habitat Requirements for Adult Reproductive Fish"). Assessments of larval and age-0 sturgeon sampling habitats and additional analysis of reaches of pallid sturgeon site affinity are ongoing. 


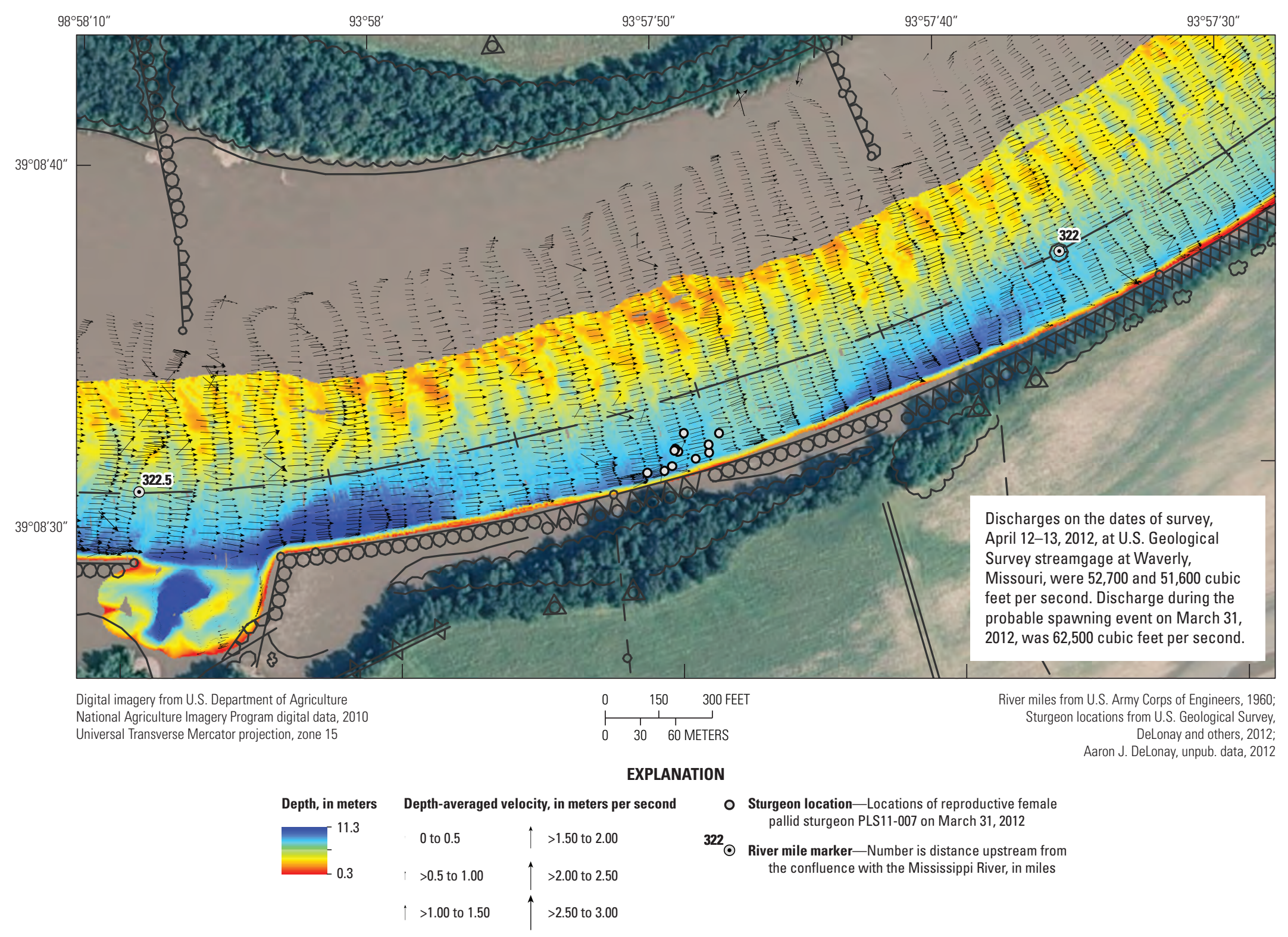

Figure 3-1. Depth and depth-averaged velocity for probable spawning site, and location of reproductive female pallid sturgeon PLS11-007 near Missouri River mile 322. 


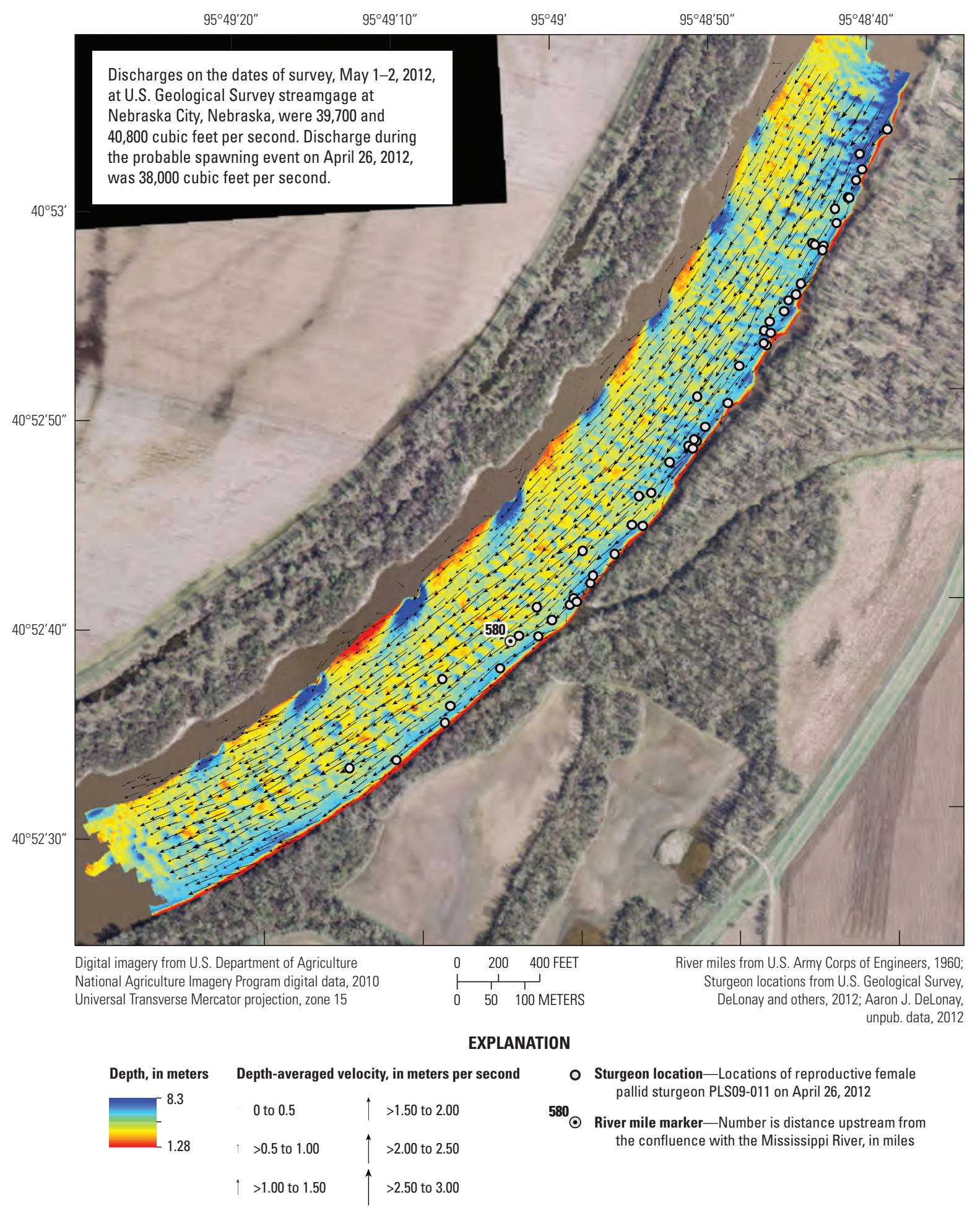

Figure 3-2. Depth and depth-averaged velocity for probable spawning site, and location of reproductive female pallid sturgeon PLS09-011 near Missouri River mile 580. 


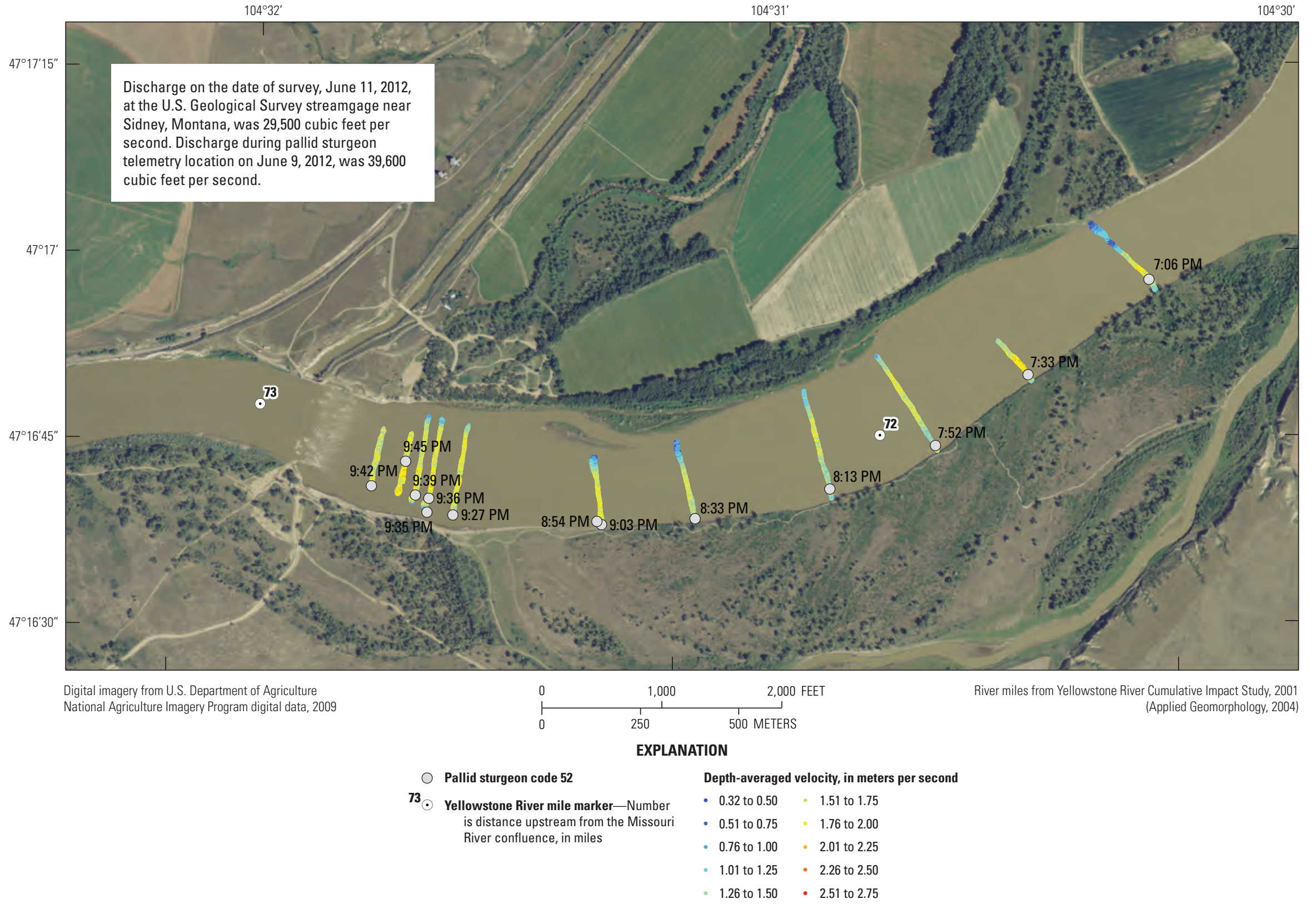

Figure 3-3. Depth-averaged velocity and pallid sturgeon telemetry locations for code 52 near Yellowstone River mile 73. 


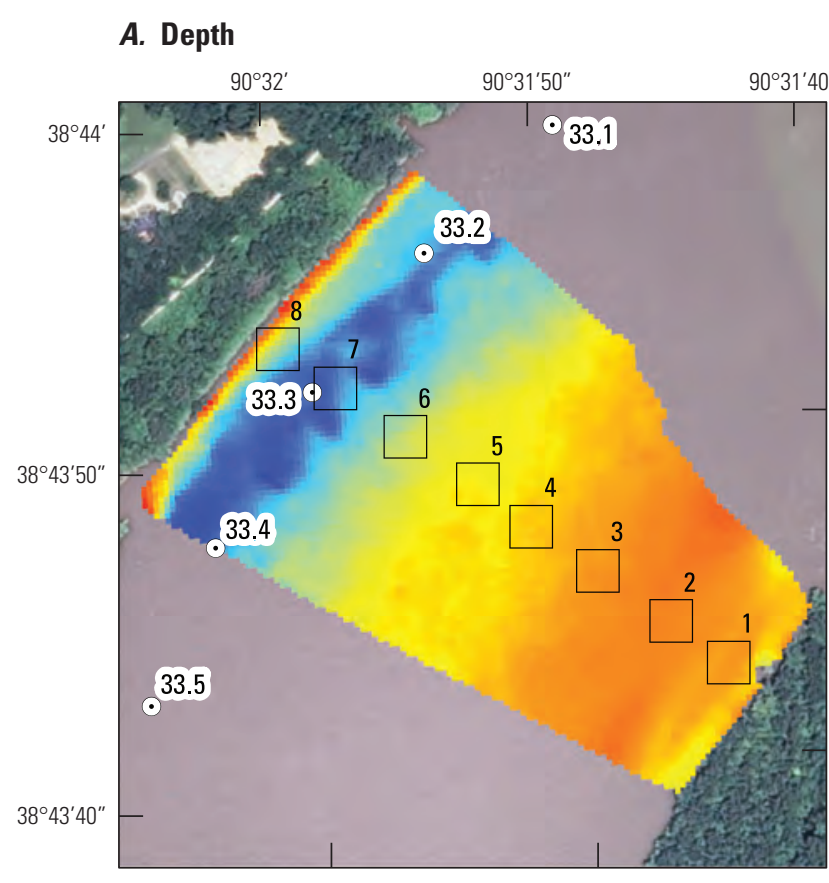

Digital imagery from U.S. Department of Agriculture National Agriculture Imagery Program digital data, 2010 Universal Transverse Mercator projection, zone 15

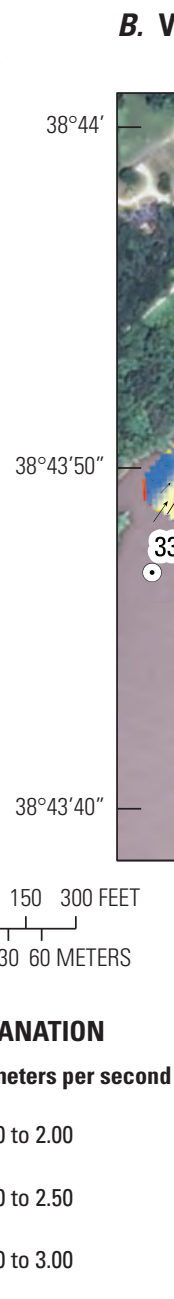

B. Velocity

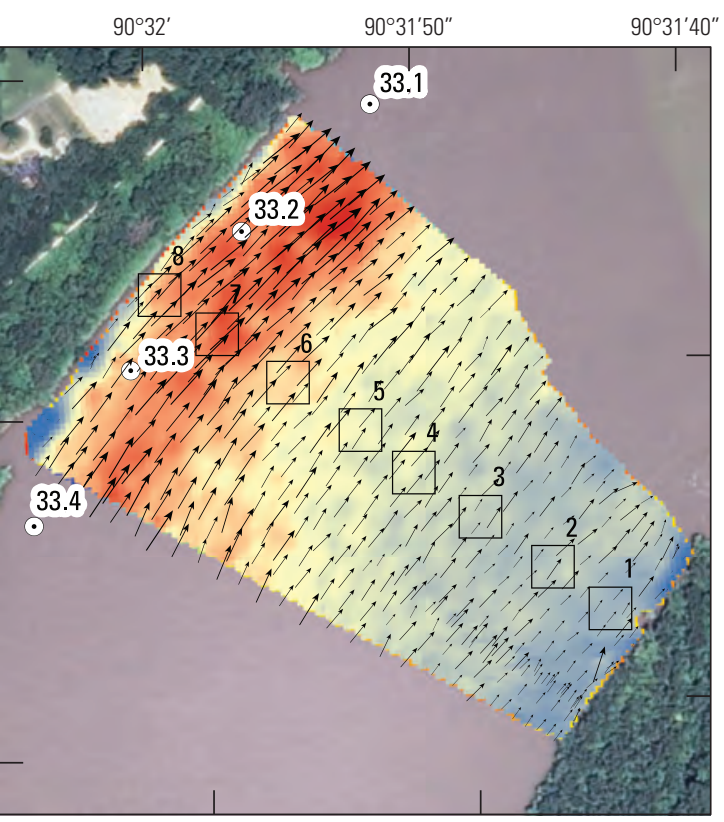

River miles from U.S. Army Corps of Engineers, 1960

$$
\begin{aligned}
& 0 \quad 150 \quad 300 \text { FEET } \\
& \begin{array}{lll}
0 & 1 \\
0 & 1060 \text { METERS }
\end{array}
\end{aligned}
$$

\begin{tabular}{|c|c|c|c|c|c|}
\hline \multirow{3}{*}{$\begin{array}{c}\text { Depth, in meters } \\
10.4\end{array}$} & & & EXPLANATION & 1 & \multirow{3}{*}{$\begin{array}{l}\text { Sampling location and number-Samples were taken } \\
\text { using ichthyoplankton sampling nets at mid-water } \\
\text { column and on or near the bed at depths }>1 \text { meter } \\
\text { and at the bed at depths }<1 \text { meter }\end{array}$} \\
\hline & Velocity, in meters & Depth-average & $y$, in meters per second & \multirow{4}{*}{33.3} & \\
\hline & 2.5 & 0 to 0.5 & $>1.50$ to 2.00 & & \\
\hline 0.9 & 0.16 & $>0.5$ to 1.00 & $>2.00$ to 2.50 & & \multirow{2}{*}{$\begin{array}{l}\text { River mile marker-Number is distance upstream from } \\
\text { the confluence with the Mississippi River, in miles } \\
\text { Discharges on the dates of survey May } 10,2012 \text {, at the } \\
\text { U.S. Geological Survey streamgage at St. Charles, } \\
\text { Missouri, was } 134,000 \text { cubic feet per second. }\end{array}$} \\
\hline & & 1. & 22.50100 .0 & & \\
\hline
\end{tabular}

Figure 3-4. Flow characteristics of free-embryo pallid sturgeon sampling locations near Missouri River mile 33.3. A, depth, and $B$, depth-averaged velocity. 
Table 3-1. Sturgeon habitat mapping 2012 data collection effort on the Missouri and Yellowstone Rivers.

[--, no data; ADCP, acoustic Doppler current profiler; YOY, young-of-year; RTK, real-time kinematic; GPS, global positioning system; DGPS, differential global positioning system]

\begin{tabular}{|c|c|c|c|c|c|c|c|}
\hline Date & $\begin{array}{l}\text { Upstream } \\
\text { river mile }\end{array}$ & $\begin{array}{l}\text { Downstream } \\
\text { river mile }\end{array}$ & $\begin{array}{l}\text { Number of fish } \\
\text { relocations } \\
\text { (migration) }\end{array}$ & Streamgage & $\begin{array}{l}\text { Discharge, } \\
\text { cubic feet per } \\
\text { second }\end{array}$ & Equipment & Products \\
\hline \multicolumn{8}{|c|}{ Lower Missouri River } \\
\hline \multicolumn{8}{|c|}{ Spawning } \\
\hline $4 / 3 / 2012$ & 322.6 & 321.8 & -- & Waverly, Missouri & 60,800 & $\mathrm{ADCP}$ & Depth and velocity patch maps \\
\hline $4 / 12 / 2012$ & 322.6 & 321.8 & -- & Waverly, Missouri & 52,500 & Multibeam & Multibeam bathymetry map of reach \\
\hline $4 / 14 / 2012$ & 322.6 & 321.8 & -- & Waverly, Missouri & 51,500 & ADCP & Depth and velocity patch maps \\
\hline $5 / 1 / 2012$ & 580.6 & 579.6 & -- & Nebraska City, Nebraska & 39,600 & $\mathrm{ADCP}$ & Depth and velocity patch maps \\
\hline $5 / 2 / 2012$ & 580.6 & 579.6 & -- & Nebraska City, Nebraska & 40,600 & Multibeam & Multibeam bathymetry map of reach \\
\hline \multicolumn{8}{|c|}{ Migration } \\
\hline \multirow[t]{2}{*}{$4 / 26 / 2012$} & 636.5 & 635.5 & 15 & Decatur, Nebraska & 30,100 & $\mathrm{ADCP}$ & 4 reciprocal ADCP transects at each fish location \\
\hline & 674.7 & 674 & 13 & Decatur, Nebraska & 30,100 & $\mathrm{ADCP}$ & 4 reciprocal $\mathrm{ADCP}$ transects at each fish location \\
\hline \multirow[t]{2}{*}{$4 / 27 / 2012$} & 591.4 & 590.6 & 8 & Nebraska City, Nebraska & 38,000 & $\mathrm{ADCP}$ & 4 reciprocal ADCP transects at each fish location \\
\hline & 592.1 & 591.7 & 11 & Nebraska City, Nebraska & 38,000 & $\mathrm{ADCP}$ & 4 reciprocal $\mathrm{ADCP}$ transects at each fish location \\
\hline \multirow[t]{2}{*}{$5 / 3 / 2012$} & 676.5 & 675.6 & 10 & Decatur, Nebraska & 30,600 & $\mathrm{ADCP}$ & 4 reciprocal ADCP transects at each fish location \\
\hline & 685.3 & 684 & 23 & Decatur, Nebraska & 30,600 & $\mathrm{ADCP}$ & 4 reciprocal ADCP transects at each fish location \\
\hline $5 / 4 / 2012$ & 694.6 & 693.7 & 16 & Decatur, Nebraska & 32,600 & $\mathrm{ADCP}$ & 4 reciprocal ADCP transects at each fish location \\
\hline $6 / 1 / 2012$ & 710.2 & 709.3 & 12 & Decatur, Nebraska & 44,500 & $\mathrm{ADCP}$ & 4 reciprocal $\mathrm{ADCP}$ transects at each fish location \\
\hline \multicolumn{8}{|c|}{ Free-embryo and larvae sampling } \\
\hline $4 / 16 / 2012$ & 34.3 & 33.5 & -- & St Charles, Missouri & 166,000 & ADCP & Depth and velocity patch maps \\
\hline $4 / 17 / 2012$ & 34.3 & 33.5 & -- & St Charles, Missouri & 155,000 & Multibeam & Multibeam bathymetry map of reach \\
\hline $5 / 10 / 2012$ & 33.4 & 33.2 & -- & St Charles, Missouri & 134,000 & $\mathrm{ADCP}$ & Depth and velocity patch maps \\
\hline $5 / 22 / 2012$ & 33.4 & 33.2 & -- & St Charles, Missouri & 75,800 & $\mathrm{ADCP}$ & Depth and velocity patch maps \\
\hline $6 / 26 / 2012$ & 33.4 & 33.2 & -- & St Charles, Missouri & 59,500 & $\mathrm{ADCP}$ & Depth and velocity patch maps \\
\hline \multicolumn{8}{|c|}{ Age-0/ YOY Sturgeon habitat } \\
\hline \multicolumn{8}{|c|}{ Sturgeon habitat } \\
\hline $5 / 23 / 2012$ & 162.7 & 161 & -- & Boonville, Missouri & 55,600 & ADCP & Depth and velocity patch maps \\
\hline $5 / 24 / 2012$ & 162.7 & 161 & -- & Boonville, Missouri & 55,200 & Multibeam & Multibeam bathymetry map of reach \\
\hline $7 / 10 / 2012$ & 162.7 & 161 & -- & Boonville, Missouri & 43,600 & $\mathrm{ADCP}$ & Depth and velocity patch maps, RTK GPS \\
\hline $7 / 11 / 2012$ & 162.7 & 161 & -- & Boonville, Missouri & 42,500 & Multibeam & Multibeam bathymetry map of reach, RTK GPS \\
\hline $8 / 9 / 2012$ & 214.5 & 214 & -- & Boonville, Missouri & 41,700 & ADCP & Depth and velocity patch maps, RTK GPS \\
\hline $10 / 4 / 2012$ & 162.7 & 161 & -- & Boonville, Missouri & 42,700 & $\mathrm{ADCP}$ & Depth and velocity patch maps, DGPS \\
\hline
\end{tabular}


Table 3-1. Sturgeon habitat mapping 2012 data collection effort on the Missouri and Yellowstone Rivers.-Continued

[--, no data; ADCP, acoustic Doppler current profiler; YOY, young-of-year; RTK, real-time kinematic; GPS, global positioning system; DGPS, differential global positioning system]

\begin{tabular}{|c|c|c|c|c|c|c|c|}
\hline Date & $\begin{array}{l}\text { Upstream } \\
\text { river mile }\end{array}$ & $\begin{array}{l}\text { Downstream } \\
\text { river mile }\end{array}$ & $\begin{array}{l}\text { Number of fish } \\
\text { relocations } \\
\text { (migration) }\end{array}$ & Streamgage & $\begin{array}{l}\text { Discharge, } \\
\text { cubic feet per } \\
\text { second }\end{array}$ & Equipment & Products \\
\hline \multicolumn{8}{|c|}{ Habitat use and home range } \\
\hline $5 / 30 / 2012$ & 582.9 & 582.5 & -- & Nebraska City, Nebraska & 51,300 & ADCP, Multibeam & Multibeam bathymetry and velocity maps of reach \\
\hline $5 / 31 / 2012$ & 638.7 & 638.3 & -- & Decatur, Nebraska & 43,400 & ADCP, Multibeam & Multibeam bathymetry and velocity maps of reach \\
\hline $10 / 10 / 2012$ & 202 & 200 & -- & Boonville, Missouri & 43,000 & ADCP & Depth and velocity reach maps, DGPS \\
\hline \multicolumn{8}{|c|}{ Yellowstone River } \\
\hline \multicolumn{8}{|c|}{ Migration } \\
\hline $5 / 21 / 2012$ & 8.2 & 7.2 & 2 & Sidney, Montana & 21,600 & $\mathrm{ADCP}$ & 4 reciprocal ADCP transects at each fish location \\
\hline \multirow[t]{2}{*}{$5 / 22 / 2012$} & 30.2 & 26.7 & 13 & Sidney, Montana & 22,100 & $\mathrm{ADCP}$ & 4 reciprocal ADCP transects at each fish location \\
\hline & 13.7 & 10.8 & 6 & Sidney, Montana & 22,100 & $\mathrm{ADCP}$ & 4 reciprocal ADCP transects at each fish location \\
\hline $5 / 23 / 2012$ & 23.7 & 20.8 & 5 & Sidney, Montana & 19,400 & $\mathrm{ADCP}$ & 4 reciprocal ADCP transects at each fish location \\
\hline \multirow[t]{2}{*}{$5 / 24 / 2012$} & 23.3 & 17.1 & 10 & Sidney, Montana & 17,100 & $\mathrm{ADCP}$ & 4 reciprocal ADCP transects at each fish location \\
\hline & 20.1 & 18.5 & 8 & Sidney, Montana & 17,100 & $\mathrm{ADCP}$ & 4 reciprocal ADCP transects at each fish location \\
\hline $5 / 25 / 2012$ & 33.3 & 28.8 & 17 & Sidney, Montana & 17,600 & $\mathrm{ADCP}$ & 4 reciprocal ADCP transects at each fish location \\
\hline $5 / 29 / 2012$ & 37.3 & 34.7 & 12 & Sidney, Montana & 20,100 & $\mathrm{ADCP}$ & 4 reciprocal $\mathrm{ADCP}$ transects at each fish location \\
\hline \multirow[t]{2}{*}{$5 / 30 / 2012$} & 29.8 & 29.3 & 2 & Sidney, Montana & 19,200 & ADCP & 4 reciprocal ADCP transects at each fish location \\
\hline & 11.9 & 11.1 & 5 & Sidney, Montana & 19,200 & $\mathrm{ADCP}$ & 4 reciprocal ADCP transects at each fish location \\
\hline \multirow[t]{2}{*}{$5 / 31 / 2012$} & 4 & 3.1 & 7 & Sidney, Montana & 18,700 & $\mathrm{ADCP}$ & 4 reciprocal ADCP transects at each fish location \\
\hline & 14.5 & 10.2 & $2,6,2$ & Sidney, Montana & 18,700 & $\mathrm{ADCP}$ & 4 reciprocal ADCP transects at each fish location \\
\hline 6/6/2012 & 40.2 & 37.7 & 7 & Sidney, Montana & 26,600 & $\mathrm{ADCP}$ & 4 reciprocal ADCP transects at each fish location \\
\hline \multirow[t]{2}{*}{$6 / 7 / 2012$} & 51 & 49 & 12 & Sidney, Montana & 32,400 & $\mathrm{ADCP}$ & 4 reciprocal ADCP transects at each fish location \\
\hline & 26.2 & 23.7 & 4 & Sidney, Montana & 32,400 & $\mathrm{ADCP}$ & 4 reciprocal $\mathrm{ADCP}$ transects at each fish location \\
\hline $6 / 11 / 2012$ & 72.8 & 67.6 & 16 & Sidney, Montana & 29,500 & $\mathrm{ADCP}$ & 4 reciprocal ADCP transects at each fish location \\
\hline \multirow[t]{2}{*}{$6 / 12 / 2012$} & 62.3 & 59 & 12 & Sidney, Montana & 29,400 & $\mathrm{ADCP}$ & 4 reciprocal ADCP transects at each fish location \\
\hline & 68.3 & 67.2 & 6 & Sidney, Montana & 29,400 & $\mathrm{ADCP}$ & 4 reciprocal ADCP transects at each fish location \\
\hline $6 / 13 / 2012$ & 48.7 & 48.4 & 6 & Sidney, Montana & 30,100 & $\mathrm{ADCP}$ & 4 reciprocal ADCP transects at each fish location \\
\hline $6 / 14 / 2012$ & 11.7 & 4.4 & 20 & Sidney, Montana & 25,700 & $\mathrm{ADCP}$ & 4 reciprocal ADCP transects at each fish location \\
\hline
\end{tabular}




\section{A. Near river mile 638.5}

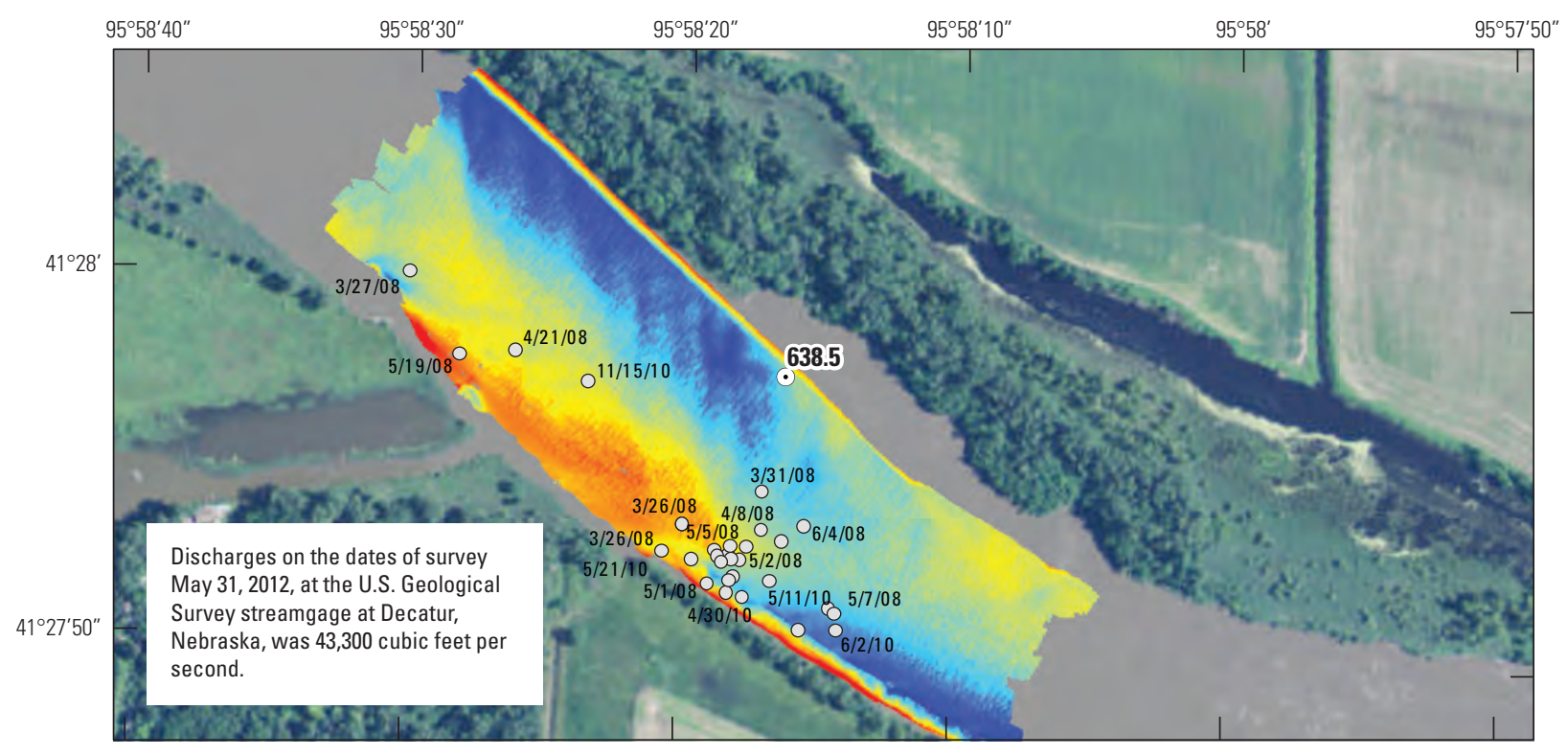

\section{B. Near river mile $\mathbf{5 8 2 . 5}$}

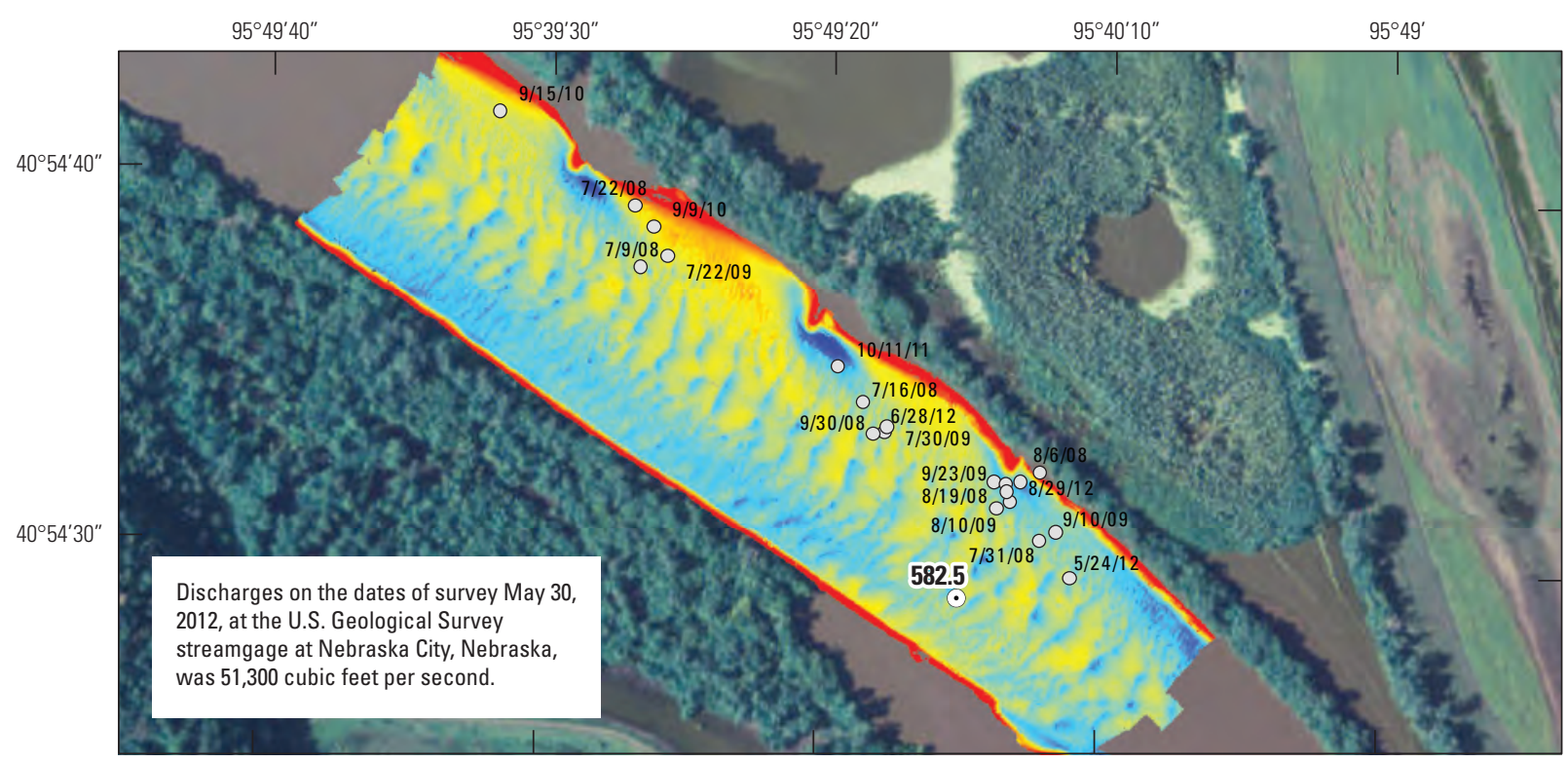

Digital imagery from U.S. Department of Agriculture National Agriculture Imagery Program digital data, 2010

Universal Transverse Mercator projection, zone 15

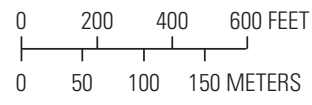

River miles from U.S. Army Corps of Engineers, 1960

\section{EXPLANATION}

Depth, in meters $\quad 5 / 24 / 12 \bigcirc$ Pallid sturgeon location and date-Locations

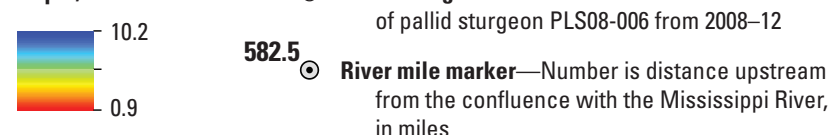

Figure 3-5. Telemetry locations and multibeam bathymetry showing depth at locations used by male pallid sturgeon PLS08-006 from 2008-12 near river miles, $A, 638.5$ and, $B, 582.5$. 


\section{References Cited}

Bonnot, T.W., Wildhaber, M.L., Millspaugh, J.J., DeLonay, A.J., Jacobson, R.B., and Bryan, J.L., 2011, Discrete choice modeling of shovelnose sturgeon habitat selection in the lower Missouri River: Journal of Applied Ichthyology, v. 27, no. 2, p. 291-300. [Also available at http://dx.doi. org/10.1111/j.1439-0426.2010.01637.x.]

Calder, B.R., and Mayer, L.A., 2003, Automatic processing of high-rate, high-density multibeam echosounder data: Geochemistry geophysics geosystems, v. 4, no. 6, p. 1-17. [Also available at http://dx.doi.org/10.1029/2002GC000486.]

Calder, B.R., and Wells, D., 2007, CUBE user's manual-Version 1.13: Durham, N.H., University of New Hampshire, Center for Coastal and Ocean Mapping, 54 p.

DeLonay, A.J., Jacobson, R.B., Papoulias, D.M., Simpkins, D.G., Wildhaber, M.L., Reuter, J.M., Bonnot, T.W., Chojnacki, K.A., Korschgen, C.E., Mestl, G.E., and Mac, M.J., 2009, Ecological requirements of pallid sturgeon reproduction and recruitment in the lower Missouri River-A research synthesis 2005-08: U.S. Geological Survey OpenFile Report 2009-5201, 59 p. [Also available at http://pubs. usgs.gov/sir/2009/5201/.]

DeLonay, A.J., Jacobson, R.B., Annis, M.L., Braaten, P.J., Chojnacki, K.A., Elliott, C.M., Fuller, D.B., Haas, J.D., Haddix, T.M., McElroy, B.J., Mestl, G.E., Papoulias, D.M., Rhoten, J.C., and Wildhaber, M.L., 2014, Ecological requirements for pallid sturgeon reproduction and recruitment in the Missouri River-Annual report 2011: U.S. Geological Survey Open-File Report 2014-1106, 96 p. [Also available at http://dx.doi.org/10.3133/ofr20141106.]

Elliott, C.M., Reuter, J.M., and Jacobson, R.B., 2009, Channel morphodynamics in four reaches of the lower Missouri River, 2006-07: U.S. Geological Survey Scientific Investigations Report 2009-5074, 258 p. [Also available at http:// pubs.usgs.gov/sir/2009/5074/.]

Huizinga, R.J., Elliott, C.M., and Jacobson, R.B., 2010, Bathymetric and velocimetric survey and assessment of habitat for pallid sturgeon on the Mississippi River in the vicinity of the proposed Interstate 70 Bridge at St. Louis, Missouri: U.S. Geological Survey Scientific Investigations Report 2009-5198, 28 p. [Also available at http://pubs.usgs.gov/ $\operatorname{sir} / 2009 / 5198 /$.

Jacobson, R.B., and Berkley, Jim, 2011, Conceptualizing and communicating ecological river restoration, in Simon, Andrew, Bennet, S.J., and Castro, J.M., eds., Stream restoration in dynamic fluvial systems - Scientific approaches, analyses and tools, Volume 194: American Geophysical Union, Geophysical Monograph 194, p. 9-28. [Also available at http://dx.doi.org/ 10.1029/2010GM000967.]
Jacobson, R.B., Johnson, H.E., III, and Dietsch, B.J., 2009, Hydrodynamic simulations of physical aquatic habitat availability for pallid sturgeon in the lower Missouri River, at Yankton, South Dakota, Kenslers Bend, Nebraska, Little Sioux, Iowa, and Miami, Missouri, 2006-07: U.S. Geological Survey Scientific Investigations Report 2009-5058, 67 p. [Also available at http://pubs.usgs.gov/ $\operatorname{sir} / 2009 / 5058 /$.

McElroy, Brandon, Delonay, A.J., and Jacobson, R.B., 2012, Optimum swimming pathways of fish spawning migrations in rivers: Ecology, v. 93, no. 1, p. 29-34. [Also available at http://www.jstor.org/stable/23144018.]

RD Instruments, 2003, WinRiver user's guide: Poway, Calif., RD Instruments, Inc., 144 p.

Reuter, J.M., Jacobson, R.B., Elliott, C.M., Johnson, H.E., III, and DeLonay, A.J., 2008, Hydraulic and substrate maps of reaches used by sturgeon (Genus Scaphirhynchus) in the lower Missouri River, 2005-07: U.S. Geological Survey Data Series 386, 442 p. [Also available at http://pubs.usgs. gov/ds/386/.]

Reuter, J.M., Jacobson, R.B., Elliott, C.M., and DeLonay, A.J., 2009, Assessment of lower Missouri River physical aquatic habitat and its use by adult sturgeon (genus Scaphirhynchus) 2005-07: U.S. Geological Survey Scientific Investigations Report 2009-5121, 81 p. [Also available at http:// pubs.er.usgs.gov/usgspubs/sir/sir20095121.] 


\section{Appendix 4. Migration Pathways, Habitat Use, and Reproduction of Pallid Sturgeon in the Yellowstone River, 2012}

\section{Background}

The upper Missouri River basin including the lower Yellowstone River and Missouri River between Fort Peck Dam and Lake Sakakawea contains a wild stock of pallid sturgeon (Scaphirhynchus albus) that is estimated to have declined from nearly 1,000 individuals in the 1960 s to fewer than 150 individuals at present (2012). The wild stock is composed of large adults $(>1,000$ millimeters [mm]; U.S. Fish and Wildlife Service, 2007) as wild-produced small individuals have not been detected during decades of netting efforts. The lack of small and young individuals in the wild population provides evidence of complete recruitment collapse for 50 or more years (Braaten and others, 2015). Multiple factors including river fragmentation and alteration of discharge and water temperature regimes for the Missouri River, and fragmentation of the Yellowstone River have been implicated as agents of recruitment failure, which negatively affects reproductive success and survival of pallid sturgeon (U.S. Fish and Wildlife Service, 1993, 2000, 2003).

The Yellowstone River is a focal point for pallid sturgeon research and restoration activities within the upper Missouri River basin. Unlike other river reaches throughout the range of pallid sturgeon, the Yellowstone River retains natural channel morphology and relatively natural hydrologic and thermal regimes that support spawning of wild-stock pallid sturgeon (Fuller and others, 2008; Fuller and Braaten, 2013). On this basis, the Yellowstone River provides the rare opportunity to understand reproductive dynamics of pallid sturgeon in a near-natural environment and provides inferences on natural reproductive processes for altered-river reaches. Although spawning is known to take place in the Yellowstone River, fragmentation of the system is hypothesized to limit recruitment from natural-spawning events through a combination of factors involving few spawning adults, barriers to migration, poor spawning success, and early life history mortality. Pallid sturgeon migration on the Yellowstone River is unrestricted for the lower 73 miles (mi) of the river upstream from the confluence with the Upper Missouri River. Upstream access beyond that point is impeded by Lower Yellowstone Intake Diversion Dam (hereinafter referred to as, Intake Dam), a rock and boulder dam constructed in the early 1900s that spans the width of the river. Pallid sturgeon will ascend the Yellowstone River to Intake Dam (Fuller and others, 2008; Fuller and Braaten, 2014), but passage over or through the dam has not been documented by wild adults in recent studies. Rehabilitation of the Yellowstone River has focused on creating passage through the reach affected by the dam as a means of facilitating access to potential upstream spawning areas. Access to and spawning in upstream reaches of the Yellowstone River will increase the length of free-flowing riverine habitat available to drifting free embryos and larvae following hatch (Braaten and others, 2008;
Braaten and others, 2012). Currently, the limited availability of free-flowing riverine habitat between spawning locations and the downstream reservoir (Lake Sakakawea, North Dakota) is one hypothesis for recruitment failure for pallid sturgeon in the fragmented upper Missouri River basin (Kynard and others, 2007; Braaten and others, 2008; Braaten and others, 2012).

Several alternatives for providing pallid sturgeon passage through the reach affected by Intake Dam have been proposed, but construction of a bypass channel around Intake Dam has emerged as a preferred design alternative (U.S. Bureau of Reclamation, 2014). In this design, a 2.9-mi long side channel approximately 150-250 feet (ft) wide would be constructed around Intake Dam (U.S. Army Corps of Engineers, 2012). The downstream entrance of the constructed side channel would join the main stem river on the south bank of the river immediately downstream from the existing dam. This alternative also includes construction of a new concrete dam slightly upstream from the existing rock dam. Although initial designs for the bypass channel alternative have been developed, limited information on migration patterns, side channel use and avoidance, swimming abilities, and depths and velocities negotiated by pallid sturgeon is available to guide design specifications for the proposed bypass channel relative to the needs of pallid sturgeon.

\section{Scope and Objectives}

In 2011, collaborative investigations between the U.S. Geological Survey (USGS) and Montana Fish, Wildlife and Parks were initiated to examine multiple facets of pallid sturgeon migrations and reproductive biology in the Yellowstone River (Braaten and others, 2015). As a pilot project in 2011, the study examined migration pathways of pallid sturgeon (for example, main-channel and side-channel routes used by migrating individuals), depths and velocities negotiated by migrating pallid sturgeon, the periodicity of pallid sturgeon arrival at Intake Dam, migration approach pathways to Intake Dam, and spawning of pallid sturgeon in the Yellowstone River. Work in 2012 expanded on the 2011 pilot project and included multifaceted objectives focused on examining migrations of pallid sturgeon to inform engineering design specifications for fish passage alternatives at Intake Dam, and examining reproductive biology of pallid sturgeon in a natural river environment.

The first objective was to determine the migrations and migration pathways of telemetered pallid sturgeon in the Yellowstone River. This objective provided information on the spatial and temporal extant of migrations in the Yellowstone River, depths and velocities negotiated by migrating individuals, use or avoidance of side channels during migrations, and pallid sturgeon migration pathways as individuals approached Intake Dam. 
The second objective was to determine the spatial and temporal dynamics of spawning in the Yellowstone River. Earlier studies documented spawning and provided inferences on the timing and location of spawning events in the Yellowstone River (Fuller and others, 2008; Braaten and others, 2015); however, the specific location(s) and date(s) of spawning had not been ascertained.

The third objective was to verify that embryos hatch by collecting free embryos in the Yellowstone River because pallid sturgeon are known to spawn in the Yellowstone River. Verification of hatch and drift entry have not been demonstrated as no pallid sturgeon embryos, free embryos, or larvae have been collected in the Yellowstone River.

\section{Methods}

A total of 41 wild adult male and female pallid sturgeon composed the telemetered research population in 2012. The telemetered population included individuals from earlier studies that carried radio transmitters, individuals that had expired or expiring transmitters from earlier studies that were reimplanted with new transmitters, and individuals that had not been previously implanted with radio transmitters. Three females (codes 30, 35, and 36) were identified as potential spawn candidates for 2012 based on the presence of black eggs and elevated reproductive hormones (testosterone [T] and estradiol [E2]) when assessed on April 25-26, 2012 (code $30, \mathrm{~T}=32.83$ nanograms per milliliter $[\mathrm{ng} / \mathrm{mL}], \mathrm{E} 2=4.58 \mathrm{ng} /$ $\mathrm{mL}$; code $35, \mathrm{~T}=49.9 \mathrm{ng} / \mathrm{mL}, \mathrm{E} 2=4.63 \mathrm{ng} / \mathrm{mL}$; code 36 , $\mathrm{T}=87.19 \mathrm{ng} / \mathrm{mL}, \mathrm{E} 2=8.47 \mathrm{ng} / \mathrm{mL}$ ).

Manual tracking by boat of the Yellowstone River and Missouri River downstream from the Yellowstone River confluence was initiated in April. Tracking was done using open watercraft (6 meters $(\mathrm{m})$ in length) with a bow mounted 4-element Yagi antenna. Pallid sturgeon relocation points and associated environmental point attributes (depth, temperature, and conductivity) were recorded on a highly customized mobile mapping and electronic data-collection application linked to a differential global positioning system (DGPS). The DGPS was located in the center of the watercraft. Location accuracy in the Yellowstone River, estimated from locating tags at known positions, was about one boat length. Locations characterized pallid sturgeon either maintaining a stationary point in the river or depicted a continuous series of point locations characterizing upstream migration pathways for actively migrating individuals. Quantification of depths and velocities at migration points and in the channel cross-section containing the migration point was executed using an acoustic Doppler current profiler (ADCP) linked to DGPS. Automated ground-based logging stations were deployed in the Yellowstone River (river mile $[\mathrm{RM}]$ 0.75, 7.0, 16.5, 37.0, 72.8) and in the Missouri River to complement manual tracking and obtain additional information on migrations and movements among river reaches.
Sampling for pallid sturgeon free embryos and larvae was done downstream from suspected spawning sites (see below) in the lower reaches of the Yellowstone River. The sampling apparatus consisted of a $3.0-\mathrm{m}$ long tapered rectangular net (1-mm mesh) affixed to a rectangular net-mouth frame ( $0.75-\mathrm{m}$ width, $0.5-\mathrm{m}$ height). Two sounding weights (4.5 kilograms $[\mathrm{kg}]$ ) were attached to the net frame. Following Braaten and others (2010), one pair of nets was fished simultaneously during deployment, and one net each deployed on the port and starboard sides of the boat. Nets were fished on the river bed. Sample contents were transferred to black pans, and all Acipenseriformes (Scaphirhynchus spp. and paddlefish Polyodon spathula) eggs, embryos, free embryos, and larvae extracted from the detritus were preserved immediately in 95-percent ethanol. All Acipenserifomes free embryos and larvae were genetically analyzed to confirm species identity as paddlefish, shovelnose sturgeon (Scaphirhynchus platorynchus), or pallid sturgeon.

\section{Results}

Flow conditions in the Yellowstone River during 2012 were lower than the 1911-2011 trends as mean discharge during April $\left(9,563\right.$ cubic feet per second $\left.\left[\mathrm{ft}^{3} / \mathrm{s}\right]\right)$, May $\left(15,643 \mathrm{ft}^{3} / \mathrm{s}\right)$, June $\left(23,957 \mathrm{ft}^{3} / \mathrm{s}\right)$ and July $\left(10,761 \mathrm{ft}^{3} / \mathrm{s}\right)$ represented 89 percent, 85 percent, 62 percent and 47 percent, respectively, of the long-term means (fig. 4-1). There were periods of elevated flow conditions in late April, mid- to late May, and early June; the maximum discharge $\left(39,600 \mathrm{ft}^{3} / \mathrm{s}\right)$ happened on June 9. There were pronounced fluctuations in water temperature throughout the season as temperature declines of as much as 8 degrees Celsius $\left({ }^{\circ} \mathrm{C}\right)$ and rapidly warming over short-term intervals (several days to two weeks) were noted in several instances. Migrations of pallid sturgeon into the Yellowstone River were initiated by early April, increased during late April and May, and reached a maximum (90 percent of the telemetered population) in late May (fig. 4-1). Use of the Yellowstone River remained high through mid-June, then declined as pallid sturgeon emigrated from the Yellowstone River.

The spatial extent and timing of migrations in the Yellowstone River during 2012 varied markedly among individuals and by reproductive status. Manual tracking complemented with detections from the telemetry logging station at Intake identified that five male pallid sturgeon (codes 42, 52, 69, 72 , and 76) migrated to Intake Dam but did not pass over the dam (fig. 4-2). No telemetered female pallid sturgeon were detected at Intake Dam. Code 42 initiated a late April upstream migration as discharge increased and reached Intake Dam on May 2. Upstream migrations by codes 52, 69, and 72 were sustained during the increasing hydrograph in early June with code 52 arriving at Intake Dam on June 9 and code 72 arriving at Intake Dam on June 13. Code 69 migrated downstream as discharge receded, and then ascended the river to Intake on June 22. Code 76 remained in the lower Yellowstone 

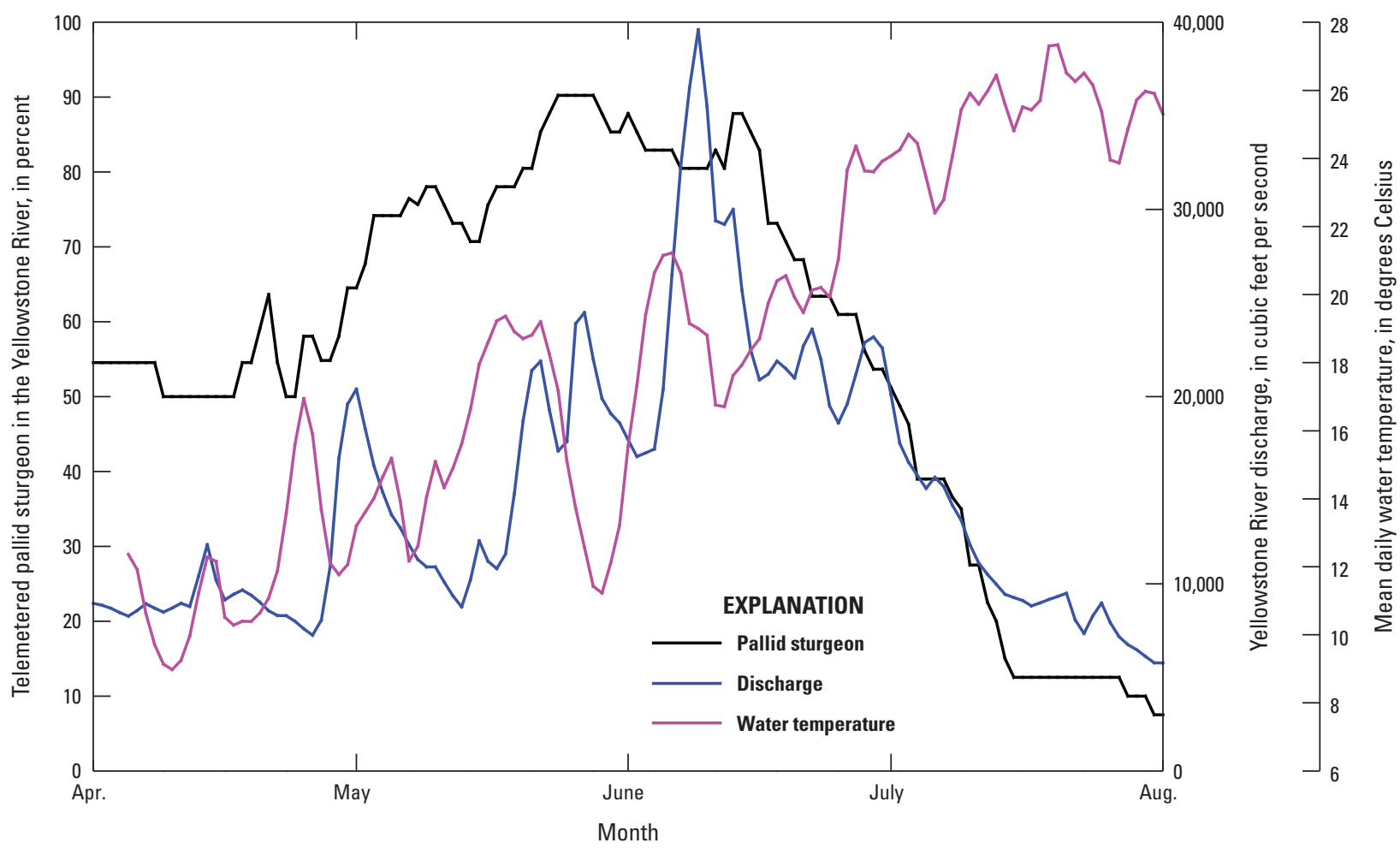

Figure 4-1. Percent of telemetered pallid sturgeon detected, discharge, and mean daily water temperature of the Yellowstone River, April-August 2012.

River through early June, migrated upstream through midJune, and reached Intake on June 22. All detected pallid sturgeon remained in close proximity to the dam for 1-2 days prior to initiating downstream migrations.

Although five male pallid sturgeon migrated to Intake Dam during 2012, most telemetered male pallid sturgeon migrated into and resided in the lower or middle reaches of the Yellowstone River; for example, male codes 10, 11, 21, 22, 51 , and 83 exhibited maximum upstream detection locations between RM 20-40 of the Yellowstone River (fig. 4-3). A second group of 18 male pallid sturgeon ascended less than 20 RM (fig. 4-3); however, whereas upstream migrations of numerous males were restricted to the lower and middle reaches of the Yellowstone River, many males (for example, codes $15,22,46,48,49,50,51,68,75$, and 77) were in the Missouri River upstream from the Yellowstone River confluence (as much as $180 \mathrm{RM}$ ) prior to Yellowstone River entry.

Gravid females again exhibited the characteristic complex migration pattern typical of the Yellowstone River. The usual pattern for females is to make successive, long distance upstream and downstream movements in the Yellowstone River, typically moving downstream into the Upper Missouri River, before stopping to spawn near an aggregation of males in the Yellowstone River. Code 30 exhibited pronounced pre-spawn migrations as this individual initially migrated nearly 40 miles (mi) into the Missouri River near Culbertson, Montana, between April 26 and May 6, resided above the
Culbertson, Mont., logging station for 5 days, then migrated downstream during May 11-15 (fig. 4-4). Following the Missouri River descent, code 30 entered the Yellowstone River on May 22 and exhibited several upstream and downstream migrations with the most upstream migration persisting to Yellowstone RM 63.8 on June 9. Similar to female code 30, female code 35 exhibited extensive upstream and downstream migrations as upstream migrations were detected to RM 27.2 on May 22, RM 26.3 on June 6, and RM 37.0 on June 19 (fig. 4-4). Female code 36 similarly exhibited upstream and downstream migrations with a maximum upstream detection point to RM 37.2 on May 23 (fig. 4-4).

Based on mean daily river locations in the Yellowstone River and Missouri River, the total distance migrated by males (the sum of all upstream and downstream movements) and females known to be gravid was estimated for the pre-spawn period. For males, the pre-spawn period was defined as the date and location of initial detection in April or May extending to mid-June when spawning activity was observed in the lower Yellowstone River and many males were included in the spawning aggregation (see below). A similar procedure was used for female codes 30 and 35, but the pre-spawn period for code 36 was terminated at June 1 as this female likely spawned close to this date (see below). The estimated prespawn migration distance for the 29 males assessed averaged $155 \mathrm{mi}$ (range $44-470 \mathrm{mi}$ ). Code 82 was the least migratory male as this individual remained primarily in the lower $10 \mathrm{mi}$ 

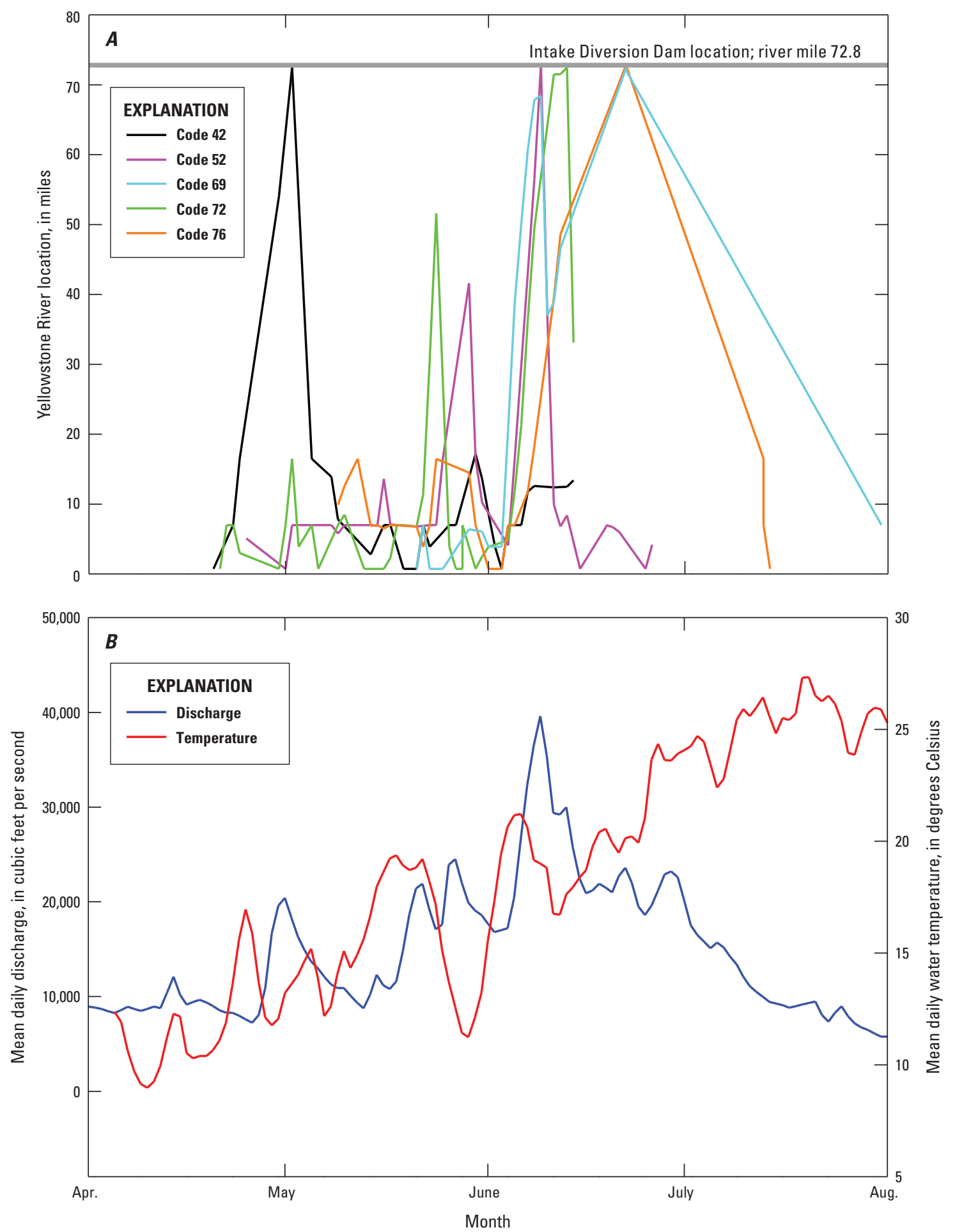

Figure 4-2. Data for five telemetered pallid sturgeon (codes $42,52,69,72$, and 76 ) migrating to Intake Dam on the Yellowstone River, April-August 2012. A, location and B, mean daily discharge and water temperature. 

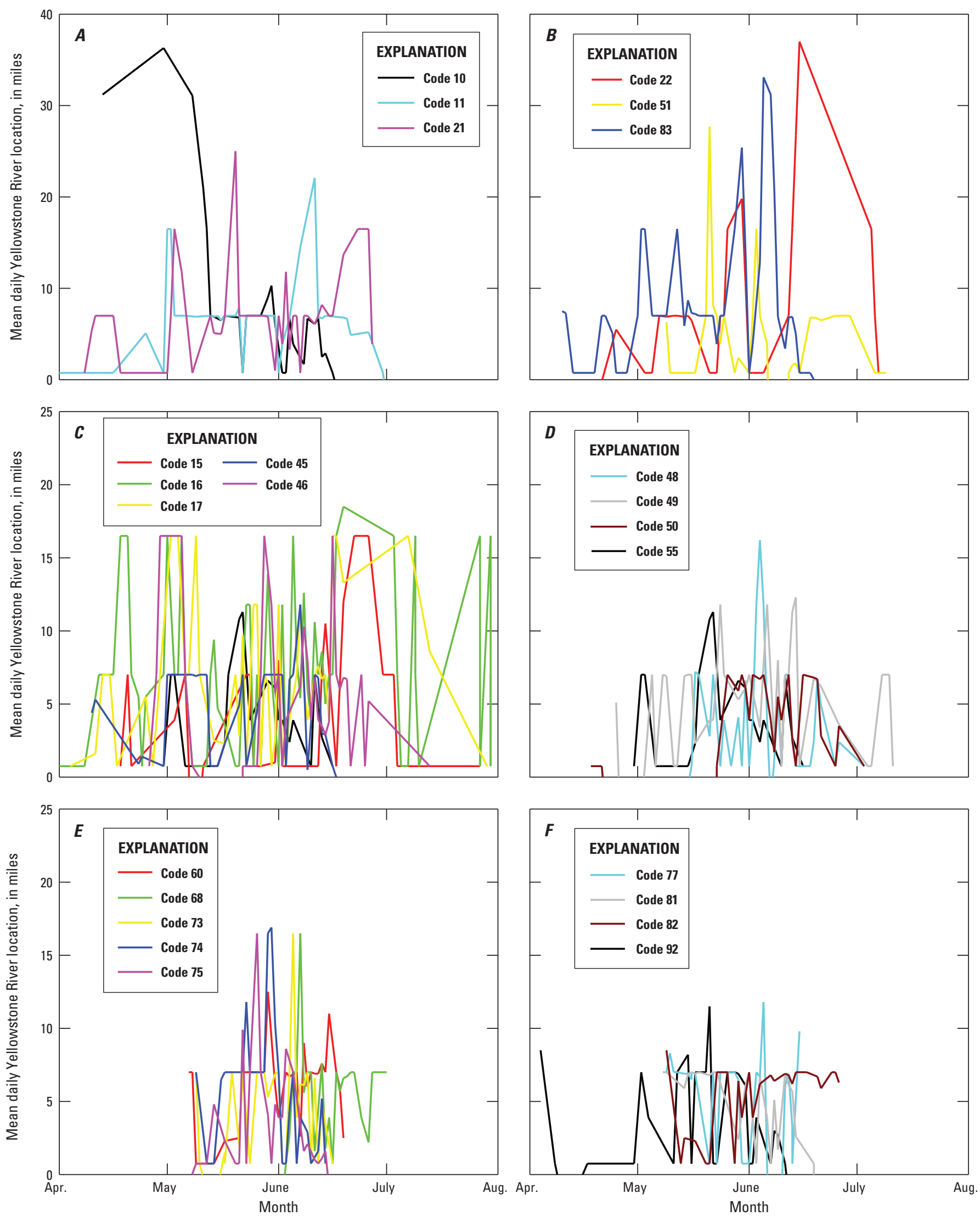

Figure 4-3. Locations of telemetered male pallid sturgeon exhibiting migrations in the Yellowstone River, April-August 2012. A, codes 10,11, and 21 ascending upstream from river mile 20; $B$, codes 22, 51, and 83 ascending upstream from river mile 20; $C$, codes $15-17,45$, and 46 remaining downstream of river mile $20 ; D$, codes $48-50$ and 55 remaining downstream from river mile 20; $E$, codes 60 , 68, and 73-75 remaining downstream from river mile 20; and $F$, codes 77, 81, 82, and 92 remaining downstream from river mile 20. 

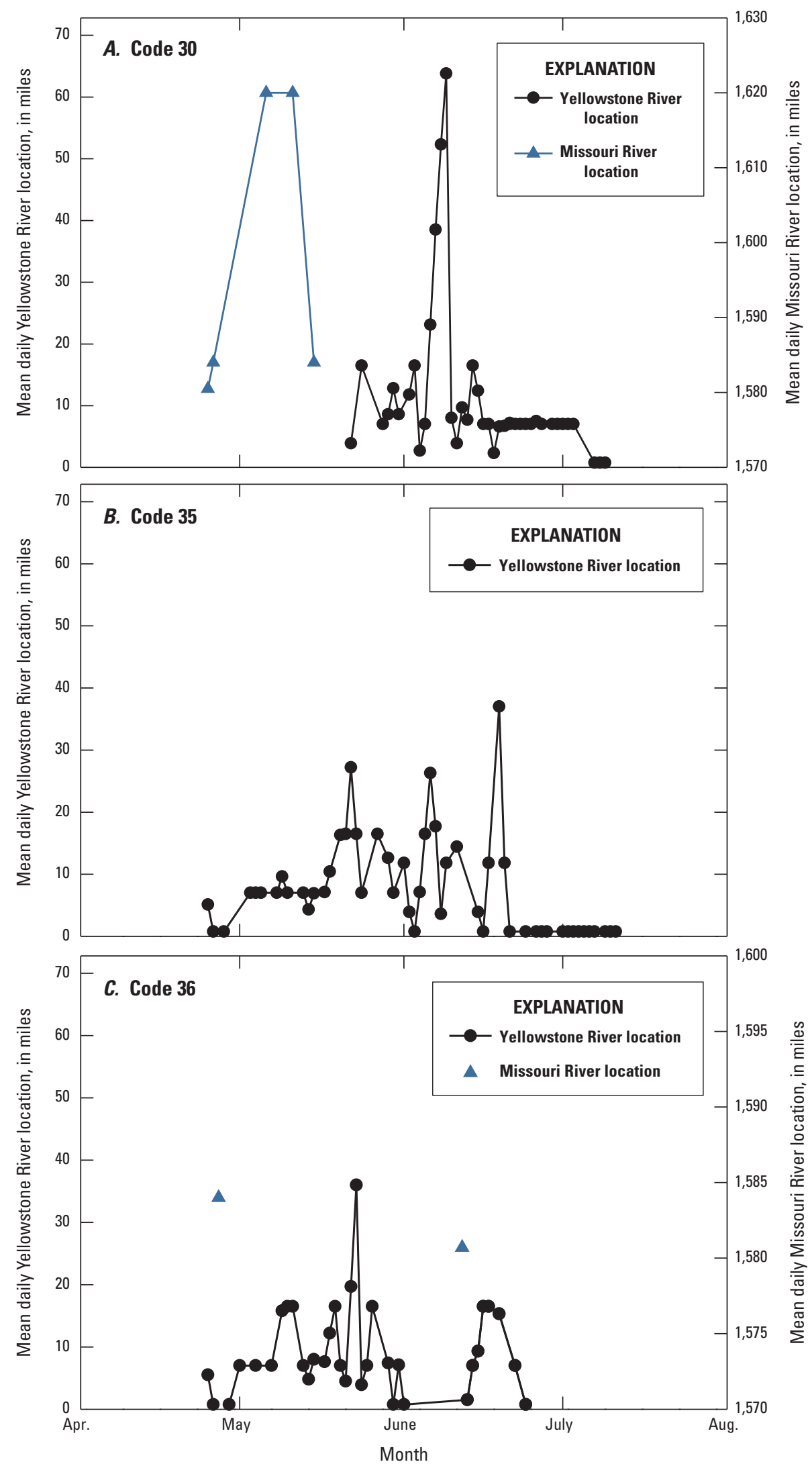

Figure 4-4. Mean daily locations of telemetered female pallid sturgeon exhibiting migrations in the Yellowstone River and Missouri River upstream from the confluence with the Yellowstone River, April-August, 2012. A, code 30; B, code 35; and C, code 36. 
of the Yellowstone River. Male code 50 exhibited the greatest migratory distance as this individual initially occupied the Yellowstone River in mid-April, exhibited extensive migrations in the Missouri River during late April and early May that extended to RM 1,760 (approximately 10 miles downstream from Fort Peck Dam), then re-entered the Yellowstone River and remained in the lower reaches. Total migration distances were categorized into groups including fish that migrated less than $(<)$ 100 mi, 101-150 mi, 151-200 mi, 201-250 mi, and greater than (>) $250 \mathrm{mi}$. Telemetered male pallid sturgeon assigned to migration distance categories at 31 percent, 21 percent, 28 percent, 10 percent, and 10 percent of the total tagged population, respectively. A crude approximation of the average pre-spawn migration distance for gravid females was $218 \mathrm{mi}$. Female code 30 exhibited the greatest migration distance (estimated $289 \mathrm{mi}$ ) as this female used the Missouri River prior to Yellowstone River entry. Female code 35 traversed an estimated $205 \mathrm{mi}$ as migrations were restricted to the Yellowstone River. Code 36 migrated through an estimated $161 \mathrm{mi}$ with migrations primarily restricted to the Yellowstone River. It should be noted that the migration distances are likely conservative as the estimates are based on mean daily locations and do not include other movements that may have happened between relocation dates.

\section{Migration Pathways}

Migration pathways for eight males (codes 16, 42, 51, $52,69,72,76,92)$, two gravid females (codes 30, 36), and one non-gravid female (code 37) were obtained between April 30 and June 13 throughout much of the Yellowstone River. Of the five male pallid sturgeon that migrated to Intake Dam, intensive tracking of codes 52 and 76 characterized pathways traversed as these individuals approached Intake Dam. On June 9, code 52 was initially located at RM 67.6 (fig. 4-5). After marking this individual at RM 69.5 (1:57 p.m.), code 52 entered a small side channel (approximately 400-m-long) on the inside bend of the main channel and proceeded upstream in the side channel. Code 52 continued moving upstream and successfully traversed the upstream inlet of the side channel at 2:45 p.m. After moving along the north bank of the main river channel from 3:31 to 4:27 p.m., code 52 crossed the channel and approached Intake Dam along the south bank of the river where upstream progression was observed until 9:42 p.m. Thereafter, slight downstream movement towards mid-river was noted for the last location at 9:45 p.m. Code 76 was first located downstream from Intake Dam at RM 71.8 (10:05 a.m.), and the approach pathway to the dam included locations extending from the south bank of the river to the southern one-half of the river channel (fig. 4-6). Upstream movement was maintained by code 76 until approximately 5:00 p.m.; thereafter, relocations for code 76 remained clustered below the dam in the mid-channel.

Under moderate flow conditions in the Yellowstone River during 2012, pallid sturgeon exhibited migration pathways primarily through main channel habitats; however, migrations through braided channel configurations and primary or secondary side channels were also noted. For example, main channel migration pathways were primary routes used by code 16 (May 17), code 30 (June 6), code 36 (May 23), code 42 (April 30), code 51 (May 21), code 72 (May 23) and code 69 (June 8) as side channels within the migration corridor received limited use (fig. 4-7 to 4-21). In other cases, use of side channels or split channel configurations by migrating pallid sturgeon were observed; however, use was not consistent among individuals. For example, code 36 and code 37 were located on May 22, moving in close proximity through the same river bend on the same day. Their migration pathways were, therefore, assessed under identical conditions (fig. 4-11). Early in the migration (from about RM 18-20), both pallid sturgeon used a similar main-channel migration pathway but did not use the short (0.5-mi long) or long (1.75-mi long) side channels available within this reach. At about RM 20, commonality in the migration pathway diverged as code 36 and code 37 used opposite channels in the split channel configuration. Additional variability in side channel use was noted between code 36 and code 69 . Specifically, on May 23 at a discharge of $19,300 \mathrm{ft}^{3} / \mathrm{s}$, code 36 migrated past the downstream entrance of a side channel joining the river at RM 36.5 and proceeded upstream along a main channel pathway (fig. 4-12). At a similar discharge of $20,400 \mathrm{ft}^{3} / \mathrm{s}$ on June 5 , code 69 was first located (2:21 p.m.) emerging from the upstream inlet of the same side channel (fig. 4-14) that was not used by code 36; thus, under similar discharge conditions, the 1.1-mile long side channel was used as a migration route by code 69 but not used by code 36 . The migration pathway of code 69 was also observed through a braided channel configuration on June 6 (fig. 4-16). Passage through the 2.4-mi-long braided channel was successful as code 69 was relocated upstream on June 7.

Upstream movement in a long $(1.7 \mathrm{mi})$ side channel near RM 63.7-63.8 was noted for code 30 on June 9. After moving upstream a distance of approximately $1.2 \mathrm{mi}$, code 30 turned around and swam downstream out of the side channel into the main channel. Failure of code 30 to completely negotiate the entire length of the side channel may have been related to unsuitable hydraulic conditions in the side channel. Alternatively, upstream migration behavior of code 30 may have been compromised by boat operations in shallow water while attempting to obtain an accurate telemetry location. 


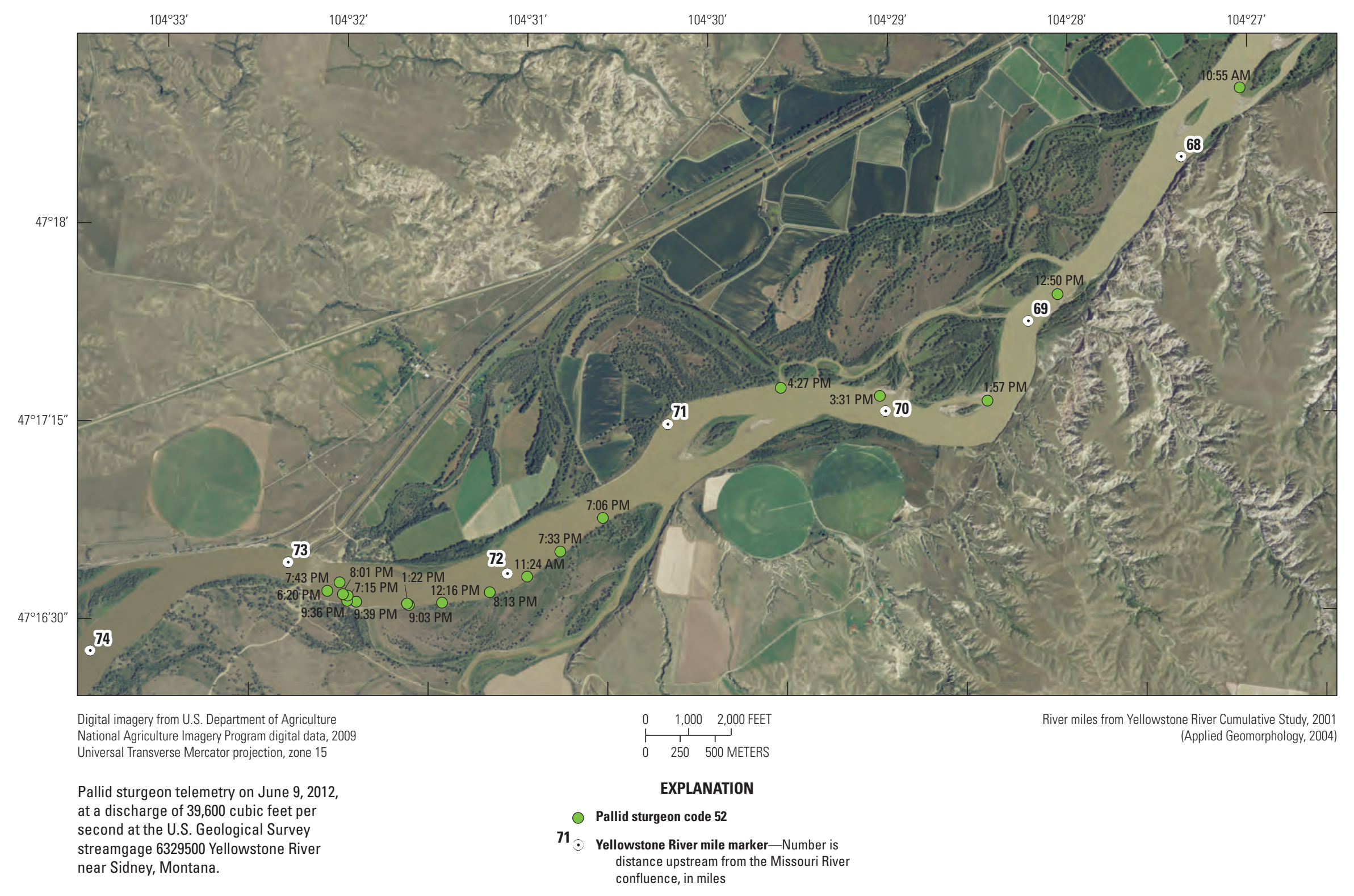

Figure 4-5. Migration pathway of male pallid sturgeon code 52 in the Yellowstone River approaching Intake Dam, June 9, 2012. 


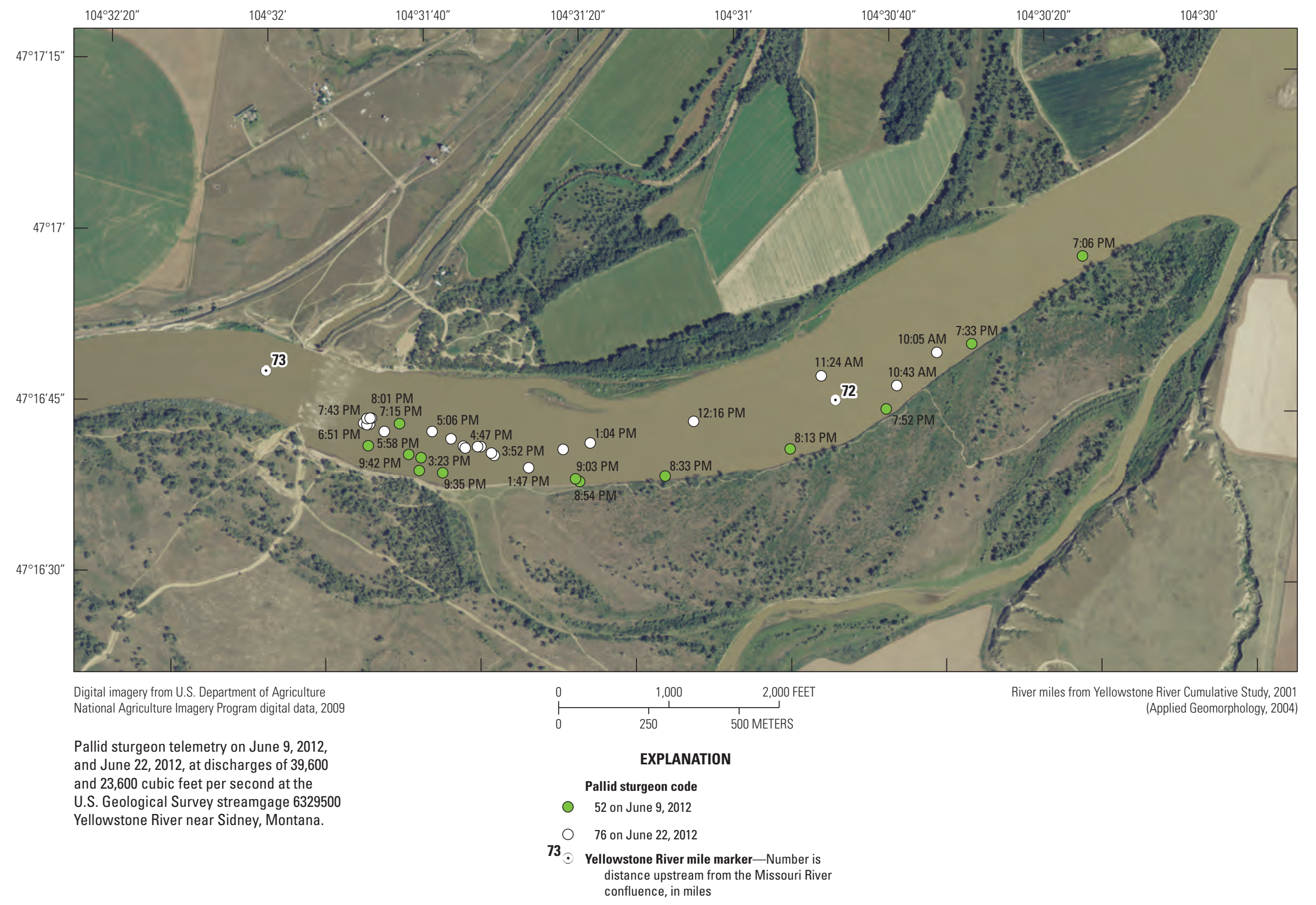

Figure 4-6. Migration pathways of male pallid sturgeon codes 52 and 76 in the Yellowstone River approaching Intake Dam, June 9 and 22, 2012. 


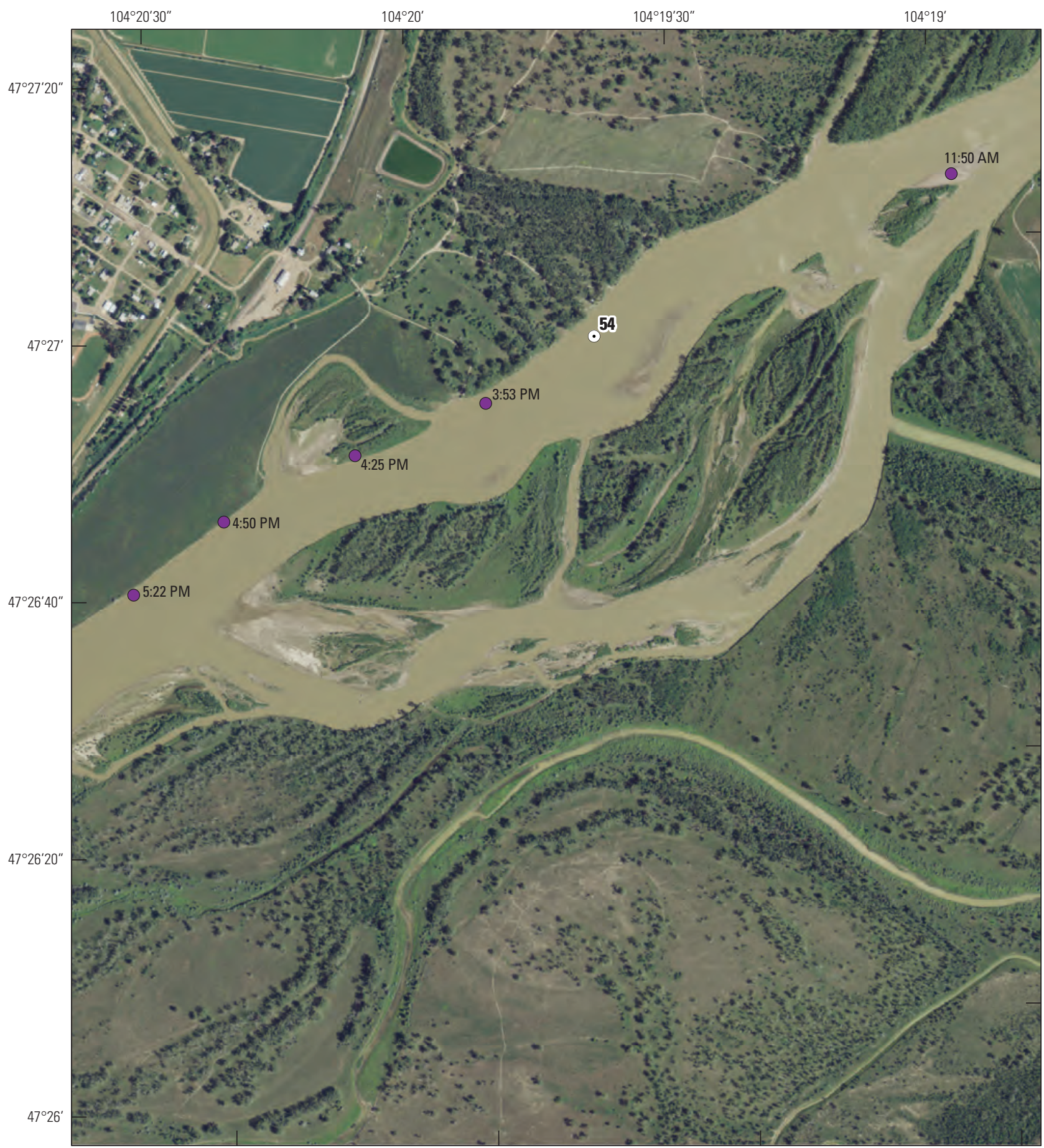

Digital imagery from U.S. Department of Agriculture National Agriculture Imagery Program digital data, 2009

Pallid sturgeon telemetry on April 30, 2012, at a discharge of 19,600 cubic feet per second at the U.S. Geological Survey streamgage 6329500 Yellowstone River near Sidney, Montana.

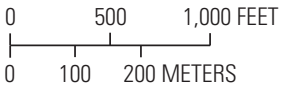

\section{EXPLANATION}

- Pallid sturgeon code 42

$54 \odot$ Yellowstone River mile marker-Number is distance upstream from the Missouri River confluence, in miles

Figure 4-7. Pallid sturgeon code 42 telemetry locations in the Yellowstone River, April 30, 2012. 


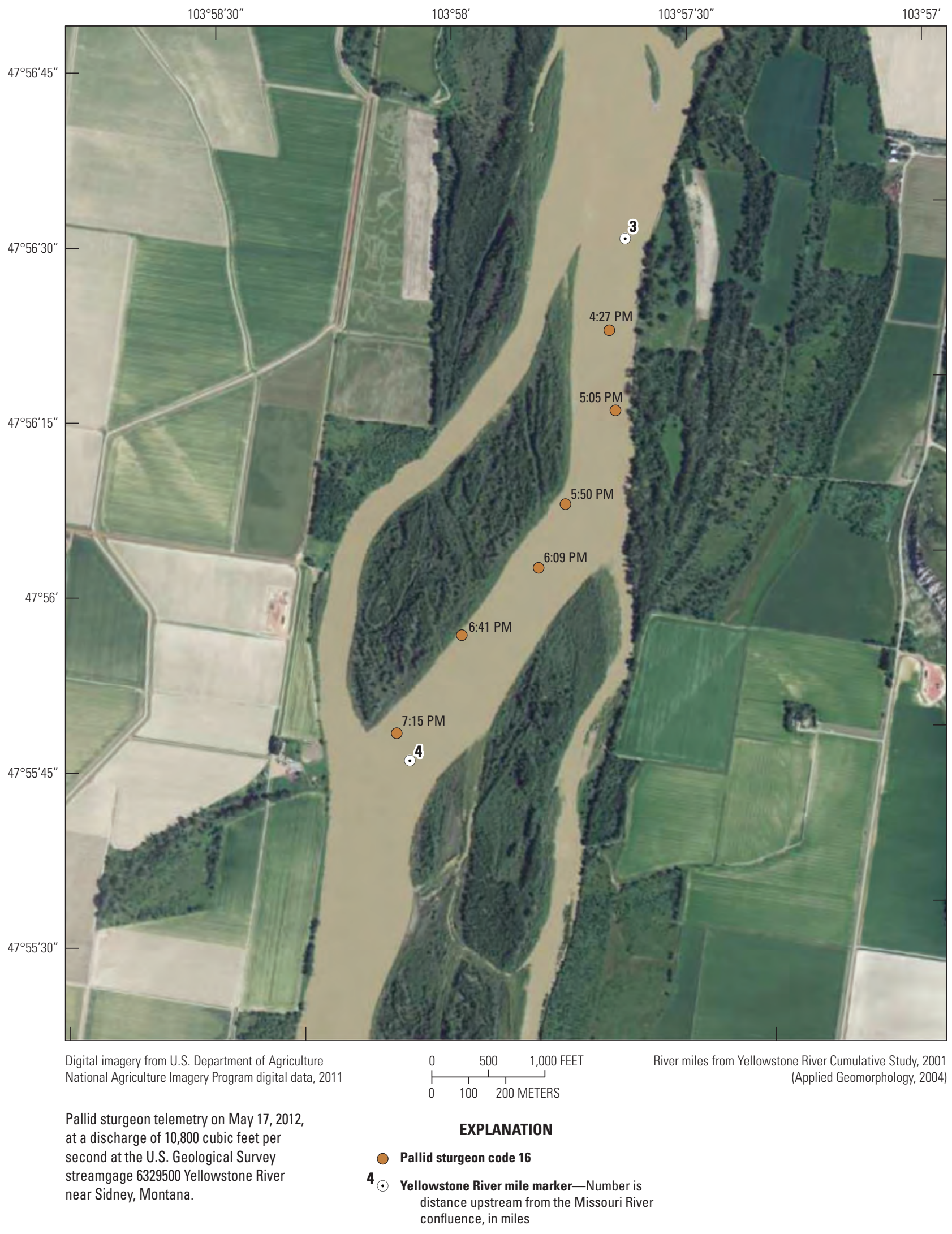

Figure 4-8. Pallid sturgeon code 16 telemetry locations in the Yellowstone River, May 17, 2012. 


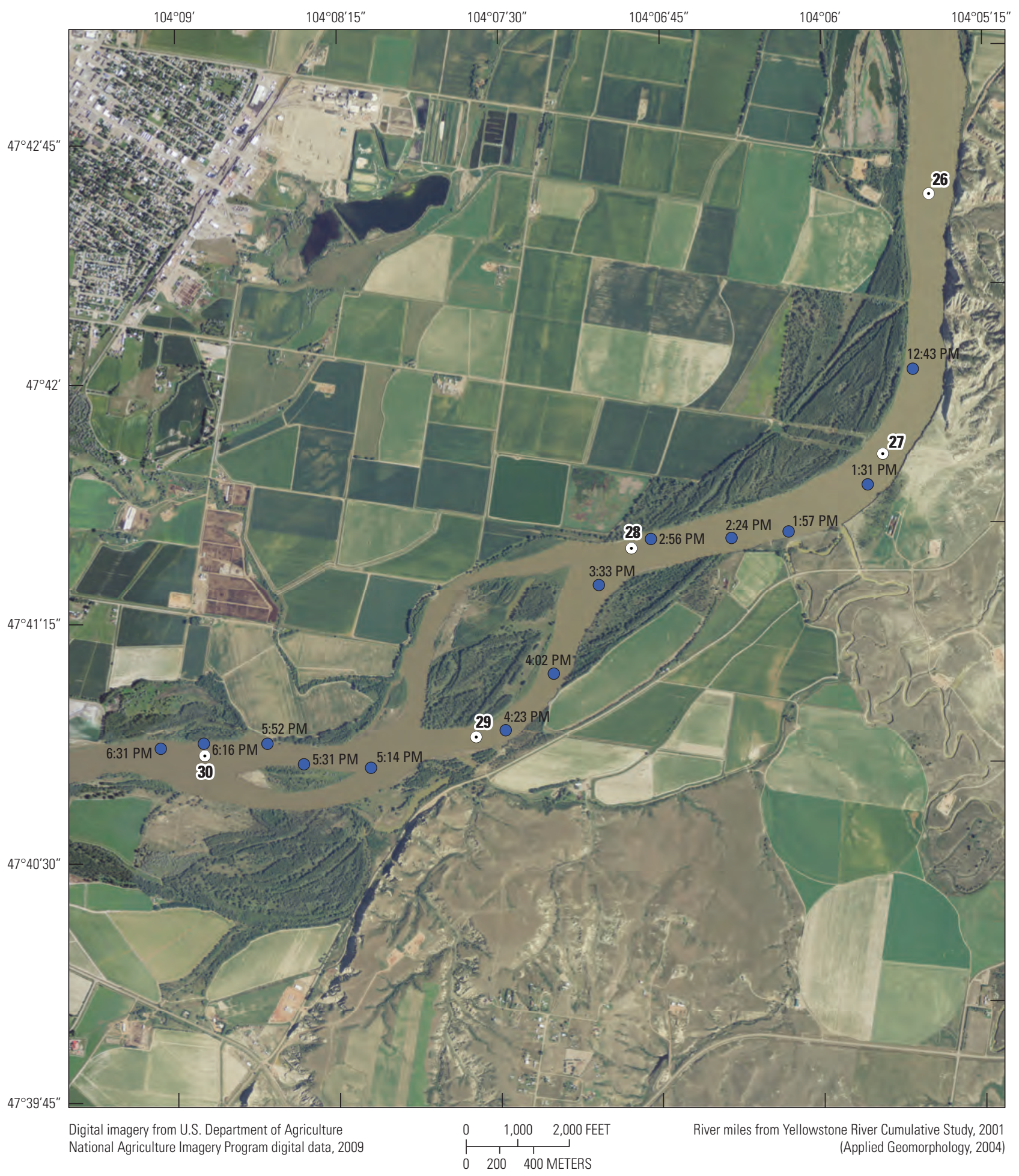

Pallid sturgeon telemetry on May 21, 2012, at a discharge of 21,400 cubic feet per second at the U.S. Geological Survey streamgage 6329500 Yellowstone River near Sidney, Montana.

\section{EXPLANATION}

- Pallid sturgeon code 51

29 Yellowstone River mile marker-Number is

distance upstream from the Missouri River confluence, in miles

Figure 4-9. Pallid sturgeon code 51 telemetry locations in the Yellowstone River, May 21, 2012. 


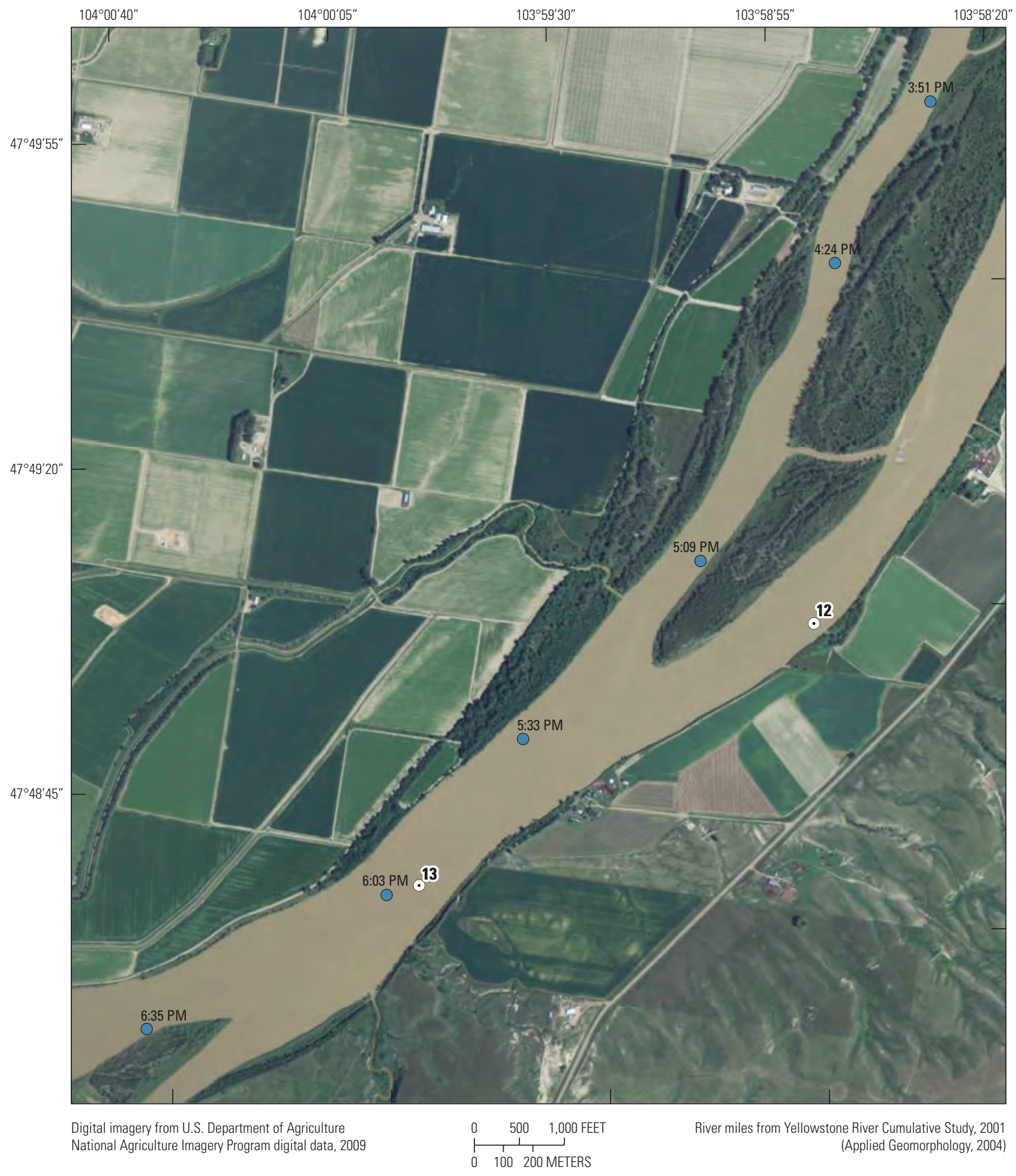

Pallid sturgeon telemetry on May 21, 2012, at a discharge of 21,400 cubic feet per second at the U.S. Geological Survey streamgage 6329500 Yellowstone River near Sidney, Montana.

\section{EXPLANATION}

Pallid sturgeon code 92

13 Yellowstone River mile marker-Number is distance upstream from the Missouri River confluence, in miles

Figure 4-10. Pallid sturgeon code 92 telemetry locations in the Yellowstone River, May 21, 2012. 


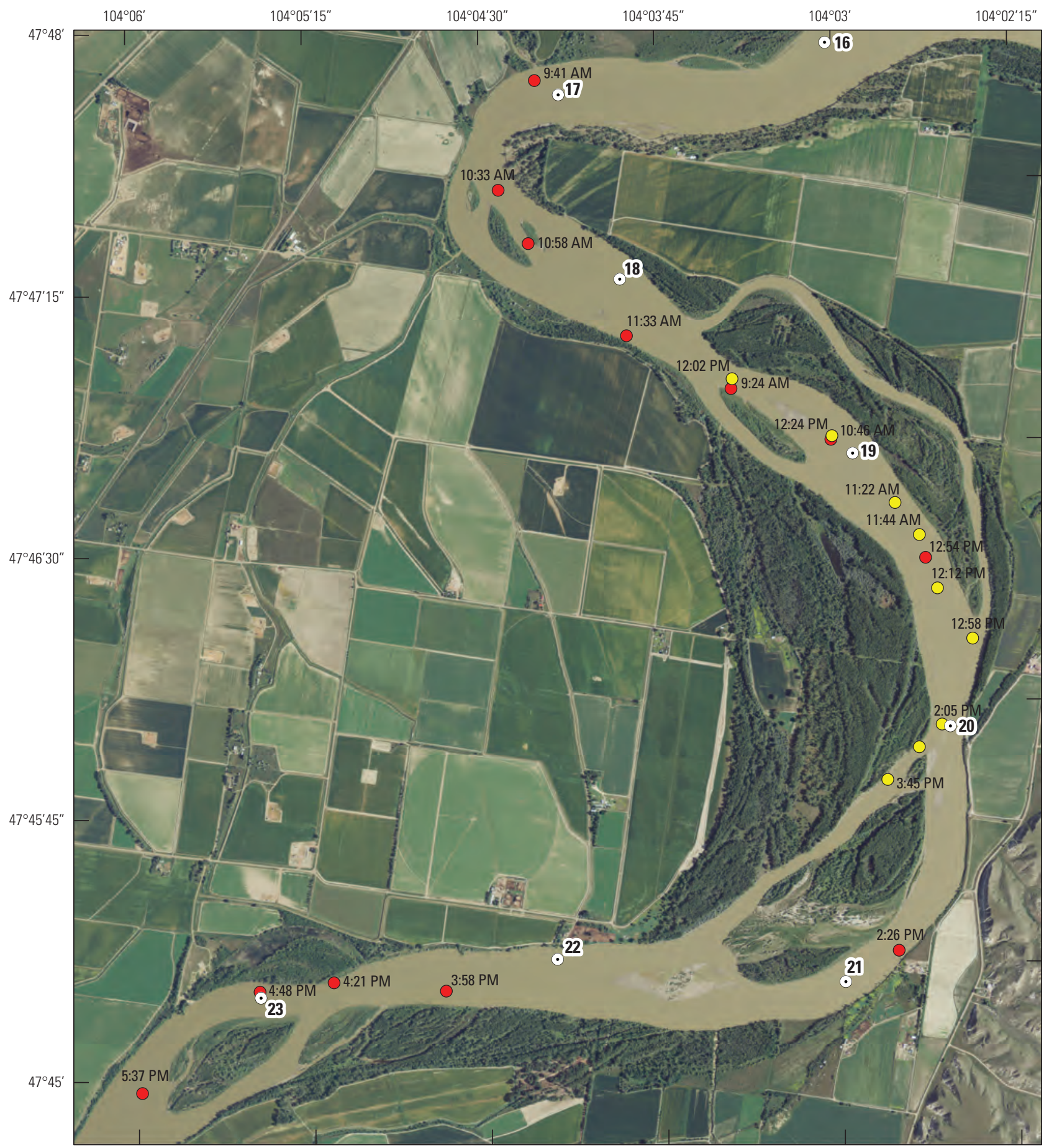

Digital imagery from U.S. Department of Agriculture National Agriculture Imagery Program digital data, 2009

Pallid sturgeon telemetry on May 22, 2012, at a discharge of 21,900 cubic feet per second at the U.S. Geological Survey streamgage 6329500 Yellowstone River near Sidney, Montana.

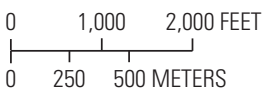

River miles from Yellowstone River Cumulative Study, 2001 (Applied Geomorphology, 2004

\section{EXPLANATION}

Pallid sturgeon code

- 36

○ 37

$23 \odot$ Yellowstone River mile marker-Number is

distance upstream from the Missouri River confluence, in miles

Figure 4-11. Pallid sturgeon codes 36 and 37 telemetry locations in the Yellowstone River, May 22, 2012. 
$104^{\circ} 12^{\prime} 45^{\prime \prime}$

$104^{\circ} 12^{\prime}$

$104^{\circ} 11^{\prime} 15^{\prime \prime}$

$104^{\circ} 10^{\prime} 30^{\prime \prime}$

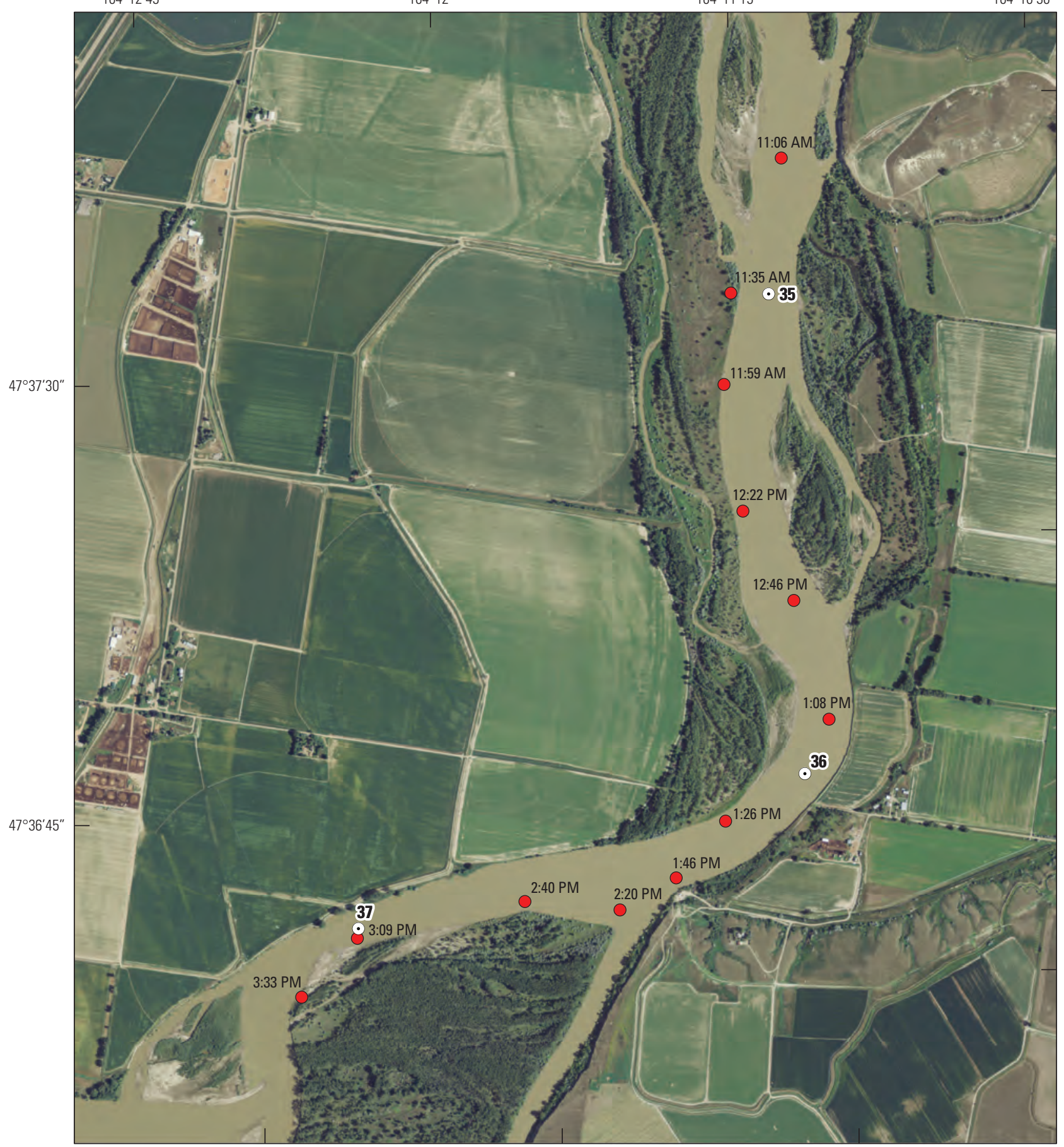

Digital imagery from U.S. Department of Agriculture

National Agriculture Imagery Program digital data, 2009

$0 \quad 500 \quad 1,000$ FEET

$0 \quad 100200$ METERS

River miles from Yellowstone River Cumulative Study, 2001 (Applied Geomorphology, 2004

Pallid sturgeon telemetry on May 23, 2012,

at a discharge of 19,300 cubic feet per

second at the U.S. Geological Survey

streamgage 6329500 Yellowstone River

EXPLANATION

near Sidney, Montana.

Pallid sturgeon rcode 36

37 Yellowstone River mile marker-Number is

distance upstream from the Missouri River confluence, in miles

Figure 4-12. Pallid sturgeon code 36 telemetry locations in the Yellowstone River, May 23, 2012. 


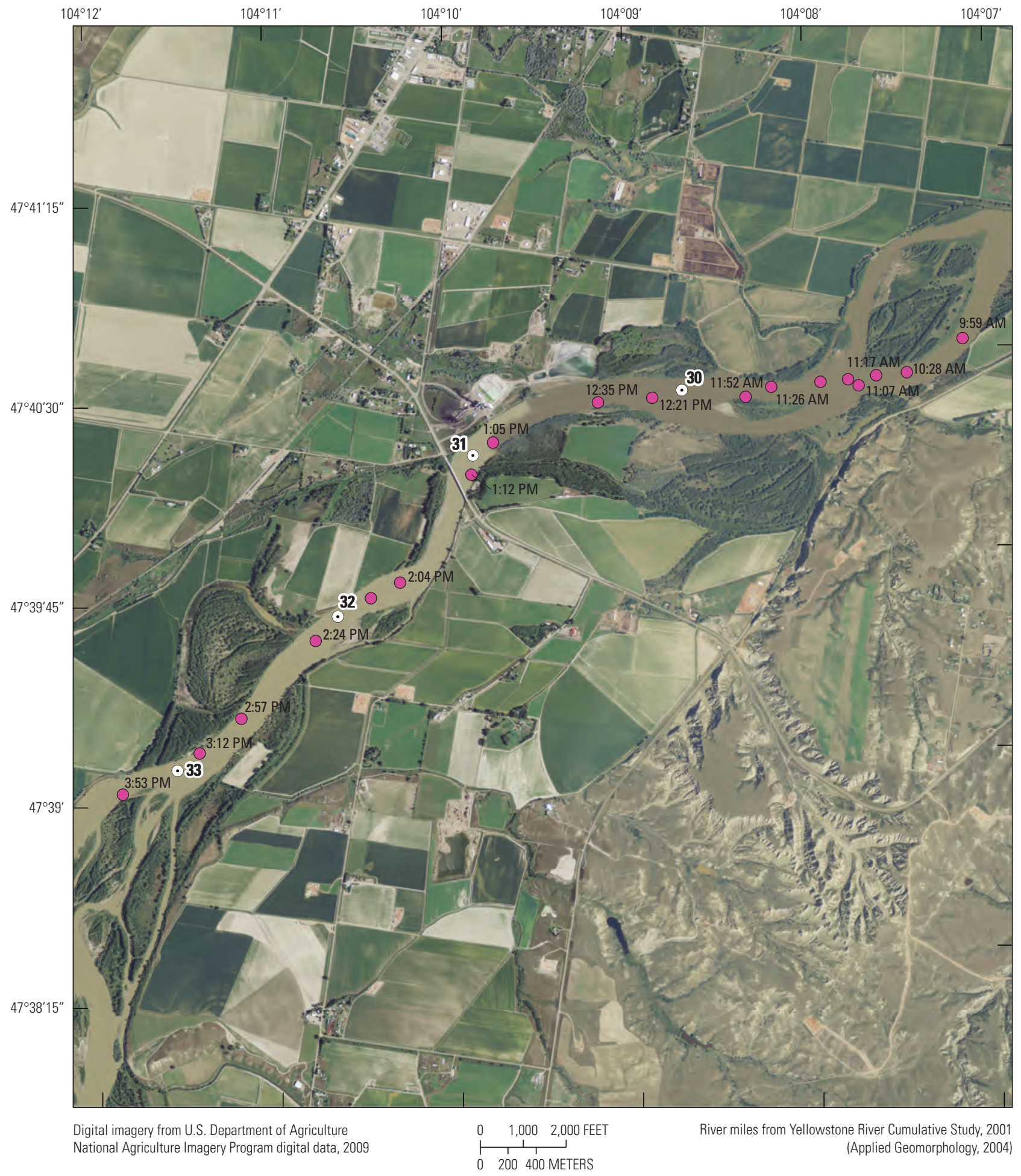

Pallid sturgeon telemetry on May 23, 2012, at a discharge of 19,300 cubic feet per second at the U.S. Geological Survey streamgage 6329500 Yellowstone River near Sidney, Montana.

\section{EXPLANATION}

- Pallid sturgeon code 72

$33 \odot$ Yellowstone River mile marker-Number is

distance upstream from the Missouri River confluence, in miles

Figure 4-13. Pallid sturgeon code 72 telemetry locations in the Yellowstone River, May 23, 2012. 


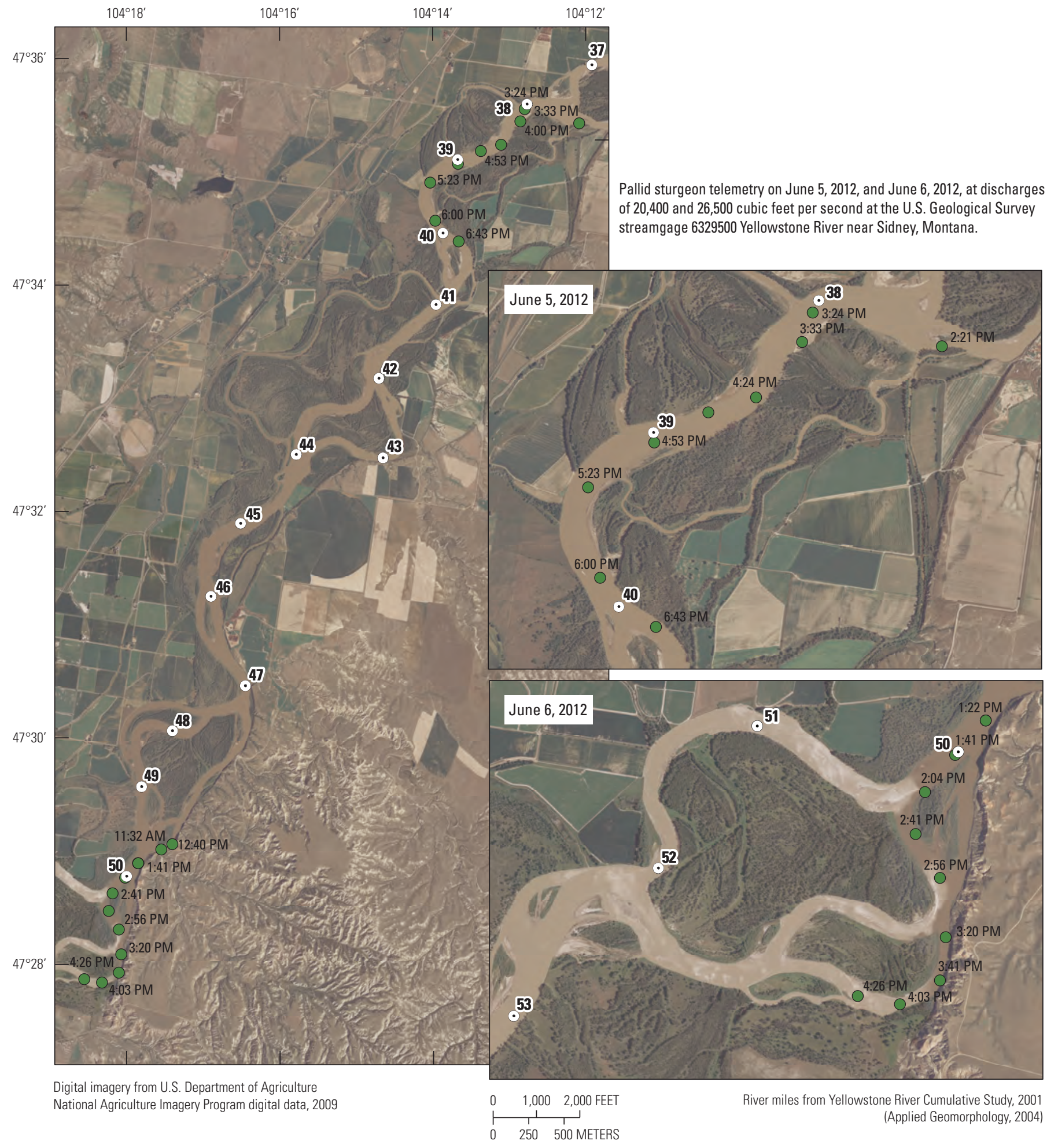

\section{EXPLANATION}

Pallid sturgeon code 69

53 Yellowstone River mile marker-Number is distance upstream from the Missouri River confluence, in miles

Figure 4-14. Pallid sturgeon code 69 telemetry locations in the Yellowstone River, June 5-6, 2012. 


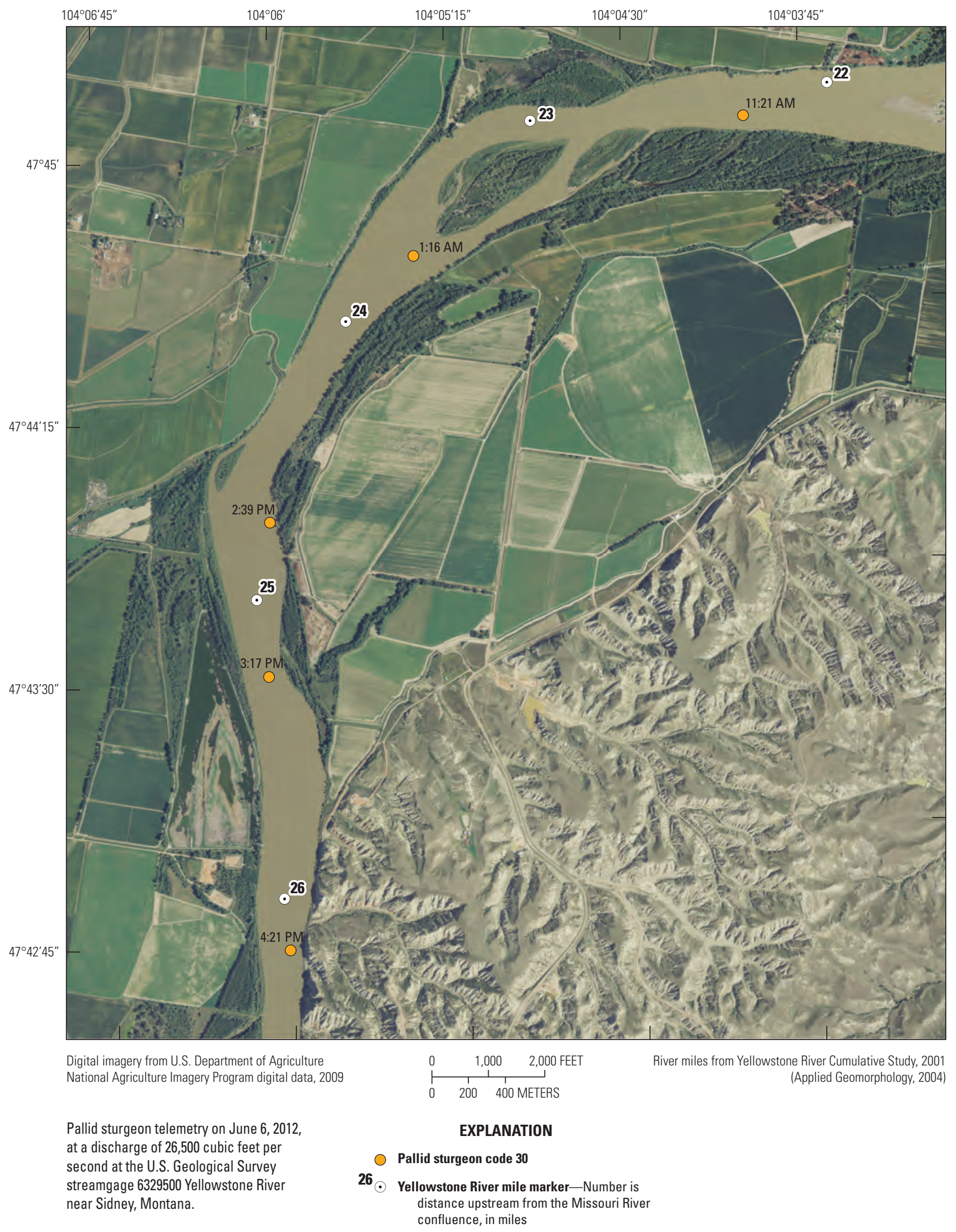

Figure 4-15. Pallid sturgeon code 30 telemetry locations in the Yellowstone River, June 6, 2012. 


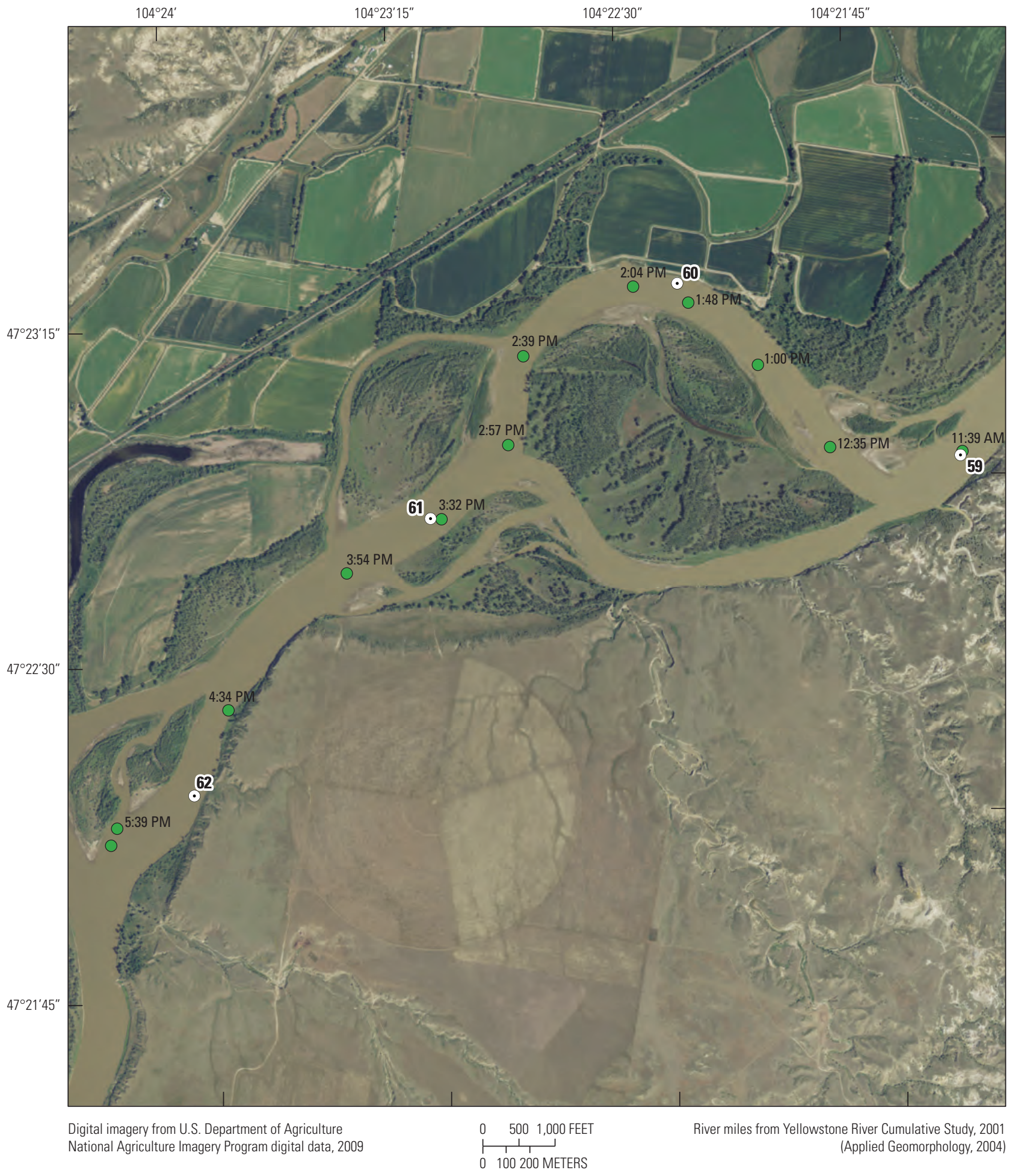

Pallid sturgeon telemetry on June 7, 2012, at a discharge of 32,300 cubic feet per second at the U.S. Geological Survey streamgage 6329500 Yellowstone River near Sidney, Montana.

\section{EXPLANATION}

Pallid sturgeon code 69

62
Yellowstone River mile marker-Number is
distance upstream from the Missouri River confluence, in miles

Figure 4-16. Pallid sturgeon code 69 telemetry locations in the Yellowstone River, June 7, 2012. 


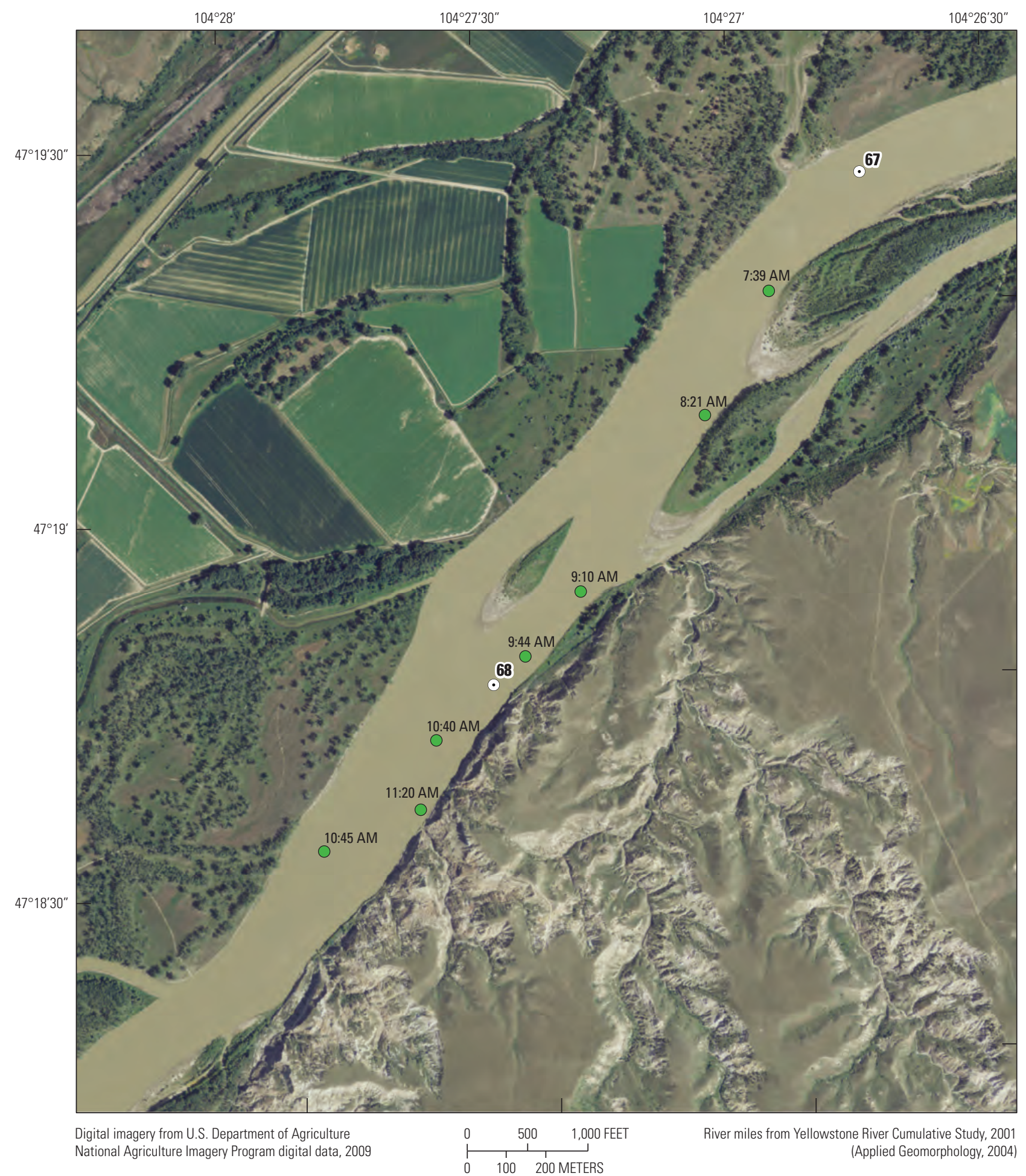

Pallid sturgeon telemetry on June 8, 2012, at a discharge of 36,500 cubic feet per second at the U.S. Geological Survey streamgage 6329500 Yellowstone River near Sidney, Montana.

\section{EXPLANATION}

Pallid sturgeon code 69

68

\footnotetext{
Yellowstone River mile marker-Number is distance upstream from the Missouri River confluence, in miles
}

Figure 4-17. Pallid sturgeon code 69 telemetry locations in the Yellowstone River, June 8, 2012. 


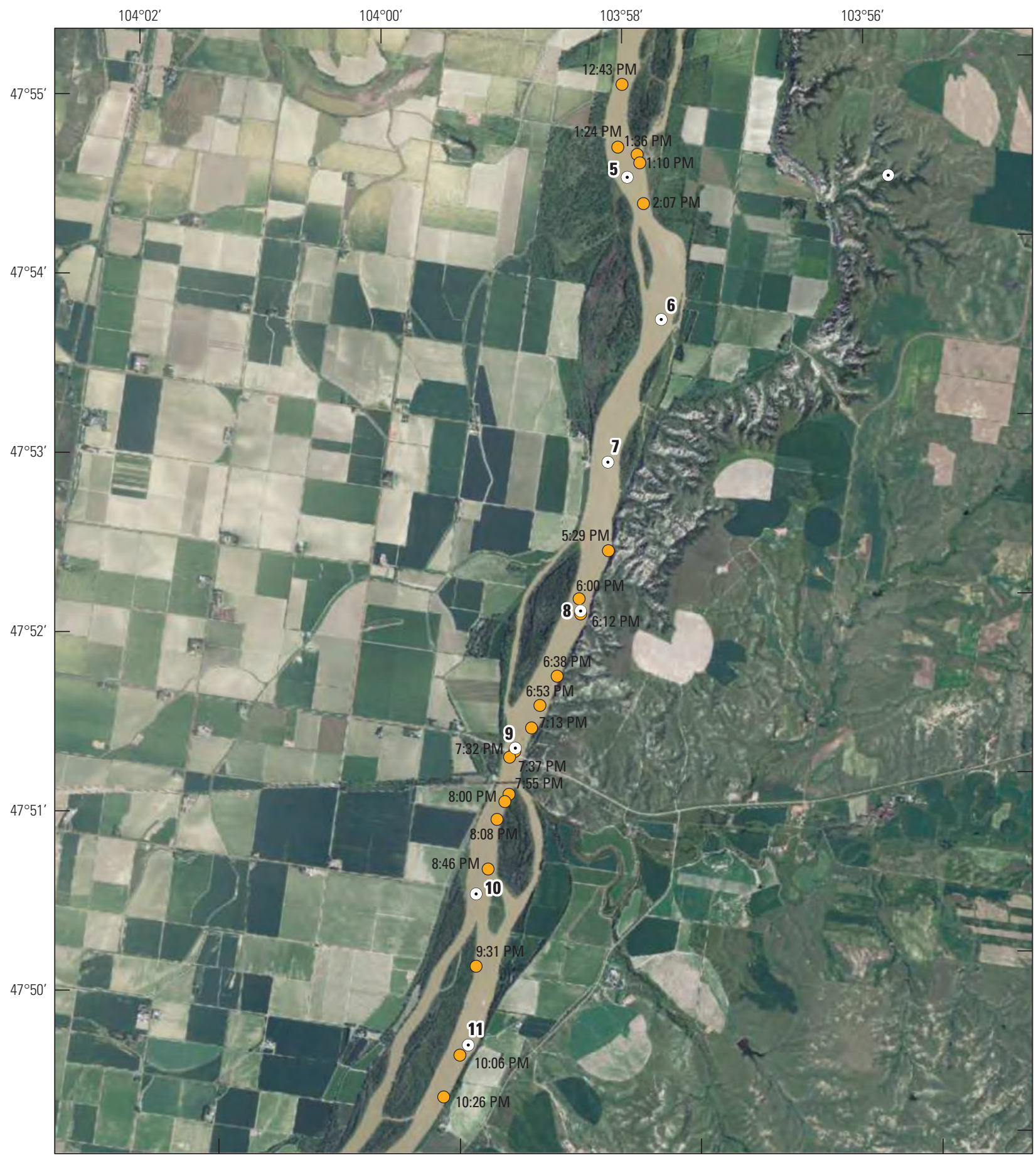

Digital imagery from U.S. Department of Agriculture National Agriculture Imagery Program digital data, 2009

Pallid sturgeon telemetry on June 13, 2012, at a discharge of 30,000 cubic feet per second at the U.S. Geological Survey streamgage 6329500 Yellowstone River near Sidney, Montana.
$0 \quad 1,5003,000 \mathrm{FEET}$

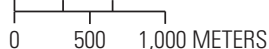

River miles from Yellowstone River Cumulative Study, 2001 (Applied Geomorphology, 2004)

\section{EXPLANATION}

Pallid sturgeon code 30

$11 \odot$ Yellowstone River mile marker-Number is distance upstream from the Missouri River confluence, in miles

Figure 4-18. Pallid sturgeon code 30 telemetry locations in the Yellowstone River, June 13, 2012. 


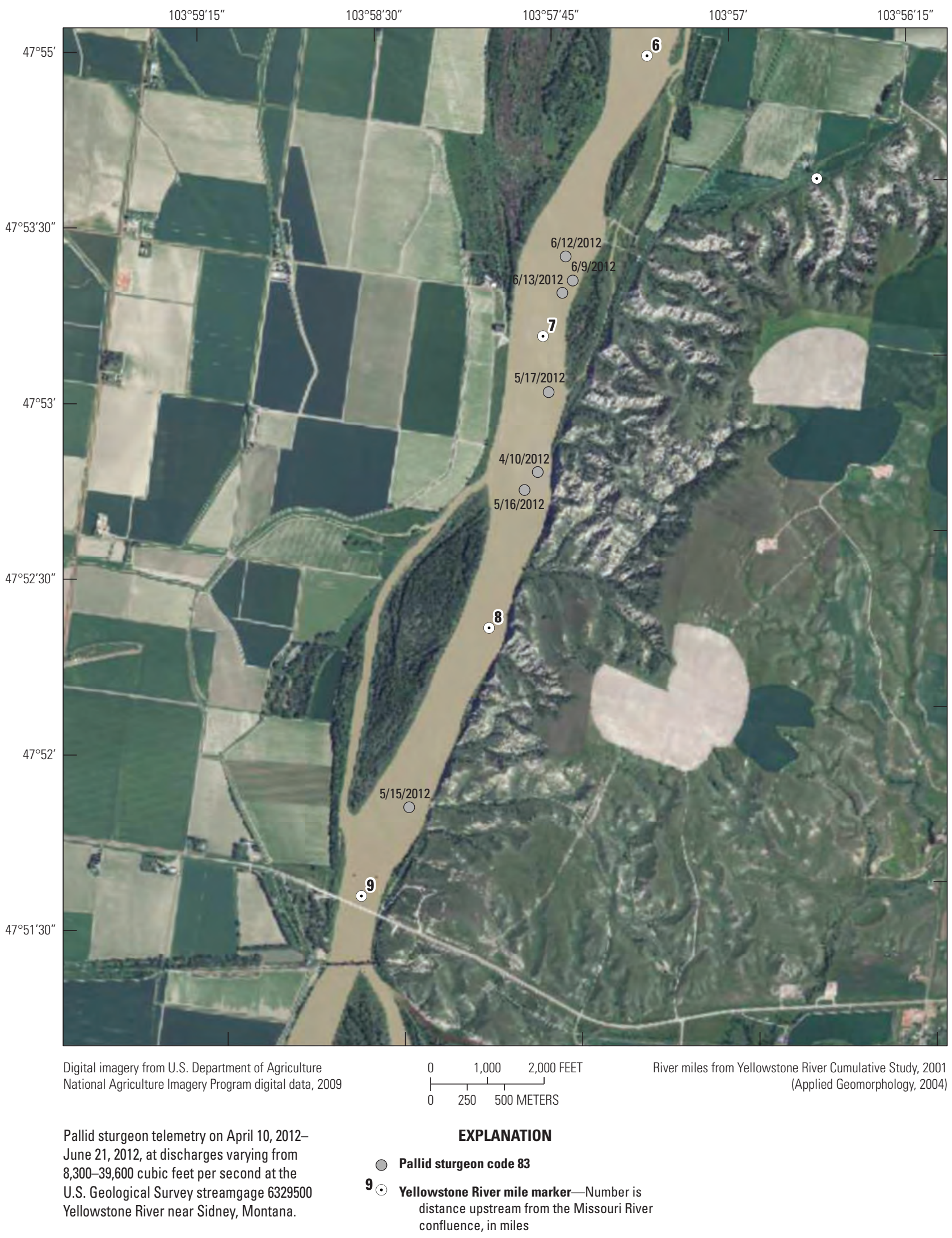

Figure 4-19. Pallid sturgeon code 83 telemetry locations in the Yellowstone River, April 10-June 21, 2012. 

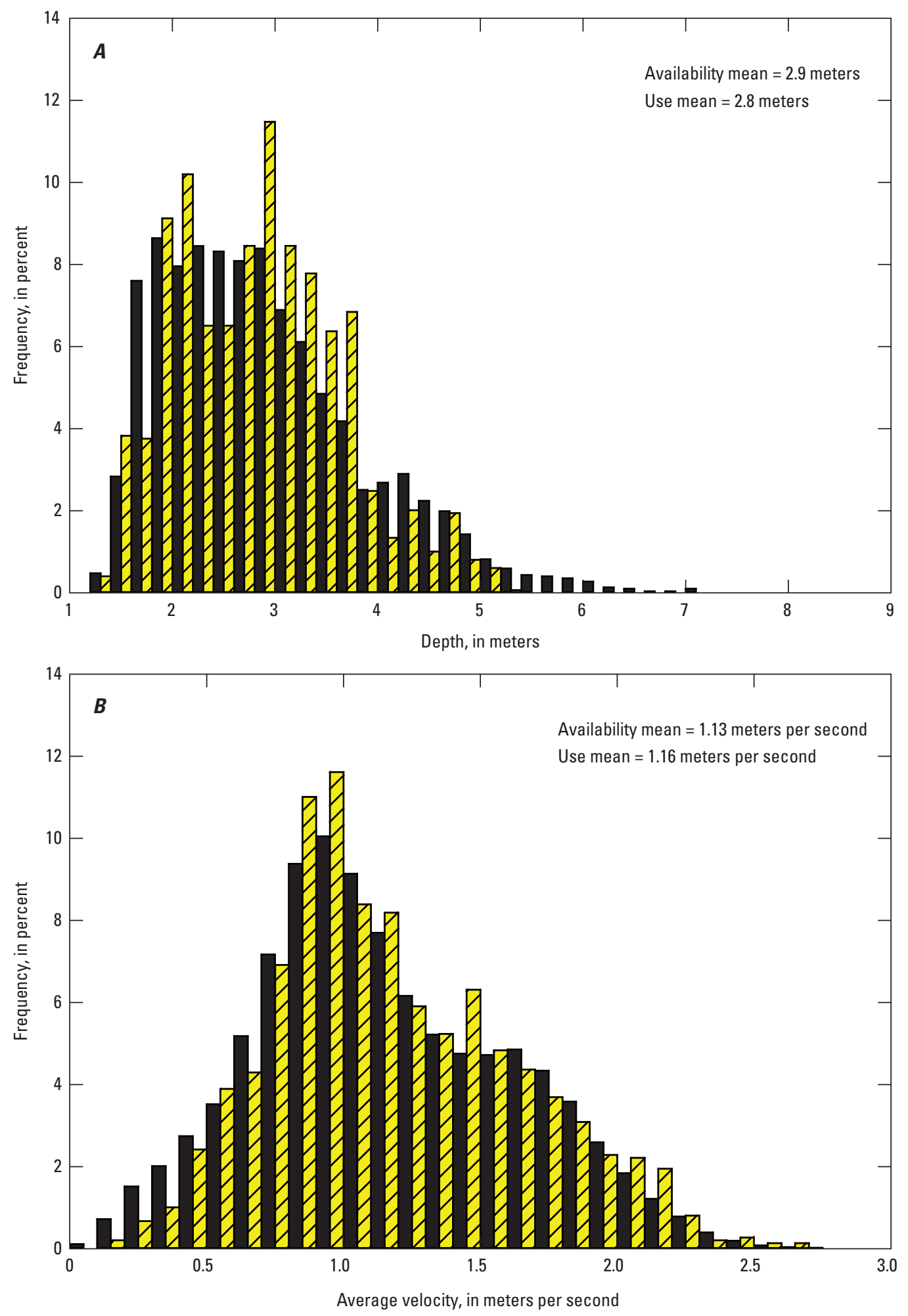

EXPLANATION

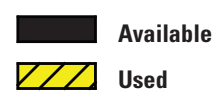

Figure 4-20. Depths and depth-averaged velocities used by and available to migrating pallid sturgeon, Yellowstone River, 2012. 

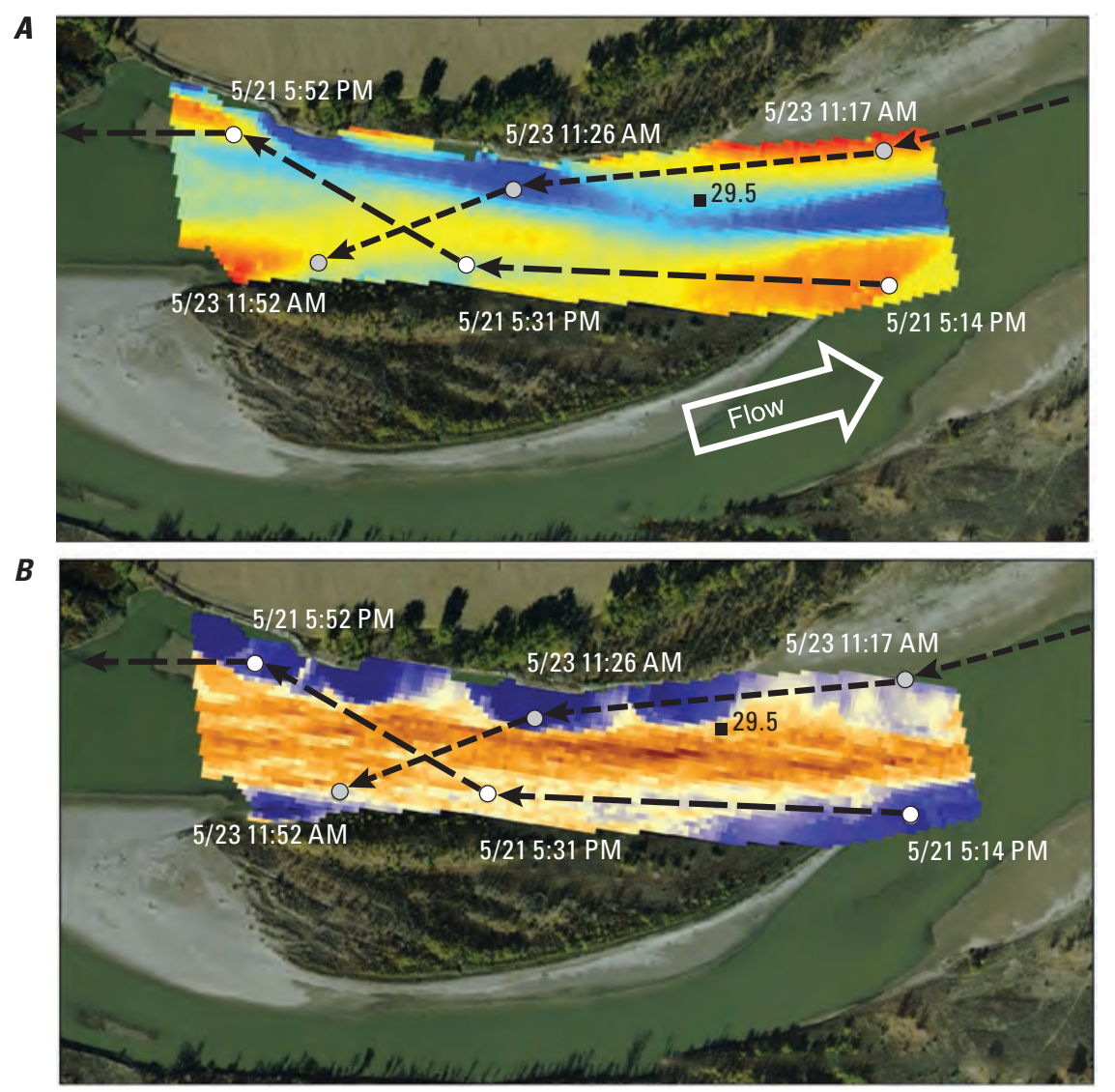

\section{EXPLANATION}

Depth, in meters

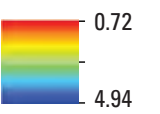

Male pallid sturgeon location

O Code 51 on May 21, 2012

O Code 72 on May 23, 2012

Depth-averaged velocity, in meters per second

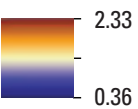

Discharges at the U.S. Geological Survey streamgage 6329500 Yellowstone River near Sidney, Montana, in cubic feet per second: $5 / 21 / 2012=21,400$ $5 / 23 / 2012=19,200$

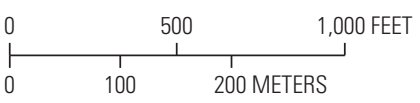

Map images are the intellectual property of Esri and is used herein under license. Copyright (C) 2015 Esri and its licensors. All rights reserved.
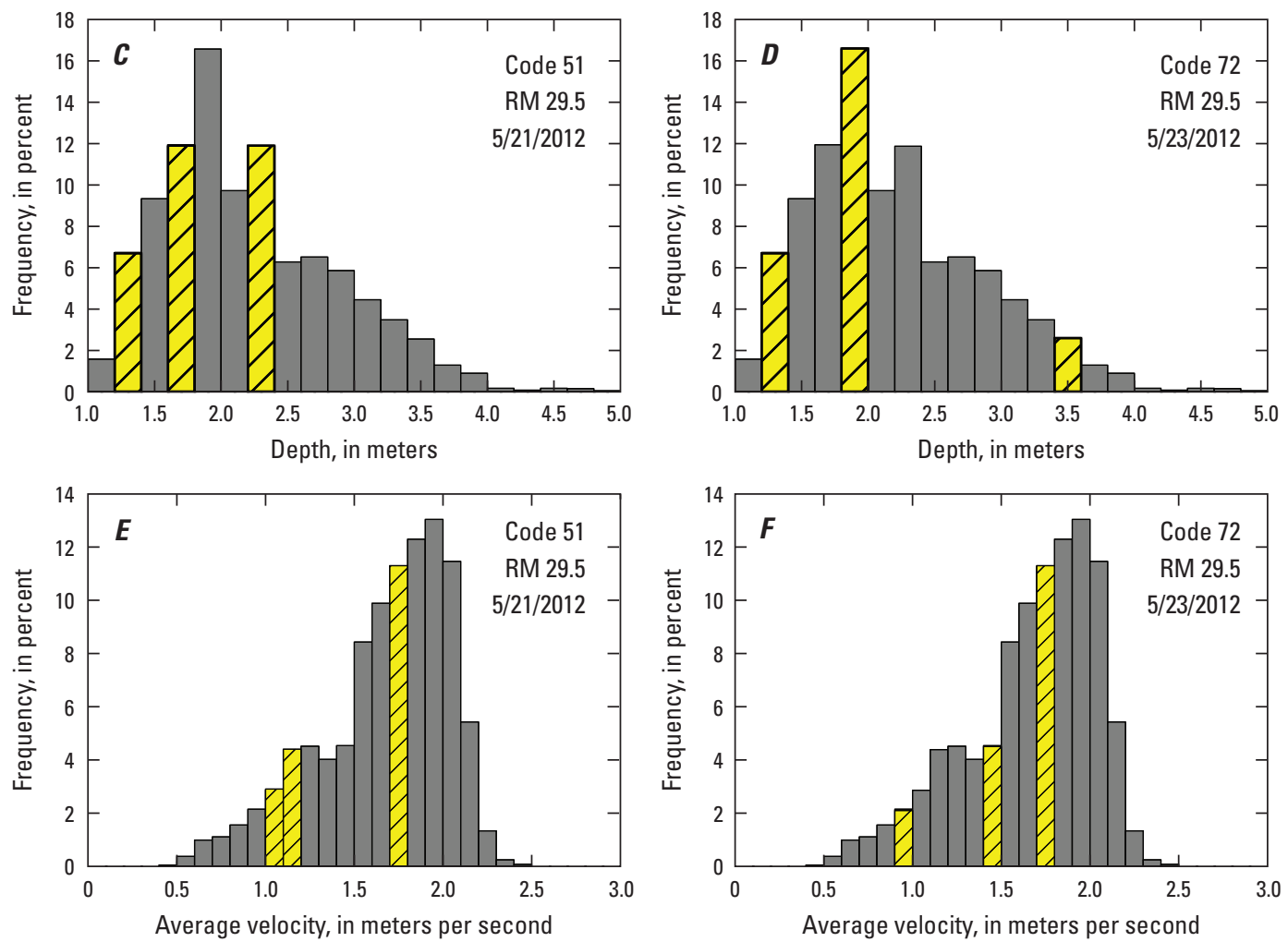

EXPLANATION

Available $\square$ Used RM River mile

Figure 4-21. Migration pathway, depth, and velocity of male pallid sturgeon codes 51 and 72 in the Yellowstone River, river mile 29.5, May 21 and 23,2012. $A$, depth and location of codes 51 and 72; $B$, depth-averaged velocity and location of codes 51 and $72 ; C$, depths used by and available to code 51, May 21, 2012; $D$, depths used by and available to code 72, May 23, 2012; $E$, depth-averaged velocity used by and available to code 51, May 21, 2012; and $F$, depth-average velocity used by and available to code 72, May 23, 2012. 
Point observations along migration pathways provided estimates of pallid sturgeon migration rates, and hydraulic conditions (depth, velocity) used by and available to migrating individuals. Across individuals, upstream migration rates of telemetered pallid sturgeon along pathways averaged 0.25 meter per second $(\mathrm{m} / \mathrm{s})$ (range $0.10-0.47 \mathrm{~m} / \mathrm{s}$; mean $=0.55$ miles per hour $[\mathrm{mi} / \mathrm{h}]$, range $0.22-1.05 \mathrm{mi} / \mathrm{h}$; $N=16$ migration pathways). Pallid sturgeon used an average depth of $2.8 \mathrm{~m}$ while migrating, and the range of depths used varied from $1.3 \mathrm{~m}$ to $5.2 \mathrm{~m}$ (fig. 4-20). About 80 percent of the depth-use observations were located in 1.0-3.5 m. In comparison, available depths averaged $2.9 \mathrm{~m}$, and ranged from $1.1 \mathrm{~m}$ to approximately $9.0 \mathrm{~m}$. Pallid sturgeon used an average water column velocity of $1.16 \mathrm{~m} / \mathrm{s}$, but used water column velocities ranged from $0.15-2.61 \mathrm{~m}$ (fig. 4-20). Nearly 75 percent of the water velocities used by pallid sturgeon were $0.5-1.5 \mathrm{~m} / \mathrm{s}$. Water column velocities available to pallid sturgeon averaged $1.13 \mathrm{~m} / \mathrm{s}$, with velocities of $0-2.7 \mathrm{~m} / \mathrm{s}$ available along the migration points. Using mean column velocity, these results suggest that the average migrating pallid sturgeon swam upstream at a sustained rate of approximately $1.41 \mathrm{~m} / \mathrm{s}$ to achieve a ground speed of $0.25 \mathrm{~m} / \mathrm{s}$ against an average water velocity of $1.16 \mathrm{~m} / \mathrm{s}$; however, pallid sturgeon swim upstream along the bottom, and mean column velocity is not necessarily an accurate approximation of the velocities that sturgeon would be expected to experience. Mean column velocities are most likely substantially greater than current that pallid sturgeon swim against while migrating upstream.

In addition to quantifying depths and velocities used and available at migration points, detailed quantification of depths and velocities composing an 800-m reach of the Yellowstone River was done to characterize pathway conditions negotiated by two migrating pallid sturgeon (fig. 4-21). Within this reach, available depths varied from about $1.0 \mathrm{~m}$ to $5.0 \mathrm{~m}$ and water velocities from $0.5 \mathrm{~m} / \mathrm{s}$ to $2.5 \mathrm{~m} / \mathrm{s}$. Pallid sturgeon code 51 and code 72 negotiated the reach using two different pathways. Code 51 entered the reach along the south bank of the main channel, maintained upstream migration along the south bank, and then crossed the channel to the north bank about mid-way through the reach. The migration trajectory for code 72 was initiated and maintained along the north bank of the river, followed by a cross-over to the south bank mid-way through the reach. Water depths used along both pathways differed slightly, but water velocities used were similar ranging from about $1.0 \mathrm{~m} / \mathrm{s}$ to $1.7 \mathrm{~m} / \mathrm{s}$ (fig. 4-21).

\section{Spawning}

Pallid sturgeon female code 30 was reproductivelyready in 2012 based on the reproductive assessment in April. Following a rapid upstream migration during June 6-9 and rapid downstream migration during June 9-10, code 30 was targeted for reproductive assessment to determine if code 30 had spawned in the upstream reaches of the Yellowstone River (fig. 4-22). On June 12, code 30 was captured at RM 11.7 and ultrasound confirmed with gonadal biopsy indicated that code 30 had not spawned upstream as her body cavity remained filled with eggs. For the next several days, code 30 exhibited upstream (to at least RM 16.5) and downstream (near the Yellowstone River confluence) movements past aggregations of males. On June 19, code 30 was targeted for reproductive assessment within an aggregation of males at RM 6.7-7.1 (fig. 4-22). Code 30 and a male pallid sturgeon were captured in the same net with both individuals freely expressing sex products. Code 30 was weighed $(16.0 \mathrm{~kg})$, blood for hormone analysis was obtained, and it was quickly released. The presence of code 30 in the male aggregation, in conjunction with the observation that sex products were being released, provided evidence that code 30 had spawned in the capture area. Identical weights of code 30 on June 12 and June 19 suggested that spawning was in the early stages as progressed spawning would be expected to decrease egg volume and reduce overall body weight. Numerous males were present in the spawning aggregation as evidenced by the detection of codes $11,46,49,50,51,52,68,77,70$, and 82. On June 20, code 30 and the male aggregation (detected codes $11,46,48,50,51,52,59,68,73,77,82)$ remained at the spawning location as of $12: 15$ p.m. Spawning activities were believed to be complete by mid- to late afternoon on June 20. Code 30 was slightly upstream from the spawn location and male aggregation at about 5:00 p.m. No other tagged sturgeon were present. At 9:30 a.m. on June 21, code 30 was about $1 \mathrm{mi}$ upstream from the spawning location where she remained for several days prior to exiting the Yellowstone River. In addition, several of the males had exited the spawn area on June 21 and were found in the lower reaches of the Yellowstone River. Hormone analysis from the June 19 collection indicated $\mathrm{T}=15.45 \mathrm{ng} / \mathrm{mL}$ and $\mathrm{E} 2=$ nondetectable. River discharge averaged 21,250 ft $3 / \mathrm{s}$ on June 19 and 20. From noon on June 19 to 5:00 p.m. on June 20, water temperature, based on hourly measurements from a data logger at river mile $(\mathrm{RM}) 2.5$, averaged $20.3{ }^{\circ} \mathrm{C}$ (minimum $=19.8{ }^{\circ} \mathrm{C}$, maximum $=21.0{ }^{\circ} \mathrm{C}$ ).

A general description of the hydraulic conditions in the code 30 spawning reach is as follows. The spawning area was along the eastern edge of the channel in a swift-flowing trough (fig. 4-23). Point measurements in several areas of the spawning reach on June 20 indicated depths of 3.0-4.6 m, and a combination of substrates including sand, gravel, cobble, and large rock. River-ward from this trough and outside of the spawning area, sand was the primary substrate. A more detailed assessment and quantification of the spawning area may be completed in 2013 .

Pallid sturgeon female code 35 was a second spawn candidate for 2012 following the initial reproductive assessment in April. Code 35 remained primarily in the lower parts of the Yellowstone River during early May, then exhibited repeated upstream (extending to RM 27.2) and downstream migrations during late May (fig. 4-22). At the initiation of another upstream migration in early June, code 35 was captured on June 4 for reproductive assessment. She remained full of eggs as determined from gonadal examination and weighed $28 \mathrm{~kg}$. 

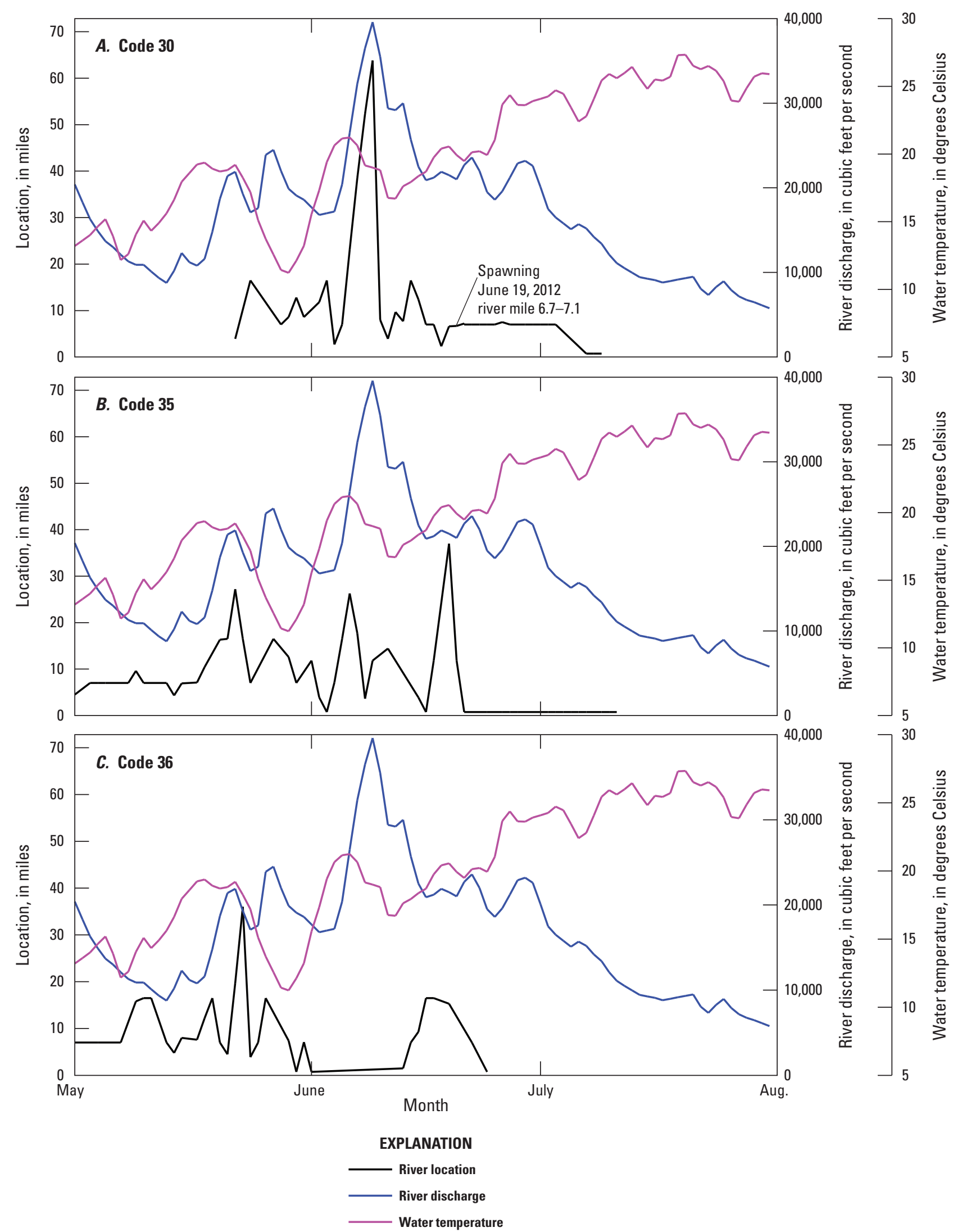

Figure 4-22. Discharge, water temperature, and locations of gravid female pallid sturgeon in the Yellowstone River, MayAugust 2012. $A$, code 30; $B$, code 35; and $C$, code 36 . 


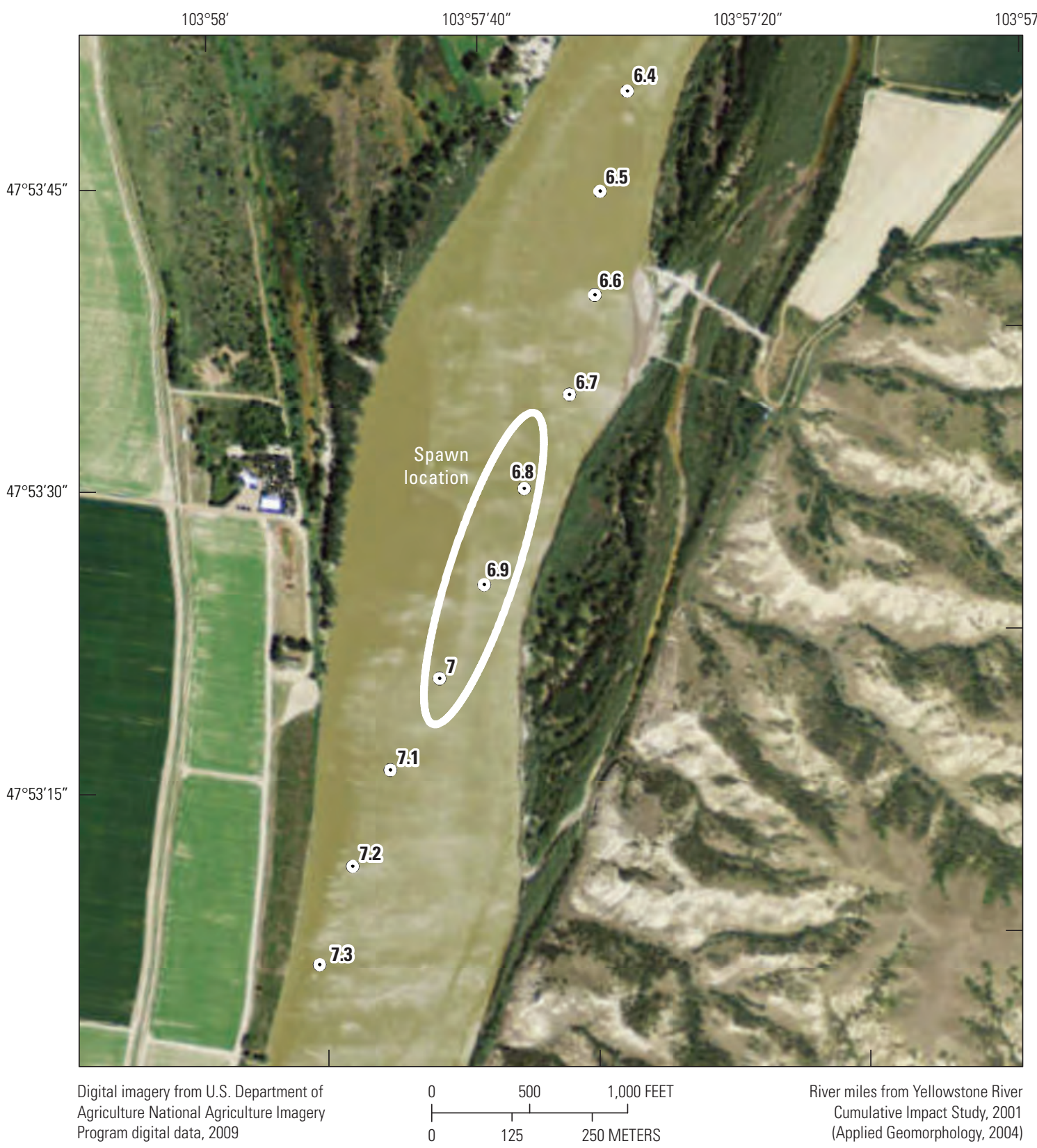

$7.3 \odot$ Yellowstone River mile marker-Number is distance upstream from the confluence with the Missouri River, in miles

Figure 4-23. Spawn location of female pallid sturgeon code 30 in the lower Yellowstone River, June 19-20, 2012. 
Although her weight on June 4 was slightly less than recorded on April 23 (30 kg), code 35 had obviously not spawned. Hormone analysis from June 4 indicated an elevated concentration of $\mathrm{T}=82.07 \mathrm{ng} / \mathrm{mL}$, but E2 had declined to a non-detectable concentration. Code 35 maintained the repeated upstream and downstream movement patterns through mid-June, and was detected at her maximum upstream location on June 19 (RM 37.0). Code 35 was detected at about 5:00 p.m. on June 20 moving downstream towards the male aggregation at the code 30 spawn site; however, code 35 maintained the downstream migration past the male aggregation. Her downstream migration was maintained as code 35 was detected moving past the lower Yellowstone River logging station around 4:00 a.m. on June 21. After exiting the Yellowstone River, code 35 was not detected in the Yellowstone River again until June 24, but contacts were restricted to the lower part of the river. It was undetermined if code 35 spawned.

Pallid sturgeon female code 36 was the third spawn candidate for 2012 based on reproductive assessment in April. After exhibiting moderate upstream and downstream migrations through mid-May, code 36 was recaptured on May 15 for reproductive assessment. She remained full of eggs and maintained a weight $(18.0 \mathrm{~kg})$ similar to the April 26 assessment $(17.5 \mathrm{~kg})$. Code 36 exhibited three additional upstream and downstream movements through late May (maximum extent to RM 37.2 on May 23), then exited the Yellowstone River after June 1 (fig. 4-22). Code 36 was not found in the Yellowstone River after June 1, but was located on June 12 in the Missouri River slightly downstream from the Yellowstone River confluence. Upon recapture, ultrasound examination determined that she had spawned. Code 36 weighed $16 \mathrm{~kg}$, representing an 11.1 percent loss of body weight because of spawning. The location and timing of the code 36 spawning event were undetermined.

\section{Collections of Free Embryos and Larvae}

Intensive sampling for pallid sturgeon free embryos and larvae was initiated on June 18 (prior to the code 30 spawning event) and continued through June 26 in attempt to verify hatch and drift-entry of progeny from the code 30 spawning event. Sampling for the collection of progeny from code 30 was based upon cumulative thermal units required for hatch. Calculations of dispersal assumed that free embryos entered the water column immediately upon hatch. Sampling was concentrated primarily below the code 30 spawning location, but sampling was also done at locations downstream to RM 2.5. A total of 184 samples was collected, partitioned among June 18 (8 samples), June 19 (14 samples), June 20 (14 samples), June 21 (12 samples), June 23 (28 samples), June 24 (28 samples), June 25 (56 samples) and June 26 (24 samples).

The sampling regime yielded 335 Acipenseriformes free embryos and larvae and 80 Acipenserifomes eggs and developing embryos. Genetic analysis differentiated all free embryos and larvae as paddlefish, shovelnose sturgeon, or pallid sturgeon (Heist and Eichelberger, 2013). Paddlefish composed
79.4 percent $(N=266)$ and shovelnose sturgeon 20.3 percent $(N=68)$ of the free embryos and larvae sampled across dates. One naturally-spawned pallid sturgeon free embryo ( 0.3 percent of all individuals sampled) was genetically identified from a sample collected on June 25 immediately downstream from the code 30 female spawn site. Results from genetic parentage analysis indicated that the pallid sturgeon free embryo was not progeny from female code 30 or any of the males detected in the spawning aggregation. Rather, the pallid sturgeon free embryo was progeny from a known female (PIT 115557463A) spawned in the hatchery in 2008 and a known male (PIT 4440A7B73) spawned in the hatchery in 2007 and 2009. Neither fish carried a transmitter, and as such, the location and timing of the spawn event that produced the wild free embryo were not known.

\section{Summary}

Migrations of pallid sturgeon into the Yellowstone River during 2012 were initiated by early April, increased through late May to a maximum of 90 percent of the telemetered population, and residency was maintained through mid- to late June. Thereafter, adult pallid sturgeon use of the Yellowstone River declined as fish returned downstream to the Upper Missouri River. The river entry and use patterns observed in 2012 were similar to most other years of study (Fuller and Braaten, 2013; Braaten and others, 2015), with the exception of 2011. In 2011, migrations into the Yellowstone River were initiated by early April but the maximum proportion of pallid sturgeon using the Yellowstone River (about 60 percent) was lower than other years (for example, more than 80 percent) as numerous pallid sturgeon migrated into and used the Missouri River below Fort Peck Dam.

Substantial variation in movements and migrations of telemetered pallid sturgeon was noted during 2012 as several individuals exhibited long-distance migrations, whereas others exhibited more restricted movements. Long-distance migrations within the Yellowstone River were depicted by male codes 42, 52, 69, 72 and 76 who exhibited migrations to Intake Dam. For most of these individuals, the persistent upstream migrations to Intake Dam generally coincided with periods of elevated discharge conditions. Pallid sturgeon arrived at Intake Dam from May 2-June 22. Seasonal maximum discharge happened on June 9. Under high discharge conditions during 2011, eight telemetered pallid sturgeon were noted at Intake Dam with arrival dates as early as May 6 and residency at the dam persisting through June 16 (Braaten and others, 2015). Although no female pallid sturgeon were detected at Intake Dam in 2012, one gravid female was detected below Intake in 2007 (Fuller and others, 2008; Braaten and others, 2015). Code 72 was a repeat migrant to Intake as this individual also migrated to Intake Dam in 2011 (telemetry code 19 in 2011, arriving on June 9 versus June 13 in 2012) at a discharge of 57,200 cubic feet per second (compared to 30,000 cubic feet per second in 2012). 
Based on the finding that pallid sturgeon arrived at Intake Dam over a broad time interval and under a range of discharge conditions, the selected fish passage alternative for the reach affected by Intake Dam should similarly facilitate pallid sturgeon passage through a broad range of discharge conditions to accommodate early, mid-, and late pre-spawn migrants arriving at the Intake reach. Migration distances for all females exceeded 160 miles with the greatest female migration distance exhibited by code 30 ( 289 miles) who used both the Missouri River and Yellowstone River. None of the females monitored in 2012 migrated all the way to Intake Dam. Most males (69 percent) exhibited migration distances that exceeded 100 miles. Based on intensive telemetry relocation efforts in 2007 and 2008, Fuller and Braaten (2013) report that total migration distance of pallid sturgeon within the Yellowstone River averaged 90 miles for males (range 14-267 miles) and 171 miles for females (range 102-242 miles).

As a fish passage alternative in the reach affected by Intake Dam, the proposed by-pass channel would be constructed on the south bank of the river with the downstream entrance of the by-pass channel joining the main stem river just downstream from the existing rock dam. One uncertainty associated with this alternative centers on pallid sturgeon approach pathways to the dam, and whether the south-bank entrance of the by-pass channel will be detected by migrating pallid sturgeon. Detailed assessments of approach pathways to Intake Dam in 2012 identified that male pallid sturgeon codes 52 and 72 approached the dam closely along the outside-bend, south bank location or within the southern one-half of the river channel. These results contrast with findings from 2011 as approach pathways and relocations of pallid sturgeon were oriented towards the middle and northern part of the river channel along the inside bend (Braaten and others, 2015). Based on a limited number of observations, differences in approach pathways to Intake Dam between years may be related to differences in discharge between years and the subsequent influence of discharge on depths and the velocity field throughout the river channel. For example, during the high-discharge year of 2011, pallid sturgeon migrated primarily along the inside bends of the main channel where velocities were lower relative to riverward areas of the main channel. The north bank inside bend location downstream from Intake Dam in 2011 may have provided more suitable velocities for upstream migration than the mid- or outside bend channel locations as code 72 approached Intake Dam at 56,300 cubic feet per second (compared to 23,600-39,600 cubic feet per second in 2012). Collectively, results from 2011 and 2012 suggest that pallid sturgeon approach pathways to Intake Dam can vary depending on flow conditions. In addition, residency at Intake Dam during 2012 was brief as manual relocations complemented with detections from the Intake logging station indicated that pallid sturgeon remained directly downstream from the dam for only $1-2$ days. Within the short time frames of assessing codes 52 and 72 , there was little evidence of extensive lateral search behavior exhibited by the pallid sturgeon. Pallid sturgeon during elevated discharge conditions of 2011 exhibited substantial variability in residence time below Intake Dam as some individuals were present for one day whereas other individuals remained for several days (Braaten and others, 2015).

Assessments of migration pathways identified pallid sturgeon swimming routes and associated habitat elements used by migrating individuals within the heterogeneous channel of the Yellowstone River. Under the moderate flow conditions of 2012, pallid sturgeon migrated primarily in the main channel along the inside bends; however, pallid sturgeon also migrated through outside bend and mid-channel habitats. These results contrast the small dataset obtained in 2011 as pallid sturgeon migrated almost exclusively along the inside bend under elevated discharge conditions of 2011. As noted earlier, migration pathways may differ under different discharge because of the effects of discharge on velocity and depth throughout the river channel.

Prior to 2011 and 2012, little information was available on pallid sturgeon use of and migrations through side channels as related to the potential by-pass channel alternative for the reach affected by Intake Dam. The limited migration-pathway dataset from 2011 identified that pallid sturgeon did use side channels (Braaten and others, 2015) as successful upstream passage was documented through short side channels (for example, $0.25-1.25$ miles long) located on the inside bends of the main channel. Pallid sturgeon also were located in longer side channels during 2011, but upstream passage was not documented as individuals were either sedentary or moving downstream through the channel. In 2012, pallid sturgeon migrated primarily in the main channel as multiple side channels (for example, 0.5-2.0 miles long) within the migration corridor were infrequently used during upstream migration; however, some use and successful passage through side channels $0.25-1.6$ miles long were documented for a few individuals. In addition, use and upstream progression was happening in a long side channel ( 1.7 miles long) by female code 30 prior to this individual turning around and moving downstream. Based on these results, we can conclude that pallid sturgeon will use side channels during upstream migrations; however, use may be infrequent. In addition, results from 2011 and 2012 depict inconsistencies in side channel use among individuals. For example, in early June 2011, two pallid sturgeon were tracked under similar discharge conditions through an inside bend complex that contained a side channel. One pallid sturgeon entered and successfully negotiated the side channel as part of the migration pathway. The other individual maintained a migration pathway exclusively in the main channel. Differences in side channel use between individuals under similar discharge conditions were observed in 2012 as presented for codes 36 and 37, and codes 36 and 69. Additional variation in migration pathways was noted for codes 51 and 72 in the main channel of the Yellowstone River.

In most cases, upstream migrations in the main channel and split channel configurations were nearly continuous. Observation of radio-tracked sturgeon in the Yellowstone River using DIDSON $^{\circledR}$ show that pallid sturgeon typically swim close to the bottom. Pallid sturgeon are highly adapted to swift currents in 
sand-bottomed rivers, and are likely efficient at exploiting flow fields and bedforms to reduce energy expenditure during migration. The velocity conditions that pallid sturgeon experience near the bottom during migration are not known. Based upon variables that can be readily measured, pallid sturgeon used migration pathways that resulted in an average ground speed of about 0.25 meter per second against an average mean-column velocity of 1.16 meters per second. Braaten and others (2015) similarly found that migrating pallid sturgeon exhibited ground speeds of about $0.20-0.25$ meters per second. Better estimates of the conditions near the bottom where pallid sturgeon forage, migrate, and spawn are needed to evaluate habitat use, availability selection, and suitability for adults.

Spawning in the Yellowstone River was documented for two females (code 30 and a non-telemetered parent of the free embryo) and spawning by a third female (code 36) in either the Yellowstone River or Missouri River was confirmed in 2012. Although the exact date(s) of spawning events was not determined for all females, results suggest slight variation in the timing of spawning events for pallid sturgeon as female code 36 spawned prior to June 12 and code 30 spawned on June 19-20. The spawning event that produced the pallid sturgeon free embryo collected in 2012 likely happened on a date similar to the code 30 spawning event given the early developmental stage of the free embryo. Under a discharge regime similar to 2012, Fuller and others (2008) suggested that spawning in 2007 likely happened between June 13-16 as a spawn-candidate female and multiple males formed an aggregation during these dates. Under elevated discharges in the Yellowstone River during 2011, spawning had not happened prior to June 21 through the last date a telemetered spawn-candidate female was found in the Yellowstone River (Braaten and others, 2015). The collection of code 30 on June 19 isolated not only the specific date of the spawning event in 2012, but also identified the specific location of a spawning event in the Yellowstone River (river mile 6.7-7.1). Fuller and others (2008) suggested that this reach of the Yellowstone River was a spawning site in 2007 as the spawn-candidate female and multiple males formed an aggregation near river mile 7.5 of the Yellowstone River. Close proximity of the 2007 aggregation site and 2012 known spawning site suggests that this reach may be a repeat spawn location under discharge conditions characteristic of 2007 and 2012. Although this has been confirmed in the lower reaches of the Yellowstone River, spawning also may happen in the middle reaches of the Yellowstone River (Fuller and others, 2008).

Collection of the wild-produced pallid sturgeon free embryo in 2012 indicates that the reproductive process from fertilization to drift-entry of free embryos was successful under the hydrological and thermal regimes characteristic of the Yellowstone River in 2012. Only one other study in the Missouri River has verified survival and hatch of pallid sturgeon embryos; a genetically confirmed wild-produced pallid sturgeon free embryo was also sampled in the Missouri River below Fort Peck Dam during 2011 (DeLonay and others, 2014).

\section{References Cited}

Braaten, P.J., Fuller, D.B., Holte, L.D., Lott, R.D., Viste, William, Brandt, T.F., and Legare, R.G., 2008, Drift dynamics of larval pallid sturgeon and shovelnose sturgeon in a natural side channel of the upper Missouri River, Montana: North American Journal of Fisheries Management, v. 28, no. 3, p. 808-826. [Also available at http://dx.doi. org/10.1577/M06-285.1.]

Braaten, P.J., Fuller, D.B., Lott, R.D., Ruggles, M.P., and Holm, R.J., 2010, Spatial distribution of drifting pallid sturgeon larvae in the Missouri River inferred from two net designs and multiple sampling locations: North American Journal of Fisheries Management, v. 30, no. 4, p. 1062-1074. [Also available at http://dx.doi.org/10.1577/ M09-149.1.]

Braaten, P.J., Fuller, D.B., Lott, R.D., Ruggles, M.P., Brandt, T.F., Legare, R.G, and Holm, R.J., 2012, An experimental test and models of drift and dispersal processes of pallid sturgeon (Scaphirhynchus albus) free embryos in the Missouri River: Environmental Biology of Fishes, v. 93, no. 3, p. 377-392. [Also available at http://dx.doi.org/10.1007/ s10641-011-9925-9.]

Braaten, P.J., Elliott, C.M., Rhoten, J.C., Fuller, D.B., and McElroy, B.J., 2015, Migrations and swimming capabilities of endangered pallid sturgeon (Scaphirhynchus albus) to guide passage designs in the fragmented Yellowstone River: Restoration Ecology, v. 23, no. 2, p. 186-195. [Also available at http://dx.doi.org/10.1111/rec.12161].

DeLonay, A.J., Jacobson, R.B., Annis, M.L., Braaten, P.J., Chojnacki, K.A., Elliott, C.M., Fuller, D.B., Haas, J.D., Haddix, T.M., McElroy, B.J., Mestl, G.E., Papoulias, D.M., Rhoten, J.C., and Wildhaber, M.L., 2014, Ecological requirements for pallid sturgeon reproduction and recruitment in the Missouri River-Annual report 2011: U.S. Geological Survey Open-File Report 2014-1106, 96 p. [Also available at http://dx.doi.org/10.3133/ofr20141106.]

Fuller, D.B., and Braaten, P.J., 2013, Fort Peck flow modification biological data collection plan compendium-Summary of 2001-2009 activities: Report submitted to the U.S. Army Corps of Engineers, Montana Fish, Wildlife and Parks, 122 p.

Fuller, D.B., Jaeger, M.E., and Webb, Molly, 2008, Spawning and associated movement patterns of pallid sturgeon in the lower Yellowstone River: Western Area Power Administration, Upper Basin Pallid Sturgeon Work Group, U.S. Army Corps of Engineers, Montana Fish, Wildlife and Parks, 22 p.

Heist, E.J., and Eichelberger, J., 2013, 2012 genetic analysis of Missouri River sturgeon larvae: Center for Fisheries, Aquaculture, and Aquatic Sciences, Southern Illinois University Carbondale, $27 \mathrm{p}$. 
Kynard, B., Parker, E., Pugh, D., and Parker, T., 2007, Use of laboratory studies to develop a dispersal model for Missouri River pallid sturgeon early life intervals: Journal of Applied Ichthyology, v. 23, no. 4, p. 365-374. [Also available at http://dx.doi.org/10.1111/j.1439-0426.2007.00908.x.]

U.S. Fish and Wildlife Service, 2007, Pallid sturgeon (Scaphirhynchus albus) 5-year review-Summary and evaluation: Billings, Mont., U.S. Fish and Wildlife Service, 120 p.

U.S. Army Corps of Engineers, 2012, Intake diversion dam modification, lower Yellowstone Project, Montana, Bypass channel 30\% design documentation report: U.S. Army Corps of Engineers.

U.S. Bureau of Reclamation, and U.S. Army Corp of Engineers, 2014, Intake diversion dam modification lower Yellowstone Project, Montana: Draft supplement to the 2010 final environmental assessment: U.S. Bureau of Reclamation, Billings, Mont., and U.S. Army Corps of Engineers, Omaha, Nebr., 144 p.

U.S. Fish and Wildlife Service, 1993, Recovery plan for the pallid sturgeon (Scaphirhynchus albus): Denver, Colo., U.S. Fish and Wildlife Service, Region 6, 55 p.

U.S. Fish and Wildlife Service, 2000, Biological opinion on the operation of the Missouri River main stem reservoir system, operation and maintenance of the Missouri River bank stabilization and navigation project, and operation of the Kansas River reservoir system: U.S. Fish and Wildlife Service, $308 \mathrm{p}$.

U.S. Fish and Wildlife Service, 2003, Amendment to the 2000 biological opinion on the operation of the Missouri River main stem reservoir system, operation and maintenance of the Missouri River bank stabilization and navigation project, and operation of the Kansas River reservoir system: U.S. Fish and Wildlife Service, 308 p. [Also available at http://www.nwd-mr.usace.army.mil/mmanual/FinalBO2003. pdf.] 


\section{Appendix 5. Adult Pallid Sturgeon Blood Chemistry}

\section{Background}

Blood diagnostic tests on fish are increasingly being used to assess general metabolic and reproductive health (Folmar, 1993; Shahsavani and others, 2010; Di Marco and others, 2011); accordingly, when the normal condition is known, such blood biomarkers may be used to identify those fish adversely affected by chemical and nonchemical stressors; however, many factors influence blood chemistry including sex, reproductive stage, nutrition, and temperature.

\section{Scope and Objectives}

The objective of this study was twofold: (1) to build datasets that can be useful in explaining the biochemical and physiological condition of adult pallid sturgeon (Scaphirhynchus albus), and (2) to explore sensitivity of pallid sturgeon blood chemistry to environmental conditions.

\section{Methods}

We sampled a blood plasma from a total of 194 pallid sturgeon of known sex and reproductive stage between 2005 and 2012. The sturgeon sampled included wild-captured adults from the Lower Missouri River, which may have been released immediately after capture, or transported and held for an indeterminate time at hatcheries as potential propagation broodstock. Adult pallid sturgeon from captive, hatchery populations were also sampled. Plasma was subjected to a series of diagnostic tests for metabolic condition. Results were examined for differences by sex, reproductive status, time elapsed since capture, and time in captivity. Male reproductive status was categorized as reproductive or nonreproductive. Female reproductive status was categorized as reproductive, nonreproductive, or post-spawn.

For all samples, blood (5-10 milliliters [mL]) was collected from the caudal vein, transferred into heparinized vials, and held on wet ice until centrifuged. Blood was centrifuged at 3,500 rotations per minute (rpm) for 10 minutes, and then plasma was removed by transfer pipette to two or three cryovials. Plasma was kept frozen until use at -80 degrees Celsius $\left({ }^{\circ} \mathrm{C}\right)$. Total cholesterol, creatinine, glucose, lactate, lipase, total triglycerides, and total protein were measured. Lactate was measured only in blood samples centrifuged within 15 minutes of collection. Measurements were made on blood plasma with a Vitros DTII (Johnson \& Johnson, Rochester, New York).

Data were first examined to compare the differences between sturgeon captured from the wild and held captive for less than $(<) 1$ month (wild) and sturgeon held in a hatchery environment for greater than $(>) 1$ month (prolonged) (table $5-1$ ). Relations between groups were studied to determine the effects of capture, transport, and acclimation to hatchery conditions on pallid sturgeon. Data were then examined a second time to consider the length of time the sturgeon spent in captivity to evaluate changes in blood chemistry for male and female, nonreproductive and reproductive pallid sturgeon (table 5-2). In this analysis four categories were used to describe the length of captivity: (1) sturgeon that were held 0-7 days (recent), (2) sturgeon there were held 8-30 days (brief), (3) sturgeon that were held $>30$ days (prolonged), and (4) sturgeon that were held all their lives (life-captive). Analysis of variance using least-squares means for pairwise comparisons $(p<0.05)$ was used to test for differences.

\section{Results}

Cholesterol is essential for cell health and development as well as for production of steroids. Cholesterol was higher in reproductively ready fish than in nonreproductive fish. Reproductive males had more cholesterol than reproductive females, and captive females had slightly higher cholesterol than wild females (fig. 5-1). Overall, cholesterol concentrations tended to be slightly higher in pallid sturgeon compared to values reported for shovelnose sturgeon (Scaphirhynchus platorynchus) (Hunn and Christenson, 1977). Sturgeon in reproductive condition with late-stage, vitellogenic oocytes (stages IV and V) are reported to have higher cholesterol than those in nonreproductive condition or post-spawn (Barannikova and others, 2008).

Creatinine is a product of the metabolism of amino acids primarily in white muscles. Although abnormal concentrations have been linked to adverse effects on the kidney in mammals, not much is known about this relation in fish (Thrall and others, 2012). Concentrations of creatinine in the blood were generally higher in males than females. Captive sturgeon showed higher concentrations of creatinine compared to their wild counterparts (table 5-1). Nonreproductive fish of either sex, wild or captive, had higher creatinine concentrations than reproductive fish. The normal range for creatinine in teleosts is from 0.5 to 2.0 milligrams per deciliter (mg/dL) (Thrall and others, 2012), similar to what has been reported for several sturgeon species (Asadi and others, 2006; Shi and others, 2006). Except for one prolonged-captive male pallid with a creatinine concentration of $5.8 \mathrm{mg} / \mathrm{dL}$, all pallid sturgeon sampled were within the range of less than or equal to $(\leq) 0.03-1.0)$.

Elevated glucose in the blood can be an indicator of stress, whereas low glucose can indicate starvation or liver damage. Glucose also may be normally mobilized during periods of strenuous activity such as migration. Male glucose concentrations were slightly higher than female concentrations. Reproductive males and nonreproductive females had higher glucose concentrations than reproductive females (table 5-1, fig. 5-2). Pallid sturgeon glucose concentrations were lower than those measured in shovelnose sturgeon, but were within the range seen in other sturgeon species (Sepúlveda and others, 2012). The same sex-specific differences were observed in shovelnose sturgeon (Sepúlveda and others, 2012). 
Table 5-1. Plasma chemistry for pallid sturgeon according to sex, reproductive state, and whether they were captured from the wild and held in captivity for less than 1 month or held captive in the hatchery environment (more than 1 month).

[Values are reported as means \pm standard deviation with range in parenthesis. \pm , plus or minus; $\leq$, less than or equal to; $\geq$, greater than or equal to; mg/dL, milligrams per deciliter; U/L, units per liter; $\mathrm{mmol} / \mathrm{L}$, millimole per liter; $\mathrm{g} / \mathrm{dL}$, gram per decilite]

\begin{tabular}{|c|c|c|c|c|c|c|c|c|c|c|}
\hline Sex & $\begin{array}{c}\text { Reproductive } \\
\text { status }\end{array}$ & Captivity & Number & $\begin{array}{c}\text { Cholesterol } \\
\text { (mg/dL) }\end{array}$ & $\begin{array}{c}\text { Creatinine } \\
\text { (mg/dL) }\end{array}$ & $\begin{array}{l}\text { Glucose } \\
\text { (mg/dL) }\end{array}$ & $\begin{array}{c}\text { Lipase } \\
\text { (U/L) }\end{array}$ & $\begin{array}{l}\text { Lactate } \\
\text { (mmol/L) }\end{array}$ & $\begin{array}{c}\text { Total protein } \\
\text { (g/dL) }\end{array}$ & $\begin{array}{c}\text { Triglycerides } \\
\text { (mg/dL) }\end{array}$ \\
\hline \multirow[t]{12}{*}{ Female } & Nonreproductive & Prolonged & 18 & $161 \pm 96$ & $0.30 \pm 0.40$ & $53 \pm 18$ & $12 \pm 10$ & ${ }^{1} 1.7 \pm 1.6$ & $4.0 \pm 1.4$ & $462 \pm 219$ \\
\hline & & & & $(25-336)$ & $(\leq 0.03-1.0)$ & $(31-103)$ & $(\leq 5-37)$ & $(0.3-5.2)$ & $(1.0-6.9)$ & $(116-\geq 800)^{2}$ \\
\hline & & Wild & 26 & $107 \pm 64$ & $0.17 \pm 0.25$ & $54 \pm 28$ & $5 \pm 2$ & $4.4 \pm 3.3$ & $2.6 \pm 1.2$ & $252 \pm 143$ \\
\hline & & & & $(25-325)$ & $(\leq 0.03-1.00)$ & $(27-139)$ & $(\leq 5-11)$ & $(0-12.0)$ & $(1.0-5.4)$ & $(118-\geq 800)$ \\
\hline & Reproductive & Prolonged & 14 & $166 \pm 83$ & $0.10 \pm 0.13$ & $40 \pm 8$ & $\leq 5 \pm 0$ & $0.5 \pm 0.8$ & $2.9 \pm 1.0$ & $360 \pm 235$ \\
\hline & & & & $(55-322)$ & $(\leq 0.03-0.40)$ & $(27-51)$ & $(\leq 5)$ & $(0-2.3)$ & $(1.0-4.9)$ & $(106-\geq 800)$ \\
\hline & & Wild & 12 & $120 \pm 71$ & $0.09 \pm 0.15$ & $45 \pm 13$ & $8 \pm 10$ & $2.9 \pm 2.0$ & $2.9 \pm 0.5$ & $409 \pm 238$ \\
\hline & & & & $(25-274)$ & $(\leq 0.03-0.50)$ & $(32-77)$ & $(\leq 5-38)$ & $(0-5.5)$ & $(2.2-3.8)$ & $(140-\geq 800)$ \\
\hline & Post-spawn & Prolonged & 5 & $67 \pm 24$ & $0.17 \pm 0.08$ & $38 \pm 7$ & $8 \pm 4$ & $1.5 \pm 0.5$ & $4.2 \pm 0.4$ & $204 \pm 48$ \\
\hline & & & & $(55-110)$ & $(\leq 0.03-0.20)$ & $(32-47)$ & $(\leq 5-13)$ & $(1.1-2.3)$ & $(3.8-4.6)$ & $(166-287)$ \\
\hline & & Wild & 9 & $154 \pm 75$ & $\leq 0.03 \pm 0$ & $64 \pm 22$ & $9 \pm 11$ & $6.6 \pm 1.9$ & $2.7 \pm 1.2$ & $421 \pm 223$ \\
\hline & & & & $(55-325)$ & $(\leq 0.03)$ & $(28-97)$ & $(\leq 5-38)$ & $(2.5-9.2)$ & $(1.0-4.8)$ & $(184-\geq 800)$ \\
\hline \multirow[t]{8}{*}{ Male } & Nonreproductive & Prolonged & 37 & $132 \pm 46$ & $0.43 \pm 0.30$ & $56 \pm 13$ & $13 \pm 8$ & $0.6 \pm 0.9$ & $4.3 \pm 1.3$ & $509 \pm 213$ \\
\hline & & & & $(59-284)$ & $(\leq 0.03-1.00)$ & $(31-78)$ & $(\leq 5-33)$ & $(0-1.6)$ & $(2.4-9.0)$ & $(132-960)$ \\
\hline & & Wild & 28 & $122 \pm 48$ & $0.12 \pm 0.22$ & $63 \pm 25$ & $6 \pm 3$ & $5.5 \pm 4.2$ & $2.6 \pm 1.2$ & $315 \pm 193$ \\
\hline & & & & $(55-285)$ & $(\leq 0.03-0.80)$ & $(36-128)$ & $(\leq 5-18)$ & $(0-12)$ & $(1.0-5.3)$ & $(94-\geq 800)$ \\
\hline & Reproductive & Prolonged & 5 & $198 \pm 66$ & $1.40 \pm 2.47$ & $75 \pm 34$ & $\leq 5 \pm 0$ & $2.0 \pm 1.7$ & $3.7 \pm 0.6$ & $540 \pm 329$ \\
\hline & & & & $(143-303)$ & $(\leq 0.03-5.80)$ & $(36-122)$ & $(\leq 5)$ & $(0.8-5)$ & $(2.7-4.2)$ & $(242-1,086)$ \\
\hline & & Wild & 11 & $256 \pm 88$ & $0.04 \pm 0.05$ & $62 \pm 29$ & $6 \pm 4$ & $3.2 \pm 3.9$ & $2.9 \pm 1.0$ & $344 \pm 175$ \\
\hline & & & & $(71-336)$ & $(\leq 0.03-0.20)$ & $(40-125)$ & $(\leq 5-18)$ & $(0.7-11.1)$ & $(1.0-4.9)$ & $(70-678)$ \\
\hline
\end{tabular}

${ }^{1}$ Only seven samples for lactate.

${ }^{2}$ The upper limit of quantitation for triglygerides was $800 \mathrm{mg} / \mathrm{dL}$. 
[Sturgeon were grouped according to sex, reproductive stage, and time in captivity. Blood was collected from recently captured fish (=Recent) within 0-7 days after capture and may have occurred while they were held temporarily in a hatchery awaiting spawning. Blood was collected from fish held for a short period (=Briefly) or long period (=Prolonged) between $8-30$ days and longer than 1 month, respectively. Blood collected from fish maintained in captivity all or most of their life (=Life-captive). Results are means \pm standard deviation. Minimum and maximum values are in parenthesis. Superscripts within each sex and reproductive status combination for a biomarker indicate significant differences at $p<0.05 ;--$, no data; \pm , plus or minus; mg/dL, milligrams per deciliter; $\mathrm{U} / \mathrm{L}$, units per liter; mmol/ L, millimole per liter; g/dL, gram per decilite]

\begin{tabular}{|c|c|c|c|c|c|c|c|c|c|c|}
\hline Sex & $\begin{array}{c}\text { Reproductive } \\
\text { status }\end{array}$ & Captivity & Number & $\begin{array}{c}\text { Cholesterol } \\
\text { (mg/dL) }\end{array}$ & $\begin{array}{c}\text { Creatinine } \\
\text { (mg/dL) }\end{array}$ & $\begin{array}{l}\text { Glucose } \\
\text { (mg/dL) }\end{array}$ & $\begin{array}{l}\text { Lipase } \\
\text { (U/L) }\end{array}$ & $\begin{array}{l}\text { Lactate } \\
\text { (mmol/L) }\end{array}$ & $\begin{array}{l}\text { Total protein } \\
\text { (g/dL) }\end{array}$ & $\begin{array}{l}\text { Triglycerides } \\
\text { (mg/dL) }\end{array}$ \\
\hline \multirow[t]{20}{*}{ Female } & Nonreproductive & Recent & 24 & $106 \pm 65$ & $0.18 \pm 0.26^{\mathrm{a}}$ & $56 \pm 29$ & $5 \pm 2^{\mathrm{a}}$ & $4.7 \pm 3.2^{\mathrm{a}}$ & $2.6 \pm 1.2^{\mathrm{a}}$ & $247 \pm 147^{a}$ \\
\hline & & & & $(25-325)$ & $(0.03-1.00)$ & $(27-139)$ & $(5-11)$ & $(0.0-12.0)$ & $(1.0-5.4)$ & $(118-\geq 800)$ \\
\hline & & Briefly & 2 & $122 \pm 58$ & $\leq 0.03 \pm 0.00^{\mathrm{a}}$ & $43 \pm 3$ & $5 \pm 0^{\mathrm{a}}$ & $0.7 \pm 0.1^{\mathrm{b}}$ & $1.7 \pm 1.0^{\mathrm{a}}$ & $315 \pm 71$ \\
\hline & & & & $(81-163)$ & $(\leq 0.03)$ & $(41-45)$ & -5 & $(0.60 .8)$ & $(1.0-2.4)$ & $(264-365)$ \\
\hline & & Prolonged & 7 & $222 \pm 130$ & $\leq 0.03 \pm 0.00^{\mathrm{a}}$ & $48 \pm 25$ & $5 \pm 0^{\mathrm{a}}$ & $1.7 \pm 1.6^{\mathrm{b}}$ & $3.1 \pm 1.3^{\mathrm{a}}$ & $408 \pm 276$ \\
\hline & & & & $(25-336)$ & $(\leq 0.03)$ & $(31-103)$ & -5 & $(0.0-5.2)$ & $(1.0-4.7)$ & $(116-\geq 800)$ \\
\hline & & Life-captive & 11 & $122 \pm 36$ & $0.47 \pm 0.37^{b}$ & $56 \pm 12$ & $16 \pm 11^{\mathrm{b}}$ & -- & $4.5 \pm 1.2^{\mathrm{b}}$ & $497 \pm 180^{b}$ \\
\hline & & & & $(81-201)$ & $(\leq 0.03-1.00)$ & $(31-72)$ & $(5-37)$ & -- & $(2.9-6.9)$ & $(198-760)$ \\
\hline & Reproductive & Recent & 8 & $93 \pm 55$ & $0.12 \pm 0.18$ & $44 \pm 15$ & $9 \pm 12$ & $4.1 \pm 1.2^{\mathrm{a}}$ & $3.0 \pm 0.6$ & $415 \pm 231$ \\
\hline & & & & $(25-159)$ & $(\leq 0.03-0.50)$ & $(32-77)$ & $(5-38)$ & $(2.6-5.5)$ & $(2.2-3.8)$ & $(194-\geq 800)$ \\
\hline & & Briefly & 8 & $165 \pm 63$ & $\leq 0.03 \pm 0.00^{\mathrm{a}}$ & $45 \pm 7$ & $5 \pm 0$ & $0.4 \pm 0.5^{\mathrm{b}}$ & $2.4 \pm 0.3$ & $406 \pm 213$ \\
\hline & & & & $(112-274)$ & $(\leq 0.03)$ & $(39-59)$ & -5 & $(0.0-1.4)$ & $(2.1-3.0)$ & $(140-\geq 800)$ \\
\hline & & Prolonged & 7 & $200 \pm 90$ & $\leq 0.03 \pm 0.00^{\mathrm{a}}$ & $43 \pm 7$ & $5 \pm 0$ & $0.5 \pm 0.8^{\mathrm{b}}$ & $3.1 \pm 0.9$ & $321 \pm 222$ \\
\hline & & & & $(56-322)$ & $(\leq 0.03)$ & $(34-51)$ & -5 & $(0.0-2.1)$ & $(2.4-4.9)$ & $(106-728)$ \\
\hline & & Life-captive & 7 & $131 \pm 65$ & $0.17 \pm 0.15^{\mathrm{b}}$ & $37 \pm 8$ & $5 \pm 0$ & $0.5 \pm 0.9^{b}$ & $2.7 \pm 1.1$ & $399 \pm 258$ \\
\hline & & & & $(55-216)$ & $(\leq 0.03-0.40)$ & $(27-50)$ & -5 & $(0.0-2.3)$ & $(1.0-4.0)$ & $(166-\geq 800)$ \\
\hline & Post-spawn & Recent & 9 & $154 \pm 75^{\mathrm{a}}$ & $\leq 0.03 \pm 0.00^{\mathrm{a}}$ & $64 \pm 22^{\mathrm{a}}$ & $9 \pm 11$ & $6.6 \pm 1.9^{\mathrm{a}}$ & $2.7 \pm 1.2^{\mathrm{a}}$ & $421 \pm 223^{\mathrm{a}}$ \\
\hline & & & & $(55-325)$ & $(\leq 0.03)$ & (28-97) & $(5-38)$ & $(2.5-9.2)$ & $(1.0-4.8)$ & $(184-\geq 800)$ \\
\hline & & Life-captive & 5 & $67 \pm 24^{b}$ & $0.17 \pm 0.08^{b}$ & $38 \pm 7^{\mathrm{b}}$ & $8 \pm 4$ & $1.5 \pm 0.5^{\mathrm{b}}$ & $4.2 \pm 0.4^{\mathrm{b}}$ & $204 \pm 48^{b}$ \\
\hline & & & & $(55-110)$ & $(\leq 0.03-0.20)$ & $(32-47)$ & $(5-13)$ & $(1.1-2.3)$ & $(3.8-4.6)$ & $(166-287)$ \\
\hline
\end{tabular}


Table 5-2. Blood chemistry of Missouri River pallid sturgeon.-Continued

[Sturgeon were grouped according to sex, reproductive stage, and time in captivity. Blood was collected from recently captured fish (=Recent) within $0-7$ days after capture and may have occurred while they were held temporarily in a hatchery awaiting spawning. Blood was collected from fish held for a short period (=Briefly) or long period (=Prolonged) between $8-30$ days and longer than 1 month, respectively. Blood collected from fish maintained in captivity all or most of their life (=Life-captive). Results are means \pm standard deviation. Minimum and maximum values are in parenthesis. Superscripts within a sex-stage category for a biomarker indicate significant differences at $p<0.05$; --, no data; \pm , plus or minus; $\mathrm{mg} / \mathrm{dL}$, milligrams per deciliter; $\mathrm{U} / \mathrm{L}$, units per liter; mmol/ L, millimole per liter; g/dL, gram per decilite]

\begin{tabular}{|c|c|c|c|c|c|c|c|c|c|c|}
\hline Sex & $\begin{array}{l}\text { Reproductive } \\
\text { status }\end{array}$ & Captivity & Number & $\begin{array}{c}\text { Cholesterol } \\
\text { (mg/dL) }\end{array}$ & $\begin{array}{c}\text { Creatinine } \\
\text { (mg/dL) }\end{array}$ & $\begin{array}{l}\text { Glucose } \\
\text { (mg/dL) }\end{array}$ & $\begin{array}{l}\text { Lipase } \\
\text { (U/L) }\end{array}$ & $\begin{array}{l}\text { Lactate } \\
\text { (mmol/L) }\end{array}$ & $\begin{array}{c}\text { Total protein } \\
(\mathrm{g} / \mathrm{dL})\end{array}$ & $\begin{array}{l}\text { Triglycerides } \\
\text { (mg/dL) }\end{array}$ \\
\hline \multirow[t]{12}{*}{ Male } & Non-Reproductive & Recent & 25 & $120 \pm 44$ & $0.12 \pm 0.23^{\mathrm{a}}$ & $65 \pm 25$ & $6 \pm 3^{\mathrm{a}}$ & $6.2 \pm 4.0^{\mathrm{a}}$ & $2.7 \pm 1.2^{\mathrm{a}}$ & $326 \pm 201^{a}$ \\
\hline & & & & $(82-285)$ & $(\leq 0.03-0.80)$ & $(36-128)$ & $(5-18)$ & $(0.0-12.0)$ & $(1.0-5.3)$ & $(94-\geq 800)$ \\
\hline & & Briefly & 5 & $126 \pm 69$ & $0.06 \pm 0.08^{\mathrm{a}}$ & $43 \pm 6$ & $5 \pm 0^{\mathrm{a}}$ & $0.5 \pm 0.3^{\mathrm{b}}$ & $1.6 \pm 0.9^{\mathrm{a}}$ & $289 \pm 101^{\mathrm{a}}$ \\
\hline & & & & $(55-222)$ & $(\leq 0.03-0.20)$ & $(37-50)$ & -5 & $(0.0-0.7)$ & $(1.0-5.3)$ & $(183-400)$ \\
\hline & & Life-captive & 37 & $132 \pm 46$ & $0.43 \pm 0.30^{\mathrm{b}}$ & $56 \pm 13$ & $13 \pm 8^{\mathrm{b}}$ & $0.6 \pm 0.9^{\mathrm{b}}$ & $4.3 \pm 1.3^{\mathrm{b}}$ & $509 \pm 213^{b}$ \\
\hline & & & & $(59-284)$ & $(\leq 0.03-1.00)$ & $(31-78)$ & $(5-33)$ & $(0.0-1.6)$ & $(2.4-9.0)$ & $(132-960)$ \\
\hline & Reproductive & Recent & 11 & $256 \pm 88$ & $0.04 \pm 0.05^{\mathrm{a}}$ & $61 \pm 29$ & $6 \pm 4$ & $3.2 \pm 3.9$ & $2.8 \pm 1.0$ & $344 \pm 175$ \\
\hline & & & & $(71-336)$ & $(\leq 0.03-0.20)$ & $(40-125)$ & $(5-18)$ & $(0.7-11.1)$ & $(1.0-4.9)$ & $(303-678)$ \\
\hline & & Prolonged & 1 & 303 & $\leq 0.03$ & 48 & 5 & 5 & 3.9 & 1,086 \\
\hline & & & & -303 & $(\leq 0.03)$ & -48 & -5 & -5 & -3.9 & $-1,086$ \\
\hline & & Life-captive & 4 & $172 \pm 34$ & $1.75 \pm 2.70$ & $82 \pm 35$ & $5 \pm 0$ & $1.2 \pm 0.3$ & $3.6 \pm 0.7$ & $404 \pm 142$ \\
\hline & & & & $(143-212)$ & $(0.20-5.80)$ & $(36-122)$ & -5 & $(0.8-1.5)$ & $(2.7-4.2)$ & $(242-550)$ \\
\hline
\end{tabular}




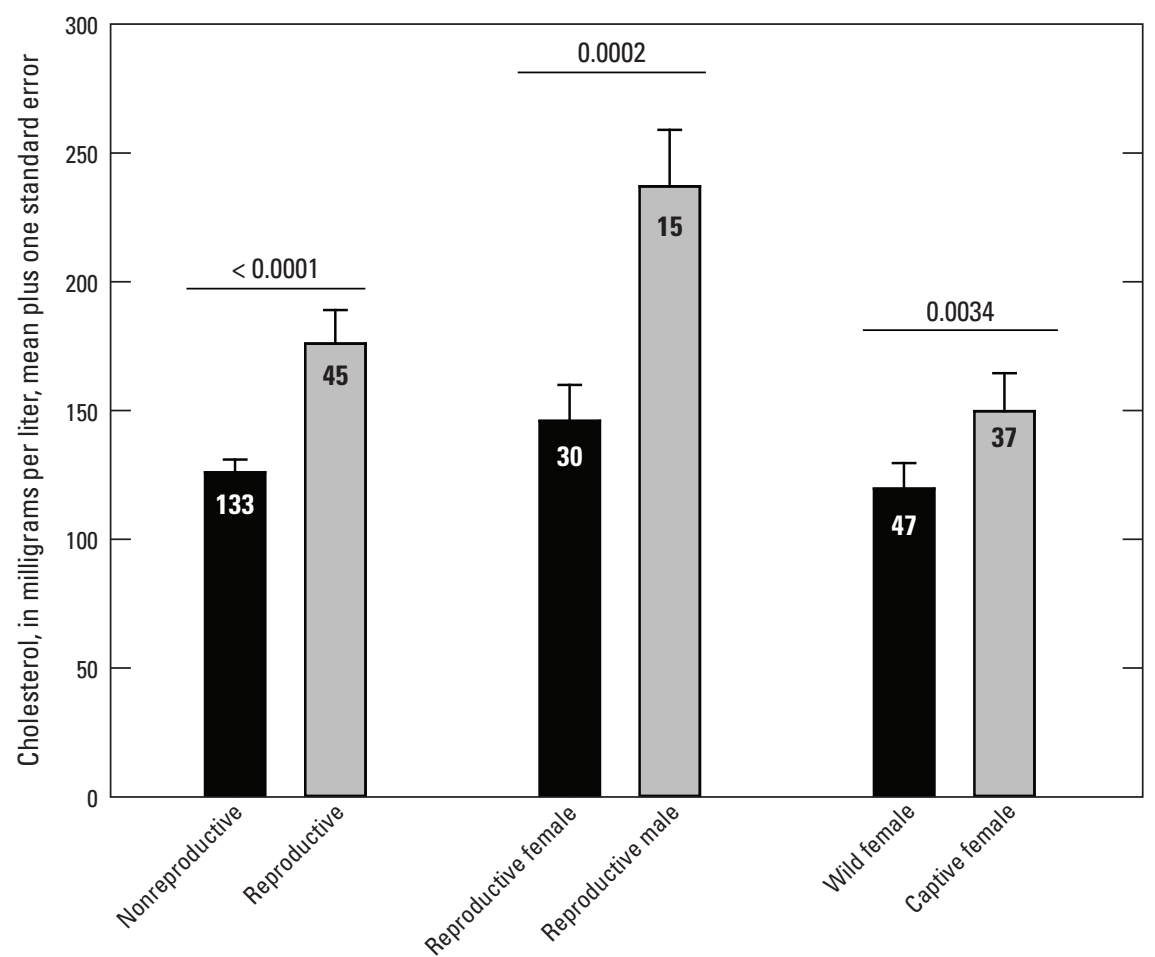

\section{EXPLANATION}

Analysis of variance using least-squares means for pairwise comparisons was used to test for differences. Horizontal lines above bars indicate means that were significantly different at $p<0.05$. P-values are noted above bars for results of post-hoc comparisons.

T Whiskers indicated one standard error

Figure 5-1. Mean plasma cholesterol concentrations in pallid sturgeon.

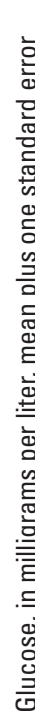

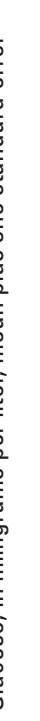

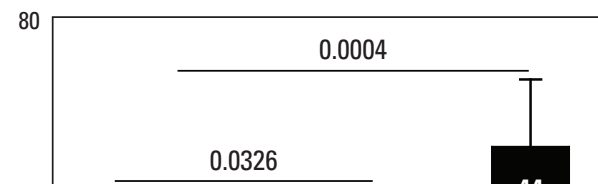

60

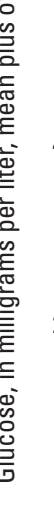
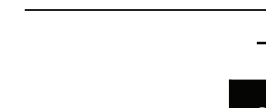

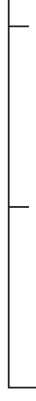

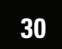

30

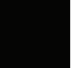

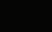

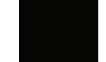

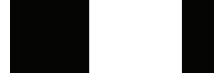

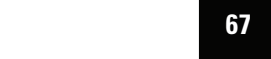

\section{7}
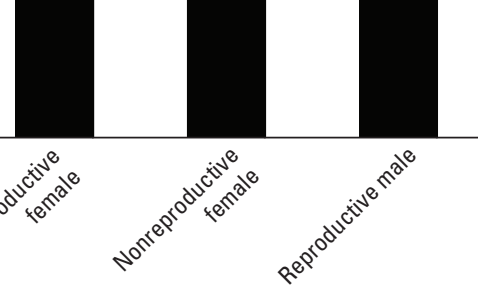

0.0027

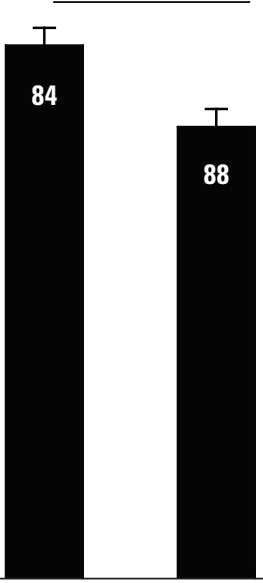

$40^{20}$

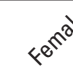

\section{EXPLANATION}

Analysis of variance using least-squares means for pairwise comparisons was used to test for differences. Horizontal lines above bars indicate means that were significantly different at $p<0.05$. $P$-values are noted above bars for results of post-hoc comparisons.

Whiskers indicated one standard error

30 Number on bar indicates number of fish

Figure 5-2. Mean plasma glucose concentrations in pallid sturgeon. 
Elevated lactate is a secondary stress response in most fish, although this response may be reduced in sturgeons (Baker and others, 2005). Lactate also increases in response to hypoxia (Heath, 1995). Results show that plasma lactate concentrations are higher in males than females. Nonreproductive fish had generally higher concentrations of lactate than reproductive fish, and wild fish had higher lactate concentrations than captive fish (fig. 5-3). Previous studies with other species of sturgeon have measured differences in lactate concentrations between sturgeon at rest (1 millimole per liter $[\mathrm{mmol} / \mathrm{L}])$ and sturgeon present with a stressor $(>4 \mathrm{mmol} / \mathrm{L})$ (Beyea and others, 2005; Zuccarelli and others, 2008).

Results from these studies indicate a comparable lactate stress response in wild pallid sturgeon in comparison to their captive counterparts.

Lipase is a fat-digesting enzyme. Adult pallid sturgeon typically have low plasma lipase concentrations because they are primarily piscivorous. Lipase concentrations were highest in nonreproductive captive pallid sturgeon when compared to either reproductive captive or nonreproductive wild pallid sturgeon (fig. 5-4). Comparative data from literature are not available; however, results suggest that diets of prolongedcaptive pallid sturgeon may have abnormally high lipids.

The total protein measurement reflects the amount of albumin and globulin in blood. Albumin contributes to cell health and globulin to proper function of the immune system.
Albumin and globulin are important in the endocrine system, especially related to reproduction. Males were slightly higher in blood total protein than females. Captive fish had higher protein than wild fish, and captive, nonreproductive fish had higher concentrations than captive, reproductive fish (fig. 5-5). Total protein in shovelnose sturgeon was only slightly higher than that measured in pallid sturgeon (Sepúlveda and others, 2012).

Stored triglycerides provide the energy source for activities such as swimming, reproduction, and detoxification. Triglyceride concentrations were higher in males compared to females and higher in wild pallid sturgeon compared to captive pallid sturgeon (fig. 5-6). Total triglyceride concentrations in pallid sturgeon were slightly lower than those reported for white sturgeon (Fynn-Aikins and others, 1992).

In a second analysis, sturgeon that had been in captivity all their lives (life-captive) regardless of sex or stage, had higher creatinine values than sturgeon that were held in captivity 0-7 days (recent), 8-30 days (brief), or $>30$ days (prolonged). Not all categories had sufficient fish for which to complete a robust analysis; however, apart from lactate, there were few differences in blood biomarker concentrations between recent-captive fish and briefly- and prolonged-captive fish. Conversely, nearly all biomarkers for these fish differed from those of the pallid sturgeon that had spent their entire lives in captivity.

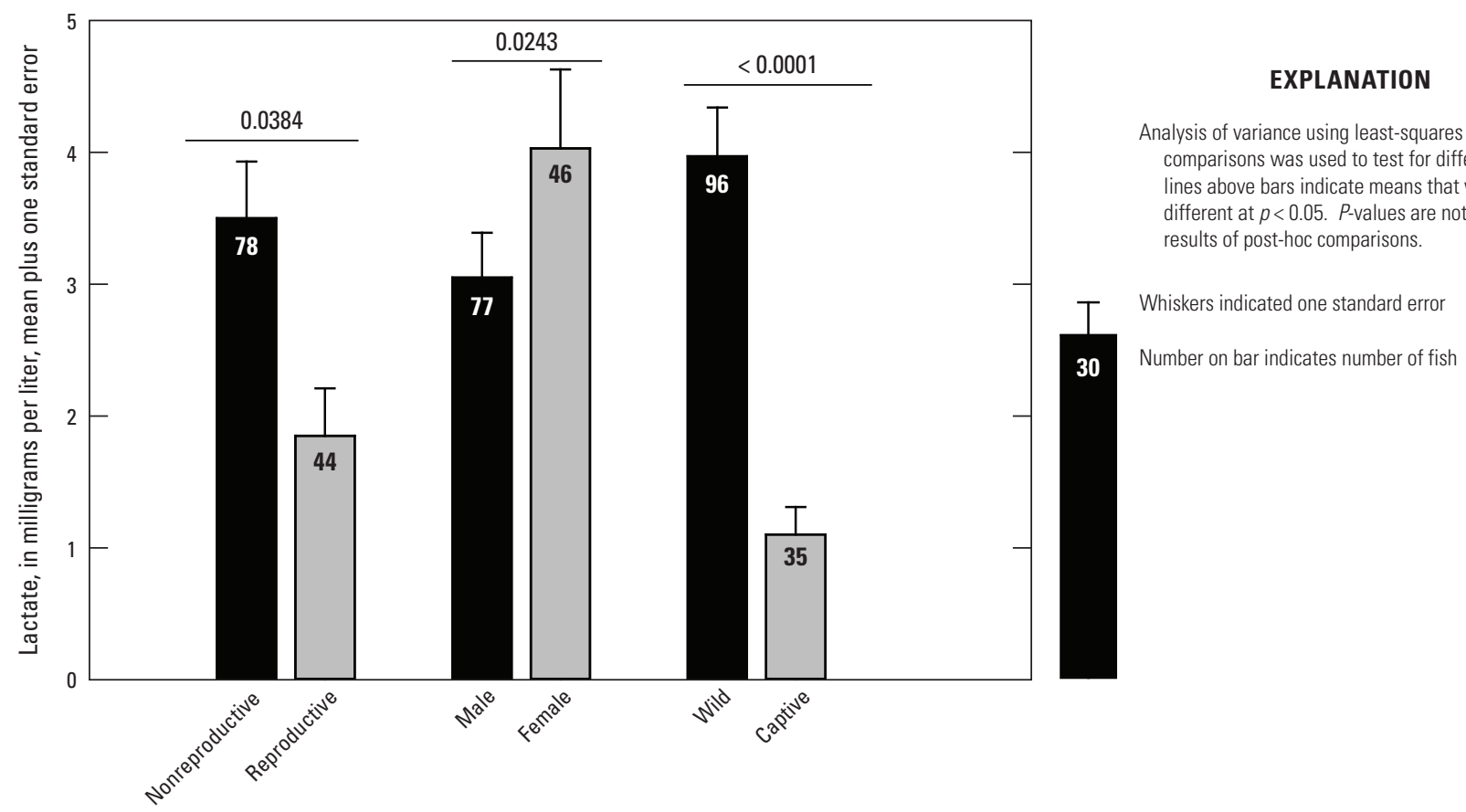

Figure 5-3. Mean plasma lactate concentrations in pallid sturgeon. 


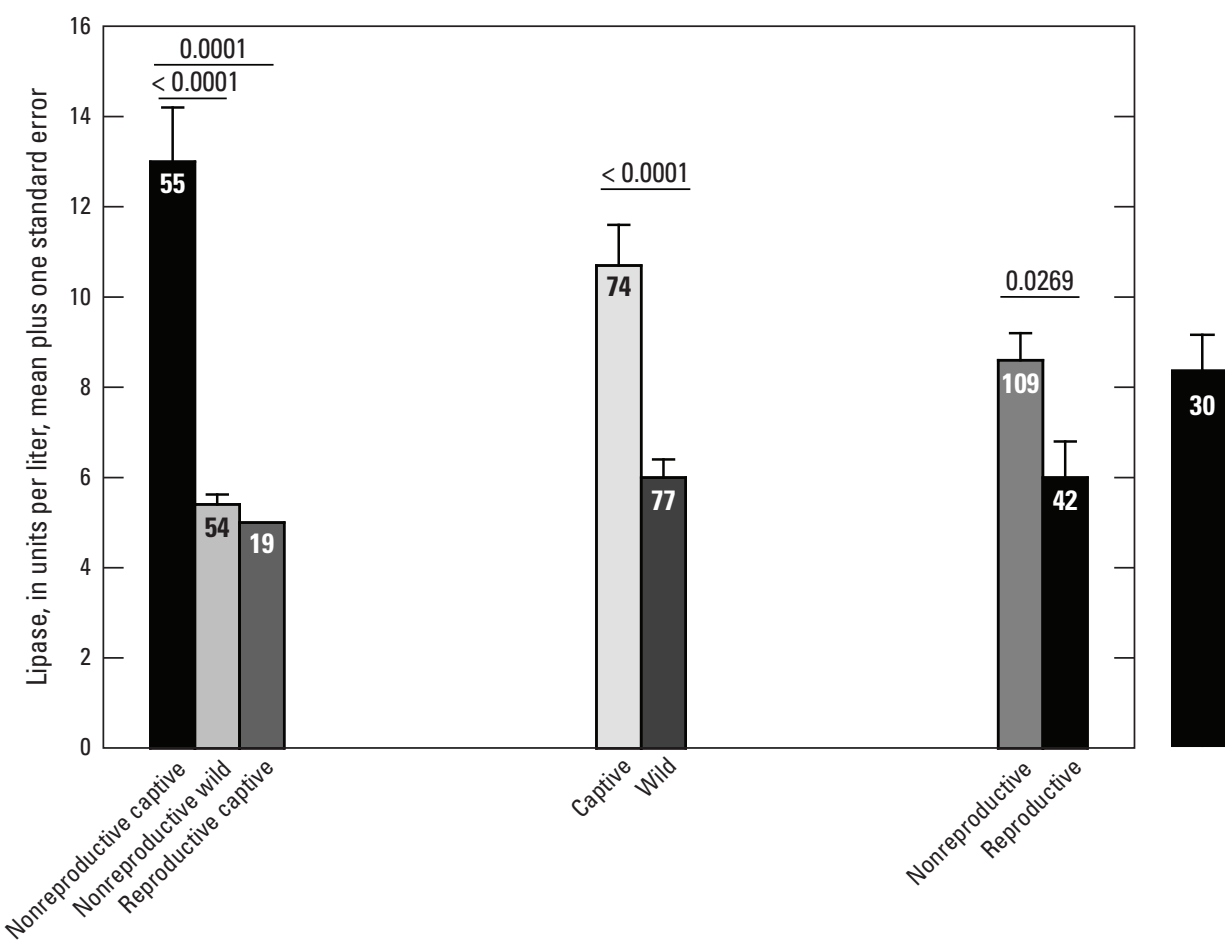

EXPLANATION

Analysis of variance using least-squares means for pairwise comparisons was used to test for differences. Horizontal lines above bars indicate means that were significantly different at $p<0.05$. P-values are noted above bars for results of post-hoc comparisons.

T Whiskers indicated one standard error

Number on bar indicates number of fish

Figure 5-4. Mean plasma lipase concentrations in pallid sturgeon.

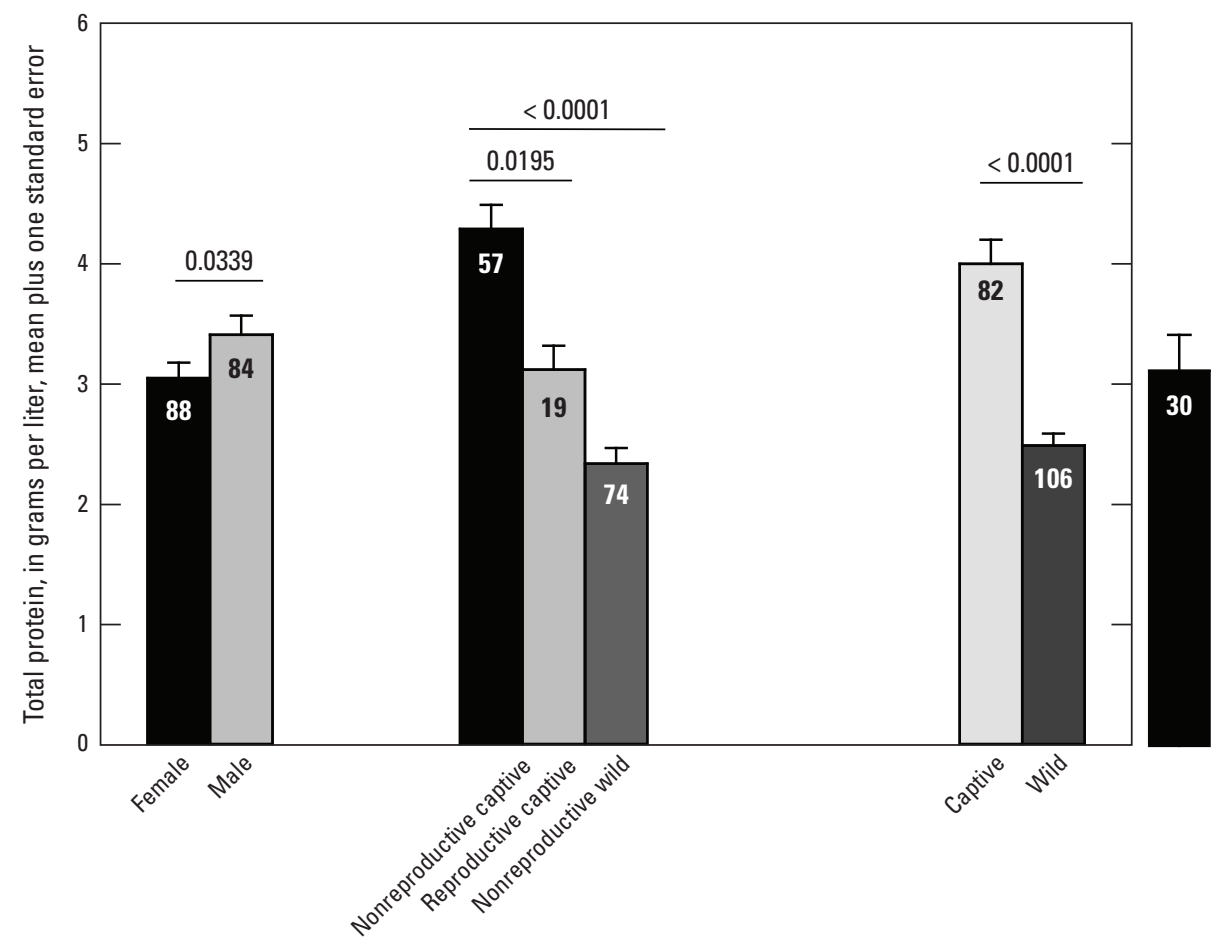

\section{EXPLANATION}

Analysis of variance using least-squares means for pairwise comparisons was used to test for differences. Horizontal lines above bars indicate means that were significantly different at $p<0.05$. $P$-values are noted above bars for results of post-hoc comparisons.

Whiskers indicated one standard error

Number on bar indicates number of fish

Figure 5-5. Mean plasma total protein concentrations in pallid sturgeon. 


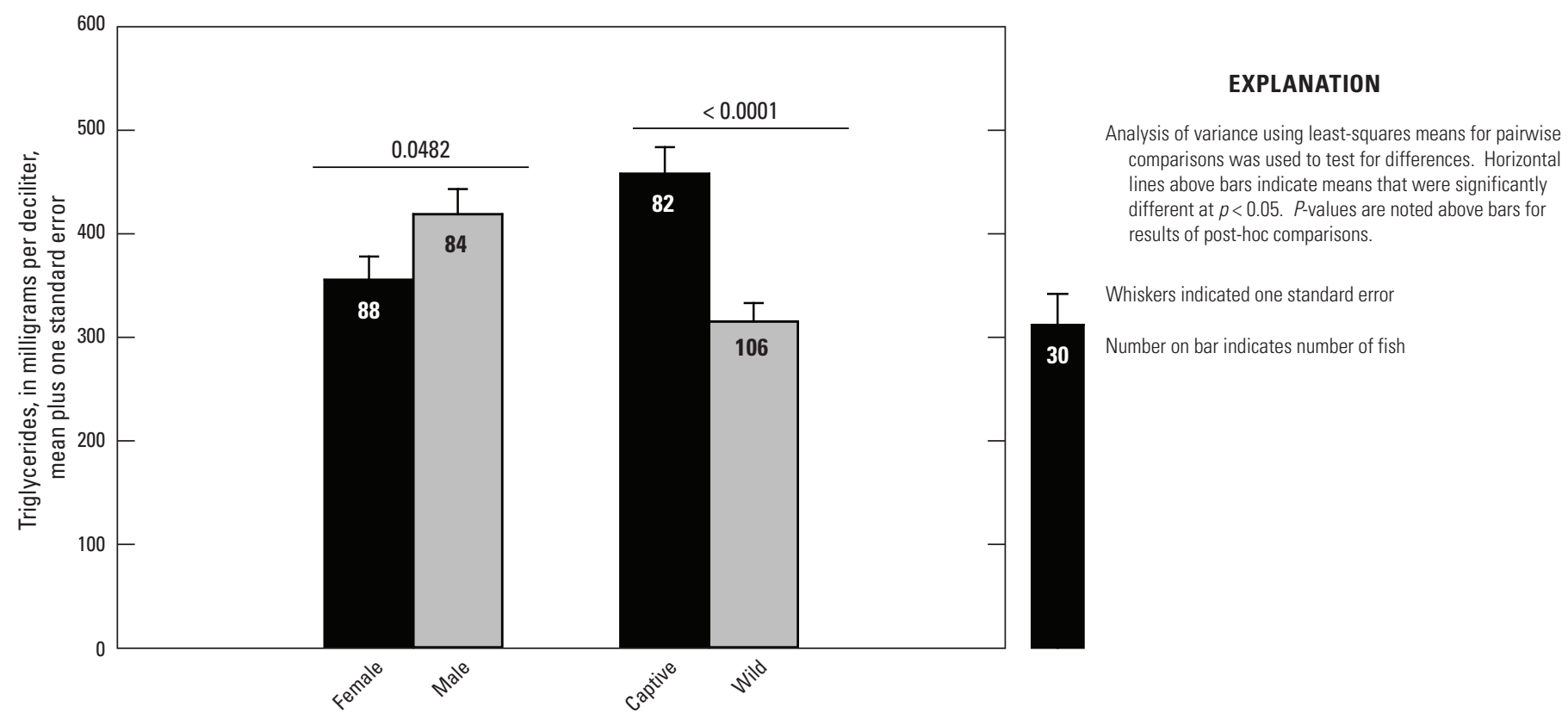

Figure 5-6. Mean plasma total triglyceride concentrations in pallid sturgeon.

\section{Summary}

When comparative data for other sturgeon species were available, sex- and stage-specific trends in pallid sturgeon blood chemistry biomarkers were similar. Differences between shovelnose sturgeon and pallid sturgeon values for some blood chemistry parameters may reflect subtle differences in physiology or ecology. Conversely, differences in environmental conditions under which the fish lived could account for the disparate values. Insights into the ecological differences between these two congenerics may be obtained by comparing measured blood chemistry of the two species under the same controlled conditions.

Captive and wild pallid sturgeon differed for all biomarkers except glucose. Not surprisingly, the fishes' physiology had changed while in captivity, highlighting the differences between the hatchery and the Missouri River for nutrition, water temperature, and a variety of other environmental variables. Concentrations of creatinine and lactate were elevated in wild fish, which suggests that capture, transport, and acclimation to the hatchery environment is stressful to pallid sturgeon. It is unknown whether that stress has consequences for the future health of the fish. Analysis of the data from fish held in captivity through time indicate that blood concentrations of these biomarkers decline by $8-30$ days in captivity, suggesting that acclimation happens during several weeks.

Extensive monitoring programs target and capture pallid sturgeon in the Missouri River to assess movement and population demographics (Welker and Drobish, 2009). Intensive coordinated capture efforts are done annually to collect and transport potential broodstock to hatcheries across the basin (U.S. Fish and Wildlife Service, 2008a, b). Broodstock may be held in unnatural conditions for an extended period of time before artificial induction of spawning and eventual release. At present (2012), little information exists to assess the physiological effect of capture and transport on juvenile and adult pallid sturgeon under field conditions. Without adequate baseline data, biologists have few tools at their disposal to assess the short-term physiological status or long-term condition of captive pallid sturgeon juveniles or adults (Barton and others, 2000). Without insight into the physiological status of broodstock, evaluation of induction and spawning success may be difficult to interpret (Bayunova and others, 2002). Development of hematological profiles of pallid sturgeon may be useful in assessing stress or changes in physiological condition that accompany propagation activities or environmental stresses such as capture, starvation, migration, or spawning (for example, Shahsavani and others, 2010; and Di Marco and others, 2011).

\section{References Cited}

Asadi, F., Masoudifard, M., Vajhi, A., Lee, K., Pourkabir, M., and Khazraeinia, P., 2006, Serum biochemical parameters of Acipenser persicus: Fish Physiology and Biochemistry, v. 32, no. 1, p. 43-47. [Also available at http://dx.doi. org/10.1007/s10695-005-5738-0.]

Baker, D.W., Wood, A.M., Litvak, M.K., and Kieffer, J.D., 2005, Haematology of juvenile Acipenser oxyrinchus and Acipenser brevirostrum at rest and following forced activity: Journal of Fish Biology, v. 66, no. 1, p. 208-221. [Also available at http://dx.doi.org/10.1111/j.00221112.2005.00595.x.] 
Barannikova, Irina, Bayunova, Liubov, Semenkova, Tatiana, and Trenkler, Igor, 2008, Physiological changes in Russian sturgeon (Acipenser gueldenstaedtii) after long-term holding and final maturation: Cybium, v. 32, no. 2, p. 321-322.

Barton, B.A., Bollig, Herbert, Hauskins, B.L., and Jansen, C.R., 2000, Juvenile pallid (Scaphirhynchus albus) and hybrid pallid x shovelnose (S. albus x platorynchus) sturgeons exhibit low physiological responses to acute handling and severe confinement: Comparative Biochemistry and Physiology Part A, v. 126, p. 125-134.

Bayunova, L., Barannikova, I., and Semenkova, T., 2002, Sturgeon stress reactions in aquaculture: Journal of Applied Ichthyology, v. 18, no. 4-6, p. 397-404. [Also available at http://dx.doi.org/10.1046/j.1439-0426.2002.00410.x.]

Beyea, M.M., Benfey, T.J., and Kieffer, J.D., 2005, Hematology and stress physiology of juvenile diploid and triploid shortnose sturgeon (Acipenser brevirostrum): Fish Physiology and Biochemistry, v. 31, no. 4, p. 303-313. [Also available at http://dx.doi.org/10.1007/s10695-005-1552-y.]

Di Marco, P., Priori, A., Finoia, M.G., Petochi, T., Longobardi, A., Donadelli, V., and Marino, G., 2011, Assessment of blood chemistry reference values for cultured sturgeon hybrids (Acipenser naccarii female x Acipenser baerii male): Journal of Applied Ichthyology, v. 27, no. 2, p. 584590. [Also available at http://dx.doi.org/10.1111/j.14390426.2011.01713.x.]

Folmar, L.C., 1993, Effects of chemical contaminants on blood chemistry of teleost fish-A bibliography and synopsis of selected effects: Environmental Toxicology and Chemistry, v. 12 , no. 2 , p. 337-375. [Also available at http://dx.doi. org/10.1002/etc.5620120216.]

Fynn-Aikins, Kofi, Hung, S.S.O., Liu, Wei, and Li, Hongbin, 1992, Growth, lipogenesis and liver composition of juvenile white sturgeon fed different levels of D-glucose: Aquaculture, v. 105, no. 1, p. 61-72. [Also available at http://dx.doi. org/10.1016/0044-8486(92)90162-E.]

Heath, A.G., 1995, Water pollution and fish physiology (2d ed.): Boca Raton, Fla., CRC Press, Inc., 384 p.

Hunn, J.B., and Christenson, L.M., 1977, Chemical composition of blood and bile of the shovelnose sturgeon: The Progressive Fish-Culturist, v. 39, no. 2, p. 59-61. [Also available at http://dx.doi.org/10.1577/15488659(1977)39[59:CCOBAB]2.0.CO;2.]

Sepúlveda, M.S., Sutton, T.M., Patrick, H.K., and Amberg, J.J., 2012, Blood chemistry values for shovelnose and lake sturgeon: Journal of Aquatic Animal Health, v. 24, no. 3, p. 135-140. [Also available at http://dx.doi.org/10.1080/089 97659.2012.675927.]
Shahsavani, Davar, Kazerani, H.R., Kaveh, Samira, and Gholipir-Kanani, Hosna, 2010, Determination of some normal serum parameters in starry sturgeon (Acipenser stellatus Pallas, 1771) during spring season: Comparative Clinical Pathology, v. 19, no. 1, p. 57-61. [Also available at http:// dx.doi.org/10.1007/s00580-009-0899-3.]

Shi, Xiaotao, Li, Dapeng, Zhuang, Ping, Nie, Fen, and Long, Liangqi, 2006, Comparative blood biochemistry of Amur sturgeon, Acipenser schrenckii, and Chinese surgeon, Acipenser sinensis: Fish Physiology and Biochemistry, v. 32, no. 1, p. 63-66. [Also available at http://dx.doi. org/10.1007/s10695-006-7134-9.]

Thrall, Mary Anna, Weiser, Glade, Allison, Robin, and Campbell, T.W., 2012, Veterinary hematology and clinical chemistry (2d ed.): Wiley-Blackwell, 776 p.

U.S. Fish and Wildlife Service, 2008a, Biological procedures and protocols for researchers and managers handling pallid sturgeon: Billings, Mont., U.S. Fish and Wildlife Service, $32 \mathrm{p}$.

U.S. Fish and Wildlife Service, 2008b, Pallid sturgeon (Scaphirhynchus albus) range-wide stocking and augmentation plan: U.S. Fish and Wildlife Service, 55 p.

Welker, T.L., and Drobish, M.R., 2009, Missouri River standard operating procedures for fish sampling and data collection: U.S. Army Corps of Engineers, Omaha District, v. $1.4,208$ p.

Zuccarelli, M.D., Kusakabe, M., Nakamura, I., Prentice, E.F., Young, G., and Ingermann, R.L., 2008, Acute stress response of Kootenai River white sturgeon Acipenser transmontanus Richardson reflected in peritoneal fluid and blood plasma: Journal of Fish Biology, v. 72, no. 7, p. 1831-1840. [Also available at http://dx.doi.org/10.1111/j.10958649.2008.01840.x.] 


\section{Appendix 6. Free-Embryo Drift Experiments in an Experimental Stream}

\section{Background}

Pallid sturgeon (Scaphirhynchus albus) continue to show limited or no recruitment in the Missouri River despite evidence of spawning by wild and by hatchery-origin adults. Hypotheses for recruitment failure have shifted to questions about survival of early life stages, from fertilization to "settling" of exogenously feeding larvae in channel-margin habitats. A critical component of this process is thought to be drift of newly hatched free embryos.

\section{Scope and Objectives}

The goal of this study is to describe the drift behavior of free-embryo pallid sturgeon from hatch to the end of dispersal. Aspects of the study will repeat the work of Kynard and others (2007). The objectives are the following: (1) to measure the depth at which free embryos and larvae drift; (2) to identify where free embryos and larvae are in the drift in the vertical and cross-channel dimensions (surface, bottom, inside bends, outside bends); (3) to measure the rate at which free embryos and larvae drift relative to water velocity; (4) to quantify the days post-fertilization or post-hatch or at what cumulative thermal units (CTU) the larvae stop drifting; (5) to identify environmental conditions where larvae are located when they stop drifting; and (6) to understand the ability of different developmental stages to maintain position in flowing at different water velocities.

\section{Methods}

Experiments were done indoors in an endless oval stream tank (fig. 6-1). Availability of tanks and pallid sturgeon embryos necessitated multiple trials in a series from May through July 2012. Testing began at hatch and ended just before complete yolk absorption. Fish were not fed during the trials.

Pallid sturgeon embryos were obtained from three different facilities through time for the study trials: Neosho National Fish Hatchery (NNFH), Neosho, Missouri; Columbia Environmental Research Center (CERC), Columbia, Mo.; and Gavins Point National Fish Hatchery (GPNFH), Yankton, South Dakota. Embryos, except all those in the second of two spawns from GPNFH, were obtained immediately after fertilization and before use of Fuller's earth so that they retained their adhesive properties and could be attached to a cobble substrate. Upon collection at the hatchery, or receipt by overnight courier, the embryos were divided into two groups for hatching: (1) those attached to a cobble substrate (approximately 50 embryos) and placed in the stream or (2) those hatched in a floating mesh basket or McDonald jar in the stream. The embryos in the basket and McDonald jar served both as a control to assess mortality because of water quality conditions without current, and to provide a pool of embryos at the identical developmental stage to replace mortalities within the artificial stream. A second batch of newly fertilized embryos from GPNFH was shipped overnight to Columbia, Mo., and all were reared in a McDonald jar in the test stream.

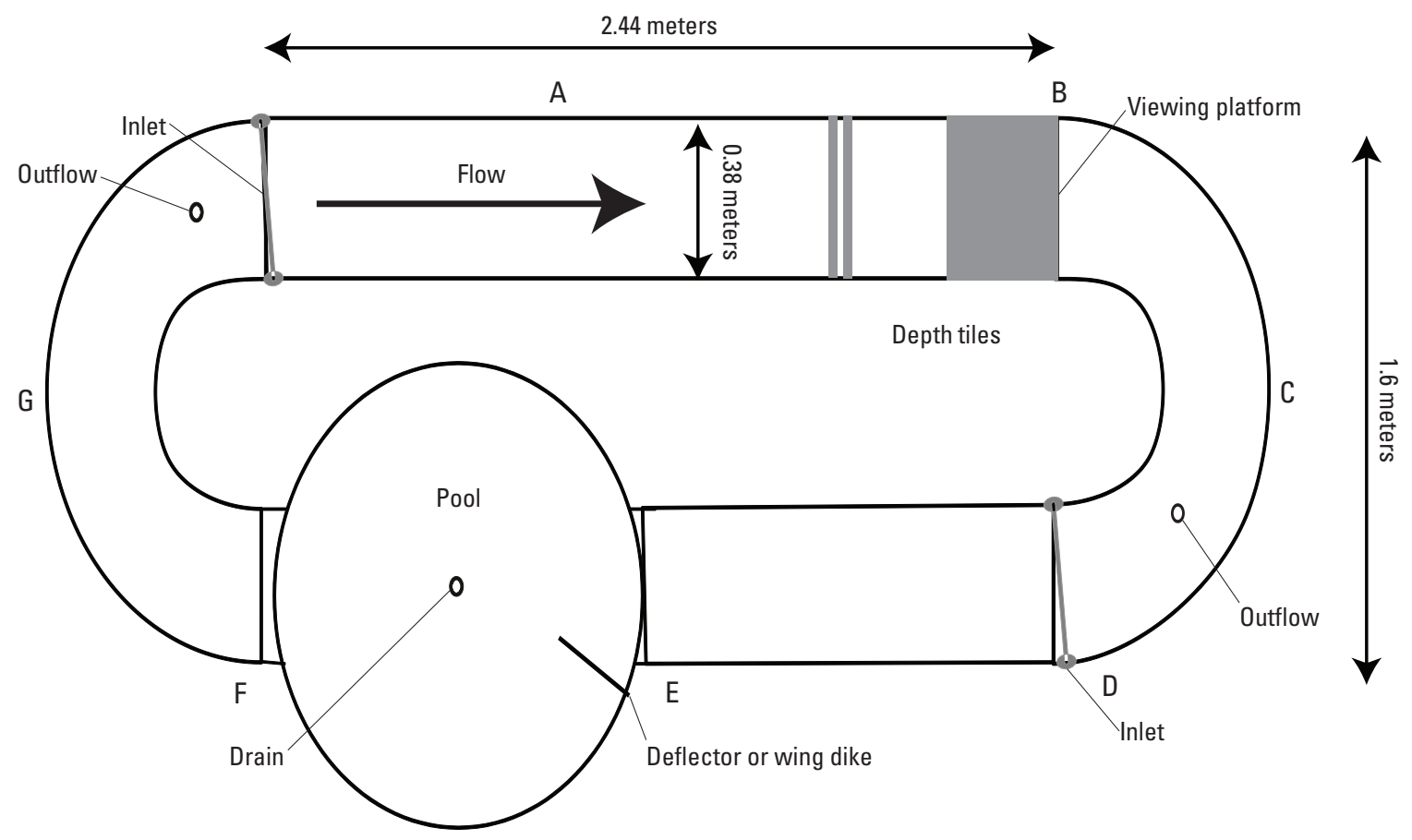

Figure 6-1. Diagram of the oval stream tank used in the free-embryo drift experiments. 
A fiberglass endless oval stream with pool configuration was used to make drift measurements (Frigid Units, Toledo, Ohio, fig. 6-1). The stream was 24 centimeters (cm) deep and $38 \mathrm{~cm}$ wide at the bottom, and consisted of a straight run section $244 \mathrm{~cm}$ long and a run section $122 \mathrm{~cm}$ long followed by a pool section $122 \mathrm{~cm}$ in diameter. A piece of plexiglass attached to the wall of the pool where it joined the channel created a 'dike-like' effect causing an eddy to form behind it. A second, larger piece of plexiglass created a wall across the pool extending from the inlet end of the channel to the outlet end. A 'ledge-like' drop from the bottom of the channel into the pool was $25 \mathrm{~cm}$. Water depth in the pool was $49 \mathrm{~cm}$. Water was one-pass flow through and entered the stream system at two positions through holes drilled in a 3-foot -one-half-inch PVC pipe extending at a 45 degree $\left(^{\circ}\right)$ angle from inlet to bottom of channel. Water drained from the surface through an overflow standpipe covered in fine mesh to prevent loss of free embryos.

Stream-drift rate and position measurements were made in a single location in the longer run channel section. A $38-\mathrm{cm} \times 38-\mathrm{cm}$ sheet of white plastic was affixed to the bottom of the stream channel with silicone adhesive to improve contrast and facilitate observations of the drifting free embryos. Slightly upstream, two plexiglass tiles $(38 \mathrm{cmx} 10 \mathrm{~cm})$ were attached across the width of the stream channel. The lower tile was placed at two-thirds water depth, or $7.7 \mathrm{~cm}$ above the channel bottom, and the upper tile at $15.3 \mathrm{~cm}$ above the channel bottom. The tiles divided the water column into three sections (bottom, mid-water, and top) to locate drifting free embryos in the stream. Additionally, the bottom of the pool was gridded to facilitate documentation of free-embryo location in the pool.

Lighting was minimal throughout the study to mimic conditions in the Missouri River (about 3-20 lux). When light was necessary, red lights were used. Video cameras, installed above the stream channel observation platform and in the pool at the base of the dropoff, recorded constantly throughout the drift experiments. A TidbiT temperature data logger (Onset Computer Company, Bourne, Massachusetts) recorded water temperature at intervals throughout the study. Current velocity was measured at random times daily at seven locations in the channel and three in the pool with a flow meter (Marsh-McBirney, Hach, Loveland, Colorado). Measurements were made at three locations in the channel along a transect perpendicular to the flow. Measurements were made at three depths $(4,11$, and $20 \mathrm{~cm}$ from the bottom) at each point along the transect.

Measurements of drift rate and position in the channel and pool were made at 3-hour intervals from hatch until the end of the trial. Drift was measured by counting the number of free embryos that passed over the observing platform in a 5-minute period with the observer noting the upstream or downstream orientation of the free embryo. Location in the channel was also measured in a 5-minute period with the observer recording the vertical (bottom, mid, or top) and horizontal position (right side, center, or left side) of the drifting free embryo. Location in the pool was measured by turning the water off for 5 minutes, recording the position of the free embryos, waiting 5 minutes, then again recording the position of the free embryos. Numbers and status (live or dead) of free embryos in the stream system were evaluated daily. Dead free embryos were replaced daily by same-age free embryos that had been held in the stream in a floating basket or in aquaria in the laboratory so as to maintain five free embryos in the stream.

On days 11, 13, and 15 post-hatch, 9 individuals from trial 2 were tested to determine their ability to withstand swimming against a current. Testing consisted of a fish being placed in the chamber of the stamina instrument and the water velocity slowly being increased. Each fish was placed in one of three 5-liter (L) swim tunnel respirometers (Loligo Systems, Denmark). The fish was placed in the test section of the tunnel $(30 \times 7.5 \times 7.5 \mathrm{~cm})$ and acclimated at a velocity 17.8 centimeters per second $(\mathrm{cm} / \mathrm{s})$ for 5 minutes. After the acclimation period, the velocity was increased by $5.09 \mathrm{~cm} / \mathrm{s}$ every 3 minutes. The test concluded when the fish fatigued (was swept downstream and was impinged on the screen for 5 seconds). Following the trial, total length and weight for each fish was obtained. The time to fatigue and the velocity of the water at fatigue were recorded.

\section{Results}

\section{Trial 1}

On May 9, 2012, 89 newly fertilized embryos were obtained from the NNFH. Fertilization rate was 91 percent. Of those 89,49 embryos were attached to the rock substrate and placed in the stream channel. The remaining embryos were placed in a mesh basket that was floated in the stream. Mortality was similar between embryos in the basket and those in the stream substrate. By 2 days post-fertilization (dpf), 60 percent of the embryos in the basket died with no additional mortality until hatch. Mortality in the stream substrate was similar but happened during a longer time. By 5 dpf, 60 percent of embryos in the substrate died. Hatching began May 15 or at $6 \mathrm{dpf}$. Video showed softening of the chorion as hatching enzymes progressively thinned the membrane. When the embryo was free of the egg, it initially fell down below the rock substrate, and then was swept into the current. At 3 days post-hatch (dph), all but one free embryo was dead. Average daily water temperature during the study was 17.9 plus or minus $( \pm) 0.5^{\circ} \mathrm{C}$, and dissolved oxygen concentration was $8.0 \pm 0.3$ milligram per liter $(\mathrm{mg} / \mathrm{L})$.

\section{Trial 2}

A pallid sturgeon from the CERC captive population was spawned on May 23, 2012, and eggs were fertilized with cryopreserved milt because no other milt was available. Fertilization was extremely poor; therefore, 4 sets of 50 embryos 
on rock substrates were placed in the stream. An additional 20 embryos were placed in a McDonald jar suspended in the stream and supplied with stream water. Hatching began on May 29, 2012. On day 1 post-hatch, 20 dead and 5 living free embryos were recovered in the pool below the ledge where the channel meets the pool. All unhatched and hatched embryos were put in floating baskets to ensure uniform conditions for growth and development of replacement embryos. The bottom of the pool was covered with black plastic and gravel to reduce potential attraction to the previously white bottom. Ten free embryos ( $2 \mathrm{dph}$ ) from the basket were added to the stream. Within 24 hours, nine were recovered in the gravel dead. Subsequently, 11 additional free embryos age $3 \mathrm{dph}$ added to the stream were all found dead, except for 1 , within 24 hours. Five same-age free embryos ( $3 \mathrm{dph}$ ) from the floating basket were added to the stream for a total of six live free embryos. One of these died on $4 \mathrm{dph}$. On $5 \mathrm{dph}$, no free embryos could be observed in the stream. On $6 \mathrm{dph}$, four living free embryos were recovered from the gravel. Five free embryos 6 dph were added to the stream, and three of these were still alive on $10 \mathrm{dph}$. Daily water temperature averaged $18.3 \pm 0.5^{\circ} \mathrm{C}$, and average dissolved oxygen concentration was $9.1 \pm 0.4 \mathrm{mg} / \mathrm{L}$ during the study.

\section{Trial 3}

On June 22, 2012, GPNFH provided 96 embryos. Of those 96,46 were attached to the rock substrate in the stream and 50 were placed in a McDonald jar in stream. Post-fertilization viability of embryos was 56 percent. Hatching began on $6 \mathrm{dpf}$ (June 28, 2012). As free embryos died, they were replaced with same-age embryos to attempt to maintain five free embryos in the stream. Mortality continued until $7 \mathrm{dph}$ at which time the fish appeared to have settled out of the drift. Daily water temperature averaged $19.3 \pm 0.8^{\circ} \mathrm{C}$, and dissolved oxygen concentration averaged $9.6 \pm 0.3 \mathrm{mg} / \mathrm{L}$.

\section{Trial 4}

A second batch of eggs was fertilized at GPNFH on June 27, 2012. These embryos were shipped to CERC by overnight courier and were, therefore, not attached to a rock substrate. Embryos arrived on July 3, 2012 (6 dpf). Hatching began the next day. On $1 \mathrm{dph}$, five free embryos were added to the stream. Same-age free embryos were added daily to replace dead fish. Mortality ceased on $8 \mathrm{dph}$ at which time fish in the stream appeared to have settled out of the drift. Average daily temperature during the study was $20.1 \pm 0.6^{\circ} \mathrm{C}$, and dissolved oxygen concentration averaged $8.1 \pm 0.3 \mathrm{mg} / \mathrm{L}$.

\section{Temperature and Velocity}

Temperatures in the test stream system were similar among the four trials, whereas water temperature increased slightly between trial 1 and the trial 4 . As a result, cumulative thermal units for days post-hatch were not exactly the same among the trials (fig. 6-2). Overall, average velocity in the tank was $13 \mathrm{~cm} / \mathrm{s}$, the mode was $12 \mathrm{~cm} / \mathrm{s}$, and the median $13.5 \mathrm{~cm} / \mathrm{s}$. The highest mean velocities were at points $\mathrm{A}$ and $\mathrm{E}$ at midwater and the surface $(23-29 \mathrm{~cm} / \mathrm{s}$; table $6-1)$. Lowest mean velocities were at points $\mathrm{A}$ and $\mathrm{E}$ on the inside of the channel nearest the bottom (table 6-1).

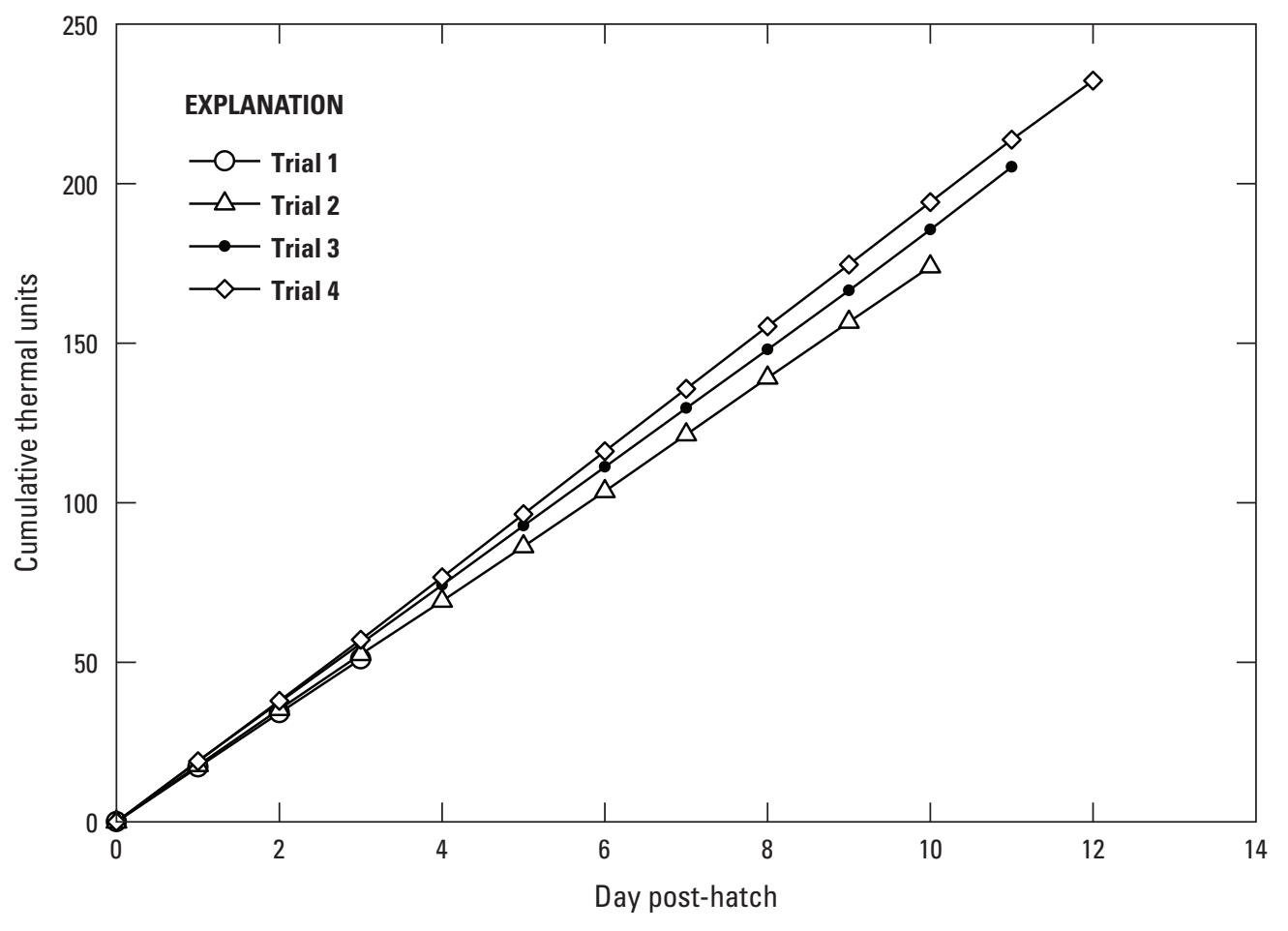

Figure 6-2. Relation between days post-hatch and cumulative thermal units calculated for trials $1-4$. 
Table 6-1. Mean, standard deviation, and range (in parentheses) of velocity in centimeters per second at seven locations (see figure 6-1) in three trials of the artificial stream channel.

$[\mathrm{cm}$, centimeter; \pm , plus or minus $]$

\begin{tabular}{|c|c|c|c|c|c|c|c|c|c|}
\hline \multirow{2}{*}{ Location } & \multicolumn{3}{|c|}{$4 \mathrm{~cm}$ from channel bottom } & \multicolumn{3}{|c|}{$11 \mathrm{~cm}$ from channel bottom } & \multicolumn{3}{|c|}{$20 \mathrm{~cm}$ from channel bottom } \\
\hline & Inside & Middle & Outside & Inside & Middle & Outside & Inside & Middle & Outside \\
\hline A & $\begin{array}{c}-1.3 \pm 0.7 \\
(-1.9--0.5)\end{array}$ & $\begin{array}{c}18.3 \pm 1.3 \\
(17.0-19.5)\end{array}$ & $\begin{array}{c}14.7 \pm 1.0 \\
(13.6-15.7)\end{array}$ & $\begin{array}{c}0.4 \pm 0.8 \\
(-0.1-1.4)\end{array}$ & $\begin{array}{c}24.7 \pm 0.8 \\
(24.0-25.5)\end{array}$ & $\begin{array}{c}16.8 \pm 1.3 \\
(15.3-17.8)\end{array}$ & $\begin{array}{c}4.1 \pm 0.6 \\
(3.5-4.6)\end{array}$ & $\begin{array}{c}16.4 \pm 0.6 \\
(15.7-17.0)\end{array}$ & $\begin{array}{c}27.6 \pm 0.8 \\
(26.8-28.5)\end{array}$ \\
\hline B & $\begin{array}{c}10.1 \pm 0.5 \\
(9.5-10.5)\end{array}$ & $\begin{array}{c}9.5 \pm 0.3 \\
(9.3-9.8)\end{array}$ & $\begin{array}{c}8.7 \pm 1.0 \\
(8.2-9.8)\end{array}$ & $\begin{array}{c}12.6 \pm 0.5 \\
(12.1-12.9)\end{array}$ & $\begin{array}{c}12.0 \pm 0.5 \\
(11.5-12.5)\end{array}$ & $\begin{array}{c}11.2 \pm 0.9 \\
(10.4-12.2)\end{array}$ & $\begin{array}{c}15.4 \pm 0.7 \\
(14.6-15.8)\end{array}$ & $\begin{array}{c}17.2 \pm 0.6 \\
(16.6-17.8)\end{array}$ & $\begin{array}{c}16.7 \pm 0.5 \\
(16.1-17.0)\end{array}$ \\
\hline $\mathrm{C}$ & $\begin{array}{c}13.5 \pm 0.2 \\
(13.4-13.7)\end{array}$ & $\begin{array}{c}13.7 \pm 0.1 \\
(13.6-13.8)\end{array}$ & $\begin{array}{c}14.6 \pm 0.5 \\
(14.2-15.1)\end{array}$ & $\begin{array}{c}12.9 \pm 0.0 \\
(12.8-12.9)\end{array}$ & $\begin{array}{c}12.5 \pm 0.5 \\
(12.0-13.0)\end{array}$ & $\begin{array}{c}14.1 \pm 0.2 \\
(13.0-14.3)\end{array}$ & $\begin{array}{c}12.2 \pm 0.4 \\
(11.8-12.6)\end{array}$ & $\begin{array}{c}11.4 \pm 0.5 \\
(10.8-11.8)\end{array}$ & $\begin{array}{c}13.8 \pm 0.4 \\
(13.4-14.2)\end{array}$ \\
\hline $\mathrm{D}$ & $\begin{array}{c}15.8 \pm 1.0 \\
(15.3-17.0)\end{array}$ & $\begin{array}{c}3.3 \pm 0.6 \\
(2.6-3.8)\end{array}$ & $\begin{array}{c}17.0 \pm 0.1 \\
(17.0-17.1)\end{array}$ & $\begin{array}{c}14.2 \pm 0.4 \\
(13.8-14.5)\end{array}$ & $\begin{array}{c}6.9 \pm 0.7 \\
(6.2-7.5)\end{array}$ & $\begin{array}{c}16.2 \pm 0.7 \\
(15.7-17.0)\end{array}$ & $\begin{array}{c}10.8 \pm 0.3 \\
(10.5-11.0)\end{array}$ & $\begin{array}{c}5.6 \pm 1.0 \\
(4.6-6.7)\end{array}$ & 15 \\
\hline $\mathrm{E}$ & $\begin{array}{c}-0.2 \pm 1.8 \\
(-1.9-1.7)\end{array}$ & $\begin{array}{c}11.5 \pm 0.7 \\
(10.7-12.0)\end{array}$ & $\begin{array}{c}12.3 \pm 1.8 \\
(10.3-13.7)\end{array}$ & $\begin{array}{c}1.8 \pm 3.3 \\
(-1.4-5.2)\end{array}$ & $\begin{array}{c}18.9 \pm 0.8 \\
(18.2-19.7)\end{array}$ & $\begin{array}{c}19.7 \pm 3.7 \\
(15.8-23.2)\end{array}$ & $\begin{array}{c}6.5 \pm 0.7 \\
(6.0-7.3)\end{array}$ & $\begin{array}{c}24.8 \pm 1.5 \\
(23.4-26.3)\end{array}$ & $\begin{array}{c}20.5 \pm 1.1 \\
(19.3-21.4)\end{array}$ \\
\hline $\mathrm{F}$ & $\begin{array}{c}17.9 \pm 0.8 \\
(17.4-18.7)\end{array}$ & $\begin{array}{c}17.3 \pm 0.2 \\
(17.2-17.5)\end{array}$ & 12.5 & $\begin{array}{c}20.3 \pm 0.5 \\
(19.9-20.8)\end{array}$ & $\begin{array}{c}15.9 \pm 0.4 \\
(15.5-16.4)\end{array}$ & $\begin{array}{c}11.0 \pm 0.4 \\
(10.6-11.5)\end{array}$ & $\begin{array}{c}20.6 \pm 0.5 \\
(20.1-20.9)\end{array}$ & $\begin{array}{c}8.6 \pm 0.6 \\
(7.9-9.1)\end{array}$ & $\begin{array}{c}6.8 \pm 0.4 \\
(6.5-7.3)\end{array}$ \\
\hline G & $\begin{array}{c}16.5 \pm 0.7 \\
(16.0-17.3)\end{array}$ & $\begin{array}{c}13.0 \pm 0.2 \\
(12.8-13.3)\end{array}$ & $\begin{array}{c}10.4 \pm 0.6 \\
(9.8-11.0)\end{array}$ & $\begin{array}{c}17.0 \pm 0.3 \\
(16.7-17.4)\end{array}$ & $\begin{array}{c}13.7 \pm 0.1 \\
(13.5-13.8)\end{array}$ & $\begin{array}{c}11.6 \pm 0.4 \\
(11.2-12.0)\end{array}$ & $\begin{array}{c}16.8 \pm 0.5 \\
(16.5-17.4)\end{array}$ & $\begin{array}{c}13.3 \pm 0.2 \\
(13.1-17.4)\end{array}$ & $\begin{array}{c}11.6 \pm 0.4 \\
(11.2-12.0)\end{array}$ \\
\hline
\end{tabular}




\section{Mortality}

Mortality increased until $4 \mathrm{dph}$, and then began to decrease. After day 7 or day 8 mortality had ceased in individual trials (fig. 6-3). Dead fish were exclusively found on the bottom of the pool in an eddy most commonly at the juncture of the channel with the pool. A video camera placed at this location recorded moribund free embryos twitching and spinning on the bottom of the pool for as much as 18 hours before dying. Dead free embryos recovered at $3 \mathrm{dph}$ showed signs of edema and hemorrhage. A subsample of free embryos $6 \mathrm{dph}$ was sent to the U.S. Fish and Wildlife Service, Fish Health Center in LaCrosse, Wisconsin, where it was determined that the fish were disease- and iridovirus-free (Corey Puzach, oral commun., 2012).

\section{Drift, Position, Stamina}

Until 6 dph, very few free embryos drifted across the observation platform, and peak drifting was observed between 6 and 9 dph (fig. 6-4). After 9 dph, observations of drifting free embryos decreased. Observations indicated the fish were beginning to hold position in the stream on the bottom of the tank. In the pool, free embryos were most often observed at the bottom of the tank below where the channel attached to the pool and in the eddy created by the plexiglass 'dike' (fig. 6-5). An analysis on ranks of the mean number of free embryos to pass the observation depth tiles for trials 2,3 , and 4 indicated differences in position associated with days post-hatch, but not time of day (Kruskal-Wallis rank sum test, $p$ less than $(<) 0.05)$. From 1 dph through $7 \mathrm{dph}$, free embryos were more likely to be observed in the bottom third of the tank (significant differences on 1, 4, 5, 6, and 7 dph) (fig. 6-6). After $7 \mathrm{dph}$, free embryos were more likely to be observed drifting past the observation tiles at the surface (significant $11 \mathrm{dph}$ ) (fig. 6-6). While there were changes in vertical position through time, a difference in lateral position within the stream tank was noted only at $7 \mathrm{dph}$ when more fish were observed midstream than at the inside bend position (data not shown).

In swim tunnel studies, larval sturgeon $11 \mathrm{dph}$ withstood a current of as much as $30 \pm 5 \mathrm{~cm} / \mathrm{s}$ for $12 \pm 4$ minutes. Larval sturgeon at $13 \mathrm{dph}$ withstood a current of as much as $39 \pm 3 \mathrm{~cm} / \mathrm{s}$ for $16 \pm 2$ minutes, and those at $15 \mathrm{dph}$ withstood a current of as much as $38 \pm 3 \mathrm{~cm} / \mathrm{s}$ for $14 \pm 2$ minutes. Sturgeon younger than $11 \mathrm{dph}$ and smaller than $18 \mathrm{~mm}$ could not be tested because they were too small for the chamber.

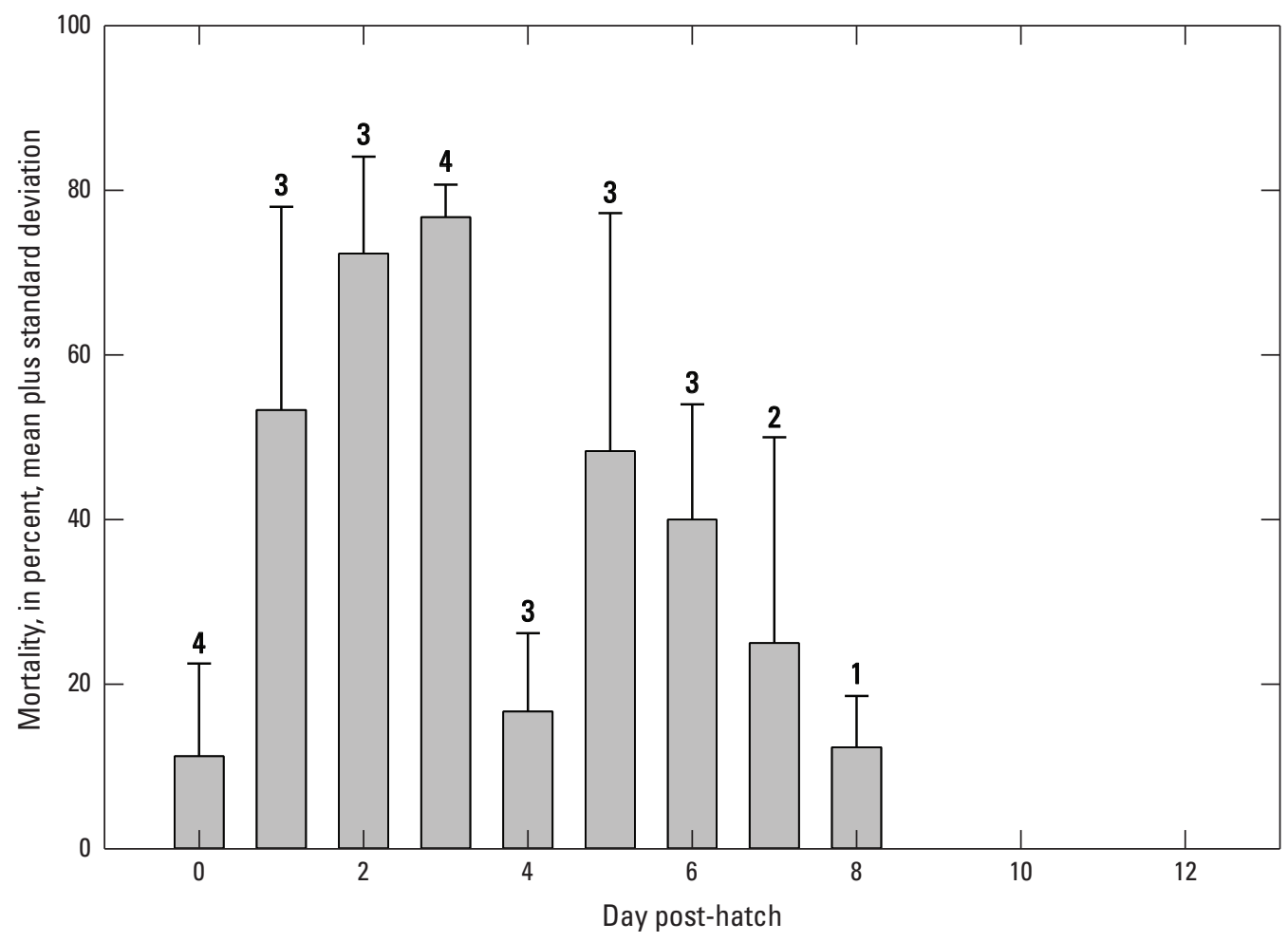

Figure 6-3. Percent mortality (mean and standard deviation) of pallid sturgeon free embryos per days post-hatch. Numbers above the bars indicate the number of trials. 


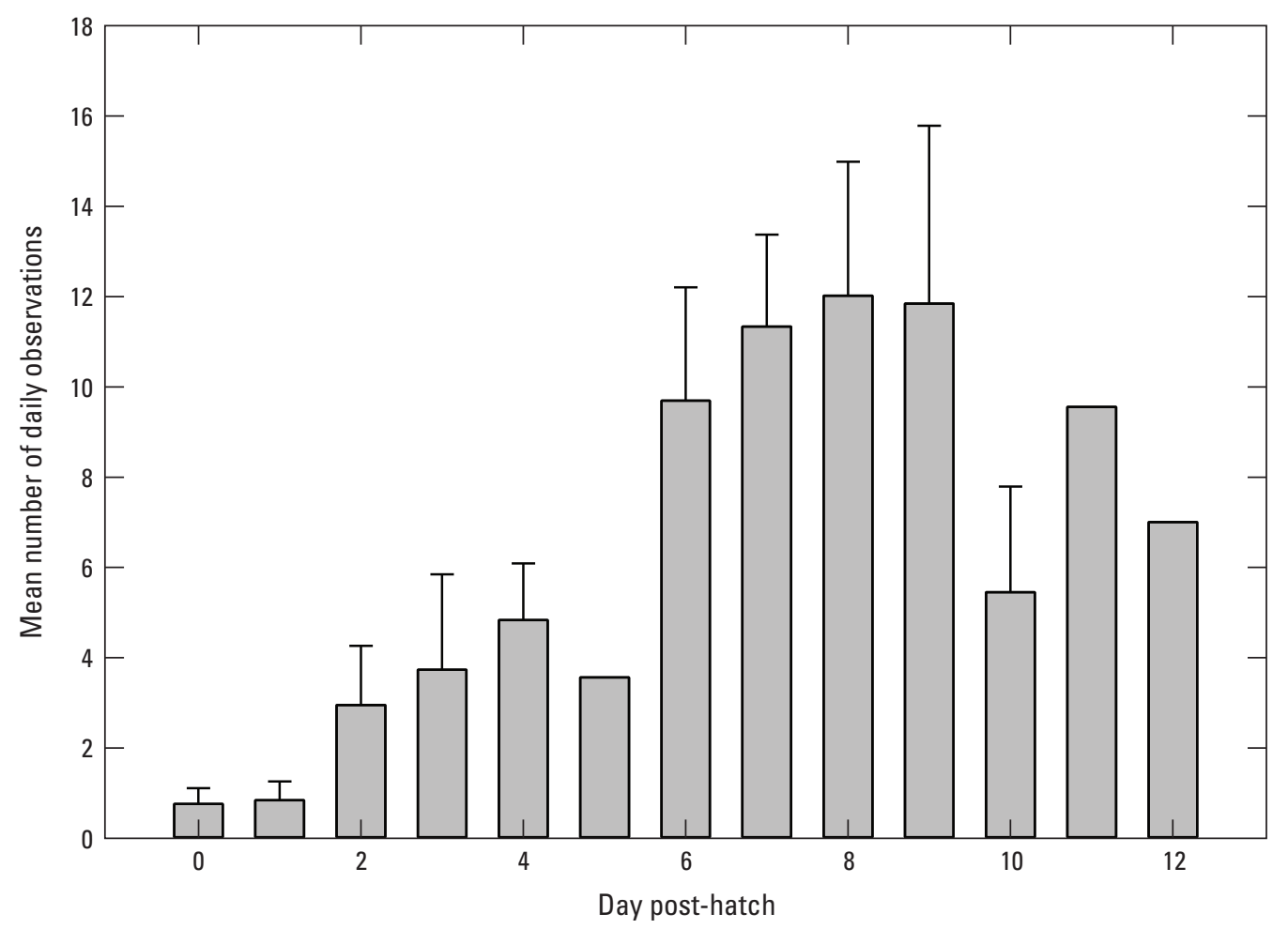

Figure 6-4. Daily observations (mean and standard deviation) of free embryos drifting past a fixed point normalized to the number of free embryos in the stream, $0-12$ days post-hatch.

Figure 6-5. Frequency of free embryos near the pool ledge and dike eddy as percent of the total number of observations during each trial.

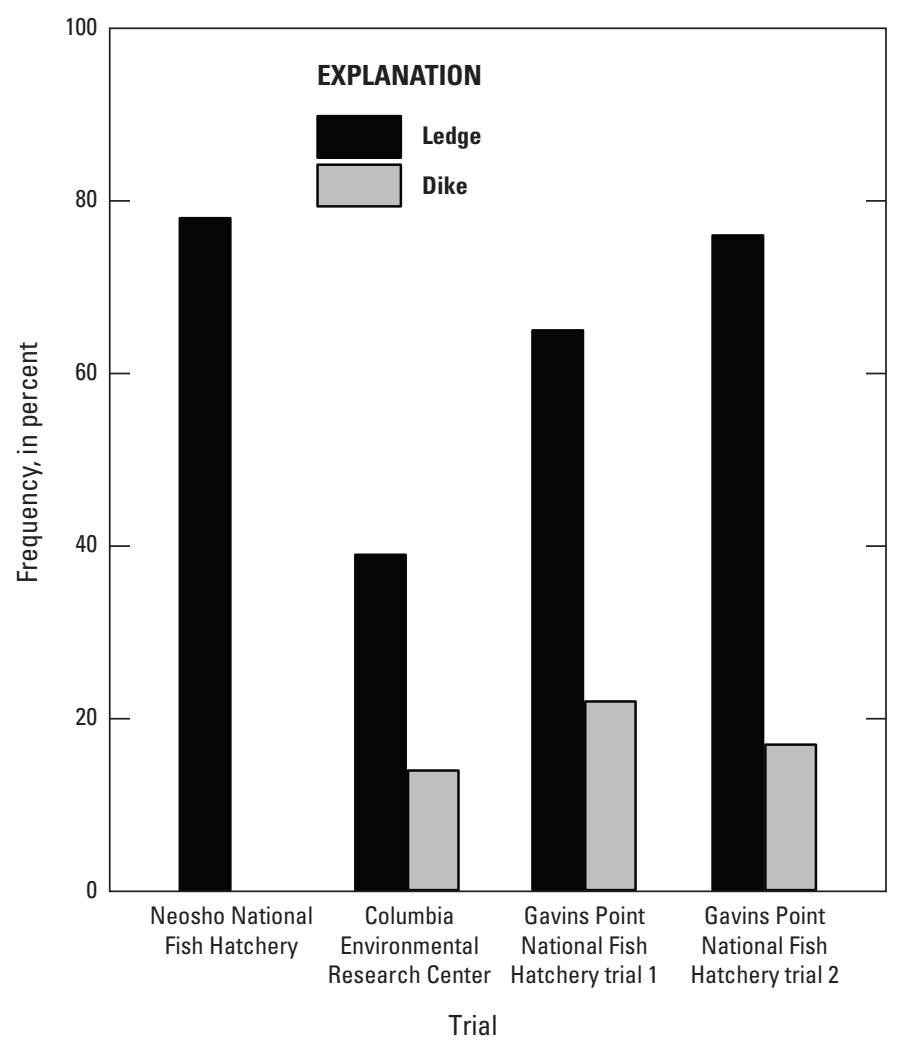




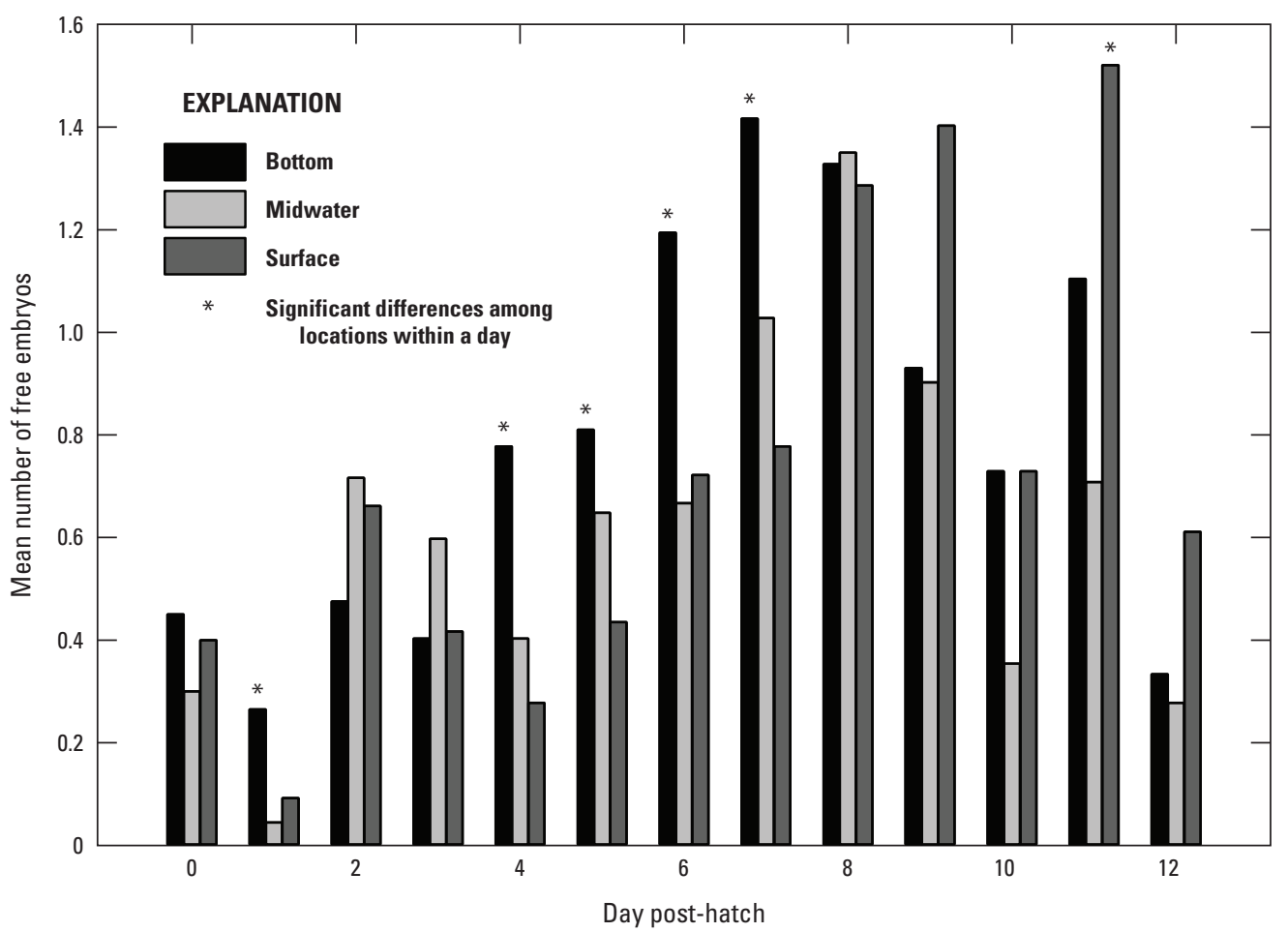

Figure 6-6. Mean number of drifting free embryos and water column positions recorded at a fixed point per days post-hatch. Asterisks indicate significant differences among locations within a day.

\section{Summary}

In this set of experimental trials the drift of free embryos was diminished for about 6 days post-hatch, apparently by enhanced mortality of very young free embryos. Drift peaked 6-9 days post-hatch as surviving free embryos were transported, mostly passively, around the experimental stream tank. After 9 days post-hatch free embryos had developed the ability to hold their position in the current at prevailing velocities. These results indicate that the first several days post-hatch are critical to survival. Many factors could have contributed to the early mortality experienced in these initial trials; however, the possibility that continuous drift at velocities as low as 20 centimeters per second may be stressful to free embryos should be explored. In a natural river environment mean velocities and turbulence would be substantially higher but there would also be diverse microhabitats in and among substrate that could serve as refugia. If $0-6$ days post-hatch free embryos were in such sheltered areas, they would have decreased energetic demands, and could have greater survival than those in the experimental stream.

\section{References Cited}

Kynard, B., Parker, E., Pugh, D., and Parker, T., 2007, Use of laboratory studies to develop a dispersal model for Missouri River pallid sturgeon early life intervals: Journal of Applied Ichthyology, v. 23, p. 365-374. [Also available at http:// dx.doi.org/10.1111/j.1439-0426.2007.00908.x.] 


\section{Appendix 7. Field Studies of Scaphirhynchus Sturgeon Embryo, Larvae, and Young-of-Year Dispersal, Distribution, and Habitat Use in the Lower Missouri River}

\section{Background}

Recruitment of pallid sturgeon (Scaphirhynchus albus) to the adult population is limited or nonexistent throughout most of the Missouri River (U.S. Fish and Wildlife Service, 2007). Limited numbers of larval and young-of-year sturgeon have been collected from the Lower Missouri River; samples collected prior to this study have been genetically confirmed to be entirely shovelnose. The low numbers of young sturgeon in Lower Missouri River samples may be explained by limited spawning, lack of successful spawning, poor fertilization, high mortality, ineffective sampling methods, inadequate sampling of drift and settling locations, or rapid dispersal and transport of sturgeon free embryos from the Missouri River into the Mississippi River. Although documentation of spawning by pallid sturgeon is a critical first step towards assessing population status and recovery, successful spawning does not ensure successful recruitment to the juvenile or adult life stages. Rather, biotic and abiotic factors operating during the free-embryo life stage (hatch to exogenous feeding) may limit survival and population growth (Dettlaff and others, 1993). This life stage commonly functions as a recruitment bottleneck for fishes because of decreased mobility and sensory ability, and increased vulnerability to anthropogenic environmental alteration (Scheidegger and Bain, 1995; Humphries and others, 2002). Given the sensitivity of the free-embryo life stage to mortality, it is imperative to identify determinants of post-hatch survival in shovelnose and pallid sturgeon (Bajer and Wildhaber, 2007; Wildhaber and others, 2007, 2011; Steffensen and others, 2013). Identification of critical environmental factors, developmental or behavioral changes, or habitat requirements during the free-embryo life stage can be used to enhance pallid sturgeon recovery efforts.

Shovelnose and pallid sturgeon begin to hatch in the laboratory after 4 to 5 days at $17-18$ degrees Celsius $\left({ }^{\circ} \mathrm{C}\right)$. After hatching, laboratory studies suggest that shovelnose sturgeon (Scaphirhynchus platorynchus) drift for a period of as much as 6 days and pallid sturgeon free embryos drift for 11-17 days (Kynard and others, 2007; Braaten and others, 2008); however, recent studies using modified laboratory systems more representative of a natural river incubation site have raised questions on findings on drift behavior from the earlier studies (see "Appendix 6"). Benthic orientation and feeding begins near the end of the free-drifting period. The total distance that sturgeon free embryos drift during ontogenetic development is dependent on substrate conditions, water velocity, localized hydraulic conditions, and temperature (Kynard and others, 2007; Braaten and others, 2008). Mean velocities measured on the Missouri River are typically $0.4-1.2$ meters per second $(\mathrm{m} / \mathrm{s})$ (Reuter and others, 2009). If localized hydraulics do not result in retention in channel margins, the prolonged drift period of free embryo sturgeon and the prevailing Missouri River velocities may require a long segment of free-flowing river to complete the ontogenetic drift cycle. If, as newer studies are showing for other sturgeon species, free embryos do not drift immediately and instead remain in close proximity to incubation sites, then hypotheses regarding long-distance drift before feeding are invalid. Authors have suggested that free embryos that drift into the headwaters of reservoirs probably do not survive (Kynard and others, 2007). The probability and benefits of retention in channel margins, rather than direct downstream transport in the thalweg, is an unknown, but critical factor in determining effective drift distance. The number of sturgeon free embryos produced in the Lower Missouri River, the proportion retained, and the proportion of those that are transported into the Mississippi River, and survive there, are unknown quantities. Locations along the channel where drifting sturgeon embryos are retained, or settle, and the availability of suitable habitat for early feeding may be critical for survival and recruitment.

\section{Scope and Objectives}

During 2011, habitat studies began to develop the hydraulic and geomorphic context of free embryo drift and potential settling areas where free embryos may be extracted from the main channel or where exogenously feeding larvae may swim under their own volition. This work was coordinated with an age-0-juvenile sampling program being carried out by the U.S. Fish and Wildlife Service (FWS, Columbia Fisheries) that is intended to assess performance of shallowwater habitat restoration projects. This ongoing research is intended to address the potential for young sturgeon to be retained within the Lower Missouri River, but the design is not intended to evaluate the export of young sturgeon out of the Lower Missouri River. To evaluate export to the Mississippi River a systematic free-embryo sampling effort was done from mid-April through early-October near the confluence with the Mississippi River. The objectives of this initial study were the following: (1) to determine our power to detect drifting freeembryo sturgeon in the Lower Missouri River, (2) to determine the timing and spatial extent of sturgeon spawning in the Lower Missouri River, (3) to assess the species composition of sturgeon embryos in the Lower Missouri River, and (4) to assess the export of early life-stage sturgeon into the Mississippi River based upon our power to detect sturgeon embryos. This work was completed in the Lower Missouri River 33.3 miles (mi) upstream of the confluence with the Mississippi River near St. Charles, Missouri (fig. 7-1). This work was designed to evaluate the contribution of early life stage 
sturgeon from the Missouri River to the Mississippi River and provide some relative indication of the importance of the Mississippi River as nursery habitat for young-of-year shovelnose and pallid sturgeon.

\section{Methods}

Since 2009, sampling efforts for the Comprehensive Sturgeon Research Project (CSRP) have focused on capturing newly hatched and drifting free embryos immediately downstream of probable pallid sturgeon spawning sites. This sampling design has been termed "verification sampling" because it was intended only to verify hatch of newly spawned embryos. "Systematic sampling" for free-embryo and larval sturgeon was initiated in 2012 to assess export of young sturgeon from the Lower Missouri River to the Mississippi River. A suitable sampling site was identified near St. Charles, Mo., downstream of the last major tributary on the Lower Missouri River and upstream of the confluence with the Mississippi River. The sampling site was representative of cross-sections of the Lower Missouri River with the thalweg on the outside bend and a wing dike-sand bar complex on the inside bend. It was not affected by backwater from the Mississippi River during high-water events and had little commercial vessel traffic. Systematic sampling focused on a single channel cross-section to provide a relative indication of the importance of the Mississippi River as nursery habitat for young-of-year shovelnose and pallid sturgeon spawned in the Missouri River. A transect with eight equidistant sampling stations was established across the river channel (fig. 7-1).

Systematic sampling for free-drifting embryos in the Lower Missouri River began in mid-April and continued through early-October 2012. Conditions suitable for sturgeon spawning are expected to vary along the length of the Lower Missouri River and potentially among the various tributaries. The sampling period was designed to capture drifting embryos that might be spawned early in the main stem Missouri River near the confluence with the Mississippi River, and later in the Missouri River nearer the Gavins Point Dam and in tributaries. Sampling for drifting free embryos into October was designed to detect spawning episodes that may be delayed because of unusual or altered environmental conditions. Late sampling also may detect the presence of fall spawning within the population.

An 8-meter (m) research vessel outfitted with paired booms and winches was deployed to sample the stations along the transect at daily to biweekly intervals. The research vessel was anchored during net deployment ("passive sampling"). Paired, 0.5 -m diameter ichthyoplankton nets (750 micrometer $[\mu \mathrm{m}]$ mesh) were equipped with General Oceanics velocity meters and attached to 100-pound (lb) (45.4 kilograms [kg]) Columbus-style sounding weights. Samples were collected just above the river bottom and at midwater column. The sample duration was 5 to 20 minutes depending on the amount of coarse organic material in the water column during the sampling effort. In the interest of safety, samples were not collected during periods of high flow or heavy debris loading. Additionally, midwater column samples were not collected if water depth was less than $2 \mathrm{~m}$. Velocities and depths along each transect were determined at representative flows using an acoustic Doppler current profiler (ADCP; see "Appendix 3"). Representative flows were within 10 percent of discharges on sampling dates.

Ichthyoplankton samples were sorted on board the research vessel shortly after collection. All free embryos identified as sturgeon (Scaphirhynchus spp.) or paddlefish (Polyodon spathula) were preserved in 70-percent ethanol for more precise identification in the laboratory. Developmental characteristics were examined in the laboratory and used to identify individual specimens to genus and developmental stage if condition allowed. Scaphirhynchus free embryos were sent for species determination using genetic analyses at Southern Illinois University Carbondale.

\section{Results}

Preliminary sampling was done in the vicinity of the site from April 17 through 19, 2012, to test collection protocols and refine the location of the transect and stations based on local conditions. During these 3 days of pilot sampling, 4 sturgeon and 22 paddlefish free embryos and larvae were collected and preserved in 70-percent ethanol. The length of sturgeon ranged from 7.88 millimeters $(\mathrm{mm})$ to $10.09 \mathrm{~mm}$. Size and developmental characteristics indicated that the sturgeon were approximately 1 day post-hatch or younger. The length of paddlefish ranged from $8.58 \mathrm{~mm}$ (estimated as less than 1 day post-hatch) to $15.43 \mathrm{~mm}$ (estimated at 8 to 11 days post-hatch). Water temperatures recorded during this time ranged from $14.9^{\circ} \mathrm{C}$ to $16.2^{\circ} \mathrm{C}$. The four sturgeon were later sent to Southern Illinois University Carbondale for genetic species determination. These specimens were collected prior to the establishment of the transect and sampling stations, and are not included in the analysis for this report.

Eight equidistant sampling stations were established along the transect across the channel of the Missouri River near St. Charles, Mo. (fig. 7-1). The stations were sampled for 65 days between April 23 and October 4, 2012. The number of sampling days at each station varied because of river conditions and associated safety concerns (table 7-1). Stations 1, 2, and 3 could not be sampled during summer and fall 2012 because of drought conditions and subsequent low flows in the Lower Missouri River. Sampling at these stations was discontinued when water depth dropped below approximately $0.75 \mathrm{~m}$ during late May or early June. Station 7 was only sampled on 3 days (May 22, 23, and 24, 2012) because of safety concerns associated with anchoring the research vessel in the swift current velocities of the navigation channel (greater than $[>] 2.5$ meters per second $[\mathrm{m} / \mathrm{s}],>10 \mathrm{~m}$ deep). Station 8 was not sampled because the relative proximity to the revetment made anchoring the research vessel impractical. Sampling period and numbers of sturgeon and paddlefish collected at each station are summarized in table $7-1$. 


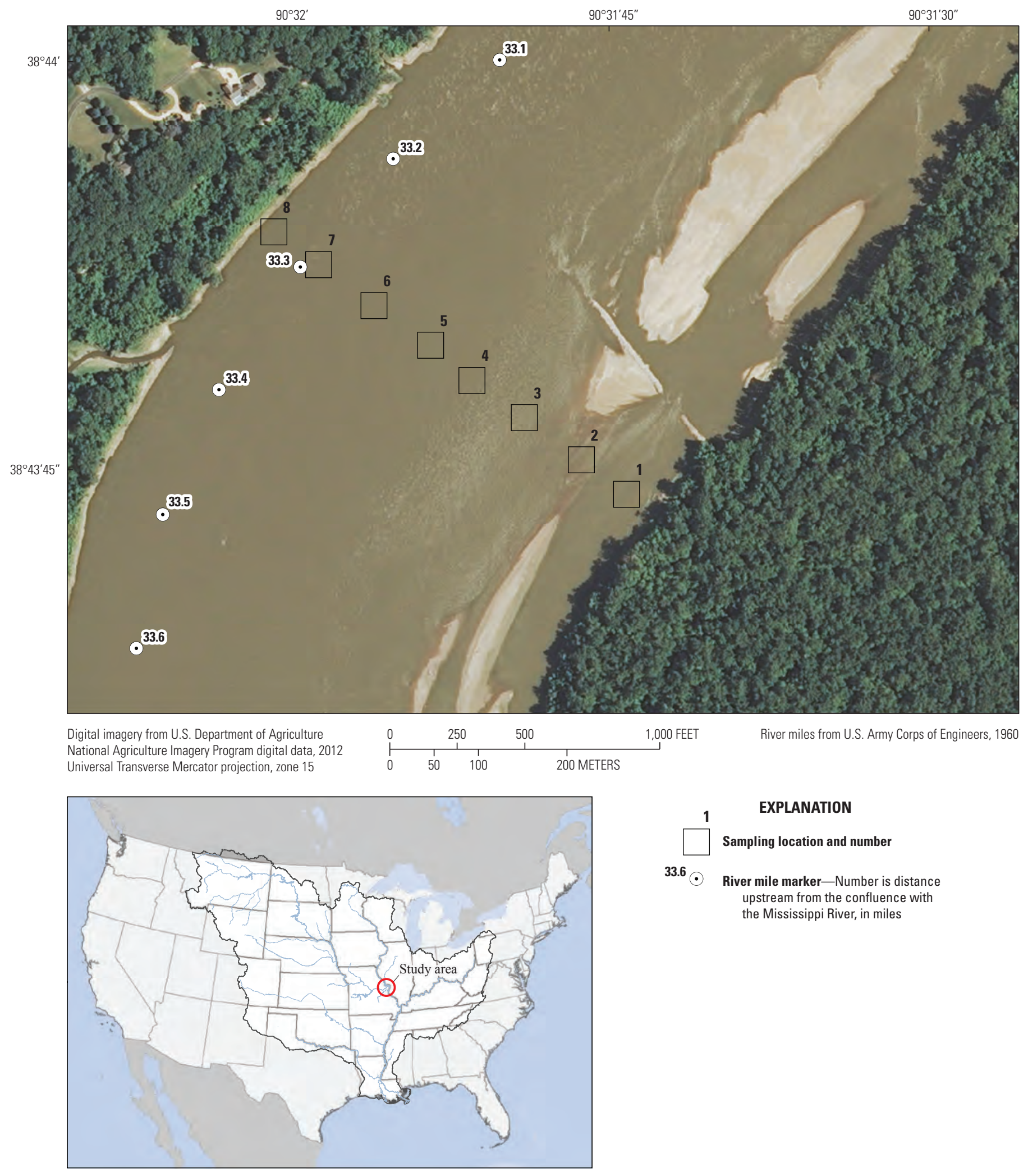

Figure 7-1. Free-embryo sampling locations in the Lower Missouri River, near river mile 33.3. 
Table 7-1. Summary of sturgeon and paddlefish free embryo and larvae collection efforts in the Missouri River near St. Charles, Missouri, during 2012.

\begin{tabular}{cccccc}
\hline Station & $\begin{array}{c}\text { First date } \\
\text { sampled }\end{array}$ & $\begin{array}{c}\text { Last date } \\
\text { sampled }\end{array}$ & $\begin{array}{c}\text { Number } \\
\text { days } \\
\text { sampled }\end{array}$ & $\begin{array}{c}\text { Number } \\
\text { sturgeon } \\
\text { collected }\end{array}$ & $\begin{array}{c}\text { Number } \\
\text { paddlefish } \\
\text { collected }\end{array}$ \\
\hline 1 & $4 / 24 / 2012$ & $5 / 22 / 2012$ & 8 & 1 & 15 \\
2 & $4 / 24 / 2012$ & $5 / 17 / 2012$ & 11 & 5 & 21 \\
3 & $4 / 24 / 2012$ & $6 / 7 / 2012$ & 18 & 14 & 42 \\
4 & $4 / 24 / 2012$ & $10 / 4 / 2012$ & 60 & 16 & 31 \\
5 & $4 / 23 / 2012$ & $10 / 4 / 2012$ & 65 & 23 & 61 \\
6 & $4 / 23 / 2012$ & $10 / 4 / 2012$ & 63 & 186 & 109 \\
7 & $5 / 22 / 2012$ & $5 / 24 / 2012$ & 3 & 91 & 44 \\
\hline
\end{tabular}

A total of 336 sturgeon and 323 paddlefish free embryos and larvae was collected at the 7 stations during 2012 sampling efforts. Of these, 321 sturgeon were collected at the 7 stations from April 24 to June 18 (tables 7-2 to 7-8). Water temperatures during this time ranged from $14.8^{\circ} \mathrm{C}$ to $27.2^{\circ} \mathrm{C}$. The length of sturgeon collected during this time ranged from $6.67 \mathrm{~mm}$ (estimated as less than 1 day post-hatch [dph]) to $35 \mathrm{~mm}$ (estimated at 30 or more dph; fig. 7-2). All 323 paddlefish were collected from April 23 to June 12 (tables 7-2-7-8). Water temperatures during this time ranged from $14.8^{\circ} \mathrm{C}$ to $24.6{ }^{\circ} \mathrm{C}$. The length of paddlefish collected during this time ranged from $7 \mathrm{~mm}$ (estimated as less than $1 \mathrm{dph}$ ) to $49 \mathrm{~mm}$ (estimated at 35 or more dph; fig. 7-3). No paddlefish were collected after June 12, 2012.

A total of 15 sturgeon was collected from late June through September 2012. Two sturgeon were found at station 6 during early summer on June 26 and 27 (table 7-7) when recorded water temperatures ranged from about $26.1^{\circ} \mathrm{C}$ to $27^{\circ} \mathrm{C}$. Size and developmental characteristics indicated that both sturgeon were approximately 12 or more dph. No sturgeon were found during 14 sampling days from July 9 to August 22 when water temperatures ranged from $31{ }^{\circ} \mathrm{C}$ to $25.3{ }^{\circ} \mathrm{C}$. During late summer and early fall, 13 sturgeon were collected during 6 sampling days from August 22 to September 20 at station 6; no sturgeon were collected at station 4 or 5 (tables 7-5 and 7-6). Water temperatures during this time ranged from a high of $26.3^{\circ} \mathrm{C}$ to a low of $21.2^{\circ} \mathrm{C}$. The length of the sturgeon free embryos and larvae collected during late summer ranged from $7.14 \mathrm{~mm}$ (estimated as less than 1 day post-hatch) to $36 \mathrm{~mm}$ (estimated at 30 or more dph; fig. 7-2).

Numbers and mean density of sturgeon and paddlefish collected varied among sampling stations (tables 7-2 to 7-10). Sturgeon were found in highest numbers and densities near and in the thalweg at stations 6 and 7. Mean density of sturgeon was highest at station 7 (2.71 sturgeon/100 cubic meters $\left[\mathrm{m}^{3}\right]$ ) where 91 were collected during 3 days of sampling in May (table 7-9). Excluding station 7, mean density of sturgeon was highest at station $6\left(0.23 / 100 \mathrm{~m}^{3}\right)$ where 186 sturgeon were collected during 63 sampling days. Mean density of sturgeon was less than or equal to 0.10 sturgeon $/ 100 \mathrm{~m}^{3}$ at stations $1-5$. Mean density of sturgeon was lowest at station $1\left(0.02\right.$ sturgeon $\left./ 100 \mathrm{~m}^{3}\right)$ where only one was collected during 8 sampling days. Mean density of paddlefish was also highest at station $7\left(1.34\right.$ paddlefish $\left./ 100 \mathrm{~m}^{3}\right)$ during the 3 sampling days; however, paddlefish were more dispersed among all stations than were sturgeon (table 7-10). Paddlefish were collected in higher numbers than sturgeon at all stations except 6 and 7. Paddlefish were not found after June 12.

Densities of free embryos and larvae sampled during 2012 varied with time among sampling stations and dates (tables 7-9 and 7-10). The highest mean density of sturgeon was recorded at station 7 on May 23 with 3.22 sturgeon/100 $\mathrm{m}^{3}$, closely followed by May 22 and 24, each with 2.45 sturgeon $/ 100 \mathrm{~m}^{3}$ (table 7-9); however, this station

Table 7-2. Summary of free embryo and larval sturgeon and paddlefish collected in the Missouri River at station 1.

[--, no data; mm, millimeters $]$

\begin{tabular}{|c|c|c|c|c|c|c|c|c|}
\hline \multirow[b]{2}{*}{$\begin{array}{c}\text { Collection } \\
\text { date }\end{array}$} & \multicolumn{4}{|c|}{ Sturgeon } & \multicolumn{4}{|c|}{ Paddlefish } \\
\hline & $\begin{array}{l}\text { Number } \\
\text { collected }\end{array}$ & $\begin{array}{l}\text { Mean } \\
\text { length, } \\
\text { in mm }\end{array}$ & $\begin{array}{l}\text { Minimum } \\
\text { length, } \\
\text { in mm }\end{array}$ & $\begin{array}{l}\text { Maximum } \\
\text { length, } \\
\text { in } \mathbf{m m}\end{array}$ & $\begin{array}{l}\text { Number } \\
\text { collected }\end{array}$ & $\begin{array}{l}\text { Mean } \\
\text { length, } \\
\text { in mm }\end{array}$ & $\begin{array}{l}\text { Minimum } \\
\text { length, } \\
\text { in } \mathrm{mm}\end{array}$ & $\begin{array}{c}\text { Maximum } \\
\text { length, } \\
\text { in } \mathrm{mm}\end{array}$ \\
\hline $4 / 24 / 2012$ & -- & -- & -- & -- & -- & -- & -- & -- \\
\hline $4 / 25 / 2012$ & -- & -- & -- & -- & 2 & 12.49 & 12.12 & 12.85 \\
\hline $5 / 2 / 2012$ & 1 & 6.89 & 6.89 & 6.89 & 7 & 14.73 & 12.47 & 16.76 \\
\hline $5 / 8 / 2012$ & -- & -- & -- & -- & 2 & 20.02 & 17.03 & 23 \\
\hline $5 / 9 / 2012$ & -- & -- & -- & -- & -- & -- & -- & -- \\
\hline $5 / 15 / 2012$ & -- & -- & -- & -- & 2 & 25 & 21 & 29 \\
\hline $5 / 16 / 2012$ & -- & -- & -- & -- & 2 & 25 & 24 & 26 \\
\hline $5 / 22 / 2012$ & -- & -- & -- & -- & -- & -- & -- & -- \\
\hline
\end{tabular}


Table 7-3. Summary of free embryo and larval sturgeon and paddlefish collected in the Missouri River at station 2.

$[--$, no data; mm, millimeters $]$

\begin{tabular}{|c|c|c|c|c|c|c|c|c|}
\hline \multirow[b]{2}{*}{$\begin{array}{l}\text { Collection } \\
\text { date }\end{array}$} & \multicolumn{4}{|c|}{ Sturgeon } & \multicolumn{4}{|c|}{ Paddlefish } \\
\hline & $\begin{array}{l}\text { Number } \\
\text { collected }\end{array}$ & $\begin{array}{c}\text { Mean } \\
\text { length, } \\
\text { in } \mathrm{mm}\end{array}$ & $\begin{array}{l}\text { Minimum } \\
\text { length, } \\
\text { in } \mathbf{~ m m}\end{array}$ & $\begin{array}{l}\text { Maximum } \\
\text { length, } \\
\text { in } \mathbf{~ m m}\end{array}$ & $\begin{array}{l}\text { Number } \\
\text { collected }\end{array}$ & $\begin{array}{l}\text { Mean } \\
\text { length, } \\
\text { in mm }\end{array}$ & $\begin{array}{l}\text { Minimum } \\
\text { length, } \\
\text { in mm }\end{array}$ & $\begin{array}{c}\text { Maximum } \\
\text { length, } \\
\text { in } \mathbf{~ m m}\end{array}$ \\
\hline $4 / 24 / 2012$ & -- & -- & -- & -- & 1 & 14.46 & 14.46 & 14.46 \\
\hline $4 / 25 / 2012$ & -- & -- & -- & -- & -- & -- & -- & -- \\
\hline $4 / 26 / 2012$ & -- & -- & -- & -- & -- & -- & -- & -- \\
\hline $5 / 1 / 2012$ & 2 & 5.7 & 13.49 & 7.91 & 5 & 13.95 & 12.85 & 15.49 \\
\hline $5 / 2 / 2012$ & 1 & 7.16 & 7.16 & 7.16 & 4 & 13.47 & 13.19 & 13.84 \\
\hline $5 / 3 / 2012$ & -- & -- & -- & -- & 7 & 13.96 & 12.37 & 14.63 \\
\hline $5 / 8 / 2012$ & 1 & 15.06 & 15.06 & 15.06 & 1 & 22 & 22 & 22 \\
\hline $5 / 9 / 2012$ & 1 & 16.83 & 16.83 & 16.83 & -- & -- & -- & -- \\
\hline $5 / 15 / 2012$ & -- & -- & -- & -- & 2 & 25.5 & 24 & 27 \\
\hline $5 / 16 / 2012$ & -- & -- & -- & -- & 1 & 23 & 23 & 23 \\
\hline $5 / 17 / 2012$ & -- & -- & -- & -- & -- & -- & -- & -- \\
\hline
\end{tabular}

${ }^{1}$ Partial specimen.

Table 7-4. Summary of free embryo and larval sturgeon and paddlefish collected in the Missouri River at station 3.

[--, no data; mm, millimeters]

\begin{tabular}{|c|c|c|c|c|c|c|c|c|}
\hline \multirow[b]{2}{*}{$\begin{array}{l}\text { Collection } \\
\text { date }\end{array}$} & \multicolumn{4}{|c|}{ Sturgeon } & \multicolumn{4}{|c|}{ Paddlefish } \\
\hline & $\begin{array}{l}\text { Number } \\
\text { collected }\end{array}$ & $\begin{array}{l}\text { Mean } \\
\text { length, } \\
\text { in mm }\end{array}$ & $\begin{array}{l}\text { Minimum } \\
\text { length, } \\
\text { in mm }\end{array}$ & $\begin{array}{l}\text { Maximum } \\
\text { length, } \\
\text { in mm }\end{array}$ & $\begin{array}{l}\text { Number } \\
\text { collected }\end{array}$ & $\begin{array}{l}\text { Mean } \\
\text { length, } \\
\text { in mm }\end{array}$ & $\begin{array}{l}\text { Minimum } \\
\text { length, } \\
\text { in mm }\end{array}$ & $\begin{array}{c}\text { Maximum } \\
\text { length, } \\
\text { in mm }\end{array}$ \\
\hline $4 / 24 / 2012$ & -- & -- & -- & -- & 2 & 13.92 & 12.76 & 15.07 \\
\hline $4 / 25 / 2012$ & 1 & 7.46 & 7.46 & 7.46 & 2 & 12.98 & 11.22 & 14.74 \\
\hline $4 / 26 / 2012$ & 1 & 6.96 & 6.96 & 6.96 & 3 & 11.56 & 8.08 & 14.11 \\
\hline $5 / 1 / 2012$ & 7 & 7.76 & 7.06 & 8.21 & 18 & 13.42 & 8.2 & 14.95 \\
\hline $5 / 2 / 2012$ & 2 & 8.41 & 8.28 & 8.54 & 4 & 14.33 & 12.86 & 16.25 \\
\hline $5 / 3 / 2012$ & 1 & 14.01 & 14.01 & 14.01 & 7 & 14.35 & 13.93 & 15.04 \\
\hline $5 / 7 / 2012$ & -- & -- & -- & -- & -- & -- & -- & -- \\
\hline $5 / 8 / 2012$ & -- & -- & -- & -- & 2 & 17.39 & 15.1 & 19.68 \\
\hline $5 / 9 / 2012$ & -- & -- & -- & -- & 2 & 17.5 & 14.99 & 20 \\
\hline $5 / 10 / 2012$ & 1 & 6.67 & 6.67 & 6.67 & -- & -- & -- & -- \\
\hline $5 / 15 / 2012$ & 1 & 17.5 & 17.5 & 17.5 & -- & -- & -- & -- \\
\hline $5 / 16 / 2012$ & -- & -- & -- & -- & 1 & 26 & 26 & 26 \\
\hline $5 / 17 / 2012$ & -- & -- & -- & -- & 1 & 24 & 24 & 24 \\
\hline $5 / 21 / 2012$ & -- & -- & -- & -- & -- & -- & -- & -- \\
\hline $5 / 29 / 2012$ & -- & -- & -- & -- & -- & -- & -- & -- \\
\hline 6/5/2012 & -- & -- & -- & -- & -- & -- & -- & -- \\
\hline $6 / 6 / 2012$ & -- & -- & -- & -- & -- & -- & -- & -- \\
\hline $6 / 7 / 2012$ & -- & -- & -- & -- & -- & -- & -- & -- \\
\hline
\end{tabular}


Table 7-5. Summary of free embryo and larval sturgeon and paddlefish collected in the Missouri River at station 4.

[--, no data; mm, millimeters $]$

\begin{tabular}{|c|c|c|c|c|c|c|c|c|}
\hline \multirow[b]{2}{*}{$\begin{array}{l}\text { Collection } \\
\text { date }\end{array}$} & \multicolumn{4}{|c|}{ Sturgeon } & \multicolumn{4}{|c|}{ Paddlefish } \\
\hline & $\begin{array}{l}\text { Number } \\
\text { collected }\end{array}$ & $\begin{array}{l}\text { Mean } \\
\text { length, } \\
\text { in mm }\end{array}$ & $\begin{array}{l}\text { Minimum } \\
\text { length, } \\
\text { in mm }\end{array}$ & $\begin{array}{c}\text { Maximum } \\
\text { length, } \\
\text { in mm }\end{array}$ & $\begin{array}{l}\text { Number } \\
\text { collected }\end{array}$ & $\begin{array}{c}\text { Mean } \\
\text { length, } \\
\text { in } \mathrm{mm}\end{array}$ & $\begin{array}{c}\text { Minimum } \\
\text { length, } \\
\text { in mm }\end{array}$ & $\begin{array}{c}\text { Maximum } \\
\text { length, } \\
\text { in } \mathrm{mm}\end{array}$ \\
\hline $4 / 24 / 2012$ & -- & -- & -- & -- & 2 & 12.74 & 12.65 & 12.83 \\
\hline $4 / 25 / 2012$ & -- & -- & -- & -- & 2 & 12.47 & 12.3 & 12.63 \\
\hline $4 / 26 / 2012$ & -- & -- & -- & -- & 3 & 9.39 & 7 & 13.44 \\
\hline $4 / 30 / 2012$ & 1 & 7.7 & 7.7 & 7.7 & 3 & 13.85 & 13.31 & 14.45 \\
\hline $5 / 1 / 2012$ & 2 & 7.77 & 7 & 8.54 & 5 & 10.98 & 7.1 & 13.96 \\
\hline $5 / 2 / 2012$ & 1 & 7.18 & 7.18 & 7.18 & 5 & 15.01 & 12.83 & 18 \\
\hline $5 / 3 / 2012$ & 4 & 8.25 & 7.56 & 8.88 & 4 & 14.18 & 13.64 & 14.81 \\
\hline $5 / 7 / 2012$ & -- & -- & -- & -- & 1 & 17.95 & 17.95 & 17.95 \\
\hline $5 / 8 / 2012$ & -- & -- & -- & -- & 1 & 19 & 19 & 19 \\
\hline $5 / 9 / 2012$ & -- & -- & -- & -- & 1 & 19 & 19 & 19 \\
\hline $5 / 10 / 2012$ & -- & -- & -- & -- & -- & -- & -- & -- \\
\hline $5 / 14 / 2012$ & 1 & 16.09 & 16.09 & 16.09 & -- & -- & -- & -- \\
\hline $5 / 15 / 2012$ & 2 & 13.23 & 7.46 & 19 & 1 & 20 & 20 & 20 \\
\hline $5 / 16 / 2012$ & 2 & 18.2 & 16.39 & 20 & 1 & 27 & 27 & 27 \\
\hline $5 / 17 / 2012$ & -- & -- & -- & -- & 1 & 21 & 21 & 21 \\
\hline $5 / 21 / 2012$ & 1 & 21 & 21 & 21 & -- & -- & -- & -- \\
\hline $5 / 22 / 2012$ & 1 & 17.13 & 17.13 & 17.13 & 1 & 17.65 & 17.65 & 17.65 \\
\hline $5 / 23 / 2012$ & -- & -- & -- & -- & -- & -- & -- & -- \\
\hline $5 / 29 / 2012$ & -- & -- & -- & -- & -- & -- & -- & -- \\
\hline $5 / 30 / 2012$ & -- & -- & -- & -- & -- & -- & -- & -- \\
\hline $5 / 31 / 2012$ & -- & -- & -- & -- & -- & -- & -- & -- \\
\hline $6 / 4 / 2012$ & -- & -- & -- & -- & -- & -- & -- & -- \\
\hline $6 / 5 / 2012$ & -- & -- & -- & -- & -- & -- & -- & -- \\
\hline 6/6/2012 & -- & -- & -- & -- & -- & -- & -- & -- \\
\hline $6 / 7 / 2012$ & -- & -- & -- & -- & -- & -- & -- & -- \\
\hline $6 / 11 / 2012$ & 1 & 16.21 & 16.21 & 16.21 & -- & -- & -- & -- \\
\hline $6 / 12 / 2012$ & -- & -- & -- & -- & -- & -- & -- & -- \\
\hline $6 / 13 / 2012$ & -- & -- & -- & -- & -- & -- & -- & -- \\
\hline $6 / 14 / 2012$ & -- & -- & -- & -- & -- & -- & -- & -- \\
\hline $6 / 18 / 2012$ & -- & -- & -- & -- & -- & -- & -- & -- \\
\hline $6 / 19 / 2012$ & -- & -- & -- & -- & -- & -- & -- & -- \\
\hline $6 / 20 / 2012$ & -- & -- & -- & -- & -- & -- & -- & -- \\
\hline $6 / 21 / 2012$ & -- & -- & -- & -- & -- & -- & -- & -- \\
\hline $6 / 25 / 2012$ & -- & -- & -- & -- & -- & -- & -- & -- \\
\hline $6 / 26 / 2012$ & -- & -- & -- & -- & -- & -- & -- & -- \\
\hline $6 / 27 / 2012$ & -- & -- & -- & -- & -- & -- & -- & -- \\
\hline $7 / 9 / 2012$ & -- & -- & -- & -- & -- & -- & -- & -- \\
\hline $7 / 10 / 2012$ & -- & -- & -- & -- & -- & -- & -- & -- \\
\hline $7 / 11 / 2012$ & -- & -- & -- & -- & -- & -- & -- & -- \\
\hline $7 / 12 / 2012$ & -- & -- & -- & -- & -- & -- & -- & -- \\
\hline
\end{tabular}


Table 7-5. Summary of free embryo and larval sturgeon and paddlefish collected in the Missouri River at station 4.Continued

[--, no data; mm, millimeters]

\begin{tabular}{|c|c|c|c|c|c|c|c|c|}
\hline \multirow[b]{2}{*}{$\begin{array}{l}\text { Collection } \\
\text { date }\end{array}$} & \multicolumn{4}{|c|}{ Sturgeon } & \multicolumn{4}{|c|}{ Paddlefish } \\
\hline & $\begin{array}{l}\text { Number } \\
\text { collected }\end{array}$ & $\begin{array}{l}\text { Mean } \\
\text { length, } \\
\text { in } \mathrm{mm}\end{array}$ & $\begin{array}{l}\text { Minimum } \\
\text { length, } \\
\text { in } \mathrm{mm}\end{array}$ & $\begin{array}{l}\text { Maximum } \\
\text { length, } \\
\text { in } \mathrm{mm}\end{array}$ & $\begin{array}{l}\text { Number } \\
\text { collected }\end{array}$ & $\begin{array}{l}\text { Mean } \\
\text { length, } \\
\text { in } \mathrm{mm}\end{array}$ & $\begin{array}{l}\text { Minimum } \\
\text { length, } \\
\text { in } \mathrm{mm}\end{array}$ & $\begin{array}{l}\text { Maximum } \\
\text { length, } \\
\text { in } \mathrm{mm}\end{array}$ \\
\hline $7 / 23 / 2012$ & -- & -- & -- & -- & -- & -- & -- & -- \\
\hline $7 / 24 / 2012$ & -- & -- & -- & -- & -- & -- & -- & -- \\
\hline $7 / 25 / 2012$ & -- & -- & -- & -- & -- & -- & -- & -- \\
\hline $7 / 26 / 2012$ & -- & -- & -- & -- & -- & -- & -- & -- \\
\hline $8 / 6 / 2012$ & -- & -- & -- & -- & -- & -- & -- & -- \\
\hline $8 / 7 / 2012$ & -- & -- & -- & -- & -- & -- & -- & -- \\
\hline $8 / 8 / 2012$ & -- & -- & -- & -- & -- & -- & -- & -- \\
\hline 8/9/2012 & -- & -- & -- & -- & -- & -- & -- & -- \\
\hline $8 / 21 / 2012$ & -- & -- & -- & -- & -- & -- & -- & -- \\
\hline $8 / 22 / 2012$ & -- & -- & -- & -- & -- & -- & -- & -- \\
\hline $8 / 23 / 2012$ & -- & -- & -- & -- & -- & -- & -- & -- \\
\hline 9/4/2012 & -- & -- & -- & -- & -- & -- & -- & -- \\
\hline $9 / 5 / 2012$ & -- & -- & -- & -- & -- & -- & -- & -- \\
\hline 9/6/2012 & -- & -- & -- & -- & -- & -- & -- & -- \\
\hline 9/17/2012 & -- & -- & -- & -- & -- & -- & -- & -- \\
\hline $9 / 18 / 2012$ & -- & -- & -- & -- & -- & -- & -- & -- \\
\hline $9 / 19 / 2012$ & -- & -- & -- & -- & -- & -- & -- & -- \\
\hline $10 / 2 / 2012$ & -- & -- & -- & -- & -- & -- & -- & -- \\
\hline $10 / 3 / 2012$ & -- & -- & -- & -- & -- & -- & -- & -- \\
\hline $10 / 4 / 2012$ & -- & -- & -- & -- & -- & -- & -- & -- \\
\hline
\end{tabular}


Table 7-6. Summary of free embryo and larval sturgeon and paddlefish collected in the Missouri River at station 5.

[--, no data; mm, millimeters $]$

\begin{tabular}{|c|c|c|c|c|c|c|c|c|}
\hline \multirow[b]{2}{*}{$\begin{array}{c}\text { Collection } \\
\text { date }\end{array}$} & \multicolumn{4}{|c|}{ Sturgeon } & \multicolumn{4}{|c|}{ Paddlefish } \\
\hline & $\begin{array}{l}\text { Number } \\
\text { collected }\end{array}$ & $\begin{array}{l}\text { Mean } \\
\text { length, } \\
\text { in mm }\end{array}$ & $\begin{array}{l}\text { Minimum } \\
\text { length, } \\
\text { in mm }\end{array}$ & $\begin{array}{l}\text { Maximum } \\
\text { length, } \\
\text { in mm }\end{array}$ & $\begin{array}{l}\text { Number } \\
\text { collected }\end{array}$ & $\begin{array}{l}\text { Mean } \\
\text { length, } \\
\text { in mm }\end{array}$ & $\begin{array}{l}\text { Minimum } \\
\text { length, } \\
\text { in mm }\end{array}$ & $\begin{array}{c}\text { Maximum } \\
\text { length, } \\
\text { in } \mathbf{m m}\end{array}$ \\
\hline $4 / 23 / 2012$ & -- & -- & -- & -- & 5 & 11.26 & 7.67 & 12.65 \\
\hline $4 / 24 / 2012$ & 1 & 7.74 & 7.74 & 7.74 & 3 & 13.36 & 12.72 & 14.62 \\
\hline $4 / 25 / 2012$ & -- & -- & -- & -- & 2 & 12.7 & 12.52 & 12.87 \\
\hline $4 / 26 / 2012$ & -- & -- & -- & -- & 5 & 13.13 & 8.14 & 16.04 \\
\hline $4 / 30 / 2012$ & 2 & 7.99 & 7.97 & 8.01 & 12 & 13.93 & 8.06 & 16.54 \\
\hline $5 / 1 / 2012$ & -- & -- & -- & -- & 9 & 13.95 & 10.75 & 15.56 \\
\hline $5 / 2 / 2012$ & 2 & 8.35 & 8.21 & 8.48 & 2 & 11.58 & 10.5 & 12.65 \\
\hline $5 / 3 / 2012$ & -- & -- & -- & -- & 9 & 14.35 & 11.06 & 16.02 \\
\hline $5 / 7 / 2012$ & -- & -- & -- & -- & 2 & 15.56 & 15.53 & 15.58 \\
\hline $5 / 8 / 2012$ & 1 & 15.42 & 15.42 & 15.42 & 3 & 19.67 & 17.88 & 23 \\
\hline $5 / 9 / 2012$ & 1 & 15.37 & 15.37 & 15.37 & -- & -- & -- & -- \\
\hline $5 / 10 / 2012$ & 1 & 16.57 & 16.57 & 16.57 & 2 & 15.4 & 14.13 & 16.67 \\
\hline $5 / 14 / 2012$ & -- & -- & -- & -- & 1 & 20 & 20 & 20 \\
\hline $5 / 15 / 2012$ & 3 & 16.7 & 15.45 & 18.25 & 1 & 22 & 22 & 22 \\
\hline $5 / 16 / 2012$ & 1 & 19 & 19 & 19 & -- & -- & -- & -- \\
\hline $5 / 17 / 2012$ & 3 & 11.07 & 7.07 & 18.69 & 1 & 22 & 22 & 22 \\
\hline $5 / 21 / 2012$ & 1 & 18 & 18 & 18 & 2 & 22.5 & 21 & 24 \\
\hline $5 / 22 / 2012$ & -- & -- & -- & -- & 2 & 20 & 19 & 21 \\
\hline $5 / 23 / 2012$ & 1 & 21 & 21 & 21 & -- & -- & -- & -- \\
\hline $5 / 24 / 2012$ & 1 & 7.53 & 7.53 & 7.53 & -- & -- & -- & -- \\
\hline $5 / 29 / 2012$ & 3 & 15.88 & 13.59 & 18.17 & -- & -- & -- & -- \\
\hline $5 / 30 / 2012$ & -- & -- & -- & -- & -- & -- & -- & -- \\
\hline $5 / 31 / 2012$ & -- & -- & -- & -- & -- & -- & -- & -- \\
\hline $6 / 4 / 2012$ & -- & -- & -- & -- & -- & -- & -- & -- \\
\hline $6 / 5 / 2012$ & -- & -- & -- & -- & -- & -- & -- & -- \\
\hline $6 / 6 / 2012$ & 1 & 16.95 & 16.95 & 16.95 & -- & -- & -- & -- \\
\hline $6 / 7 / 2012$ & -- & -- & -- & -- & -- & -- & -- & -- \\
\hline $6 / 11 / 2012$ & -- & -- & -- & -- & -- & -- & -- & -- \\
\hline $6 / 12 / 2012$ & -- & -- & -- & -- & -- & -- & -- & -- \\
\hline $6 / 13 / 2012$ & 1 & 28 & 28 & 28 & -- & -- & -- & -- \\
\hline $6 / 14 / 2012$ & -- & -- & -- & -- & -- & -- & -- & -- \\
\hline $6 / 18 / 2012$ & -- & -- & -- & -- & -- & -- & -- & -- \\
\hline $6 / 19 / 2012$ & -- & -- & -- & -- & -- & -- & -- & -- \\
\hline $6 / 20 / 2012$ & -- & -- & -- & -- & -- & -- & -- & -- \\
\hline $6 / 21 / 2012$ & -- & -- & -- & -- & -- & -- & -- & -- \\
\hline $6 / 25 / 2012$ & -- & -- & -- & -- & -- & -- & -- & -- \\
\hline $6 / 26 / 2012$ & -- & -- & -- & -- & -- & -- & -- & -- \\
\hline $6 / 27 / 2012$ & -- & -- & -- & -- & -- & -- & -- & -- \\
\hline $7 / 9 / 2012$ & -- & -- & -- & -- & -- & -- & -- & -- \\
\hline $7 / 10 / 2012$ & -- & -- & -- & -- & -- & -- & -- & -- \\
\hline
\end{tabular}


Table 7-6. Summary of free embryo and larval sturgeon and paddlefish collected in the Missouri River at station 5.Continued

[--, no data; mm, millimeters]

\begin{tabular}{|c|c|c|c|c|c|c|c|c|}
\hline \multirow[b]{2}{*}{$\begin{array}{l}\text { Collection } \\
\text { date }\end{array}$} & \multicolumn{4}{|c|}{ Sturgeon } & \multicolumn{4}{|c|}{ Paddlefish } \\
\hline & $\begin{array}{l}\text { Number } \\
\text { collected }\end{array}$ & $\begin{array}{l}\text { Mean } \\
\text { length, } \\
\text { in } \mathrm{mm}\end{array}$ & $\begin{array}{l}\text { Minimum } \\
\text { length, } \\
\text { in } \mathbf{m m}\end{array}$ & $\begin{array}{l}\text { Maximum } \\
\text { length, } \\
\text { in } \mathbf{m m}\end{array}$ & $\begin{array}{l}\text { Number } \\
\text { collected }\end{array}$ & $\begin{array}{l}\text { Mean } \\
\text { length, } \\
\text { in } \mathbf{m m}\end{array}$ & $\begin{array}{l}\text { Minimum } \\
\text { length, } \\
\text { in } \mathrm{mm}\end{array}$ & $\begin{array}{l}\text { Maximum } \\
\text { length, } \\
\text { in } \mathbf{m m}\end{array}$ \\
\hline $7 / 11 / 2012$ & -- & -- & -- & -- & -- & -- & -- & -- \\
\hline $7 / 12 / 2012$ & -- & -- & -- & -- & -- & -- & -- & -- \\
\hline $7 / 23 / 2012$ & -- & -- & -- & -- & -- & -- & -- & -- \\
\hline $7 / 24 / 2012$ & -- & -- & -- & -- & -- & -- & -- & -- \\
\hline $7 / 25 / 2012$ & -- & -- & -- & -- & -- & -- & -- & -- \\
\hline $7 / 26 / 2012$ & -- & -- & -- & -- & -- & -- & -- & -- \\
\hline $8 / 6 / 2012$ & -- & -- & -- & -- & -- & -- & -- & -- \\
\hline 8/7/2012 & -- & -- & -- & -- & -- & -- & -- & -- \\
\hline $8 / 8 / 2012$ & -- & -- & -- & -- & -- & -- & -- & -- \\
\hline 8/9/2012 & -- & -- & -- & -- & -- & -- & -- & -- \\
\hline $8 / 20 / 2012$ & -- & -- & -- & -- & -- & -- & -- & -- \\
\hline $8 / 21 / 2012$ & -- & -- & -- & -- & -- & -- & -- & -- \\
\hline $8 / 22 / 2012$ & -- & -- & -- & -- & -- & -- & -- & -- \\
\hline $8 / 23 / 2012$ & -- & -- & -- & -- & -- & -- & -- & -- \\
\hline 9/4/2012 & -- & -- & -- & -- & -- & -- & -- & -- \\
\hline 9/5/2012 & -- & -- & -- & -- & -- & -- & -- & -- \\
\hline 9/6/2012 & -- & -- & -- & -- & -- & -- & -- & -- \\
\hline $9 / 17 / 2012$ & -- & -- & -- & -- & -- & -- & -- & -- \\
\hline $9 / 18 / 2012$ & -- & -- & -- & -- & -- & -- & -- & -- \\
\hline $9 / 19 / 2012$ & -- & -- & -- & -- & -- & -- & -- & -- \\
\hline $9 / 20 / 2012$ & -- & -- & -- & -- & -- & -- & -- & -- \\
\hline $10 / 1 / 2012$ & -- & -- & -- & -- & -- & -- & -- & -- \\
\hline $10 / 2 / 2012$ & -- & -- & -- & -- & -- & -- & -- & -- \\
\hline $10 / 3 / 2012$ & -- & -- & -- & -- & -- & -- & -- & -- \\
\hline $10 / 4 / 2012$ & -- & -- & -- & -- & -- & -- & -- & -- \\
\hline
\end{tabular}


Table 7-7. Summary of free embryo and larval sturgeon and paddlefish collected in the Missouri River at station 6.

[--, no data; mm, millimeters $]$

\begin{tabular}{|c|c|c|c|c|c|c|c|c|}
\hline \multirow[b]{2}{*}{$\begin{array}{c}\text { Collection } \\
\text { date }\end{array}$} & \multicolumn{4}{|c|}{ Sturgeon } & \multicolumn{4}{|c|}{ Paddlefish } \\
\hline & $\begin{array}{l}\text { Number } \\
\text { collected }\end{array}$ & $\begin{array}{l}\text { Mean } \\
\text { length, } \\
\text { in mm }\end{array}$ & $\begin{array}{l}\text { Minimum } \\
\text { length, } \\
\text { in mm }\end{array}$ & $\begin{array}{l}\text { Maximum } \\
\text { length, } \\
\text { in mm }\end{array}$ & $\begin{array}{l}\text { Number } \\
\text { collected }\end{array}$ & $\begin{array}{l}\text { Mean } \\
\text { length, } \\
\text { in } \mathrm{mm}\end{array}$ & $\begin{array}{l}\text { Minimum } \\
\text { length, } \\
\text { in mm }\end{array}$ & $\begin{array}{l}\text { Maximum } \\
\text { length, } \\
\text { in } \mathrm{mm}\end{array}$ \\
\hline $4 / 23 / 2012$ & -- & -- & -- & -- & 1 & 12.53 & 12.53 & 12.53 \\
\hline $4 / 24 / 2012$ & -- & -- & -- & -- & 2 & 13.7 & 11.88 & 15.52 \\
\hline $4 / 25 / 2012$ & 1 & 8.77 & 8.77 & 8.77 & 6 & 11.13 & 7.05 & 13.16 \\
\hline $4 / 26 / 2012$ & -- & -- & -- & -- & 6 & 10.37 & 7.01 & 13.38 \\
\hline $4 / 30 / 2012$ & 3 & 12.34 & 9.63 & 14.96 & 15 & 12.58 & 8.16 & 15.01 \\
\hline $5 / 1 / 2012$ & 3 & 7.73 & 7.36 & 8.12 & 8 & 13.2 & 8.57 & 15.29 \\
\hline $5 / 2 / 2012$ & 1 & 10.06 & 10.06 & 10.06 & 4 & 14.86 & 13.27 & 16.58 \\
\hline $5 / 8 / 2012$ & 1 & 14.02 & 14.02 & 14.02 & 7 & 18.24 & 15.45 & 20 \\
\hline $5 / 9 / 2012$ & 1 & 10.16 & 10.16 & 10.16 & 4 & 18.65 & 17.26 & 20 \\
\hline $5 / 10 / 2012$ & 4 & 14.99 & 13.16 & 17.46 & 7 & 16.71 & 14.71 & 20 \\
\hline $5 / 14 / 2012$ & 2 & 11.56 & 10.35 & 12.77 & -- & -- & -- & -- \\
\hline $5 / 15 / 2012$ & 7 & 14.98 & 11.12 & 18.37 & 3 & 21.33 & 20 & 23 \\
\hline $5 / 16 / 2012$ & 1 & 13.73 & 13.73 & 13.73 & 2 & 23 & 20 & 26 \\
\hline $5 / 17 / 2012$ & -- & -- & -- & -- & -- & -- & -- & -- \\
\hline $5 / 21 / 2012$ & 9 & 16.6 & 13.17 & 18.66 & -- & -- & -- & -- \\
\hline $5 / 22 / 2012$ & 18 & 14.47 & ${ }^{1} 5.97$ & 17.61 & 5 & 19.98 & 16.45 & 24 \\
\hline $5 / 23 / 2012$ & 37 & 14.78 & 6.85 & 20.8 & 12 & 20.52 & 16 & 28 \\
\hline $5 / 24 / 2012$ & 14 & 14.28 & 9.58 & 16.42 & 3 & 19.33 & 18.99 & 20 \\
\hline $5 / 29 / 2012$ & 17 & 13.95 & 9.97 & 19 & 5 & 21.6 & 20 & 23 \\
\hline $5 / 30 / 2012$ & 11 & 13.37 & 9.81 & 16.7 & 8 & 21.63 & 19 & 25 \\
\hline $5 / 31 / 2012$ & 9 & 14.59 & 13.08 & 16.65 & 8 & 25 & 23 & 27 \\
\hline $6 / 4 / 2012$ & -- & -- & -- & -- & 1 & 28 & 28 & 28 \\
\hline $6 / 5 / 2012$ & 4 & 17.08 & 15.99 & 18.25 & -- & -- & -- & -- \\
\hline $6 / 6 / 2012$ & 5 & 13.66 & 10.7 & 17.9 & -- & -- & -- & -- \\
\hline $6 / 7 / 2012$ & 7 & 11.56 & 8.14 & 13.92 & -- & -- & -- & -- \\
\hline $6 / 11 / 2012$ & 1 & 16.18 & 16.18 & 16.18 & 1 & 24 & 24 & 24 \\
\hline $6 / 12 / 2012$ & 3 & 18.74 & 15.3 & 25 & 1 & 49 & 49 & 49 \\
\hline $6 / 13 / 2012$ & 8 & 17.66 & 12.58 & 35 & -- & -- & -- & -- \\
\hline $6 / 14 / 2012$ & 2 & 17.57 & 17.51 & 17.63 & -- & -- & -- & -- \\
\hline $6 / 18 / 2012$ & 2 & 18.48 & 16.17 & 20.79 & -- & -- & -- & -- \\
\hline $6 / 19 / 2012$ & -- & -- & -- & -- & -- & -- & -- & -- \\
\hline $6 / 20 / 2012$ & -- & -- & -- & -- & -- & -- & -- & -- \\
\hline $6 / 21 / 2012$ & -- & -- & -- & -- & -- & -- & -- & -- \\
\hline $6 / 25 / 2012$ & -- & -- & -- & -- & -- & -- & -- & -- \\
\hline $6 / 26 / 2012$ & 1 & 18.98 & 18.98 & 18.98 & -- & -- & -- & -- \\
\hline $6 / 27 / 2012$ & 1 & 16.49 & 16.49 & 16.49 & -- & -- & -- & -- \\
\hline $7 / 9 / 2012$ & -- & -- & -- & -- & -- & -- & -- & -- \\
\hline $7 / 10 / 2012$ & -- & -- & -- & -- & -- & -- & -- & -- \\
\hline $7 / 11 / 2012$ & -- & -- & -- & -- & -- & -- & -- & -- \\
\hline $7 / 12 / 2012$ & -- & -- & -- & -- & -- & -- & -- & -- \\
\hline
\end{tabular}


Table 7-7. Summary of free embryo and larval sturgeon and paddlefish collected in the Missouri River at station 6.Continued

[--, no data; mm, millimeters]

\begin{tabular}{|c|c|c|c|c|c|c|c|c|}
\hline \multirow[b]{2}{*}{$\begin{array}{c}\text { Collection } \\
\text { date }\end{array}$} & \multicolumn{4}{|c|}{ Sturgeon } & \multicolumn{4}{|c|}{ Paddlefish } \\
\hline & $\begin{array}{l}\text { Number } \\
\text { collected }\end{array}$ & $\begin{array}{l}\text { Mean } \\
\text { length, } \\
\text { in } \mathrm{mm}\end{array}$ & $\begin{array}{l}\text { Minimum } \\
\text { length, } \\
\text { in } \mathrm{mm}\end{array}$ & $\begin{array}{l}\text { Maximum } \\
\text { length, } \\
\text { in } \mathrm{mm}\end{array}$ & $\begin{array}{l}\text { Number } \\
\text { collected }\end{array}$ & $\begin{array}{l}\text { Mean } \\
\text { length, } \\
\text { in } \mathrm{mm}\end{array}$ & $\begin{array}{l}\text { Minimum } \\
\text { length, } \\
\text { in } \mathrm{mm}\end{array}$ & $\begin{array}{l}\text { Maximum } \\
\text { length, } \\
\text { in } \mathrm{mm}\end{array}$ \\
\hline $7 / 23 / 2012$ & -- & -- & -- & -- & -- & -- & -- & -- \\
\hline $7 / 24 / 2012$ & -- & -- & -- & -- & -- & -- & -- & -- \\
\hline $7 / 25 / 2012$ & -- & -- & -- & -- & -- & -- & -- & -- \\
\hline $7 / 26 / 2012$ & -- & -- & -- & -- & -- & -- & -- & -- \\
\hline $8 / 6 / 2012$ & -- & -- & -- & -- & -- & -- & -- & -- \\
\hline 8/7/2012 & -- & -- & -- & -- & -- & -- & -- & -- \\
\hline 8/8/2012 & -- & -- & -- & -- & -- & -- & -- & -- \\
\hline 8/9/2012 & -- & -- & -- & -- & -- & -- & -- & -- \\
\hline $8 / 20 / 2012$ & -- & -- & -- & -- & -- & -- & -- & -- \\
\hline $8 / 21 / 2012$ & -- & -- & -- & -- & -- & -- & -- & -- \\
\hline $8 / 22 / 2012$ & 1 & 12.26 & 12.26 & 12.26 & -- & -- & -- & -- \\
\hline $8 / 23 / 2012$ & -- & -- & -- & -- & -- & -- & -- & -- \\
\hline 9/4/2012 & 5 & 23.11 & 16.21 & 36 & -- & -- & -- & -- \\
\hline 9/5/2012 & 4 & 15.94 & 12.69 & 18.26 & -- & -- & -- & -- \\
\hline 9/6/2012 & 1 & 16.94 & 16.94 & 16.94 & -- & -- & -- & -- \\
\hline $9 / 17 / 2012$ & 1 & 7.14 & 7.14 & 7.14 & -- & -- & -- & -- \\
\hline $9 / 18 / 2012$ & -- & -- & -- & -- & -- & -- & -- & -- \\
\hline 9/19/2012 & -- & -- & -- & -- & -- & -- & -- & -- \\
\hline $9 / 20 / 2012$ & 1 & 19.15 & 19.15 & 19.15 & -- & -- & -- & -- \\
\hline $10 / 1 / 2012$ & -- & -- & -- & -- & -- & -- & -- & -- \\
\hline $10 / 2 / 2012$ & -- & -- & -- & -- & -- & -- & -- & -- \\
\hline $10 / 3 / 2012$ & -- & -- & -- & -- & -- & -- & -- & -- \\
\hline $10 / 4 / 2012$ & -- & -- & -- & -- & -- & -- & -- & -- \\
\hline
\end{tabular}

${ }^{1}$ Partial specimen.

Table 7-8. Summary of free embryo and larval sturgeon and paddlefish collected in the Missouri River at station 7.

[data; mm, millimeters]

\begin{tabular}{|c|c|c|c|c|c|c|c|c|}
\hline \multirow[b]{2}{*}{$\begin{array}{c}\text { Collection } \\
\text { date }\end{array}$} & \multicolumn{4}{|c|}{ Sturgeon } & \multicolumn{4}{|c|}{ Paddlefish } \\
\hline & $\begin{array}{l}\text { Number } \\
\text { collected }\end{array}$ & $\begin{array}{l}\text { Mean } \\
\text { length, } \\
\text { in mm }\end{array}$ & $\begin{array}{l}\text { Minimum } \\
\text { length, } \\
\text { in } \mathrm{mm}\end{array}$ & $\begin{array}{l}\text { Maximum } \\
\text { length, } \\
\text { in mm }\end{array}$ & $\begin{array}{l}\text { Number } \\
\text { collected }\end{array}$ & $\begin{array}{l}\text { Mean } \\
\text { length, } \\
\text { in mm }\end{array}$ & $\begin{array}{l}\text { Minimum } \\
\text { length, } \\
\text { in mm }\end{array}$ & $\begin{array}{c}\text { Maximum } \\
\text { length, } \\
\text { in } \mathrm{mm}\end{array}$ \\
\hline $5 / 22 / 2012$ & 30 & 11.62 & 6.99 & 20.25 & 22 & 19.21 & 12 & 35 \\
\hline $5 / 23 / 2012$ & 34 & 11.24 & 6.86 & 17.54 & 15 & 18.75 & 15.68 & 23 \\
\hline $5 / 24 / 2012$ & 27 & 12.27 & 6.86 & 18.18 & 7 & 18.64 & 15.47 & 20 \\
\hline
\end{tabular}




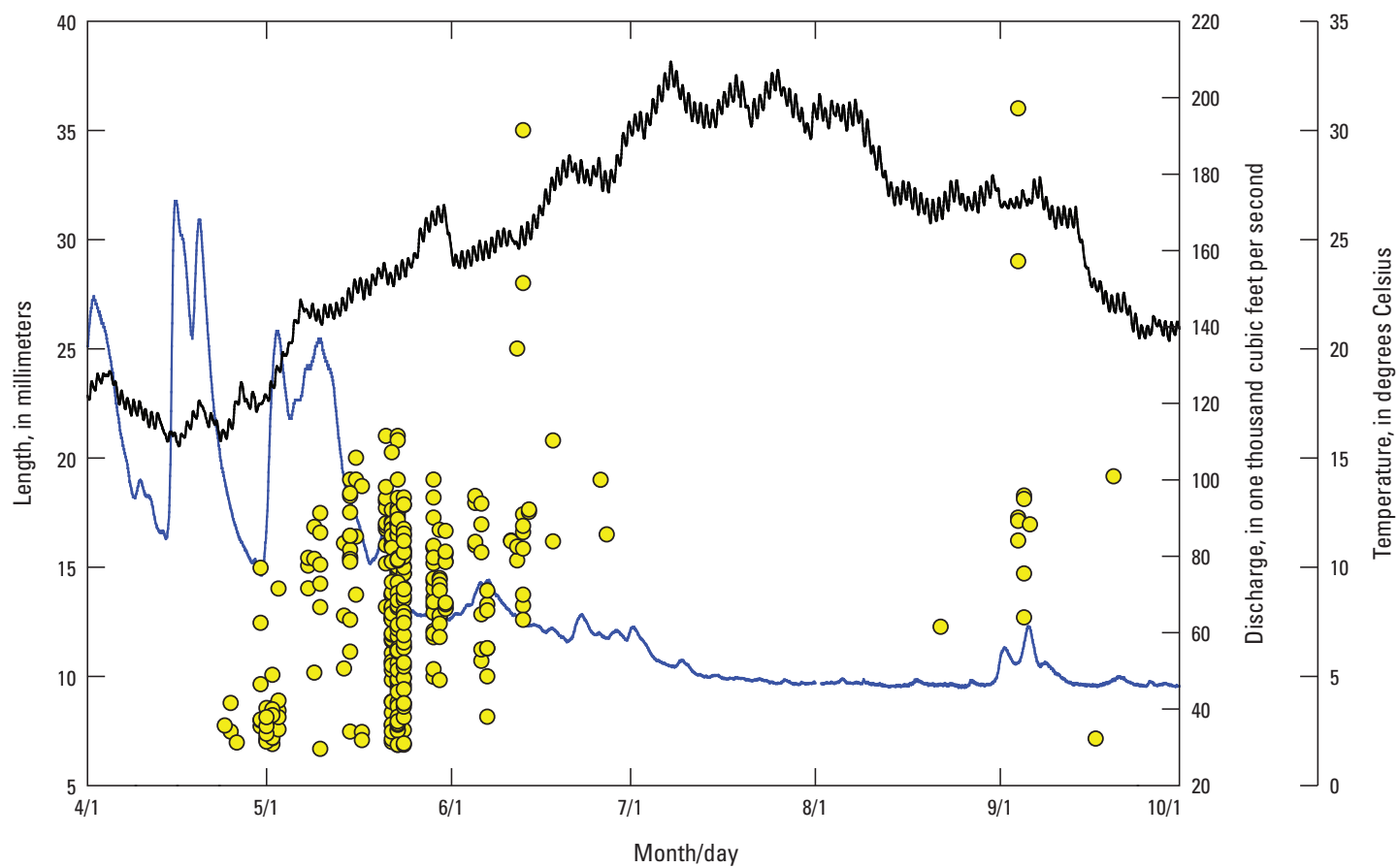

EXPLANATION

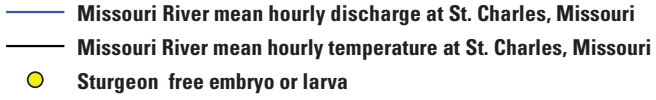

Figure 7-2. Length of sturgeon free embryos and larvae, and mean hourly temperature and discharge from the U.S. Geological Survey streamgage near St. Charles, Missouri, 2012.

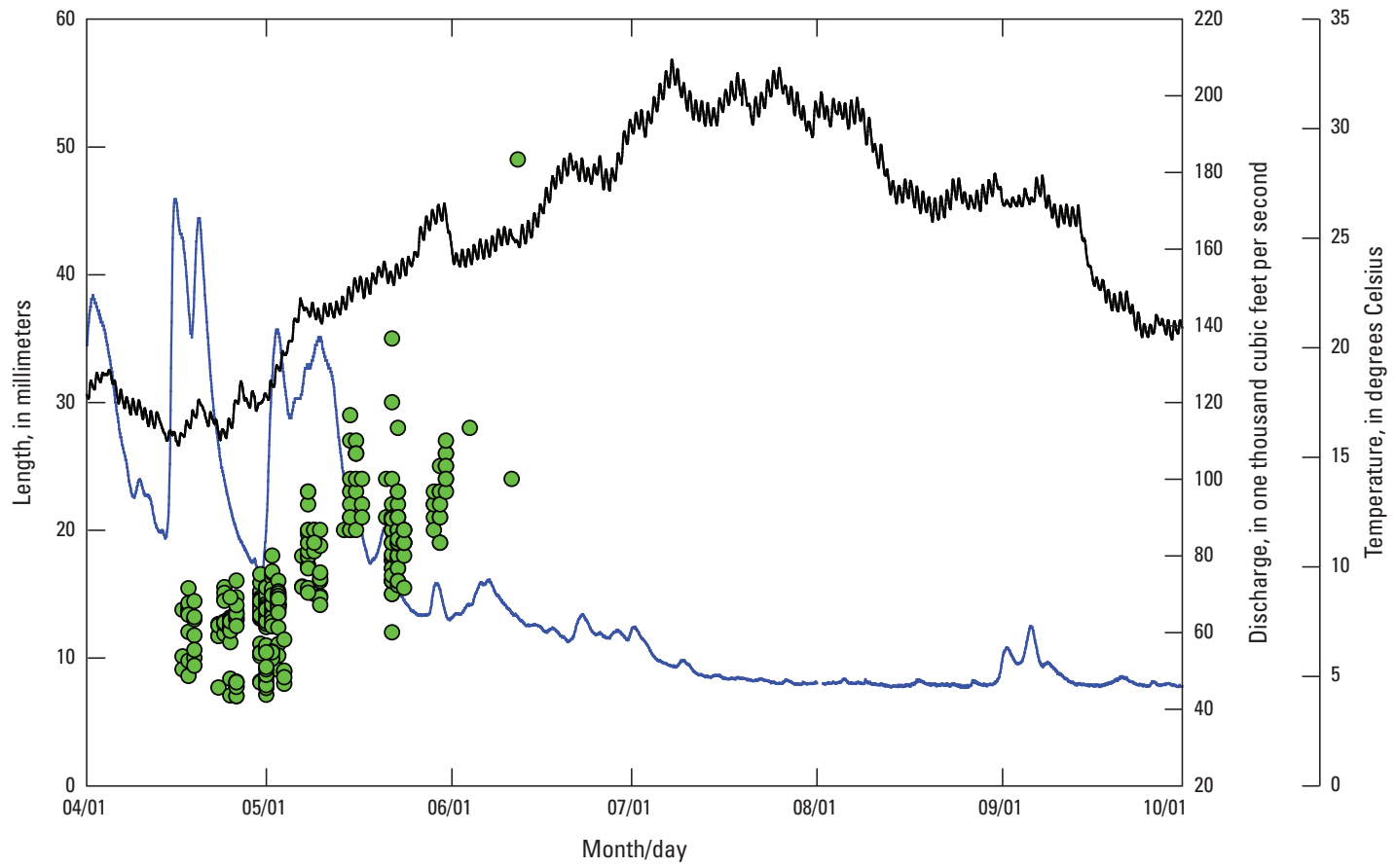

EXPLANATION

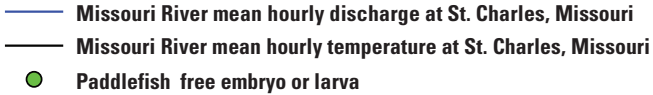

Figure 7-3. Length of paddlefish free embryos and larvae, and mean hourly temperature and discharge from the U.S. Geological Survey streamgage near St. Charles, Missouri, 2012. 
Table 7-9. Mean density, number per 100 cubic meters, of sturgeon free embryos and larvae collected in the Missouri River per sampling day.

$[--$, no data $]$

\begin{tabular}{|c|c|c|c|c|c|c|c|}
\hline \multirow{2}{*}{ Date } & \multicolumn{7}{|c|}{ Station number } \\
\hline & 1 & 2 & 3 & 4 & 5 & 6 & 7 \\
\hline $4 / 23 / 2012$ & -- & -- & -- & -- & 0 & 0 & -- \\
\hline $4 / 24 / 2012$ & 0 & 0 & 0 & 0 & 0.13 & 0 & -- \\
\hline $4 / 25 / 2012$ & 0 & 0 & 0.15 & 0 & 0 & 0.17 & -- \\
\hline $4 / 26 / 2012$ & -- & 0 & 0.14 & 0 & 0 & 0 & -- \\
\hline $4 / 30 / 2012$ & -- & -- & -- & 0.13 & 0.26 & 0.28 & -- \\
\hline $5 / 1 / 2012$ & -- & 0.26 & 0.87 & 0.25 & 0 & 0.32 & -- \\
\hline $5 / 2 / 2012$ & 0.15 & 0.14 & 0.27 & 0.11 & 0.5 & 0.25 & -- \\
\hline $5 / 3 / 2012$ & -- & 0 & 0.11 & 0.44 & 0 & -- & -- \\
\hline $5 / 7 / 2012$ & -- & -- & 0 & 0 & 0 & -- & -- \\
\hline $5 / 8 / 2012$ & 0 & 0.13 & 0 & 0 & 0.13 & 0.1 & -- \\
\hline $5 / 9 / 2012$ & 0 & 0.12 & 0 & 0 & 0.09 & 0.09 & -- \\
\hline $5 / 10 / 2012$ & -- & -- & 0.12 & 0 & 0.11 & 0.48 & -- \\
\hline $5 / 14 / 2012$ & -- & -- & -- & 0.14 & 0 & 0.23 & -- \\
\hline $5 / 15 / 2012$ & 0 & 0 & 0.13 & 0.23 & 0.32 & 0.63 & -- \\
\hline $5 / 16 / 2012$ & 0 & 0 & 0 & 0.25 & 0.12 & 0.09 & -- \\
\hline $5 / 17 / 2012$ & -- & 0 & 0 & 0 & 0.31 & 0 & -- \\
\hline $5 / 21 / 2012$ & -- & -- & 0 & 0.12 & 0.11 & 0.98 & -- \\
\hline $5 / 22 / 2012$ & 0 & -- & -- & 0.12 & 0 & 0.96 & 2.45 \\
\hline $5 / 23 / 2012$ & -- & -- & -- & 0 & 0.06 & 1.68 & 3.22 \\
\hline $5 / 24 / 2012$ & -- & -- & -- & -- & 0.11 & 1.65 & 2.45 \\
\hline $5 / 29 / 2012$ & -- & -- & 0 & 0 & 0.37 & 1.52 & -- \\
\hline $5 / 30 / 2012$ & -- & -- & -- & 0 & 0 & 0.55 & -- \\
\hline $5 / 31 / 2012$ & -- & -- & -- & 0 & 0 & 0.45 & -- \\
\hline $6 / 4 / 2012$ & -- & -- & -- & 0 & 0 & 0 & -- \\
\hline $6 / 5 / 2012$ & -- & -- & 0 & 0 & 0 & 0.21 & -- \\
\hline $6 / 6 / 2012$ & -- & -- & 0 & 0 & 0.07 & 0.25 & -- \\
\hline $6 / 7 / 2012$ & -- & -- & 0 & 0 & 0 & 0.76 & -- \\
\hline $6 / 11 / 2012$ & -- & -- & -- & 0.12 & 0 & 0.08 & -- \\
\hline $6 / 12 / 2012$ & -- & -- & -- & 0 & 0 & 0.12 & -- \\
\hline $6 / 13 / 2012$ & -- & -- & -- & 0 & 0.06 & 0.35 & -- \\
\hline $6 / 14 / 2012$ & -- & -- & -- & 0 & 0 & 0.2 & -- \\
\hline $6 / 18 / 2012$ & -- & -- & -- & 0 & 0 & 0.19 & -- \\
\hline $6 / 19 / 2012$ & -- & -- & -- & 0 & 0 & 0 & -- \\
\hline $6 / 20 / 2012$ & -- & -- & -- & 0 & 0 & 0 & -- \\
\hline $6 / 21 / 2012$ & -- & -- & -- & 0 & 0 & 0 & -- \\
\hline $6 / 25 / 2012$ & -- & -- & -- & 0 & 0 & 0 & -- \\
\hline $6 / 26 / 2012$ & -- & -- & -- & 0 & 0 & 0.05 & -- \\
\hline $6 / 27 / 2012$ & -- & -- & -- & 0 & 0 & 0.12 & -- \\
\hline 7/9/2012 & -- & -- & -- & 0 & 0 & 0 & -- \\
\hline $7 / 10 / 2012$ & -- & -- & -- & 0 & 0 & 0 & -- \\
\hline $7 / 11 / 2012$ & -- & -- & -- & 0 & 0 & 0 & -- \\
\hline
\end{tabular}


Table 7-9. Mean density, number per 100 cubic meters, of sturgeon free embryos and larvae collected in the Missouri River per sampling day.-Continued

[--, no data]

\begin{tabular}{|c|c|c|c|c|c|c|c|}
\hline \multirow{2}{*}{ Date } & \multicolumn{7}{|c|}{ Station number } \\
\hline & 1 & 2 & 3 & 4 & 5 & 6 & 7 \\
\hline $7 / 12 / 2012$ & -- & -- & -- & 0 & 0 & 0 & -- \\
\hline $7 / 23 / 2012$ & -- & -- & -- & 0 & 0 & 0 & -- \\
\hline $7 / 24 / 2012$ & -- & -- & -- & 0 & 0 & 0 & -- \\
\hline $7 / 25 / 2012$ & -- & -- & -- & 0 & 0 & 0 & -- \\
\hline $7 / 26 / 2012$ & -- & -- & -- & 0 & 0 & 0 & -- \\
\hline $8 / 6 / 2012$ & -- & -- & -- & 0 & 0 & 0 & -- \\
\hline 8/7/2012 & -- & -- & -- & 0 & 0 & 0 & -- \\
\hline 8/8/2012 & -- & -- & -- & 0 & 0 & 0 & -- \\
\hline 8/9/2012 & -- & -- & -- & 0 & 0 & 0 & -- \\
\hline $8 / 20 / 2012$ & -- & -- & -- & -- & 0 & 0 & -- \\
\hline $8 / 21 / 2012$ & -- & -- & -- & 0 & 0 & 0 & -- \\
\hline $8 / 22 / 2012$ & -- & -- & -- & 0 & 0 & 0.04 & -- \\
\hline $8 / 23 / 2012$ & -- & -- & -- & 0 & 0 & 0 & -- \\
\hline $9 / 4 / 2012$ & -- & -- & -- & 0 & 0 & 0.67 & -- \\
\hline 9/5/2012 & -- & -- & -- & 0 & 0 & 0.14 & -- \\
\hline 9/6/2012 & -- & -- & -- & 0 & 0 & 0.08 & -- \\
\hline $9 / 17 / 2012$ & -- & -- & -- & 0 & 0 & 0.18 & -- \\
\hline $9 / 18 / 2012$ & -- & -- & -- & 0 & 0 & 0 & -- \\
\hline 9/19/2012 & -- & -- & -- & 0 & 0 & 0 & -- \\
\hline $9 / 20 / 2012$ & -- & -- & -- & -- & 0 & 0.06 & -- \\
\hline $10 / 1 / 2012$ & -- & -- & -- & -- & 0 & 0 & -- \\
\hline $10 / 2 / 2012$ & -- & -- & -- & 0 & 0 & 0 & -- \\
\hline $10 / 3 / 2012$ & -- & -- & -- & 0 & 0 & 0 & -- \\
\hline $10 / 4 / 2012$ & -- & -- & -- & 0 & 0 & 0 & -- \\
\hline
\end{tabular}


Table 7-10. Mean density, number per 100 cubic meters, of paddlefish free embryos and larvae collected in the Missouri River per sampling day.

[--, no data]

\begin{tabular}{|c|c|c|c|c|c|c|c|}
\hline \multirow{2}{*}{ Date } & \multicolumn{7}{|c|}{ Station number } \\
\hline & 1 & 2 & 3 & 4 & 5 & 6 & 7 \\
\hline $4 / 23 / 2012$ & -- & -- & -- & -- & 0.59 & 0.09 & -- \\
\hline $4 / 24 / 2012$ & 0 & 0.14 & 0.28 & 0.33 & 0.4 & 0.17 & -- \\
\hline $4 / 25 / 2012$ & 0.31 & 0 & 0.28 & 0.19 & 0.36 & 2.02 & -- \\
\hline $4 / 26 / 2012$ & -- & 0 & 0.44 & 0.41 & 0.67 & 0.59 & -- \\
\hline $4 / 30 / 2012$ & -- & -- & -- & 0.4 & 1.42 & 1.54 & -- \\
\hline $5 / 1 / 2012$ & -- & 0.7 & 2.29 & 0.59 & 0.94 & 1.08 & -- \\
\hline $5 / 2 / 2012$ & 1.02 & 0.58 & 0.49 & 0.59 & 0.4 & 0.87 & -- \\
\hline $5 / 3 / 2012$ & -- & 0.94 & 0.9 & 0.43 & 1.07 & -- & -- \\
\hline $5 / 7 / 2012$ & -- & -- & 0 & 0.11 & 0.18 & -- & -- \\
\hline $5 / 8 / 2012$ & 0.27 & 0.13 & 0.22 & 0.13 & 0.34 & 0.67 & -- \\
\hline $5 / 9 / 2012$ & 0 & 0 & 0.11 & 0.11 & 0 & 0.44 & -- \\
\hline $5 / 10 / 2012$ & -- & -- & 0 & 0 & 0.19 & 0.77 & -- \\
\hline $5 / 14 / 2012$ & -- & -- & -- & 0 & 0.1 & 0 & -- \\
\hline $5 / 15 / 2012$ & 0.26 & 0.28 & 0 & 0.11 & 0.11 & 0.22 & -- \\
\hline $5 / 16 / 2012$ & 0.25 & 0.15 & 0.16 & 0.11 & 0 & 0.17 & -- \\
\hline $5 / 17 / 2012$ & -- & 0 & 0.16 & 0.12 & 0.12 & 0 & -- \\
\hline $5 / 21 / 2012$ & -- & -- & 0 & 0 & 0.22 & 0 & -- \\
\hline $5 / 22 / 2012$ & 0 & -- & -- & 0.11 & 0.25 & 0.25 & 2.07 \\
\hline $5 / 23 / 2012$ & -- & -- & -- & 0 & 0 & 0.51 & 1.33 \\
\hline $5 / 24 / 2012$ & -- & -- & -- & -- & 0 & 0.34 & 0.61 \\
\hline $5 / 29 / 2012$ & -- & -- & 0 & 0 & 0 & 0.45 & -- \\
\hline $5 / 30 / 2012$ & -- & -- & -- & 0 & 0 & 0.4 & -- \\
\hline $5 / 31 / 2012$ & -- & -- & -- & 0 & 0 & 0.38 & -- \\
\hline 6/4/2012 & -- & -- & -- & 0 & 0 & 0.11 & -- \\
\hline $6 / 5 / 2012$ & -- & -- & 0 & 0 & 0 & 0 & -- \\
\hline $6 / 6 / 2012$ & -- & -- & 0 & 0 & 0 & 0 & -- \\
\hline $6 / 7 / 2012$ & -- & -- & 0 & 0 & 0 & 0 & -- \\
\hline $6 / 11 / 2012$ & -- & -- & -- & 0 & 0 & 0.09 & -- \\
\hline $6 / 12 / 2012$ & -- & -- & -- & 0 & 0 & 0.05 & -- \\
\hline $6 / 13 / 2012$ & -- & -- & -- & 0 & 0 & 0 & -- \\
\hline $6 / 14 / 2012$ & -- & -- & -- & 0 & 0 & 0 & -- \\
\hline $6 / 18 / 2012$ & -- & -- & -- & 0 & 0 & 0 & -- \\
\hline $6 / 19 / 2012$ & -- & -- & -- & 0 & 0 & 0 & -- \\
\hline $6 / 20 / 2012$ & -- & -- & -- & 0 & 0 & 0 & -- \\
\hline $6 / 21 / 2012$ & -- & -- & -- & 0 & 0 & 0 & -- \\
\hline $6 / 25 / 2012$ & -- & -- & -- & 0 & 0 & 0 & -- \\
\hline $6 / 26 / 2012$ & -- & -- & -- & 0 & 0 & 0 & -- \\
\hline $6 / 27 / 2012$ & -- & -- & -- & 0 & 0 & 0 & -- \\
\hline 7/9/2012 & -- & -- & -- & 0 & 0 & 0 & -- \\
\hline $7 / 10 / 2012$ & -- & -- & -- & 0 & 0 & 0 & -- \\
\hline $7 / 11 / 2012$ & -- & -- & -- & 0 & 0 & 0 & -- \\
\hline
\end{tabular}


Table 7-10. Mean density, number per 100 cubic meters, of paddlefish free embryos and larvae collected in the Missouri River per sampling day.-Continued

$[--$, no data $]$

\begin{tabular}{|c|c|c|c|c|c|c|c|}
\hline \multirow{2}{*}{ Date } & \multicolumn{7}{|c|}{ Station number } \\
\hline & 1 & 2 & 3 & 4 & 5 & 6 & 7 \\
\hline 7/12/2012 & -- & -- & -- & 0 & 0 & 0 & - \\
\hline $7 / 23 / 2012$ & -- & -- & -- & 0 & 0 & 0 & - \\
\hline $7 / 24 / 2012$ & -- & -- & -- & 0 & 0 & 0 & - \\
\hline $7 / 25 / 2012$ & -- & -- & -- & 0 & 0 & 0 & - \\
\hline 7/26/2012 & -- & -- & -- & 0 & 0 & 0 & - \\
\hline 8/6/2012 & -- & -- & -- & 0 & 0 & 0 & - \\
\hline 8/7/2012 & -- & -- & -- & 0 & 0 & 0 & - \\
\hline 8/8/2012 & -- & -- & -- & 0 & 0 & 0 & - \\
\hline 8/9/2012 & -- & -- & -- & 0 & 0 & 0 & - \\
\hline $8 / 20 / 2012$ & -- & -- & -- & -- & 0 & 0 & - \\
\hline $8 / 21 / 2012$ & -- & -- & -- & 0 & 0 & 0 & - \\
\hline 8/22/2012 & -- & -- & -- & 0 & 0 & 0 & - \\
\hline 8/23/2012 & -- & -- & -- & 0 & 0 & 0 & - \\
\hline 9/4/2012 & -- & -- & -- & 0 & 0 & 0 & - \\
\hline 9/5/2012 & -- & -- & -- & 0 & 0 & 0 & - \\
\hline 9/6/2012 & -- & -- & -- & 0 & 0 & 0 & - \\
\hline 9/17/2012 & -- & -- & -- & 0 & 0 & 0 & - \\
\hline 9/18/2012 & -- & -- & -- & 0 & 0 & 0 & $\ldots$ \\
\hline 9/19/2012 & -- & -- & -- & 0 & 0 & 0 & $\ldots$ \\
\hline $9 / 20 / 2012$ & -- & -- & -- & -- & 0 & 0 & - \\
\hline $10 / 1 / 2012$ & -- & -- & -- & -- & 0 & 0 & - \\
\hline $10 / 2 / 2012$ & -- & -- & -- & 0 & 0 & 0 & - \\
\hline $10 / 3 / 2012$ & -- & -- & -- & 0 & 0 & 0 & - \\
\hline $10 / 4 / 2012$ & -- & -- & -- & 0 & 0 & 0 & $\ldots$ \\
\hline
\end{tabular}


was only sampled on these 3 days because of dangerous sampling conditions caused by the deep, swift water of the thalweg. Water temperatures at the site during this time were about $22^{\circ} \mathrm{C}$. Excluding station 7 , mean density of sturgeon was highest at station 6 on May $23\left(1.68\right.$ sturgeon $\left./ 100 \mathrm{~m}^{3}\right)$, closely followed by May 24 and $29\left(1.65\right.$ sturgeon $/ 100 \mathrm{~m}^{3}$ and 1.52 sturgeon $/ 100 \mathrm{~m}^{3}$, respectively). Water temperatures recorded during this time ranged from $22.3{ }^{\circ} \mathrm{C}$ to $25^{\circ} \mathrm{C}$. Mean density of paddlefish was more variable among sampling stations than mean density of sturgeon; however, the collection of paddlefish was more synchronous during the sampling period. The highest mean density of paddlefish was 2.29 paddlefish $/ 100 \mathrm{~m}^{3}$ recorded at station 3 on May 1 , followed by 2.07 paddlefish $/ 100 \mathrm{~m}^{3}$ collected at station 7 on May 22 and 2.02 paddlefish $/ 100 \mathrm{~m}^{3}$ collected at station 6 on April 25 (table 7-10). Water temperatures recorded during this time ranged from $15.4^{\circ} \mathrm{C}$ to $22.5^{\circ} \mathrm{C}$.

In total, 338 specimens, 4 collected during preliminary sampling and 334 collected at seven stations, were analyzed for genetic species determination. Two sturgeon were unintentionally allowed to desiccate, rendering genetic analysis impossible. These two samples were not sent for genetic analysis. Results from species determination of Scaphirhynchus spp. specimens indicated that none of the 338 samples were pure pallid sturgeon, and 333 of the 338 samples were shovelnose sturgeon ( $p>0.95$; Heist and Eichelberger, 2013). Analysis of the remaining five specimens was consistent with shovelnose sturgeon, or possibly a hybrid or backcross of shovelnose sturgeon with pallid sturgeon (Heist and Eichelberger, 2013). The current (2015) genetic techniques cannot precisely identify the exact type of hybridization (for example, first generation, or backcross between a hybrid and a genetically pure individual of either species) between pallid and shovelnose sturgeon because only subtle differences in allele frequencies exist, not fixed differences. These five specimens were collected from April 30 through June 7, 2012, at stations 6 and 7.

\section{Summary}

During 2012, most paddlefish appeared to spawn during April and May. Collection of free-embryo and larval specimens indicated that paddlefish spawning began earlier in the spring and was more synchronous than sturgeon spawning. Most sturgeon spawned from April through early June; however, this research also documented sturgeon spawning in late August and into September. One small sturgeon (7.14 millimeters total length) was collected at station 6 on September 17, 2012, when water temperature was approximately 22.4 degrees Celsius. Size and developmental characteristics indicated that this sturgeon free embryo was less than 1 day post-hatch. These findings support earlier suggestions that shovelnose sturgeon in the Missouri River below Gavins Point Dam have a protracted spawning period (Simpkins and LaBay, 2007).
Free-embryo and larval sturgeon were found in highest numbers and densities near and in the thalweg at stations 6 and 7, despite the fact that station 7 was only successfully sampled on 3 days; therefore, it seems that many sturgeon are drifting in or near the thalweg where velocities are highest, and were likely underrepresented because of the limitations of sampling at station 7 . This finding limits our ability to estimate the export of dispersing free-embryo sturgeon and paddlefish transported by the Missouri River. It does, however, seem to support the hypothesis (DeLonay and others, 2009) that sturgeon free embryos and larvae may drift long distances and may be drifting out of the Lower Missouri River into the Mississippi River. It has not been determined whether or not drift into the Mississippi River is beneficial or detrimental to survival. The extent to which the contemporary engineered channel facilitates downstream transport and enhances export of free embryos is an important research need.

Despite documentation of spawning by female pallid sturgeon (DeLonay and others, 2009; DeLonay and others, 2010; DeLonay and others, 2012), the relative success of spawning in the Lower Missouri River remains unknown. To date, only two confirmed pallid sturgeon free embryos have been collected in the Yellowstone and Upper Missouri Rivers and none in the Lower Missouri River (Heist and Eichelberger, 2013) suggesting that natural spawning, hatch, or both are severely limited. Additionally, though there is some uncertainty surrounding the exact genetic species assignment of the 5 specimens collected during 2012 that did not strongly assign to either pallid or shovelnose sturgeon, the detection of these potential genetically-introgressed specimens may indicate some level of hybridization between pallid and shovelnose sturgeon in the Lower Missouri River.

\section{References Cited}

Bajer, P.G., and Wildhaber, M.L., 2007, Population viability analysis of lower Missouri River shovelnose sturgeon with initial application to the pallid sturgeon: Journal of Applied Ichthyology, v. 23, no. 4, p. 457-464. [Also available at http://dx.doi.org/10.1111/j.1439-0426.2007.00879.x.]

Braaten, P.J., Fuller, D.B., Holte, L.D., Lott, R.D., Viste, William, Brandt, T.F., and Legare, R.G., 2008, Drift dynamics of larval pallid sturgeon and shovelnose sturgeon in a natural side channel of the upper Missouri River, Montana: North American Journal of Fisheries Management, v. 28, no. 3, p. 808-826. [Also available at http://dx.doi. org/10.1577/M06-285.1.] 
DeLonay, A.J., Jacobson, R.B., Papoulias, D.M., Simpkins, D.G., Wildhaber, M.L., Reuter, J.M., Bonnot, T.W., Chojnacki, K.A., Korschgen, C.E., Mestl, G.E., and Mac, M.J., 2009, Ecological requirements of pallid sturgeon reproduction and recruitment in the lower Missouri River-A research synthesis 2005-08: U.S. Geological Survey OpenFile Report 2009-5201, 59 p. [Also available at http://pubs. usgs.gov/sir/2009/5201/.]

DeLonay, A.J., Jacobson, R.B., Papoulias, D.M., Wildhaber, M.L., Chojnacki, K.A., Pherigo, E.K., Bergthold, C.L., and Mestl, G.E., 2010, Ecological requirements of pallid sturgeon reproduction and recruitment in the lower Missouri River-Annual Report 2009: U.S. Geological Survey OpenFile Report 2010-1215, 64 p. [Also available at http://pubs. usgs.gov/of/2010/1215/.]

DeLonay, A.J., Jacobson, R.B., Papoulias, D.M., Wildhaber, M.L., Chojnacki, K.A., Pherigo, E.K., Haas, J.D., and Mestl, G.E., 2012, Ecological requirements for pallid sturgeon reproduction and recruitment in the lower Missouri River-Annual report 2010: U.S. Geological Survey OpenFile Report 2012-1009, 51 p. [Also available at http://pubs. usgs.gov/of/2012/1009/.]

Dettlaff, T.A., Ginsburg, A.S., and Schmalhausen, O.I., 1993, Sturgeon fishes-Developmental biology and aquaculture: Berlin, Springer-Verlag, $300 \mathrm{p}$.

Heist, E.J., and Eichelberger, J., 2013, 2012 genetic analysis of Missouri River sturgeon larvae: Center for Fisheries, Aquaculture, and Aquatic Sciences, Southern Illinois University Carbondale, $27 \mathrm{p}$.

Humphries, Paul, Serafini, L.G., and King, A.J., 2002, River regulation and fish larvae-Variation through space and time: Freshwater Biology, v. 47, no. 7, p. 1307-1331. [Also available at http://dx.doi.org/10.1046/j.13652427.2002.00871.x.]

Kynard, B., Parker, E., Pugh, D., and Parker, T., 2007, Use of laboratory studies to develop a dispersal model for Missouri River pallid sturgeon early life intervals: Journal of Applied Ichthyology, v. 23, p. 365-374. [Also available at http:// dx.doi.org/10.1111/j.1439-0426.2007.00908.x.]

Reuter, J.M., Jacobson, R.B., Elliott, C.M., and DeLonay, A.J., 2009, Assessment of lower Missouri River physical aquatic habitat and its use by adult sturgeon (genus Scaphirhynchus) 2005-07: U.S. Geological Survey Scientific Investigations Report 2009-5121, 81 p. [Also available at http:// pubs.er.usgs.gov/usgspubs/sir/sir20095121.]

Scheidegger, K.J., and Bain, M.B., 1995, Larval fish distribution and microhabitat use in free-flowing and regulated rivers: American Society of Ichthyologists and Herpetologists, Copeia, v. 1995, no. 1, p. 125-135. [Also available at http:// www.jstor.org/stable/1446807.]
Simpkins, D.G., and LaBay, S.R., 2007, Site-specific assessment of spawning behavior and habitat use, in Korschgen, C., ed., Factors affecting the reproduction, recruitment, habitat, and population dynamics of pallid sturgeon and shovelnose sturgeon in the Missouri River: U.S. Geological Survey Open-File Report 2007-1262, p. 217-254. [Also available at http://pubs.usgs.gov/of/2007/1262/pdf/OF20071262.pdf.]

Steffensen, K.D., Pegg, M.A., and Mestl, G., 2013, Population prediction and viability model for pallid sturgeon (Scaphirhynchus albus, Forbes and Richardson, 1905) in the lower Missouri River: Journal of Applied Ichthyology, v. 29, no. 5, p. 984-989. [Also available at http://dx.doi.org/10.1111/ jai.12277.]

U.S. Fish and Wildlife Service, 2007, Pallid sturgeon (Scaphirhynchus albus) 5-year review-Summary and evaluation: Billings, Mont., U.S. Fish and Wildlife Service, 120 p.

Wildhaber, M.L., DeLonay, A.J., Papoulias, D.M., Galat, D.L., Jacobson, R.B., Simpkins, D.G., Braaten, P.J., Korschgen, C.E., and Mac, M.J., 2007, A conceptual life-history model for pallid and shovelnose sturgeon: U.S. Geological Survey Circular 1315, 18 p. [Also available at http://pubs.usgs.gov/ circ/2007/1315/.]

Wildhaber, M.L., DeLonay, A.J., Papoulias, D.M., Galat, D.L., Jacobson, R.B., Simpkins, D.G., Braaten, P.J., Korschgen, C.E., and Mac, M.J., 2011, Identifying structural elements needed for development of a predictive life-history model for pallid and shovelnose sturgeons: Journal of Applied Ichthyology, v. 27, no. 2, p. 462-469. [Also available at http:// dx.doi.org/10.1111/j.1439-0426.2011.01731.x.] 


\section{Appendix 8. Influence of Channel Morphology and Flow Regime on Free- Embryo Drift of Pallid Sturgeon in the Lower Missouri River}

\section{Background}

Downstream transport of a constituent, or passively drifting organisms, is a function of mean channel velocity (advection) and hydraulic factors that tend to distribute particles longitudinally around the center of mass of the particles (dispersion). Particle transport is typically mathematically expressed using the one-dimensional advection-dispersion equation (Fischer, 1973), in which the strength of the longitudinal dispersion is quantified by the longitudinal dispersion coefficient (henceforth referred to as the dispersion coefficient $\left.\left[D_{L}\right]\right)$. Traditionally, $D_{L}$ has been estimated by direct measurement from tracer studies (Yotsukura and others, 1970) or calculated using empirical relations (Jobson, 1996); however, tracer experiments are costly endeavors, yielding results that apply to a limited range of flow conditions, and empirical relations may only provide accuracy to within an order of magnitude. Recent advances in instrumentation that allow for the rapid collection of stream velocity and bathymetric data have facilitated an alternative approach, in which estimates of $D_{L}$ may be derived directly from the theory of shear dispersion and velocity data (Carr and Rehmann, 2007; Kim, 2012).

Correctly estimating $D_{L}$ is critical to accurately predicting the longitudinal distribution of particles in transport; however, dispersion coefficients also may be used as a metric to evaluate the relative retention capacity of geomorphically distinct sections of river. Higher values of the coefficient suggest a greater retentive potential at a given cross-section, thus increasing dispersion in the along-stream direction.

\section{Scope and Objectives}

To explore the effects of flow regime and channel morphology on drift of free-embryo pallid sturgeon (Scaphirhynchus albus), $D_{L}$ was calculated for several velocity measurement sites along the Lower Missouri River. Additionally, reach average values of $D_{L}$ were used to model drift at documented spawning sites to provide a first-order estimation of cumulative drift distances along the Lower Missouri River.

\section{Methods}

Dispersion coefficients were calculated using velocity data collected by an acoustic Doppler current profiler (ADCP) in 11 reaches on the Lower Missouri River (fig. 8-1, table 8-1). Calculations were made using existing ADCP data and selection of data was determined by the following factors: (1) river mile, (2) discharge, (3) data quality and continuity, (4) the number of transects contained within the dataset, and (5) channel curvature. Because the goal was to quantify longitudinal patterns in dispersion in the Lower Missouri
River, measurement sites were selected from the Gavins Point, Ponca, Big Sioux, Kansas, and Grand segments. Dispersion coefficients are highly sensitive to variations in discharge, and discharge varies substantially along the length of the Lower Missouri River; thus, to facilitate comparison of values among measurement sites, datasets used were limited in this analysis to those collected when discharge was within a limited range of flow exceedance values (64-82 percent exceedance) as measured at the U.S. Geological Survey (USGS) streamgage location nearest each measurement site for the period of regulated flows, 1967-2012 (Galat and Lipkin, 2000) (table 8-1). All data selected for use in the present (2015) analysis were collected in 2005, 2006, or 2007. Although more recent ADCP data have been collected on the Lower Missouri River, the largest availability of data were collected in numerous segments at comparable flow exceedances for the period from 2005 to 2007 . Analysis was limited to datasets where most cross-sections fully spanned the wetted channel and transects contained limited missing ensembles. Additionally, datasets surveyed in bends with high curvature were excluded since theoretical determination of $D_{L}$ is less accurate at sites where patterns of secondary circulation dominate the flow field. All velocity measurements were done using a Rio Grande ADCP (Teledyne RD Instruments, Poway, California). Data were originally reported by Reuter and others (2009).

Dispersion coefficients were calculated using AdcpXP, a software package developed at the University of Iowa Department of Hydroscience and Engineering for post-processing ADCP data (www.iihr.uiowa.edu/research/pulications-andmedia/adcpxp-software-release-ii/). The $\mathrm{D}_{\mathrm{L}}$ was determined for each cross-section, using the one-dimensional equation for the longitudinal dispersion coefficient (Fischer, 1973):

$$
D_{L}=-\frac{1}{A} \int_{0}^{B} u^{\prime}(y) h(y) d y \int_{0}^{y} \frac{1}{D_{y} h\left(y^{\prime}\right)} d y^{\prime} \int_{0}^{y^{\prime}} u^{\prime}\left(y^{\prime \prime}\right) h\left(y^{\prime \prime}\right) d y^{\prime \prime}
$$

where

$$
\begin{aligned}
A & \text { is cross-sectional area, } \\
B & \text { is channel width, } \\
y & \text { is the cross-stream coordinate, } \\
h & \text { is depth, and } \\
D_{y} & \text { is the transverse mixing coefficient. }
\end{aligned}
$$

The depth-averaged velocity deviation from the mean cross-sectional velocity is:

$$
u^{\prime}(y)=u(y)-\bar{U}
$$

where

$u^{\prime}(y) \quad$ is the mean cross-sectional velocity,

$u(y)$ is the depth-averaged streamwise velocity, and

$\bar{U} \quad$ is the cross-sectionally-averaged streamwise velocity. 


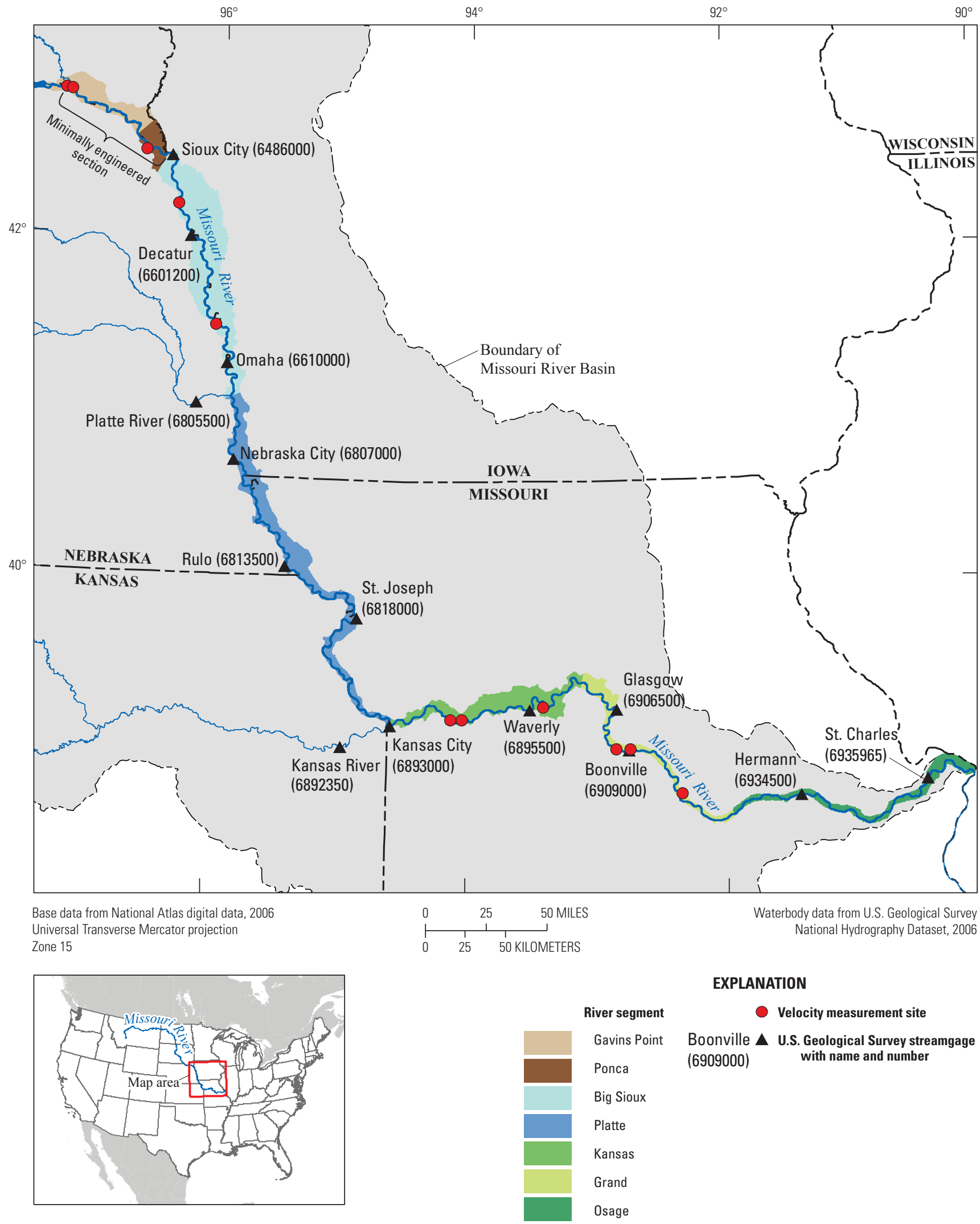

Figure 8-1. Missouri River segments, U.S. Geological Survey streamgages, and velocity measurement sites used for calculation of longitudinal dispersion coefficients. 
Table 8-1. Characteristics of Missouri River sites used to obtain data for estimating dispersion coefficients.

$\left[\mathrm{m}^{3} / \mathrm{s}\right.$, cubic meter per second]

\begin{tabular}{ccccccccc}
\hline $\begin{array}{c}\text { Measured } \\
\text { site } \\
\text { number }\end{array}$ & Segment & $\begin{array}{c}\text { River } \\
\text { mile }\end{array}$ & Date & $\begin{array}{c}\text { Mean daily } \\
\text { discharge } \\
\left(\mathbf{m}^{3} / \mathbf{s}\right)\end{array}$ & Closest streamgage & $\begin{array}{c}\text { Streamgage } \\
\text { river mile }\end{array}$ & $\begin{array}{c}\text { Flow } \\
\text { exceedance, } \\
\text { in percent }\end{array}$ & $\begin{array}{c}\text { Number of } \\
\text { transects } \\
\text { used }\end{array}$ \\
\hline 1 & Gavins & 799 & 22 May, 2007 & 702 & Sioux City, Iowa & 732 & 69 & 21 \\
2 & Gavins & 797 & 1 June, 2007 & 637 & Sioux City, Iowa & 732 & 74 & 12 \\
3 & Ponca & 745 & 25 May, 2007 & 646 & Sioux City, Iowa & 732 & 74 & 26 \\
4 & Big Sioux & 707 & 13 June, 2007 & 733 & Sioux City, Iowa & 732 & 66 & 90 \\
5 & Big Sioux & 640 & 16 June, 2007 & 858 & Omaha, Nebraska & 616 & 64 & 87 \\
6 & Kansas & 332 & 20 June, 2006 & 1,008 & Kansas City, Missouri & 366 & 79 & 73 \\
7 & Kansas & 328 & 24 May, 2006 & 1,093 & Kansas City, Missouri & 366 & 73 & 75 \\
8 & Kansas & 278 & 14 June, 2006 & 1,059 & Waverly, Missouri & 293 & 64 & 54 \\
9 & Grand & 202 & 6 June, 2006 & 1,135 & Boonville, Missouri & 197 & 78 & 60 \\
10 & Grand & 196 & 7 June, 2006 & 1,076 & Boonville, Missouri & 197 & 82 & 78 \\
11 & Grand & 162 & 10 May, 2005 & 1,147 & Boonville, Missouri & 197 & 78 & 70 \\
\hline
\end{tabular}

In AdcpXP, the transverse mixing coefficient is defined as:

$$
D_{y}=0.6 u^{*} h
$$

where

$u^{*} \quad$ is shear velocity.

Shear velocity is calculated using a reach-scale estimate:

$$
u^{*}=(g R S)^{0.5}
$$

where

$$
\begin{array}{ll}
g & \text { is gravity, } \\
R & \text { is hydraulic radius, and } \\
S & \text { is water surface slope (Kim, 2012). }
\end{array}
$$

A constant $S$ of $2.0 \times 10^{-4}$ was inputted based on estimates of the slope of the 75 percent exceedance water surface elevation, also known as the Missouri River Construction Reference Plane (CRP) (U.S. Army Corps of Engineers, unpub. data). The variation in $D_{L}$ resulting from variations in slope within the range of values reported for the Lower Missouri River is small relative to the variation in $D_{L}$ resulting from variability in the flow field.

When calculating dispersion coefficients using the theoretical framework developed by Fischer (1973) based on ADCP data, it must be ensured $D_{L}$ reflects deviations of depthaveraged velocities from the mean cross-sectional velocity, not the small-scale turbulence-induced fluctuations in velocity; thus, calculations of $D_{L}$ were compared based on single transects and multiple reciprocal transects (pairs of transects surveyed across the current in opposing directions) at select sites. The difference among values from multiple passes at a given transect and the average of those values is small compared to the variability observed between one transect and another; thus, because our calculations of longitudinal dispersion coefficients were insensitive to averaging reciprocal transects and there was very limited data where repeat velocity transects were collected at the same cross-section, single transects were used to calculate $D_{L}$ in this analysis.

Drift of free embryos for two sites were modeled where spawning has been documented on the Lower Missouri River. Total drift distances were calculated using the one-dimensional advection-dispersion equation (Fischer, 1973):

$$
C=\left[\frac{M}{2 A \sqrt{\pi D_{L} t}}\right] e^{\frac{-(x-\bar{U} t)^{2}}{4 D_{L} t}}
$$

where

$$
\begin{aligned}
C & \text { is concentration of free embryos, } \\
M & \text { is the number of free embryos released, } \\
t & \text { is time post-release, and } \\
x & \text { is distance downstream. }
\end{aligned}
$$

The first drift simulation is for a spawning event that began on April 28, 2010, at about river mile (RM) 634. The second spawning event considered began on May 17, 2011, at RM 216. In each simulation the median $D_{L}$ value determined at the site nearest the spawning location was used (RM 640 for the 2010 spawning event and RM 202 for the 2011 spawning event). Mean cross-sectional velocity was determined from the nearest USGS streamgage on the initial day of spawning and treated as a constant.

Interpretation of advection-dispersion model results must be considered in light of several important assumptions. First, the approach assumes that drift is entirely passive, an assumption challenged by empirical data that suggest that free embryos drift downstream at a rate slightly slower than the mean channel velocity and tend to seek the bottom (Braaten and others, 2012). It is unknown, however, the degree to which drifting free embryos exert control over position in the water column and cross-section in such a swift and turbulent 
environment as the Lower Missouri River. Second, the model used here is one-dimensional; thus, although calculation of the $D_{L}$ reflects the cross-stream variability in velocity, the approach greatly simplifies the effects of hydraulic heterogeneity on dispersion and drift. Third, input parameters for each site were taken from the location where spawning was documented; therefore, the simulations do not account for longitudinal variation in model inputs, such as velocity and $D_{L}$; consequently, because velocity steadily increases in the downstream direction, calculations may represent a conservative estimate of total downstream transport.

Despite these assumptions, the model results provide a valuable first-order estimate of total drift distance along the Lower Missouri River. The analysis provides a more robust approach for calculating total drift distance than simple estimates of total travel distance based on mean velocity because it explicitly accounts for dispersion of free embryos along a longitudinal gradient; moreover, incorporation of the dispersion coefficient into the model allows exploration of the effects of varying channel morphology on downstream transport of drifting free embryos.

\section{Results}

Median values of $D_{L}$ range from about 100 meters squared per second $\left(\mathrm{m}^{2} / \mathrm{s}\right)$ in a reach of the Big Sioux segment to greater than $(>) 2,000 \mathrm{~m}^{2} / \mathrm{s}$ in one reach within the Grand segment (table $8-2$ ). Within each reach, there is a large range in calculated values of $D_{L}$ (fig. 8-2), reflecting the within-reach hydraulic variability induced by variations in engineering structures and channel form. The interquartile range (IQR) of $D_{L}$ among measured reaches was $109 \mathrm{~m}^{2} / \mathrm{s}$ to $2,629 \mathrm{~m}^{2} / \mathrm{s}$.

Values of $D_{L}$ vary longitudinally (table $8-2$ ). The highest values of $D_{L}$ are in the Kansas and Grand segments where the median values range from 866 to $2,206 \mathrm{~m}^{2} / \mathrm{s}$. The Kansas and Grand segments also contain the greatest variability in calculated values of $D_{L}$. The IQR within these reaches ranges from 1,330 to $2,629 \mathrm{~m}^{2} / \mathrm{s}$. The lowest median values and the lowest IQR are in the Big Sioux segment. The two reaches in the Big Sioux segment have median values of 102 and $137 \mathrm{~m}^{2} / \mathrm{s}$, and IQR of 327 and $109 \mathrm{~m}^{2} / \mathrm{s}$. The measurement reach within the Ponca segment also has a low median value $\left(D_{L}=163 \mathrm{~m}^{2} / \mathrm{s}\right)$. Dispersion coefficients in the Gavins segment fall in between the high values calculated for the downstream Lower Missouri River and the low values in the Big Sioux segment farther upstream. The median $D_{L}$ in the two measurement reaches within the Gavins segment were 1,154 and $445 \mathrm{~m}^{2} / \mathrm{s}$.

Dispersion coefficients reported compare favorably to estimates of $D_{L}$ determined from tracer studies done in a 227-kilometer (km) (141-mile [mi]) reach of the Lower Missouri River between Sioux City, Iowa, and Plattsmouth, Nebraska (Yotsukura and others, 1970). At the time of the tracer experiment, discharge at the measurement sites ranged from about 880 to 980 cubic meters per second $\left(\mathrm{m}^{3} / \mathrm{s}\right)$ $\left(31,200-34,500\right.$ cubic feet per second $\left.\left[\mathrm{ft}^{3} / \mathrm{s}\right]\right)$, and the calculated dispersion coefficients ranged from 690 to $2,472 \mathrm{~m}^{2} / \mathrm{s}$,

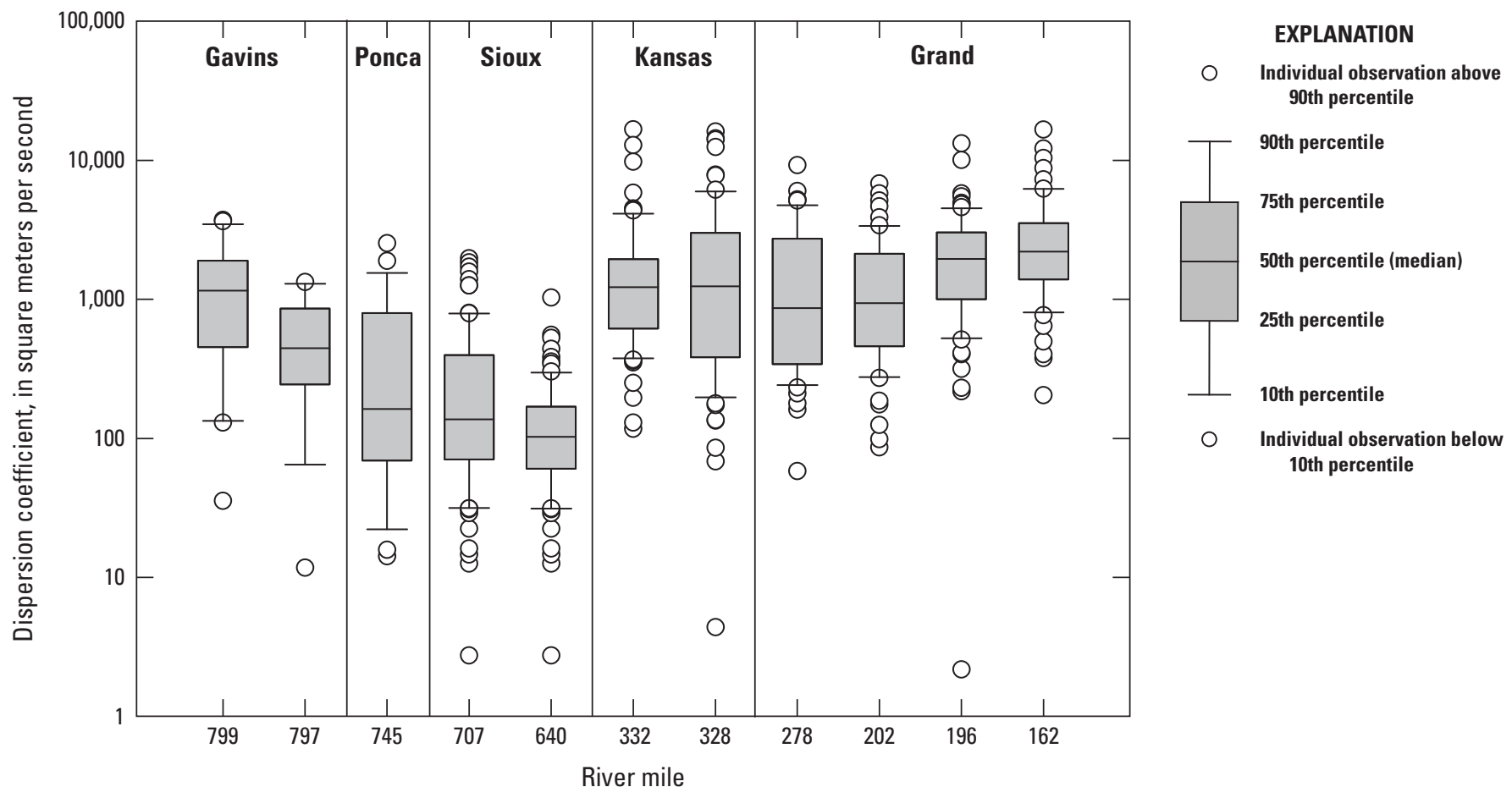

Fgure 8-2. Dispersion coefficients calculated for velocity measurement sites along the Lower Missouri River. 
Table 8-2. Descriptive statistics for longitudinal dispersion coefficient calculated for each measurement site in the Missouri River.

$\left[D_{L}\right.$, dispersion coeffiecient; $\mathrm{m}^{2} / \mathrm{s}$; square meter per second $]$

\begin{tabular}{ccccccccc}
\hline $\begin{array}{c}\text { Measured } \\
\text { site } \\
\text { number }\end{array}$ & Segment & $\begin{array}{c}\text { River } \\
\text { mile }\end{array}$ & Date & $\begin{array}{c}\text { Mean } \\
\mathbf{D}_{\mathbf{L}}\left(\mathbf{m}^{2} / \mathbf{s}\right)\end{array}$ & $\begin{array}{c}\text { Standard deviation } \\
\boldsymbol{D}_{\mathbf{L}}\left(\mathbf{m}^{2} \mathbf{s} \mathbf{s}\right)\end{array}$ & $\begin{array}{c}\mathbf{1 s t} \text { quartile } \\
\left(\mathbf{m}^{2} / \mathbf{s}\right)\end{array}$ & $\begin{array}{c}\text { Median } \\
\mathbf{D}_{\mathbf{L}}\left(\mathbf{m}^{2} / \mathbf{s}\right)\end{array}$ & $\begin{array}{c}\text { 3rd quartile } \\
\left(\mathbf{m}^{2} \mathbf{s}\right)\end{array}$ \\
\hline 1 & Gavins & 799 & 22 May, 2007 & 1,353 & 1,062 & 453 & 1,154 & 1,898 \\
2 & Gavins & 797 & 1 June, 2007 & 562 & 410 & 245 & 445 & 860 \\
3 & Ponca & 745 & 25 May, 2007 & 470 & 639 & 69 & 163 & 798 \\
4 & Big Sioux & 707 & 13 June, 2007 & 317 & 422 & 70 & 137 & 397 \\
5 & Big Sioux & 640 & 16 June, 2007 & 142 & 146 & 60 & 102 & 169 \\
6 & Kansas & 332 & 20 June, 2006 & 1,921 & 2,642 & 616 & 1,227 & 1,946 \\
7 & Kansas & 328 & 24 May, 2006 & 2,404 & 3,319 & 384 & 1,242 & 3,013 \\
8 & Kansas & 278 & 14 June, 2006 & 1,769 & 1,929 & 342 & 866 & 2,726 \\
9 & Grand & 202 & 6 June, 2006 & 1,503 & 1,469 & 459 & 938 & 2,125 \\
10 & Grand & 196 & 7 June, 2006 & 2,333 & 2,050 & 1,003 & 1,954 & 3,023 \\
11 & Grand & 162 & 10 May, 2005 & 3,110 & 2,909 & 1,390 & 2,206 & 3,532 \\
\hline
\end{tabular}

depending on the length of river over which the tracer data were integrated. Yotsukura and others (1970) determined the most representative $D_{L}$ value to be approximately $1,487 \mathrm{~m}^{2} / \mathrm{s}$. This value is higher than the $D_{L}$ determined in this study at the ADCP measurement site upstream from Omaha (RM 640) where ADCP data were collected in 2007 (median $D_{L}=102 \mathrm{~m}^{2} / \mathrm{s}$ ); however, the tracer experiments were completed 40 years before the ADCP data, during which time the morphology of the Missouri River has continued to evolve (Jacobson and others, 2009; Pinter and others, 2010; U.S. Army Corps of Engineers, 2012). It is not exactly clear how $D_{L}$ values would necessarily have been affected by the morphologic trends through time, but it is possible that ongoing deposition on channel margins and in dike pools has resulted in diminished flow complexity and lower $D_{L}$ values. The results of the tracer experiment indicate that high values of $D_{L}$ calculated using the theoretical approach employed are within the range of expected values for a river the size of the Lower Missouri River.

Simulations of drift done using the one-dimensional advection-dispersion model indicate that pallid sturgeon free embryos that originated at spawning locations in the Lower Missouri River may drift into the Mississippi River before they begin exogenous feeding. Drift distances modeled for the May 17, 2011, spawning event, which happened near RM 216 in the Grand segment, show that at 3 days post-hatch (dph) most free embryos would have been advected downstream into the Mississippi River (fig. 8-3). Modeled drift distances for April 28, 2010, when spawning originated much farther upstream at RM 634 in the Big Sioux segment, suggest that most drifting free embryos may remain in the Missouri River through $9 \mathrm{dph}$; however, the model results suggest that by $11 \mathrm{dph}$, most of the drifting free embryos would have been exported into the Middle Mississippi River.
Estimates of drift distance and dispersion are sensitive to $D_{L}$, with larger values of $D_{L}$ resulting in a greater longitudinal spread of the distribution (fig. 8-4). Although downstream advection is determined by mean cross-sectional velocity and the central tendency of the distribution remains unchanged with varying $D_{L}$, channel morphology that promotes dispersion and retention of drifting particles may have significant implications on retention of drifting free embryos within the Lower Missouri River. For example, in the simulation of drift for the April 28, 2010, spawning event, a shift towards a longtailed longitudinal distribution of drifting free embryos would substantially increase the proportion of pallid sturgeon remaining in the Missouri River System at $11 \mathrm{dph}$.

\section{Interpretation of Longitudinal Dispersion Coefficients}

The wide range in calculated values for $D_{L}$ at each measurement site reflects the within-reach heterogeneity in channel morphology and hydraulic patterns. Transects where the channel and flow field are more uniform have low values of $D_{L}$, whereas flow transects with more variable channel morphology have a more pronounced transverse velocity gradient and thus higher values of $D_{L}$. The assumption underlying equation (1) that flow is one-dimensional may limit the validity of the equation where strong patterns of secondary circulation exist, such as in tightly curved bends or in the protected zone in between wing dikes (Carr and Rehmann, 2007). Nonetheless, the equation does accurately reflect the physical reality that at transects where there is a pronounced transverse velocity shear, the local hydraulic conditions promote greater retention and longitudinal dispersion of drifting free embryos. 
A. Drift simulation for May 17, 2011, spawning location

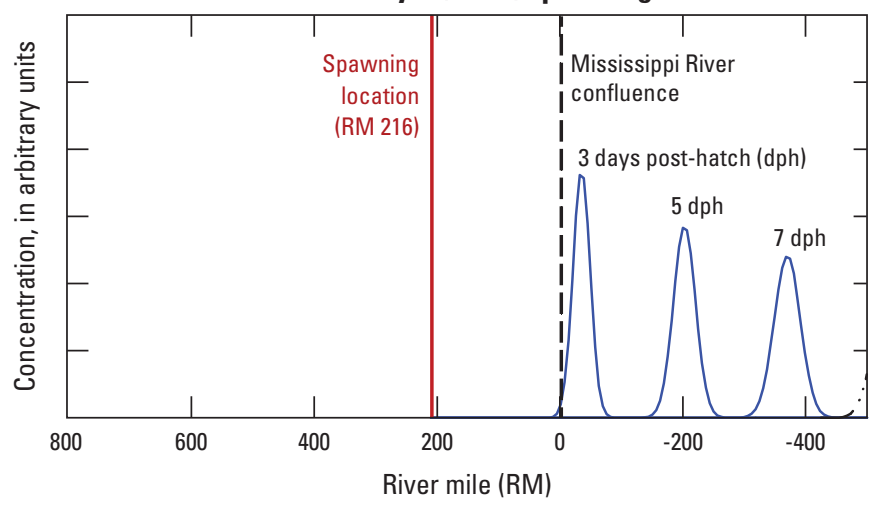

B. Drift simulation for April 28, 2010, spawning location

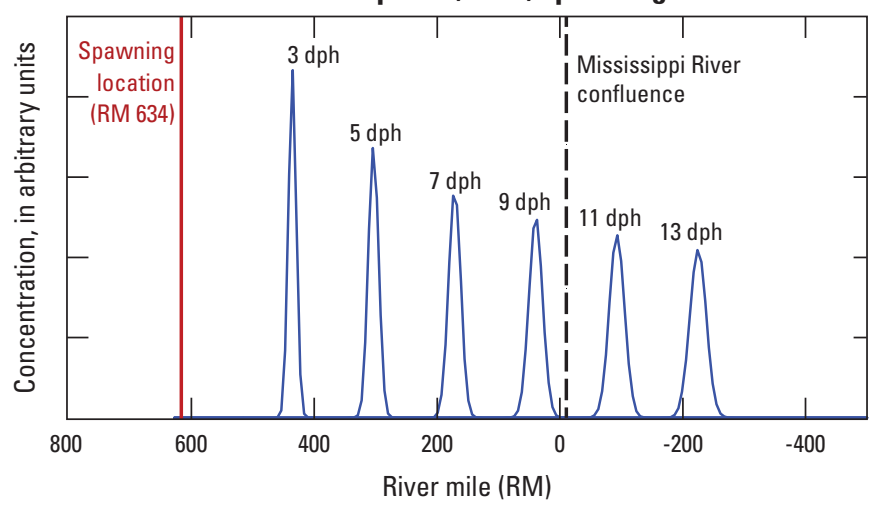

Figure 8-3. Downstream transport and dispersion of passively drifting free embryos using the one-dimensional advectiondispersion equation. $A$, drift simulation for May 17, 2011, spawning location at 3,5, and 7 days post-hatch; and $B$, drift simulation for April 28, 2010, spawning location at $3,5,7,9,11$, and 13 days posthatch.

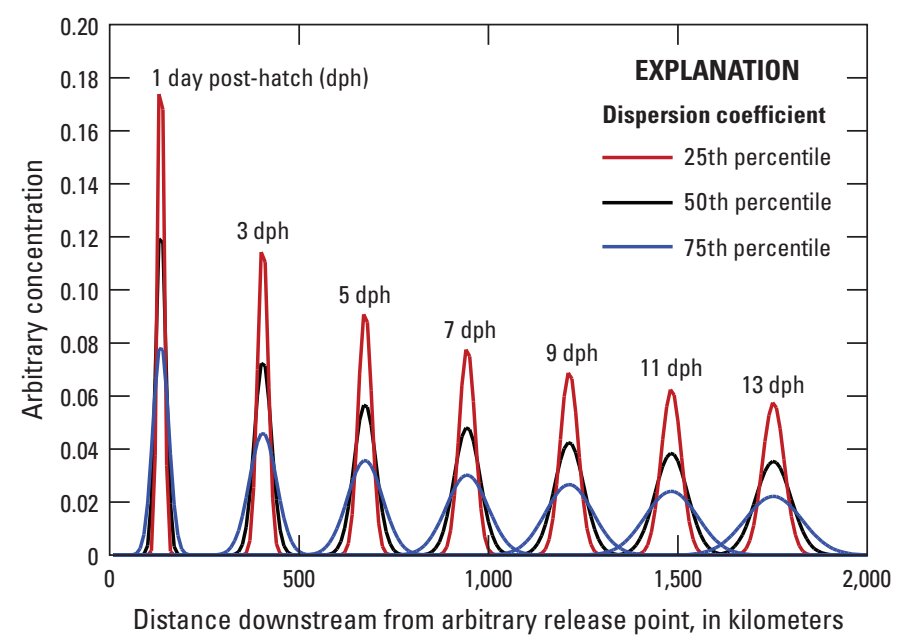

Figure 8-4. Relation between free embryo downstream drift distance and concentration of free embryos released at an arbitrary upstream point.
In addition to the intra-reach variability, inter-reach differences in the $D_{L}$ highlight the distinct geomorphic characteristics and styles of channel engineering employed in different segments of the Lower Missouri River. The channel immediately downstream from Gavins Point Dam is the least engineered section of the Lower Missouri River. The channel within the Gavins segment is multithreaded, containing numerous bars, islands, and side channels, which are features that promote hydraulic variability across a range of discharges. Farther downstream, in the Ponca segment, values of $D_{L}$ decrease compared to those of the Gavins segment, reflecting the reduced morphologic and hydraulic heterogeneity. Downstream from Sioux City, in the Big Sioux segment, channel morphology changes dramatically because of channelization by wing dikes and bank revetment. The effects of conversion of the channel to a single-threaded, self-scouring navigation channel are apparent in the values of $D_{L}$. Dispersion coefficients within the Big Sioux segment are the lowest calculated in this analysis. Additionally, the Big Sioux reach has the smallest spread in the data.

Interestingly, both the highest median values of $D_{L}$ and the greatest intra-reach variability in $D_{L}$ are in the downstream Lower Missouri River. The values of $D_{L}$ calculated for the Kansas and Grand segments reflect the abrupt change in the style of channel engineering near Rulo, Nebraska, as described in the section of this report titled, "Missouri River Management Context." Within the downstream Lower Missouri River, large dikes generate pronounced zones of recirculation and strong cross-stream velocity gradients, resulting in high dispersion coefficients. In reality, these zones of recirculation, or "dead zones", create zones of transient storage for constituents in transport and the true effects of these features cannot be captured in a one-dimensional model. The exchange rate between the main channel and dead zones associated with dikes is controlled by factors such as dike geometry, inclination, flow depth, and turbulent intensity in both the main channel and zone of recirculation. These unique physical attributes interact to determine the complex patterns of recirculation within the dead zone and the hydraulics of the shear zone at the boundary between the main channel and dead zone. In general, these zones of transient storage increase retention and retard mean transport velocity (Jirka and Weitbrecht, 2005).

It is important to emphasize that data used in this analysis were collected during a limited range of flows, and $D_{L}$ is highly sensitive to discharge. Calculation of $D_{L}$ for transects where velocity data have been collected over a range of discharges demonstrates that site-specific morphologic characteristics strongly influence the effects of changes in discharge of dispersive potential (fig. 8-5A); for example, near RM 197, ADCP data were collected at three discharges $(1,218$, 2,571 , and $6,089 \mathrm{~m}^{3} / \mathrm{s}$, or $43,000,90,800$, and $215,000 \mathrm{ft}^{3} / \mathrm{s}$ ).

As discharge increases, but dikes remain emergent, $D_{L}$ increases because of the stronger transverse velocity gradient (fig. 8-5B); however, when flow overtops the dikes, there is a decrease in $D_{L}$ because cross-stream flow becomes more uniform and there is a reduction in the relative transverse velocity 
shear. In contrast, near RM 177, where ADCP data were collected over a similar range of discharges $(1,529,2,373$, and $6,004 \mathrm{~m}^{3} / \mathrm{s}$, or $54,000,83,800$, and $212,000 \mathrm{ft}^{3} / \mathrm{s}$ ), the trend is quite different (fig. 8-5). Dispersion coefficients remain low at a range of low discharges because flow is confined to the navigation channel along the right bank of the river. Inundation of the sand bar along river left substantially increases the transverse velocity gradient and provides a zone of elevated retention, which is reflected in higher values of $D_{L}$. Analyses at these two sites highlight the sensitivity of $D_{L}$ to discharge, but more importantly highlight the site-specific interactions of local morphology, engineered structures, and hydraulics that combine to determine patterns in dispersion of drifting particles.

\section{Implications for River Management}

Complex interactions of discharge, hydraulics, and channel morphology determine drift and dispersion of free embryos. Flow regime affects drift in two distinct ways: (1) discharge and mean velocity control the advection, or downstream transport, of free embryos; and (2) changes in flow

\section{A. Change in dispersion coefficient with discharge near river mile 197}

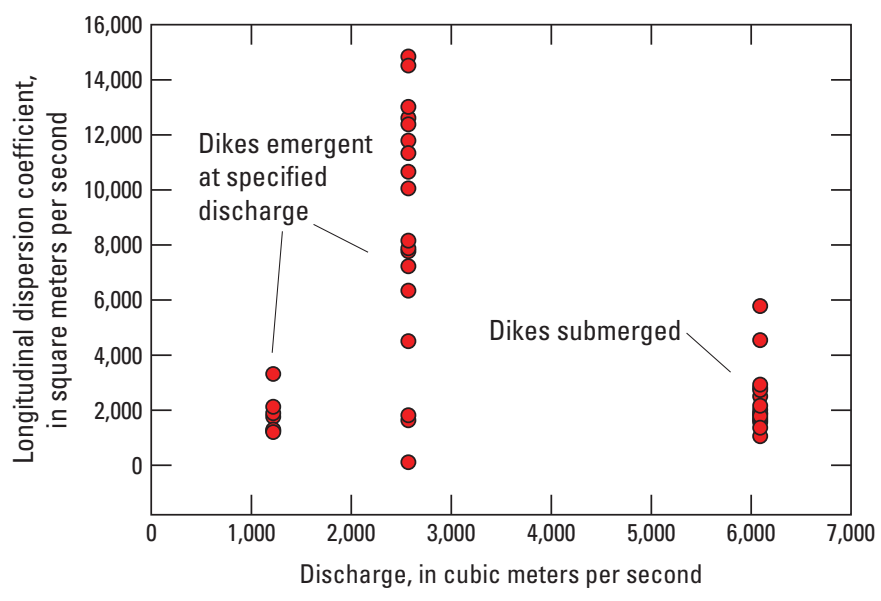

B. Change in dispersion coefficient with discharge near river mile 177

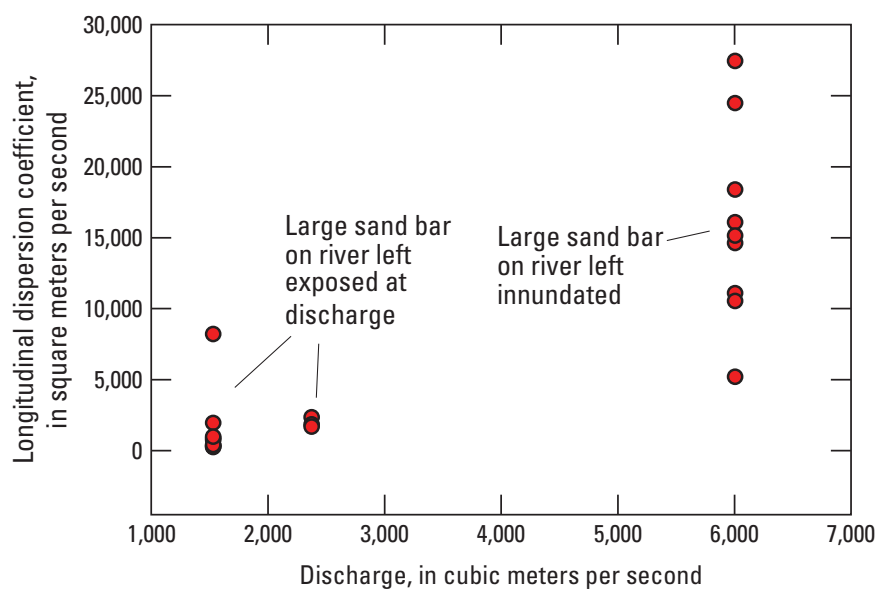

Figure 8-5. Change in the longitudinal dispersion coefficient with discharge. $A$, river mile 197 and $B$, river mile 177 . regime alter channel hydraulics, which affect the dispersion and retention of free embryos; thus, although higher flows would increase downstream advection of drifting pallid sturgeon free embryos, flow pulses also have the potential to increase dispersion of drifting free embryos, spreading them out more along a longitudinal gradient.

Retention of pallid sturgeon free embryos is influenced by the availability of littoral shallow water habitat, which has been substantially reduced throughout the Missouri River Basin by flow regulation and channel alterations (Bowen and others, 2003; Jacobson and Galat, 2006); however, although total area of shallow water habitat is substantially less than would have occurred in the absence of channel alterations, high flows have the potential to increase retention of free embryos by inundating low-lying alluvial surfaces within the active channel, secondary channels, and vegetated riparian habitats in the channel margins as may exist in natural or restored reaches of the river. The reduced flow velocities and high roughness values characteristic of these environments increase hydraulic gradients, thus promoting retention of drifting free embryos. Studies using theoretical models (Wallis and Manson, 2005) indicate that dispersion coefficients steadily increase with discharge in simplified channels, reaching a maximum when flow has just overtopped the channel banks and inundated the floodplain; thus, flow regime modifications have the potential to substantially influence patterns of retention and dispersion of drifting free embryos by altering how flow interacts with various channel and floodplain environments.

The effects of flow regime on dispersion of free embryos are tightly coupled to channel morphology. A spring flow pulse may affect dispersal of free embryos in very different ways in different parts of the Missouri River, reflecting the unique interaction of discharge, channel engineering, and hydraulics; for example, Jacobson and Galat (2006) demonstrated that in channelized reaches of the river that display reduced morphologic and hydraulic complexity, increases in discharge result in no increase in total area of shallow water habitat until the channel overtops its banks. In contrast, hydrodynamic models of flow through reconstructed topography for the unchannelized river demonstrate that total shallow water habitat would have steadily increased with discharge as low elevation alluvial surfaces were gradually inundated. The implications of this analysis for drift of free embryos is that in segments of the Lower Missouri River with minimal channel engineering, such as the segment downstream from Gavins Point Dam, changes in flow regime have greater potential to increase retention of larval sturgeon than in reaches where hydraulic variability is less sensitive to discharge, such as the Big Sioux segment of the river.

Present (2015) understanding of the potential for channel engineering to retain and grow free embryos to the larval stages is based on the concept of shallow water habitat, which defines a volume of habitat but fails to address the processes that lead to exchange between the main channel and marginal habitats. Improved understanding of the details of hydraulics 
at scales ranging from individual wing dikes to bends of rivers, combined with intensive sampling of free embryos and larvae, will be needed to establish how channel engineering and flow regime may be optimized to retain early life-stage pallid sturgeon in supportive habitats.

\section{Summary}

The distinct geomorphic characteristics and styles of channel engineering employed in different segments of the Lower Missouri River are manifested in longitudinal dispersion coefficients calculated from acoustic Doppler current profiler data. The lowest values of the longitudinal dispersion coefficient are found in the Ponca and Big Sioux segments where the flow field is homogeneous. Increased topographic and hydraulic complexity within the Gavins segment translates into higher dispersion coefficients, reflecting the greater potential for retention of drifting free embryos within this reach. Although the Kansas and Grand segments are highly engineered, these sections of river have the highest dispersion coefficients because large dikes generate pronounced zones of recirculation and strong transverse velocity shear.

Drift simulations completed using the one-dimensional advection-dispersion equation suggest that most passively drifting free embryos are exported from the Lower Missouri River into the Middle Mississippi River. The analysis assumes drift is entirely passive, an assumption which is contested by limited field data, and this one-dimensional approach neglects the effects of zones of transient storage on retention of drifting free embryos. Nonetheless, the model results provide a valuable estimate of total drift distance along the Lower Missouri River, and the analysis highlights the complex local interactions of channel morphology, engineering, and flow regime that control retention and drift of free embryos.

\section{References Cited}

Bowen, Z.H., Bovee, K.D., and Waddle, T.J., 2003, Effects of channel modification on fish habitat in the upper Yellowstone River-Final report to the USACE, Omaha: U.S. Geological Survey Open-File Report 2003-476, 30 p.

Braaten, P.J., Fuller, D.B., Lott, R.D., Ruggles, M.P., Brandt, T.F., Legare, R.G, and Holm, R.J., 2012, An experimental test and models of drift and dispersal processes of pallid sturgeon (Scaphirhynchus albus) free embryos in the Missouri River: Environmental Biology of Fishes, v. 93, no. 3, p. 377-392. [Also available at http://dx.doi.org/10.1007/ s10641-011-9925-9.]

Carr, M.L., and Rehmann, C.R., 2007, Measuring the dispersion coefficient with acoustic Doppler current profilers: Journal of Hydraulic Engineering, v. 133, no. 8, p. 977-982.
Fischer, H.B., 1973, Longitudinal dispersion and turbulent mixing in open-channel flow: Annual Review of Fluid Mechanics, v. 5, no. 1, p. 59-78.

Galat, D.L., and Lipkin, Robin, 2000, Restoring ecological integrity of great rivers - Historical hydrographs aid in defining reference conditions for the Missouri River: Hydrobiologia, v. 422-423, p. 29-48.

Jacobson, R.B., and Galat, D.L., 2006, Flow and form in rehabilitation of large-river ecosystems - An example from the lower Missouri River: Geomorphology, v. 77, no. 3-4, p. 249-269.

Jacobson, R.B., Blevins, D.W., and Bitner, C.J., 2009, Sediment regime constraints on river restoration-An example from the lower Missouri River, in James, L.A., Rathburn, S.L., and Whittecar, G.R., eds., Management and restoration of fluvial systems with broad historical changes and human impacts: Denver, Colo., Geological Society of America Special Paper 451, p. 1-22.

Jirka, G.H., and Weitbrecht, Volker, 2005, Mixing models for water quality management in rivers - Continuous and instantaneous pollutant releases, in Czernuszenko, Wlodzimierz, and Rowinski, P.M., eds., Water quality hazards and dispersion of pollutants: New York, Springer, p. 1-34.

Jobson, H.E., 1996, Prediction of traveltime and longitudinal dispersion in rivers and streams: Reston, Va., U.S. Geological Survey Water-Resources Investigations Report 96-4013, $69 \mathrm{p}$.

Kim, D., 2012, Assessment of longitudinal dispersion coefficients using Acoustic Doppler Current Profilers in large river: Journal of Hydro-environment Research, v. 6, no. 1, p. 29-39. [Also available at http://dx.doi.org/10.1016/j. jher.2011.06.001.]

Pinter, N., Jemberie, A.A., Remo, J.W.F., Heine, R.A., and Ickes, B.S., 2010, Cumulative impacts of river engineering, Mississippi and lower Missouri Rivers: River Research and Applications, v. 26, no. 5, p. 546-571. [Also available at http://dx.doi.org/10.1002/rra.1269.]

Reuter, J.M., Jacobson, R.B., Elliott, C.M., and DeLonay, A.J., 2009, Assessment of lower Missouri River physical aquatic habitat and its use by adult sturgeon (genus Scaphirhynchus) 2005-07: U.S. Geological Survey Scientific Investigations Report 2009-5121, 81 p. [Also available at http:// pubs.er.usgs.gov/usgspubs/sir/sir20095121.]

U.S. Army Corps of Engineers, 2012, Missouri River Stage Trends: U.S. Army Corps of Engineers, Northwestern Division, Reservoir Control Center Technical Report A-10, 43 p. [Also available at http://www.nwd-mr.usace.army.mil/ rcc/reports/pdfs/Ja07MRStageTrends.pdf.] 
Wallis, S., and Manson, R., 2005, On the theoretical prediction of longitudinal dispersion coefficients in a compound channel, in Czernuszenko, W., and Rowinski, P.M., eds., Water quality hazards and dispersion of pollutants: New York, Springer, p. 69-84.

Yotsukura, N., Fischer, H.B., and Sayre, W.W., 1970, Measurement of mixing characteristics of the Missouri River between Sioux City, Iowa, and Plattsmouth, Nebraska: U.S. Government Printing Office, p. 29.

Publishing support provided by: Rolla Publishing Service Center

For more information concerning this publication, contact: Director, USGS Columbia Environmental Research Center 4200 New Haven Road Columbia, MO 65201

(573) 875-5399

Or visit the Columbia Environmental Research Center Web site at: http://www.cerc.usgs.gov/ 

